\title{
Hibridni rod
}

\section{Došen, Miljenka}

\section{Doctoral thesis / Disertacija}

2020

Degree Grantor / Ustanova koja je dodijelila akademski / stručni stupanj: University of Zagreb, University of Zagreb, Faculty of Humanities and Social Sciences / Sveučilište u Zagrebu, Filozofski fakultet

https://doi.org/10.17234/2020.20100584

Permanent link / Trajna poveznica: https://urn.nsk.hr/urn:nbn:hr:131:188468

Rights / Prava: In copyright/Zaštićeno autorskim pravom.

Download date / Datum preuzimanja: 2023-04-26

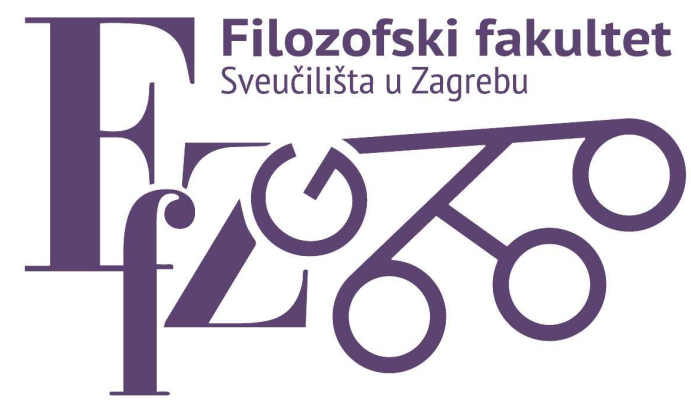

Repository / Repozitorij:

ODRAZ - open repository of the University of Zagreb

Faculty of Humanities and Social Sciences
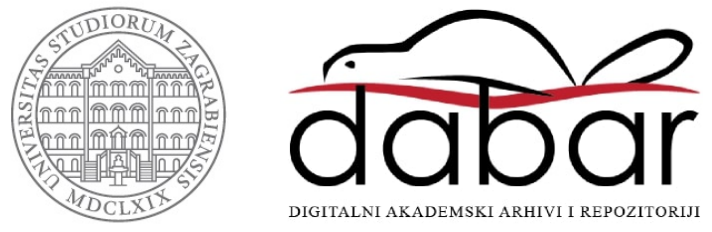


\section{(2) \\ Sveučilište u Zagrebu \\ FILOZOFSKI FAKULTET}

Miljenka Došen

\section{HIBRIDNI ROD - MODELI \\ ANDROGINIJE U KNJIŽEVNOSTI BEČKE MODERNE}

DOKTORSKI RAD

Zagreb, 2020. 


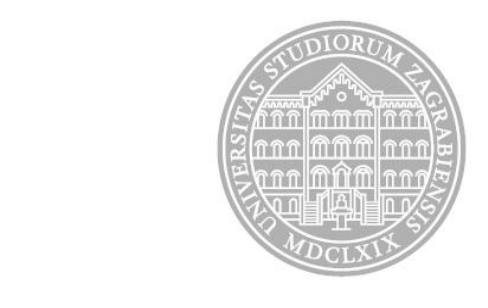

Sveučilište u Zagrebu

FILOZOFSKI FAKULTET

Miljenka Došen

\title{
HIBRIDNI ROD - MODELI \\ ANDROGINIJE U KNJIŽEVNOSTI BEČKE MODERNE
}

\author{
DOKTORSKI RAD \\ Mentor: \\ prof. dr. sc. Svjetlan Lacko Vidulić
}

Zagreb, 2020. 


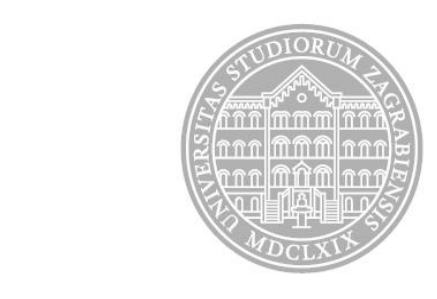

University of Zagreb

FACULTY OF HUMANITIES AND SOCIAL SCIENCES

Miljenka Došen

\section{HYBRID GENDER - PATTERNS OF ANDROGYNY IN THE LITERATURE OF VIENNA MODERNISM}

DOCTORAL DISSERTATION

Supervisor:

Prof. Svjetlan Lacko Vidulić

Zagreb, 2020 
Ovaj doktorski rad posvećujem mojim roditeljima koji su bili sve vrijeme uz mene, bodrili me i motivirali.

No bez strpljenja moga mentora, koji me usmjeravao na ovaj put i uvijek bezrezervno savjetom podržavao i bodrio, teško bih mogla privesti kraju doktorski rad.

Hvala Vam! 


\section{Životopis mentora}

Dr. sc. Svjetlan Lacko Vidulić, red. prof., rođen je u Zagrebu 1968. godine. Studirao je germanistiku i komparativnu književnost u Zagrebu (1988-1993), Mainzu (1991) i Beču (1993/94, Herderova stipendija). Magistrirao 1998. s radom o dramskoj poetici Hermanna Bahra, doktorirao 2003. s komparativno-historijskim radom o ljubavnoj semantici u austrijskoj prozi oko 1900. i oko 2000. godine. Od 1994. mlađi asistent, od 1998. asistent, od 2004. viši asistent, od 2005. docent, od 2010. izvanredni profesor, od 2019. redoviti profesor na Odsjeku za germanistiku Filozofskog fakulteta Sveučilišta u Zagrebu. Sudjelovao u radu niza znanstvenih projekata Ministarstva znanosti, obrazovanja i sporta odnosno Hrvatske zaklade za znanost. Stipendist Zaklade Alexander von Humboldt (2011). Glavni urednik znanstvenog časopisa "Zagreber Germanistische Beiträge" (od 2012). 


\section{Sažetak}

U svojoj doktorskoj disertaciji istražila sam narativne i dramske modele androginije u tekstovima bečke moderne. Analizirala sam književna djela Huga von Hofmannsthala, Leopolda von Andriana, Arthura Schnitzlera, Richarda Beer-Hofmanna, Petera Altenberga, Hermanna Bahra i Roberta Musila. Pojam androginije koristila sam kao operativni pojam za sve tipove neodređenog ili relativiranog roda koji bitno odstupaju od onodobne normativne polarizacije spolova/rodova u građanskom društvu. Diskurzivne efekte tako shvaćenog motiva androginije možemo nazvati hibridnim rodom. Obrazlagala sam na koji se način pripovjedne odnosno dramske strukture, teme, motivi i likovi u tekstovima bečke moderne mogu klasificirati kao rodno-obilježeni obrasci. Analiza metodološki počiva na kombinaciji strukturalistički orijentirane naratologije s jedne i rodnih studija (gender studies) s druge strane. Posebno težište stavila sam na analogije ili homologije između (de)konstrukcije roda i različitih narativnih odnosno dramskih postupaka.

U uvodu disertacije ukratko sam prikazala povijest androginije (A. Aurnhammer 1986), rodni poredak u građanskom društvu bečkog fin-de-siècle-a i njegovu krizu, te na kraju obrazložila pojave ,androginizacije“ zapadnih industrijskih društava od 1960-ih godina naovamo.

Prvi cilj istraživanja bio je sistematizirati motive i tipove androginije u poznatim i manje poznatim tekstovima bečke moderne. Drugi je cilj istraživanja bio dovesti u vezu hibridni rod u književnosti bečke moderne s „konstruktivističkim“ shvaćanjem roda koje je postalo samorazumljivo u kontekstu postfeminističke teorije i rodnih studija. Treći je cilj bio istražiti hibridni rod u kontekstu teze o anticipativnom postmodernom potencijalu bečke moderne, $\mathrm{s}$ obzirom na to da se dekadentne, esteticističke, (auto)ironijske i društveno-kritičke paradigme u oblikovanju hibridnog roda u suvremenoj recepciji mogu reaktualizirati.

Rezultati se vide u zaključku disertacije: bečka moderna predstavlja prijelazno razdoblje između tradicionalnog, viktorijanskog doba i liberalnog društva (permissive society), budući da književnici toga razdoblja na manje ili više radikalan način propituju, (re)produciraju i subvertiraju onodobne rodne obrasce (fin-de-siècle).

Ključne riječi: analiza drame, androginija, bečka moderna, feministička teorija, hibridni rod, naratološka analiza, postfeministička teorija, postmoderna, rodna polarizacija, rodni studiji 


\begin{abstract}
My doctoral dissertation aims to explore the narrative and dramatic patterns of androgyny in the texts of Vienna Modernism (in German: Wiener Moderne). The analysis is focused upon the literary works of Hugo von Hofmannsthal, Leopold von Andrian, Arthur Schnitzler, Richard Beer-Hofmann, Peter Altenberg, Hermann Bahr and Robert Musil. I have used the notion of androgyny as an umbrella term for all types of uncertain or relativised gender which essentially depart from the turn-of-the-century $\left(19^{\text {th }}-20^{\text {th }}\right.$ century) normative polarisation of sexes/genders within the bourgeois society. Discursive effects of the thus understood motif of androgyny can be named hybrid gender.
\end{abstract}

The first aim of my research has been to systematise the motifs and types of androgyny in well-known as well as less known texts of Vienna Modernism. My second aim has been to connect hybrid gender in the literature of Vienna Modernism with the „social-constructivist“ understanding of gender which has become self-evident within the context of postfeminist theory and gender studies. The third aim has been to explore hybrid gender in the context of the thesis of anticipatory postmodern potential of Vienna Modernism, taking into account the fact that the decadent, aestheticist, (self)ironic and socially-critical paradigms in shaping the hybrid gender can be re-actualised in contemporary literary reception.

The notion of androgyny is useful in order to further explain the motif of hybrid gender within the period of Vienna Modernism as a period of the crisis of gender (the specific crisis of gender relations and gender identities). However, the motif of androgyny within the modernisation processes around the turn of the century $\left(19^{\text {th }}-20^{\text {th }}\right.$ century) is not only portrayed as a notion of the crisis of identity (whether male or female crisis of identity), but it also represents the following intentions of writing (literary works of Viennese authors): 1. cultural pessimism and scepticism, which already designate the hybridisation of gender identities, 2. world-weariness of aesthetical natures that is highly portrayed within the literary works of Viennese authors: the portrayal of literary characters of effeminate (hypersensitive) aesthetes, flâneurs, dandies, and neurasthenic natures (whether male or female natures), which all carry the characteristic of primary narcissism, taking into account the fact that the notion of primary narcissism can also have a positive meaning of a relation of literary characters with the beings surrounding them, or a relation to one's interior world (one's own subconscious level), 3. social critique. The principal question being posed within the literature of Viennese 
authors is the following: do the Viennese writers subvert, question, transcend or even give an utopian perspective with regard to gender roles and gender identities? It has to be emphasised that Viennese writers somehow retain the traditional, even stereotypical portrayal of female characters (stereotypically representing women as passive, irrational and reproductive beings), while, on the other hand, they describe both male and female characters as androgynous (to a certain extent). However, this kind of androgyny (better to say, hybrid gender) stems from the more or less extreme gender ambivalence, which is created through the male demonising (or androgynising) of female beings, and, in consequence, the internalisation of female characteristics within the male psyche (as a male rebellion against the patriarchal order). In the analysis of the texts of Viennese authors, I have explained the way in which narrative and dramatic structures, themes, motifs and characters can be classified as gendered patterns (whether these categories belong to gender specific or gender neutral patterns). The analysis methodologically rests upon the combination of structuralist-oriented narratology on the one hand and gender studies on the other hand, taking into account the feminist and post-feminist theories, in order to further explain gendered patterns within the texts of Viennese authors. I have put a special emphasis upon the analogies or homologies between the (de)construction of gender and various narrative and dramatic procedures.

Social, cultural and ethical questions of this specific period of Vienna Modernism, when considered within the framework of gender studies, do not only mirror the content and the themes in the literary works of Viennese authors, but are also present within the narrative and dramatic structures, i.e. in the manner of the representation: Who speaks and who represents whom? Who is the subject and who the object of narrative or dramatic presentation, i.e. whose point of view dominates the narrative or dramatic literary work? One must take into account the fact that the specific period of Vienna Modernism, at the turn of the century $\left(19^{\text {th- }}\right.$ $20^{\text {th }}$ century), was imbued with various discourses which have made an impact upon the writers of Vienna Modernism, and the (social and cultural) discourses are the following:

1. the crisis of language and cognition, a notion that stems from Ludwig Wittgenstein, who was a philosopher of language, 2. a notion of unsaved ego, the notion that stems from Ernst Mach, who was a philosopher of science and physicist, and who contributed to the development of impressionistic style of writing of many Viennese authors, 3. the notion of the crisis of bourgeois way of perceiving, taking into account Sigmund Freud's foundation of psychoanalysis.

The introductory part of my dissertation has dealt with the history of androgyny (A. Aurnhammer 1986). I have structured this chapter into 5 parts: 1 . antique sources of 
understanding of the notion of androgyny that are related to the teachings of Plato and Ovid, and that have mythical origins, 2. Christian sources of understanding of the notion of androgyny: we can emphasise here that Jesus Christ is the foundation of Christianity, the perfect being who represents the notion of androgynous perfection- the person who embodies all the best male and female characteristics, 3. Renaissance sources of understanding of the notion of androgyny: the notion of Platonic love, and also the notion of a sacred form of marriage, according to Neo-Platonist ideas, and also the notion of gallant behaviour in French courts (the reversal of male and female gender roles), 4. the period of Enlightenment and romanticism: it has to be emphasised that, although the age of Enlightenment was especially inimical to the notion of androgyny, it nevertheless wanted to present androgyny within the frames of anthropological world-view, while the period of romanticism emphasised the spontaneous cultivation of feelings, trying to find the roots for this notion in the philosophy of nature (i.e. the androgyny of plants), 5. the period of the turn of the century $\left(19^{\text {th }}-20^{\text {th }}\right.$ century), which emphasised the notion of autonomous artists and their Utopian (we could say, ideal or contemplative) way of living, connected with the ivory tower existence.

Furthermore, in the third chapter, I have analysed the gender order within the bourgeois society of Vienna Modernism and its crisis. The bourgeois society has divided the spheres into a private sphere (which was traditionally coded as a female sphere), and a public sphere (which was traditionally coded as a male sphere). This dichotomisation of sexes/genders was inimical to women, who seeked emancipation within patriarchal order. Within the literary works of the authors of Vienna Modernism, the gender standards are either (re)produced, questioned, subverted or idealised.

In the fourth chapter, I have analysed the following literary works:

1. Hugo von Hofmannsthal: Andreas (oder die Vereinigten). This fragment of a novel is about the gender ambivalence of a hypersensitive aesthete (his oscillation between homoerotic and heterosexual gender orientation), while, on the other hand, the main literary character creates his ideal of femininity.

2. Hugo von Hofmannsthal: Das Märchen der 672. Nacht. This novella (or a short story) is about an unsuccessful conversion of the main male character (also an idealist, or, better to say, a hypersensitive aesthete) to an active way of life ( he eventually remains in an ivory tower). The main male character oscillates between a kind of demonisation of women (the fear of a maternal realm) and the idealisation of women (internalisation 
of female characteristics within his soul), while, on the other hand, he also has some homoerotic inclinations.

3. Hugo von Hofmannsthal: Gestern. This drama also represents, in its lyrical form (in German: Versdrama), a male aesthete through a kind of reversal of gender roles, whereby this male aesthete retains stereotypically connoted feminine characteristics (whimsicalness, moodiness), retaining the habitus of an amoral aesthete.

4. Leopold von Andrian: Der Garten der Erkenntnis. This novella represents a worldweary and nostalgic male aesthete and his homoerotic inclinations, but also his yearning for the maternal realm.

5. Richard Beer-Hofmann: Der Tod Georgs. This novel represents a world-weary aesthete, whose soul mirrors two (fictional) characters: a male character, his male friend, and an ornamentally described sensitive young woman, who is dying. These two (fictional) characters represent, in a metaphorical way, hybridisation of gender of the main male character.

6. Arthur Schnitzler: Die Fremde. This short story represents a kind of chivalric young man, also a male aesthete, who sacrifices his life for a young woman, who extremely oscillates in her gender identity (the notion of unsaved ego, while, on the other hand, she combines the characteristics of femme fragile and femme fatale, two typical characteristics of Vienna Modernism portrayal of women).

7. Arthur Schnitzler: Die Braut. This short story represents, through male discourse, a young woman's life story. The young woman had a certain tendency of becoming a good wife, but then her sensuality discouraged her, and she became a prostitute. Schnitzler's principal aim is to portray a kind of privileged female perspective, and he wants to emphasise the (im)possibility of realisation of female desire within the categories of bourgeois (or, better to say, patriarchal) society.

8. Arthur Schnitzler: Reigen. This experimental drama (or, comedy) represents various frivolous (or, melancholic) characters who belong to different social classes. These characters enter into sexual relationships with each other, in a merry-go-round manner. Elaborate dialogues among the characters (Schnitzler wants to emphasise the various manners of different social classes) only serve to stress their equal interests (by which Schnitzler subverts the anthropology of that period $\left(19^{\text {th }}-20^{\text {th }}\right.$ century)), a kind of anthropology that prefers male libido). Schnitzler subverts the double standards of his contemporaries. 
9. The prose sketches of Peter Altenberg. Altenberg (in a more or less voyeuristic manner) describes little girls (in their androgynous nature), and, on the other hand, expresses his disgust towards mature women, thereby criticising the pragmatism of bourgeois way of thinking. Altenberg retains his phase of primary narcissism of an aesthete.

10. Hermann Bahr: Die Mutter. This subversive grotesque drama represents the degenerated and neurasthenic characters, whose hybridisation of gender is expressed in their sexual hyperaesthesia.

11. Robert Musil: Die Verwirrungen des Zöglings Törleß. This novel portrays the psychological development of a young man in a boarding school (who, eventually, represents an amoral kind of aesthete) where he meets various colleagues who have amoral and pathological inclinations that he tacitly (or, better to say, in a masochistic way) tolerates.

I have divided the analysis of the literary works of Viennese writers into 4 parts: 1. the introductory part, 2. explicit gender (which is more related to literary themes), 3. implicit gender (which is more related to the narrative procedures, presented in their gendered forms), 4. the conclusion to each literary work.

In the fifth chapter, I have explained the ,androgynisation“ of the Western industrial societies since 1960-ies. I have explained the ,bisexuality“ of each human individual (in a less or more radical way), in order to portray the hybridisation of gender within the literary works of Vienna Modernism. One must take into account the fact that many people, in our contemporary world, have a tendency of either not belonging to any gender (a tendency toward asexual or gender neutral behaviour), or a tendency of belonging to both genders (a bisexual tendency): Elisabeth Badinter, who belongs to a culturally-sociologically-historical views about gender relations and gender identities, has presented these views.

According to Julia Kristeva, who belongs to a feminist and psychoanalytical way of thinking, the male character oscillates (is ambivalent) in his yearning to return to the mythic plenitude of maternal body (mythic plenitude is a notion that is also mentioned in Rita Felski's book under the title The Gender of Modernity), while, on the other hand, a male subject feels a certain disgust (or, abjection) towards the maternal body.

According to Judith Butler, who belongs to a postfeminist way of thinking, the performative potential of gender identities creates a possibility of (re)creating of gender identities and gender relations. She emphasises a social-constructivist thesis that a biological sexual identity 
already becomes a gender identity, and that this gender identity can also differ from a desire (a personal inclination).

In the final section of the fifth chapter, I have emphasised that Vienna Modernism already contains, in its (post-)modern essence, intellectual (or, cultural) themes which have the anticipatory postmodern potential: a more or less radical individualism, then pluralisation of various forms of life, gender dehierarchisation and an overall modernisation. Of course, this implies the fragmentation and decentering of identity of individuals. Through my doctoral dissertation, I have explored the notion of hybrid gender in the context of a thesis of anticipatory postmodern potential of Vienna Modernism, taking into account the fact that the decadent, aestheticist, (self)ironic and socially-critical paradigms in shaping the hybrid gender can be re-actualised in contemporary literary reception.

In the conclusion of my dissertation, I must emphasise a change of gender dynamics at the turn of the century, i.e. the masculinisation of women and the feminisation of men. On the one hand, women are striving towards an emancipation, while men, on the other hand, are more and more losing their firmness when confronted with growing modernisation processes, since they are under the pressure of growing industrialisation. It has to be said that female emancipation within the patriarchal society becomes connected to an adaptation of women to a kind of masculinist culture.

The results can be observed in the conclusion of my dissertation: Vienna Modernism represents the intermediate period between traditional, Victorian period on the one hand, and liberal, permissive society on the other hand, since the authors of that period (in a more or less radical way) question, (re)produce and subvert gender patterns of that period (turn-of-thecentury).

Key words: androgyny, drama analysis, feminist theory, gender polarisation, gender studies, hybrid gender, narrative analysis, postfeminist theory, postmodernism, Vienna Modernism 


\section{Kazalo}

1. UVOD: PREDMET RADA, METODE, STANJE ISTRAŽIVANJA, KLJUČNE TEZE .......1

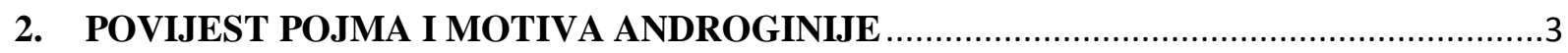

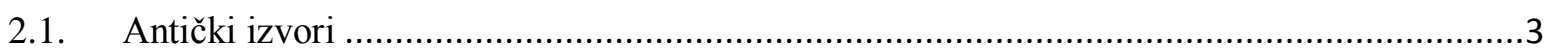

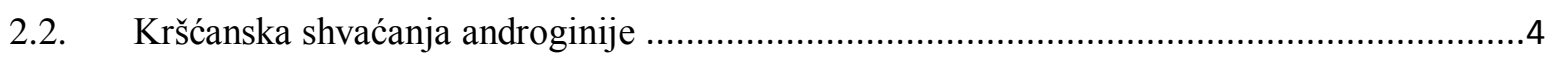

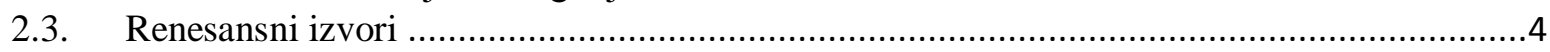

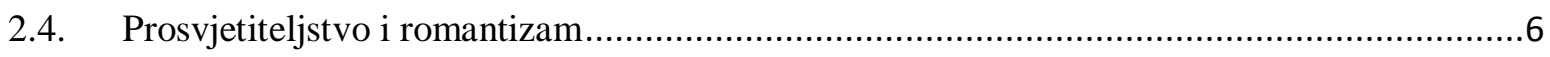

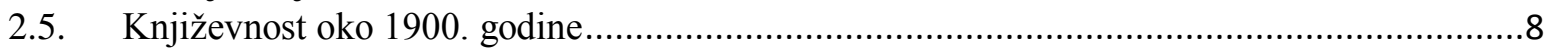

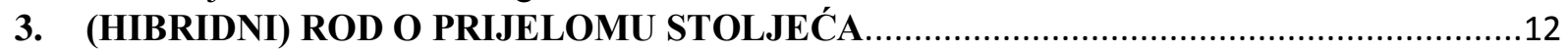

3.1. Bipolarizacija rodova u građanskom društvu oko 1900. godine ........................................12

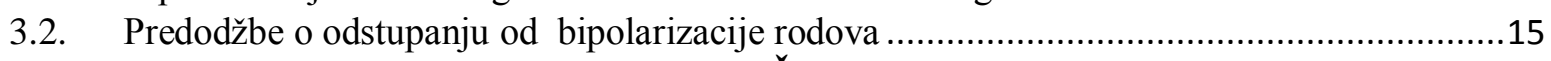

4. MODELI ANDROGINIJE U DJELIMA BEČKE MODERNE .......................................18

4.1. Hugo von Hofmannsthal: Andreas oder Die Vereinigten (Andreas ili sjedinjeni)................18

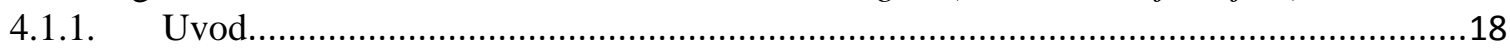

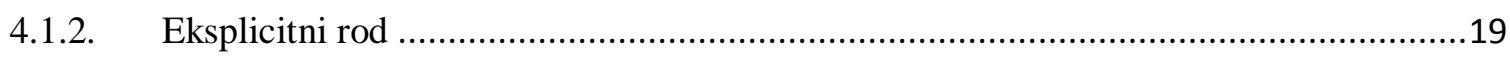

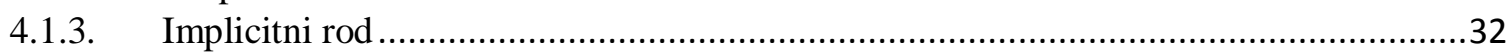

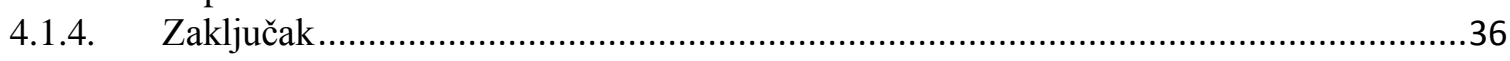

4.2. Hugo von Hofmannsthal: Das Märchen der 672. Nacht (Bajka 672. noći) ..........................40

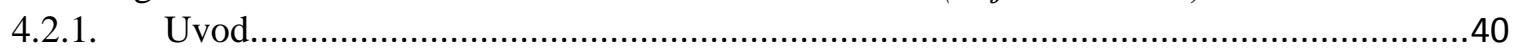

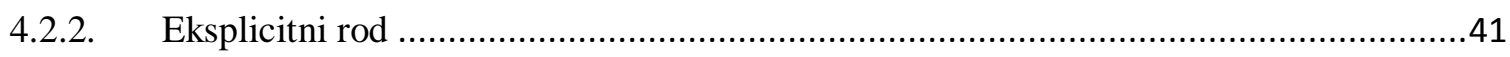

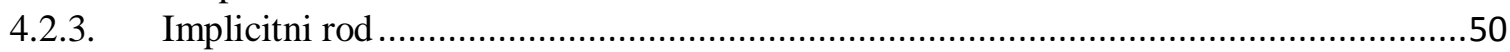

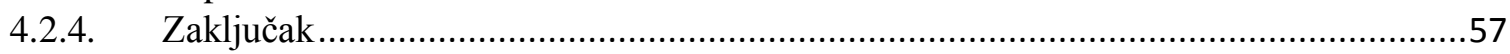

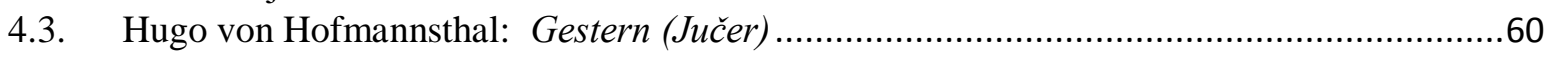

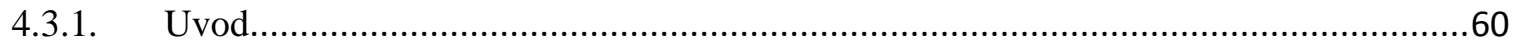

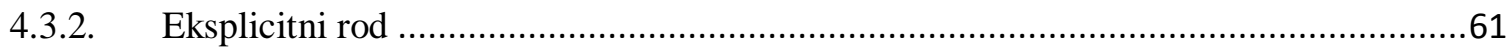

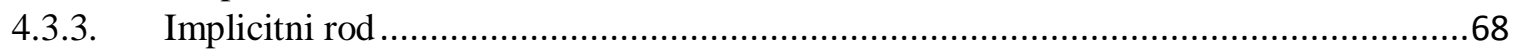

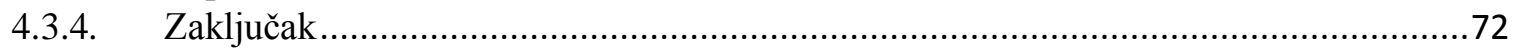

4.4. Leopold von Andrian: Der Garten der Erkenntnis (Vrt spoznaje).........................................73

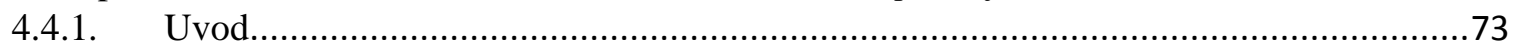

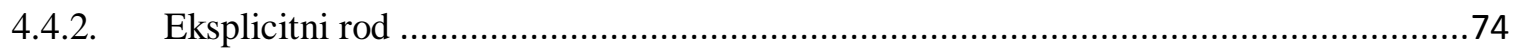

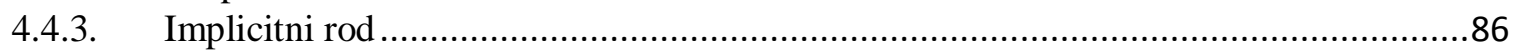

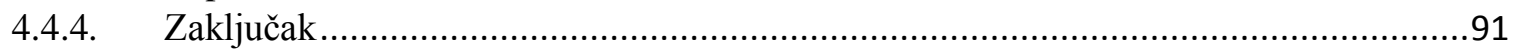

4.5. Richard Beer-Hofmann: Der Tod Georgs ( Smrt Georgova) ............................................94

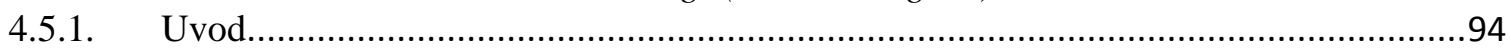

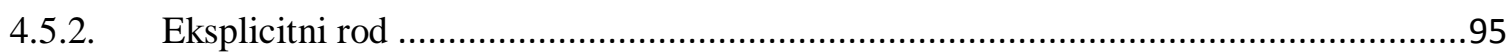

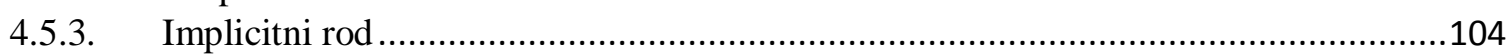

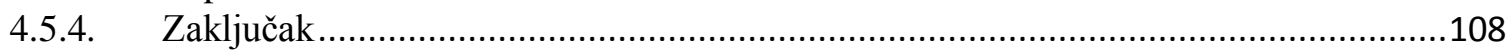

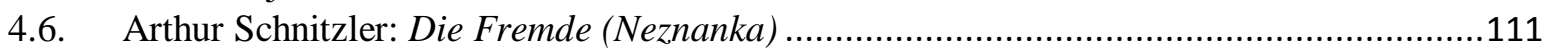

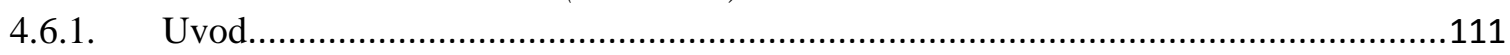

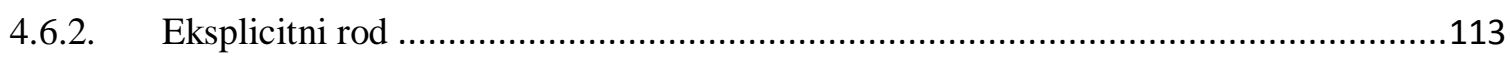

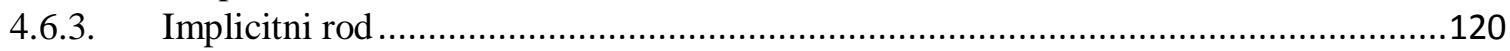

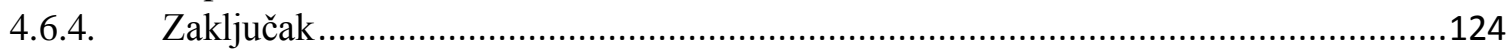

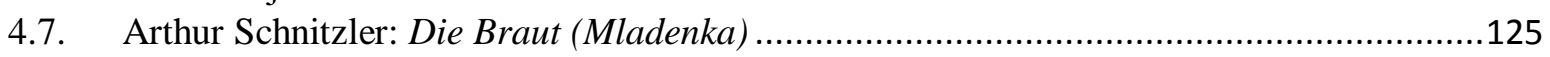

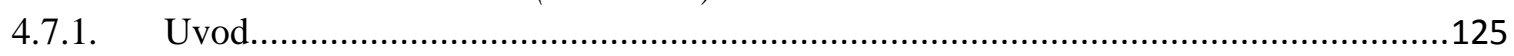

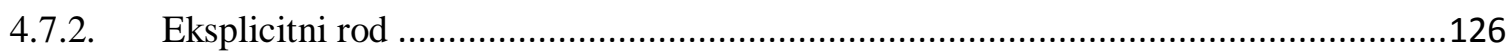

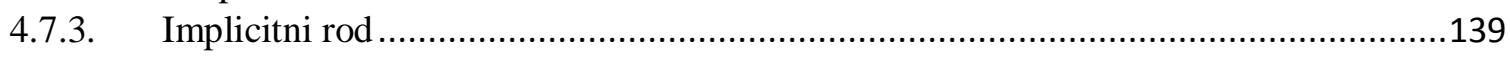

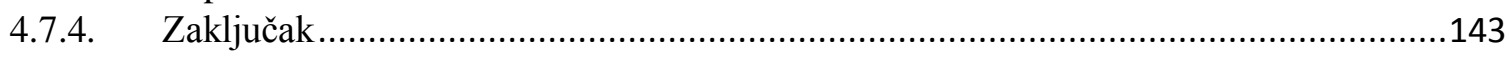

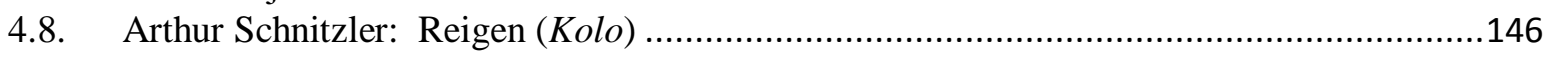




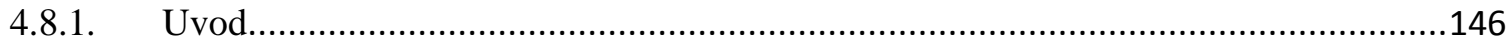

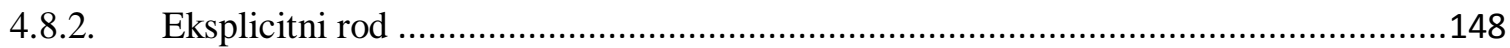

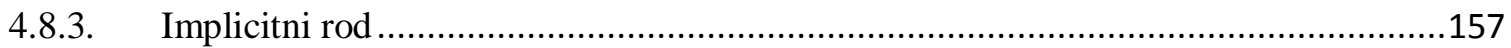

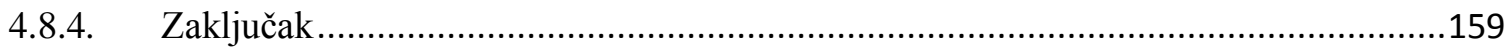

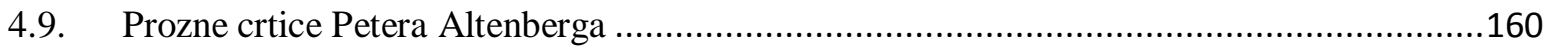

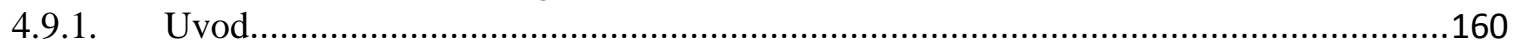

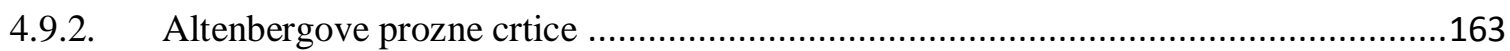

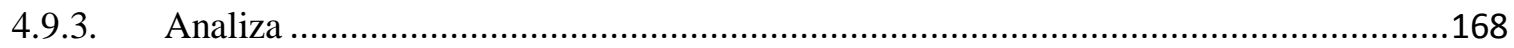

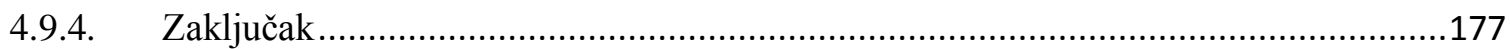

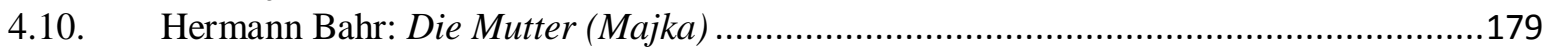

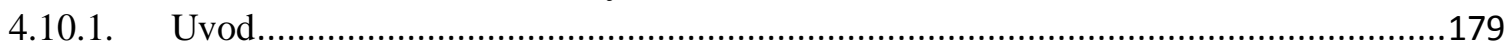

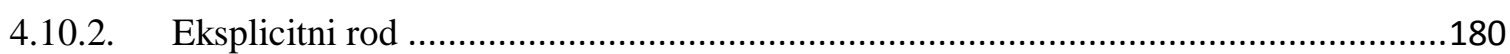

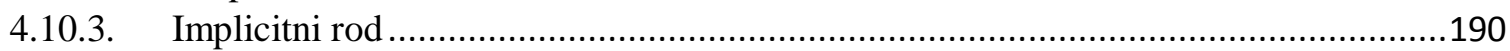

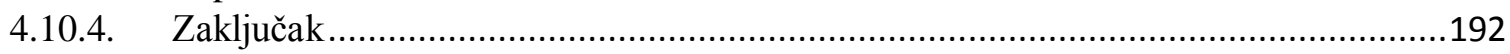

4.11. Robert Musil: Die Verwirrungen des Zöglings Törleß (Pomutnje gojenca Törlessa) ....194

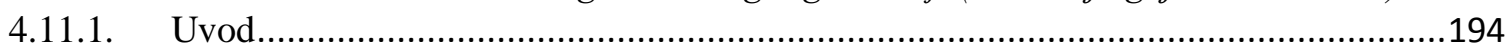

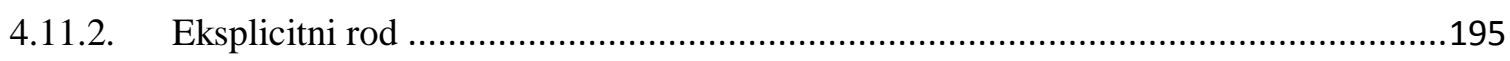

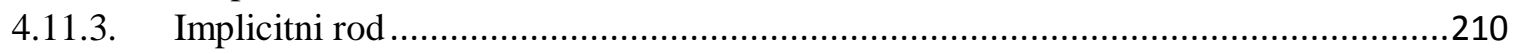

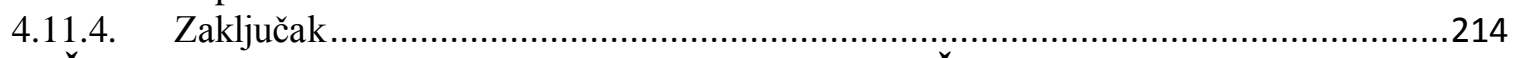

5. BEČKA MODERNA U SVJETLU SUVREMENIH DRUŠTVENIH I TEORIJSKIH

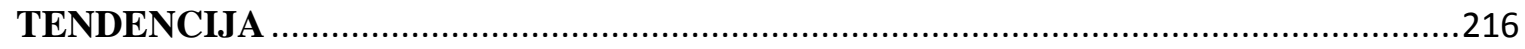

5.1. Sažetak interpretacija: hibridni rod u bečkoj moderni ..............................................216

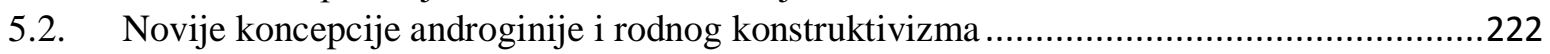

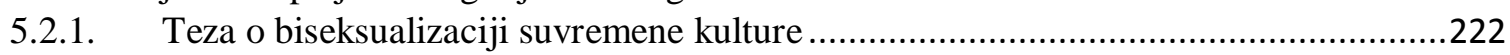

5.2.2. Teorija socijalnog konstruktivizma naspram teorije esencijalizma .........................227

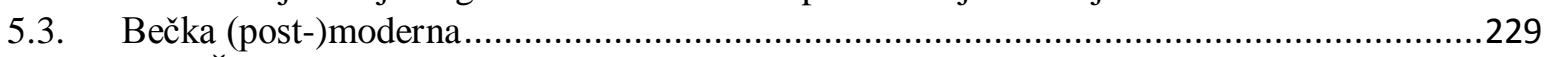

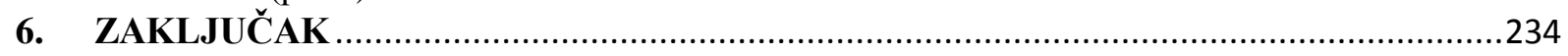

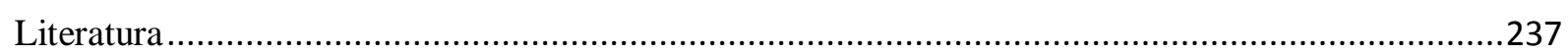

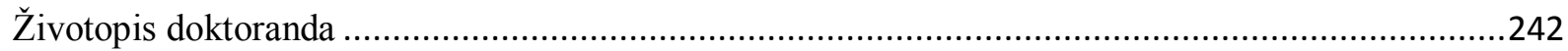




\section{UVOD: PREDMET RADA, METODE, STANJE ISTRAŽIVANJA, KLJUČNE} TEZE

Cilj moje disertacije je istražiti narativne i dramske modele androginije u tekstovima bečke moderne. U analizi tekstova bečke moderne obrazlažem na koji se način pripovjedne odnosno dramske strukture, teme, motivi i likovi mogu klasificirati kao rodno specifični ili rodno neutralni obrasci. $\mathrm{Na}$ ovu analizu primjenjujem analitičke kategorije rodno senzibilizirane književne teorije i interpretacije, kao i postavke suvremene feminističke naratologije. Društveno-politička i etička pitanja u okviru rodnih studija ne odražavaju se samo na ispripovijedani sadržaj i teme $u$ djelu, već su sveprisutna i u narativnim i dramskim strukturama, u načinu reprezentacije: Tko govori i tko predstavlja koga? ${ }^{1}$ Tko je subjekt a tko objekt prezentacije, odnosno iz čijeg rakursa se pripovijeda, ili tko je u fokusu dramske prezentacije? Kako povezati oblike reprezentacije sa normama i vrijednostima rodnih odnosa? Kakav je odnos između prezentiranog roda i roda prezentacije? Kako je u pojedinom djelu ustrojeno vrijeme i mjesto pripovijedanja i koje je njegovo rodno značenje?

Teorijski pristupi koje primjenjujem u interpretaciji analitičkih rezultata istraživanja su kulturološko-sociološko-povijesni pristup (Jacques Le Rider, Bettina Pohle), zatim feministički rakurs (Elisabeth Badinter, Judith Butler) i feminističko-psihoanalitička teorija (Julia Kristeva).

Bečka moderna sadrži anticipativni postmoderni potencijal: iz perspektive postmoderne pluralizacije i relativizacije roda, bečka se moderna pojavljuje kao razdoblje krize rodnih odnosa i identiteta. U svojoj disertaciji rastakanje rodnih identiteta i uloga koji dovode do pojave hibridnog roda i androginije tumačim kao aspekt anticipativnog potencijala bečke moderne. Posebice propitujem mogućnosti čitanja tekstova u smislu te „postmoderne“ anticipacije.

Pojam androginije poslužit će za osvjetljavanje motiva hibridnog roda u bečkoj moderni kao razdoblja krize roda (rodnih odnosa i rodnih identiteta). Međutim, motiv androginije $u$ modernizacijskim procesima oko 1900. godine (u razdoblju fin-de-siècle-a) ne biva samo medijem krize, kako se to najčešće prikazuje, već i medijem različitih intencija, kao što su: 1 . konzervativni katastrofizam, koji označava rastakanje rodnih polariteta, 2. dekadencija, koja se manifestira književnim prikazima zamora od života (Lebensüberdruss): prikazom

\footnotetext{
${ }^{1}$ Vidi Nieberle/ Strowick 2006, str. 32.
} 
književnih likova feminiziranih esteta, flanera, dendija ili neurastenika, čije je koncipiranje u djelima vezano uz književne subverzije i dekonstrukcije rodnih identiteta, 3. društvena kritika. Prvenstveno se kritizira onodobna rodna bipolarizacija (svođenje muških i ženskih subjekata na stereotipne rodne karakteristike), te se nastoje propitati i transcendirati takve stereotipne rodne uloge (iracionalnost $\mathrm{i}$ pasivnost ženskih subjekata, te racionalnost, aktivnost i produktivnost muških subjekata, prema tradicionalnoj podjeli, odnosno dihotomizaciji).

U svojoj analizi književnih djela bečke moderne rastakanju rodnih polariteta pristupam kako sa kulturološko-povijesno-sociološke pozicije, tako i sa pozicije koja se formirala u okviru rodnih studija, a prema kojoj se rodni identitet ne shvaća isključivo kao biološki determinirana kategorija (ahistorijski koncept), već kao društveno-kulturalna, odnosno diskurzivna pojava. Ova perspektiva socijalnog konstruktivizma ističe da su i muškost i ženskost povijesno i kulturalno prožeti konstrukti (povijesnost rodnog identiteta), ali koji jednako tako ovise i o individualnim interakcijama unutar pojedinog kulturalnog miljea.

Inovativnost moga pristupa sastoji se u prevladavanju monorodnog pristupa (fokusiranosti isključivo na ženski subjekt), budući da androginiju koristim kao krovni pojam za rastakanje polarizacije roda u kontekstu bečke moderne. Rodne konstrukte razmatram u strukturnom odnosu - kroz rodne konstelacije, odnosno različite oblike društvene interakcije ali i društvene (de)hijerarhizacije, interpretirajući ih na način kako se oni pojavljuju u djelima književnika bečke moderne. Osim toga, izrađujem tipologiju androginih figura (u smislu likova i u smislu konstelacija), kao što su primjerice: Mannweib, feminizirani estet i androgina samodostatnost, utopijska perspektiva androginosti kao ujedinjenosti muškoga i ženskoga principa, itd. Inovativan aspekt moga rada je i uključivanje izvora koji su do sada bili zanemareni u kontekstu razmatranja motiva androginije (npr. Hermann Bahr).

Stanje istraživanja na području u koje spada tema moga rada: postoje mnoge analize (istraživanja) o slici žene $\mathrm{i}$ njezinom pozicioniranju u doba moderne (npr. Pohle, Wiltschnigg), te o krizi muškog subjekta (Le Rider). Sva su ta istraživanja pretežno monorodno fokusirana (na ženski, rjeđe na muški subjekt) i time aficirana povijesnim odnosima koji su predmet istraživanja, ali ne bi smjeli biti i perspektivom istraživanja.

Pojam androginije koristit ću kao operativni (heuristički) pojam u svom radu, za razliku od različitih povijesnih upotreba tog i semantički srodnih termina, o čemu je bilo riječi u prethodnim poglavljima.

U drugom poglavlju rada ukratko prikazujem povijesni razvoj pojma androginije (odnosno različite moduse androginizacije kroz povijest), koji dodatno pojašnjava pojam hibridnog roda. 
U trećem poglavlju disertacije slijedi detaljna analiza rodnih odnosa i rodnih identiteta o prijelomu stoljeća: pojašnjenje bipolarizacije spolova u građanskom društvu fin-de-siècle-a te u drugom dijelu ovog poglavlja analiza predodžbi o odstupanju od bipolarizacije koju dovodim u vezu sa pojavom hibridnog roda (androginije, trećeg spola, hermafroditizma) u bečkoj moderni.

U četvrtom poglavlju disertacije obradit ću pojedinačno djela bečke moderne, povezujući pripovjedne i dramske strukture, teme, motive itd. s postavkama rodno-senzibilizirane književne teorije i interpretacije, kao i s postavkama suvremene feminističke naratologije, kako bih na taj način razvila tezu o hibridnom rodu u bečkoj moderni. Pod eksplicitnim rodom razumijem prije svega izravnije tematiziranje roda, a pod implicitnim rodom obilježja teksta koja nose rodne konotacije (prostor, vrijeme, tip pripovijedanja i dr.).

$\mathrm{U}$ petom poglavlju disertacije cilj je istraživanja dovesti u vezu hibridni rod u književnosti bečke moderne s novijim koncepcijama pojma androginije, gdje uz pomoć suvremenih psihoanalitičkih, dekonstrukcijskih i konstruktivističkih teorija E. Badinter, J. Kristeve i J. Butler ocrtavam koncepcije biseksualizacije kulture i hibridizacije roda.

$\mathrm{U}$ istom poglavlju disertacije prikazat ću anticipativni postmoderni potencijal bečke moderne, koji se očituje ponajprije kroz krizu metafizičkog i ontološkog nazora na svijet, što uzrokuje krizu identiteta (npr. prikazi izrazitog subjektivizma, modernizacije, beznadnog pluralizma i sve veće dehijerarhizacije u rodnim odnosima), koji su u razdoblju bečke moderne prikazani tek u naznakama, dok se u razdoblju postmoderne ova kriza (rodnog) identiteta radikalizira.

Napomena o korištenju literature: U pojedinim poglavljima ovoga rada intenzivno se oslanjam na pojedine monografije (Aurnhammer $1986 \mathrm{u}$ poglavlju 2.1., Badinter $1986 \mathrm{u}$ poglavlju 5.2. i dr.), pri čemu je teško razlikovati parafrazu od izravnog prijevoda koji bi se mogao navesti i kao citat. Za sve parafraze navodim odgovarajući izvor.

Napomena o prijevodima: svi prijevodi u tekstu koji su navedeni bez izvora moji su prijevodi. Prevela sam nekoliko Altenbergovih crtica u cijelosti, kako bih olakšala praćenje interpretacije.

\section{POVIJEST POJMA I MOTIVA ANDROGINIJE}

\subsection{Antički izvori}

Antičko doba obiluje različitim mitskim prikazima androginije. Motiv androginije se pojavljuje u svom utopijskom potencijalu: Platonov Androgynos, Ovidijeve Metamorfoze (Hermaphroditos-Salmakis), zatim biblijski motiv Adama i Eve. Ovi mitski prikazi 
predstavljaju određene personifikacije androginije, koja se očituje u motivu androgine samodostatnosti (njem. androgyne Vollkommenheit). ${ }^{2}$ Platon naglašava prvobitnu androginost svih ljudskih bića u svom utopijskom potencijalu, pri čemu se polovice bića koje su ostale razdvojene ponovo trebaju sastati u vidu simbolontičkog kurikuluma: „Mensch-HälfteMensch“. ${ }^{3}$ „Platonova podjela spolova na tri prvobitna spola postaje temeljem predestinacijske teorije o ljubavi, prema kojoj se sve spolne kombinacije legitimiraju kao nastojanje da se pronađe izgubljena polovica, kako bi se ponovo zadobila prvobitna cjelovitost". ${ }^{4}$

\subsection{Kršćanska shvaćanja androginije}

U prvom dijelu Biblije, u knjizi Postanka spominje se ,jedinstvo muškog i ženskog bića“. U mnogim spisima svećenstva pojavljuje se muško-ženski princip (androginija- njem. Mannweiblichkeit) izvornog ili prvobitnog čovjeka, Adama, kao dokaz njegove sličnosti Bogu, tako da se kao podloga ovog shvaćanja pojavljuje teza o androginiji Boga kao Stvaratelja svijeta (njem. mannweiblicher Schöpfergott). ${ }^{5}$ Androgino se savršenstvo (njem. die mannweibliche Vollkommenheit), koje se često povezuje s askezom, smatralo božanskim privilegijem i otkupljujućom snagom čovječanstva. Na taj se način „,nastojala premostiti rodna dihotomija, odnosno rodna podjela (njem. die Geschlechtstrennung) koja ide ruku pod ruku s rodnom podjelom rada“. ${ }^{6}$ Predodžba o androginom Adamu, iz čijeg je rebra stvorena Eva, nalazi se u biblijskoj knjizi Postanka. Kasnije je ova predodžba transformirana na Isusa Krista, koji, mogli bismo reći, predstavlja savršeno androgino biće, u kojem su u čistom obliku ujedinjene sve najpozitivnije i muške i ženske karakteristike. „Sve do 18. stoljeća mogu se pronaći ženske reprezentacije Isusa Krista. Teološke spekulacije o androginom Kristovom tijelu ostaju ipak izuzete iz ortodoksnih religioznih shvaćanja“. ${ }^{7}$ Tako se ženska Kristova strana mogla poistovjetiti sa njegovom svetošću, ${ }^{8}$ dok on kao biće predstavlja androgino savršenstvo.

\subsection{Renesansni izvori}

U razdoblju renesanse ističe se talijanski neoplatonizam, koji rehabilitira androgini potencijal često zanemaren u razdoblju srednjeg vijeka. On povezuje poganske koncepcije androginije

\footnotetext{
${ }^{2}$ Aurnhammer: 1986, str. 9-37.

${ }^{3}$ Ibid., str. 10.

4 Ibid.

${ }^{5}$ Ibid., str. 23.

${ }^{6}$ Ibid., str. 31.

${ }^{7}$ Ibid., str. 24.

${ }^{8}$ Ibid.
} 
sa pojmom biblijskog Adama, koji prema tumačenjima Biblije isprva ujedinjuje oba spola. Talijanski neoplatonizam (Ficino, Leone Ebreo) naglašava pojam platonske ljubavi, koja predstavlja intelektom obogaćenu i idealnu ljubav, koja se često navodi u ranorenesansnim traktatima talijanskih autora, a spominje se i ideal kršćanskog braka kroz biblijsku paradigmu muškarca i žene kao jednog tijela. ${ }^{9}$ U razdoblju renesanse, govori se o stanju ,jedinstva u dvojstvu“ (njem. Zweieinigkeit), koje upućuje na izjednačavanje rodnih uloga. Ficino u platonskom izvornom čovjeku (njem. Urmensch) vidi odraz dvostruke prirode ljudske duše, koja je u svom prvobitnom stanju stvaranja bila „opremljena“ sa dva svjetla: ,jednim urođenim prirodnim, za čisto materijalni svijet stvorenim svjetlom (lat. lumen ingenitum) i jednim natprirodnim svjetlom, koje je stvoreno za nebeske prostore duše (lat. lumen infusum) “. ${ }^{10}$ Istočnim grijehom, koji predstavlja odjeljenje božanske polovice duše, čovjek postaje zarobljenikom materijalnog svijeta. Rano-novovjekovna alkemija pridaje značenje prirodoznanstvenim pojmovima i procesima, prevodeći ih u hermetične slike vezane uz motiv hermafroditizma, ${ }^{11}$ koji se pojavljuje i u djelima književnika modernizma (npr. Thomas Mann, Robert Musil). Simboli i personifikacije koje su književnici moderne često upotrebljavali su Sunce (koje je u alkemiji često bilo povezano sa zlatom), te Mjesec (koji se $\mathrm{u}$ alkemiji često povezivao sa srebrom), dok se element tekućeg metala žive povezivao sa posrednim principom između Sunca i Mjeseca, odnosno, živi su se pridavale androgine karakteristike, kao i planetu Merkuru, koji nosi isti naziv kao i živa. No literatura o čudovišnim pojavama (Monsterliteratur), koja je isto tako prisutna u vrijeme renesanse, s druge strane predstavlja moralno diskreditiranje androginije: ovi stereotipni prikazi hermafroditizma dodjeljuju androginiji negativan predznak. Ipak, prisutna je i paradigma koja promiče ravnopravnost antike i kršćanstva te se javlja još jedna struja unutar renesanse koja pozitivno vrednuje pojam androginije: dvorsko pjesništvo i dvorska kultura ophođenja (ideal galantnog ponašanja u Italiji i Francuskoj, koji se kasnije proširio i na druge europske zemlje). Dvorsko je pjesništvo nastojalo prilagoditi motiv androginije kršćanskom obrascu braka i kršćanskoj seksualnoj etici. Dvorska je galanterija bila strogo ograničena na plemićki sloj, te se na dvorovima odvijala aristokratska razgovorna kultura. Motiv androginije omogućavao je široki repertoar načina ponašanja, koji je sudionicima razgovora omogućavao uživljavanje u različite rodne uloge koje su nadilazile stroge rodne podjele. U dvorskoj se galantnoj zamjeni uloga muškarci mogu ponašati na ,ženski“ način, a žene preuzeti „muške“ obrasce ponašanja:

\footnotetext{
${ }^{9}$ Aurnhammer 1986, str. 55

${ }^{10}$ Ibid., str. 47.

${ }^{11}$ Ibid., str. 118.
} 
nudi se cijela skala mogućnosti i obrazaca ponašanja čija galantna izmjena dokida monotoniju „,normativnih“ rodnih uloga. Ova vrsta androginije koja je bila ograničena na dvorski miljê postaje metom anti-dvorske opozicije, koja koristi u društvu prisutan sraz vrijednosti u svrhu žigosanja vladara kao hermafrodita. ${ }^{12}$

\subsection{Prosvjetiteljstvo i romantizam}

Razdoblje prosvjetiteljstva bilo je neprijateljski nastrojeno prema androginiji. Ono je odijelilo androginiju od mitskih prikaza te ju je znanstvenom revnošću ukorijenilo u antropološke teorije o podrijetlu ljudske vrste. U svome 1655. godine objavljenom traktatu pod naslovom Prae-Adamitae kalvinist Isaak de la Peyrère postavlja tezu da su ,prvi ljudi stvoreni čak i prije Adama“. ${ }^{13}$ Antropološke su teorije inspirirale književnike toga doba (npr. Gabriel Foigny), koji su nastojali te prikaze estetski „nadmašiti“ i propitati, estetizirajući čovjekovo udaljavanje od njegovog prvobitnog, ,porijekla“. Teorija o pred-adamitima nastojala je pronaći androgine suvremenike, koji predstavljaju androginu cjelovitost, u drugim rasama i dalekim narodima- etnografski i antropološki opisi, npr. vezano uz australske prastanovnike (Aboridžine), koji žive u stanju prvobitne civilizacije, koja predstavlja izvornost i nevinost, budući da oni ne poznaju pojam istočnog grijeha i osjećaj srama koji proizlazi iz toga. ${ }^{14}$

Postoje i teorije koje govore o „povijesti spasa“ ljudske rase, a koje su vezane uz kršćansku religiju: npr. Jacob Boehmeova koncepcija androginog izvornog i savršenog čovjeka, a koji odražava kršćanski oblik androginije, (njem. des androgynen und vollkommenen Urmenschen- Adama, ali prvenstveno Krista), posebice u njegovom spisu Mysterium Magnum, djelovala je sve do 19. stoljeća i utjecala prvenstveno na njemačku idealističku filozofiju (Hegel, Baader, Tieck, Novalis, Schelling). ${ }^{15}$

Antropolog Franz von Baader izvodi ideju prvobitne cjelovitosti iz razmatranja filozofije prirode. On povezuje predodžbu o androginiji isključivo s pretpostavkom da rodna podjela (podjela spolova) dovodi do stanja prevladavanja jedne rodne karakteristike (muške ili ženske), uz načelo principijelne biseksualnosti. U izvornom bi čovjeku projicirana izniveliranost obje rodne karakteristike postala uvjerljivom, budući da te androgine (ili hermafroditske) karakteristike već postoje u prirodi: kod biljaka i životinja. ${ }^{16}$ Prema Baaderu, i kršćanski bračni moral, na kojemu se temelji njegov pojam androginije, postaje,

\footnotetext{
12 Aurnhammer 1986, str. 39-135.

${ }^{13}$ Ibid., str. 137.

${ }^{14}$ Ibid., str. 144.

15 Ibid., str. 153 .

${ }^{16}$ Ibid., str. $158-159$.
} 
posredstvom ljubavi u braku (također u stilu shvaćanja braka u razdoblju romantizma i klasičnog njemačkog idealizma), modus premošćivanja rodnih razlika. ${ }^{17}$ Baaderovo se obnavljanje naučavanja Jakoba Boehmea o androginom Adamu povezuje i sa tvrdnjom da je i Eva ,poput ženskog Krista“, te da je „svo rođenje grijeh, dok je smrt izbavljenje od grijeha“. Baader, slijedeći Boehmeova razmatranja, govori o Kristu, koji pripada budućnosti, a predstavlja androgini oblik izbavljenja od grijeha: nivelacija rodnih karakteristika, budući da treba naglasiti činjenicu da je Isus Krist rođen samo od žene, bez posredstva muškarca. ${ }^{18}$

Otkrivanje dvospolnosti u biljaka potvrđuje androginiju kao biološku činjenicu. Botanička se dvospolnost koristi u romantičkoj filozofiji prirode te se ona prenosi i na čovjeka, $u$ vidu komplementarnih polovica koje aludiraju na platonički mit ${ }^{19}$ (Goethe, Novalis, Schiller, F. Schlegel). Goethe u svome djelu Wilhelm Meisters Lehrjahre ne osuđuje bratsko-sestrinsku ljubav, uspoređujući ju sa biologijom biljaka, nadograđujući na to čak i motiv ljiljana kao simbola nevinosti (aluzija na Isusa Krista). Goethe svoju kritiku upućuje „neprirodnim zakonima jednog navodno na razumskim zasadama utemeljenog društva, koje zbog revolucionarnih posljedica racionalnih zahtjeva ne udovoljava vladavini prirode i srca““. ${ }^{20}$ Goethe aludira na simbolontički kurikulum (zatvaranje ciklusa), koji je prepoznao u androginom životu biljaka. ${ }^{21} \mathrm{U}$ romanu Friedricha Schlegela pod naslovom Lucinde biljni svijet također postaje metaforom suprotnosti između androgine cjelovitosti (savršenstva) bića $\mathrm{s}$ jedne, a pogubnosti rodnog dimorfizma kroz društveno-ekonomski utemeljenu rodnu diferencijaciju s druge strane. Istočni grijeh je, prema Schlegelu, uveo rodnu podjelu rada, podijelivši strogo rodne uloge, kojima Schlegel pretpostavlja idilu dokoličarenja, koja se u razdoblju romantizma i predromantizma smatrala prirodnijom, budući da Schlegel spominje metaforu „čistog vegetiranja“, koje oduhovljenim biljkama želi približiti božanski lik čovjeka kao rajskom obliku života, koji svakom pojedincu, neovisno o njegovu/njezinu spolu dozvoljava identične načine ponašanja. Primat pasivnog vegetiranja naspram društvenih obveza koje razdvajaju spolove Schlegel obrazlaže ne samo sa etičke, već i sa estetičke strane. $^{22}$

S druge strane, Winckelmannov estetski ideal u kiparstvu i umjetnosti općenito prezentira androginiju kao estetsku dvoznačnost umjetničkog djela, predstavljajući hermafroditizam, koji mijenja svoje rodno određenje ovisno o kutu gledanja promatrača. Postoji težnja

\footnotetext{
${ }^{17}$ Aurnhammer 1986, str. 159.

${ }^{18}$ Ibid., str. 191.

${ }^{19}$ Ibid., str. 177.

${ }^{20}$ Ibid., str. 179.

${ }^{21}$ Ibid., str. 182.

${ }^{22}$ Ibid., str. 197.
} 
predstavljanja izjednačenosti muškosti i ženskosti kao kriterij ljepote. I ova se Winckelmannova teorija sredine veže uz znanstveno obrazloženje androginije u teorijama o porijeklu ljudske vrste. $^{23}$

Postoji također i teorija o androginu kao idolu osamljenog umjetnika (Balzac, Gautier, Péladan). Prema Balzacu (njegovom djelu Séraphîtus-Séraphîta) androgina je ljepota odraz anđeoske prirode, u kojoj se muškost i ženskost susreću, pri čemu se Balzac referira na Swedenborgovu mistiku. ${ }^{24}$ Swedenborg ističe nauku o stupnjevanju ljudskog bitka kroz produhovljenu poveznicu „muškarca“ i ,žene“ te ovu poveznicu predstavlja kao pred-stadij božanske egzistencije. Swedenborg kritizira analitičko razmišljanje, koje razdvaja ono što je spojeno. $^{25}$ Kod Balzaca, Gautiera i Péladana izjednačava se pojam androginije i djevičanstva. ${ }^{26}$ Prema romanu Joséphina Péladana pod naslovom L'Androgyne (1891. godina), androgin egzistira samo u djevičanskom stanju: s gubitkom djevičanstva androgin postaje ili muškarac ili žena te gubi svoje savršeno, s Božjom emanacijom usporedivo anđeosko stanje. ${ }^{27}$ Prema riječima Maksima Gorkoga, koji u hermafroditskom idealu ljepote pred-rafaelitskih slikara vidi temelje novovjekovne osamljenosti umjetnika: „Jedan takav način života ne ostavlja prostora za pjesnike, i stoga oni tragaju za ljepotom na grobljima prošlosti. Ne postoji poticajna sadašnjost niti svijetla budućnost, stoga se pjesnici okreću drevnim vremenima. Nevolja intelektualaca dolazi iz njihove osamljenosti, njihove odvojenosti od života“. ${ }^{28}$ Androgin stoga, kroz izmirenje suprotnosti muškost-ženskost postaje važnom imaginacijskom slikom o prijelomu stoljeća, idealom savršene izniveliranosti muških i ženskih karakteristika. ${ }^{29}$

\subsection{Književnost oko 1900. godine}

Književnost oko 1900. godine prikazuje motiv androginije na utopijski, ezoteričan i hermetičan način i zaziva androginu cjelovitost (odnosno, androgino savršenstvo) kao kultnu imaginacijsku sliku. Osamljeni individuum nalazi se u svijetu koji razdvaja muški i ženski princip: književnost oko 1900. nudi alternativnu utopijsku perspektivu ovoj rodnoj bipolarizaciji (S. Przybyszewski). Utopijska je perspektiva najčešće izražena u stiliziranju osame pojedinca u njegovu androginu autonomnost (Leopold von Andrian). U svezi s

\footnotetext{
${ }^{23}$ Aurnhammer 1986, str. 137-208.

${ }^{24}$ Ibid., str. 201-202.

25 Ibid., str. 202.

${ }^{26}$ Ibid., str. 205.

${ }^{27}$ Ibid.

28 Vidi. M. Gorki, cit. prema izložbenom katalogu pod naslovom Präraffaeliten, Baden-Baden 1973.godine, 164.str., cit. u: Aurnhammer 1986, str. 208.

${ }^{29}$ Vidi također Tegtmeier 1986, str. 113-119.
} 
onodobnom seksualnom psihologijom, koja postavlja tezu o biseksualnom ustroju svakog ljudskog bića, uspostavljaju se različite narcističke verzije androginije. Razvija se čežnja za utopijskim androginim stanjem, koje se temelji na sublimaciji seksualnosti, ali se to savršenstvo, prema Weiningeru, ne može postići u „kulturi koja promiče spolne odnose“, već kroz spolno uzdržavanje oba spola. ${ }^{30} \mathrm{U}$ svojoj knjizi Geschlecht und Charakter (Spol i karakter), Otto Weininger naglašava da „u askezi muškarca, odnosno muškom životu bez seksualnosti, leži i izbavljenje žene od spolnosti““. ${ }^{31}$ Weininger je muški asketizam smatrao nužnom pretpostavkom sublimacije biseksualne sklonosti u rajsko stanje androginije. ${ }^{32}$ Time Weininger naglašava pojam androginog savršenstva. U književnim likovima o prijelomu stoljeća može se otkriti ova karakteristika ujedinjavanja oba spola (i muškog i ženskog) samih u sebi (odnosno, u vlastitoj psihi), te se na taj način novi oblik osamljenosti (esteta) nastoji revitalizirati kao autonomna cjelovitost psihe. Pojavljuje se i metafora ,jedinstva u dvojstvu“ (njem. Zweieinigkeit), posebice u književnim motivima kod Franza Kafke (Uroboros kao alkemijski simbol prisutan u razdoblju moderne).

Kod Rainer Maria Rilkea narcistički je oblik androginije pokušaj da se prevlada rodni dimorfizam, odnosno stroga podjela na muški i ženski spol. Za Rilkea je posebice ženski subjekt sposoban dosegnuti „samodostatno“ androgino savršenstvo. Žene u ogledalu pronalaze same sebe- ogledalo je za njih hermetični prostor veze samih sa sobom : slika u ogledalu dopunjava ih u vidu jedinstva u dvojstvu. U pjesmi Requiem für eine Freundin Rilke opisuje nespojivost ,ženski“ konotirane narcističke androginije i „muški“ konotirane seksualnosti. Trudnoća, koju Rilke oplakuje vezano uz svoju umrlu prijateljicu, usko je vezana uz pogubnu muški konotiranu seksualnost, a čežnja za utopijskim stanjem androgine samodostatnosti i djevičanstva pretače se u savršenu egzistenciju u ogledalu (narcistička čežnja za androginim savršenstvom). Tako mitski lik Narcisa postaje važnom imaginacijskom slikom o prijelomu stoljeća: „stvaralačka snaga imaginacije izvire iz osobitog oblika osamljenosti modernog čovjeka i umjetnika“. ${ }^{33}$ U mističnom se obliku zrenja (njem. Schau) slika i njezin pan-dan (njem. Gegenbild) spajaju, tako da se „onaj/ona koji/a gleda „,dokida“ ili „pohranjuje“ u onome što gleda“ “ ${ }^{34}$ Statičnost kontemplativnog života esteta podrazumijeva povlačenje iz dualističkog svijeta (koji promiče rodnu diferencijaciju) u svijet ogledala. Na taj način Rilkeov lik Narcisa uzima obličje savršenstva anđela, kod kojega je vidljivo rajsko

\footnotetext{
${ }^{30}$ Weininger 1920; Grabowsky: Die Zukunftsreligion und Zukunftswissenschaft auf Grundlage der Emanzipation des Mannes vom Weibe (1897).

${ }^{31}$ Weininger 1920, str. 456-457.

${ }^{32}$ Aurnhammer 1986, str. 216.

${ }^{33}$ Ibid., str. 225-226.

${ }^{34}$ Ibid., str. 226.
} 
stanje sjedinjenosti muškog i ženskog principa, koje je „uskraćeno“ ljudskim bićima koja su zapala u dualizam duše i tijela. Alegoriju anđela Rilke poistovjećuje sa dvoje koji se vole (ljubavnim parom), tako da anđeo simbolički predstavlja njihovu sintezu. Mistična se razmjena srca (njem. Herztausch) dvoje zaljubljenih, koji simboliziraju anđela, odvija u umjetničkom prostoru (njem. Kunstraum) vrta, a predstavlja simboliku prirode ovjekovječene u umjetnosti.

Pjesnik Stefan George, koji pripada ezoteričnim strujanjima o prijelomu stoljeća, obrađuje pojam narcizma u pjesmi pod naslovom Algabal, u kojoj obrađuje povijesni lik Heliogabala, kojeg su već francuski simbolisti proglasili ,kultnim likom autonomnog artificijelnog protuživota (njem. Gegenlebens)“: George predstavlja lik rimskog cara, a njegovu biseksualnu prirodu povezuje sa samoinscenacijom sebe kao Boga. ${ }^{35}$ Algabal čezne za vječnom srećom božanske androginije toliko da, zbog nedostatka stvarnih mogućnosti, sam iz sebe stvara svoju vlastitu žensku dopunu (motiv zrcalne slike). ${ }^{36}$ George naglašava pojam ,androgine izvorne slike“ vremena u kojem je vladala svjetlost (stanje androginog savršenstva koje on uspoređuje s metaforom pod ezoteričnim nazivom Blutleuchte), karakterizirajući androginog izvornog čovjeka kao Lichtmenschen (čovjeka svjetla, prev. s njem.): u rajskom, odnosno prvobitnom bi se stanju „oprečne“ supstance („muškost“ naspram „ženskosti“) trebale izjednačiti. Rajsko je stanje, koje je predstavljeno u viziji o androginiji, ponovljivo u povijesnom vremenu, no uvjet za to je pojavljivanje suprotnog spola u svakom pojedincu (harmonizacija spolova). George spominje pojam Sonnenkind (dijete sunca, prev. s njem.), te ga povezuje sa Kristom.

Gustav Meyrink u svome djelu pod naslovom Golem prikazuje lik androgina, koji na simboličan način povezuje muški i ženski lik iz njegovog romana (Athanasius Pernath i njegova ljubav iz sna Mirjam). Meyrink u liku Golema predstavlja misterij androginije, ali također i rascjepljenje jastva (njem. Ichspaltung), koje se može premostiti samo sjećanjem i pronalaskom samih sebe.

U romanu Hermanna Brocha Der Tod des Vergil, lik hermafrodita izmiruje ne samo jastvo i ne-jastvo, već i posreduje između života i smrti. Na taj način Broch smrt karakterizira kao hermafroditsku „zrcalnu sliku“ te ju povezuje sa životom. ${ }^{37} \mathrm{U}$ svome romanu hermafroditski psihagog postaje narcističkim projekcijskim likom pjesnika Vergilija. Ovaj psihagog (odnosno, zazivač duhova) pod imenom Lysanias rješava zemaljske opreke između ovoga i

\footnotetext{
${ }^{35}$ Aurnhammer 1986, str. 233.

${ }^{36}$ Ibid.

${ }^{37}$ Ibid., str. 258.
} 
onoga svijeta, prošlosti i budućnosti i spaja te suprotnosti u jednu višu cjelinu. Ženski lik u djelu pojavljuje se iz ogledala (što upućuje na čežnju esteta za svojom drugom polovicom), te anticipira trajno androgino sjedinjenje duša. ${ }^{38}$

Androgina bratsko-sestrinska ljubav isto tako postaje jedna od imaginacijskih slika o prijelomu stoljeća (Georg Trakl, Robert Musil, Thomas Mann). ${ }^{39}$ Prema riječima Roberta Musila, vezano uz njegov roman Der Mann ohne Eigenschaften, „sestra blizanka je biološki nešto vrlo rijetko, ali ona u svima nama živi kao duhovna utopija, kao ideja našeg sebstva““. ${ }^{40}$ U svojoj je pjesmi Isis und Osiris Robert Musil obradio u lirskom obliku androgini mit o bratu i sestri, napomenuvši da u svim ljudima leži velika čežnja za onim stanjem kojem se genij približava, naime, djevičanskim stanjem jedinstva ženskosti i muškosti.

Georg Trakl, u koncipiranju pojma bratsko-sestrinske ljubavi (njegova pjesma u prozi Traum und Umnachtung, Offenbarung und Untergang, Helian, Passion, Frühling der Seele) opisuje svoju ljubav prema vlastitoj sestri Margarethe. U njegovim se pjesmama ona pojavljuje kao lirska šifra ${ }^{41}$, kao nevini lik iz vizije, koji je povezan sa sjenovitom egzistencijom u području smrti (mortifikacija se ovdje ipak pokazuje kao modus idealizacije, budući da Trakl svoju sestru izdvaja iz materijalnog svijeta). Traklova metafora mističnog svjetla također postaje dio njegove vizije vlastite sestre, koju on poima kao duhovni misterij: uočljiva je čežnja za anđeoskom prirodom svjetla, koja se gubi rođenjem i tek se u smrti ponovo može steći. ${ }^{42}$ Trakl naglašava da jedino bratsko-sestrinski pan-dan može spasiti pojedinca iz materijalnog (tjelesnog svijeta) u duhovni, transcendentni svijet. ${ }^{43} \mathrm{Na}$ taj način u Traklovom pjesništvu sestra dobiva androgino značenje, budući da Trakl spominje bratsko-sestrinsko sjedinjenje u liku androgina. Epiteti still i rein karakteriziraju sestru kao nebeski sjenoviti lik, kao aseksualno biće. ${ }^{44} \mathrm{Na}$ taj način androgina ljubav, koja se povezuje s kršćanskom predodžbom o Kristovom uskrsnuću, postaje oprečnom slikom zemaljskom rodnom dimorfizmu, koji se temelji na istočnom grijehu. ${ }^{45}$

Androgini prikazi kod Thomasa Manna vežu se uz pojam Hermesa kao božanskog posrednika, a kojega on opisuje kao božanskog posrednika između spiritualnog i materijalnog svijeta. Pridaje mu karakteristike androginog Mjeseca (njem. mannweiblicher Mond), koji postaje simbolom umjetnosti, budući da Mjesec, koji je u ranom razdoblju čovječanstva u

\footnotetext{
${ }^{38}$ Aurnhammer 1986, str. 259.

${ }^{39}$ Ibid., str. 209-299.

${ }^{40}$ Musil u intervjuu Was arbeiten Sie?, cit. u: Aurnhammer 1986, str. 285.

${ }^{41}$ Aurnhammer 1986, str. 267.

42 Ibid., str. 274.

43 Ibid., str. 275.

${ }^{44}$ Ibid., str. 280-283.

${ }^{45}$ Ibid., str. 281.
} 
svojoj dvoznačnosti predstavljao svetost, predstavlja posrednika između Sunca i Zemlje, odnosno čisto duhovnog i čisto materijalnog svijeta. Time Mjesec postaje posrednikom između smrtnosti i besmrtnosti, te predstavlja simbol umjetnosti i svrstavanja umjetnosti između duha (duše) i života, kao ,ženskost u odnosu na duhovnu stranu i muškost u odnosu na stvaralačku snagu života“. ${ }^{46}$ Likovi u djelima Thomasa Manna humaniziraju, prema obrascu božanskog posrednika, hermetično spajanje suprotnosti: „oni posreduju između života i smrti, Boga i čovjeka, duha i tijela, muškarca i žene“, međutim, ipak kroz „erotsko ruho hermafrodita“ ${ }^{47}$ Djela u kojima se pojavljuju ovi Mannovi opisi androginije su npr. njegov roman iz 1954. godine pod naslovom Bekenntnisse des Hochstaplers Felix Krull, zatim njegovo djelo o bratsko-sestrinskoj ljubavi pod naslovom Wälsungenblut. U djelu Thomasa Manna Der Tod in Venedig također se opisuje Aschenbachova žudnja prema dječaku Tadziu.

\section{3. (HIBRIDNI) ROD O PRIJELOMU STOLJEĆA}

\subsection{Bipolarizacija rodova u građanskom društvu oko 1900. godine}

Potrebno je detaljno ocrtavanje rodnih konstrukata i rodnih odnosa unutar građanskog društva fin-de-siècle-a, budući da se pojam hibridnog roda u bečkoj moderni definirao u (radikalnom ili manje radikalnom) odstupanju od onodobnih rodnih konstrukata. Dakle, treba uzeti u obzir da se književnici bečke moderne u svojim djelima ambivalentno, kritički ili pak subverzivno pozicioniraju u odnosu na onodobne rodne polaritete (nastoje ih propitati, transcendirati ili pak subvertirati).

Model rodnog polariteta $\mathrm{u}$ građanskom društvu značio je radikalnu bipolarizaciju i stereotipizaciju spolova te time oštro odijelio (,mušku“) od privatne (,ženske“) sfere. Ovakvom je podjelom rodnih uloga muškarac bio okarakteriziran kao utjelovljenje racionalnosti, moralnosti, aktivnosti i produktivnosti, dok je ženi pripala emocionalna, iracionalna, pasivna i reproduktivna sfera. Medicina i antropologija 18. i 19. stoljeća samo je prenijela ovu dihotomiju spolova iz društvenog okruženja u ,prirodne postulate (zakone) “48 te iz nje izvela zaključak o ,zasebnim ženskim antropološkim karakteristikama“ (Drugost žene). Time se muškarcu dodjeljuje civilizacijska uloga, dok se ženu svodilo na puki objekt i identificiralo s prirodom i senzualnošću. Rodna je polarizacija fenomen kasnog 18. i 19.

\footnotetext{
${ }^{46}$ Aurnhammer 1986, str. 261., cit. iz djela Thomasa Manna pod naslovom Schopenhauer (1938), Gesammelte Werke, IX: Reden.

${ }^{47}$ Aurnhammer 1986, str. 261.

${ }^{48}$ Pohle 1998, str. 24.
} 
stoljeća koji se koncem 19. stoljeća zaoštrava u kontekstu krize rodnih odnosa. Nadalje, postoji cijeli niz stereotipiziranih karakternih osobina koje su odražavale poimanje žene i muškarca kao dijametralno oprečnih. ${ }^{49}$ Što se tiče podjele rodnih uloga u društvenom životu, muškarac je imao ulogu racionalnog hranitelja obitelji (lat. pater familias), dok je žena bila ograničena na ulogu supruge i majke, te je time bila svedena na kućnu sferu (domestificirana). Žena je također bila odgovorna za emocionalno etabliranje obitelji. Stvaranjem patrijarhalnih užih obitelji s jedne, te sve većom industrijalizacijom s druge strane, došlo je do podjele sfera na privatnu sferu (koja je bivala ženski kodirana) i javnu sferu (koja je bila muškom domenom), obzirom da se sada ekonomski život odvija izvan kućne sfere. ${ }^{50}$ Građanska je uža obitelj tijekom 18. i 19. stoljeća slovila kao idealno utjelovljenje zajedničkog života.

Međutim, u obitelji se također provodila hijerarhijska dominacija muškarca nad ženom: svođenje žene na puku dekoraciju i kućni ornament zapravo je omogućavalo građanskom muškarcu potvrdu njegova u društvu prihvaćenog prava na isključivo tjelesno posjedovanje žene-supruge te time implicitno i potvrdu njegovog superiornog položaja u društvu. Ženska krhkost i bolećivost- to eterično i pasivno stanje, koje se može razumjeti kao oznaka ženske konstitucije, imalo je između ostaloga za cilj i održavanje muške autonomije i kontrole u braku. ${ }^{51}$ Žena, čiji je društveni položaj izveden iz njenog biološkog definiranja kao „spolnoga bića “52, mogla je- bilo u umjetnosti, književnosti ili medicini- iz muške perspektive nastupiti samo kao objekt. „Muški““ pogled na ženu dopušta autoru najčudnovatije i najmaštovitije generalizacije o ženskom spolu kao „drugome“. Društveno nadmoćan muškarac služi se sredstvima stilizacije da bi u „drugome“, ženskome, odredio svog „suparnika“ te ga onda likovno ili književno mortificirao. ${ }^{53} \mathrm{~S}$ metaforičkim razgraničenjem i izuzimanjem žene iz područja racionalnog, produktivnog $\mathrm{i}$ aktivnog, ide se na ruku tradicionalnoj društvenoj podjeli uloga na muške i ženske. Drugim riječima: dokle god muškarac ženu promatra kao objekt, kreaturu, dijete, dotle latentna opasnost gubitka moći muškaraca i u privatnom i u javnom životu postaje rizikom koji se može kontrolirati. ${ }^{54}$ Tako se zapravo formirao trajni oblik imaginacije o ženstvenosti. Tim je oblicima imaginacije svojstvena redukcija ženstvenosti na spolnost- na čisto fizičku ljepotu žene, čime se ona svodi samo na sferu animalnoga. Normalnom se ženom u usporedbi sa muškarcem smatrala u svim situacijama

\footnotetext{
${ }^{49}$ Vidi Hausen 1976., str. 368. (tablica)

50 Žmegač 1978, str. 114.

${ }^{51}$ Pohle 1998, str. 29.

${ }^{52}$ Weininger 1920.

${ }^{53}$ Pohle 1998, str. 12.

${ }^{54}$ Ibid., str. 12.
} 
pasivna žena. ${ }^{55}$ Ova učestala poimanja žena, koja ženski rod reduciraju na spolnost, iracionalnost i koja ženu smatraju kreaturom, pojavljuju se oko 1900. godine najčešće u 3 verzije: slici žene kao supruge i majke, kao fatalne žene i kao žene-djeteta (Kindfrau). ${ }^{56}$ Imaginacija „prijeteće“ ženstvenosti dosegnula je oko prijeloma stoljeća u Europi svoj vrhunac. Muški strah od gubitka moći slijeva se u fantazije želje i straha, čije je simboličko utjelovljenje žena.

Smatralo se da je jedina sudbina žene građanski brak, naročito pragmatizam građanskog braka, njegova uobičajena rutina, koja nije pružala dovoljno prostora za umjetničke izljeve osjećajnosti. Krajem 19.stoljeća u pravilu je zaposleni muškarac unutar građanske institucije braka imao produktivan, autonoman položaj, dok je žena bila ograničena na domaćinstvo i reprodukciju. ${ }^{57}$ Jasno je vidljivo da je takav model braka bio ravan ugovorom utemeljenoj, materijalistički svrhovitoj zajednici. Potencijalni bračni drug morao je biti generalno o miljen i uvažavan čovjek, čvrsta karaktera. ${ }^{58}$ Kod žena su prioriteti biti moralnost, ali i poslušnost. Sa svojim je potpisom bračnog ugovora žena preuzimala ne samo prezime muškarca, već i jedan dio njegove egzistencije te mu je bila dužna izražavati zahvalnost i poslušnost. Djevojke su iz očeva autoriteta nerijetko prelazile $u$ autoritet nerijetko postarijeg muža- time je zapravo još jednom bio potvrđen hijerarhijski odnos između muža i žene. ${ }^{59}$ Funkcija braka bila je materijalno i društveno osiguravanje egzistencije žene, tako da se svaki raskid braka smatrao štetnim po ženu. ${ }^{60}$ Dakle, radilo se o pravno utemeljenoj međusobnoj obvezi, pri čemu je muškarac bio skrbnik i odgovoran za društveno etabliranje, dok je žena bila čuvarica i majka. ${ }^{61}$ Ovi će odnosi biti dovedeni u krizu sve većom modernizacijom, dehijerarhizacijom i individualizacijom društva te krizom identiteta koja je posljedica relativizacije patrijarhalnih vrijednosti. Međutim, treba naglasiti da je građanski oblik obitelji (čak i u pater familias matrici) postojao kao normativni ideal za sve društvene slojeve, kao životna zajednica roditelja $\mathrm{i}$ djece, te da je funkcija odgoja djece $\mathrm{s}$ jedne, a privređivanje $\mathrm{s}$ druge strane proizlazilo iz društveno-povijesnog odvajanja privatne i javne sfere (mjesta stanovanja i mjesta rada). Međutim, u tome je razdoblju privatna sfera (domaćinstvo) bila cijenjena domena privatnog života. ${ }^{62} \mathrm{~S}$ utemeljenjem građanskog modela obitelji išla je ruku pod ruku i individualizacija i emocionalizacija obiteljskih odnosa, koja je svoj normativni izričaj imala u 
građanskim idealima kućevnosti, braka iz ljubavi, ljubavi supružnika i roditelja. Idealizacijom kućne sfere obitelj je postajala mjestom očuvanja i njegovanja građanskih vrijednosti i vrlina, koja se treba očuvati od ćudoredne nedostatnosti i opasnosti koje prijete iz izvanjskog svijeta. ${ }^{63}$ Građanski ideal ljubavi i braka proglasio je ljubav bračnim temeljem i tako uzdrmao predgrađanske nazore o bračnoj i izvanbračnoj ljubavi, između pragmatične i idealizirane koncepcije ljubavi. U 18.stoljeću započela je normativna polarizacija spolova, koja je kao „simbolički poredak spolova“ okarakterizirala sva „patrijarhalna“ društva. Ovaj se proces polarizacije spolova može u društveno-povijesnom kontekstu izvesti iz specifičnih potreba stabilizacije i legitimacije nove građanske strukture obitelji i rodno-specifične podjele rada. ${ }^{64}$

Koncept romantične ljubavi, koju su posebice promicali njemački rani romantičari a načelno ju provodili i u vlastitom životu, predstavlja idealizirano, pa i idealno (utopijsko) radikaliziranje onih zahtjeva koje je novi građanski ideal ljubavi postavljao vezano na izbor supružnika i bračnu vezu. U povijesnom kontekstu ovaj se koncept pojavljuje kao dio antigrađanskog pokreta. Koncept romantične ljubavi okreće se, u ime subverzivne kulture osjećaja i spontanosti ne samo protiv normativnih i pragmatičnih ograničenja građanskog braka i obitelji, već i protiv prisila građanskog društva uopće. Romantička se ljubav pojavljuje kao specifično radikaliziranje građanskih ideala ali, s druge strane, i kao utopijski kontraprogram građanskoj stvarnosti. ${ }^{65}$

\subsection{Predodžbe o odstupanju od bipolarizacije rodova}

Važno je naglasiti specifični povijesni kontekst bečke moderne koji je prožet problematikom destabilizacije rodnih odnosa te zahvaćen krizom tradicionalnog i patrijarhalnog (19.stoljetnog) svjetonazora. Od polovice 19.-stoljeća javljaju se pokreti za emancipaciju žena. Novo vrijeme zahtijevalo je reforme ,polovične moderne“ (njem. halbierte Moderne, E. Beck-Gernsheim) ${ }^{66}$, te se javljaju nove predodžbe o ženskom spolu, suprotstavljene tradicionalnoj (patrijarhalnoj) koncepciji žene. Rodni se polariteti relativiraju, žena se sve više „maskulinizira“ dok se muškarac, pritisnut sve većim zahtjevima društva i strahom od ženske emancipacije, „feminizira“. Rastakanje rodnih polariteta, koje se očituje uslijed krize građanskog patrijarhalnog poretka i konvencija, bit će predmet mnogih književnih djela u razdoblju bečke moderne. Književnost bečke moderne tematizira sveopću krizu identiteta

\footnotetext{
${ }^{63}$ Lacko Vidulić 2007, str. 13.

${ }^{64}$ Ibid., str. 13.

${ }^{65}$ Ibid., str. 13-16.

${ }^{66}$ Vidi Beck/Beck-Gernsheim 1990., str. 41.
} 
(kriza jezika i spoznaje, Machov empiriokriticizam, zatim kriza liberalizma i njegovog pojma autonomnog i racionalnog subjekta te Freudova teza o krizi građanskog subjekta). Sve se te krize odražavaju na krizu roda u kulturi bečke moderne.

Dok književnost i umjetnost općenito estetiziraju ,autonomnog hermafrodita“, koji predstavlja ujednačenost rodnih karakteristika, u znanosti se, s druge strane, relativiraju i redefiniraju kategorije „,muškosti“ i i „ženskosti““ ${ }^{67}$ Poznata teza J.J. Bachofena (1815-1887) o pravima matrijarhata, prema kojoj patrijarhalni ustroj zapadnjačkog društva predstavlja samo sekundarni stadij, a koji je zamijenio primarno matrijarhalno tumačenje svijeta, potkopava univerzalno važenje patrijarhalnih rodnih uloga i određenja. Institucije kao što su rodna podjela rada i brak počinju slabiti. Posljedica toga je to da rodne uloge, koje stvaraju dihotomiju spolova na temelju podjele rada, više ne važe kao nepovredivi prirodni zakoni, već se počinju definirati kao povijesni i društveni konstrukti. I onodobna filozofija također kritizira rodni dimorfizam, koji se čak pretapao i u strogo dualističko tumačenje svijeta. Kritika je, naravno, bila usmjerena i na jezik i spoznaju: umjesto jezično utemeljene percepcije o suprotnostima muškog i ženskog spola, koje su se sa razine čisto bioloških razlika prenijele na duševno ustrojstvo, nužno je postaviti fluidne granice (prijelaze) između rodnih određenja. Umjesto suprotnosti postavlja se teza o različitom stupnjevanju muških i ženskih karakteristika (O. Weininger i dr.). Sociolog Georg Simmel otkrio je djelovanja patrijarhalnih struktura moći u maskuliniziranom karakteru pojmovnoga para „muškarac“ i „Žena“, budući da jezična uporaba naglašava suprotnost spolova (na temelju rodnog dimorfizma) te postavlja pojam muškosti kao nadređeni i objektivni ideal. ${ }^{68}$ Sada se, naprotiv, spoznalo da se muške i ženske karakteristike međusobno prožimaju (u različitim omjerima) u svakom ljudskom biću. Prema riječima Waltera Benjamina, „Europa se sastoji od individua, a ne od muškaraca i žena“. ${ }^{69}$ Filozofska koncepcija hermafroditizma usko je povezana s onodobnom seksologijom i psihologijom. Danas potvrđena činjenica potencijalne biseksualnosti svakog pojedinog organizma potječe iz 19. stoljeća, kad je utvrđena dvospolnost $u$ botanici $i$ zoologiji. Ljudskim se hermafroditizmom označavala $u$ psihopatologiji pojava nepotpune spolne izdiferenciranosti tijela: pri tome se razlikovao „pseudohermafroditizam“ od „potpunog hermafroditizma“. Medicinsko istraživanje seksualnosti, koje je započeto u drugoj polovici 19. stoljeća, nije isključivo ograničilo spolne razlike na fiziološke spolne karakteristike, koje se dijele na primarne (spolni organi) i

\footnotetext{
${ }^{67}$ Aurnhammer 1986, str. 209.

${ }^{68}$ Ibid., str. 210.

${ }^{69}$ Walter Benjamin, cit. u Aurnhammer 1986, str. 210.
} 
sekundarne (specifično muška ili ženska građa tijela i organa), već se proširilo i na tercijarne i kvartarne spolne karakteristike, koje su se odnosile na duševno ustrojstvo pojedinca i njegovo socijalno ponašanje (uključivanje neanatomskih karakteristika). Filozofski i psihijatrijski spisi 90-ih godina 19. stoljeća svjedoče o ljudskoj biseksualnosti, posebice oni liječnika Wilhelma Fließa, koji teorijom o biseksualnosti svake ljudske jedinke zasniva „novu biološku sliku svijeta“. ${ }^{70}$ Fließ smatra da koncepcija psihe umjetnika demonstrira određeni udio suprotnog spola, da čak ukazuje i na samodostatnost hermafrodita. Prema Fließu, rodno-tipizirani i standardizirani obrasci ponašanja (a koji pripadaju tercijarnim i kvartarnim rodnim obilježjima) ovisni su o socioekonomskoj organizaciji pojedinog društva. ${ }^{71}$ Sigmund Freud se u svojoj teoriji spolnosti isključivo poziva na Fließa, no njegovoj tezi da svaka osoba posjeduje istodobno muško i žensko spolno ustrojstvo pridodaje i bitne posljedice na psihu pojedine osobe. Freud naglašava pojam ,potiskivanja“ (njem. Verdrängung) kao konflikt između muških i ženskih tendencija u pojedincu ${ }^{72}$, te naglašava biseksualnost osobe kao objašnjenje za seksualnu inverziju i osjećaj privlačnosti prema hermafroditičnim seksualnim objektima. ${ }^{73}$ Spoznaja o biseksualnim sklonostima razrađena je u teoriju seksualnih međustadija (njem. sexuelle Zwischenstufen). Ta je teza primarno povezana sa teorijama Magnusa Hirschfelda, koji opovrgava tezu o dualističkoj shemi muškarac/žena u svrhu postavljanja paradigme o fluidnim prijelazima između spolova (i rodnih identiteta). U tu će svrhu poslužiti i tradicionalni prikaz hermafrodita kao estetskog idola. U svojoj brošuri Was soll das Volk vom dritten Geschlecht wissen Magnus Hirschfeld prikazuje homoeroticizam i homoseksualizam kao prirodni poriv te zagovara ispravljanje nepravdi i predrasuda prema trećem spolu, ističući da homoseksualne veze nisu nužno i moralno nepoćudne. Hirschfeld ističe da se „sve tjelesne i duševne karakteristike koje smatramo tipično muškima, pojedinačno mogu pojaviti i kod žena i obratno““. ${ }^{74}$ Postoje mnogi među-stadiji između oba spola, koji se mogu sažeti pod pojmom „,treći spol““ ${ }^{75}$

Iako u svojoj knjizi Geschlecht und Charakter promiče rodne polaritete, naglašavajući esencijalnu nekompatibilnost i suprotnost muškog i ženskog spola (pri čemu obrazlaže da je tipološki muškarac /M/ nadređen tipološkoj ženi /W/ budući da posjeduje „,racio i moć logičkog rasuđivanja, svijest $\mathrm{i}$,transcendentalno ja“( ${ }^{76}$, Otto Weininger ipak nastoji dati

\footnotetext{
${ }^{70}$ Aurnhammer 1986, str. 212.

${ }^{71}$ Ibid., str. 212.

72 Ibid., str. 213.

73 Ibid.

${ }^{74}$ Hirschfeld, 1901, str. 4.

75 Ibid.

${ }^{76}$ Vidi Weininger 1920.
} 
biološko pojašnjenje biseksualnosti u društvu te razrađuje tezu o seksualnim međustadijima (njem. sexuelle Zwischenstufen). On ističe da u biljaka i životinja već postoji dvospolnost, no kod ljudskoga se bića ipak mora moći utvrditi pripada li ono muškom ili ženskom spolu. ${ }^{77}$ Ipak, Weininger naglašava i biseksualnost ljudskih bića, u kojima je uvijek, mada u različitim omjerima kod svake individue, prisutan i jedan segment suprotnoga spola. Weininger $\mathrm{u}$ Geschlecht und Charakter čak postavlja i tezu da je biseksualnost ljudskih bića sadržana u svakoj pojedinoj stanici ljudskog tijela.

Pored pojma „biološkog hermafroditizma“ etablirao se u suvremenoj, mahom psihoanalitičkoj i medicinskoj literaturi, pojam ,psihičkog hermafroditizma“ koji je označavao transseksualnost.

$\mathrm{U}$ bečkom miljeu susrećemo oprečne interpretacije i stavove o androginiji. S jedne strane imamo utopijske predodžbe o ujednačenosti muških i ženskih karakteristika u svakom pojedincu, koja bi dovela do ravnopravnosti žene i muškarca u bračnoj zajednici: Rosa Mayreder, npr. zastupa stav da ,moderni androgin nije ni muškarac ni žena, već sinteza jednoga i drugoga“.${ }^{78}$ Ona je zamišljala androginiju kao ravnopravni, prijateljski odnos žene i muškarca prema uzoru Platonove Gozbe: „Ono što se opisuje kao najveća ljubav između mlađeg i starijeg prijatelja, to je za moderni način osjećanja ništa drugo doli prikaz najplemenitijih heteroseksualnih veza“" ${ }^{79}$

$\mathrm{S}$ druge strane, u bečkoj se moderni hibridni rod i androginizacija prije svega poimaju kao izraz krize patrijarhalnog poretka, kao vrsta pobune protiv androcentričnog društva ili kao simptom gubitka identiteta: prema Alfredu Adleru, prevlast muškoga principa $u$ patrijarhalnom društvu dovela je do pojave neuroza ili psihoza, te se muški protest (i u književnosti bečke moderne) protiv takvog poretka počeo manifestirati pojavom ženskih karakternih crta u muškarca (npr. neurastenija, histerija ili efeminacija esteta).

\section{MODELI ANDROGINIJE U DJELIMA BEČKE MODERNE}

\subsection{Hugo von Hofmannsthal: Andreas oder Die Vereinigten (Andreas ili sjedinjeni)}

\subsubsection{Uvod}

Hofmannsthalov fragment nastao je oko 1912. godine, a njegovo je pisanje započeto već 1907. godine. Posthumno je objavljen 1932. godine, u izdanju S. Fischer u Berlinu.

\footnotetext{
${ }^{77}$ Bruns 1997, str. 225.

${ }^{78}$ Ibid., str. 226.

${ }^{79}$ Bruns 1997, str. 226., iskaz Rose Mayreder.
} 
Djelo je, prema analizi Achima Aurnhammera, koncipirano u vidu ,simbolontičkog kurikuluma“" (sjedinjenost-razjedinjenost-ponovna sjedinjenost dvaju bića), koji predstavlja utopijski konotiranu težnju glavnog lika, Andreasa von Ferschengeldera, za ponovnom uspostavom prvobitne harmonije u odnosu prema ženskom biću (Romana). Hugo von Hofmannsthal ostavio je svoj roman nedovršenim, što između ostalog upućuje na fragmentarnost karaktera glavnog lika, Andreasa von Ferschengeldera, ali odražava i autorova unutarnja previranja. U ovome djelu pojavljuje se koncepcija Andreasove ličnosti kao narcističke projekcije osamljenog i kontemplativnog mladića, kojem, kao što bi to bilo karakteristično za habitus umjetnika-aristokrata, internalizacija ženskog principa pruža osjećaj svemoći (njem. Allmachtphantasien) i androgine cjelovitosti (njem. androgyne Vollkommenheit). U Hofmannsthalovoj daljnjoj skici romana pod naslovom: Das venezianische Erlebnis des Herrn von $N$. ponovno se pojavljuje metafora „polovice“ koja simbolizira Andreasov povratak Romani, s kojim je Hofmannsthal želio završiti svoj roman: ovdje se govori o „dvije polovice Andreasovog bića“, 80 odnosno o njegovoj rodnoj rascijepljenosti, koja bi prestala „spajanjem tih dviju polovica“. To sjedinjenje sa samim sobom (i napuštanje fragmentacije vlastitog rodnog identiteta) omogućilo bi Andreasu „povratak u simbolontički kurikulum“ “81, koji biva započet Romaninom metaforičkom „oproštajnom radnjom“ u Andreasovu snu, u kojoj ona „raskida lanac u dva simbola, pri čemu jedan komad ostaje kod nje, dok drugi daje Andreasu“ ${ }^{82}$ Povratak samog sa sobom izmirenog Andreasa Romani najavljen je kao paradoks: „,može se vratiti natrag, mislio je, kao isti i kao drugačiji“ ${ }^{83} \mathrm{U}$ ovoj je frazi (,kao isti i kao drugačiji“) uočljiva fragmentacija Andreasova rodnog identiteta.

\subsubsection{Eksplicitni rod}

Hofmannsthal u svome fragmentarnom romanu Andreas oder die Vereinigten (Andreas ili sjedinjeni) obrađuje utopijsku androginu čežnju za pronalaskom samoga sebe vezano uz glavni lik Andreasa, koji mora premostiti rascjepljenje svoga jastva i svoj ambivalentni stav prema ženskosti kako bi mogao stvoriti čvrstu vezu sa svojim idealom ženskosti (Romana). ${ }^{84}$

\footnotetext{
80 „Andreas' zwei Hälften, die auseinanderklaffen“, Andreas oder die Vereinigten, str. 265.

${ }^{81}$ Vidi Aurnhammer 1986, str. 251.

82 „Endlich riß die Kette, ein Stück glitt ihr ins offene Hemd, das andere blieb ihr in der Hand. Dieses drückte sie Andreas von oben her auf den Handrücken...", cit. u Aurnhammer 1986, str. 251., Andreas, str. 237.

${ }^{83}$ (...) wiederkommen kann ich, dachte er, und bald, als der Gleiche und als ein Anderer., cit. u Aurnhammer: 251, vidi također Andreas, str. 237.

${ }^{84}$ Usp. Aurnhammer 1986, str. 246 -258.
} 
Gotovo je cijeli fragment koncipiran kao teleološki orijentirana težnja za uspostavom (revitalizacijom) vlastitog rodnog identiteta, u vidu Andreasove želje da se ponovo sjedini sa svojom idealnom vizijom ženskosti, personificiranom u liku nevine seoske djevojke Romane.

Andreasova kriza identiteta, koja se ogleda i u fragmentarnosti same strukture djela, naznačena je u njegovoj djelomičnoj biseksualnoj sklonosti i homoerotičkim impulsima (lik maskiranog Venecijanca, lik Andreasovog vjeroučitelja iz djetinjstva, Sacramozo), ali prvenstveno u općenitoj krizi identiteta ${ }^{85}$ potaknutoj kako zazorom od ženskosti, tako i općom feminizacijom i fragmentacijom jastva. Na simboličkoj se razini romana odvija Andreasova unutarnja borba između ideala i stvarnosti, subjekta i objekta, idealne vizije ženskosti i stvarnih žena, poimanja žene kao djevičanske (spiritualne) esencije (franc. femme fragile) i poimanja žene kao čiste senzualnosti (franc. femme fatale, cocotte), na što posebice utječe Freudova koncepcija udvajanja psihičkog života građanskog muškarca u čistu (spiritualnu) žudnju prema ženi i, s druge strane, poimanje žene kao izvora zazornosti (njem. Abscheu). Le Rider posebice ističe da se o prijelomu stoljeća, uz pojavu trećeg spola ${ }^{86}$, dakle, muškaraca koji demonstriraju homoeroticizam i homoseksualizam, pojavljuje i jedna druga skupina, naime oni muškarci koji osjećaju zazor od ženskosti ${ }^{87}$ a koji se pretvara u osjećaj anksioznosti prema ženskom spolu. Ovaj ambivalentan spoj žudnje prema ženi i zazora od ženskosti, koji je Julia Kristeva opisala u svome djelu pod naslovom Powers of Horror, često je uvjetovan ambivalentnim osjećajem građanskog muškarca prema majčinom (a kasnije ženskom) tijelu (svetost i gađenje), te njegovim ambivalentnim odnosom prema prvotnim incestuoznim željama, koje očinski, simbolički poredak (Zakon Oca) zabranjuje.

Andreasova se žudnja polarizira između spiritualnosti i senzualnosti, između podsvjesne koncepcije žene kao femme fragile i femme fatale, a kao dodatni element otuđenja od ženskosti pojavljuju se i homoerotički impulsi. Anksiozan stav prema ženskosti je, prema tome, jedan od simptoma Andreasove krize identiteta, koja nastaje u doba sve veće dehijerahizacije i modernizacije muško-ženskih odnosa. Lik Romane tako na simboličkoj razini predstavlja uporišnu točku moguće stabilizacije i (heteroseksualne) normativizacije Andreasova rodnog identiteta, budući da predstavlja Andreasov podsvjesni ideal (lat. anima; imago) ženskosti. Revitalizacijom i re-konstrukcijom svoje potisnute podsvjesne ženske strane (anima), ovom internalizacijom ženskosti, Andreasu bi bilo moguće premostiti razjedinjenost vlastitog bitka i ponovo stupiti u harmoničan odnos sa ženskim bićem.

\footnotetext{
${ }^{85}$ Usp. Le Rider 1990.

${ }^{86}$ Usp. letak Magnusa Hirschfelda pod naslovom Was soll das Volk vom dritten Geschlecht wissen, 1901.

${ }^{87}$ Vidi Le Rider 1990, str. 135-139.
} 
Lik Andreasa koncipiran je kao dinamičan (budući da se na individuacijski način ovaj lik neprestano razvija), višedimenzionalan (rodno kompleksno koncipiran), djelomično tipološki (plemićki stalež; senzibilni estet), a djelomično koncipiran u vidu individue, zatim kao otvoren (višeznačan) i izrazito psihološki koncipiran lik (unutarnja previranja na svjesnoj i podsvjesnoj razini). Ovaj lik demonstrira veći udio tradicionalno ženski konotiranih karakteristika: ${ }^{88}$ povlačenje u unutarnju transcendenciju vlastite psihe, pasivnost, predavanje ženskoj esenciji, kolebljivost $\mathrm{i}$ nepostojanost (napose oscilacije u njegovom rodnom identitetu), skromnost, prilagodba, osjećaj povezanosti s prirodom, emocionalnost, receptivnost i religioznost. Udio tradicionalno muški konotiranih karakteristika kod Andreasa je manji: ovo je njegova reakcija na krizu rodnih odnosa, a treba napomenuti i Andreasovu podsvjesnu identifikaciju s nasilnikom Gotthelffom. Andreas u svome ponašanju demonstrira ambivalenciju između statičnog i kontemplativnog obrasca ponašanja (engl. being) i dinamičnog, odnosno promjenjivog načina ponašanja (engl. becoming). ${ }^{89}$ Njegov se karakter na taj način također polarizira između konsolidacije sa ženskošću, koja je predstavljena kroz njegovu romantičnu potragu za ljubavlju (narativni obrazac romance) i neprestanog redefiniranja vlastitog rodnog identiteta koje je simbolički predstavljeno kroz njegova putovanja (quest)..$^{90}$

Ženski su likovi u djelu statično i tipološki koncipirani (Romana, Maria-Mariquita), pri čemu lik Marie-Mariquite, zbog svoga topografski fikcionaliziranog prikaza, možemo tumačiti kao 1. personifikaciju (eksternalizaciju) Andreasovih unutarnjih previranja, odnosno njegove psihološke podvojenosti između femme fragile i femme fatale, ili 2. kao njegovo personificirano viđenje vlastite ličnosti, podvojenost između ideala i stvarnosti, dok lik Mariquite može simbolički predstavljati i svojevrsni autoerotizam ili latentni homoeroticizam. Tematika romana povezana je s pokušajima kultivacije profinjenih osjećaja prema idealu ženskosti, čežnje za sjedinjenjem s voljenim ženskim bićem, mistične čežnje za internalizacijom Drugoga (žene) u vlastiti identitet i analitičkog definiranja vlastite ličnosti, te prema tome i određenja vlastitog rodnog identiteta i stava prema ženama i ženskosti. Roman prikazuje anksioznosti i neuspjehe socijalno neiskusnog mladića koji se suočava sa zabrinjavajućim pojavama (stereotipima) ženskosti i proživljava krizu svog rodnog identiteta. $^{91}$

\footnotetext{
${ }^{88}$ Usp. Hausen 1976, tablica: str. 368.

${ }^{89}$ Usp. Nünning/Nünning, Erzähltextanalyse und Gender Studies, 2004, str. 86.

${ }^{90}$ Ibid., str. 112.

${ }^{91}$ Le Rider 1990, str. 135.
} 
Provodni motivi fragmenta romana Andreas oder die Vereinigten su sljedeći: 1. Andreasova čežnja za idealom ženskosti (personificirana kroz lik Romane) i prevladavanjem zazora od ženskosti, 2. tipološki prikazi ženskih likova (Romana, Maria-Mariquita, Nina) koji, osim što služe kao koncepti za kreiranje određene Andreasove slike o ženskosti, demonstriraju i same dihotomije i oscilacije unutar Andreasove psihe, odnosno predstavljaju personifikcije Andreasove ženskosti, 3. provodni motivi prirode i Koruške, koji simboliziraju pastoralnu viziju pred-edipalne zaštićenosti u domovini (njem. Heimat), a predstavljaju ženski konotiranu pastoralnu idilu i mističnu harmoniju bitka u suprotnosti s muški konotiranim otuđenjem i fragmentacijom Andreasove ličnosti u Veneciji kao gradu labirintu, 4. motiv zrcala, ne tako čest u ovome Hofmannsthalovom djelu, ali čest u njegovom opusu (npr. Das Märchen der 672. Nacht), 5. motiv homoeroticizma (npr. maskirani Venecijanac, Andreasov vjeroučitelj, Sacramozo), 6. motivi ptica (npr. orao), koji na simboličkoj razini predstavljaju Andreasov mistični osjećaj svemoći (njem. Allmachtsphantasien) i harmonizaciju njegova rodnog identiteta (vlastite prirode), 7. motiv tuđine (njem. die Fremde) kao izvora otvorenih mogućnosti, ali i opasnosti, koji je prikazan kroz Andreasov boravak u Veneciji, 8. provodni motiv anksioznih sjećanja iz djetinjstva.

Andreasovi roditelji šalju svoga sina u Veneciju u želji da tamo usavrši svoju naobrazbu i stekne znanje o običajima stranih zemalja. ${ }^{92}$ Ovdje treba povući paralelu s djelom Thomasa Manna Der Tod in Venedig (Smrt u Veneciji). U Hofmannsthalovu fragmentu iz 1912. godine pod naslovom Die Dame mit dem Hündchen (Dama s psićem) odlazak u Veneciju je motiviran ovako: „Andreas- Razlog da ga se pošalje na putovanje: teška, polagana rekonvalescencija nakon jedne duševne krize, naznake anhedonije, gubitak osjećaja za vrijednosti, zbrkanost pojmova“" 93

Naracija, dakle, započinje Andreasovim dolaskom u Veneciju, grad koji Andreas percipira kao labirint i koji metaforički predstavlja njegovu psihičku dezorijentiranost i fragmentaciju njegovog (rodnog) identiteta. Treba istaknuti i simboliku ovoga grada vezano uz kontekst bečke moderne: Venecija, naime, nosi dekadentan i esteticistički predznak. Na početku romana prikazan je Andreasov susret s maskiranim Venecijancem, koji simbolički otkriva Andreasove homoerotičke impulse: „verbindliche Bewegung“- prisna, obvezujuća kretnja

\footnotetext{
${ }^{92}$ „Nun hätten sie ihn auf eine kostspielige Reise in fremdes Land ausgeschickt- wozu? um fremde Menschen kennenzulernen, fremde Landesgebräuche zu beobachten, um sich in den Manieren zu vervollkommnen., Andreas oder die Vereinigten, str. 224.; „Das würde seinem Vater Vergnügen machen zu erfahren, denn er war sehr darauf aus, das Besondere und Kuriose fremder Länder und Gebräuche zu sammeln“., Andreas, str. 204.

93 „Andreas. Grund, ihn auf die Reise zu schicken: schwierige schleppende Rekonvaleszenz nach einer seelischen Krise, Spuren von Anhedonia, von Verlust des Wertgefühles, Verwirrung der Begriffe“, Andreas, str. 287.
} 
Venecijanca prema Andreasu, zatim Andreasova zbunjenost u vezi vlastitog latentnog homoeroticizma- „er war tödlich verlegen“- on je bio smrtno zbunjen, a njegova se zbunjenost i nesigurnost u vezi vlastitog rodnog identiteta očituje i u statičnom motivu maske kao metafore za sjenovitu egzistenciju i neodrediv (fluidan) rodni identitet. ${ }^{94}$ Nedugo nakon dolaska u Veneciju, Andreas se prisjeća svog boravka u Koruškoj, koji je na formalnoj razini predstavljen kroz unutarnju pripovijest (njem. Binnenerzählung): „Sramio se sam pred sobom i nije čak želio niti pomisliti na ona tri zlosretna dana u Koruškoj, ali je pred njim već stajalo lice njegovog pokvarenog sluge, i, želio on to ili ne, morao se svega prisjetiti, u svim detaljima i od početka“. ${ }^{95}$ Andreas se prisjeća kako mu se njegov budući sluga (Gotthelff) na proputovanju kroz Villach nametnuo kao pratnja: već u ovome segmentu radnje otkriva se Andreasova feminiziranost, budući da ne raspolaže tradicionalno muški konotiranom čvrstinom i odlučnošću i ne demonstrira jačinu volje, već pokazuje znakove ženski konotirane pasivnosti i podložnosti ,jačemu“: „Onaj drugi je osjetio po nesigurnom (Andreasovu) tonu tko je jači i postavio svoju nogu na vrata... (...) kao da je to već bilo dogovoreno između njih“. ${ }^{96}$ Andreas kreće sa slugom Gotthelffom prema Koruškoj. Način na koji njegov sluga govori o kćerima gostioničara i mlinara ga s jedne strane sablažnjava, a s druge strane budi u njemu seksualnu znatiželju spolno neiskusna mladića. Ova je polarizacija u Andreasovu razmišljanju potaknuta udvajanjem njegove žudnje na spiritualni ideal s jedne i senzualnost, odnosno čistu tjelesnost s druge strane. U ovom momentu radnje Andreasov se rodni identitet polarizira između stereotipno ženskog (sramežljivost, čednost) i stereotipno muškog (agresivni seksualni interes) karaktera. Gotthelff nastavlja seksualno provocirati Andreasa: pripovijeda mu o svojim erotskim avanturama, zbunjujući ga, pa se u Andreasovoj podsvijesti počinju pojavljivati znakovi anksioznosti. Iako Gotthelff Andreasu postaje zazoran,

\footnotetext{
94 „Da trat aus einem Gäßchen ein Maskierter hervor (...) es war ein Mann, der vertrauenswürdig aussah, und nach seinen Bewegungen und Manieren gehörte er zu den besten Ständen. Andreas wollte sich beeilen, es dünkte ihn unartig, einen Herrn, der nach Hause ging, zu dieser Stunde aufzuhalten (...) sogleich erschien ihm überflüssig, daß er dies erwähnt hatte, er wurde verlegen und verwirrte sich im Italienischreden.; Der Fremde trat mit einer sehr verbindlichen Bewegung näher und sagte, daß er ganz zu seinen Diensten sei. Von dieser Gebärde war vorne der Mantel aufgegangen, und Andreas sah, daß der höfliche Herr unter dem Mantel im bloßen Hemde war, darunter nur Schuhe ohne Schnallen und herabhängende Kniestrümpfe, die die halbe Wade bloß ließen; Der Maskierte schlug den Mantel fester um die Hüften und versicherte, er habe durchaus keine Eile. Andreas war tödlich verlegen im Gedanken, daß der andere nun wisse, er habe sein besonderes Negligé gesehen; durch die alberne Bemerkung von der kalten Morgenluft und vor Verlegenheit wurde ihm ganz heiß, so daß er unwillkürlich auch seinerseits den Reisemantel vorne auseinanderschlug“ (...), Andreas, str. 198.

95 „Er schämte sich vor sich selber und wollte einmal an die drei unheilvollen Tage in Kärnten nicht denken, aber da stand schon das Gesicht des schurkischen Bedienten vor ihm, und ob er wollte oder nicht, mußte er sich an alles erinnern, haarklein und von Anfang an“, Andreas, str. 205.

96 „Da spürte der andere am unsicheren Ton, wer in diesem Handel der Stärkere war, und stemmte seinen Fuß gegen die Tür...(...) als wäre das zwischen ihnen abgemachte Sache“., Andreas, str. 207.
} 
Andreasova podsvjesna razmišljanja bivaju prožeta seksualnim fantazijama i gotovo dionizijskom voljom za moći:

Tip mu je bio odvratan kao pauk, ali je od njegova brbljanja Andreasova dvadesetdvogodišnja krv uzavrela, i njegove su misli odlutale negdje drugdje. Razmišljao je, kad bi samo te večeri došao u dvorac u Pormbergu i bio tamo primljen sa drugim gostima. (...) Lijepa grofica $u$ njegovoj blizini, njezin se pogled poigrava s njim kao on sa životom šumskih životinja. Onda odjednom ostanu nasamo, u posve osamljenoj odaji, on sam s groficom, hvat debeli zidovi, grobna tišina. Hvata ga jeza pred činjenicom da je ona žensko biće a ne više grofica, a on više nije mladi kavalir i nema tu više ničega galantnog, časnog, također ničeg lijepog, već je to divlji čin, ubijanje u mraku. (...) Želi se vratiti s groficom natrag u blagovaonicu, tamo gdje je sve veselo i časno (...). ${ }^{97}$

U ovome odlomku primjećujemo Andreasovu anksioznost (zazor) od žena, odnosno strah pred dominantnom (agresivnom) ženskošću. Ovakva anksioznost odražava onodobni stav prema ženama, njihovu demonizaciju u Weiningerovskom ${ }^{98}$ smislu: „lektira djela Andreas oder die Vereinigten prenosi dojam da je za onodobnog muškarca seksualna veza sa ženom bila najškakljivije, najopasnije i najneizvjesnije pitanje uopće, pa čak i nerješiva zadaća““.99 Međutim, u Andreasu se budi i potencijalni erotski interes, pomiješan s osjećajem grižnje savjesti zbog agresivne muškosti s jedne, a s druge strane sa strahom od približavanja ženskom biću. Ne želeći se suočiti sa vlastitim gubitkom sigurnosti (rodnog) identiteta, on izražava eskapističko-religioznu želju za spasenjem identiteta: „Želio bi da je sve to već odavno prošlo, želio bi biti stariji i već imati djecu, i da je to njegov sin koji putuje u Veneciju. Ali želio je da je to posve drugačiji čovjek nego on, pravi čovjek, i da je sve čisto i prijateljski kao u nedjeljno jutro, kad se čuju zvona. “100 Andreas i Gotthelff stižu na veliko imanje obitelji Finazzer, koje simbolički predstavlja utopijsko utočiše za Andreasov gubitak sigurnosti identiteta i revitalizaciju njegove empatije prema ženskosti: „Ljudi tako dobri, susretljivi, sve je tako časno i ćudoredno, bezazleno, vlasnik seoskog imanja pristojno izgovara molitvu prije ručka, a njegova žena se brižno odnosi prema stranom gostu kao prema

\footnotetext{
97 „Der Bursch war ihm widerlich wie eine Spinne, aber von dem Gerede war sein zweiundzwanzigjähriges Blut aufgeregt, und seine Gedanken gingen woanders hin. Er dachte, wenn er diesen Abend ankäme auf dem Pormbergischen Schloß und wäre erwartet und andere Gäste auch. (...) Die schöne Gräfin in seiner Nähe, wie er schießt, spielt ihr Blick so mit ihm wie er mit dem Leben der Waldtiere. -Dann sind sie auf einmal allein, ein ganz einsames Gemach, er mit der Gräfin allein, klafterdicke Mauern, totenstill. Ihm graust, daß es ein Weib ist und nicht mehr eine Gräfin, auch nicht der junge Kavalier, nichts Galantes, Ehrbares mehr, auch nichts Schönes, sondern ein wildes Tun, ein Morden im Dunkeln.“(...) „Er will mit der Gräfin wieder in den Speisesaal zurück, dorthin wo alles fröhlich ist und ehrbar (...).“, Andreas, str. 211.

${ }^{98}$ Vidi Weininger: Geschlecht und Charakter, 1920.

${ }^{99}$ Le Rider 1990, str. 139.

100 „Er möchte, das wäre alles längst vorüber, möchte älter sein und schon Kinder haben, und das wäre sein Sohn, der nach Venedig ritte. Aber ein ganz andrer Kerl als er, ein rechter Mann, und alles rein und freundlich wie an einem Sonntagmorgen, wenn man die Glocken hört.“, Andreas, str. 211.
} 
sinu...“. ${ }^{101}$ Nakon objeda Andreas ponovo susreće Romanu, kćer Finazzerovih: u tom se susretu objelodanjuje Andreasova zbunjenost i anksioznost vezano uz ženu, što potvrđuje njegov manjak inicijative prema Romani, koji predstavlja manjak tradicionalno muški kodirane hrabrosti i odlučnosti. Hofmannsthal ovdje aludira na mušku krizu identiteta, na gubitak sigurnosti muškog identiteta u doba moderniteta. Romanina iskonska nevinost, nepatvorenost i pobožnost, karakteristike koje su tipološke odrednice femme fragile i Kindfrau, predstavljaju faktor koji umanjuje Andreasovu rodnu nesigurnost: „,nosila je malu zdjelu sa svetom vodicom s pažljivošću punom strahopoštovanja, kako ne bi prosula nijednu kap. Upravo je u toj svojoj promišljenoj ozbiljnosti nalikovala djetetu, dok je nesvjesno, po svojoj ljupkosti, odavala dojam mlade žene.“102 Andreasovo poimanje Romane, pored njegove idealizacije, također odaje dojam stereotipiziranja ženskog bića, promatranja ženskog bića isključivo kroz prizmu fizičke ljepote: „ona pogleda svojim blistavim smeđim očima grobove (svoje braće i sestara): bilo joj je lijepo biti ovdje, kao što joj je bilo lijepo tijekom objeda sjediti za stolom između oca i majke i prinositi žlicu svojim lijepo oblikovanim ustima. Slijedila je Andreasov pogled; njezin je pogled mogao biti tako čvrst, (...) i upiti pogled drugog, tamo gdje bi on odlutao“.

Zatim se pojavljuje izrazito esteticistički opis prirode i Romane, koju Andreas podsvjesno poistovjećuje s pojmom ,sestre duše“:

\begin{abstract}
U međuvremenu su prešli preko dvorišta (...) Andreasu je bilo divno to što je djevojka tako otvoreno i bez kompleksa o svemu razgovarala s njim, kao da je on njezin brat. U međuvremenu se spustila večer, a sivi oblaci su se na jednoj strani spustili na planine, dok je na drugoj strani nastupila prodorna svjetlost i čistoća, pojedinačne zlatne pahulje tu i tamo na nebu, sve u pokretu na tamnoplavom nebu, mlaka s patkama blistave vatreno-zlatne boje, bršljan na zidu kapelice poput smaragda, crvendać je kliznuo iz zelene tame, kriješteći slatkim tonovima na svjetlucavom, poput niti istkanom zraku. Romanine su usne bile ono najljepše, blistave, prozirne, purpurno-crvene boje, a njezine su žustre i bezazlene riječi izlazile iz njezinih usta poput vatrenog daha, u kojem je izbijala njezina duša, istovremeno kao iz smeđih očiju sjaj pri svakoj riječi. ${ }^{103}$
\end{abstract}

\footnotetext{
101 „Die Leute so gut, so zutraulich, alles so ehrbar und sittlich, arglos, das Tischgebet schön vorgesprochen vom Bauer, die Bäuerin sorglich zu dem fremden Gast wie zu einem Sohn...“., Andreas, str. 213.

102, ,...) sie trug das kleine Becken mit ehrfürchtiger Achtsamkeit, keinen Tropfen zu verschütten. Gerade in ihrem bedachten Ernst war sie ein Kind, im Unbewußten aber und in der Lieblichkeit und Größe eine Jungfrau."“, Andreas, str. 215.

103 „Indem waren sie über den Hof gegangen (...) Andreas war es wunderbar, wie das Mädchen so ungehemmt alles zu ihm redete, als ob er ihr Bruder wäre. (...) eine durchdringende Helligkeit und Reinheit, einzelne goldene Flocken da und dort am Himmel, alles in Bewegung auf dem dunkelblauen Himmel, der Tümpel mit den aufgeregten Enten wie sprühendes Feuer und Gold, der Efeu drüben an der Mauer der Kapelle wie Smaragd, ein Zaunschlüpfer oder Rotkehlchen glitt aus dem grünen Dunkel hervor, überschlug sich mit einem süßen Laut in der webend leuchtenden Luft. Das Schönste waren Romanas Lippen, die waren von leuchtendem durchsichtigem Purpurrot, und ihre eifrig arglosen Reden kamen dazwischen heraus wie eine Feuerluft, in der ihre Seele hervorschlug, zugleich aus den braunen Augen ein Aufleuchten bei jedem Wort.“, Andreas, str. 218.
} 
Nije slučajno da Andreas primjećuje kako „mu je ta djevojka tako otvoreno i bez kompleksa sve pričala, kao da je on njezin brat". ${ }^{104}$ Ova metafora sestre pojavljuje se i u Hofmannsthalovu djelu Das Märchen der 672. Nacht (Bajka 672. noći), gdje metafora „sestre duše“ predstavlja utopijski pokušaj revitaliziranja vlastite ženskosti, kreiranja empatije prema ženskom biću i prevladavanja zazora od žena kao Drugosti. Heterodijegetski pripovjedač, poistovjećujući se s likom Andreasa, esteticističkim vokabularom uspoređuje ljepotu prirode i Romaninu ljepotu: on na određeni način stereotipizira žensko biće, povlađujući dihotomiji žene kao simbola prirode (njem. Naturwesen Frau) i muškarca kao simbola kulture (njem. Kulturwesen Mann). Andreasova druga, podsvjesna, tradicionalno muški kodirana i vitalistička strana personificirana je kroz lik Gotthelffa, nasilnog i vulgarnog Andreasovog sluge: lik Gotthelffa utjelovljenje je brutalne, animalne muškosti i kroz njega se metaforički ogleda gubitak sigurnosti Andreasovog rodnog identiteta (motiv dvojnika). Podsvjesna identifikacija s Gotthelffom, koja naznačuje problem depersonalizacije ličnosti, odnosno predstavlja Andreasovu nesigurnost oko ontološke utemeljenosti (fiksnosti) njegova jastva, uzrokuje Andreasov osjećaj grižnje savjesti i odlazak s imanja Finazzerovih. Gotthelff, predstavljen kao antagonistička struja utopijskoj perspektivi ženskosti u djelu, utjelovljenje je druge, animalne, muški konotirane podsvjesne težnje u Andreasovoj psihi, koju Andreas želi otkloniti kako bi, revitaliziran i empatijski priklonjen ženskosti, mogao izgraditi harmoničan odnos sa svojim idealom ženskosti. Princip psihičke podvojenosti i fragmentacije rodnog identiteta ne odnosi se u fragmentu romana samo na Andreasa, već se prikazuje i kroz simbolično i metaforičko pojavljivanje lika Marie-Mariquite, koja predstavlja dvije suprotstavljene strane ženskosti (stereotipne koncepcije femme fragile i femme fatale), a ujedno simbolizira i unutarnji konflikt između muškosti i ženskosti unutar Andreasovog karaktera. Na taj je način tipološki koncipirani lik Marie-Mariquite zapravo personifikacija Andreasove rodne podvojenosti. Drugi dio imena, Mariquita, prema Achimu Aurnhammeru metaforički predstavlja Andreasovu feminizaciju, obzirom da mariquita na španjolskom znači i „feminiziran muškarac“. ${ }^{105}$ Budući da se Andreas prisjeća trauma iz djetinjstva, te traume služe kao barijera koja onemogućava harmonično spajanje (i izmirenje) sa vlastitom potisnutom ženskošću. U vremenskom periodu između Gotthelffovog zločina i Andreasovog odlaska sa imanja Finazzerovih Andreas, obuzet sjećanjima iz djetinjstva, sanja dva sna: snovi u kojima se Andreas traumatično prisjeća kako je, kao dječak, sadistički slomio svome psu

\footnotetext{
104 „Andreas war es wunderbar, wie das Mädchen so ungehemmt alles zu ihm redete, als ob er ihr Bruder wäre“., Andreas, str. 218.

${ }^{105}$ Aurnhammer 1986, str. 246.
} 
kralježnicu, analogni su Gotthelffovim sličnim zločinima (trovanje psa Finazzerovih), pa, sukladno tome, lik Gotthelffa personificira Andreasovu drugu, mračnu, muški konotiranu, u podsvijest potisnutu stranu, on je, prema tumačenjima Achima Aurnhammera, njegov alter ego, odnosno Doppelgänger u Freudijanskom smislu. Lik Gotthelffa simbolički predstavlja das Unheimliche: nešto što je naoko strano i zazorno Andreasovoj psihi, a što je zapravo sastavni, iako skriveni dio njegove psihe. Važno je istaknuti i vremenski paralelizam između Gotthelffovoa trovanja psa Finazzerovih i Andreasova sna o mački kojoj je kao dječak slomio kralježnicu: „uz vremensku koincidenciju sna i događaja, Andreasovo sjećanje na ubojstvo mačke i Gotthelffovo ubojstvo psa Finazzerovih sada toliko sliče jedno drugome da je u Andreasovoj viziji iz sna glava mačke istovremeno i mačja i pseća““106. „Pridjev 'pseći' otkriva ubojstvo mačke kao Andreasovu reminiscenciju u tome istome snu na događaj kada je

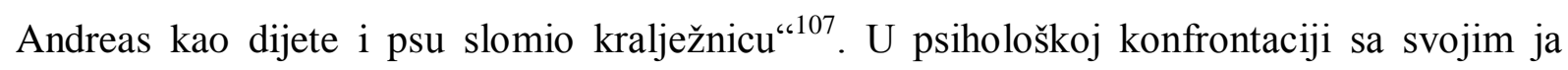
otprije 10 godina, u tome psihološki regresivnom vraćanju unatrag, upravo se manifestira Andreasov rascijep ličnosti, njegova nemogućnost razlikovanja prošlosti od sadašnjosti, tuđega i svoga jastva: „Andreas izražava nesigurnost je li to zlodjelo počinio baš on ili pak njegovo prijašnje 'ja'“‘. ${ }^{108}$ U ključnoj se rečenici, koja prikazuje Andreasovu reminiscenciju na taj događaj iz djetinjstva, vrijeme glagola mijenja iz preterita u prezent, ističući njegovu duboku ambivalentnost $i$ nesigurnost $u$ samoga sebe. „Andreas se, prema tome, ne osjeća krivim samo za smrt svoga psa, koju smatra da je skrivilo „neko njemu nepoznato (iako njegovo vlastito) ja““109, već latentno i za zločin koji je njegov sluga Gotthelff počinio prema Romani: u ovoj se točki pokazuje ambivalencija Andreasova rodnog identiteta, koja je sadržana i u kontrastu između njegovog imena koje dolazi od grčke riječi muškarac i njegove psihičke težnje za ženskošću i usvajanjem empatijskog stava prema ženskosti.

Heterodijegetska, s likom Andreasa konsolidirana instanca pripovjedača povlađuje nesigurnosti samog Andreasa u odlučivanju je li zločin počinio baš on ili neko njegovo prijašnje ,ja“: nepouzdanost heterodijegetske pripovjedne instance ogleda se u nedistanciranom prikazivanju Andreasove emocionalne nesigurnosti, budući da se pripovjedač gotovo u potpunosti konsolidira s likom Andreasa (približavanje personalnoj perspektivi). Hofmannsthal je u svojim djelima često naglašavao pojmove dvojništva (njem. Doppelgängertum) ili sjećanja iz djetinjstva (njem. Kindheitserinnerungen) kao probleme

\footnotetext{
106 Aurnhammer 1986, str. 248-249.

${ }^{107}$ Ibid., str. 249.

108 Ibid.

109 Aurnhammer 1986, str. 249., vidi i esej Sigmunda Freuda o problemu dvojnika (Doppelgängertum) pod naslovom Das Unheimliche, Imago. Zeitschrift für Anwendung der Psychoanalyse auf die Geisteswissenschaften V, 1919, str. 297-324.
} 
rascjepljenja ličnosti: Andreasovo prijašnje ja nastupa prema njegovom sadašnjem ja kao Drugost. ${ }^{110}$ Andreasova nesposobnost pronalaženja (i fiksiranja) vlastitoga jastva, odnosno vlastitog rodnog identiteta, završava $\mathrm{u}$,shizofrenoj disocijaciji ličnosti i projiciranju samoga sebe u svećenika koji prolazi ulicom: nakon projiciranja samoga sebe u svećenika, koje je prikazano u slobodnom neupravnom govoru (njem. Erlebte Rede), Andreas se gubi u cijelom nizu projekcija“111: ,,̌̌as bi pomislio da je on njegov ujak Leopold, koji je poput fauna u šumi skočio za jednom seoskom djevojkom, a čas da je zločinac i ubojica poput Gotthelffa, za kojim je poslana potjera“..112 Motiv mrtvoga psa u romanu kreira vezu između Andreasa i Gotthelffa, potiče Andreasovu identifikaciju sa njim. No tu je i san, u kojem Andreas sanja da i Finazzerova kći Romana ne može razlikovati njega i Gotthelffa. „Na kraju sna Andreas projicira rascijep svoje ličnosti na Romanu: prebacivanje glagolskog vremena iz preterita $\mathrm{u}$ prezent pruža uvid u to da rascijep ličnosti (a time i rasap njegova rodnog identiteta) stoji na putu njegovoj vezi s Romanom““. ${ }^{113}$ Romanino ponašanje u snu prikazano je u svojevrsnoj hibridnosti rodnih karakteristika, koja je analogna Andreasovoj objektifikaciji i dihotomizaciji ženskog bića na femme fragile i femme fatale: ${ }^{114}$ u ovoj je sceni vidljiv paralelizam između Romane i Marie-Mariquite, te je proleptički nagoviješten budući Andreasov susret sa simboličkim likom Marije-Mariquite u Veneciji, koji služi kao personifikacija Andreasove rodne podvojenosti.

U mističnoj, spiritualnoj i ekstatičnoj viziji duhovnog sjedinjenja s Romanom (ili s vlastitim ženskim bitkom) u šumi ${ }^{115}$, Andreas doživljava svojevrsnu anagnorisis (grč.): odjednom shvaća da je „razdvojenost samo iluzija, da jedan pogled odozgo sjedinjuje sve razdvojene i da je samoća samo varka“. ${ }^{116}$ Jedini moment u fragmentu u kojem Andreasov identitet u potpunosti teži svojoj stabilizaciji i normativizaciji identiteta ova je mistična vizija $u$ šumi, $u$

\footnotetext{
${ }^{110}$ To je posebice vidljivo u Hofmannsthalovoj pjesmi pod naslovom Terzinen, I. Über Vergänglichkeit: „Und daß mein eignes Ich, durch nichts gehemmt, /herüberglitt aus einem kleinen Kind/ mir wie ein Hund unheimlich stumm und fremd, 3. strofa, Hugo von Hofmannsthal, Gesammelte Werke in zehn Einzelbänden, (Gedichte, Dramen I, 1891-1898, Fischer Taschenbuch Verlag, str. 21.

111 Vidi Aurnhammer 1986, str. 249-250.

112 „,bald meinte er, er wäre der Onkel Leopold, der wie ein Faun im Wald sprang, einer Bauerndirn nach, bald, er wäre ein Verbrecher und ein Mörder wie der Gotthelff, dem die Häscher nachsetzten“, Andreas, str. 233., cit. u Aurnhammer 1986, str. 250.

${ }_{113}^{113}$ Vidi Aurnhammer 1986, str. 250.

114 „Was bist du denn für eine“, rief er ihr staunend entgegen. -,,So eine halt", sagt sie und hält ihm den Mund hin, ,nein, so eine“, ruft sie, wie er sie umfassen will, und schlägt mit dem Rechen nach ihm.“, Andreas, str. 235. ${ }^{115}$ Treba naglasiti da priroda i šumska osama tradicionalno predstavljaju konsolidaciju sa vlastitom dušom, animom: time se uvodi Jungovska problematika anima/animus kao potisnuti dio vlastite ličnosti, dok sama priroda tradicionalno predstavlja ženski, regenerativni i reproduktivni princip, te je time utopijski naglašeno potencijalno harmoniziranje i feminizacija Andreasova rodnog identiteta.

${ }^{116}$ Cit. u Aurnhammer, str. 251: ,daß ein Blick von hoch genug alle Getrennten vereinigt und daß die Einsamkeit nur eine Täuschung ist.“, vidi također Andreas, str. 238.
} 
kojoj se on u mislima nakratko ponovo spaja s principom ženskosti u sebi, koja tvori „,središte njegove duše“, odnosno fiksnost njegovog rodnog identiteta:

Njegovo je tijelo bilo hram, u kojem je stanovala Romanina bit, a vrijeme koje je iščezavalo okruživalo ga je i igralo na stepenicama hrama. ${ }^{117}$

Andreas se u prirodi osjećao kao nikad prije. Osjećao je kao da je sve ovo jednim naletom iz njega proizašlo: ova moć, ova težnja prema gore, a nadasve ova čistoća. (...) u čije je plavičaste sjene spuštao pogled, tražeći neku mladu srnu (...) Svo zamračenje duha, sva sapetost, uzmicala je pred njim. Slutio je da jedan pogled sa dovoljne visine sjedinjuje sve razdvojene i da je samoća samo varka. U svemu je vidio (imao) Romanu- mogao ju je u sebe upiti gdje god je želio. Onaj brijeg, koji se uzdizao ispred njega i stršao u nebo, bio mu je poput brata i čak i više nego brat. Kao što je u velebnim prostranstvima štitio nježnu srnu, pokrivao ju sjenovitim hladom, plavičastom tamom ju skrivao od progonitelja, tako je u njemu živjela Romana. Ona je bila (...) središte a oko nje raj, koji nije bio ništa manje stvaran no onaj koji se prostirao iza doline. Gledao je duboko u svoju dušu i tamo vidio Romanu kako kleči i moli. (...) Krugovi su se smjenjivali. Molio je zajedno s njom, i kad je pogledao preko puta, primijetio je da brijeg nije ništa drugo nego njegova molitva. Obuzela ga je neizreciva sigurnost: to je bio najsretniji trenutak u njegovom životu. (...). ${ }^{118}$

Andreasov dolazak u Veneciju rezultira novim homoerotičkim impulsima:

Andreasa je toliko zaokupila pojava gospodina koji je pisao za stolom: (...) predugačke ruke, koje nisu nalazile dovoljno mjesta za stolom, jako dugi prsti, (...) ništa nije moglo ljepše otkriti ono bitno na tom muškarcu od te neudobnosti i načina na koji ju je podnosio, prevladavao (...) a ipak je postojao sklad u svim njegovim udovima, jedna- koliko to čudno može zvučati- usrdnost prema mrtvim predmetima, (...) neobaziranje na neudobnost položaja, koje je bilo neusporedivo s bilo čim. Jaki nalet vjetra otpuhnuo je jedan list prema Andreasu. Andreas se požurio da doda neznancu taj list, (...) a neznanac ga je s polovičnim naklonom primio, pri čemu su se njegove tamne oči susrele s Andreasovim, oči koje su se Andreasu učinile lijepima, iako su bile dio lica koje nitko nije mogao smatrati lijepim. (...) Andreas je želio saznati toliko toga o tome čovjeku. ${ }^{119}$

Andreas je impresionistički fasciniran nečim neobjašnjivim u tome muškarcu, što odražava njegove homoerotičke impulse, narcističku povučenost u sebe, preispitivanje vlastitog identiteta i zbunjenost u vezi vlastitog rodnog identiteta:

\footnotetext{
${ }^{117}$ Sein Leib war ein Tempel, in dem Romanas Wesen wohnte, und die verrinnende Zeit umflutete ihn und spielte an den Stufen des Tempels“, Andreas, str. 236.

118 „Andreas war zumut wie noch nie in der Natur. Ihm war, als wäre dies mit einem Schlag aus ihm selber hervorgestiegen: diese Macht, dies Empordrängen, diese Reinheit zuoberst. (...) in deren bläuliche Schatten er hinabäugte, nach einem jungen Reh (...) Jede Verdunklung, jede Stockung wich von ihm. Er ahnte, daß ein Blick von hoch genug alle Getrennten vereinigt und daß die Einsamkeit nur eine Täuschung ist. Er hatte Romana überall- er konnte sie in sich nehmen wo er wollte. Jener Berg, der vor ihm aufstieg und dem Himmel entgegenpfeilerte, war ihm ein Bruder und mehr als ein Bruder. Wie jener in gewaltigen Räumen das zarte Reh hegte, mit Schattenkühle es deckte, mit bläulichem Dunkel es vor dem Verfolger barg, so lebte in ihm Romana. Sie war ein lebendes Wesen, ein Mittelpunkt und um sie ein Paradies, nicht unwirklicher, als dort jenseits des Tales sich entgegentürmte. Er sah in sich hinein und sah Romana niederknien und beten (...) Kreise lösten sich ab. Er betete mit ihr, und wie er hinübersah, war er gewahr, daß der Berg nichts anderes war als sein Gebet. Eine unsagbare Sicherheit fiel ihn an: es war der glücklichste Augenblick seines Lebens.: Andreas, str. 238-239.

${ }_{119}$ „Andreas hörte kaum zu, so sehr beschäftigte ihn die Erscheinung des schreibenden Herrn. Es war ein überlanger, schmaler Körper, (...) unter welchem die langen Beine keinen Platz fanden als durch Bescheidenheit, überlange Arme, die sich notdürftig unterbringen konnten, überlange Finger, (...). ...nichts hätte das Wesentliche des Mannes schöner enthüllen können als diese Unbequemlichkeit und wie er sie ertrug, besiegte (...). ...und doch war eine Beherrschung in allen seinen Gliedern, eine- so seltsam das Wort klingen mag- Verbindlichkeit gegen die toten Gegenstände, (...) ein Hinwegsehen über die Unbequemlichkeit der Lage, das unvergleichlich war. Ein starker Luftzug warf eines der Blätter zu Andreas hinüber. Andreas fuhr auf und beeilte sich, dem Fremden das Blatt zu reichen, (...) mit einer halben Neigung das gereichte in Empfang nahm, wobei Andreas der Blick seiner dunklen Augen traf, die ihm schön schienen, obwohl sie in einem Gesicht saßen, das niemand für schön halten konnte. (...) Er hätte mögen viel von diesem Manne wissen...“, Andreas, str. 246-247.
} 
Bilo je to nešto više od gracilnosti, neka prava neponovljiva otmjenost, s kojom ga je vitez slušao kad je uzimao list papira, i Andreas je bio uvjeren da nikad prije nije percipirao čudesniji sklad između držanja (nastupa) muškarca i zvuka njegova glasa. (...) Činilo se da njegovo toplo i istovremeno spiritualno lice izražava duboko prijateljstvo koje dopire iz dubine njegove duše. (...) Andreas je kao beživotan stajao pred tim strancem, njegovo mu se vlastito tijelo učinilo nezgrapnim (...). Vratio se natrag i već se počeo jako truditi da zadrži u sjećanju izraz tih očiju i zvuk toga glasa, kao nešto u nepovrat izgubljeno- i upitao se: jesam li ga već negdje prije vidio? Kako bi mi se inače ta slika u tom trenutku tako urezala u pamćenje? Preko njega mogu saznati nešto o samome sebi! ${ }^{120}$

Nova narativna epizoda nastupa nakon što Andreasov pratitelj u Veneciji Zorzi odlazi najaviti Andreasa kćeri grofa Gasparo (s obzirom da protječe neko vrijeme od Zorzijeva odlaska i dolaska natrag Andreasu), što metaforički upućuje na Andreasovu vremensku i prostornu dezorijentaciju u Veneciji kao ,gradu labirintu“: događa se Andreasov simbolični susret sa Mariom-Mariquitom koji proleptički anticipira potencijalno utopijsko i androgino harmoniziranje (izmirenje) njegovog rodnog identiteta.

Andreas, dakle, projicira vlastitu psihičku rascjepljenost na lik Marie-Mariquite: njegovo voljno susprezanje sumnje u autentičnost Marie-Mariquite otkriva imaginarnost ovog lika, koji figurira kao produkt Andreasove rodne fragmentiranosti. Naracija otkriva da je MariaMariquita zapravo njegov alter ego, odnosno Doppelgänger: u naoko površnoj sumnji da se radi o transvestitizmu Hofmannsthal je otkrio hermafroditsku prirodu ovoga lika, koji prestavlja utopijsko sjedinjenje dviju otuđenih polovica. Osim toga, lik Marie-Mariquite simbolizira i podvojenost unutar samog ženskog karaktera, te odražava dvije oprečne, stereotipne slike žene u fin-de-siècle-u: „odjednom se dobra dama pretvara u zlu cocotte “. ${ }^{121}$ Dualizam ovog ženskog lika povezuje se s dualizmom prošlosti i sadašnjosti; androgine cjelovitosti i fragmentacije; idealnog i realnog; čistoće i poročnosti: ove dvije oprečne koncepcije lika Marie-Mariquite odražavaju Andreasovu unutarnju borbu između čežnje za idealnom, utopijskom, androginom cjelovitošću i njegovog sadašnjeg stanja fragmentarnosti identiteta, u kojem se ogleda i njegova ambivalencija između dvije potpuno oprečne tipologije ženskosti-femme fragile i femme fatale. Premošćivanje ova dva zrcalno suprotna lika, koje se prvenstveno odnosi na Andreasovo premošćivanje opreka ženskost-muškost, odnosno

\footnotetext{
120 „Es war mehr als Grazie, eine wahre unnachahmliche Vornehmheit, mit der der Ritter ihn anhörte und das Blatt entgegennahm, und Andreas glaubte niemals eine wunderbarere Übereinstimmung zwischen der Haltung eines Menschen und dem Klang seiner Stimme wahrgenommen zu haben. (...) Sein herzenswarmes und zugleich seelenvolles Gesicht schien eine tiefe, aus der Seele dringende Freundlichkeit auszudrücken. (...) Andreas stand vor dem Fremden wie entseelt, sein Körper kam ihm plump (...) Er ging zurück und war schon in sich dumpf bemüht, den Ausdruck dieser Augen, den Klang dieser Stimme festzuhalten, als wäre es für die Ewigkeit ein Verlorenes,- fragte sich: hab ich den schon früher gesehen? Wie könnte mir sonst das Bild im Augenblick so tief eingedrückt sein? Von mir selbst kann ich über ihn erfahren!“", Andreas, str. 248-249.

${ }^{121}$ Vidi Hugo von Hofmannsthal: Andreas oder die Vereinigten: str. 275., cit. u Aurnhammer 1986, str. 257.
} 
njegovo izmirenje sa vlastitom ženskošću, predočeno je simbolom kruga kao vječnog spajanja i povratka.

U susretu s Ninom Gasparo Andreas demonstrira manjak odlučnosti i hrabrosti, odnosno mješavinu straha i žudnje pred potencijalno emancipiranom ženskošću, koju naziva prostitucijskom (njem. dirnenhaft). Slijede daljnji tipološki opisi žene kao stereotipne koncepcije femme fatale: „oči pune drske, hladne vatrenosti“ ${ }^{122}$ Andreasova zebnja odražava onodobni strah da će se njegova muška snaga urušiti, on osjeća svoju vlastitu feminiziranost (njem. Verweiblichung) pred ženskim emancipacijskim impulsima: „Mislite li i vi, da su muškarcima njihova veća snaga, njihov jači razum, i grublji glas dani samo zato da nama jadnim ženama otežavaju život?“"123 Andreasovi strahovi od žena zazivaju utopijsko i idilično sjećanje na Romanu, budući da ona simbolizira utopijsku, idealnu ženstvenost: „Pojavila se djevojka Romana, da bi opet nestala. Osjećao je da se nešto čarobno, ali istovremeno i tjeskobno polako spustilo na njegovo srce, da bi tamo opet nestalo“. ${ }^{124} \mathrm{U}$ želji da prevlada strah od žene, Andreas demonstrira fantazije o svemoći (njem. Allmachtsphantasien) koje služe kako bi učvrstile njegovo muško samopouzdanje: međutim, i ovdje se perpetuiraju rodni stereotipi, kao što je muška nadmoć nad ženom: „Kao u snu osjećao je ono svoje drugo jastvo: ovo nije bio slučajni posjet, (...) on je bio prijatelj koji ima pravo na to, gospodar ovoga čarobnog vrta i gospodar svoje gospodarice. Izgubio se u neodređenom osjećaju sreće...". ${ }^{125}$ Paraliza Andreasove muškosti ogleda se u njegovom manjku inicijative prema ženskoj osobi i njegovoj samozatajnosti, iz čega izvire njegova idealizacija ženskog bića: „Bio bi rado kleknuo pred nju i položio glavu u njeno krilo, ali je sve ovo, a naročito zadnju rečenicu izrekao hladnim i gotovo sumornim tonom, jer je mislio da žena mora pogoditi sve što se u njegovoj nutrini događa. “126 Lik Andreasa demonstrira radikalni oblik feminizacije, budući da mu nedostaju tradicionalne, tipično muški konotirane karakteristike odlučnosti, hrabrosti i postojanosti. „Ništa ga nije moglo dublje i intenzivnije prestrašiti od onih znakova

\footnotetext{
122 „die Augen hafteten mit frechem kaltem Feuer auf dem Beschauer“, Andreas, str. 258.

123 „Meinen Sie denn auch, daß den Männern ihre größere Kraft, ihr schärferer Verstand, ihre stärkere Stimme nur gegeben sind, um uns armen Weibern das Leben schwer zu machen?“, Andreas, str. 258-259.

124 „Das Bauernmädchen Romana tauchte herauf, um sich gleich wieder in Luft aufzulösen. Er fühlte, wie etwas Entzückendes, zugleich Bangmachendes sich sanft auf sein Herz niedersenkte, sich dort zu lösen. „Nun sind wir allein“, sagte er, ,aber wer weiß wie lange.“, Andreas, str. 258-259.

125 „Aber wie anders stand er dort vor ihr- traumartig fühlte er jenes andere Selbst: er war kein zufälliger esuch, (...) er war der berechtigte Freund, der Herr dieses Zaubergartens und der Herr seiner Herrin. Er verlor sich in ein unbestimmtes Gefühl von Beglückung“, Andreas, str. 260.

126 „Er wäre gerne vor ihr niedergekniet und hätte seinen Kopf in ihren Schoß gelegt, aber er sagte alles und insbesondere den letzten Satz in einem kalten und beinahe finsteren Ton, denn er glaubte, daß eine Frau alles erraten müsse, was in ihm vorging“., Andreas, str. 261.
} 
koji bi nekog drugog muškarca možda ohrabrili ili ga čak učinili drskim. Bio je zbunjen preko svake mjere. Kako je mogao shvatiti ono što je bilo tako jednostavno i tako blizu!‘‘. ${ }^{127}$

U fragmentu se također pojavljuju i statični motivi vinove loze i delfina ${ }^{128}$, koji simboliziraju boga Dioniza te služe kao metafora za ženski princip vitalizma i iracionalnosti nasuprot apolonijskom, racionalnom, muškom principu. Hofmannsthal ovdje posebice aludira na rodnu ambivalenciju Dioniza te se implicitno referira na Friedricha Nietzschea. Pojava Dioniza, koji simbolizira opojnost, vitalizam, ali i umjetnost, aluzija je i na simbolontički kurikulum, na Nietzscheov princip vječnog povratka istoga: „budući da svijet, koji se raspada $\mathrm{u}$ individue, teži k jedinstvu, Dionysos Zagreus teži ka ponovnom rođenju“. ${ }^{129}$ Lik rastrganog i ponovno ujedinjenog Dioniza simbolički predstavlja samog Andreasa: ova se simbolika analogno odražava i na fragmentarni karakter samog romana, koji u svojoj biti teži za ponovnim uspostavljanjem cjelovitosti. Fragmentacija rodnog identiteta logička je posljedica oštrog odvajanja muškog i ženskog spola u građanskom društvu, koje muškom i ženskom spolu pripisuje različite, ali također i nehomogene rodne karakteristike (i ženski se spol, npr. tipizira u nekoliko potpuno različitih obrazaca, kao i muški, tako da nema neke unificirane, fiksne karakterizacije niti muškog niti ženskog spola). Tako se ova rodna podjela (rodna bipolarizacija) očituje kao umjetno iskonstruirana ${ }^{130}$, neprirodna.

\subsubsection{Implicitni rod}

Treba naznačiti i to da Andreasov karakter odražava onodobnu koncepciju nestabilnog, promjenjivog jastva (njem. das unrettbare Ich, Wandelbarkeit des Ich), budući da se Andreasove percepcije (trenutačna zapažanja), misli i osjećaji nižu u neprekinutom, ponekad i kontradiktornom slijedu i odražavaju impresionističku letimičnost dojmova.

Aurnhammer navodi činjenicu da je na ovo Hofmannsthalovo djelo utjecala i jedna studija američkog psihijatra Mortona Princea o pojmu depersonalizacije ličnosti. ${ }^{131} \mathrm{~S}$ druge strane, lik Marie-Mariquite predstavlja i hermafroditsko premošćivanje razdvojenosti u Andreasa.

\footnotetext{
127 „Nichts konnte ihn tiefer und jäher erschrecken als diese Zeichen, die einen andern vielleicht kühn, ja frech gemacht hätten. Er war verwirrt über die Maßen. Wie konnte er fassen, was so einfach und so nahe war!“, Andreas, str. 261.

128 „Weinlaub und Rebendach, die schöne Form der Weinblätter, Traubenduft“, str. 254-255.; „Er stand vor der Haustür, es war die mit dem Delphin“, Andreas, str. 255.

${ }^{129}$ Vidi Hugo von Hofmannsthal: Gesammelte Werke, (X), str. 106., cit. u Aurnhammer: str. 257.

${ }^{130}$ Vidi Metzler Lexikon Gender-Studies/Geschlechterforschung. 2002., opreka Essentialismus-onstruktivismus, članak pod naslovom Konstruktivismus, str. 210-212., i članak pod naslovom Essentialismus, str. 87-89.

${ }^{131}$ Aurnhammer 1986, str. 246., Usp. također i Morton Prince: The Dissociation of a Personality. A Biographical Study in Abnormal Psychology, 1906.
} 
Lik Romane predstavlja idealizirani prikaz autentične ženskosti (koncepciju vječne ženskosti), dok pastoralni prostor Koruške (Kärnten) simbolizira čežnju za domovinom (Heimat), budući da se Andreas nalazi na putovanju prema Veneciji, koja predstavlja tuđinu. Dok domovina simbolizira pred-edipalni prostor zaštićenosti i sigurnosti, prostor u kojem je integritet identiteta zajamčen, te predstavlja utjelovljenje majke i žene, tuđina, nasuprot tome, simbolizira ono iracionalno i nepredvidivo, dezorijentaciju, fragmentaciju identiteta, obilje mogućnosti, ali i opasnosti. ${ }^{132} \mathrm{~S}$ druge strane, prostor prirode u kojem Andreas doživljava svoju mističnu viziju duhovnog sjedinjenja s Romanom i konsolidaciju sa ženskošću u sebi također predstavlja pred-edipalno utočište pred prijetnjama moderniteta, te simbolizira harmonizaciju i stabilizaciju Andreasova rodnog identiteta.

Što se tiče vremenskih predodžbi u ovome djelu, one se, shodno obrascima koje predlaže David L. Higdon ${ }^{133}$, mogu polarizirati između procesnog vremena (engl. process time), budući da djelo prikazuje svjesne i podsvjesne procese unutar Andreasove ličnosti, i retrospektivnog vremena (engl. retrospective time), koje je prikazano u Andreasovom nostalgičnom prisjećanju na događaje u Koruškoj. Shodno analizi Martina Middekea, u djelu možemo razlikovati tri dimenzije proživljenog vremena: vremenitost i kontemplativni protok vremena u Andreasovoj viziji u prirodi (njem. Zeitlichkeit der Natur), zatim dimenzija društvenog vremena, u njegovim susretima i interakcijama s različitim likovima $u$ djelu, $u$ kojima se ogleda fragmentacija njegovog identiteta (njem. soziale Zeit), i dimenzija subjektivnog vremena (njem. subjektive Zeit), ${ }^{134}$ koja je prikazana kroz Andreasovu raščlambu vlastite svijesti i podsvijesti.

Roman je strukturiran putem cikličkog i diskontinuiranog pripovijedanja uz analeptičko vraćanje $\mathrm{u}$ prošlost (njem. aufbauende Rückwendung) koje odražava Andreasovu reminiscenciju na njegov boravak u pastoralnoj Koruškoj i susret koji je središnji događaj u djelu. Andreasovo je sjećanje na Korušku koncipirano kao unutarnja pripovijest (njem. Binnenerzählung), dok okvirnu pripovijest (njem. Rahmenerzählung) čini Andreasov dolazak u Veneciju, koja se naspram idilične i pastoralne Koruške ispostavlja kao moralna kaljuža, prostor dekadencije, ali i prostor Andreasove psihološke dezorijentacije.

Struktura romana pokazuje karakteristike razvojnog romana (njem. Entwicklungsroman) budući da prati obuhvatan razvoj ličnosti. Početak naracije opisuje Andreasov dolazak u Veneciju, zatim njegovo nostalgično sjećanje na boravak u Koruškoj, a pri kraju se naracija

\footnotetext{
132 Nünning/Nünning 2004, str. 51.

133 Ibid., str. 74

134 Ibid.
} 
ponovo vraća na Andreasov osjećaj psihološke dezorijentacije u Veneciji, gradu labirintu, koji simbolički predstavlja ono podsvjesno (njem. das Unbewusste) u Andreasu. Andreasovi snovi i snovita stanja duše također ukazuju na njegovu podsvijest i ono što je potisnuto (njem. das Unbewußte, das Verdrängte), posebice oni u kojima se prisjeća anksioznih doživljaja iz vlastitog djetinjstva. Doživljaji u Koruškoj i traumatični događaji iz njegova djetinjstva čine ga hipersenzibilnim, socijalno anksioznim i nesigurnim. Njegova je socijalna anksioznost povezana prvenstveno s njegovom ambivalentnom slikom žene, odnosno s njegovim kontradiktornim poimanjem žene i ženskosti, koje izvire kako iz traumatičnih događaja u djetinjstvu, tako i iz tradicionalne slike žene. Lik Andreasa odražava razdoblje rodnih previranja i ,još neodlučenu novu preraspodjelu muških i ženskih uloga o prijelomu stoljeća“"135: kroz ovaj lik autor izriče svoj stav o problemima muškosti i gubitku sigurnosti muškoga subjekta u vremenu ugroze patrijarhalnog sustava koja je potaknuta ženskim emancipacijskim procesom. Berlinski seksolog Iwan Bloch posvetio je godine 1906. jedno poglavlje svoje knjige pod naslovom Das Sexualleben unserer Zeit (Spolni život našeg vremena) muškom odricanju od žena. ${ }^{136}$ Ovaj se fenomen po njegovu mišljenju radikalno razlikovao od homoseksualnosti, a dobio je svoj poticaj u učenjima Schopenhauera i Weiningera te u Strindbergovim književnim djelima. Neprijateljstvo prema ženama on je nazvao jednom vrstom ,četvrtog spola“ (njem. das vierte Geschlecht). Iwan Bloch je u ovoj formi zazora prema ženama vidio zahtjev za jednom novom „muškom kulturom“ i „emancipacijom muškarca“. ${ }^{137}$ Arthur Schnitzler je u svome dnevniku iz 1892. godine spomenuo jednu izjavu mladog Hofmannsthala, koji je osjećao „strah od žene“ a „ponekad i teoretski strah da se u njemu uopće neće probuditi čežnja za ženom“. „Uostalom“, dodaje Hofmannsthal obraćajući se Schnitzleru, „vaša mi djela ulijevaju strah od žena“. ${ }^{138}$

Introspektivni prikaz oscilacija Andreasove svijesti i podsvijesti formalno je koncipiran djelomice kroz preklapanje ispripovijedanog vremena i vremena pripovijedanja a djelomice $\mathrm{i}$ kroz usporeni tijek pripovijedanja, a na razini modusa pripovijedanja izmjenom slobodnog neupravog govora (Andreasova sjećanja), upravnog govora (u dijalozima), i neupravnog govora u glagolskom načinu konjunktivu. Zamjetljive su također i oscilacije između upravnog i neupravnog govora, posebice u Andreasovim dijalozima s Romanom, što upućuje na, istovremeno, neposrednost- približavanje ženskosti i posrednost-distancu od ženskosti kroz vlastitu svijest i kroz djelomično posredni prikaz Andreasove svijesti putem heterodijegetskog

\footnotetext{
${ }^{135}$ Le Rider 1990, str. 139.

${ }^{136}$ Cit. u Le Rider 1990, str. 135.

${ }^{137}$ Le Rider 1990, str. 135.

138 Ibid.
} 
pripovjedača, čije se pripovijedanje ipak na empatijski način približava personalnoj perspektivi. U naraciji je, dakle, prisutna ambivalencija između tradicionalno muški konotiranog načina racionalnog, kontroliranog „pregleda“ nad događajima korištenjem instance autorskog, heterodijegetskog pripovjedača $s$ jedne strane i, s druge strane, približavanja personalnom načinu pripovijedanja, koji predstavlja tradicionalno ženski konotirano fokusiranje na percepcije, misli i osjećaje glavnog lika. Svojevrsno malo distanciranje heterodijegetske pripovjedne instance od lika Andreasa (odnosno, izbjegavanje pripovijedanja u 1. licu) može se povezati s autorovom implicitnom kritikom onodobnih muško-ženskih uloga i s njegovom kritikom esteticizma, ali i s prikrivanjem autobiografskih elemenata pripovijesti.

Možemo uočiti da Andreas svoje tijelo percipira u vidu internalizacije ,ženskog principa“ unutar svoje psihe: njegovo je tijelo „hram“, dakle, vrsta simboličke maternice, u kojoj boravi „Romanina bit“, dakle, ženska esencija, elementi ženske psihe. Na taj način Andreas barem na psihičkoj razini postaje androgino izmiren sa svojom ranije potisnutom ženskom stranom. Andreas ipak donekle stereotipizira ovaj oblik „vječne ženstvenosti“, izražavajući ga konvencionalnim metaforama bolećive, ranjive i krhke ženskosti (tipološke femme fragile i Kindfrau).

Labirintski odnos ulica (simbolizirajući zrcaljenja identiteta) proizvodi „specifičan način percipiranja: teškoće $u$ orijentiranju i zrcaljenja proizvode u Andreasu fragmentirano percipiranje, kod kojeg se briše granica između sna i jave“. ${ }^{139}$ Tipološki koncipiran lik MarieMariquite, koji je zapravo personifikacija podvojenosti i fragmentiranosti Andreasove psihe, poprima funkciju Andreasove projekcije, budući da je njezino pojavljivanje i zbog „topografskih okolnosti na razini romana neuvjerljivo“. ${ }^{140}$ „Mitskim prostorima susreta, hermetičnim mjestima bez ljudi, kojima je moguć samo jedan jedini pristup, pripisuje se inicijacijska funkcija: Andreas u njima uočava zrcaljenje jedinstva i dvojstva“. ${ }^{141}$ Prostor u koji Andreas ulazi ima oblik jajeta: budući da je ,jaje u kršćanstvu simbol uskrsnuća i spasenja, a ono ima sakralno značenje“, ovo se simboličko značenje može metaforički povezati s mogućom revitalizacijom Andreasova rodnog identiteta. ${ }^{142}$ Maria-Mariquita se pojavljuje netom nakon što je Andreas uočio ,arhitektonsku dvospolnost" prostora:

\footnotetext{
139 vidi Aurnhammer 1986, str. 252.

${ }^{140}$ Ibid., str. 253.

141 Ibid.

142 Ibid.
} 
promatrajući ovaj lik iz vizije, Andreas ,izlazi iz samoga sebe i promatra sebe kao stranog aktera“. ${ }^{143}$

\subsubsection{Zaključak}

Hofmannsthalovo fragmentarno djelo „Andreas oder die Vereinigten“ roman je koji prikazuje razvoj ličnosti mladića Andreasa von Ferschengeldera, potaknut Hofmannsthalovim spoznajama o psihološkoj rascijepljenosti (muških) pojedinaca njegova vremena. Jedna od mogućnosti premošćivanja te rascijepljenosti predstavljena je kroz internalizaciju androgine cjelovitosti (odnosno, osvješćivanje vlastite anime). Stoga androgino savršenstvo kojem teži glavni lik ovog fragmenta romana služi kao korektiv narušenih muško-ženskih odnosa o prijelomu stoljeća, ali i kao osobno Hofmannsthalovo svjedočanstvo želje za premošćivanjem vlastite duhovne paralize, revitalizacijom vlastitog rodnog identiteta i premošćivanjem vlastitog anksioznog i zazornog stava prema ženama i ženskosti.

Andreasovi napadi anksioznosti, zatim zamor od života i utopijski pokušaj regeneracije duha simptomi su sveopće duhovne krize o prijelomu stoljeća: Andreasove se misli, poput misli plemića u Hofmannsthalovom pismu lorda Chandosa ${ }^{144}$, rastvaraju, konvencije se, poput konvencionalnih (rodnih) podjela, kao i fiksnih definicija pojmova, urušavaju, a predodžbe zamućuju i on osjeća svojevrsnu duhovnu paralizu (njem. geistige Starrnis). Ovo stanje duha prouzrokovano je zamorom od života (njem. Lebensüberdruss) koji nastupa u doba sveopće duhovne krize. Cijeli je fragment romana koncipiran kao introspektivna analiza, kao želja da se izađe iz duhovne paralize vlastitog beznadno pluralističkog vremena koje odvaja spolove, i pokušaj da se utopijski konotiranim androginim savršenstvom (njem. androgyne Vollkommenheit) premosti rodna bipolarizacija. Budući da Andreas demonstrira nestabilnost (promjenljivost) vlastitog identiteta (njem. das unrettbare Ich) i impresionističku fluidnost i letimičnost percepcija, pojavljuje se potreba za uspostavom stabilnijeg, fiksnog identiteta kroz prizmu androgine cjelovitosti.

Metafora alle Getrennten und Vereinigten (svi razdvojeni i ponovo sjedinjeni, prev. s njem.) prvenstveno se odnosi na Andreasovo traganje za vlastitim rodnim određenjem, na njegovu želju za re-kreiranjem vlastite ženskosti kako bi se empatijom mogao približiti ženskom biću i regenerirati kao cjelovita ličnost (njem. androgyne Vollkommenheit). Ova se metafora psihološke rascijepljenosti i potom ujedinjenosti može tumačiti kao težnja za stabiliziranjem

\footnotetext{
143 vidi Aurnhammer 1986, str. 253.

${ }^{144}$ Vidi Hugo von Hofmannsthal: Ein Brief. Brief des Lord Chandos an Francis Bacon, u: Wunberg 1981, str. 431-444.
} 
vlastite ličnosti koja je preduvjet za premošćivanje apatičnosti u muško-ženskim odnosima. U fokusu Andreasovih razmišljanja je borba između ideala i stvarnosti, ovaj se lik pozicionira između želje za utopijskim približavanjem ženskom objektu njegove žudnje (Romana), odnosno rekreiranjem vlastite ženskosti s jedne, te stvarne nemogućnosti određivanja vlastite pozicije prema ženskosti (objektifikacija ženskoga, strah od ženskosti, potpuno odbacivanje ženskoga (zazor), žudnja ili pak internalizacija ženskosti). Treba uzeti u obzir važnu činjenicu da je autor djela, Hugo von Hofmannsthal, poput mnogih njegovih suvremenika, i sam često izražavao svoju duboku ambivalenciju prema ženskim subjektima, pa čak gajio i određeni animozitet prema ženskosti. Takav je stav prema ženskosti bio uvjetovan destabilizacijom rodnih odnosa i rodnih identiteta u doba bečke moderne i fin-de-siècle-a općenito te se moglo označiti kao simptom jednog vremena sveopće zaokupljenosti ženom i ,ženskim principom“. Važno je napomenuti da je bečka moderna obilovala mizoginim prikazima žena koji su bili uvjetovani strahom od ženske emancipacije i općenito zazorom od ženskoga, ali i zazorom od „feminizacije kulture“ (njem. Verweiblichung der Kultur). ${ }^{145}$ Empatijski odnos prema ženskosti jedan je od modusa koji bi poslužili kako u učvršćenju normativne, heteroseksualne matrice, tako i u prevladavanju zazora prema Drugosti.

Andreasova čežnja za Romanom kao njegovim idealom ženskosti pretapa se u čežnju za internalizacijom empatije prema ženskosti, i predstavlja simbol Hofmannsthalovog oponiranja (i vlastitom) zazornom stavu prema ženskosti. Ta se čežnja transformira u mitsku čežnju za neoplatonističkim idealom, čija je umjetnička kreacija potaknuta Hofmannsthalovom željom za prevladavanjem «četvrtog spola », odnosno muškog zazora prema ženskosti. Hofmannsthal kreira ovaj pastoralni ideal kao vlastitu psihološku opoziciju razjedinjenom svijetu, „beznadnom pluralizmu modernog doba“, ali i kao želju da se fragmenti njegova vlastitog identiteta ponovo harmoniziraju (njegovo razjedinjeno vlastito jastvo, kao i dihotomiziran stav prema ženskosti, simbolički je prikazan kroz gotovo alegorijski lik MarieMariquite). Moguća stabilizacija vlastitog rodnog identiteta prikazana je, dakle, kroz simboličnu utopijsku čežnju. Ta vrsta čežnje je utopijska čežnja za androginim savršenstvom, čežnja u kojoj se, prema riječima u romanu, „dvije polovice njegova bića, koje su bile razdvojene, otrgnute, ponovo spajaju u jedno."146 Roman Andreas oder die Vereinigten subvertira pojam racionalnog, stabilnog, produktivnog i aktivnog muškog protagonista, te prikazuje habitus senzibilnog, pasivnog i receptivnog esteta (feminizacija muškog jastva).

\footnotetext{
${ }^{145}$ Vidi Le Rider 1990, str. 105-112.

${ }^{146}, \ldots . .$. ist ihm, als ob zwei Hälften seines Wesens, die auseinandergerissen waren, wieder in eins sammengingen“", Hugo von Hofmannsthal: Andreas, str. 286.
} 
Roman prikazuje onodobni, na prijelazu iz 19./20. stoljeće (fin-de-siècle) stav prema ženskosti i krizu muškog subjekta u bečkoj moderni, te na taj način odražava i praksu onodobnog kodiranja kulturalnog sjećanja.

Djelo pokazuje da je za onodobnog muškarca seksualna veza sa ženom postala „kontroverzno i škakljivo pitanje“, ${ }^{147}$ te da je podijeljeni stav prema ženskosti odražavao duboku nesigurnost onodobnog muškog karaktera. Stoga je Hofmannsthalov fragment romana pokušaj redefiniranja vlastitog rodnog identiteta, kao i pokušaj redefiniranja onodobnih muško-ženskih odnosa i normativnih obrazaca, ali i duboka refleksija o naravi moderne. Andreasova detaljna sjećanja i introspektivno poniranje u sebe (koje je tradicionalno ženski konotirano) upisani su u kolektivno sjećanje jednog razdoblja društvenih previranja. Odabir tradicionalnog žanra Entwicklungsromana ovdje je poslužio za prikaz fragmentirane svijesti muškog protagonista i feminizaciju njegovog bitka, perpetuirajući na taj način hegemoniju (kolektivnog) muškog nad (kolektivnim) ženskim sjećanjem (u fokusu je muški lik). Shodno tome, ženski likovi bivaju opredmećeni kroz mušku svijest (male gaze, odnosno, muški pogled na ženu, prev.s engl.): u djelu se tematiziraju problemi muško-ženskih identiteta i odnosa te nastojanje reintegriranja empatije prema ženskosti unutar psihe muškog subjekta.

U Hofmannsthalovom fragmentu ciklički, diskontinuirani i regresivni (retrospektivni) tijek pripovijedanja, odnosno nelinearno strukturirani oblik pripovijedanja, odražava fragmentarno (nedovršeno) definiranje vlastitog rodnog identiteta glavnog muškog lika, nedovršenu utopijski konotiranu harmonizaciju muškosti i ženskosti unutar Andreasove psihe, koja bi prevladala unutarnji konflikt vezano uz rodni identitet protagonista i umanjila njegov zazor od žena. Naravno, treba uzeti u obzir činjenicu da Hofmannsthal nije uspio završiti pisanje romana, te da je u svojim bilješkama (skicama) dao određene natuknice za nastavak djela: iz tih se natuknica može protumačiti mogući utopijski konotiran završetak romana (Andreasova konačna konsolidacija sa svojim idealom ženskosti, odnosno njegov povratak Romani). Međutim, lik Romane ne proizlazi iz Hofmannsthalove biografije: on je prikaz umjetnikove potisnute anime i projekcija njegovog podsvjesnog ideala ženskosti (imago).

Aluzija na samoga sebe kao sina obitelji Finazzer, a kasnije i kao brata Finazzerove kćeri Romane ukazuje na to da lik Romane personificira Andreasovu animu i njegov ideal ženskosti. Međutim, Andreasa pritišće Gotthelffova prisutnost, pojava vulgarnog i brutalnog muškarca koji postaje simbolika Andreasovog alter-ega, druge, mračnije strane njegove ličnosti.

${ }^{147}$ Vidi Le Rider 1990, str. 139. 
Andreasov boravak na imanju Finnazerovih i njegovo isprva idilično poznanstvo $\mathrm{s}$ Romanom, koja tipološki predstavlja utjelovljenje vječne ženstvenosti, početak je njegove utopijske čežnje za usvajanjem ženskih karakteristika u vlastitoj psihi, kako bi se približio svom idealu žene: „Andreasu je bilo kao da gleda u neki kristal, u kojem je ležao cijeli svijet, ali u nevinosti i čistoći.“148 $\mathrm{Na}$ taj način Romana zapravo predstavlja i personifikaciju Andreasove potisnute ženskosti (njem. das Verdrängte). Kao simbol vječne ženskosti, ona je isto tako i simbol prirode (koja je tradicionalno kodirana kao ženski princip) i pastoralne Austrije, budući da živi izvan licemjerne, otuđene i korumpirane gradske sredine: lik Romane predstavlja utopijski i otkupljujući potencijal ženskosti koja je za Andreasa kao muškarca smanjene sigurnosti u svom tradicionalnom muškom identitetu potencijalno utočište pred prijetnjama pragmatičnog i materijalističnog doba $^{149}$ povezanog $\mathrm{s}$ rastrojenošću psihe, gubitkom (rodnog) identiteta i zazorom od ,prijeteće“ ženskosti.

Unutarnji konflikt između ideala (standardna, heteroseksualna orijentacija, normativni rodni identitet, ukotvljenost Andreasa u svome vlastitome, fiksnome jastvu i prevladavanje brutalnog oblika muškosti) i stvarnosti (njegova podložnost neprestanom kreiranju i rekreiranju vlastitog rodnog identiteta, nesigurnost i oprobavanje različitih rodnih identiteta, pa čak i latentni homoeroticizam) na kraju fragmenta romana ostaje neriješen: fragmentarna pripovjedna struktura odgovara paradigmi onodobne krize muškog identiteta, unutarnjoj rascijepljenosti i neizvjesnosti pronalaženja fiksnog, ontološki utemeljenog jastva. Ova je kriza identiteta odraz Andreasove rodne hibridnosti, njegove pat-pozicije u određivanju vlastitog rodnog identiteta. Hofmannsthal je, doduše, želio završiti svoj roman idiličnim povratkom Andreasa svojem prvobitnom idealu ženskosti, kako bi lik Andreasa, iz nesigurnosti i osciliranja u određenju vlastitog rodnog identiteta, u smislu fiksnosti žudnje pronašao put prema tradicionalnom i normativno percipiranom stabilnom, heteroseksualnom, monogamnom rodnom identitetu, dok bi u rodnom smislu (engl. gender) postao empatijski priklonjeniji ženskom ,principu“ unutar vlastite psihe. Andreasova ambivalencija prema Romani treba biti prevladana kako bi se kroz internaliziranje ženskosti približio ženskom subjektu i prevladao onodobnu poziciju ,četvrtog spola“, koja je predstavljala zazor prema ženama i ženskosti. ${ }^{150}$

\footnotetext{
148 „es war Andreas, als schaue er in einen Kristall, in dem lag die ganze Welt, aber in Unschuld und Reinheit“., Andreas, str. 216.

${ }^{149}$ Usp. Felski: Gender of Modernity, 1995, str. 35-60.

${ }^{150}$ Vidi Le Rider 1990, str. 135.
} 


\subsection{Hugo von Hofmannsthal: Das Märchen der 672. Nacht (Bajka 672. noći)}

\subsubsection{Uvod}

Hofmannsthalovo djelo Das Märchen der 672. Nacht (Bajka 672. Noći), kraća je pripovijetka objavljena u studenome 1895. godine u bečkom tjednom časopisu Die Zeit. Iako napisana u ranijoj fazi autorova stvaralaštva, ova pripovijetka sadrži zrela promišljanja esteticističke egzistencije, pružajući uvid u autorovu kritiku pasivnog, esteticističkog nazora na svijet: ona prikazuje put esteta od egzistencije u „bjelokosnoj kuli“, njegovih pokušaja re-definiranja vlastitih predodžbi o ženskosti, zatim identificiranja s različitim rodnim identitetima (od heteroseksualne, ali gotovo neoplatonistički orijentirane žudnje prema ženi, preko zazora prema ženskosti, zatim homoeroticizma) te na kraju njegove ,jezive smrti“, koja pronosi svojevrsnu spoznaju o prednosti aktivnog života nad umjetničkom, bezinteresnom kontemplacijom ljepote. Hofmannsthal odabire žanr kraće pripovijetke, koncipirajući djelo kao modernistički novum kroz koji se prikazuje, u formi didaktički konotirane parabole, neuspjelo obraćenje esteta na aktivni život (vita activa naspram vita contemplativa). Lik trgovčevog sina dijelom je autobiografski koncipiran, a primarni recipijenti teksta mahom su Hofmannsthalovi (muški) suvremenici, koji se donekle mogu poistovjetiti s likom senzibilnog umjetnika. Sam Hofmannsthal izrekao je svoj stav o ,paralizirajućoj ne-djelotvornosti“ esteticističke egzistencije, te je označio svoju pripovijetku kao osudu esteticizma, koju je prikazao kroz modus orijentalnog oblika bajkovite naracije. S obzirom na vremenski kontekst u kojem se odvija pripovijetka, njezina je aktualnost (razdoblje moderne) vrlo izvjesna, iako je ta aktualnost zaodjenuta $\mathrm{u}$ historicističko ruho, s obiljem orijentalnih aluzija na Priče iz 1001. noći. Posebice prikaz alijenacije esteta u doba psihološkog vakuuma svjedoči o izrazitoj aktualnosti pripovijetke.

U sveopćoj alijenaciji modernog doba i grada, u otuđenju moderne egzistencije za koju je Hofmannsthal jednom rekao da je potaknuta činjenicom da je moderni svijet postao beznadno pluralističan, stvarnost i psiha pojedinca, pa tako i sam rodni identitet prikazuje se kao fluidan: „Izazovi (privlačnosti) i prijetnje čudnovato su pomiješani; postalo nam je sablasno (njem. unheimlich) pri srcu; plašila nas je unutarnja samoća, izgubljenost, a ipak nas je hrabrost i čežnja tjerala naprijed, u labirintski put.“151

\footnotetext{
${ }^{151}$ Hofmannsthal, Reden und Aufsätze I, str. 362., cit. u: Le Rider 1990, str. 118-119., usp. Wolfgang Köhler, Hugo von Hofmannsthal und Tausendundeine Nacht, Bern-Frankfurt/Main 1972.
} 


\subsubsection{Eksplicitni rod}

U fokusu pripovijetke je muški lik i muška intimna pripovijest koncipirana u trećem licu jednine (heterodijegetski pripovjedač). Nakon prvog dijela pripovijetke, koji završava kontemplativnim unutarnjim monologom trgovčevog sina o redefiniranju stava prema vlastitom podsvjesnom ženskom dijelu psihe, a koji je prikazan u direktnom (upravnom) govoru u 1. licu jednine (dokidanje distance pripovjedača i lika), nastupa kratka, implicitno izražena narativna elipsa, nakon čega se nastavlja 2. dio pripovijetke koji in medias res uvodi problematiku homoeroticizma kroz prikaz pisma upućenog trgovčevom sinu od strane nepoznatog pošiljatelja. Ovaj nagli prijelaz od direktnog suočavanja trgovčevog sina s vlastitom (potisnutom) ženskošću u 1. dijelu pripovijetke na problematiziranje homoerotičnih impulsa u 2. dijelu svjedočanstvo je nestabilne psihe trgovčevog sina, odnosno krize njegova (rodnog) identiteta. Impresionistički nijansirana naracija dosljedno prati krizu rodnog identiteta trgovčevog sina.

Povezivanje motiva slijedi u okvirima simbolističke (pa i neoromantičke) umjetničke koncepcije, budući da se djelo rukovodi estetskom motivacijom: esteticistička pozadina djela ogleda se u liku trgovčevog sina kao pasivnog i receptivnog.

Trgovčev sin s jedne strane predstavlja psihološki koncipiran, kompleksan (otvoren i višedimenzionalan) lik auto-refleksivnog individualista koji se nalazi u konfliktnom (ambivalentnom) odnosu prema svojoj potisnutoj ženskosti: mori ga anksioznost prema ženskim subjektima, mješavina žudnje i zazora prema (vlastitoj) ženskosti, dok s druge strane predstavlja tipološki koncipiran lik senzibilnog, pasivnog i receptivnog esteta.

U pripovijetci se na simbolistički način razrađuje više provodnih motiva: 1. motiv smrti (koji služi kao kritika neproživljenog života trgovčevog sina i ujedno kao kritika esteticističkog, „sterilnog“, pa i asketskog svjetonazora), zatim 2. motiv staklenika (koji predstavlja izolaciju esteta i njegovu egzistenciju u bjelokosnoj kuli umjetnosti kao svojevrsnu reakciju na otuđenost modernog vremena), 3. motiv ornamenta (čija dekorativnost također predstavlja jedinstvo suprotnosti mističnog doživljaja svijeta od strane esteta (lat. coincidentia oppositorum), odnosno kompleksnost svijeta, ali služi ujedno i kao supstitut za život), 4. motiv konja (implicirajući Freudovu anamnezu o dječaku Hansu koji se boji konja, konj metaforički predstavlja strah od kastracije (gubitka muškosti) i strah od već prisutne ženske „kastriranosti“ koji uvjetuje anksiozan stav prema ženskosti), 5. motiv ogledala (predstavlja primarni narcizam osamljenog esteta, koji je solipsistički usmjeren sam na sebe): tako se čežnja trgovčevog sina za promatranjem samoga sebe u ogledalu ispostavlja kao 
čežnja za vlastitom animom, potraga za ženskim pandanom vlastite psihe, 6. motiv vojnika (koji predstavljaju grubu, virilnu muškost i seksualnost, koja se protivi koncepciji lika trgovčevog sina kao senzibilnog esteta i njegovoj asketskoj egzistenciji), 7. floralni motivi, koji predstavljaju simbole ženskosti, a posebice karanfil, koji simbolizira orijentalnu koncepciju pojma duše i predstavlja čežnju za smrću, 8. motiv prijetećeg pisma, koji implicitno simbolizira optužbe zbog homoerotičkih impulsa, 9. motiv artefakata u trgovini oca glavnog protagonista, koji su opisani kao „bezdušna, lijepa djeca“ i simboliziraju estetsku distancu od života i ljudi kroz isključivo priklanjanje umjetničkim objektima.

Prikaz emocionalnog habitusa esteta i njegovog pokušaja revitalizacije odnosa prema vlastitoj animi (podsvjesnom ženskom dijelu psihe) čini naraciju bliskoj tradicionalnom obrascu romance, dok s druge strane težnja esteta za samospoznajom i pronicanjem u bit života te njegovo traženje smisla u besmislu moderne egzistencije čini djelo bliskom tradicionalnom obrascu quest.

Ostali likovi koji se pojavljuju u djelu potvrđuju fragmentarnost psihe esteta i fluidne prijelaze u njegovu rodnom identitetu. Ženski likovi (starija služavka, mlada služavka- 15godišnja djevojka, zatim djevojčica koju trgovčev sin susreće ispred staklenika) metaforički predstavljaju problematičan odnos trgovčevog sina prema ženskosti. Ovi su likovi prikazani ornamentalno i dekorativno, s vidljivom dozom objektifikacije ženskosti, na donekle rodnostereotipan i tipološki način. Oni su odraz esteticizma, hermetizma i orijentalne ezoteričnosti modernističkih književnih, stiliziranih prikaza ženskosti, uvjetovanih duhom epohe o prijelomu stoljeća (esteticizam i dekadencija fin-de-siècle-a).

Poseban provodni motiv u djelu čine elementi prirode (biljke, npr. karanfili, narcise, anemone), koji simbolički predstavljaju fetiše ženskog tijela, ${ }^{152}$ što upućuje na pojam fetišizma $^{153}$ koji se povezivao s efeminacijom muškarca (esteta) i čisto neoplatonskom (idealnom, nespolnom) žudnjom prema ženi. Biljke predstavljaju metaforu majčinskog tijela i uranjanje trgovčevog sina u kontemplaciju ženskosti (esencijaliziranje ženskoga). Cvijeće simbolički predstavlja pred-edipalne želje zaštićenosti i izvornosti, koje su povezane sa stanjem primarnog narcizma mističnog esteta.

Grad u koji trgovčev sin odlazi kako bi razjasnio prijeteće pismo nepoznatog pošiljatelja predstavlja izazove spolnosti (trgovčev sin u bijednim četvrtima nailazi na beskućnike i prostitutke) i leglo poroka, ali s druge strane i otvorenost mogućnosti. Unutarnji nemir koji

\footnotetext{
152 Pri čemu karanfili simboliziraju kako ženskost, tako i smrt, dok narcise simboliziraju samospoznaju i poniranje u vlastiti unutarnji svijet.

${ }^{153}$ Vidi i Krafft-Ebing: Psychopathia Sexualis (1898), 1993.
} 
inače statičnog trgovčevog sina tjera na odlazak $u$ grad odraz je njegove unutarnje ambivalencije između paralize voljnih mehanizama (unutarnje zapretanosti) i želje da promijeni svoj statični način života.

Trgovčev sin većinu vremena provodi u kući sa svojom poslugom, pa se njegova egzistencija veže prvenstveno za privatnu sferu (tradicionalno ženski konotirani prostor), budući da on radikalno odstupa od stereotipa građanskog muškarca u javnoj sferi sveprisutnog, produktivnog, racionalnog i aktivnog. Njegova je statičnost, emocionalnost, pasivnost i receptivnost koja vodi u kontemplaciju i izolaciju od društva simptom „feminizacije“, koja je, prema mojem mišljenju, ipak izvor njegovog udivljenja i sućuti (mudre smirenosti) prema bićima i stvarima koja ga okružuju, pa na taj način trgovčev sin predstavlja prototip mističnog esteta.

Trgovčev sin ženskost doživljava kao vrstu neoplatonske esencije, što svjedoči o feminizaciji njegove psihe. Njegovo povlačenje u svijet kontemplacije i u stanja mističkog jedinstva sa svijetom, koji odražavaju poniranje u podsvjesne prostore, odvojivi su od normativnog stereotipa onodobnog muškog karaktera. Trgovčev se sin još nalazi u prededipalnoj fazi, u kojoj vlada spolna neodređenost (biseksualnost), a koja odražava stanje primarnog narcizma esteta. On još nije ušao u simbolički poredak, odnosno u edipalnu fazu, u kojoj se spolnost oštro diferencira. Ženski simboli (cvijeće, staklenik) funkcioniraju stoga u djelu kao utopijski, otkupljujući, majčinski (zaštitnički) prostor.

Impresionistički koncipirana fluidnost dojmova sveprisutna je u naraciji, a vidljiva je posebice u načinu subjektivne semantizacije prostora i minucioznim opisima osobnih doživljaja, percepcija, dojmova, emocija i raspoloženja esteta, koji su ženski konotirani. ${ }^{154}$

Koristeći šablonski početak pripovijetke, Hofmannshal proizvodi bajkoviti učinak na čitatelja, mistificirajući „sjenovitu“, otuđenu egzistenciju hipersenzibilnog esteta, koju možemo usporediti s traganjem za spoznajom smisla života i smisla umjetničke egzistencije u djelu Leopolda von Andriana Der Garten der Erkenntnis. Sam naslov pripovijetke simbolički aludira na Bajku iz 1001. noći, dakle, uzima za predložak orijentalnu bajku kako bi 1. označio sklonost bečke kulture i fin-de-siècle-a egzotičnim, pa i ezoteričnim, ,alternativnim“ sadržajima, i 2. metaforički portretirao Beč kao porta orientis (istočna vrata, vidi Le Rider), odnosno: prema Hofmannsthalovim riječima, Beč je postao ,istočna vrata za onaj tajanstveni

\footnotetext{
$\overline{{ }^{154} \text { Vidi Nünning/Nünning 2004, str. } 62 .}$
} 
istok“, koji, shodno Freudovoj koncepciji pojma das Unbewusste (nesvjesno), predstavlja „carstvo nesvjesnog“. 155

Hofmannsthalova pripovijetka započinje opisom fizičkog izgleda glavnog lika, trgovčevog sina koji se ističe androginom ljepotom i koji je odrastao bez majke i oca (već se u ovome segmentu pripovijetke može uočiti duboka kriza (rodnog) identiteta trgovčevog sina). Umjesto bliskosti s ljudima, on je okružen dekorativnim predmetima, čija mu ornamentalnost evocira oblike vanjskog svijeta: „U ornamentima je prepoznavao začaranu sliku svjetskih čuda“. ${ }^{156}$ Naracija prati osamljenost (otuđenost od svijeta) trgovčevog sina i njegovu aristokratsku, esteticističku egzistenciju koja se može označiti metaforom „bjelokosna kula“ (njem. Elfenbeinturm), često korištenom metaforom o prijelomu stoljeća koja označava autorefleksivno obilježenu alijenaciju iznimnog pojedinca (nerijetko umjetnika) od građanskog društva. Potraga za smislom ljudske egzistencije koja karakterizira osamljene i samodostatne estete (androgina samodostatnost) ispostavlja se kao nemoguća zbog toga što je pojam života odveć kompleksan (višeznačan). Udivljenje trgovčevog sina prema umjetničkim predmetima i njegova potraga za ,čudima svijeta“ koja mu sugeriraju različiti ornamenti predstavlja otuđenost pasivne, esteticističke egzistencije kojoj je nemoguće „dohvatiti“ aktivni, stvarni život (lat. vita contemplativa nasuprot vita activa).

Pripovijetka obiluje larpurlartističkim elementima i životnim stavom koji je blizak Kantovoj estetici „,bezinteresnog“ promatranja vanjskog svijeta: trgovčev sin ne želi posjedovati, on je samo „pasivni“ i receptivni promatrač vanjskog svijeta, koji uranja u vlastiti svijet misli iz kojega pokušava projicirati vanjski svijet. Trgovčev sin se, poput Erwina u djelu Der Garten der Erkenntnis, ne približava stvarima i bićima oko sebe: one, inače neprijateljske i str 43 trgovčevom sinu nude samo izvanjski poticaj, impuls, koji kasnije biva preoblikovan njegovim percepcijama, njegovom ,snagom volje“. ${ }^{157}$ Dekadentna ljubav prema umjetničkim predmetima koji su često povezani s ženskim likovima u djelu, npr. ornamentalni nakit, statue indijskih božica, itd., simptom je otuđenja od „beznadnog pluralizma“ svijeta i autorefleksivnog poniranja u vlastiti unutarnji svijet.

Činjenica da trgovčevog sina ne zaokuplja ljepota niti jedne žene, barem ne u tolikoj mjeri da bi ju želio ,posjedovati“, a nekad mu ona čak postaje i nepodnošljivom, ukazuje i na

\footnotetext{
155 „porta orientis für jenen geheimnisvollen Osten“, Hugo von Hofmannsthal: Wiener Briefe, in: ders., Gesammelte Werke. Reden und Aufsätze II: 1914-1924, str. 185-196., cit. u: Csáky, Böhlau Verlag, Wien, Köln, Weimar, 2010., Das Gedächtnis der Städte: Kulturelle Verflechtungen- Wien und die urbanen Milieus in Zentraleuropa, str. 130-132.

${ }^{156}$ „Er erkannte in den Ornamenten, die sich verschlingen, ein verzaubertes Bild der verschlungenen Wunder der Welt“, Das Märchen der 672. Nacht, str. 9., cit. također u Le Rider 1990, str. 113.

${ }^{157}$ I ovdje treba povući paralelu s likom Erwina u pripovijetci Leopolda Andriana Der Garten der Erkenntnis.
} 
njegov ambivalentan (a nerijetko i zazoran) stav prema ženskosti. Vidljivo je to posebice u njegovom distanciranom udivljenju prema služavkama.

Lik trgovčevog sina, poput lika Erwina u djelu Der Garten der Erkenntnis Leopolda Andriana, predstavlja hipersenzibilnog, pasivnog i receptivnog esteta koji se udaljava od racionalne, produktivne i aktivne muškosti svoga vremena, pa je stoga njegova atipična muškost, otuđenost od svijeta i predanost idealu vlastitog imaga i anime odraz androgine samodostatnosti (cjelovitosti) umjetnika (njem. androgyne Vollkommenheit). Lik trgovčevog sina stoga je pravi primjer narcističke ličnosti: „mladi sin trgovca, koji je bio jako lijep i nije imao ni oca ni majku, ubrzo se nakon svoje 25 . godine zasitio društva“. ${ }^{158}$ Već sama formulaičnost pripovjedačeve uvodne rečenice (tzv. pripovjedna šablona) implicira bajkovitu, ezoteričnu, otuđenu egzistenciju esteta. Osobenjačka egzistencija mladog esteta slična je esteticističkoj i dekadentnoj egzistenciji koja je opisana u romanu Oscara Wildea The Picture of Dorian Gray, u kojoj se također pojavljuje književni motiv zaljubljenosti u vlastiti odraz u ogledalu, međutim s jednom razlikom: trgovčev se sin u Hofmannsthalovu djelu distancira od dekadentne, pa i agresivne senzualnosti koja je svojstvena Dorianu Grayu, budući da više naginje tipu nježnog sanjara, odnosno svojevrsnog idealista. On nalikuje i književnom tipu dendija, budući da pomno pazi na svoju vanjštinu: „Također nije zanemarivao niti njegu vlastitog tijela ni svojih lijepih ruku, a niti ornamente u svome stanu“. ${ }^{159}$ Raznorodnost ornamenata ukazuje na mističnu povezanost esteta sa svijetom, na svojevrsno „renesansno“ jedinstvo suprotnosti (lat. coincidentia oppositorum), tako da su za trgovčevog sina ornamenti predstavljali „božansku kreaciju svih rodova“"160, što ukazuje na androgino savršens 44 odnosno potpunu ravnotežu muškog i ženskog principa koju on traži u ornamentima i dekorativnim predmetima. Pa ipak, „osjećao je isto tako i ništavnost svih tih stvari, kao i njihovu ljepotu; nikada ga zadugo nije napuštala misao o smrti“. ${ }^{161}$ Estetizacija života i estetizacija smrti ovdje su nerazdruživo povezani, posebice kroz metafore „lijepih misli“, „ljepote njegove mladosti“ i ,ljepote samoće“162, zatim ljepote njegovog samotnog djetinjstva, koje je ,čeznutljivo volio“. ${ }^{163}$

\footnotetext{
158 „Ein junger Kaufmannssohn, der sehr schön war und weder Vater noch Mutter hatte, wurde bald nach seinem fünfundzwanzigsten Jahre der Geselligkeit und des gastlichen Lebens überdrüssig.“, Das Märchen, str. 9.; cit. također u Le Rider 1990, str. 113.

159 „Auch vernachlässigte er weder die Pflege seines Körpers und seiner schönen Hände noch den Schmuck seiner Wohnung“, Das Märchen, str. 9.

160 „das göttliche Werk aller Geschlechter“, Das Märchen, str. 10.

161 „Doch er fühlte ebenso die Nichtigkeit aller dieser Dinge wie ihre Schönheit; nie verließ ihn auf lange der Gedanke an den Tod", Das Märchen, str. 10.

162 „Denken schöner Gedanken“, ,,an der Schönheit seiner Jugend und Einsamkeit“, Märchen: str. 10.

163 „Erinnerung an seine Kindheit, die er sehnsüchtig liebte“, Das Märchen, str. 11.
} 
U svojoj je osamljenosti tražio u knjigama i stihovima supstitut za stvarni život ${ }^{164}$, a njegov se esteticizam ogledao čak i u predodžbi vlastite „lijepe smrti“: „"Tamo gdje trebaš umrijeti, tamo te nose tvoje noge“, i smatrao je sam sebe lijepim, poput jednog kralja zalutalog u lovu, u nekoj nepoznatoj šumi pod čudnovatim drvećem, koji ide ususret nekoj čudnoj i divnoj sudbini“. ${ }^{165}$ Motiv kralja ovdje predstavlja nerazriješeni sukob sa vlastitim muškim identitetom i problematiku krize patrijarhata u modernom, pluralističkom društvu fin-desiècle-a.

Trgovčev sin ima četvero slugu, koji ga u njegovoj otuđenosti i anksioznosti „okružuju kao psi“6166: jednu stariju ženu, gazdaricu, čija je pokojna kćer bila njegova dadilja i koja mu je zamijenila njegovu preminulu majku; jednu otprilike osamnaestogodišnju djevojku, koja ga poslužuje svaki dan i koja predstavlja zavodljivost ženstvenosti, od čije se 'konzumacije' asketski i esteticistički nastrojeni trgovčev sin suzdržava, budući mu se žensko tijelo čini „kao zagonetni jezik zatvorenog (hermetičnog) i čudesnog svijeta“. ${ }^{167}$ Opis mlade djevojke izrazito je ornamentalan, prožet svojevrsnom orijentalnom stiliziranošću: misli trgovčevog sina nisu usmjerene na pragmatičnu konzumaciju ljubavi sa služavkom, već se njegova naklonost, odnosno, „čežnja“ (njem. Sehnsucht), a ne spolno obilježena „požuda“ (njem. Begierde) prema njoj odražava u kantovskom „bezinteresnom promatranju“ bez želje za posjedovanjem; zatim jednu petnaestogodišnju, povučenu djevojku; i jednoga slugu, koji predstavlja homoerotičke sklonosti trgovčevog sina.

U drugom dijelu pripovijetke, trgovčev sin dobiva zagonetno pismo nepoznatog pošiljatelja. Ovaj događaj u djelu predstavlja zaokret: pošiljatelj optužuje slugu trgovčevog sina, a implicitno i samog trgovčevog sina, za nekakav strašan zločin, ali sama priroda zločina i autor pisma ostaju nepoznati. Ostaje neriješenim radi li se o poruci upućenoj trgovčevom sinu od strane njegove vlastite podsvijesti (grižnja savjesti zbog homoseksualne žudnje), je li zapravo odnos između sluge i trgovčevog sina prožet homoeroticizmom. „Neodređenost““ pisma na metaforičkoj razini može funkcionirati kao prijetnja feminizacijom (Verweiblichungsdrohung), budući da se u trgovčevom sinu javlja grižnja savjesti zbog homoseksualnih poriva. Najznačajnije objašnjenje prijetećeg pisma dao je Eugene Weber ${ }^{168}$, koji je ukazao na to da se iste godine kad je Hofmannsthal napisao Märchen održao sudski

\footnotetext{
164 „Denn oft schöpfte der Kaufmannssohn einen großen Stolz aus dem Spiegel, aus den Versen der Dichter, aus seinem Reichtum und seiner Klugheit", Das Märchen, str. 10.

165 „Wo du sterben sollst, dahin tragen dich deine Füße“, und sah sich schön, wie ein auf der Jagd verirrter König, in einem unbekannten Wald unter seltsamen Bäumen einem fremden wunderbaren Geschick entgegengehen“, Das Märchen, str. 10.

166 „,aber seine vier Diener umkreisten ihn wie Hunde“, Das Märchen, str. 11.

167 „die rätselhafte Sprache einer verschlossenen und wundervollen Welt"“, Das Märchen, str. 13.

${ }^{168}$ Cit. u: Le Rider 1990, str. 117.
} 
proces protiv Oscara Wildea: prvi redci pripovijetke Das Märchen der 672. Nacht potječu iz travnja iste godine, a Hofmannsthal o tome govori i u pismu svome ocu od 9. kolovoza 1895. godine. Tempo pripovijetke se mijenja u trenutku kad trgovčev sin napušta kuću da bi razjasnio ovaj događaj. Prvi dio Hofmannsthalove pripovijetke prikazivao je njegov povučeni život i kontemplativna duševna stanja. No u drugome dijelu Hofmannsthalove pripovijetke počinje nagli i dinamičniji slijed događaja koji vode do psihičkog sloma i smrti trgovčevog sina: ovakav slijed događaja udovoljava „neumoljivoj i zagonetnoj kauzalnosti“. ${ }^{69}$ Fragmentiranost psihe trgovčevog sina i njegova duboka rodna ambivalencija tjeraju ga na lutanje, na tumaranje najbjednijim gradskim četvrtima, ulicama u kojima se nalaze prostitutke i beskućnici. U svome besciljnom lutanju trgovčev sin prolazi gotovo zamrlim ulicama, poput Gustava von Aschenbacha, lika iz Mannove novele Der Tod in Venedig. Doživljaji trgovčevog sina prelaze iz esteticizma u snovito, podsvjesno tkanje, oni poprimaju nejasne obrise potisnutih psihičkih sadržaja. Pripovijetka u ovome drugom dijelu prelazi u svojevrsnu fantastiku. ${ }^{170}$ Slučaj lutajućeg i rodno ambivalentnog trgovčevog sina može se lako povezati i s Freudovim esejem pod naslovom Das Unheimliche, u kojem Freud govori, između ostalog, i o rascjepu ličnosti i efektu dvojnika (njem. Doppelgängertum) te povezuje ova dva fenomena s događajima (ili traumama) iz ranog djetinjstva. Narativno oblikovana potraga trgovčevog sina zapravo metaforički predstavlja njegovu potragu za vlastitim rodnim identitetom, a ona je određena zakonima nesvjesnoga. „U ovome drugome dijelu pripovijetke, trgovčev je sin u potrazi za baš onim ženskim elementom koji ga je u prvom dijelu pripovijetke ispunjavao osjećajem straha (anksioznosti)“. ${ }^{171}$

Jedini muškarac unutar posluge trgovčevog sina njegov je povučeni i susretljivi sluga, kojeg je upoznao pri jednom prijemu kod perzijskog poslanika i koji je očigledno na njega izvršio jaku homoerotičku privlačnost:

iskazivao je neobičnu privrženost svome gospodaru, čiju je naklonost i odbojnost šutke odgonetavao, tako da je i ovaj osjećao sve veću naklonost prema njemu. “172 Sluga je obziran i uslužan prema trgovčevom sinu, a po karakteru je povučen i skroman. ${ }^{173}$ Trgovčev sin i prema njemu osjeća ne toliko homoseksualnu koliko isključivo neoplatonsku naklonost, koja korespondira $\mathrm{s}$ homoerotičkim impulsima: „,...tako da je trgovčevom sinu bilo draže promatrati ga (...). ${ }^{174}$

\footnotetext{
${ }^{169}$ Cit. u: Le Rider 1990, str. 117.

${ }^{170}$ Ibid, str. 118.

${ }^{171}$ Ibid.

172 „Er zeigte eine seltene Anhänglichkeit an seinen Herrn, dessen Wünschen er zuvorkam und dessen Neigungen und Abneigungen er schweigend erriet, so daß auch dieser eine immer großere Zuneigung für ihn faßte“", Das Märchen, str.12., također Le Rider 1990, str. 114.

173 ,und war von einer solchen Zuvorkommenheit und Umsicht und schien gleichzeitig von so großer Eingezogenheit und Bescheidenheit...", Das Märchen, str. 12.

174 „daß der Kaufmannssohn mehr Gefallen daran fand, ihn zu beobachten...“, Das Märchen, str. 12.
} 
Trgovčevog sina poslužuje jedna mlada djevojka, koja je dvije ili tri godine starija od najmlađe sluškinje. Ne čini mu se osobito lijepih crta lica, ali ga se duboko doimaju estetski detalji u njezinu izgledu: „neusporediva ljepota njezinih očnih kapaka i usana, kao i trome, nevesele kretnje njezina lijepog tijela“, koje mu se čine poput „zagonetnog jezika jednog zatvorenog i čudesnoga svijeta“. ${ }^{175} \mathrm{U}$ ovome je opisu također vidljivo da trgovčev sin ženskost promatra kao vrstu neoplatonističke esencije, koju želi isključivo promatrati, ali ne i posjedovati. U tome se, između ostaloga, ogleda njegova feminizacija: distanciranje od želje za „pragmatičnim“ posjedovanjem ženskog bića stvara u njemu habitus mističnog esteta i asketa. Žensko tijelo za njega postaje lirska šifra, jedan dio nedokučivog i nepristupačnog svijeta, ono postaje simbolom ,vječne ženskosti““.

Kućepaziteljica, starija žena, trgovčevog sina podsjeća na njegovu preminulu majku i na ranu fazu djetinjstva, koje on čeznutljivo voli: u ovome se ogleda primarni narcizam esteta, želja senzibilnog muškarca da se vrati u stanje povezanosti s majkom.

S njezinim je dopuštenjem u kuću primljena i njezina daljnja rođakinja, jedna gotovo petnaestogodišnja djevojka. Ova je djevojka, koju je trgovčev sin primio u kuću, izazvala prvu pravu anksioznost u egzistenciji trgovčevog sina. Mlada, 15-godišnja djevojka činila mu se nekako sablasno povučenom i bilo mu je neshvatljivo zašto se tako strogo odnosi prema sebi. Trgovčev sin je zapanjen „,̌udnovatom i prerano zrelom ljupkošću njezinog lica““176: u ovom opisu djevojka predstavlja književnu tipologiju žene-djeteta (Kindfrau). Jedino zazorno što on primjećuje je oblik njezinih usta: pridjev unheimlich označava u Freudovom smislu nešto istovremeno zazorno i poznato, ali potisnuto. „Ostalo mu je zagonetkom zašto se djevojka u napadu bijesa i očaja bacila s prozora i ozlijedila“. ${ }^{177} \mathrm{Kad}$ ju je prvi put promatrao kako spava, njezino ga je dječje lice uznemiravalo: „u trenu se njezino mrtvački blijedo lice (djevojka sad već predstavlja spoj tipoloških odrednica femme fragile i Kindfrau) u napadu bijesa obojilo u zelenkasto-bijelu boju, ona se onesvijestila i vratila se, kao da je mrtva, u svoj prijašnji položaj“. ${ }^{178}$ Smisao ovoga djetinjeg napada bijesa zapravo služi kao prolepsa (pripovjedna strategija anticipacije, nagovještaja) spoznaje koja će biti otkrivena tek na početku drugog dijela pripovijetke: trgovčev sin po prvi put shvaća „ono što ga je kao dječaka uvijek ogorčivalo, anksioznu ljubav, s kojom je njegov otac gledao na ono što je stekao, na

\footnotetext{
175 „ergriff ihn die unvergleichliche Schönheit ihrer Augenlider und ihrer Lippen, und die trägen, freudlosen Bewegungen ihres schönen Leibes waren ihm die rätselhafte Sprache einer verschlossenen und wundervollen Welt“", Das Märchen, str. 13.

176 ,...und war erstaunt uber die seltsame und altkluge Anmut ihres Gesichtes“, Das Märchen, str. 11.

${ }_{177}$ Le Rider 1990, str. 114.

${ }^{178}$ „Im Augenblick verfärbte sich ihr totenblasses Gesicht ins Grünlich-weiße, sie wurde ohnmächtig und fiel wie tot in ihre frühere Lage zuruck“, Das Märchen, str. 12.
} 
bogatstva njegove trgovine, na lijepu, bezosjećajnu djecu na koju je usmjerio svoju pažnju i brigu.“179 Prema tumačenju Le Ridera, „sada on shvaća da je baš ta vrsta gnjeva natjerala djevojku da se baci s prozora: ljubomora djeteta koje se osjetilo zanemarenim od oca (ili zamjenskog oca) naspram druge „lijepe, bezosjećajne djece“, artefakata koje je trgovčev sin sakupljao baš kao i njegov otac“. ${ }^{180}$ Prema Le Rideru, ,ista je vrsta ljubomore morila i trgovca u odnosu prema njegovom ocu: djevojka se, dakle, pojavljuje kao dvojnik (Doppelgänger) njegovog vlastitog djetinjeg $\mathrm{Ja}^{\text {“. }}{ }^{181}$ „Nasilje djevojke prema samoj sebi odgovara upravo onom nasilju koje je trgovčev sin činio sam nad sobom kako bi se podsvjesno identificirao s očevom slikom i potisnuo svoju vlastitu želju za povratkom u stanje djetinjstva, koja je istovremeno i želja za povratkom u majčinu, žensku sferu““. ${ }^{182}$ Zbirka dekorativnih predmeta, dakle, na metaforičkoj razini funkcionira kao nagovještaj objektifikacije, ali i idealizacije ženskih likova (ženski likovi kao objets d'art).

„Na početku drugog dijela pripovijetke Das Märchen der 672. Nacht postaje jasno da osjećajna vrijednost umjetničke zbirke hipersenzibilnog esteta, koji se identificirao sa ženskošću, zapravo počiva na identifikaciji s ocem“. ${ }^{183}$ U pripovijetci se spominju i sjećanja iz djetinjstva, u kojima trgovčev sin sebe uspoređuje sa svojim ocem: ovime on preispituje razmjere muškosti i ženskosti vlastite psihe, pri čemu se ambivalencija između patrijarhalnog nazora i feminizacije psihe konstituira i u metafori „velikog kralja“ koji je zalutao u „,nepoznatoj šumi“, a koji predstavlja Zakon Oca, odnosno simbolički poredak. No na početku 2. dijela pripovijetke Das Märchen der 672. Nacht već se javlja kritika kolekcionarskog, esteticističkog mentaliteta, koji opredmećuje kako ženska bića, tako i stvarnost: trgovčev sin po prvi put shvaća da prevelika ljubav njegovog oca prema umjetničkim predmetima (,lijepoj, bezosjećajnoj djeci“, „tajanstvenim izrodima nejasnih dubokih želja njegova života“), ${ }^{184}$ koju je i on naslijedio od oca, zapravo simbolički predstavlja umjetnički supstitut za neproživljeni život, za puninu života i ideale koji ostaju samo na razini čežnje. On shvaća da bi ,veliki kralj iz davnih vremena morao umrijeti kad bi mu se oduzeli njegovi posjedi (...) o kojima je sanjao kako će zavladati njima i koji su bili tako beskrajno veliki, da nije imao

\footnotetext{
179 „Er begriff zum erstenmal, was ihn als Knabe immer zum Zorn gereizt hatte, die angstvolle Liebe, mit der sein Vater an dem hing, was er erworben hatte, an den Reichtümern seines gewölbten Warenhauses, den schönen, gefühllosen Kindern seines Suchens und Sorgens, den geheimnisvollen Ausgeburten der undeutlichen tiefsten Wünsche seines Lebens“, Das Märchen, str. 18.

${ }^{180}$ Le Rider 1990, str. 114.

181 Ibid.

${ }^{182}$ Ibid.

${ }^{183}$ Ibid., str. 115.

184 „den schönen, gefühllosen Kindern“; „den geheimnisvollen Ausgeburten der undeutlichen tiefsten Wünsche seines Lebens“, Das Märchen, str. 18.
} 
nikakvu moć (vlast) nad njima niti kakvu korist od njih osim spoznaje da ih je podčinio i da nitko drugi doli on nije bio vladar nad njima.“"185

U ovome dijelu pripovijetke može se uočiti fragmentarnost karaktera glavnog lika te njegova duboka neodlučnost između vlastitog rodnog određenja (ženskost ili muškost). Veza trgovčevog sina sa simbolima očevog života je duboko ambivalentna: „On je ipak osjećao kako ljepotu, tako i ništavnost tih stvari; nikad ga zadugo nije napuštala pomisao na smrt.“،186

\subsubsection{Implicitni rod}

Način pripovijedanja u djelu je punktualno slobodni neupravni govor (njem. erlebte Rede), u epskom preteritu, zatim se koristi i upravni i neupravni govor (njem. direkte und indirekte Rede). Samo mjestimično korištenje slobodnog neupravnog govora u pripovijedanju odražava djelomice Hofmannsthalovo distanciranje od esteticizma, budući da on u odlomcima sveznajućeg, autorskog pripovijedanja zauzima svojevrsnu kritičku distancu prema ponašanju glavnog lika. Međutim, korištenje slobodnog neupravnog govora, koji prema teoretičarki Kathy Mezei predstavlja smanjivanje distance od lika, tzv. srednji put između „muške kontrole (moći) i ženske žudnje“6187, odražava također i empatijski odnos heterodijegetskog pripovjedača prema glavnom liku i predmetu pripovijedanja.

Djelo Das Märchen der 672. Nacht biva pozicionirano na srednjem putu (odnosno, nedefiniranom prostoru) između hijerarhijski nadređenog, distanciranog pripovjedača, koji na simboličkoj razini djela predstavlja kritiku ,tamnice esteticizma“ prisutne u psihi glavnog lika s jedne, i empatijskog približavanja glavnom liku koje uvjetuje svojevrsna identifikacija Hofmannsthalovog pripovjedača sa unutarnjom vizurom trgovčevog sina s druge strane.

Važno je istaknuti da je:

u prvom dijelu pripovijetke život glavnog lika prikazan iz perspektive autorskog pripovjedača, dok se u drugom dijelu pripovijetke sve više pojavljuju percepcije, zapažanja i osjećanja glavnog lika, prikazana iz unutarnje vizure. Time naoko zaštićeni prostor projekcija otpočetka biva ugrožen. Zrcalne se slike osamostaljuju, rastvaraju se i otkrivaju svoju prazninu; blizina se pretvara u daljinu, a zaštićenost esteta se $u$ drugom dijelu pripovijetke pretvara $u$ anksiozno stanje. ${ }^{188}$

\footnotetext{
185 „Er begriff, daß der große König der Vergangenheit hätte sterben müssen, wenn man ihm seine Länder genommen hätte...(...) die er zu beherrschen träumte und die doch so unendlich groß waren, daß er keine Macht über sie hatte und keinen Tribut von ihnen empfing als den Gedanken, daß er sie unterworfen hatte und kein anderer als er ihr König war“, Das Märchen, str.18.

186 „Doch er fühlte ebenso die Nichtigkeit aller dieser Dinge wie ihre Schönheit; nie verließ ihn auf lange der Gedanke an den Tod“, Das Märchen, str.10.

${ }^{187}$ Usp. Nünning/Nünning 2004: str. 172-173.

${ }^{188}$ Usp. Hofmannsthal Handbuch, 2016, str. 276, članak Rolanda Innerhofera.
} 
U ovom se drugom dijelu pripovijetke može primijetiti ,gubitak kontrole nad prostorom ljepote i kontemplacije“. ${ }^{189}$

Perspektiva pripovijedanja načelno je autorska (heterodijegetski pripovjedač, u 3. licu jednine), s postupnim približavanjem personalnoj perspektivi (unutarnjoj vizuri) glavnog lika (,ova konstelacija, što se tiče tehnike pripovijedanja, odgovara pojmu interne fokalizacije $\left.{ }^{(6190}\right)$.

Naracija pripovijetke oslanja se uglavnom na prikaz unutarnjih, duševnih procesa trgovčevog sina i demonstrira manjak radnje. „Dok prvi dio pripovijetke tematizira jedan neodređeni vremenski raspon, koji se proteže kroz čitav niz godina, zgušnjava se ispripovijedano vrijeme $\mathrm{u}$ drugom dijelu pripovijetke na svega jedan dan. Nagli kraj pripovijetke predstavlja radikalnu opreku slici kontemplativnog života“. ${ }^{191}$

Djelo Das Märchen der 672. Nacht protječe u kronološkom vremenskom nizu, sa povremenim retrospektivnim mislima trgovčevog sina na ljepotu njegovih služavki. Ovi su povremeni retrospektivni trenutci odraz kontemplativnosti esteta, ali i tendencije $\mathrm{k}$ psihološkoj regresiji.

Što se tiče samog doživljaja vremena u psihi mističnog esteta, možemo reći da u djelu prevladava procesni i retrospektivni obrazac vremena, zatim subjektivno vrijeme, koje se očituje poniranjem heterodijegetske instance pripovjedača u psihu glavnog lika, te određene naznake mitskog vremena kroz obilje orijentalnih aluzija koje poprimaju obilježje razdoblja esteticizma. U djelu je prisutno i neprestano cikličko vraćanje esteta u mislima na ljepotu njegovih služavki i na njegovo vlastito djetinjstvo (sjećanja senzibilnog esteta na djetinjstvo upućuju na njegovo regresivno traganje za revitalizacijom podsvjesnih sadržaja psihe, što je ženski konotirana karakteristika). Prisutan je i orijentalni koncept mističnog jedinstva sa svijetom kroz kontemplaciju umjetničkih objekata i kontemplaciju ženske ljepote, viđene kroz prizmu opisa floralnih motiva.

U drugom dijelu pripovijetke trgovčev sin, izlazeći iz draguljarnice, dospijeva u vrt u kojem se nalazi staklenik. Vrt općenito simbolizira prijelaznu zonu između privatne i javne sfere ${ }^{192}$, između prirode i civilizacije i često se povezuje sa ženskom sferom. Sličnu konotaciju ženske, kreativne, ali i kontemplativne sfere ima i zatvoreni prostor staklenika, u kojem se nalaze „čudnovate“ biljke, koje metaforički predstavljaju izoliranu egzistenciju esteta i njegov život u ,čistoj“, odnosno sterilnoj sferi umjetnosti, koja postaje supstitut za život.

\footnotetext{
${ }^{189}$ Usp. Hofmannsthal Handbuch, 2016, str. 276, članak Rolanda Innerhofera.

${ }^{190}$ Ibid.

191 Ibid., str. 277.

192 Vidi Nünning/Nünning 2004, str. 54.
} 
Teškoće kretanja u prostoru i manjak prostorne orijentacije u ovom dijelu pripovijetke simbolički označavaju poniranje u zakučastu podsvijest glavnog lika. Gubitak kontrole nad prostorom u kojem se kreće i besciljno lutanje gradom još jednom naglašavaju feminizaciju psihe glavnog lika.

U djelu prevladava mješavina obrazaca being i becoming, odnosno bivanja (statičnog identiteta) i postajanja (dinamičnog identiteta): u prvom dijelu pripovijetke načelno prevladava prvi obrazac, dok se u drugom dijelu radnja ipak malo više dinamizira kretanjem trgovčevog sina kroz labirintske prostore grada i vrta koji se nalazi u blizini draguljarnice.

U psihi glavnog protagonista sve je izraženiji subjektivni gubitak osjećaja za stvarnost, predodžbe se zamućuju: na to posebice utječe i impresionističko nizanje dojmova i percepcija, ali i sklonost naracije defabularizaciji. ${ }^{193}$

Treba primijetiti i to da u drugom dijelu pripovijetke nailazimo na elemente nepouzdanog pripovijedanja, budući da se trgovčev sin gubi kako u labirintskim prostorima grada i vrta, tako i u kolopletu svojih percepcija, strahova i misli, a sve to ukazuje na duboke, ali nejasne, podsvjesne sadržaje njegove psihe. Kontrola pripovjedača nad likom u drugom se dijelu pripovijetke maksimalno smanjuje, budući da pripovjedač empatijski ulazi u dublje slojeve psihe glavnog protagonista. Nepouzdano pripovijedanje ovdje nastoji prikazati fragmentarnost psihe glavnog lika i njezinu nekoherentnost. Ovakvo fluidno, tradicionalno „ženski konotirano pripovijedanje“ u suprotnosti je s pripovijedanjem koje zadržava kontrolu i distancu od predmeta o kojem se pripovijeda: ono također odražava anksioznost glavnog lika vezano na definiranje vlastitog (rodnog) identiteta.

U svom dezorijentiranom traganju, trgovčev sin ulazi u draguljarnicu kako bi kupio broš za stariju služavku. U ogledalu ugleda svoj ženski pandan, koji ga podsjeća na jednu od njegovih mladih služavki: ovdje se po prvi put konkretizira njegova potraga za vlastitim ženskim dijelom psihe (animom). Nakon što je napustio draguljarnicu, trgovčev sin ulazi u prostor vrta, koji simbolički označava njegovu potisnutu ženskost, i kod staklenika susreće djevojčicu, koja mu na neobičan način sliči njegovoj petnaestogodišnjoj sluškinji. Djevojka predstavlja i njegova sjećanja iz djetinjstva, ona je njegov djetinji pandan. On sada dospijeva u tajanstveni predio, koji metaforički predstavlja njegovu erotsku inicijaciju. Ovdje se isprepliću eros i tanatos, popraćeni motivom cvijeća: trgovčev sin ulazi u staklenik i nailazi na „čudnovate i rijetke narcise i anemone“194, koje predstavljaju alijenaciju njegove narcističke ličnosti od vanjskog svijeta.

\footnotetext{
${ }^{193}$ Usp. Paetzke 1992.

${ }^{194}$ Das Märchen, str. 21.
} 
$\mathrm{Na}$ samom kraju pripovijetke dolazi u predio niskih kuća, gdje stanuju vojnici, koji simboliziraju virilnu muškost naspram njegove nježnosti (feminiziranosti).

Prema Le Rideru, identifikacija trgovčevog sina s ocem prelazi u megalomanske snove koji se kreću oko lika velikog kralja ${ }^{195}$, a „njegovo se ja tek tada pokazuje kao izrazito krhko, budući da ga prisutnost slugu čini nesigurnim“. ${ }^{196} \mathrm{U}$ prvome se dijelu pripovijetke spominje određena fobija trgovčevog sina od vlastite posluge, ali i ljudi općenito: „Nelagoda zbog prisutnosti posluge pojačava se do prave fobije, i to u trenutku kad se sin trgovca sljedećeg ljeta povlači sa svoja četiri člana posluge u ladanjsku kuću“. ${ }^{197}$ Vjeruje da ga promatraju i više ih se u mislima ne može osloboditi: „Osjećao je da oni žive, jače, prodornije nego što je za sebe osjećao da živi““. ${ }^{198}$ Uzrok ove zagonetne tjeskobe i strepnje je neproživljeni život trgovčevog sina, unutarnja borba između duhovne askeze (kontemplacije, koja kod njega vodi do neurastenije i anksioznosti) i njegove latentne želje za životom, odnosno vitalizma, koji se ogleda i u spolnosti.

„U prvom dijelu Hofmannsthalove je pripovijetke sin trgovca razapet između identifikacije sa slikom oca (fantazija o velikom kralju i njegova naklonost prema lijepim stvarima) i raspada njegovog jastva, t.j. feminizacije njegovog jastva u prisutnosti posluge“ ${ }^{199}$ Fragmentacija njegovog jastva očituje se i u ambivalentnom položaju između heteroseksualnosti i homoeroticizma: „njegove ga lijepe služavke istodobno ispunjavaju i fascinacijom i osjećajem gnušanja (zazora), dok s druge strane prema perzijskom slugi osjeća naklonost koja je homoseksualne prirode“، ${ }^{200}$

Pred kraj prvog dijela pripovijetke trgovčev sin napušta kuću jer ne može više podnijeti tjelesnu prisutnost svojih lijepih sluškinja, u potrazi za smirenjem i ,cvijetom čiji bi mu oblik i miris mogao na trenutak pružiti istu onu slatku draž mirnog posjedovanja, kakva je postojala u ljepoti njegovih služavki, a koja ga je zbunjivala i uznemiravala“. ${ }^{201}$ Cvijet ovdje metaforički predstavlja ideal ženskosti, te postaje fetiš, uz čiju pomoć trgovčev sin pokušava kamuflirati žudnju i strah od ženskog tijela. Nevoljko ponavlja stihove pjesnika: „u stabljikama karanfila koji su se njihali, u mirisu zrelog žita pobudila si moju čežnju; ali kad

\footnotetext{
${ }^{195}$ Le Rider 1990, str. 115.

196 Ibid.

${ }^{197}$ Ibid.

${ }^{198}$ Cit. u: Le Rider 1990, str. 115., vidi također Das Märchen, str. 14.: „Er fühlte sie leben, stärker, eindringlicher, als er sich selbst leben fühlte“.

${ }^{199}$ Le Rider 1990, str. 116.

${ }^{200}$ Ibid.

201 „und suchte lange, obgleich er wußte, daß er vergeblich suchen werde, nach einer Blume, deren Gestalt und Duft (...) ihm für einen Augenblick genau den gleichen süßen Reiz zu ruhigem Besitz geben könnte, welcher in der Schönheit seiner Dienerin lag, die ihn verwirrte und beunruhigte“., Das Märchen, str. 16., Le Rider 1990, str. 116.
} 
sam te našao, to što sam tražio nisi bila ti, već sestra tvoje duše“. ${ }^{202}$ Postoji više mogućih tumačenja ovog stiha: metafora sestra duše s jedne strane predstavlja čežnju trgovčevog sina za uspostavljanjem harmoničnog odnosa sa svojom potisnutom animom (ženskom stranom), ili, jednostavno, čežnju za svojim ženskim pan-danom. Međutim, ova metafora predstavlja i neodređenost (fluidnost) ljudskog identiteta uopće, budući da je često korišteni provodni motiv duše u bečkoj moderni predstavljao neodređen i ezoteričan pojam. Metafora sestra duše u orijentalnim bi tumačenjima zapravo metaforički označila krhkost ljudskog ,jastva“ i ne-fiksnost identiteta općenito (ukazujući uostalom i na učenja Ernsta Macha), ali i svojevrsni orijentalni pojam reinkarnacije. S druge strane, Hofmannsthal ovom izrazito poetičnom i auto-refleksivnom metaforom ukazuje i na tradiciju neoplatonističke misli koja je isticala dominaciju duše nad materijom, u što je uključena estetizacija ženskog bića i ženskosti (duše) općenito, koja je sažeta u metaforama cvijeća (karanfila, koji simboliziraju ljubav i smrt, Eros i Tanatos) kao simbola ženstvenosti (književna koncepcija žene kao prirode- Naturwesen Frau). Hofmannsthal prikazuje fluidnost potrage trgovčevog sina za nedohvatljivom i nepristupačnom vječnom ženskošću, koja se uvelike razlikuje od neke realne koncepcije ženskog bića. Iz njegovog se stava o nedohvatljivoj i tajanstvenoj ženi dade iščitati općeniti stav bečke moderne o ženskosti koja muški subjekt ispunjava ambigvitetom žudnje i zazora (njem. Verweiblichung der Kultur). Pat-pozicija trgovčevog sina prema ženskosti, kao i prema životu samome ${ }^{203}$ pretače se u estetiziranje smrti i života istovremeno: naracija pripovijetke Das Märchen der 672. Nacht koncipirana je u obliku svojevrsnog ,psihograma“ koji odražava cikličku i diskontinuiranu unutarnju borbu trgovčevog sina sa samim sobom, sa vlastitim konfliktnim stavom prema ženskosti i životu.

Njegovo inicijacijsko putovanje kroz grad poprima oblik ,anksioznog sna“ (njem. Angsttraum), ono postaje poput nekog podsvjesnog sukoba između ideala (vlastite) ženskosti i straha od realne spolnosti, pa i od virilne muškosti.

U svojoj potrazi za majčinskim, ženskim elementom, trgovčev sin ima namjeru kupiti nakit za svoju staru služavku. Biva uspoređen sa Narcisom, koji se zaljubio u svoj vlastiti odraz u

\footnotetext{
202 „In den Stielen der Nelken, die sich wiegten, im Duft des reifen Kornes erregtest du meine Sehnsucht; aber als ich dich fand, warst du es nicht, die ich gesucht hatte, sondern die Schwester deiner Seele“, Das Märchen, str. 17.

${ }^{203}$ I u djelu Leopolda von Andriana žena („die Frau“) i život („das Leben“) postaju sinonimi. Andrian suprotstavlja estetiku i etiku, umjetnost i život, zazor od života i želju za životom, sakralno i profano, spiritualnost i senzualnost. U svim ovim dihotomijama ženi i ženskosti pripada mjesto bliskosti životu (shodno književnoj koncepciji „Naturwesen Frau“), budući da žena, za razliku od Erwinova „,besplodnog, jalovog““ odnosa sa muškim subjektima (prvenstveno s Clemensom), simbolizira plodnost, senzualnost i novi život koji Erwinovoj esteticističkoj egzistenciji ostaje stran. Time se i Andrian smješta u red književnika koji recipiraju djelo Otta Weiningera Geschlecht und Charakter, budući da Andrianova usporedba žene i života jasno konotira žensku senzualnost.
} 
vodi: „tada je on po drugi put ugledao svog ženskog dvojnika u ogledalu“. ${ }^{204}$ Djevojka iz ogledala, koja se ovdje metaforički prikazuje kao vlastito žensko ja (lat. anima) trgovčevog sina, prikazana je izrazito ornamentalno i dekorativno. „Susret sa ženskim elementom njegove vlastite biseksualne sklonosti trgovčev je sin prvi put osjećao kao prijetnju i agresiju: sada je, naprotiv, ona pokazivala čar djetinjstva“. ${ }^{205}$

Otkrivanje ženskog lika u ogledalu draguljarnice u ovom drugom dijelu pripovijetke odraz je kako narcističke ličnosti trgovčevog sina (primarnog narcizma esteta), tako i redefiniranja njegovog stava prema ženama. Opis ove žene ,iz ogledala“ na simboličkoj razini odgovara opisu njegove mlade služavke iz 1. dijela pripovijetke: autorski pripovjedač opisuje ornamentalnu ljepotu žene, njezin „teški nakit“, „poniznu dječju gracilnost“ njezinih ramena $i$ njezinog vrata, te njezino „,ratničko lice“, lice „,mlade kraljice“. ${ }^{206} \mathrm{~S}$ glavama indijskih božica koje je nosila u rukama, lik djevojke poprima odraz ratničkog ženskog lica ${ }^{207}$ te odražava književnu tipologiju femme fatale ili virago, dakle, egzotične ili ezoterične žene-amazonke. S druge strane, ovaj ženski lik nosi obilježja i femme fragile i Kindfrau (opis njenih „nježnih ramena،“208): ovakav ambigvitet prikaza ženskog lika ukazuje na androgini spoj muških i ženskih karakteristika (androgino savršenstvo, njem. androgyne Vollkommenheit). Trgovčev je sin zadivljen njezinom gotovo androginom ljepotom, ali istovremeno je svjestan toga da mu posjedovanje te ljepote ne bi ništa značilo, budući da ga žena ispunja čežnjom, a ne spolno konotiranom žudnjom. Međutim, ovo mu lice ipak izgleda kao prijetnja (agresija), u njemu se budi „muški protest“ protiv ovakve agresivne, demonske ženskosti (femme fatale), ali i protiv vlastite ženskosti koju je otkrio kroz nju.

„Trgovčev sin zatim iza stakala staklenika ugleda dijete, koje ga ljutito promatra, a na neopisiv način sliči 15-godišnjoj djevojci koja je bila njegova služavka“.${ }^{209}$ Prema Le Rideru, „kod djevojčinog prvog pojavljivanja u ogledalu, ona utjelovljuje nevinost ženskosti, koja biva povrijeđena sputanošću (nesigurnošću) koja trgovčevog sina drži zatočenog u njegovom muškom identitetu“. ${ }^{210}$ „Sada se trgovčev sin osjeća kao „krvnik“ baš one djevojke koja predstavlja njegovu potisnutu ženskost. Ispunjen strahom i osjećajem krivnje, on bježi“. 211

\footnotetext{
${ }^{204}$ Le Rider 1990, str. 119.

205 Ibid.

206 „Da kam ihm aus einem anderen Spiegel im Innern das Bild des Mädchens entgegen mit den dunklen Köpfen der ehernen Göttinnen zu beiden Seiten; flüchtig empfand er, daß sehr viel von ihrem Reiz darin lag, wie die Schultern und der Hals in demütiger kindlicher Grazie die Schönheit des Hauptes trugen, des Hauptes einer jungen Königin“, Das Märchen, str. 20.

207 „wie eine Königin im Kriege“, Das Märchen, str. 16.

208 „,zarte Schultern“, Das Märchen, str. 16.

${ }^{209}$ Le Rider 1990, str. 120.

${ }^{210}$ Ibid.

${ }^{211}$ Ibid.
} 
„Nagon ga tjera da se vrati na staro stanje, vraća njegove misli natrag u zaštićeni svijet esteta i „velikog kralja“: no vizija trijumfirajuće muškosti se ipak ispostavlja kao samoobmana“. 212 „Tako u svojem bijegu od raja ženskosti (odnosno, uronjenosti u „vječnu ženskost“ i vlastitu potisnutu ženskost) trgovčev sin nakraju dospijeva baš u područje najgrublje muškosti: „na rešetkastom prozoru sjedilo je nekoliko vojnika sa žutim licima i tužnim očima i nešto su mu dovikivali. (...) Ali on nije razumio što žele od njega“. ${ }^{213}$ Susret s vojnicima, koji simboliziraju grubu, virilnu muškost, izaziva anksioznost u trgovčevom sinu: vojnici simbolički predstavljaju suprotnost esteticizmu i feminizaciji psihe trgovčevog sina, oni su element personifikacija 'estetike ružnoće'. Prema Le Rideru, „dovikivanje vojnika sigurno je predstavljalo samo prezir junačina kad su ugledali feminiziranog muškarca“. ${ }^{214}$ „Ovi zvjerski nastrojeni muškarci, koji su bili poput kažnjenika, bavili su se timarenjem konja i izgledali su odbojno, bili su snažni i ulijevali su strah“. ${ }^{215}$ Le Rider povezuje ovaj događaj u djelu s Freudovim esejem iz 1909. godine koji povezuje strah malog Hansa od konja sa strahom od kastracije koji je opet uvjetovan strahom od ženskoga. Shodno tome, ovaj se strah trgovčevog sina od konja u dvorištu vojne četvrti može povezati sa strahom od uništenja njegovoga muškoga ja. ${ }^{216}$ Trgovčev sin povezuje mrski pogled konja s izobličenim licem ružnog siromašnog čovjeka, kojeg je jedan jedini put vidio u trgovini svoga oca: time je povukao analogiju između trgovine svoga oca i straha od kastracije izazvanog ugrizom konja. S obzirom na to da je trgovčev otac tog ,ružnog, siromašnog“ čovjeka izbacio kao lopova, to se „poniženje krivca čini jednako dojmljivim kao i očeva demonstracija moći“. ${ }^{217}$ Nespretnim potezom, smaragdni broš trgovčevog sina, koji je simbolizirao njegovu težnju za majkom, pada pod konjsku potkovu. Sada se protiv prijašnje čežnje za ženskim, za majkom, izdiže „muški protest“ $u$ nesvjesnom dijelu njegove psihe: on želi u potpunosti odbaciti želju za ženskošću. ${ }^{218}$ No ipak u posljednjem trenutku mijenja svoju odluku: „sagnuo se, konj ga je udario kopitom svom snagom u slabine, a on je pao na leđa“. ${ }^{219}$ Trgovčev je sin sada doživio simboličku kastraciju i umro je bijednom smrću. Prema Le Riderovom tumačenju, na kraju se

\footnotetext{
${ }^{212}$ Le Rider 1990, str. 120.

${ }^{213}$ Ibid. Vidi također H. von Hofmannsthal: Das Märchen, str. 26: „An einem vergitterten Fenster saßen ein paar Soldaten mit gelblichen Gesichtern und traurigen Augen und riefen ihm etwas zu. (...) Aber er verstand nicht, was sie von ihm wollten“.

${ }^{214}$ Le Rider 1990, str. 120.

215 Ibid.

${ }^{216}$ Ibid., str. 121.

${ }^{217}$ Ibid.

218 Ibid.

${ }^{219}$ Le Rider 1990, str. 121., vidi također Das Märchen, str. 28.: „Er bückte sich, das Pferd schlug ihm den Huf mit aller Kraft nach seitwärts in die Lenden und er fiel auf den Rücken“.
} 
ipak ispostavilo da uništenje uskogrudnog, narcističkog jastva nije dovelo trgovčevog sina do inicijacije koja bi ga pomirila sa njegovom potisnutom ženskošću. ${ }^{220}$

\subsubsection{Zaključak}

Portretiranje narcizma (i motiva djetinjstva) slično je prikazano u Hofmannsthala, kao i u Leopolda von Andriana: primarni narcizam esteta može se protumačiti kao modus mistične povezanosti sa svijetom i s vlastitim podsvjesnim ženskim dijelom psihe (animom). Međutim, ovakav kontemplativni život $\mathrm{u}$ esteticističkoj izolaciji ima komponentu demonizacije spolnosti i aktivnog života: Hofmannsthal svojom parabolom Das Märchen der 672. Nacht izriče osudu čisto kontemplativne, esteticističke egzistencije, on kritizira isključivo povlačenje esteta u svoj vlastiti unutarnji svijet i odbacivanje društvene stvarnosti. Sfera umjetnosti i ezoteričnih nazora na svijet na taj način postaje konotirana kao privatna, statična, ženska sfera koja je oprečna od stereotipno muške, javne, racionalne i produktivne sfere.

Djelo predstavlja i kritiku građanskog kolekcionarskog mentaliteta, koji naglašava posjedovanje umjetničkih predmeta naspram razvijanja empatije za vanjski svijet. No treba naglasiti da je u doba bečke moderne estetska kultura bila na sličan način odlika kako aristokracije, tako i građanstva: estetska je egzistencija bila supstitutom za vakuum političke i društvene stvarnosti. Međutim, perspektiva koju djelo Das Märchen razvija na sličnom liku kao što je glavni lik u Andrianovu djelu Der Garten der Erkenntnis, prema tumačenju Iris Paetzke, ipak donekle stoji u suprotnosti s Andrianovim djelom, budući da Andrian patnje i samoću kneza Erwina predstavlja svojevrsnim ,slavljeničkim patosom i veže egzistenciju esteta na čeznutljivo doživljeni slom aristokracije i njezine kulture“. ${ }^{221}$

Unutarnja nesigurnost rodnog identiteta lika trgovčevog sina postiže se pretapanjem autorske pripovjedne perspektive u personalnu, rastakanjem svijesti u „konglomerat sjećanja i osjećaja straha te polu-nesvjesnih sadržaja svijesti“‘222 koji obuzima trgovčevog sina i kojim on ne može vladati.

Inhibiranost trgovčevog sina u definiranju svoga odnosa prema ženskosti zbog miješanog osjećaja žudnje i zazora prema ženama ogleda se u njegovim esteticističkim koncepcijama ženskosti i svojevrsnom asketskom stavu prema vlastitoj spolnosti. Le Rider stoga postavlja tezu da bi jastvo glavnog lika bilo „spašeno“ da je trgovčevom sinu uspjelo otvoriti svoje psihičke potencijale prema ženskome, odnosno da je prihvatio svoj „,novi“, ,ženski“ identitet.

\footnotetext{
${ }^{220}$ Le Rider 1990, str. 121

${ }^{221}$ Paetzke 1992, str. 49.

${ }^{222}$ Ibid., str. 48.
} 
Oba Hofmannsthalova djela (Das Märchen der 672. Nacht i Andreas oder die Vereinigten) zapravo prikazuju nemogućnost ontološke utemeljenosti ljudskog jastva, njegovu podložnost fluktuacijama (promjenama) te nemogućnost i sapetost, odnosno paralizu onodobnog (muškog) subjekta u pronalaženju svog stvarnog rodnog identiteta. Stoga ova oba djela demonstriraju Hofmannsthalovo visoko estetizirano i ludičko propitivanje (rodnog) identiteta uopće, naglašavajući nemogućnost čvrste ukotvljenosti jastva muških protagonista bilo u muškosti ili u ženskosti, čime i muškost i ženskost bivaju okarakterizirani kao artificijelni konstrukti koji se pozicioniraju onkraj dinamičnosti kako društvene stvarnosti, tako i stvarnosti individualne psihe. U fokusu oba Hofmannsthalova djela je prikaz muške svijesti i podsvijesti s narativnim naglaskom na unutarnjoj vizuri (muških) protagonista koji se ističu svojom hipersenzibilnošću i estetskom prijemčivošću.

Hofmannsthal je više puta povlačio paralelu između unutarnje krhkosti jastva trgovčevog sina i jedne rečenice engleskog pjesnika romantizma Johna Keatsa, koji je 1818. godine napisao: „Kad bih se našao $\mathrm{s}$ drugim ljudima u istoj prostoriji i kad bih bio slobodan od misli na tvorevine moga vlastitog uma, onda se moje ja ne bi više vraćalo samome sebi, već bi identitet svakog pojedinca u prostoriji počeo vršiti pritisak na mene, tako da bih za kratko vrijeme moje jastvo bilo potpuno uništeno.“223 Za Keatsa, kao i za Hofmannsthala, ova krhkost karakterizira fluidno jastvo pjesničkog genija koji se, budući da je otvoren svijetu i drugome, sastoji od čiste senzibilnosti. ${ }^{224}$ Karakteristika pjesničkog senzibiliteta, kao i fluidnost jastva tradicionalno su konotirane kao ženske osobine, budući da su se empatija (mogućnost uživljavanja) i tankoćutnost tradicionalno pripisivale ženama. ${ }^{225}$ Usporedba $\mathrm{s}$ Ottom Weiningerom omogućuje točnije određenje karaktera trgovčevog sina: Weininger objašnjava, vezano uz nastanak svoje analize genijalnosti u djelu Geschlecht und Charakter: „Apsolutna žena nema svoje ja“. ${ }^{226}$ Time se zapravo umjetnikovo uživljavanje u okolni svijet, njegova hipersenzibilnost i krhkost njegova (rodnog) identiteta može shvatiti kao simptom feminizacije. Ženskost i genijalnost se, prema Weiningeru, mogu shvatiti kao bliski pojmovi, budući da Weininger kasnije u djelu Geschlecht und Charakter majčinstvu priznaje podređeni oblik genijalnosti. Weininger također naglašava da se genijalni stvaratelj ranjivošću svoga ja približava ženskom principu. ${ }^{227}$

\footnotetext{
${ }^{223}$ Usp. David D. Perkins, English Romantic Writers, New York 1967, cit. u Le Rider 1990, str. 115.

${ }^{224}$ Le Rider 1990, str. 116.

${ }^{225}$ Vidi članak Karin Hausen: Die Polarisierung der Geschlechtercharaktere, 1976.

${ }^{226}$ Weininger: Geschlecht und Charakter 1920, str. 232., cit. u: Le Rider 1990, str. 116.

${ }^{227}$ Le Rider 1990, str. 116.
} 
Izmirenje sa ženskošću unutar vlastite psihe omogućilo bi trgovčevom sinu harmoniju (uravnoteženost) njegove biseksualne prirode time što bi ga dovelo do androginog internaliziranja ženskosti a time latentno $\mathrm{i}$ do približavanja ženskom subjektu. U Hofmannsthalovu djelu Andreas oder die Vereinigten to je samo nakratko uspjelo glavnom liku, što je prikazano u sceni mističnog sjedinjenja sa, ženskim principom“ te mu je ta mistična vizija privremeno stvorila i psihički potencijal za sjedinjenje sa ženskim subjektom. Nasuprot tomu, Hofmannsthalova pripovijetka o trgovčevom sinu zaista je portret „sudnjega dana“- ne samo esteticizma, nego i rodnog identiteta.

Potrebno je istaknuti i činjenicu da i pripovjedna perspektiva u Hofmannsthalovoj pripovijetci također ukazuje na krizu identiteta: postepeno pretapanje autorske perspektive u personalnu (kroz koju se prikazuju podsvjesni i svjesni sadržaji psihičkog univerzuma glavnog protagonista, dakle koloplet njegovih percepcija, dojmova, sjećanja i emocija) svjedoči o zaranjanju u nesvjesne predjele psihe, u kojima se događa dezorijentacija glavnog lika vezano na vlastiti (rodni) identitet, tako da se identitet lika sve više poistovjećuje s fluidnim jastvom (njem. das unrettbare Ich). Estetski senzibilitet glavnog lika svjedoči o autorefleksivnosti, o njegovom poniranju u još neistražene dijelove vlastite psihe. Treba napomenuti i to da je onodobna kriza metafizičkog i ontološkog nazora na svijet dovela do fragmentacije ljudske psihe i do gubitka etičkih vrijednosti, pri čemu se kao supstitut javljaju esteticističke vrijednosti, koje dovode do kolekcionarskog mentaliteta. Slom liberalizma i njegovih prosvjetiteljskih zasada stabilnog i racionalnog subjekta iznjedrio je u razdoblju bečke moderne njegovanje estetske kulture, ${ }^{228}$ koja je bivala supstitutom za vakuum političke i društvene, beznadno pluralističke, stvarnosti.

Hofmannsthalova je pripovijetka prikaz muškoga protesta i krize rodnog identiteta ${ }^{229}$, prikaz muške osobe koja osjeća strah i ambivalenciju prema vlastitoj ženskosti i prema ženskosti općenito. Prema Richardu Alewynu ${ }^{230}$, ova pripovijetka predstavlja „parabolu o obraćenju osamljenog esteta koji je neprestano živio okružen neživim artefaktima, zatvoren kao egoist u svome vlastitom „umjetnom raju““،231 , u svome „paralelnom“, transcendentnom svijetu umjetničke kontemplacije. Alewynova interpretacija razmatra Hofmannsthalov tekst kao prikaz „krize sazrijevanja“ (težnje za re-definiranjem i rekonstruiranjem vlastitog rodnog identiteta), koju umjetnik ili pjesnik mora proći čim napusti svoju esteticističku

\footnotetext{
${ }^{228}$ Vidi knjigu Die Frauen der Wiener Moderne, herausgegeben von Lisa Fischer und Emil Brix, Verlag für Geschichte und Politik Wien R. Oldenbourg Verlag München, 1997.

${ }^{229}$ Le Rider 1990, str. 112.

${ }^{230}$ Vidi također Richard Alewyn: Über Hugo von Hofmannsthal, Göttingen 1967, str.174. i dalje, cit.u: Le Rider: str. 112.

${ }^{231}$ Le Rider: str. 112.
} 
'predegzistenciju' (Hofmannsthalov termin Präexistenz) ${ }^{232}$. Esteticistička 'predegzistencija' trgovčevog sina predstavlja, shodno mojoj interpretaciji, 1. na psihoanalitičkoj razini njegovu neprevladanu pred-edipalnu fazu iz djetinjstva, u kojoj on još boravi u mitskom obilju povezanosti s majkom (ili, simbolički, s vlastitom unutarnjom ženskošću) i 2. njegov povučeni život obilježen idealizacijom nedostižne esencije „,ječne ženskosti“ (njem. das Ewig-Weibliche), i želju za uspostavljanjem stabilnosti vlastitog rodnog identiteta, odnosno otkrivanje „,vječne ženskosti““ $u$ vlastitoj umjetnički senzibilnoj psihi (anima u podsvijesti) kako bi se prevladao ambivalentan osjećaj žudnje i zazora prema ženama.

Estetizacija života i larpurlartistički stav da je umjetnost supstitut za život i ljepota sama sebi svrhom osnovna su okosnica ovoga djela. Na kraju „hipersenzibilni estet shvaća da mora napustiti svoju infantilnu genijalnost, koja označava neku vrstu mistične intimnosti s univerzumom, kako bi započeo proces inicijacije u stanje odraslosti i stvorio stabilan identitet". ${ }^{233}$

\subsection{Hugo von Hofmannsthal: Gestern (Jučer)}

\subsubsection{Uvod}

Radnja Hofmannsthalove jednočinke pod naslovom Gestern (Jučer) svedena je na minimum. Dramu Gestern Hofmannsthal je napisao 1891. godine kao svoje prvo djelo. Izvor dramskog zapleta Hofmannsthalove jednočinke bračna je nevjera žene (Arlette) spram muža (Andrea) i problematika rodnih odnosa o prijelomu stoljeća. Kroz tu se problematiku prolama i problematika esteticističke egzistencije amoralnog esteta (Andrea) i njegove reakcije na ženinu bračnu nevjeru (zamjetljiva je zamjena rodnih uloga o prijelomu stoljeća).

Cjelokupni personal djela Gestern sastoji se od 11 likova, od kojih je dvoje glavnih protagonista (Andrea i Arlette), a sve ostalo su sporedni likovi. Simbolika naslova (Gestern) upućuje na impresionističku potku djela: vremenski obrazac koji se poima kroz letimičnost percepcija, naglašavajući topos „sve teče“ (grč. panta rei) prisutan u književnosti modernizma; međutim, samo inzistiranje na ,fiksiranju“ vremenskog obrasca na gestern (jučerašnji dan) ukazuje na Hofmannsthalov kritički stav prema fluidnosti percepcija i na njegovu latentnu kritiku čisto esteticističkog nazora na svijet, budući da estet Andrea u jednom segmentu djela mijenja stav pa izriče trajnost stanovitog momenta u ljudskom životu (svojevrsna kritika fluidnog impresionističkog nazora).

\footnotetext{
${ }^{232}$ Usp. Hofmannsthal Ad me ipsum, u: Mayer/Werlitz (ur.): Hofmannsthal Handbuch-Leben-Werk-Wirkung, str. 90., vidi također Le Rider: str. 113.

${ }^{233}$ Ibid., str. 113.
} 
Mjesto radnje „ovog barokno-renesansnog proverbija vrtna je sala u kući senzibilnog esteta Andree, u Imoli, a vrijeme radnje je vrijeme „velikih slikara“ u kasnoj renesansi koju karakterizira rastakanje identiteta (njem. Auflösungszeit). Estet Andrea dolazi iz svijeta „bolno rafiniranog kulta jastva““234, on je narcistički obilježen. Usprkos svojoj baroknoj dikciji, Andrea je potpuno moderan lik: ,,autorefleksivan i nespreman za djelovanje zbog nedostatka voljnog mehanizma. Kod njega čak ne postoji niti žudnja, a sve to zbog prevelike pasivnosti i receptivnosti: temeljni instinkti njegova bića prošli su kroz njegove kompleksne misli i tamo se raspali na komadiće; sada svaki taj djelić misli za sebe i ima svoje razloge koji opstruiraju jedan drugoga i potpuno se dokidaju“. ${ }^{235}$

Estetu Andrei, dakle, pripada nadređena perspektiva, koja se djelomično i implicitno poklapa s autorskom intendiranom perspektivom ${ }^{236}$, budući da izražava onodobni stav autora (Hofmannsthal) o vlastitoj egzistenciji senzibilnog esteta. Dok s jedne strane autor ove drame izražava svoj kritički stav o „tamnici esteticizma“, fluidnosti percepcija, zatim gubitku identiteta i njegovom razlijeganju u impresionističkoj letimičnosti dojmova, čini se da on $\mathrm{s}$ druge strane implicitno dijeli Andrein stav o fluidnoj prirodi ženskog bitka. Treba, naravno uzeti u obzir i činjenicu da je Hofmannsthalova jednočinka njegovo prvo napisano djelo; ono, dakle, sadrži Hofmannsthalovo najranije promišljanje o biti esteticističke egzistencije.

\subsubsection{Eksplicitni rod}

Tema ove drame, prema riječima Hofmannsthalove suvremenice Marie Herzfeld, „slika je karaktera (impresionistička Charakterbild), koja se razvija u nizu dijaloga, a koji su fluidno sročeni od strane nekoliko likova u nekoliko situacija u komadu“. ${ }^{237}$ Andrea je „lik iz svijeta dekadentnog egoizma i amoralnog esteticizma. Taj egoizam nije čak niti sposoban sam sebe provesti, već se vraća u svoju „vlastitu kuću“ i gradi jedan svijet iz sebe samoga““238 (vlastiti mikrokozmos raspoloženja i dojmova). On retorički gradi svoj mikrokozmos sam iz sebe, jedan narcistički svijet koji je stran i dalek životu. Taj svijet koristi ljude kao poligone za svoj vlastiti perceptivni svijet: on „baca ljestve u carstvo materije i grube stvarnosti da bi na kraju dohvatio samo materijal za svoju stvarnost, koja je nematerijalni svijet snova “. ${ }^{239}$ Andrea doduše suosjeća s ljudima (posebice se pokušava empatijski uživjeti u Arlettinu ,žensku“

\footnotetext{
${ }^{234}$ Marie Herzfeld, cit. u: Wunberg 1981, str. 310.

${ }^{235}$ Ibid., str. 311.

${ }^{236}$ Pojam koji koristi Pfister 2001, str. 90.

237 Članak Marie Herzfeld u knjizi Gottharta Wunberga Wiener Moderne, 1981, pod naslovom Ein junger Dichter und sein Erstlingstück, Über Hugo von Hofmannsthal Gestern: str. 310.

${ }^{238}$ Ibid., str. 311.

239 Ibid.
} 
situaciju): on se empatijski uživljava u duše svih oko njega a ipak se od svih ljudi izolira, te pretače tuđe osjećaje u autorefleksivno i narcističko razmišljanje. „Uživljavanje u tuđe psihe i doživljaje nadomješta njegove neproživljene osjećaje, senzacije i strahove, koje mu njegovo vlastito ograničeno jastvo ne može omogućiti; to je suosjećanje koje odražava rezerviranost sebstva, puku znatiželju prema drugima i poriv za spoznajom, koja je jedina Andreina aktivna muški konotirana karakteristika i jedino životno uporište, koje mu još preostaje kao modernom dekadentu“. ${ }^{240}$ „I tako nastaje iz tog „suosjećanja“, čiji je pokretač virtuozni hedonizam jednog skeptičnog egoista, jedna vrsta panteizma, jedna identifikacija, koja nije rastakanje jastva u svemir, već prelaženje svemira u to jastvo.“241 Andreino ponašanje je dekadentno, regresivno, skepticističko i kulturno pesimističko, pa i pomalo u stilu mizoginije Otta Weiningera. Nije slučajno da je Hofmannsthal kao vrijeme radnje odabrao renesansno razdoblje. Prema Achimu Aurnhammeru, renesansno je razdoblje obilježeno ludičkom zamjenom rodnih uloga u dvorskom miljeu. ${ }^{242}$ Što se tiče barokne dikcije u drami Gestern, ona je obilježena visokom stiliziranošću, težnjom da se stil i sadržaj sjedine. Tematski je, pak, prema riječima Marie Herzfeld, Gestern odraz impresionističke „filozofije jednog čovječanstva koje živi od danas na sutra, od mrvica trenutačnih doživljaja“243 (vedri hedonizam bečke moderne).

U fokusu ove Hofmannsthalove jednočinke je, dakle, muški lik, koji kroz obilje monoloških replika izražava vlastiti, često na impresionistički način promjenjivi stav o prirodi žene i bračnoj nevjeri, te o rodnim odnosima njegova vremena općenito. Na samom kraju drame lik esteta Andree, u svojevrsnom obraćanju samome sebi (monolog), ženi (Arlette) i publici (lat. ad spectatores), karakterizira žensku prirodu (viđenu kroz muški pogled na ženu, engl. male gaze, ali i svojevrsni empatijski, anti-tradicionalni pristup ženi) donekle na tragu Weiningerova pristupa ženskom spolu, u kojem se žensko biće percipira kao ,apsolutna žena، ${ }^{\text {‘244 }}$ i povezuje s onim prirodnim, instinktivnim, kao i s emocionalnim mijenama. Kroz ove Andreine generalizacije i stereotipne karakterizacije žene kao prirodnog bića (njem. Naturwesen Frau), sam ženski glas ostaje utišan i sveden na replike manjeg obujma i manje uvjerljivosti. No iako se u cijelom tekstu donekle perpetuira teza o rodnoj asimetriji, o hijerarhijskoj nadmoći muškog spola (veći udio izgovorenog teksta izgovara glavni protagonist djela, estet Andrea), s druge se strane ipak tematizira obrat u muško-ženskim

\footnotetext{
240 Članak Marie Herzfeld u knjizi Gottharta Wunberga Wiener Moderne, 1981, pod naslovom Ein junger Dichter und sein Erstlingstück, Über Hugo von Hofmannsthal Gestern: str. 310.

${ }^{241}$ Ibid.

${ }^{242}$ Usp. Aurnhammer, 1986.

${ }^{243}$ Herzfeld, cit. u: Wunberg 1981, str. 311.

244 vidi Weininger: Geschlecht und Charakter, 1920, str. 232.
} 
odnosima (ženska nevjera, odnosno zamjena onodobnih stereotipnih rodnih uloga) i problematizira feminizacija i fragmentacija jastva esteta te njegovo empatijsko i patetično uživljavanje u žensku ,esenciju“.

S druge strane, Andreina žena Arlette prikazana je stereotipno: ona predstavlja utjelovljenje žene kao prirodnog, instinktivnog bića u stilu koncepcije Otta Weiningera (njem. absolutes Weib, Frau als Naturwesen), ${ }^{245}$ dok se muškarcu, Andrei, pridaje karakteristika centralne (transcendentalne) svijesti, koja na tematskoj razini odgovara koncepciji muškarca kao nadređenog bića kulture i umjetnosti (njem. Kulturwesen Mann), iako se njegova esteticistička egzistencija latentno kritizira. Dok je glavni muški lik u drami Gestern pasivni i receptivni estet (feminizacija esteta), glavni ženski lik, napose u završnom Andreinu monologu, predstavlja zagonetnu „Drugost“ i nestalnost ženske prirode (stereotipna koncepcija žene).

U drami Gestern se, osim glavne radnje koja opisuje konfrontaciju Andree i njegove supruge Arlette oko njezine bračne nevjere, pojavljuju i često epizodne, odnosno sporedne radnje (npr. susret Andree s Marsiliom u drugoj sceni, koji nije od presudne važnosti za cjelokupnu radnju drame). Scene koje su od presudne važnosti za tijek radnje su napose prva, treća, sedma i zadnja scena, dok su scene u kojima se izravno sučeljavaju Andrea i Arlette prva i zadnja scena. Na samom početku drame, kad se otkriva Arlettina prijevara, publika je još nedovoljno informirana (njem. Informationsrückstand). Tek u drugom dijelu te iste prve scene dobivamo informaciju da se radi o bračnoj nevjeri, a daljnja se radnja razvija u nizu reakcija esteta na ovu problematiku. Radnja se, kao i u najvećem dijelu dramske tradicije razvija kronološki.

Drama započinje Andreinim ulaskom u kuću, pri čemu zamalo uhvati svoju ženu u preljubu s njegovim prijateljem Lorenzom. Arlette s pomoću ženske lukavosti i prijetvornosti, koje ju stavljaju u red senzualnih žena Weiningerovske tipologije, pokušava uvjeriti Andreu u njezinu vjernost njemu. Aludira na njihov romantičan susret u parku Trevi, ali Andreina replika označava impresionističku potku djela, koja naglašava tri onodobna pojma (koncepta), a koji prožimaju cijelu jednočinku: 1. die Laune (ćudljivost, hirovitost), 2. Trieb (nagon), 3. Stimmung (raspoloženje, ili trenutno raspoloženje), aludirajući na prolaznost ovozemaljske ljubavi i izražavajući onodobni koncept prolaznosti svega (poput Hofmannsthalovog stiha „Daß alles gleitet und vorüberrinnt“ $).{ }^{246}$ Arlette glumi svoju ljubav prema Andrei, oslanjajući se na stereotipne ženske karakteristike. Međutim, treba također naglasiti da je, u prvoj sceni,

\footnotetext{
${ }^{245}$ vidi Weininger: Geschlecht und Charakter, 1920, str. 232.

${ }^{246}$ Vidi Hofmannsthalovu pjesmu pod naslovom Terzinen (Über Vergänglichkeit, 1. dio), str. 21.
} 
Arlette tijekom jedne vožnje brodom po olujnom moru nesvjesno zamijenila Andreu s njegovim prijateljem Lorenzom. ${ }^{247} \mathrm{Kad}$ Andrea, poput narcisoidnog umjetnika, izjavi da ga ženski spol voli ,isključivo zato što je najpametniji““248, Arlette mu u stilu žene-virago odgovara da ga ,ženski spol voli, jer ga može iskorištavati“‘249, upućujući 1. na ludičku renesansnu zamjenu muško-ženskih uloga, i 2. na feminizaciju esteta. Andreina ponovna replika (i kraći monolog) ide u smjeru konstatacije kako je jastvo pojedinca jedini izvor poimanja svijeta, aludirajući na supremaciju jastva narcističkog esteta, koje samo iz sebe stvara svoj svijet.

U ovoj je drami naglašena pasivnost esteta, koji ne reagira sa strastvenim renesansnim osjećajima, već se povlači u samotni oblik rezignacije. Ova supremacija perceptivnog svijeta i prevlast osjeta upućuju na esteticističku i impresionističku kulturu, te na Hofmannsthalovu recepciju Machovog djela Analyse der Empfindungen, u kojem Mach postulira promjenjivost percepcija i osjeta unutar isključivo subjektivnog svijeta pojedinca i naglašava koncepciju fluidnog (promjenjivog) jastva (njem. das Ich ist unrettbar). ${ }^{250}$ Andrea na samom početku oprašta Arletti njezinu nevjeru, oslanjajući se na impresionističku letimičnost dojmova i ljudskih percepcija: „Jučer je lažno a samo ono što je danas je istina!“‘251; „I kad bi me prevarila i iznevjerila moju ljubav,/ Ipak bi za mene ostala ona ista!“ ‘. ${ }^{252}$ Andrea zatim, utišanim glasom, koji djelomično predstavlja repliku sa strane (lat. a parte) izriče izreku u stilu baroknog proverbija, koja služi kao provodni motiv cijelog djela Gestern: „Ta život je nijemi nastavak putovanja/ Milijuna ljudi, koji se ne razumiju,/ A kad dvoje i pogledaju u oči jedno drugo,/ Svatko vidi u onome drugome samo sebe.“253 Andrea naglašava kult jastva: opservaciju koja kazuje da i u onima, koje naziva prijateljima, pojedinac ,jasnije prepoznaje svoje jastvo, odnosno samoga sebe“ “. ${ }^{254}$ Andreine i Arlettine su percepcije i želje od trenutka do trenutka podložne promjeni, što upućuje na ćudljivost, koja je tradicionalno bila konotirana kao ženska karakteristika. Posebice se ovo može uočiti u sljedećem Andreinom monologu: „U meni vrije žestoka želja/ da odjašem brzo, ludo.../ Što me se to tiče, ako je ćudi udovoljeno!/

\footnotetext{
${ }^{247}$ Hofmannsthal Handbuch 2016, str. 172.

248 „Die lieben mich, weil ich der Klügste bin“, Gestern, str. 215.

249 "Sie lieben dich, weil sie dich brauchen können", Gestern, str. 215.

250 Andrea: „Nur aus sich selber strömt, was wir empfinden,/Und nur Empfindung findet rück die Pforte:/ Ohnmächtig sind die Taten, leer die Worte!/ Ergründen macht Empfinden unerträglich,/ Und jedes wahre Fühlen ist unsäglich...“, Gestern, erste Szene: str. 215.

251 „Das Gestern lügt und nur das Heut ist wahr!“, Gestern, str. 215.

252 „Und wenn du mich betrögest und mein Lieben,/ Du wärst für mich dieselbe doch geblieben!”, Gestern, str. 215.

${ }^{253}$ „Es ist ja Leben stummes Weiterwandern/ Von Millionen, die sich nicht verstehn,/ Und wenn sich jemals zwei ins Auge sehn,/ So sieht ein jeder sich nur in dem andern.“, Gestern, erste Szene: str. 216.

${ }^{254}$ Arlette: Und was sind jene, die wir Freunde nennen!; Andrea: „Die, drin wir klarer unser Selbst erkennen“, Gestern, erste Szene: str. 216.
} 
Neki drugi put teče kroz moju dušu/ Nejasna žudnja/ Za tonovima, koji me drhturavo obavijaju...“. ${ }^{255}$ On naglašava da sve što živi živi isključivo kroz život ljudske ćudi, kaprice, promjene raspoloženja. Slika svijeta je, prema Andrei, naša subjektivna slika svijeta, slika svijeta prema našim percepcijama i „kompleksima osjeta“ (shodno konceptima filozofa impresionizma Ernsta Macha), koja se odražava i kroz izrazito subjektivnu koncepciju vremena u ovoj jednočinki i ,transcendenciju“ unutarnjeg svijeta esteta. Društvene komponente gotovo da i nema: koncept ženine nevjere pomaknut je u sferu i u fokus narcističkog jastva esteta. No ipak, u ovom amoralnom esteticizmu, konceptu promjenjivosti ljudske ćudi, Andrea izražava i blagu skepsu prema ovim mijenama, kao i svojevrsnu etičku misao o prolaznosti ovozemaljskog užitka: „Jer, samo jedan strah postoji u mojoj duši:/ Da sam ipak propustio ono najuzvišenije, najdublje!“6256, „Stoga, Arlette, osjećam tjeskobu pri svakom užitku (...) Sumnja kriči u meni pri svakom poljupcu“, povezujući tu skepsu sa strahom od smrti, ali istovremeno i čežnjom za nečim uzvišenijim od ovozemaljskoga.

Misao o promjenjivosti ljudskog jastva, isticanje hedonizma i samoinscenacije života izraženi su i u sljedećoj Andreinoj rečenici, pri čemu prva dva stiha ipak sadrže naznaku nekih viših etičkih vrijednosti, nečega uzvišenog za čime svako ljudsko biće traga, ali i ta spoznaja potom biva prožeta skepticizmom epohe i spoznajom o ljudskom konformizmu: „Srce ne sluti ono što mu nedostaje/ I što mu dopadne, to drži vrijednim/ Ali ja ne želim polusan, želim buđenje/ Želim svoj život osjećati, opjevati, stvoriti!‘ ${ }^{257}$ Stvaralački zanos koji Andrea osjeća zapravo je narcistička samoinscenacija vlastitog života u kult umjetnosti. Nakon što Arlette spomene jučerašnji dan (dan njezine nevjere), Andrea odgovara teoretizirajućom replikom o biti sadašnjeg, trenutačnog, perceptivnog trenutka, naglašavajući pojam impresionističke letimičnosti dojmova, osjećaja i misli:

Moraš li stalno ometati danas jučerašnjim danom?“, „Čitav jaz nas dijeli od toga dana, sedam sati/ Zauvijek je taj jučerašnji dan nestao!“, „Ako se odučiš od ustrajanja na jučerašnjem danu/ od osluškivanja toga mrtvog, šupljeg zova:/ Pusti da ti promjenjive silnice današnjice/ Užici i patnje, šume kroz dušu/ Zaboravi ono nerazumljivo, ono što je bilo: /Jučer laže a samo je danas istinito!/ Pusti da te ponese svaki trenutak,/To je put za ostati samom sebi vjeran/ Slijedi trenutno raspoloženje, (...) Predaj mu se, tako ćeš sačuvati samu sebe/ Jer od već preživljenoga prijete ti opasnosti (...)“. ${ }^{258}$ Andrein

\footnotetext{
255 „Es gärt in mir ein ungestümes Wollen,/ Nach einem Ritt, nach einem wilden, tollen.../Was kümmerts mich, die Laune ist gestillt!/ Ein andermal durch meine Seele quillt/ Ein unbestimmtes, schmelzendes Verlangen/ Nach Tönen, die mich bebend leis umfangen...“, Gestern, erste Szene: str. 216.

${ }^{256}$ „Weil eine Angst nur ist in meiner Seele:/ Daß ich das Höchste, Tiefste doch verfehle!“”, „Darum, Arlette, bangt mir im Genusse (...) Ein Zweifel schreit in mir bei jedem Kusse“, Gestern, erste Szene: str. 217.

${ }^{257}$ „Es ahnt das Herz je nicht, was es entbehrt,/ Und was ihm zugefallen, hält es wert./ Ich aber will kein Dämmern, ich will Wachen,/ Ich will mein Leben fühlen, dichten, machen!, Gestern, erste Szene: str. 217.

${ }^{258}$ „Mußt du mit gestern stets das Heute stören?“; „Ein Abgrund trennt uns davon, sieben Stunden,/ Für immer ist dies Gestern hingeschwunden!“; „Verlerntest du am Gestern nur zu halten,/ Auf dieses Toten hohlen Ruf zu lauschen:/ Laß dir des Heute wechselnde Gewalten,/ Genuß und Qualen, durch die Seele rauschen,/ Vergiß das
} 
hedonizam vidljiv je i u trećoj sceni, u riječima: „Život može pružiti još mnogo toga neproživljenoga $(\ldots . .)^{259}$

Međutim, sukladno Machovoj koncepciji fluidnog jastva, on odmah mijenja svoj stav: „Samo na jedno ne želim nikada pomisliti: Koliko će sve te stvari biti isprazne, kad ih jednom iskusim!“‘.260 Ovdje Hofmannsthal ističe svoju kritiku vedrog hedonizma i amoralnog esteticizma. Česte promjene Andreinog raspoloženja koje su izražene u didaskalijama (npr. „prvo nestrpljivo, a potom s toplinom koja raste iz trenutka u trenutak“ ${ }^{261}$ također upućuju na Machovu koncepciju fluidnog jastva, kao i sljedeći stihovi: „Zar se ćud ne mijenja, zar nema tu snagu?/ Zar se ne budi i ne umire svaka strast?/ Tko nas je učio da naziv „duša“ damo/ Koegzistenciji tisuće života?/ Što je to što čini staro poželjnim a novo lošim?,“262 Ovi stihovi su radikalni primjer onodobne krize metafizičkog nazora na svijet, posebice teza o nepostojanju nekog fiksnog jastva, odnosno fiksnog pojma duše, i svođenju pojma duše na Machovu tezu o kompleksima osjeta. Ovdje se, posebice u nastavku, problematizira pojam problematičnog održanja vjernosti u ljubavi, posebice u sljedećim stihovima: „Tko smije zahtijevati, tko obećati vjernost?“263 Različiti stavovi o smislu ljudske egzistencije i različita, potpuno oprečna naličja ljudskog bića izražena su u sljedećim stihovima: „Nije me strah nijednog moga nagona:/ Osluškujem samo ono što svaki nagon zahtijeva!/ Jedan želi drhtati u askezi/ Okružiti se čednim Giottovim anđelima,/ Drugi želi zrelo ruho života...“264, koji demonstriraju nestalnost ljudskog jastva, dualizam duše i tijela u ljudskom životu. Prema Freudovoj koncepciji, jastvo više nije gospodar u vlastitoj kući, odnosno ljudsko biće teško može ovladati svojim porivima: porivi ovladaju njime („Ti ne nosiš svoje raspoloženje, već puštaš da ono tebe nosi!“‘) ${ }^{265}$. Andrea, u stilu hedonizma i amoralnog esteticizma odgovara Fortuniju na njegovu repliku: „Zar nije ovo „prepuštanje“ također jedan oblik djelovanja?/ Zar nije mudro svojom voljom se mijenjati,/ Kad se mi moramo neprestano mijenjati?/ Novim osjetilima osjetiti novu požudu,/ Kad one stare žudnje izgube svoju draž,/ Od jučerašnjeg

Unverständliche, das war:/ Das Gestern lügt und nur das Heut ist wahr!/ Laß dich von jedem Augenblicke treiben,/ Das ist der Weg, dir selber treu zu bleiben;/ Der Stimmung folg, (...) Gib dich ihr hin, so wirst du dich bewahren,/ Von Ausgelebtem drohen dir Gefahren (...)“, Gestern, erste Szene: str. 218.

259, „Noch ungefühltes kann das Leben schenken (...), Gestern: str. 222.

260 "Nur an das eine möcht ich niemals denken: Wie schal dies sein wird, wenn ichs ausgelebt!, Gestern: str. 222.

261 „erst ungeduldig, dann mit steigender Wärme“, Gestern: str. 223.

262 „Hat nicht die Laune Wechsel, nicht die Kraft?/ Erwacht und stirbt nicht jede Leidenschaft?/ Wer lehrte uns, den Namen „Seele“ geben/ Dem Beieinandersein von tausend Leben?/ Was macht das Alte gut und schlecht das Neue?, Gestern: str. 223.

${ }^{263}$ „Wer darf verlangen, wer versprechen Treue?“", Gestern: str. 223.

264 „Mir ist von keinem meiner Triebe bange:/ Ich lausche nur, was jeglicher verlange!/ Da will der eine in Askese beben,/ Mit keuschen Engeln Giottos sich umgeben,/ Der andere will des Lebens reife Garben...", Gestern: str. 223.

${ }^{265}$ „Du trägst die Stimmung nicht, du lasst dich tragen!“, Gestern: str. 223. 
dana se otrgnuti slobodnom snagom... “266. Jedino što Andrea poštuje, to je nagon, trenutačni poriv, i kod njega nema želje za nekim višim moralnim standardima. Andrea čak i umjetnost izjednačuje s nagonom, sa ,zlatnim lažima“, odnosno, on postavlja umjetnost kao lijepu laž: „O lijepe laži,.../ Poriv umjetnosti, na nesvjesnim usnama!“‘267. Opreka Schein (privid) i Sein (bitak) izražena je u sljedećem stihu: „Sve dok se laž i istina potpuno ne stope“ ${ }^{268}$ Ustrajanje na prolaznosti trenutka izraženo je i u sljedećoj rečenici: „Koliko čovjek čini svetogrđe kad pothranjuje ono što je mrtvo,/ A nagon navike pogrešno naziva „,ciljem““269. U šestoj sceni Arlette na stereotipno ženski, koketan i prijetvoran način uvjerava kardinala u svoju vjernost Andrei, dok on koristi situaciju da lascivnim odnosom prema njoj i njenoj ženskosti dekonstruira tu tvrdnju o tobožnjoj vjernosti. U ovoj sceni uočavamo perpetuiranje muškoženskih stereotipa, pomalo u stilu commedie dell'arte. U sedmoj sceni Andrea ponovo u stilu baroknog proverbija izriče sljedeći stih: „Zar nije cijela vječna priroda/ Samo simbol ćudljivosti naše duše?/ A što mi u njoj drugo i tražimo doli naš vlastiti trag?“", ${ }^{270}$ koji ponovo naglašava Machovu koncepciju naše subjektivne slike svijeta, svijeta jedino kao odraza naših percepcija, potvrđuje habitus egoističnog esteta. U osmoj sceni se također pojavljuje jedan barokni proverbij, koji simbolizira doba vakuuma a istovremeno i potrage za nekim višim smislom života: „U jednom životu bez smisla izgubljeni:/ A rijetko se bliži ono što nazivamo milošću,/ Svetom, istinskom spoznajom,/ Kojoj težimo kao najvišoj milosti/ Najvećeg znanja i najveće umjetnosti““ ${ }^{271} \mathrm{U}$ devetoj sceni pjesnik Fantasio izriče svoj stav o prirodi trenutka i trenutačnog osjećanja, sročenog u pojmu ,slučajnog“, odnosno koincidentnog, što upućuje na radikalni oblik skepticizma epohe i amoralnog esteticizma u kojem se etičke vrijednosti, koje važe kao stup društva, dovode u pitanje: „Trebamo se prepustiti slučaju,/ Jer prave razloge ipak ne možemo nikada dokučiti!“‘. 272

Andrea u devetoj sceni izjavljuje da mu je samo ono trenutačno važno, da bi na kraju to u desetoj sceni u potpunosti opovrgnuo, rekavši kako je jučerašnji dan još prisutan, kako je jučerašnji dan čvrsto povezan s Arlettinim bitkom: „ovo jučer je toliko povezano s tvojim

\footnotetext{
266 „Ist nicht dies „Tragenlassen“ auch ein Handeln?/ Ist es nicht weise, willig sich zu wandeln,/ Wenn wir uns unaufhaltsam wandeln mussen?/ Mit neuen Sinnen neue Lust zu spüren,/ Wenn ihren Reiz die alten doch verlieren,/ Vom Gestern sich mit freier Kraft zu reißen..., Gestern: str. 223.

${ }^{267}$ „O goldne Lügen,.../ Ein Trieb der Kunst, im unbewußten Mund!“, Gestern: str. 225.

268 „Bis Lüg und Wahrheit sanft zusammenfließen“, Gestern: str. 225.

269 "Wie sehr man frevelt, wenn man Totes nährt,/ Und der Gewohnheit Trieb mißnennet „Ziel“; Gestern: str. 226.

${ }^{270}$ „Ist nicht die ganze ewige Natur/ Nur ein Symbol fur unsrer Seelen Launen?/ Was suchen wir in ihr als unsre Spur?, Gestern: str. 232.

${ }^{271}$ „In einem Leben ohne Sinn verloren:/ Und selten nahet, was sie Gnade nennen,/ Das heilige, das wirkliche Erkennen,/ Das wir erstreben als die hochste Gunst/ Des großen Wissens und der großen Kunst“, Gestern: str. 235-236.

272 „Wir sollen uns dem Zufall überlassen,/ Weil wir ja doch die Gründe nie erfassen!“, Gestern: str. 237.
} 
bitkom,/ Ne možeš ga izbrisati niti zaboraviti:/ Ono jest, dokle god znamo da je bilo“. ${ }^{273}$ Andrea nastavlja svoj završni monolog konstatacijom o rastanku s Arlette, ali i o načelnom empatijski prožetom opraštanju, koje nosi obilježje senzibilnog esteta: „I to što si me prevarila i iznevjerila moju ljubav,/ Nije ostao nijedan bolni trag.../ Ipak, jedno ti nikad neću oprostiti:/ To što si uništila topli, svijetli sjaj,/ Koji je za mene postojao u vremenu koje je minulo.“274 Potom se u sporednom tekstu kratko opisuje emotivno stanje feminizacije esteta, ali i empatijski potencijal suosjećanja s ženom koje nadilazi rodne stereotipe. U završnim riječima svog monologa, estet Andrea pokazuje empatijsko uživljavanje u bit ženske psihe, iako je ovo uživljavanje obilježeno i stereotipnim poimanjem žene kao tajanstvene „Drugosti“, a u Weiningerovskom smislu i čiste senzualnosti:

Tako dobro mogu razumjeti nevjerne žene.../ Tako dobro da mi se čini da mogu gledati u njihove duše./ U njihovim očima vidim žudnju da se predaju,/ Da drhte u žudnji prema nikad iskušanom, prema zabranjenom.../ Žudnju za igrom, žudnju da same sebe stave na kocku,/ Požudu za pobjedom i zanosom, za prijevarom i ranjavanjem.../ Vidim njihov osmijeh i (zastajući) nerazumne suze,/ Zagonetno traganje, nemirnu čežnju.../ Osjećam kako ih to tjera na nerazborite odluke,/ Kako zatvaraju oči i kako moraju mučiti,/ Kako svako jučer pokapaju da bi našle sutra,/ I kako ne razumiju to što su ubile čovjeka. (Guši se u suzama). ${ }^{275}$

Ovdje možemo primijetiti kako žena biva koncipirana kao čisto prirodno biće (njem. Naturwesen Frau), dok ona s druge strane na neki način predstavlja i animu samog esteta. Obrat u Andreinu ponašanju može se također protumačiti kroz impresionističku letimičnost dojmova $^{276}$, koja ukazuje na promjenu percepcija od trenutka do trenutka, koja je izražena kroz lik senzibilnog i senzualnog esteta.

\subsubsection{Implicitni rod}

Hofmannsthalov Gestern lirska je drama, odnosno, drama u stihovima: ova vrsta drame bila je pogodna za prikaz impresionističkog nizanja percepcija, dojmova i raspoloženja glavnog

\footnotetext{
273 „dies Gestern ist so eins mit deinem Sein,/ Du kannst es nicht verwischen, nicht vergessen/ Es ist, so lang wir wissen, daß es war", Gestern: str. 242.

${ }^{274}$ „Und daß du mich betrogen und mein Lieben,/ Davon ist kaum ein Schmerz zurückgeblieben.../ Doch eines werd ich niemals dir verzeihn:/ Daß du zerstört den warmen, lichten Schein,/ Der für mich lag auf der entschwundnen Zeit, Gestern: str. 242-243.

275 „Ich kann so gut verstehen die ungetreuen Frauen.../ So gut, mir ist, als könnt ich in ihre Seelen schauen./ Ich seh in ihren Augen die Lust, sich aufzugeben,/ Im Niegenossenen, Verbotenen zu beben.../ Die Lust am Spiel, die Lust, sich selber einzusetzen,/ Die Lust am Sieg und Rausch, am Trügen und Verletzen.../ Ich seh ihr Lächeln und (stockend) die törichten, die Tränen,/ Das rätselhafte Suchen, das ruhelose Sehnen.../ Ich fühle, wie sies drängt zu törichten Entschlüssen,/ Wie sie die Augen schließen und wie sie quälen müssen,/ Wie sie ein jedes Gestern für jedes Heut begraben,/ Und wie sie nicht verstehen, wenn sie getötet haben. (Tränen ersticken seine Stimme).“, Gestern: str. 243.

${ }^{276}$ Vidi Žmegač: Duh impresionizma i secesije, 1993. str. 15-27.
} 
protagonista, za ocrtavanje njegovog subjektivnog univerzuma, ali je služila i kao adekvatan žanr u prikazivanju fluidnog i ontološki nestabilnog jastva esteta. Ova, kako ju je Hofmannsthal nazvao „dramska studija“ predstavlja svojevrsnu analizu i tematiziranje (esencijaliziranje) ženskosti i ženske nevjere, ali i vrstu sublimne igre rodnih konstelacija i identiteta koja se donekle čak pretače i u komični žanr.

Hofmannsthalova je lirska jednočinka podijeljena na deset scena, koje su manjeg opsega, a već sam podnaslov Dramatische Studie in einem Akt in Versen (prev. s njem., dramska studija u jednom činu i u stihovima) ukazuje na njezinu eksperimentalnu prirodu, kako na razini motiva bračne nevjere kroz zamjenu rodnih uloga, tako i na razini dramske forme impresionističkog monološkog poniranja u svijet percepcija, osjećaja i raspoloženja glavnog muškog lika, esteta Andree. Prema riječima Marie Herzfeld, Gestern predstavlja „studiju u rimama“, „psihološku studiju rijetke jezgrovitosti i frapantne osebujnosti, u graciozno izgrađenim, elegantnim stihovima“. ${ }^{277}$

U djelu donekle prevladava struktura zatvorene perspektive ${ }^{278}$, tip drame u kojem recipijent sam mora dokučiti konvergencijsku liniju korespondirajućih i kontrastirajućih perspektiva likova, odnosno mora sam odgonetnuti intendiranu recepcijsku perspektivu: kontrastirajući perspektive Andree i Arlette, te suprotstavljajući fluktuacije (oprečna razmišljanja) lika Andree, aktivira se rasudbena moć gledatelja (ili čitatelja) drame odnosno kazališnog komada, odnosno recepcijska perspektiva. Direktna didaktičnost na taj način ustupa mjesto indirektnom modusu prezentacije različitih stajališta. ${ }^{279}$ Treba naglasiti kompleksnost (višedimenzionalnost, otvorenost i dinamičnost) koncepcije psihe glavnog protagonista $u$ vidu impresionizma njegove dikcije, shodno koncepciji Ernsta Macha koja glasi „das Ich ist unrettbar", ali s druge strane i stereotipnost (tipizaciju) njegovog lika esteta, koji predstavlja identifikacijsku figuru onodobne generacije esteta (problematizacija umjetničkog jastva u bečkoj moderni).

Ova Hofmannsthalova lirska drama, međutim, sadrži i neke epske elemente: npr. opširne monologe esteta Andree, zatim karakteristiku dokidanja dramskog finaliteta ${ }^{280}$, budući da ova drama ne teži $\mathrm{k}$ nekom teleološkom završetku konflikta, već završava Andreinim generalizirajućim empatijskim stavom o ženskoj prirodi, koji proizlazi iz njegova subjektivnog stava. Međutim, drama ipak donekle teži finalitetu- usmjerena je k razrješenju

\footnotetext{
${ }^{277}$ Vidi Marie Herzfeld, članak pod naslovom „Ein junger Dichter und sein Erstlingsstück (str. 310-211.) u knjizi Gottharta Wunberga: Wiener Moderne, 1981, str. 310.

${ }^{278}$ Vidi Manfred Pfister: Das Drama, 2001, str. 101.

${ }^{279}$ Ibid., str. 101-104.

${ }^{280}$ Ibid., str. 103-104.
} 
Andreine dvojbe oko nevjere vlastite žene, što je povezano s napetošću orijentiranom na kraj radnje. Varijabilnost i promjenjivost subjektivne stvarnosti i stavova esteta Andree služi kao svojevrsni retardirajući moment.

Budući da drama počiva na izvještajnom modusu (u stilu književnog impresionizma), više nego na modusu prikaza, Gestern ne obiluje toliko nekom razrađenom radnjom (odnosno, dinamičnom strukturom radnje), već se orijentira na impresionistički prikaz centralnog unutarnjeg konflikta i unutarnjih fluktuacija glavnog muškog protagonista.

$\mathrm{Na}$ samom početku drame pojavljuje se poduža didaskalija kojom se uvodi problematika esteticizma i dekadencije u drami, predstavljajući eksterijer Andreine kuće u Imoli, dok se vrijeme radnje označuje kao razdoblje kasne renesanse (svojevrsna paralela sa suvremenim esteticizmom), tj. razdoblje velikih renesansnih slikara. Nakićenost eksterijera također upućuje na feminizaciju esteta (njegovu sklonost ornamentalnom i dekorativnom).

U ovom se Hofmannsthalovu djelu pojavljuju i didaktičke i apstraktne maksime, generalizirajuće istine o prirodi muško-ženskih odnosa i o esteticizmu općenito: ovo distancirano, monološko komentiranje esteta, ovo ispadanje iz vlastite uloge (njem. Aus-derRolle-Fallen) donekle transcendira prostorno-vremenski obrazac situacije i potiče gledatelja (čitatelja) na formiranje vlastite recepcijske perspektive. Općevažeće apstraktne maksime (proverbiji) ili sentence pojavljuju se kad refleksija ili komentar lika premašuju stanje svijesti lika (time lik poprima obilježje transpsihološki koncipiranog lika). ${ }^{281}$

U jednočinki se demonstrira trajno stanje, odnosno habitus esteta, iako ne završava cikličkim vraćanjem na početak drame, kao što se to događa, primjerice, u Schnitzlerovom djelu Reigen s eksperimentalnim konstelacijama parova, već kraj drame predstavlja konačnu Andreinu konstataciju o prirodi žene (odluku da joj ne može do kraja oprostiti, ali da se ipak empatijski konsolidira s njezinom zagonetnom ženskom prirodom, njezinom „Drugošću“). Na taj način kraj ove Hofmannsthalove drame ostaje samo provizornim, pa donekle odražava i skepticizam epohe u vezi rodnih pitanja i dinamike rodnih odnosa. Fokus na stanja svijesti glavnih likova (posebice Andree), epizodne sekvence i druga obilježja odgovaraju tipu otvorene drame. Međutim, budući da se očuvalo aristotelijansko jedinstvo mjesta, vremena i radnje, te da drama ipak ima provizorni završetak i fiksan početak, postoje i obilježja drame zatvorenog tipa.

Budući da Gestern predstavlja modernu dramu u stihovima (njem. „Versdrama“), u njoj se dikcija i jezična komunikacija poetiziraju, retorički stiliziraju i metrički reguliraju (stih:

\footnotetext{
${ }^{281}$ Pfister 2001, str. 120.
} 
petostopni jamb). Stoga se uspostavlja velika distanca prema „normalnom“, odnosno standardnom jeziku, što je formalno obilježje esteticizma. Što se tiče funkcija dramskog govora, prevladavaju ekspresivna (emotivna, izražajna) funkcija, u kojoj se otkriva karakter lika, njegovi osjećaji i misli, koje upućuju na dramski lik koji izgovara repliku ${ }^{282}$, napose u obliku refleksijskog monologa (Andrea, često u 1. licu jednine, ali i apelativnom „,du“), zatim apelativna funkcija, koja se fokusira na komunikacijsku vezu s dijaloškim partnerom (Andrea prema Arlette) i odražava ponekad svojevrsnu hijerarhijsku dominaciju muškarca nad ženom, a ponekad empatijsko obraćanje ženi, i poetska funkcija, budući da Gestern predstavlja visoko stiliziranu komunikaciju u stihovima. Ova je funkcija iskaz cijeloga teksta drame, budući da predstavlja estetski gustu formu na temu esteticističke egzistencije, posebno monolozi esteta Andree sadrže jaku poetsku stilizaciju govora uz veliku poetsku gustoću ${ }^{283}$, brojne usporedbe i metafore i ritmičko oblikovanje. Poetska karakteristika jezika „služi usmjeravanju empatije recipijenta“، ${ }^{284}$

Monolozi esteta Andree uglavnom su upućeni vlastitoj ženi (Arlette), pa prema tome više korespondiraju s anglosaksonskim terminom monologue, za razliku od termina soliloquy, koji predstavlja čisti razgovor sa samim sobom i nije namijenjen drugim protagonistima. ${ }^{285} \mathrm{~S}$ druge strane, i unutar samih Andreinih monologa pojavljuju se različiti konteksti i različita, oprečna mišljenja, koja ukazuju na psihološku podvojenost subjekta. U tom smislu riječ je o tipu dijaloškog monologa, motiviranog i spontanog monologa kao reakcije na ženinu nevjeru (jedinstvo mišljenja, osjećanja i govora). To su ujedno statični monolozi koji nemaju tendenciju k akciji, već određenoj vrsti kontemplacije i prikaza stanja svijesti, lirski i refleksivni monolozi koji služe kao vrsta komentara. U zadnjem Andreinom monologu vidljiva je tendencija transpsihološke konvencionalnosti monologa, budući da estet izražava generalizirajuće stavove o ženskoj dispoziciji, koji služe kao svojevrsni komentari o ženskoj prirodi i premašuju samu psihologiju lika.

Barokni proverbiji, koji su relativno kratki segmenti ovih monologa, premašuju stanje svijesti osobe koja govori i predstavljaju opće ,istine“. U drami Gestern nailazimo na veću prisutnost pathosa i ethosa naspram logosa, budući da je ova drama ipak prvenstveno orijentirana na ekspresivnu i apelativnu funkciju govora.

\footnotetext{
${ }^{282}$ Pfister 2001, str. 157.

${ }^{283}$ Ibid., str. 166.

284 Ibid., str. 167.

${ }^{285}$ Ibid., str. 180. i dalje.
} 


\subsubsection{Zaključak}

Nastanak djela Gestern popraćen je intenzivnim Hofmannsthalovim bavljenjem talijanskom renesansom i Nietzscheovim djelom Menschliches, Allzumenschliches. ${ }^{286}$ Ova Hofmannsthalova lirska drama u stihovima naglašava antinaturalističku tendenciju. ${ }^{287}$

Radnja djela Gestern događa se u vrijeme velikih slikara u jednom danu u kući esteta Andree u Imoli. Jednočinka Gestern sastoji se od deset scena. Prva i zadnja scena prikazuju svaka po jedan dijalog između protagonista Andree i njegove žene Arlette, dok druga i deveta scena prikazuju Andrein razgovor sa svojim prijateljem iz mladosti Marsiliom.

Ciklička struktura, kao i manjak radnje ${ }^{288}$ tipične su za ovu Hofmannsthalovu poetsku formu: sentenciju u stihovima. Hofmannsthal sam o ovome svome djelu kaže sljedeće: „Na početku protagonist postavlja jednu tezu (govori da ga se jučer uopće ne tiče), a potom mijenja svoje mišljenje (obrće ovu svoju tezu) i konstatira da nikada neće moći zaboraviti jučerašnji dan.

Poezija esteta Andree upućuje na Hofmannsthalov habitus esteta, a povezana je i s autorovom implicitnom kritikom esteticizma, njegovim auto-refleksivnim promišljanjem onodobne krize identiteta, amoralnog i narcističkog esteticizma, promjene dinamike u rodnim odnosima i re-definiranja stava o ženi, ženskoj vjernosti i ženskoj „Drugosti““. Poetski intenzitet, prožet impresionističkom letimičnošću dojmova, nalazimo u ovoj Hofmannsthalovoj barokno-renesansnoj drami, dok manjak neke izvanjske radnje odražava poziciju glavnog protagonista (Andrea) kao senzibilnog, ali i pasivnog i receptivnog esteta, sklonog promjeni raspoloženja, što upućuje na njegovu krizu identiteta (njem. das unrettbare Ich). Likovi u ovome djelu imaju pretežno zvučna imena, koja je Hofmannsthal preuzeo iz renesansne književnosti.

Brojne didaskalije, koje u prvom redu služe kao kratki opisi emotivnih stanja likova, opsegom variraju posebice kod esteta Andree: u tome pogledu on demonstrira ženski konotiranu promjenjivost čuvstvenih stanja, napose u zadnjoj sceni i u završnom monologu. Hipersenzibilnost esteta simptom je njegove podložnosti ženama i ženskosti.

Lik Andree često je zapleten u idiosinkrazije vlastitog karaktera esteta, koje izražava duljim monolozima. Prema Manfredu Pfisteru, čak i sama „tendencija monološkog govora može upućivati na egocentričnost lika“, na želju za dominacijom, ${ }^{289}$ no s druge strane i na sklonost introspekciji (povlačenju esteta samoga u sebe), koja je tradicionalno konotirana kao ženska

\footnotetext{
286 Članak Achima Aurnhammera pod naslovom Gestern. Dramatische Studie (1891), u: Hofmannsthal Handbuch, Leben-Werk-Wirkung, Mayer/Werlitz (ur.), J. B. Metzler Verlag GmbH, Stuttgart, 2016., str. 172.

${ }^{287}$ Ibid., str. 172 .

288 Ibid.

${ }^{289}$ Pfister 2001, str. 179.
} 
karakteristika. Glavna tema jednočinke je aristokratska, rafinirana egzistencija esteta, prikazana kroz spoj suvremenog impresionizma, barokne sentencije i latentno predočene aristokratske renesansne kulture koja podržava ludičku zamjenu rodnih uloga (žena koja donekle predstavlja utjelovljenje renesansne virago, dok je muškarac feminizirani estet).

\subsection{Leopold von Andrian: Der Garten der Erkenntnis (Vrt spoznaje)}

\subsubsection{Uvod}

Pripovijetka Leopolda von Andriana pod naslovom Der Garten der Erkenntnis (Vrt spoznaje) nastala je zimi 1894/95. godine, a objavljena je u proljeće 1895. godine kod izdavača S. Fischera. ${ }^{290}$ Ovoj je autobiografski koncipiranoj pripovijetci u maniri i tematici Jugendstila Andrian prvobitno dodijelio naslov Fest der Jugend ${ }^{291}$ (svetkovina mladosti), ali je kasnije promijenio njezin naslov u konačni naslov pripovijetke. U studenome iste te godine objavio je bečki tjednik Die Zeit tekst koji je po svojoj tematici i koncepciji sličan pripovijetci Der Garten der Erkenntnis: Hofmannsthalov tekst Das Märchen der 672. Nacht. ${ }^{292}$ Oba književna teksta demonstriraju slično koncipiranje narcizma u likovima esteta, pri čemu se ističe provodni motiv djetinjstva ${ }^{293}$, sjećanja i impresionističke letimičnosti dojmova. I Erwin, kao i sin trgovca iz Hofmannsthalove pripovijetke, pokazuje manjak povezanosti s okolinom, odnosno esencijalnu osamljenost umjetnički nastrojenog pojedinca unutar građanskog društva. Zajedničko im je, prema Iris Paetzke, također i demoniziranje spolnosti ili njezino neutraliziranje u estetskom promatranju stvarnosti ${ }^{294}$, koje se ogleda u slično narativno koncipiranoj stilizaciji neproživljene erotike u ,tajnu života“. Fluidni, impresionistički opisi koji se uglavnom fokusiraju na prikaz unutarnjeg svijeta glavnog lika, kneza Erwina, osim hipersenzibilnosti i otuđenosti demonstriraju i esencijalnu fragmentaciju, fluidnost i decentriranost Erwinovog (rodnog) identiteta.

Radnja djela se odvija u aristokratskom okruženju mladog esteta Erwina, koji je u ranoj dobi izgubio oca, a njegov je odnos prema majci duboko ambivalentan, iz čega proizlazi kriza identiteta, u kojoj nastaje ambivalencija između homoerotičkih sklonosti i heteroseksualne privlačnosti prema (pomalo androginim) ženskim likovima. Treba također naglasiti da Erwin

\footnotetext{
290 vidi Paetzke: Erzählen in der Wiener Moderne, 1992, str. 48.

291 Ovaj podatak, kao i kraću analizu Andrianova života i konteksta njegove pripovijetke iznosi Jens Malte Fischer u svojoj knjizi Fin de siècle, 1978.

${ }^{292}$ Paetzke 1992, str. 48.

293 Ibid.

294 Ibid.
} 
u ranoj mladosti posjećuje katolički internat, pa se u njemu javlja čežnja da postane svećenikom. Kasnije on dolazi u Beč, grad otvorenih mogućnosti, ali, budući da predstavlja velegrad, također i opasnosti. Tamo Erwin vodi uglavnom osamljenu egzistenciju, a na samom kraju života, nakon što se on i njegova majka uslijed jednog razgovora o smislu ljudske egzistencije ponovo razilaze, pripovjedač konstatira da je „knez umro, a da nije spoznao bit života“.

Avangardni i inovativni pripovjedni postupci ukazuju na kontekst nastanka pripovijetke: naime, na prikaz subjektivizma, individualizma i fluidnog jastva moderne. Što se tiče problematike književnog žanra, ova pripovijetka predstavlja avangardni novum u pogledu stila i tematike koji prikazuju impresionistički konotirana sjećanja i razmišljanja osamljenog esteta. Garten predstavlja nostalgičnu evokaciju stare aristokratske kulture Beča, kao i pokušaj redefiniranja vlastitog identiteta i stava prema ženskosti kroz niz Erwinovih filozofskih, autorefleksivnih razmišljanja o prirodi vlastitog vremena i vlastitog života esteta.

Djelo je u prvom redu namijenjeno Andrianovim suvremenicima i prijateljima, budući da Erwin, koji se nalazi u fokusu ove intimne pripovijesti, predstavlja identifikacijski lik cijele jedne generacije esteta. Lik Erwina odraz je bolećivosti, tankoćutnosti i „hipohondrije““295 esteta i aristokrata i kao takav on odražava duh vremena jedne epohe u kojoj zamire aristokratska (plemićka) kultura. Erwinova neurastenija odraz je, kako sumorne dekadencije (zamora od života), tako i hipersenzibilne prirode umjetnika, koji živi u doba društvenih previranja i gašenja aristokracije. Djelo je autobiografsko svjedočanstvo autorefleksivnog aristokrata koji je prerano sazrio ${ }^{296}$ i koji posjeduje dar minucioznog promatranja pojava oko sebe, stilizirajući te pojavnosti svoga života u umjetničko djelo.

\subsubsection{Eksplicitni rod}

Na početku pripovijetke nalaze se tri glavne misli vodilje: „Ego Narcissus“, zatim Danteovo geslo koji glasi „Piu ch'un anima e alta e perfetta/Piu sente in ogni cosa il buono ed il malo“ (, Je erhabener und vollkommener eine Seele ist, desto mehr fühlt sie in jedem Ding das Gute und Böse"), u prijevodu: „Što je neka duša uzvišenija, to ona više osjeća u svakoj stvari dobro

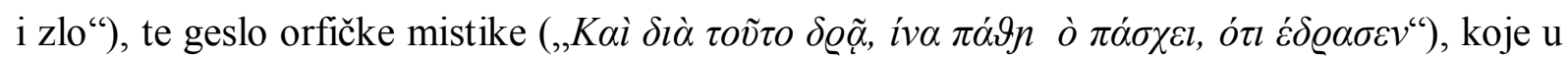
prijevodu na njemački i hrvatski jezik glasi: „Und deswegen handelt er, damit er erleidet, was er erleidet, weil er gehandelt hat" „I upravo zato on djeluje (čini), da bi pretrpio to što je pretrpio jer je činio (djelovao)“.

\footnotetext{
${ }^{295}$ Fischer 1978, str. 148.

296 Ibid., str. 154.
} 
Ove moralne sentencije ujedno služe i kao provodni motivi pripovijetke: u njima se može iščitati Andrianov svojevrsni kritički stav prema relativizaciji morala njegova doba, u kojoj duboko participira i oblik amoralnog esteticizma. Danteov citat je zanimljiv iz razloga što uvodi biblijsku sposobnost razlikovanja dobra i zla kao dokaz savršenstva duše: ovaj je stav u suprotnosti s habitusom esteticizma bečke moderne, i ne samo bečke moderne, već je ovakav esteticistički stav vidljiv i u sljedećoj rečenici Oscara Wildea: „Shvatiti ljepotu neke pojave, to je najizvrsnija točka do koje možemo stići. Čak je i smisao za boje važniji za razvitak pojedinca nego osjećaj za dobro i loše ‘297. U tom kontekstu jasno se očituje Andrianova kritika onodobnog vakuuma moralnih vrijednosti.

Andrian na idiosinkratičan način revitalizira teoriju ljudskih percepcija u moralnom smislu i predstavlja svojevrsni kritički stav prema čisto esteticističkom (moralno relativizirajućem i otuđenom) promatranju života. Citat orfičke mistike pretpostavlja pak mudrost kontemplativnog stava o životu aktivnom, dionizijskom prihvaćanju života i kritički se osvrće na pojam života u bečkoj moderni: razdoblja koje je promicalo svojevrsni vedri oblik hedonizma i tražilo izlaz iz tamnice esteticizma u revalorizaciji dionizijske opojnosti. Prvi moto, koji glasi Ego Narcissus zapravo je temeljni provodni motiv cijele pripovijetke: narcistička okrenutost esteta u vlastitu nutrinu, koji svijet doživljava kao kompleks osjeta (Ernst Mach) i orijentira se na čisto esteticističko i impresionističko poimanje stvari oko sebe. Ljudi i pojave u suptilnoj dikciji ove proze postaju „lirske šifre“, gotovo poput ideja ili simbola. $^{298}$

U fokusu pripovijetke je lik kneza Erwina, osamljenog senzibilnog esteta, koji, poput trgovčevog sina u Hofmannsthalovu djelu Das Märchen der 672. Nacht, živi uronjen u svijet vlastitih perceptivnih doživljaja vanjskog svijeta, orijentiran više na prošlost i budućnost nego na sadašnji, aktivni trenutak: u njemu prevladava kontemplativni život (ženski konotiran) naspram aktivnog, produktivnog života, koji se često identificirao s „,muškim principom“:

Tada (kad je navršavao 12.-godinu) bio je Erwin tako osamljen i sam sebi dostatan kao nikada kasnije; njegovo tijelo i njegova duša živjeli su, jedno u drugome, gotovo dvostruki život na tajanstven način; stvari vanjskoga svijeta imale su za njega vrijednost, koju inače imaju u snu; one su bile riječi jednog jezika, koji je samo slučajno bio njegov, ali su tek kroz njegov voljni mehanizam dobile svoje značenje, mjesto i nijansu. ${ }^{299}$

\footnotetext{
${ }^{297}$ Complete works of Oscar Wilde, The Critic as Artist, HarperCollins Publishers 1994, str. 1154.

${ }^{298}$ Vidi Žmegač: Duh impresionizma i secesije, 1993.

299 „Damals (er ging ins zwölfte Jahr) war der Erwin so einsam und sich selbst genug, wie niemals später; sein Körper und seine Seele lebten ein fast zweifaches Leben geheimnisvoll ineinander; die Dinge der äußeren Welt hatten ihm den Wert, den sie im Traume haben; sie waren Worte einer Sprache, welche zufällig die seine war, aber erst durch seinen Willen erhielten sie Bedeutung, Stellung und Farbe.", Der Garten der Erkenntnis, str. 8.
} 
Prema riječima Iris Paetzke, i sama „objektivna“ priroda dobiva obilježje osjećajnosti i estetske prijemčivosti glavnog lika, dobiva obrise njegovog subjektivnog, introspektivnog viđenja. $\mathrm{U}$ jednom trenutku u pripovijetci se u opisu prirode spominje ,ljepota bestjelesne linije ${ }^{6300}$, koja metaforički ukazuje na asketizam esteta. I suptilna se naracija u djelu također može metaforički usporediti s „bestjelesnošću“ (spiritualnošću) misaonog horizonta glavnog lika. Ova se metafora također može usko povezati sa sličnom metaforom u djelu Richarda Beer-Hofmanna Der Tod Georgs, gdje se ona, međutim, koristi u svrhu esteticističkog opisa androgine, aseksualne femme fragile.

Mnogobrojna Erwinova putovanja simboliziraju eskapizam esteta i težnju za prevladavanjem monotonije, dok se, s druge strane, lik stranca (njem. der Fremde) metaforički može povezati s Erwinovom percepcijom o stranosti vlastite psihe, koju on sam poima kao prostor žudnje i anksioznosti, pa i zazora (njem. das Unheimliche).

Provodni motivi pripovijetke su: 1 . motiv narcizma, usmjerenosti esteta na vlastitu psihu i percipiranje svijeta oko sebe 2. motiv dubokoumne ljepote (njem. tiefsinnige Schönheit), 3. motiv samoće (njem. Einsamkeit) esteta i njegove lijepe smrti (njem. schöner Tod), 4. pojam duše (njem. Seele), koji je nejasno određen te ukazuje na koncepciju fluidnog identiteta (krize identiteta) s jedne, ali i orijentalne koncepcije duše s druge strane koja je bliska mističkoteozofskim pokretima o prijelomu stoljeća, 5. motiv života (njem. Leben) kao vitalistički koncept koji je u opreci s esteticistički koncipiranom otuđenom egzistencijom esteta, i koji, s druge strane, u svojoj „mnogostrukosti i beskonačnosti“301 predstavlja nešto tajanstveno i neobjašnjivo, 6. motiv kiše, koja simbolizira oplodnju i predstavlja vitalistički topos naspram jalove, dijelom homoerotički konotirane i samodostatne egzistencije esteta, 7. motiv sna, koji predstavlja snovitu egzistenciju esteta i njegovo poniranje u podsvjesne prostore vlastite psihe (njem. das Unbewusste), 8. motiv stranca (njem. der Fremde), koji, prema Freudu, predstavlja Erwinov alter-ego (dvojnika njegove psihe), sadržaj koji je potisnut duboko u podsvijest (njem. das Verdrängte) pa se percipira kao nešto istodobno poznato i strano, odnosno zazorno (njem. das Unheimliche) ${ }^{302}$, a s druge strane predstavlja i život sam i njegovu „prijeteću“ senzualnost, 9. motiv žene, koja je izrazito ornamentalno i dekorativno (statično) prikazana, 10. motiv smrti, povezan s dekadentnim zamorom od života i otuđenim boravkom u prededipalnoj fazi esteta, ali ponegdje u djelu smrt dobiva i dionizijsko, gotovo vitalističko značenje, 11. motiv homoeroticizma (Lato, Clemens, mladi oficir, Heinrich Philipp) koji je

\footnotetext{
${ }^{300}$ Der Garten der Erkenntnis, str. 42.

${ }^{301}$ Ibid., str. 49-50.

${ }^{302}$ Vidi Freudov esej pod naslovom das Unheimliche, Imago. Zeitschrift für Anwendung der Psychoanalyse auf die Geisteswissenschaften V, 1919, str. 297-324.
} 
odraz krize (gubitka sigurnosti) muškog identiteta u bečkoj moderni, ali i anksioznog stava prema ženskosti te je predstavljen kao suprotnost životnom vitalizmu i odraz ,jalovosti egzistencije esteta“ i 12. motiv zrcala, koji predstavlja kako narcizam, tako i svojevrsni autoerotizam.

Motivi nisu povezani kauzalno, već slijede okvire impresionističke i simbolističke (pa i neoromantičke) umjetničke koncepcije koja pojave i bića prikazuje letimično i stilizirano. Ornamentalnost opisanih pojava i zagonetnost likova odgovara ezoteričnim i hermetičnim prikazima simbolizma.

Iako pripovijetka Der Garten der Erkenntnis po svome formalnom ustrojstvu predstavlja oblik naracije usmjerene na razvoj ličnosti i traženje spoznaje, ona ne koncipira glavni lik u njegovom teleološkom razvoju (tradicionalno muški konotiran oblik naracije), već prikazuje cikličnost čuvstvenih stanja glavnog lika, njihovu hermetičnost (ezoteričnost) i fragmentarnost (tradicionalno ženski konotiran oblik naracije). ${ }^{303}$ Pripovijetka predstavlja problematiku traženja biti i smisla života (esteticističke egzistencije), te re-definiranja vlastitog (rodnog) identiteta esteta, koji su narativno koncipirani po svojevrsnom neoromantičkom i simbolističkom, engl. quest (potraga) - obrascu.

U Andrianovoj pripovijetci postoje i impresionistički konotirana ponavljanja (njem. repetitives Erzählen), kojih ima i u djelu Richarda Beer-Hofmanna Der Tod Georgs. U 2. dijelu pripovijetke pojavljuje se jedan repetitivni obrazac, koji se odnosi na Erwinovu majku, jednoličnost njezina života poslije muževljeve smrti, nakon čega se njezin interes usmjerava prema impresionistički i esteticistički koncipiranom pluralitetu pojavnosti. ${ }^{304}$

Nakon što se Erwin i njegova majka raziđu, ona se, zamorena životom, vraća samoj sebi i ornamentalnim pojavama oko sebe, koje figuriraju kao supstitut za život. ${ }^{305} \mathrm{Na}$ taj način žena i ženskost postaju amblem statičnosti. Nabrajanjem raznolikih ornamentalno koncipiranih pojava pripovjedač nostalgično evocira staru aristokratsku kulturu Beča i aristokratsku povijest vlastite obitelji.

\footnotetext{
303 Vidi analizu tradicionalno muški i tradicionalno ženski konotiranog oblika naracije u: Nünning/Nünning, 2004.

304, ,... sie hatte nach dem Tode ihres Gatten, was sie in einem nicht gefunden hatte, in vielem gesucht. Sie hatte die Edelsteine, die kostbaren Stoffe und die gestickten Seiden geliebt und die Schauspiele, die Folgen der Länder und die Kunstwerke der Künstler und den wechselnden Himmel mit dem wechselnden Mond und den gleichbleibenden Sternen und den großen Aufgang und den großen Untergang der Sonne.“, Der Garten, str. 4748.

305 „Bald darauf gingen sie auseinander; (...) Etwas müder kehrte die Mutter zu ihren Edelsteinen, ihren kostbaren Stoffen und gestickten Seiden zurück und zu den Schauspielen und zu den Folgen der Länder und den Kunstwerken der Künstler und zum wechselnden Mond und zu den gleichbleibenden Sternen und zum großen Aufgang und zum großen Untergang der großen lebenden, für sie toten Sonne.“, Der Garten, str. 51.
} 
Lik kneza Erwina okarakteriziran je kao majci sličan, hipersenzibilni estet, koji je narcistički obuzet vlastitim karakterom i zrcaljenjem vlastite ličnosti: u tom aspektu Erwin demonstrira svojevrsnu ,androginu samodostatnost“, odnosno svojevrsni „,neutralni rod“, koji i negira i ujedinjuje karakteristike tipične muškosti i tipične ženskosti. Lik Erwina djelomično je prikazan tipološki, kao predstavnik cijele jedne generacije esteta, a djelomično psihološki, kao kompleksan, višedimenzionalan, dinamičan i otvoreno koncipiran lik u čijoj se psihi na impresionistički način smjenjuju dojmovi (koncepcija das unrettbare Ich). Njegova osamljenost poligon je za ulazak u raščlambu vlastite ličnosti, kojoj su izvanjske osobe i predmeti (,ne-ja“) samo refleksije vlastitih duševnih stanja. Pripovijetka je koncipirana kao niz razmišljanja o dvojstvu duha i tijela, subjekta i objekta, vlastite psihe i vanjskog svijeta, spiritualnog i materijalnog, sakralnog i profanog, koja se ogleda i u metafori viteške borbe dvaju ratnika, koji metaforički predstavljaju Erwinovu unutarnju rascijepljenost između dviju suprotnosti i simptom je hibridizacije njegova identiteta između tipološke ženskosti i tipološke muškosti. ${ }^{306}$ Erwinova sličnost s majkom, koja je naglašena na početku pripovijetke, odraz je kako njegove narcističke ličnosti, tako i njegove fizičke i psihičke feminizacije (njem. Verweiblichung), dok ipak u prvom dijelu pripovijetke nailazimo i na odjek obrazaca patrijarhalne kulture i zakona oca u Erwinovoj usporedbi samoga sebe s ,izaslanikom nekog dalekog kralja“307: „Im zweiten Jahr ihrer Ehe gebar sie ihm einen Sohn, der im Heranwachsen seiner Mutter ähnlich wurde. (...) Aber der Erwin hatte ihre Hände und ihre Stimme.“

U procesu socijalizacije hipersenzibilni Erwin nailazi na prepreke, na vlastitu nemoć u suočavanju s okolinom u katoličkom internatu, koju poima kao „ne-ja“, kao nešto strano i zazorno: „budući da se „vanjski svijet“ ovdje više ne da ograničiti samo na subjektivnu sliku, već nužno pristupa Erwinu u liku njegovih školskih kolega, Erwin doživljava tajanstveno dvojstvo subjekta i vanjskog svijeta, „duše“ i „tijela“ kao konkretnu prijetnju- školski su prijatelji, koje Erwin ne razumije, njegovi „neprijatelji““‘308 Budući da on sam nužno sudjeluje u njihovom životu, odnosno da ga oni okružuju i utječu na njegov život, događi 77 oblik udvostručenja jastva, koje se može prepoznati kao otuđenje od samoga sebe. Ovakav

\footnotetext{
${ }^{306}$ Vidi Der Garten, str. 11-12.: „Das Leben würde ein Kampf der Kirche gegen die Welt sein. Aber seine Gedanken gaben diesem Zweikampf eine so vielfältige Höflichkeit, ein so erhabenes Zeremoniell, so gesuchte Formen, daß er fast zu einer Parade wurde, zu einem Vorwand für die beiden großen ebenbürtigen Gegner, einander gegenüber zu stehen, die fremde Herrlichkeit zu bewundern und an der fremden Größe der eigenen gewahr zu werden; so, wie wenn von den Enden der Welt zwei Helden zu kämpfen kommen, der tapferste Held des Morgenlands und der tapferste Held des Abendlands, und sie sich begrüßt haben und mit gesenkten Lanzen und geöffneten Visieren fast des Kampfes vergessen, weil sie einander anschauen“.

${ }^{307}$ Der Garten, str. 12.

${ }^{308}$ Paetzke 1992, str. 29.
} 
radikalni subjektivizam i individualizam, koji se čak pojavljuje i u „osamostaljenju riječi i stvari“6309, ukazuje na problematiku otuđenja modernog doba koja je karakteristična za bečku modernu i fin-de-siècle. Iskustvo osamljenosti, koje počinje od Erwinova najranijeg djetinjstva, ,prisiljava“ ga na razvijanje autorefleksivnosti, koja se profilira u ,jalovu potragu za spoznajom“. ${ }^{310}$ Psihički horizonti hipersenzibilnog esteta koji naginje primarnom narcizmu nužno isključuju bliskost sa okolinom: fiksiranost esteta na vlastito ,ja“ ne dopušta nikakav osobni odnos s drugima, bilo da se radi o ljubavi ili prijateljstvu, o heteroseksualnom ili homoseksualnom odnosu i bliskosti. Čak je i Erwinova senzualnost usmjerena na njega samoga: provodni motiv zrcala i zrcaljenja pojavljuje se više puta u djelu: ,zrcalo ga je zavaralo“; „njegova je duša uživala u sjećanju na požudu njegova tijela“. ${ }^{311}$ I Erwinov prijatelj Clemens, ali i Erwinova žena djeluju- iz perspektive glavnog lika, ali i iz perspektive pripovjedača- u potpunosti artificijelno, oni su lišeni vlastitog identiteta. Oni postaju estetski objekti, poput dekorativnih objekata kojima se Erwin okružio, prema kojima se on odnosi kao distancirani promatrač. ${ }^{312}$

Lik kneza Erwina oscilira između ovog ćutilnog zanosa i statične autorefleksivnosti, koji nastaju na temelju Erwinove narcističke upućenosti na samoga sebe. Manjak osobnih doživljaja, koji je izražen u odnosu sa prijateljima (Clemens, Lato) i s mladom ženom, pretače se u „objektifikaciju“, odnosno postvarivanje drugih osoba, koje je u naraciji pripovijetke oblikovano u vidu prikaza individuacije psihe esteta, njegovog suočavanja $\mathrm{s}$ vlastitim otuđenjem od senzualnosti i od stvarnosti. Prema Iris Paetzke, latentni homoeroticizam u djelu Der Garten der Erkenntnis možemo tumačiti samo u njegovoj povezanosti sa narcističkim sebeljubljem koje isključuje, odnosno sprječava seksualnost kao takvu.

Na početku teksta pojavljuje se metafora dvaju ratnika koji simbolički predstavljaju istok i zapad, spiritualnost i senzualnost, duhovno i materijalno: kroz cijelu se naraciju Erwinov psihički mikrokozmos upravo polarizira između askeze i materijalizma, narcizma smrti (njem. Todesnarzißmus) i narcizma života (njem. Lebensnarzißmus) $)^{313}$, pri čemu se ženskosti i muškosti u različitim dijelovima naracije na paradoksalan način pridaju čas jedne, čas druge karakteristike. Ženskost se većinom povezuje uz pojam života, plodnosti i senzualnosti, iako je sama koncepcija ženskih likova daleko od bilo kakve životnosti jer upućuje na izolaciju esteta. Muškost je u djelu ponekad poistovjećena s pojmom smrti i erosa (mladi oficir),

\footnotetext{
${ }^{309}$ Paetzke 1992, str. 30.

${ }^{310}$ Ibid.

311 „ein Spiegel hatte ihn getäuscht“; ,seine Seele genoß die Erinnerung an die Lust seines Leibes“, Der Garten, str. 43.

${ }^{312}$ Paetzke 1992, str. 37.

${ }^{313}$ Ova dva pojma posebice razrađuje Le Rider u knjizi pod naslovom Das Ende der Illusion, 1990, str. 89.
} 
ponekad ukazuje na jalovu egzistenciju esteta i kreira lik esteta kao androginog narcisa (Erwin, Lato, Clemens i Heinrich Philipp), dok je lik stranca (Der Fremde) poistovjećen s pojmom života.

Budući da su Erwinovi opažaji i misli fragmentirane, fragmentirano je i njegovo iskušavanje različitih rodnih identiteta, što je vidljivo ponajprije u neodrživosti njegovih društvenih veza: veze s prijateljem iz djetinjstva Latom, Heinrichom Philippom (koji u opisu dobiva asketske konotacije), zatim s mladim oficirom, prijateljem u zrelijoj dobi Clemensom (duboka veza koja ostavlja poseban trag u Erwinovoj psihi) te se naposljetku njegova rodno neizdiferencirana žudnja usmjerava prema ornamentalno i dekorativno prikazanoj, androgino koncipiranoj mladoj ženi, koja odražava književni prototip žene-amazonke. Svi Erwinovi pokušaji definiranja i re-definiranja vlastitog (rodnog) identiteta ukazuju na decentriranost njegove psihe, na njezinu fragmentarnost i fluidnost.

Muški likovi u Andrianovoj pripovijetci opisani su kao izrazito asketski i simboliziraju smrt (pojam „lijepe smrti“ usko je vezan prvenstveno za jalovu, dijelom homoerotičku egzistenciju esteta), a i žene $u$ djelu na sličan način simboliziraju stilizaciju života $u$ umjetničko djelo i metaforički se povezuju s pojmom smrti: Erwinova je majka, posebice na kraju teksta, opisana kao „slika, koja mu se pojavljivala na putovanjima“, zatim pripovjedač Erwina povezuje s pojmom života, „niskosti“ i vremenitosti, a Erwinovu majku s pojmom „smrti“, „umjetničkim djelom“ i ,vječnošću“. 314

Žene, koje kod Andriana, kao i kod Hofmannsthala, nose simboličan značaj ornamentalnosti, statuesknosti (mortificiranosti), dekorativnosti i anonimnosti, bivaju stilizirane u neživi artefakt, društveno dekontekstualizirane i pretvorene u simbolične prikaze anime esteta, pa tako žena s kojom Erwin kratko zajedno živi sliči nekom ,azijskom kralju“ ili pak ,rimskoj carici“‘: „Godinu dana nakon toga živio je Erwin s jednom ženom. Ona je bila lijepa, poput ljepote drevnih bista, kod kojih se na trenutak može biti neodlučan pokazuju li one mladog azijskog kralja ili ostarjelu rimsku caricu“. ${ }^{315}$ Ovakav motiv androgine ljepote, koju analogijski možemo povezati s androginom ličnošću esteta, nema u ovome kontekstu pripovijetke toliko erotsko značenje, te ne upućuje izravno na heteroseksualnu ili pak možda i homoerotičku orijentaciju glavnog lika, već nosi obilježje aseksualnosti, narcizma ali i

\footnotetext{
${ }^{314}$ „Aber beide fanden das Geheimnis des Lebens nicht. Sie war wohl das Bild, das ihm auf der Reise erschienen war; sie waren wirklich eins, und was in ihm war, war in ihr; aber in ihm durchzittert von der Niedrigkeit und vom Schmerze und von der Rührung des Lebens und in ihr wie ein Kunstwerk; er war von der Zeit, sie war von der Ewigkeit; oder er war ihr Leben, und sie war sein Tod, und dieser Tod und dieses Leben waren tief und geheimnisvoll verknüpft“, Der Garten, str. 48.

315 „Ein Jahr später lebte der Erwin mit einer Frau. Sie war schön von der Schönheit der späten Büsten, bei denen man einen Augenblick zweifelt, ob sie uns einen jungen asiatischen König zeigen oder eine alternde römische Kaiserin“, Der Garten, str. 34
} 
svojevrsne seksualne askeze, odnosno uzdržavanja od seksualnosti: Erwinova žena, slično kao i njegov prijatelj Clemens, ali i sama Erwinova psiha, nosi karakteristike i ženskosti i muškosti, mladosti i starosti, istoka i zapada. ${ }^{316}$ Statično-ornamentalna koncepcija ženskog lika, koji jasno pokazuje aseksualne, androgine karakteristike, ponajprije odražava anksioznost esteta prema ženama i ženskosti. Pojedini ženski likovi u Andrianovom tekstu, kao i u Hofmannsthalovoj pripovijetci Das Märchen der 672. Nacht, odražavaju ratničku ženstvenost te $\mathrm{u}$ tom pogledu djelomično odudaraju od stereotipne koncepcije ženske pasivnosti: dok su neke koncepcije ženstva kod Andriana, kao i kod Hofmannsthala bliske književnom stereotipu femme fragile ${ }^{317}$ druge su koncepcije, međutim, odraz jednog drugog književnog prototipa ženstva, naime, žene-amazonke koja muški subjekt prožima ujedno strahom i fascinacijom. Ova „nadređenost“ „ratničke ženstvenosti“ i aluzija na dominaciju žene nad muškarcem, portretiranim u liku senzibilnog, pasivnog i receptivnog esteta, veže se uz: 1. gubitak sigurnosti esteta (odnosno, umjetnika), vezano uz njegov muški identitet, u doba sve veće modernizacije i dehijerarhizacije rodnih odnosa (destabilizacije muško-ženskih odnosa i identiteta), 2. arhaične evokacije starog antičkog ili renesansnog prototipa ženstva, koje je ovdje u službi čisto esteticističkog, odnosno larpurlartističkog pogleda na ženu, 3. provodne motive pripovijetke, a to su život, smrt i eros i 4. stereotipno koncipiranje žene kao zagonetne „Drugosti“ koja istodobno izaziva fascinaciju i zazor.

Lik pjevačice, koji se pojavljuje na samom početku pripovijetke, na neobičan način zaokuplja Erwina, a na simboličkoj razini predstavlja opreku zbilje (bitka) i privida (njem. Sein und Schein), života i umjetnosti: karakter pjevačice oslanja se na performativnost, budući da ona na ludički način (kroz igranje uloge) uspostavlja privid umjetnosti kao zbilju, da bi potom taj isti karakter (ulogu) opovrgnula kao laž koja služi isključivo privlačenju pažnje publike. Na taj način čitav život pjevačice biva stiliziran u vidu umjetničkog djela. U Erwinovim je mislima ona koncipirana u vidu stereotipne ženske senzualnosti, te demonizirana kroz karakteristike ,vulgarnosti, lascivnosti i stereotipno ženskog prepuštanja“. ${ }^{318}$ Učinak koji pjevačica proizvodi kod publike može se protumačiti kroz

\footnotetext{
${ }^{316}$ Paetzke 1992, str. 37.

317 Andrianov kratak opis bečkih djevojaka nježnog stasa u bijelim haljinama na 20. stranici djela Der Garten der Erkenntnis svjedoči o tome: „,...und junge Wiener Mädchen mit schönen weichen Gestalten in weißen Kleidern mit großen farbigen Seidenschleifen“; zatim djelomice i opis glumice koja, na način jedinstva suprotnosti karakterističnih za bečku modernu (coincidentia oppositorum), u Erwinovoj imaginaciji jednako predstavlja književni prototip žene-djeteta (Kindfrau) i starije žene: „sie war wirklich nicht schön und sie war alt, aber dennoch war sie wie ein Mädchen“, Der Garten, str. 16.

318 „Diese Zweiheit des Spiels färbte dem Erwin sonderbar ihren Reiz; denn ihre Gemeinheit, Laszivität und Hingebung wurden durch das Theater, die Musik und die Lichter zu einer großartigen schattenhaften insolenten Proklamation, aber das Gepränge und der Jubel auf der Bühne mischte sich mit dem Beifall der Zuschauer zu
} 
performativnu intenciju njenog nastupa: ona želi svoju ulogu (nastup) prezentirati kao stvarnost, pretočiti umjetnost (privid) u život, a ta joj „lijepa laž“ kod publike donosi popularnost. U ovome prikazu ženski je lik, koji predstavlja svojevrsnu žensku prijetvornost, ${ }^{319}$ izrazito opredmećen, a i sam je fizički izgled žene prikazan kao odraz ,artificijelnosti“" njezine izvedbe. ${ }^{320}$

Paetzke naglašava i to da su svi ti „,nedostižni, beživotni i strani““321 ženski likovi estetskom stilizacijom povezani s predodžbama o moći i veličini: i sama je ,ljepota u pripovijetci uglavnom povezana s veličinom, moći i uzvišenošću“. ${ }^{322}$ Statua koja prikazuje dvije zagrljene žene, ovijene jedna oko druge, zapravo prikazuje sjedinjenje istoga, što ukazuje kako na homoerotičke impulse, a tako i na hermafroditsku samodostatnost koja Erwinu predstavlja ,neizrecivu dražesnost“. ${ }^{323}$

Jedina žena s kojom Erwin stvara uistinu blisku vezu njegova je majka. S likom Erwinove majke naglašena je temeljna problematika pripovijetke: kroz koncepciju kulturalnog pesimizma epohe percipirana ,uzaludna“ potraga za „tajnom“ života koja bi postojala izvan njega samoga, izvan njegove vlastite osobnosti ${ }^{324}$. Erwinova povezanost s njom opisana je u tekstu pripovijetke kao „zrcaljenje“ i transcendiranje samoga sebe u drugome: ${ }^{325}$ kao dijete osjećao je „da nije sam, već da je jedno s njom, čudesno isti kao ona, iako je bio malen i slab i bolestan a ona velika i strana i lijepa““. ${ }^{326}$ Ovo povezivanje majke s pojmovima veličine i ljepote upućuje na koncipiranje žene i ženskoga kao amblema stanja primarnog narcizma, u kojem muški subjekt osjeća gotovo mitsku sjedinjenost s majčinim tijelom. Erwin se čeznutljivo prisjeća vlastitog djetinjstva, što predstavlja androginu upućenost na samoga sebe, ali i regresiju u stanje mitskog obilja, odnosno primarnog narcizma, spojenosti s majkom. Produljeno stanje djetinjstva i fiksiranost na majku u konfliktu je s procesom Erwinovog odrastanja, naročito s razdobljem buđenja spolnosti. Čežnja za vremenom kad je mogao biti „tako sam i sam sebi dovoljan“ postaje neispunjivom. Paetzke naglašava povezanost motiva

einem seltsam wirklichen und sehr hohen Triumph für sie und für ihren sehr kostbaren Leib.“, Der Garten, str. 15.

${ }^{319}$ Vidi analize ženskosti i ženske senzualnosti u knjizi Bettine Pohle: Kunstwerk Frau, 1998.

$320, \ldots .$. und sie selbst vor die Lichter kam, brennend von Schminke, mit leuchtenden Augen und dem etwas faden Lächeln der Apotheose, und mit einer Rührung in der Stimme, an der ihn besonders rührte, daß sie erlogen war, die leichtsinnige und lügnerische Moral ihrer Fabel in die Menge warf.“, Der Garten, str. 16.

321 Paetzke 1992, str. 39.

322 Ibid., str. 42

323 „Wenige Tage später freilich an einem Januarabend fühlte er dort den unsagbaren Reiz einer Statue, auf der sich zwei Frauen umschlungen hielten; hinter ihnen stieg über wenigen Sternen ein hoher grauer Himmel auf, die Erde war weiß von Schnee, nur etwas Licht von einem verwischten Mond fiel auf sie“., Der Garten, str. 33.

${ }^{324}$ Paetzke 1992, str. 39.

325 Ibid.

${ }^{326}$ Ibid., str. 39., vidi također Der Garten, str. 47.: ,und zugleich fühlte er, dass er nicht allein sei, sondern eins mit ihr, wunderbar dasselbe, obwohl er klein und schwach und krank und sie groß und fremd und schön war". 
djetinjstva i primarnog narcizma s Freudovim djelom Zur Einführung des Narzißmus (1914. godina). Freud je naglašavao da se „zdravi razvoj čovjekovog jastva“ sastoji u „udaljavanju od primarnog narcizma“ $i$,,premještanju libidinozne želje na neki izvanjski objekt (ideal)“. 327

Glavni lik u djelu senzibilni je estet Erwin, izrazito višedimenzionalan, otvoreno i dinamično koncipiran ${ }^{328}$, odnosno psihološki razrađen lik, no ipak predstavlja tipološku i identifikacijsku figuru cijele jedne generacije esteta.

Stav prema Latu, dječaku kojeg Erwin upoznaje u katoličkom internatu, pored Erwinovog implicitnog homoeroticizma, ostaje ambivalentan (mješavina žudnje i zazora): „Zapravo mu je Lato, koji je imao posve svijetlu kosu i svijetle oči, bio draži; ali on je otišao s njegovim neprijateljima“. ${ }^{329}$ Homoerotička naklonost prema Latu, ali i prema oficiru, a kasnije Heinrichu Philippu i Clemensu, prožeta je narcizmom, svojevrsnom narcistički konotiranom askezom, ali i kultom umjetnosti koji zamjenjuje život: „Naravno, taj mu je život sad bio lijep i zbog same ljepote, koju je u vrijeme, kad ju je proživljavao, pronalazio u drugim očekivanjima. Ali on to nije primjećivao, i čeznuo je za tim da se vrati u samostansku školu“. 330

Na putu u Bozen, u Innsbrucku, Erwin doživljava poznanstvo s mladim oficirom koji boluje od tuberkuloze. Ovo saznanje izaziva melankoliju u Erwinu, te ga potiče na refleksiju o oficirovoj skoroj smrti, ali i o vlastitoj smrti (svojevrsna proleptička najava Erwinove smrti): „Cijelu je noć Erwin mislio na njega i na to da mora umrijeti; učinilo mu se strašnim da ga nikad više neće vidjeti; i odjednom mu je, uz očajničko kajanje, palo na pamet da čak ne zna niti njegovo ime“. ${ }^{331}$ Erwinova percepcija mladog oficira odražava i njegov latentni homoeroticizam (posebice interes za njegov fizički izgled): „Bio je jako mlad, ne baš elegantan, sramežljive i ganutljive uljudnosti; govorio je ponešto okolišavo i malo je u izgovoru naglašavao nenaglašene vokale. Erwinu je bio jako drag“، ${ }^{332}$

\footnotetext{
${ }^{327}$ Cit. u Paetzke 1992, str. 40.

${ }^{328}$ Što se posebice veže uz Erwinovo neprekidno re-definiranje vlastitog unutarnjeg svijeta i vlastitog (rodnog) identiteta, te uz njegovu potragu za smislom svijeta i vlastitog života: u jednom se segmentu u djelu koristi metafora mora (koje sadrži protejski element) koja simbolički upućuje na pluralitet i impresionističku kvalitetu Erwinovog unutarnjeg svijeta.

329 „Eigentlich war ihm Lato, der ganz lichtes Haar und ganz lichte Augen hatte, lieber; aber der ging mit seinen Feinden“, Der Garten, str. 12.

${ }^{330}$ „Freilich war ihm dieses Leben jetzt auch von der Schönheit schön, die er zur Zeit, als er es durchlebte, in anderen Erwartungen fand. Aber das merkte er nicht, und er sehnte sich, in das Konvikt zurückzukehren", Der Garten, str. 14.

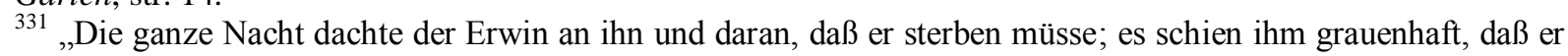
ihm nie wieder begegnen solle; und plötzlich fiel ihm mit verzweiflungsvoller Reue ein, daß er nicht einmal seinen Namen wisse.", Der Garten, str. 13.

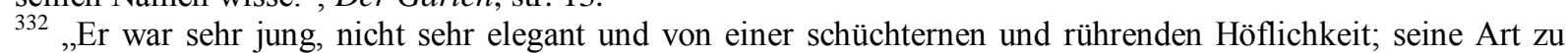
reden war etwas umständlich und er betonte ein wenig die tonlosen Vokale. Der Erwin hatte ihn gern.", Der Garten, str. 13.
} 


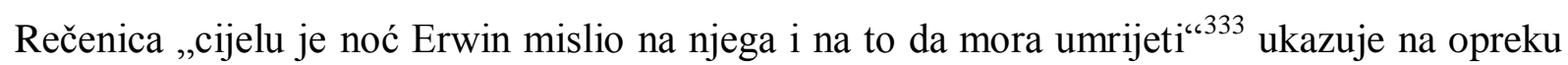
između Erwinovog djelomice vitalističkog doživljaja svijeta, odnosno želje za čuvstvenom, intimnom, opojnom bliskošću sa mladim časnikom (homoerotički impulsi) s jedne, te njegovog kontemplativnog, pasivnog i receptivnog, ženski-konotiranog i asketskog nazora na svijet (simboliziranog metaforom smrti). Treba primijetiti da bi se Erwinovi homoerotički impulsi, koji su naročito povezani s likovima Clemensa i Lata, mogli protumačiti kao ,jalovi“, gotovo asketski i ,,aristokratski““ konotirani impulsi, dok se naklonost prema oficiru i, posebice, prema ženama (napose glumica u Bozenu, zatim Erwinova majka) povezuju s tjelesnom čežnjom (ženski konotiranom senzualnošću) i smrti. Ovakva je koncepcija smrti usporediva s koncepcijom dionizijske, vitalističke smrti u Hofmannsthalovoj drami Der Tor und der Tod.

Lik starog svećenika i fizičara na Erwina ostavlja poseban dojam, budući da simbolizira svojevrsne okultne moći znanosti: svećenik Erwina podučava prirodnim naukama, posebice magnetizmu. Privlačna i odbojna sila metaforički predstavljaju Erwinov hibriditet roda: psihičko stanje cikličkog izmjenjivanja odbojnog i privlačnog stava prema pojedinim osobama u Erwinovu životu. Stilizacija života u umjetničko djelo ogleda se i u Erwinovoj stilizaciji znanosti u ,pripovijest“. U znanosti, kao kasnije i u umjetnosti, Erwin traži vitalističku potvrdu ,punine života“ i u njoj vidi mogućnost dokidanja jalove egzistencije esteta.

Heinrich Philipp, kojeg Erwin upoznaje prve školske godine, pripovijeda Erwinu o Beču, u kojem je živio do svoje 16. godine, i pobuđuje u njemu interes za velegrad i njegove mogućnosti, koje kriju i mnoge opasnosti (njem. verbotene Dinge). Lik Heinricha Philippa odražava asketske karakteristike, tako da je njegov život čak uspoređen s hagiografijom svetaca:

Heinrich Philipp imao je tri osobine (...) poput tri svijetleća dragulja. (...) Posjedovao je veliku dobrotu svetaca, koja je bila poput shvaćanja najvećih dubina duše svakog bića; bio je udvoran, budući da je prema svakome iskazivao njima prikladnu formu te uljudnosti, i bio je ljubazan i susretljiv, budući da je toliko puno mislio na druge. ${ }^{334}$

Opis Heinricha Philippa upućuje na esteticizam epohe i nosi jasne aristokratske konotacije. U njegovom se karakteru mogu iščitati elementi esteticističke profinjenosti, pa i svojevrsnog

\footnotetext{
${ }^{333}$ Der Garten, str. 13. („Die ganze Nacht dachte der Erwin an ihn und daran, daß er sterben müsse“)

334 „Heinrich Philipp hatte drei Eigenschaften, (...) wie drei leuchtende Edelsteine. (...) Er besaß die große Güte der Heiligen, die wie ein Verstehen des tiefsten Grundes in allen Wesen ist; höflich war er, indem er ihr jedem einzelnen gegenüber die passende Form gab, und liebenswürdig, weil er so viel an die anderen dachte“., Der Garten, str. 16-17.
} 
hedonizma i uronjenosti u „veliki svijet“, koji otkrivaju drugu, oprečnu stranu njegove ličnosti:

Kako ga je Erwin bolje upoznavao, ponekad mu se činio potpuno promijenjenim; kao da nije razgovarao izravno s Erwinom nego je govorio negdje mimo njega a njegove su se riječi vraćale njemu samome; tada je Erwin saznao za neke riječi, koje prije nije poznavao, i saznao je značenje tih drugih riječi koje prije nije razumio; ili je naprosto saznao da postoji cijeli niz tajni, čak i u onome u čemu se činilo da nema tajni, i da postoje stvari koje su loše i zabranjene a istovremeno privlačne. I o Beču je tada govorio Heinrich Philipp, ali jednim drugim tonom nego inače; onda je Erwin mutno shvaćao, da je jedna strana bečkog života na neki način povezana s tim zabranjenim riječima (...).

Erwinovi homoerotički impulsi često podrazumijevaju i objektifikaciju muškaraca u njegovom životu, što upućuje na to da je Erwinova psiha isključivo stjecište mnogobrojnih impresija i da su bića, stvari i pojave vanjskog svijeta za njega objekti njegovog subjektivnog i estetskog doživljaja. To se najbolje može uočiti u njegovoj esteticističkoj usporedbi mlade gospode i fijakera: ,ali Erwin nije pronašao u fijakerima ono što je od njih očekivao; oni su uistinu nalikovali mladoj gospodi, kao njihov stil odijevanja, tako su i suprotnosti njihovih duša bile jače razrađene. (...) forme njihove uljudnosti bile su nježnije ali iscifranije.“335

Erwinova veza s Clemensom, „siromašnim i jednostavnim“ mladićem ${ }^{336}$, kojeg Erwin u dekadentnom i esteticističkom smislu uspoređuje sa samim sobom, zapravo predstavlja potragu za samim sobom, odnosno za ,sličnošću sa vlastitom osobnošću“ ${ }^{337}$ I lik Clemensa je opisan u svojoj višedimenzionalnosti pa $\mathrm{i}$ on predstavlja ,androgini“ topos jedinstva suprotnosti (lat. coincidentia oppositorum) ${ }^{338}$ koji je uvelike prisutan u književnosti bečke moderne:

Clemens je bio siromašan i vrlo jednostavan; bio je znatiželjan, iskvaren poput nekog uličnog derana a gotovo patetično naivan i nevin; sve je na njegovom licu bilo svijetlo, osim crnih podočnjaka. U njegovoj je svijetloj kosi, koja je izgledala zagasito, kao da je napudrana, u mekoj bujnosti dinamičnih crta njegova lica i linija ispod očiju ležala dirljiva ljepota davnih vremena. Imao je isti glas kao onaj časnik, s kojim se Erwin vozio u Bozen; ali nije mu bio sličan. ${ }^{339}$

Opis Clemensove pomalo androgine i „drevne“, odnosno renesansne ljepote ukazuje na feminizaciju i narcizam kako Clemensa, tako i Erwina kao esteta. Sljedeći motivi u djelu također ukazuju na dendijevsku egzistenciju esteta: „Erwin ga je volio poprskati novim

\footnotetext{
335, „(...) aber der Erwin fand nicht in den Fiakern, was er von ihnen erwartet hatte; sie glichen wirklich den jungen Herren, nur wie ihr Stil in der Kleidung, so waren die Gegensätze ihrer Seelen stärker herausgearbeitet. (...) und die Formen ihrer Höflichkeit waren zarter aber verschnörkelter.“, Der Garten, str. 23-24.

${ }^{336}$ Der Garten, str. 24.

${ }^{337}$ Paetzke 1992, str. 38.

${ }^{338}$ Vidi Viktor Žmegač: Bečka moderna, 1998.

339 „Der Clemens war arm und sehr einfach; er war neugierig, verdorben wie ein Gassenbub und fast pathetisch unschuldig; alles in seinem Gesicht war hell, bis auf die schwarzen Ringe um seine Augen. In seinem lichten Haar, das matt aussah, wie wenn es gepudert wäre, im weichen Reichtum der bewegten Linien seines Gesichtes und unter seinen Augen vor allem lag die rührende Schönheit der späten Zeiten. Er hatte die Stimme jenes Offiziers, mit dem der Erwin nach Bozen gefahren war; aber er glich ihm nicht"., Der Garten, str. 24-25.
} 
parfemima i poklanjao mu je stvari čiju se ljepotu, budući da je bila iznenađujuća i neharmonična, moglo nazvati elegancijom: tkanine i materijale iz Pariza, koje su bile neobične po kroju i boji, zlatne narukvice i kutije za cigarete od srebra ili čelika...“. 340

Erwinov i Clemensov narcizam esteta poprima razmjere nečeg sveopćeg i univerzalnog, ali uglavnom predstavlja okrenutost esteta u vlastitu nutrinu, „ljubav prema samima sebi, i ljubav jedno prema drugome ili ljubav prema svemu što su zajednički voljeli, ili ljubav prema ovoj austrijskoj domovini, koja im je sve dala i od koje se nije moglo pobjeći“‘ ${ }^{341}$

Lik stranca (Der Fremde) posebno je zanimljiv, budući da predstavlja alegorijski lik i objedinjuje sve Erwinove čežnje i strahove i predstavlja njegov alter-ego, odnosno nesvjesni dio njegove psihe. Prema Paetzke, ovaj lik utjelovljuje Erwinovu podsvjesnu čežnju za životom koja mu se sad prezentira u vidu ,prijeteće“ senzualnosti, kao prijeteća „Drugost““342 vlastite psihe.

\subsubsection{Implicitni rod}

Pripovijedanje u djelu koncipirano je kroz djelomice empatički prikaz unutarnjih fluktuacija psihe esteta od strane heterodijegetske pripovjedne instance, koja ipak zauzima svojevrsnu kritičku distancu spram glavnog lika pripovijetke. Naime, narativna perspektiva je ambivalentna: autorska pripovjedačka svijest (instanca) s početka pripovijetke postepeno prelazi u personalnu perspektivu, koja gotovo neposredno prikazuje unutarnja duševna stanja glavnog lika. U drugom dijelu pripovijetke, napose u dijelu koji prikazuje sirotinjsko predgrađe, heterodijegetska pripovjedna instanca gotovo se $\mathrm{u}$ potpunosti konsolidira $\mathrm{s}$ prikazom unutarnjeg Erwinovog svijeta, te se pripovijedanje približava personalnoj pripovjednoj perspektivi. Gubitak sigurnosti esteta u njegovom identitetu tako u potpunosti dolazi do izražaja kroz prikaz u personalnoj perspektivi. Gotovo cijela pripovijetka (izuzevši ključni Erwinov dijalog s majkom, prikazan u direktnom međusobnom obraćanju likova, dakle, u upravnom govoru) koncipirana je u slobodnom neupravnom govoru. Većina pripovijedanja odvija se u 3. licu jednine, s naglaskom na generičku karakteristiku kneza Erwina (der Erwin), upućujući 1. na kolektiviziranje lika esteta, koji predstavlja cijelu jednu generaciju i svjetonazor epohe (identifikacijska figura) i 2. na svojevrsnu bliskost Erwina i

\footnotetext{
${ }^{340}$ „Er liebte es auch, ihn mit neu erfundenen Parfüms zu besprengen oder ihm jene Dinge zu schenken, deren Schönheit man, weil sie überraschend und unharmonisch ist, Eleganz nennt: jene Stoffe und Gewebe aus Paris, seltsam in Zeichnung und Farbe, und goldene Armbänder und Zigarettentaschen aus Silber oder Stahl...", Der Garten, str. 25.

${ }^{341}$ „eine Liebe ihrer selbst oder eine Liebe zueinander oder eine Liebe zu allem, was sie geliebt hatten, oder eine Liebe zu diesem österreichischen Vaterland, das ja alles gab und vor dem kein Entrinnen war“., Der Garten, str. 26.

${ }^{342}$ Paetzke 1992, str. 46.
} 
čitatelja, s obzirom na to da heterodijegetska pripovjedna instanca želi prikazati intimnu ispovijest. Razlog zbog kojeg se većina pripovijetke odvija u slobodnom neupravnom govoru, povezana je s neznatnom kritičkom distancom pripovjedača (poniranje u lik). Erwinov život osamljenog esteta i ,tamnicu esteticizma“ često je kritizirao Hofmannsthal.

Prostor Beča u djelu nosi karakteristike nečeg zabranjenog (metafora Beča kao Porta orientis), a kao velegrad nudi pluralitet mogućnosti. Mnoge su pojave (pa i gradske vedute Beča) kaleidoskopski prikazane, kao brza izmjena unutarnjih $\mathrm{i}$ vanjskih $\operatorname{dojmova}^{343} \mathrm{i}$ percepcija.

Koncepcija vremena u cijeloj je Andrianovoj pripovijetci orijentirana na prikaz subjektivnog vremena naspram društvenih odnosa, koji su na neki način izostavljeni ili samo sumarno prikazani kroz svijest esteta: ovo subjektivno koncipirano vrijeme ${ }^{344}$ odražava transcendenciju unutarnjeg svijeta esteta, prožetu sjećanjima na prošlost ${ }^{345}$ i anticipacijom budućih doživljaja, što je u suprotnosti s društvenim vremenom koje neumitno teče. Prema Paetzke, društvena je situacija u onodobnoj Austriji uvjetovala povlačenje kako građanski, tako i aristokratski orijentiranih slojeva u privatnu sferu u kojoj se tražilo utočište. Paetzke naglašava da je mlada generacija esteta, koja je imala tendenciju ,promatranja izvanjske stvarnosti iz pozicije stilizirane distance umjetnika, radikalizirala jednu širu tendenciju povlačenja iz javnog svijeta politike u privatnu sferu, u kojoj su obrazovanje, kultura i umjetnost dobili takvo značenje kao gotovo nigdje drugdje u Europi“ ${ }^{346}$ Erwin ostaje upućen sam na sebe, odražavajući hermafroditsku samodostatnost (napose $\mathrm{u}$ ranom periodu djetinjstva) i živeći život isključivo unutar svoje nutrine, koja je prikazana kroz impresionistički konotiran, fluidan oblik naracije, gdje vrijeme pripovijedanja na mnogim mjestima premašuje ispripovijedano vrijeme (usporeni tempo pripovijedanja, njem. zeitdehnendes Erzählen). Erwin vanjski svijet doživljava isključivo kroz impresionistički konotirane perceptivno-doživljajne impulse (Machova koncepcija fluidnog jastva), u kojima stvari vanjskog svijeta služe tome da potaknu niz unutarnjih doživljaja esteta.

Vremenski okvir (vrijeme u kojem se odvija radnja) pripovijetke nije pobliže naznačen, ali sve upućuje na to da se radnja odvija u razdoblju bečke moderne, budući da je pripovijetka izrazito autobiografski koncipirana. Defabularizacija, odnosno manjak radnje u djelu ukazuje na vrstu introspektivne proze koja je ženski konotirana: ta je vrsta naracije karakteristična za

\footnotetext{
${ }^{343}$ Vidi Žmegač: Duh impresionizma i secesije, 1993.

${ }^{344}$ Nünning/Nünning 2004, str. 74. (v. Martin Middeke: ,subjektive Zeit“)

345 Prema Nünning/Nünning 2004, ova je koncepcija vraćanja u prošlost bliska podjeli Davida L. Higdona na retrospektivno vrijeme, a približava se također i koncepciji procesnog oblika vremena, budući da se naracija odvija kroz procese individuacije svijesti esteta, str. 74, vidi također str. 88-89.

346 Paetzke 1992, str. 42.
} 
razvoj personalnog oblika pripovijedanja u bečkoj moderni. Naracija nije linearna i teleološka, već ciklička i diskontinuirana, budući da odražava fragmentarnost Erwinova jastva u kojem jedan dojam smjenjuje onaj drugi, u svijesti kroz koju sve teče. Iako je pripovijetka narativno koncipirana kao prikaz razvoja Erwinove ličnosti, ona ne završava Erwinovom spoznajom o smislu ljudske egzistencije, već njegovom spoznajom o nemogućnosti spoznaje uslijed pluraliteta i višeznačnosti života.

U jednom psihoanalitičkom eseju koji se pojavio 1921. godine u časopisu Imago pod naslovom Narzißmus als Doppelrichtung ${ }^{347}$, književnica Lou Andreas-Salomé naglašava kako se narcizam može tumačiti i kroz svoj pozitivno konotiran, utopijski sadržaj: on predstavlja nezatomivu čežnju za izgubljenim rajem, zlatnim dobom i velikom cjelinom čovjeka, Boga i kozmosa. Ovo stanje sjedinjenosti pojedinca s univerzumom (,oceanski osjećaj“, prema riječima Romaina Rollanda ${ }^{348}$ ), stanje „mitskog obilja“ koje nosi predznake ženskog „principa“, predstavlja kontrapunkt dobu čisto znanstvene racionalnosti, koje promiče psihičku rascijepljenost subjekta. Prema teoretičarki Riti Felski, ženski konotirano utopijsko stanje, koje revalorizira empatijski odnos prema svijetu služi kao utopijska utjeha pred prijetnjama modernog doba koje muški subjekt tjera u psihozu. Na taj način i Erwinova samoća esteta djelomice predstavlja njegovu utopijsku čežnju za povratkom u ,majčinsko obilje“ primarnog narcizma, u kojem jastvo i svijet, subjekt i objekt, duša i tijelo, odnosno ,ja“ i ,ne-ja“ još nisu nastupili kao odvojene sfere. Erwinov narcizam, odnosno preslikavanje vanjskih objekata kroz vlastitu svijest predstavlja stoga, osim eskapističkog povlačenja u sebe, također i auto-refleksivno stanje „zaboravljanja“ vlastitog jastva u pokušaju ,ženski konotiranog“, pasivnog i receptivnog spajanja s univerzalnim, odnosno ,poistovjećenja“ s bićima i stvarima oko sebe kako bi ih se bolje razumjelo. Prema riječima Lou AndreasSalomé, dakle, „narcizam stvara preduvjete za harmoničan i stvaralački odnos subjekta prema Drugome i prema stvarnosti“‘ 349

Lou Andreas Salomé nadopunila je Freudove fragmentarne izjave o primarnom narcizmu, budući da je Freud narcizam smatrao manje vrijednim, „primitivnim“ i animističkim stanjem razvoja kulturne povijesti čovječanstva, u kojem prevladava „magična vjera u moć riječi i svemoćnost misli“. ${ }^{350}$ Njezin se originalni doprinos i dopuna Freudovoj teoriji narcizma, prema Le Rideru, sastoji u percipiranju sličnosti umjetničkog genija i žene: prema Salomé, oboje su u stanju „osjetiti još neizdiferencirani bitak“. Umjetnički genij i žena „manje su

\footnotetext{
${ }^{347}$ Le Rider 1990, str. 83.

${ }^{348}$ Ibid., str. 85.

${ }^{349}$ Ibid., str. 91 .

${ }^{350}$ Ibid., str. 90 .
} 
gospodari svojih sposobnosti i duševnih stanja, osjetljiviji su i osjećajniji, više na njih utječu skrivene sile koje ih zanose protiv njihovog svjesnog razmišljanja i protiv njihove volje““. ${ }^{351}$ Narcizam, to jest upućenost esteta samog na sebe, Freud psihoanalitički tumači i kao neodvojivost (muškog) pojedinca od majčinskog principa, koji uvjetuje boravak esteta u prededipalnoj fazi. Karakteristika sanjara i umjetnika je boravak u ovom stanju primarnog narcizma. Međutim, Freud smatra da ovo stanje dovodi do otuđenja pojedinca od društvene okoline. U Andrianovoj je pripovijetci Erwinova otuđenost od društva, njegova izolacija umjetnika, naročito vidljiva na samom početku:

dvanaestogodišnji sin kneza bio je „tako osamljen i sam sebi dovoljan, kao nikad poslije; njegovo tijelo i duša živjeli su gotovo dvostruki život jedno u drugome; stvari vanjskog svijeta za njega su imale onu vrijednost, koju imaju u snovima; bile su riječi jednog jezika, koji je pukom slučajnošću bio njegov, no tek su njegovom voljom one dobivale značenje, mjesto i boju. ${ }^{352}$

Povlačenje esteta u vlastiti unutarnji svijet, u kojem stvari vanjskog svijeta postaju tek slučajni poligoni za kreiranje vlastitog svijeta može se povezati s psihoanalitičkim pojmom pred-edipalnog stanja, u kojem vanjski svijet još ne nastupa kao od subjektivnosti odvojen objekt. Pred-edipalna se faza često uspoređuje sa mitskim, majčinskim obiljem, budući da se u njoj majka još ne nazire kao zasebni, vanjski objekt, te su subjektivno jastvo pojedinca i objekt njegovih razmatranja neodvojivi jedno od drugoga. Cijela naracija pripovijetke zapravo prati ovu psihološku matricu, prema kojoj je vanjski svijet bića, stvari i pojava neodvojiv od subjektivnog svijeta esteta, od njegove percepcije tog vanjskog svijeta: stoga gotovo cijela pripovijetka naginje ,pounutrenju svijeta“ koje svoj narativni izričaj nalazi u sklonosti defabularizaciji.

Pripovijetka je prožeta larpurlartističkim, elitističko-aristokratskim stavom narcisa o stilizaciji i estetiziranju vlastitog života u umjetničko djelo, pri čemu se, sukladno Freudovim tumačenjima i Nietzscheovim poimanjima, apolonijska kultura i statičnost (koju simbolizira sublimacija nagona u umjetničko stvaralaštvo) donekle pretpostavlja dionizijskoj opojnosti koja predstavlja vitalistički, dinamični način života (priroda, biološko, spolnost). Međutim, kroz cijelu se naraciju provlači Nietzscheova misao o „uništenju bitka“, odnosno nestajanju, zaboravljanju i „utapanju“ bitka u „dionizijskoj opojnosti“ koja je simbolična upravo za vitalistička shvaćanja o prijelomu stoljeća: ovaj oblik modernog eskapizma ukazuje, pored ženski konotiranog iracionalizma i zaborava vlastitog jastva (identiteta), također i na manjak

\footnotetext{
${ }^{351}$ Le Rider 1990, str. 93.

352 „Damals (er ging ins zwölfte Jahr) war der Erwin so einsam und sich selbst genug, wie niemals später; sein Körper und seine Seele lebten ein fast zweifaches Leben geheimnisvoll ineinander; die Dinge der äußeren Welt hatten ihm den Wert, den sie im Traume haben; sie waren Worte einer Sprache, welche zufällig die seine war, aber erst durch seinen Willen erhielten sie Bedeutung, Stellung und Farbe“, Der Garten, str. 8.
} 
neposrednog doživljavanja svijeta koji je usko povezan s androginiziranom, odnosno hermafroditski samodostatnom psihom senzibilnog i umjetnički nastrojenog pojedinca. Problematika bijega od stvarnosti usko se veže uz fragmentarnost identiteta, odnosno njegovu (rodnu) neodređenost, uz rascjepljenost ličnosti (njem. Ich-Spaltung), koja uvjetuje Erwinovu anksioznost. Nietzscheanska je filozofija premoći umjetnosti bila tipična za kraj stoljeća, odnosno vrijeme bečke moderne: ona je u razdoblju sveopćeg gubitka vrijednosti (svojevrsnog vakuuma vrijednosti ${ }^{353}$ ), pa i moralnih vrijednosti, pružala „utjehu“ i tražila izlaz iz kaotične svakodnevice i osjećaja besmisla ljudske egzistencije u specifičnom stanju opojnosti i zanesenosti ljepotom umjetnosti, koja je podrazumijevala i gubitak identiteta.

Erwinov je narcizam usko povezan s njegovom psihičkom orijentacijom na traženje smisla života. Ciklički i fragmentarni karakter pripovijetke, odnosno ne-linearno, fragmentarno, neteleološki usmjereno pripovijedanje odražava, kako je naznačeno u naslovu, Erwinovu neprestanu, mistično konotiranu potragu za spoznajom biti i smisla života: ta se potraga na kraju, shodno skepticizmu epohe, ispostavlja jalovom, budući da Erwin umire a da zapravo bit života nije spoznao. U razgovoru s majkom Erwin izriče da je ,najveća tajna u nama“, odnosno u ljudskoj duši, ali zaključuje da „naša duša nije samo u nama““354: ova misao ukazuje 1. na fragmentarnost Erwinovog (rodnog) identiteta koja je odraz sveopće krize identiteta (njem. das unrettbare Ich), ali i 2. na mistično jedinstvo svih bića, stvari i pojava, koja se približava mističkim strujama misli o prijelomu stoljeća i orijentalnim motivima, koji su često prožimali mnoga djela bečke moderne.

Epizoda Erwinovog razgovora s majkom najdetaljnija je i najdulja u cijelom Gartenu. Polazna točka ovoga odlomka sjećanje je na djetinjstvo, koje prethodi susretu s majkom. Erwin se prisjeća samoga sebe kao osmogodišnjeg slabog i bolećivog dječaka, čija bespomoćnost kontrastira sa sigurnim nastupom njegove majke (što aludira na majčinu svojevrsnu distanciranost prema sinu Erwinu). Citat:

Svoju majku je on sada vidio na način kao što si je on jednom u njegovoj devetoj godini predočio nakon njegove duže bolesti i osjećao se napuštenim i bespomoćnim kako se samo osjećaju oboljela mala djeca; onda je ona ušla unutra nakićena svilom, cvijećem i dragim kamenjem i uzela knjigu u ruku i počela mu čitati iz te knjige; To se njemu činilo kao neka čudesna blagonaklonost sa primjesama podcjenjivanja, jer je ona za njega bila velika i strana osoba. ${ }^{355}$

Ovi estetski atributi predstavljaju Erwinovu majku kao neki natprirodni, gotovo nedostupni lik, a Erwin je poima kao idealnu voljenu (njem. "Traum-Geliebte“). ${ }^{356}$

\footnotetext{
${ }^{353}$ Ovaj pojam naročito napominje Le Rider u svojoj knjizi o problematici bečke moderne pod naslovom Das Ende der Illusion, 1990, str. 409-414.

${ }_{355}^{354}$ Der Garten, str. 50.

355 Ibid., str. 46-47.

356 Vidi Renner 1981, str. 187.
} 


\subsubsection{Zaključak}

Temeljna razlika Andrianove pripovijetke Der Garten der Erkenntnis i Hofmannsthalove pripovijetke slične tematike i stila pod naslovom Das Märchen der 672. Nacht je u tome što se u Andrianovoj pripovijetci tematizira Erwinov bezinteresni, aristokratski esteticizam (esteticizam koji nije usmjeren na neku pragmatičnu svrhu), dok se kod Hofmannsthala ipak promiče vlasničko-posjednički (odnosno, kolekcionarski) mentalitet građanskog sloja. ${ }^{357}$ Temeljna sličnost ove dvije pripovijetke je pak u tome što se u oba djela narcizam $i$ povlačenje esteta $\mathrm{u}$ vlastiti unutarnji svijet ispostavljaju kao simptom na samo gubitka identiteta u doba bečke moderne, već i kritike racionalno-liberalne slike svijeta ranije generacije i njezine vjere u napredak s kojom se senzibilni i umjetnički nastrojeni esteti više nisu mogli poistovjetiti. ${ }^{358}$ Stoga se psihološka regresija esteta može protumačiti kao simptom bijega od društvene stvarnosti i povlačenje u estetsku kulturu. Povlačenje u vlastiti „umjetni raj“ izraz je kako narcizma tako i nostalgije za aristokratskom kulturom koja se pomalo gasi. Kod Hofmannsthala se, međutim, taj narcizam usko veže uz povijesnu situaciju u kojoj se našlo građanstvo ${ }^{359}$, dok se kod Andriana narcizam ulijeva u nejasan patos i nostalgičnu evokaciju aristokracije koja se nalazi na svome zalazu. Hofmannsthalov estet je, ponajprije, bogati nasljednik oca trgovca, koji, po uzoru na patrijarhalnu matricu, dijelom oponaša vlasnički i estetsko-kolekcionarski mentalitet svoga oca, budući da i ljude i predmete na impresionistički način promatra kao estetske objekte, bez ikakve želje za nekom dubljom komunikacijom s njima $\mathrm{i}$ bez želje da ih posjeduje. U djelu se čak pojavljuje metafora „unutarnji posjed“, naglašavajući da se radi o objektima kao neodvojivima od psihe pojedinačnog promatrača i njegovih percepcija stvarnosti. Kod Hofmannsthala se dokida opreka između naoko nesvrhovitog esteticizma s jedne i vlasničko-posjedničkog mentaliteta građanstva s druge strane, te se esteticizam zapravo svodi na svoje materijalne uvjete, pri čemu gubi svoju elitističku, aristokratsku poziciju ${ }^{360}$ kakvu ima u Andrianovom djelu Der Garten der Erkenntnis. U Andriana se patnje i anksioznosti kneza Erwina prožimaju slavljeničkim patosom i vežu egzistenciju esteta na čeznutljivu refleksiju o propasti plemstva i njegove kulture. ${ }^{361}$ Nostalgična evokacija bečkih veduta i karakterističnih likova, ovaj slijed impresionistički obojenih slika stvarnosti također predstavlja i odraz perceptivnih mehanizama individualne psihe koja su-kreira vlastitu stvarnost, shodno filozofskim

\footnotetext{
${ }^{357}$ Paetzke 1992, str. 49.

${ }^{358}$ Usp. Paetzke 1992, str. 34.

${ }^{359}$ Ibid., str. 49.

${ }^{360}$ Ibid.

${ }^{361}$ Ibid.
} 
zasadama fizičara i teoretičara impresionizma Ernsta Macha, Jungovom pojmu kolektivne podsvijesti i Freudovom pojmu individualne podsvijesti (njem. das Unbewusste). Radnja (izvanjski događaji) u obje pripovijetke stoga biva svedena na minimum, jer se pripovijedanje uglavnom oslanja na prikaz psihičkog mikrokozmosa esteta. U djelu Der Garten der Erkenntnis posebice se ističe povezanost unutarnjeg univerzuma umjetnika sa cijelim kozmosom i s pluralitetom pojavnosti, odnosno, prema riječima Iris Paetzke, ,povezanost esteta sa životom samim putem njegove duše, u kojoj su jastvo i svijet sjedinjeni u mističnom jedinstvu“3362: metafore „duše“ i ,života“ i njihove međusobne povezanosti odražavaju djelomičnu srodnost onodobne književnosti s mističkim pravcima misli oko 1900. godine. Problematika esteta koji je usmjeren na samoga sebe upućuje na društveno stanje nostalgične evokacije profinjene kulture metropole Habsburške Monarhije. Beč se stoga uglavnom pojavljuje kao bajkoviti grad, a bečke su vedute oslikane suptilnim i melodioznim izričajem koji odražava profinjenost esteta. No prisutna je i Andrianova skepsa prema brzom razvoju metropole kao nešto istovremeno zazorno (zabranjeno) i privlačno.

Stilizacija života esteta u zagonetni „Schauspiel“ (ovu bi se višeznačnu riječ moglo prevesti kao „drama“, „,igrokaz“ ili „prizor“) upućuje na alijenaciju esteta, odnosno, upućenost esteta na samoga sebe (narcističko percipiranje stvarnosti ili svojevrsno pounutrenje stvarnosti). Erwin demonstrira izrazitu feminizaciju svojom pasivnošću (nedostatkom djelovanja) i receptivnošću: njegova se psiha koncentrira uglavnom na impresionistička poimanja vanjskog svijeta, bez neke manifestne reakcije na pojave vanjskog svijeta. Ova se upućenost esteta na samoga sebe može objasniti i krizom identiteta, odnosno „gubitkom osjećaja za stvarnost““363 u razdoblju o prijelomu stoljeća. Stoga pripovijetka Der Garten der Erkenntnis ujedno predstavlja i kritiku esteticističkog nazora na svijet i eskapizma koji on promiče.

Temeljna karakteristika lika kneza Erwina njegov je habitus senzibilnog esteta koji nosi obilježje narcističke samodostatnosti (svojevrsna androgina samodostatnost). ${ }^{364}$ Erwinovi pokušaji da dođe do samospoznaje ne uspijevaju budući da on traži uvijek samo svoju zrcalnu sliku. Međutim, Erwinov pokušaj pronalaženja samoga sebe može se tumačiti kao njegova želja za povezanošću sa srodnim dušama. „Unutarnja namjera čovjeka je prepoznati samoga sebe“. ${ }^{365}$ Međutim ovakav pokušaj ipak završava Erwinovom regresijom u stanje sna ili stanje smrti. Prema Ursuli Renner ${ }^{366}$, Erwin „regredira“ u stanja jastva (njem. „Ich-Zustände“") koja

\footnotetext{
362 Paetzke 1992, str. 41

${ }^{363}$ Ibid., str. 33

${ }^{364}$ Usp. Renner 1981, str. 215.

365 Ibid., str. 216.

${ }^{366}$ Ibid., str. 215.
} 
se mogu pretočiti u njegovu čežnju za sjedinjenjem s majkom (ponekad i bijeg u stanje sna), a pripovjedač mu daje ulogu njegovog oca, budući da ga na samom kraju pripovijetke naziva istom titulom kneza (njem. ,Fürst" ${ }^{\circ}$ ).

Primarni narcizam esteta prije svega postaje odraz društvenog miljea kojem Erwin pripada (Erwinov aristokratski habitus). San koji Erwin sanja kratko prije svoje smrti još jednom zaokružuje sav njegov dosadašnji život. To je san koji predstavlja njegov narušeni proces komunikacije s drugima. ${ }^{367}$

Uzrok Erwinovog manjkavog interesa za vanjski svijet njegova je melankolija i gubitak sposobnosti za ljubav, osjećaj manje vrijednosti koji se kasnije izražava u osjećaju krivice. (vidi S. Freud: Trauer und Melancholie, Stud. III, 198.str.). Ursula Renner u svojoj studiji ovo stanje definira kao melankoličnu depresiju (unutarnji umor, zamor od života, prazninu). ${ }^{368}$

Motiv stranca (der Fremde), koji se pojavljuje u djelu, zapravo predstavlja na simbolički način Erwinovog oca, odnosno Erwinov potencijalni susret sa „zakonom“ oca, budući da Erwin cijeli život osjeća nedostatak oca, zbog ranog gubitka oca, u najranijem djetinjstvu. Erwinova čežnja za povratkom u majčino tijelo čežnja je za sigurnošću i zaštićenošću od vanjskog svijeta, od školskih kolega koji ga nerado prihvaćaju i zaobilaze.

Erwinova čežnja za majkom, poput njegove čežnje za snom kao nečim što će ga zaštititi, nosi u sebi regresivnu crtu, ali s druge strane predstavlja i nježnost (senzibilnost) esteta. ${ }^{369}$ Zbog Erwinove (homoseksualne) identifikacije sa majkom, majčine represivne i ambivalentne crte vezano na ponašanje prema njemu padaju u zaborav. ${ }^{370}$ Sada se on, poput njegove majke, u svom rodnom identitetu identificira sa ženskošću, te se njegova žudnja usmjerava ili prema muškarcima ili prema androginim ženama.

Paetzke napominje još jedan značajan detalj: „dok Erwinovi muški prijatelji imaju imena, žene naprotiv ostaju bezimene, anonimne“. ${ }^{371}$ Ovaj detalj (onodobne društvene okolnosti kao kontekst: žene su objektivno bile „bezimenije i anonimnije“ od muškaraca- ime su dobivale od oca ili muža) možemo usko povezati s problematikom muškog subjekta u bečkoj moderni i njegovim otuđenjem od žena i ženskosti, koja je prikazana i u Hofmannsthalovim djelima. Ukazujući na gubitak sigurnosti muškog subjekta kao dio muškog protesta, odnosno reakcije

\footnotetext{
${ }^{367}$ Usp. Renner 1981, str. 213.

368 Ibid., str. 212.

${ }^{369}$ Ibid., str. 187.

${ }^{370}$ Ibid., str. 188 .

${ }^{371}$ Ibid., str. 39.
} 
na žensku emancipaciju, problematika modernih prikaza ženskosti izvire iz modernističkog stava prema ženi: ambivalentnog muškog položaja straha i žudnje prema ženskom subjektu.

\subsection{Richard Beer-Hofmann: Der Tod Georgs ( Smrt Georgova)}

\subsubsection{Uvod}

Richard Beer-Hofmann svojevrsni je autsajder unutar književne grupacije Junges Wien, kao uostalom i Leopold von Andrian. ${ }^{372}$ Temeljna stilska karakteristika ova dva književnika je fluidnost dikcije, kroz koju se prikazuje kriza identiteta glavnih protagonista, budući da se njihov unutarnji univerzum rastače u nizu dojmova, osjećaja, raspoloženja, sjećanja na prošlost i anksioznih anticipacija budućnosti. Poput Andriana, i Beer-Hofmannova se književna karijera dugo vremena zasnivala na manjim proznim uradcima kao što je njegov roman Der Tod Georgs (Smrt Georgova) i pjesma Schlaflied für Mirjam, koja je objavljena 1898. godine u časopisu Pan. Kontekst nastanka Beer-Hofmannovog romana Der Tod Georgs je sljedeći: „Beer-Hofmann je morao emigrirati u SAD, a u New Yorku je proživljavao sjećanja na svoju ženu i Austriju“6373 koja se tada nalazila u prijelomnom razdoblju. Njegovo djelo odlikuje neobična mješavina dostojanstvenosti (svojevrsna distanca i asketska crta) i skurilnosti. Već na ljeto 1893. godine Beer-Hofmann je počeo raditi na ovoj većoj pripovijetci (odnosno, kraćem romanu) pod prvotnim naslovom Der Götterliebling (Miljenik bogova), koji je kasnije preimenovao u Der Tod Georgs. Bilo je potrebno pet godina da se barem jedan fragment ovog kraćeg romana objavi, i to zajedno s Hofmannsthalovim djelom Die Frau im Fenster 1898. godine u časopisu Pan, dok je tek 1900. godine objavljen cjelokupni tekst kod izdavača S. Fischera. Samo nekoliko godina ranije, 1895. godine, objavio je Leopold von Andrian svoju pripovijetku Der Garten der Erkenntnis. Likovi Andrianova i BeerHofmannovog djela demonstriraju velike sličnosti: Paul i Erwin, oba bez nekog konkretnog zanimanja i oslobođeni materijalnih briga, dijele sklonost permanentnoj auto-refleksivnosti i samosažaljenju, čežnji za djetinjstvom i nedostatak neposrednih doživljaja, koji je popraćen konstantnom recepcijom (lektirom), odnosno onim prenesenim, predajom.

Senzibilni estet Paul potresen je smrću svoga prijatelja Georga, koji se u Paulovoj imaginaciji isprepliće s likom Paulove žene koja poprima „dječački izgled“ te se na taj način zapravo i Georg i Paulova žena, koji (u okviru fiktivne radnje) figuriraju na granici imaginarnih i stvarnih ličnosti, zrcale jedno kroz drugo u psihi esteta koji na kraju romana

\footnotetext{
372 Vidi Fischer 1978, str. 197.

${ }^{373}$ Ibid.
} 
pronalazi utjehu u poistovjećenju sa svojim židovskim podrijetlom, koje ga vodi „stopama njegovih predaka“.

Neobičan prvotni naslov romana (njem. Götterliebling) nosi svojevrsne motivske paralele s jednom epizodom $\mathrm{u}$ drugom dijelu romana, naime vizijom hrama i proljetnje svetkovine $\mathrm{u}$ Hijerapolisu u snu glavnog protagonista romana, esteta Paula. Ova epizoda, koja na ornamentalan i dekorativan način (esteticističkim opisima) prikazuje svojevrsna prethistorijska, mitska vremena čovječanstva, služi kao simbolički kontrapunkt ostatku romana: prikazu sterilne egzistencije moderniteta i individualizaciji epohe o prijelomu stoljeća, predstavljenoj kroz Paulov samotni život esteta i zrcaljenja njegovog identiteta u drugim likovima, umirućoj mladoj ženi i njegovom umirućem prijatelju Georgu. Likovi u Beer-Hofmanna, Andriana i Hofmannsthala utjelovljenje su književno-povijesno utemeljenog tipološkog lika esteta koji se odvaja od života (njem. lebensferner, weltmüder Ästhet). BeerHofmann, poput Andriana i Hofmannsthala, opisuje esteticizam djelomice kao gubitak životnog vitaliteta i naglašava manjak veza s vanjskim svijetom koje s jedne strane otuđuju estetski prijemčive pojedince, a s druge ih strane uvode u osjećaj mistične povezanosti svih stvari u kozmosu („oceanski osjećaj“). ${ }^{374}$ U djelima Beer-Hofmanna, Andriana i Hofmannsthala naglašena je problematika primarnog narcizma umjetnika: orijentacija esteta na vlastitu pred-edipalnu fazu iz djetinjstva, njihova potraga za re-kreiranjem vlastitog podsvjesnog ženskog dijela psihe (svojevrsna internalizacija ženskosti).

\subsubsection{Eksplicitni rod}

„Ispreplitanje i uklapanje vizija jednih u druge, snovi i sanjarenja, koji pritišću psihu glavnog lika Paula, vrlo su kompleksni“375, a tematski prvenstveno govore o dijalektičkoj „borbi“ dvaju principa u psihi glavnog protagonista Paula: vitalizma (lat. vita activa) i pasivnosti (lat. vita contemplativa). Po tim se obrascima pripovijedanja i po demonstriranju hibridnog rodnog identiteta Beer-Hofmannovo djelo može također usporediti $s$ Andrianovom i Hofmannsthalovom pripovijetkom.

Ono što kod Beer-Hofmanna povezuje san i stvarnost, dakle vrijeme fantaziranja (imaginacije) i realno vrijeme, to je uska mreža provodnih motiva $u$ djelu. ${ }^{376}$ Temeljni provodni motivi su sljedeći: 1. motiv smrti i lijepe smrti, koji odražavaju habitus esteta Paula i njegov zamor od života, 2. brojni floralni motivi, koji služe kao metonimijski i metaforički

\footnotetext{
${ }^{374}$ Vidi Le Rider, 1990, str. 85.

${ }^{375}$ Fischer 1978, str. 198.

${ }^{376}$ Ibid., str. 199.
} 
obrasci za prikazivanje i estetizaciju ženskog tijela, 3. motiv života, koji se pojavljuje u Paulovim kontemplacijama o smislu života i univerzuma, a blizak je monističkoj filozofiji, 4. motiv sudbine (njem. Geschick, Schicksal) koja se poima na fatalistički način i pomoću koje se nastoji premostiti skepticizam i beznadni pluralizam, pa i vakuum epohe, 5. motiv života kao igre ili igrokaza (njem. Das Leben als Spiel, Schauspiel), pri čemu se život na esteticistički način izjednačuje s umjetnošću (supremacija umjetničkog stava prema svijetu), 6. motiv zemlje (njem. die Erde), pri čemu se kroz primarni narcizam esteta pojam zemlje metaforički povezuje s pojmom majke (njem. Die Mutter), 7. motiv djetinjstva (njem. Kindheit, das Kind), za koje je glavni protagonist djela, estet Paul, posebno vezan (primarni narcizam, ali i poveznica s pojmom sudbine koja se najavljuje već u ranom djetinjstvu), 8. motiv ljepote (njem. die Schönheit) i njenog bezinteresnog promatranja, bez želje za posjedovanjem, 9. motiv sna (njem. der Traum) i snovitog, što ukazuje na mehanizme potiskivanja (njem. die Verdrängung, das Verdrängte), i na podsvjesne (njem. das Unbewusste) sadržaje psihe, pri čemu se zaranjanjem u podsvijest i pasivnošću introspektivnog i kontemplativnog života lik esteta Paula feminizira, 10. motiv ogledala (njem. Spiegel) i ogledala prirode (njem. Spiegel der Natur), kroz koje se glavni lik konstituira u svom narcizmu i primarnom narcizmu, svojoj upućenosti na vlastitu androginu samodostatnost, 11. motiv uvelog lišća (njem. braune Blätter), koji predstavlja esteticistički konotirani zamor od života i Paulovu čežnju za smrću, 12. pojam duše (njem. die Seele), koji predstavlja čest topos u književnosti bečke moderne (napose Hofmannsthal, Andrian i BeerHofmann), a simbolički označava mističnu povezanost esteta s univerzumom; čest je u djelima ovih književnika pokušaj ponovnog kreiranja vlastite anime, pokušaj internalizacije ženskosti prema kojoj se osjeća anksiozan stav, a koji se želi premostiti.

Likovi mladih žena, koje Paul „susreće“, a koje se tijekom djela čitatelju ispostavljaju kao mentalne konstrukcije Paulove mašte (dio njegovog nesvjesnog djela psihe, njegove anime), tipološki- odnosno, samo dijelom stereotipno, a dijelom ipak demonstriraju androginu, gotovo dječačku krhkost te predstavljaju svojevrsnu fin-de-siècleovsku kategoriju ljepote (franc. beauté malade), određeni su opisima koji se ponavljaju: sve su te žene krhke, dječačkog izgleda (njem. knabenhaft), anemične (njem. bleichsüchtig), imaju valovitu tamnu kosu koju heterodijegetski pripovjedač simbolički opisuje kao dunkle Haarflut (njem.), pri čemu kosa, koja predstavlja erotski, ženski konotirani simbol, stoji u suprotnosti sa njihovim drugim asketskim crtama. Žena ovdje, kao kontrapunkt uvriježenom stavu fin-de-siècle-a o ženskoj demonskoj crti, biva aseksualnom, gotovo plošno prikazanom (dvodimenzionalnom, u maniri Jugendstila) i bestjelesnom (njem. körperlos) figurom, te postaje oličenje tipične femme 
fragile i Kindfrau. Žena postaje depersonaliziranom, ona postaje simbolom i lirskom šifrom koja se izdiže iznad stvarnosti (stvarnih žena). Jedine sličnosti između narativnih prikaza ovih krhkih žena s jedne i „demonskih“, prijetećih žena u epizodi svetkovine u Hijerapolisu su 1. izrazito esteticistički opis jednih i drugih likova, i 2. tipološki prikaz, kojim se ženi oduzimaju bilo kakve individualne (psihološke) karakteristike. Svi se ti ženski i jedan muški lik (lik Paulovog prijatelja Georga) zrcale jedni kroz druge, pri čemu su stjecišta ovih prelamanja (zrcaljenja) identiteta u Paulovoj psihi i u njegovoj krizi identiteta. Paulova psiha postaje obilježena svojevrsnom unutarnjom transcendencijom ${ }^{377}$ njegovog subjektivnog svijeta, pri čemu subjektivna koncepcija vremena prevladava nad socijalnom (društvenom) koncepcijom vremena, a nalaze se i naznake politemporalnosti vremena, pri čemu mitsko vrijeme (koje predstavlja epizoda iz Hijerapolisa), a kroz koje se prikazuje pretpovijesna kultura, stoji u svojevrsnom kontrastu sa stvarnim, otuđenim društvenim okruženjem esteta Paula i njegovih suvremenika.

Lik esteta Paula koncipiran je izrazito psihološki: kao otvoren lik, višedimenzionalan, pa čak i kontradiktoran, što je povezano s problematikom depersonalizacije (odnosno, krize identiteta). Paul se, kao usamljeni flaneur (šetač, a time i receptivni sanjar i atipičan muškarac koji odudara od onodobnog stereotipa aktivnog, racionalnog i produktivnog muškarca) koji je duboko utonuo u svoje misli, sve više udaljuje od stvarnosti, od životnog vitalizma i aktivne snage, te njegova snovita vizija proljetne svetkovine u Hijerapolisu zapravo predstavlja dekadentni „,nadomjestak“ neproživljenog života, odnosno želju da se neproživljeni život i nedostatak komunikacije ,zaboravi“ uranjanjem vlastitog jastva u „oceanski“, mistični osjećaj jedinstva s univerzumom, u vidu zaboravljanja vlastitog jastva (odnosno, vlastite individualnosti) u sjedinjenosti s drugim bićima: eskapistička tendencija ipak prenaglašava ono biološko, animalno u životu prirode i čovjeka. Zbog naglašavanja karakteristika ženske senzualnosti i iracionalnosti, tipično ženskog prepuštanja, ovaj kult i kolektivni ritual nosi predznak stereotipno ženskog ,principa“ i služi kao simptom feminizacije kulture bečke moderne.

Bestjelesne i idealizirane slike žena također predstavljaju Paulovo udaljavanje od muškog racija i života, njegov eskapizam u neke „transcendentne“ realitete, iako na asketski način. Prikaz umiruće mlade žene u djelu predstavlja upravo ovo uznesenje žene u transcendentne prostore smrti, mortifikaciju njene senzualnosti, a time implicitno i njezinu androginizaciju. To je svojevrsni pokušaj „racionalizacije“, odnosno „asketizacije“ ženske senzualnosti,

\footnotetext{
${ }^{377}$ Vidi Nünning/Nünning 2004, str. 88-89.
} 
umrtvljenja onoga „demonskoga“ u ženi, umrtvljenja „,apsolutne žene“6378 koja bi postala opasna za muški subjekt i ugrozila njegov integritet.

U nastojanju da prebrodi krizu identiteta, Paulov se psihički obzor prelama u nizu slika o ženskosti $\mathrm{s}$ jedne strane, a s druge strane ga muči (donekle jednako tako fiktivna) smrt prijatelja Georga. Rodna hibridnost glavnog lika ogleda se u ambivalenciji između visoko estetiziranih prikaza (fiktivne) žene s jedne strane, te latentnih homoerotičkih impulsa s druge strane (Paulov prijatelj Georg). Ovakva rodna neodređenost uklapa se u niz kontemplativnih iskaza o smislu (moderne) egzistencije i predstavlja implicitnu kritiku beznadnog pluralizma epohe, koji u prvom redu uvjetuje krizu identiteta.

U romanu pratimo Paulove unutarnje, psihičke obzore, koji na narativnoj razini (kroz narativni obrazac quest-a, odnosno Paulovog traženja smisla esteticistički konotirane egzistencije) izgledaju diskontinuirani i ispresijecani: njegov proces samopreispitivanja (introspekcije i autorefleksije), prikaz njegovih vizija i snova, i posebice autorefleksiju i refleksiju o smrti njegova prijatelja Georga, koji i sam poprima ženska obilježja koja mu pridaje Paulova psiha. Paul preispituje svoju estetsku egzistenciju, te na kraju habitus esteta podliježe kritici (kritika esteticizma, slično kao kod Andriana i Hofmannsthala), a na samom kraju tog procesa autorefleksije, Paul „nalazi novi smisao u uključivanju u vlastitu tradiciju židovskog naroda“. ${ }^{379}$ Netom prije kraja pripovijetke čitatelj saznaje da je Paul Židov: „A njihove je krvi bio i on“. ${ }^{380}$ Smisao ovog uključivanja u genealogiju vlastitog naroda i rase Paulov je pokušaj definiranja i učvršćenja svog (rodnog) identiteta, koji je prethodno u djelu prikazan kao fluidan i diskontinuiran.

Glavni lik djela Der Tod Georgs, estet i flaneur Paul, opire se normativnoj racionalnosti, produktivnosti i aktivnosti, karakteristikama koje su smatrane tipično muškima u fin-desiècle-u: on je sanjar koji uranja u vlastiti poetski konotirani univerzum, a time se odvaja od građanske svakodnevice. Paulov ideal, pored njegove krize identiteta i pokušaja re-definiranja vlastitog rodnog identiteta, usmjeren je, između ostalog, i na ono majčinsko, zaštitničko u ženskom subjektu s jedne, te na esencijaliziranje (hipostaziranje) umiruće ženskosti s druge strane:

Ondje gdje čovjek u opojnosti lišća napuštenih vrtova počiva sa svojom voljenom, licem priljubljen na njezine grudi; i u svakom dahu, koji njezine grudi stišće uz naš obraz, tako da ti pupoljci dršćući dotiču naše usne vlažne od ljubavi, osjeća se život...a sita osjetila sanjare, i sva čežnja je usnula... ${ }^{381}$; „bijahu

\footnotetext{
${ }^{378}$ Vidi Weininger 1920, str. 183. i str. 232.

${ }^{379}$ Fischer 1978, str. 202.

380 „Und von ihrem Blute war auch er“, Der Tod Georgs, str. 219.

381 „Wo man in schwülen Lauben verlassener Gärten mit der Geliebten ruht, das Gesicht an ihre Brust geschmiegt; und in jeder Atemwelle, die ihren Busen gegen unsere Wange drängt, daß seine Knospen zitternd
} 
to pupoljasti, oskudni oblici, koji su se odavali- a ne pokazivali; njezine velike smeđe oči su gledale, ali se činilo kao da još nisu niti naučile gledati ${ }^{382}(\ldots)$,Osjećao je da manje pati tek otkada je pored njega živjela ona koja je sada tamo dolje umirala. Prazna i bez oslonca, ona se oslanjala na njega, kao da je on naslijedio snagu i vrlinu svih stvari, koje je u njoj umrtvio i koje su bile slabije snage nego njegova riječ. Čeznula je za sadržajem i puninom. ${ }^{\text {(383 }, K r u t a ~ i ~ n e p o d a t n a ~ b i l a ~ j e ~ n j e z i n a ~ m a n i r a, ~ s ~ k o j o m ~ s e ~}$ obraćala nekome; malko je podsjećala na prebrzo izrasle dječake; a pritom je odavala i tromo prepuštanje beskrvnih, anemičnih djevojaka“384 ${ }^{38 .}$,.,njezina se vitka ruka izdizala iz čaške širokih vršaka koji su se spuštali; njezini mali, bijeli prsti, koji su, razgranavši se kao u neki štitasti cvijet, rasli iz njezine ruke, raširili su se kako bi obuhvatili voće, koje nisu mogli obuhvatiti. ${ }^{385}$

Svi ovi citati svjedoče o dvojnoj slici žene: 1. žena je s jedne strane uspoređena s cvijetom, dakle prirodom (njem. Naturwesen Frau), što odgovara stereotipnoj koncepciji žene kao statičnog i pasivnog bića, dok je, s druge strane, 2. žena predstavljena u svojoj androginoj samodostatnosti a njezin se fizički izgled ocrtava pridjevom „dječački izgled“, njem. knabenhaft. U ovim je opisima prisutna i rodna asimetrija, budući da Paul u očima žene predstavlja zaštitnika i baštinika svih vrijednosti, pri čemu se muškom spolu i stereotipnoj muškosti pridaje hijerarhijski viša uloga. Žena ostaje bezglasna, odnosno nijema, ona figurira kao čisto likovni prikaz: ona je ispražnjena od svih vrijednosti, društveno je dekontekstualizirana, a muškarac (Paul) se pojavljuje kao instanca koja dopunjava njezine vrijednosti. U ženskom se biću nastoji mortificirati apsolutna žena ${ }^{386}$ koja bi potencijalno ugrozila mušku dominaciju i muški ego, ali se lik žene s druge strane pretapa u lik Paulovog umirućeg prijatelja Georga, o čemu svjedoči i sljedeća rečenica: „...jedna žena, koja nikada nije niti živjela! (...) jedan san, koji je sanjao puno mjeseci ranije- u noći u kolovozu, u kojoj je Georg umro! ‘387

U djelu Der Tod Georgs nalazimo karakteristična stilska obilježja secesije: žene u ovome romanu bivaju stilizirane, ornamentalne i dekorativne estetske tvorevine. Razdoblju fin-desiècle-a pripadaju ovakvi likovi žena, koji tipološki utjelovljuju tip femme fragile $i$ Kindfrau. Motiv Ofelije Beer-Hofmann preuzima od engleskih pred-rafaelitnih slikara (npr. John

unsere liebesfeuchten Lippen streifen, fühlt man Leben... und die satten Sinne träumen, und alle Sehnsucht ist eingeschlafen", Der Tod Georgs, str. 18.

${ }_{382}, \ldots .$. es waren knospende, dürftige Formen, die sich verrieten- nicht zeigten; ihre großen braunen Augen sahen, aber es schien, als hätten sie noch nicht blicken gelernt“, Der Tod Georgs, str. 32.

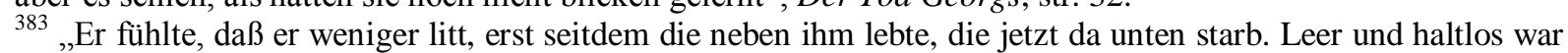
sie ihm zugesunken, als hätte er die Kraft und Tugend aller Dinge geerbt, die er ihr getötet und die schwächer gewesen als sein Wort. Sie sehnte sich nach Inhalt und Fülle“, Der Tod Georgs, str. 69.

384 „Hart und ungefügig war ihre Art, sich nach einem zu wenden; ein wenig an zu rasch gewachsene Knaben erinnernd; und daneben hatte sie das träge Sichgleitenlassen blutleerer, bleichsüchtiger Mädchen gehabt", Der Tod Georgs, str. 70.

${ }_{385}^{38 . . .}$ stieg ihr schlanker Arm aus einem Kelch zurückfallender breiter Spitzen; ihre schmalen, weißen Finger, die aus ihrer Hand, wie zu einer Dolde sich verästelnd, wuchsen, spreizten sich um die Frucht, die sie nicht umspannten“, Der Tod Georgs, str. 70.

${ }^{386}$ Vidi Otto Weininger 1920.

$387, \ldots . .$. eine Frau, die nie gelebt hatte! (...) einen Traum, den er vor Monaten geträumt- in der Augustnacht, in der Georg gestorben war!“, Der Tod Georgs, str. 188. 
Everett Millais). Taj je motiv naročito vidljiv u opisu „kose utopljenice“, a pripada fin-desiècle-u i Jugendstilu. I vodene nimfe Gustava Klimta također karakterizira bujna kosa koja se raspliće u vodi, često kontrapunktirana plošnim dekoracijama. Vizija odlučujućeg susreta između Paula i njegove žene izgleda ovako:

\begin{abstract}
Na zimu je otputovao i samo je rijetko mislio na nju. Ali kad se na proljeće vratio u Beč, čeznuo je za tim da vidi njezino blijedo, djetinje lice. Ona više nije bila u Beču. Bila je bolesna i ranije je nego inače otputovala sa svojom majkom u planine. Sreo ju je u Aussee-u. U suton, on je stajao nasuprot nje; na obronku livade, između visokih, bijelih narcisa, koji su rasli tako zgusnuto, da je svaki korak prijetio da slomi vitke stabljike. Iza nje sastajao se rub livade sa svijetlim večernjim nebom, a od njega su se oštro odvajali gusto stisnuto mirisno cvijeće i njezina bijela pojava. Ležerno je podbočila ruku na visoku dršku suncobrana, i kako je polagano koračala niz brijeg, njezin se obris prelijevao sa svijetlog neba na obronak livade u bijelom cvatu, koji se uzdizao koso, poput zida iza nje. Cinila se gotovo bestjelesnom; samo njezina vlastita bijela slika, koja se u neobičnim linijama izdizala iznad cvijeća i mnoštva stabljika tapeta prekritih narcisama. ${ }^{388}$
\end{abstract}

Narcistička egzistencija i esencijalna osamljenost ocrtavaju i bojama bogatu scenu svetkovine u Hijerapolisu, u kojoj Paulova erotska fantazija traži zadovoljenje koje ne može naći u preidealiziranim, aseksualnim i hermafroditičnim, boležljivim, krhkim i umirućim ženskim likovima koji ga okružuju u stvarnosti. $^{389}$ Udvajanje psihološkog života patrijarhalnog, građanskog muškarca i senzibilnog umjetnika ujedno u idealiziranu čežnju za eteričnom ženskom ,esencijom“ s jedne i čisto fizičku žudnju (spolnost) s druge strane predstavlja na tematskoj razini romana sukob asketizma i spolnosti, duha i tijela, spiritualnog i materijalnog koji je glavno obilježje književnosti o prijelomu stoljeća. Ovaj kontrast između asketizma (narcizma esteta, njegovog kontemplativnog života) i njegovog priklanjanja senzualnosti (aktivnom životu) na simboličkoj je razini romana predstavljeno kroz udvajanje u dvije tipološke slike žene fin-de-siècle-a: femme fragile, odnosno krhki, bolećivi ženski lik, i svojevrsnu femme fatale, koja predstavlja „demonizirajuću“ žensku spolnost i senzualnost. Beer-Hofmannov roman tipičan je primjer ambivalencije između tipiziranih, tradicionalnih, dijelom viktorijanski konotiranih prikaza ženskosti, dok se s druge strane u svom prikazu Paulovog gubitka identiteta (psihološka problematika depersonalizacije) svrstava u red

\footnotetext{
388 „Den Winter war er verreist und hatte nur selten und flüchtig an sie gedacht. Als er aber im Frühjahr nach Wien zurückkam, sehnte er sich, ihr blasses Kindergesicht wiederzusehen. Sie war nicht mehr in Wien. Sie war krank gewesen und früher als sonst mit ihrer Mutter ins Gebirge gereist. In Aussee traf er sie. Im Dämmern stand er ihr gegenüber; am Wiesenhang, zwischen hohen weißen Narzissen, die so dicht wuchsen, daß jeder Schritt die schlanken Stiele zu knicken drohte. Hinter ihr stieß der Saum der Wiese an den lichten Abendhimmel, und scharf grenzten sich von ihm ab, die dichtgedrängten, duftenden Blumen und ihre schmächtige weiße Gestalt. Lässig stützte sie ihren Arm auf den zu hohen Griff des Schirmes, und wie sie langsam bergab schritt, glitt ihr Umriß vom lichten Himmel ab auf den weißblühenden Wiesenhang, der steil wie eine Wand hinter ihr emporstieg. Fast körperlos schien sie; nur ihr eignes weißes Bild, das sich in fremden Linien von den Blüten und Stengelgewirr der narzissenübersäten Tapete hob.“, Der Tod Georgs, str. 33-34.
}

${ }^{389}$ Fischer 1978, str. 202. 
paradigmatskih djela moderniteta. U Paulovu snu, u kojem on sanja da mu umire žena, kršćanske asocijacije igraju veliku ulogu. Sudbinu svoje žene on uspoređuje sa Kristovom sudbinom, a svoj odnos s njom uspoređuje sa odnosom Jude prema Isusu. Znak križa postaje jasno vidljiv u sceni umiranja. „Izdajnik“ Paul, koji se osjeća krivim zbog smrti svoje žene, daje joj Judin poljubac- krivica se donekle može metaforički svesti i na pretapanje ženskog lika u muški, odnosno Paulove prikrivene homoerotičke sklonosti, te njegovu ambivalenciju između homoeroticizma i normativne heteroseksualnosti.

Postupak likovne stilizacije ženskog tijela blizak je umjetnosti Jugendstila i njegovom preferiranju isječaka života, pri čemu dijelovi ženskog tijela djeluju kao fetiš. Ženska se ruka poistovjećuje sa floralnim motivima i prikazuje se kao „Dolde“ ili „Kelch“, ona je stilizirano prikazana, kao i ženski lik u cjelini.

U djelu se pojavljuju i likovi dviju žena, čije crte lica Paul slabo raspoznaje, ali ga fascinira njihova krhka vanjska pojavnost i „sličnost“ mlađe žene njegovoj fiktivnoj umirućoj ženi: „Nosile su tamnu odjeću; nije razlikovao njihove crte“. ${ }^{390}$; „Gdje li je to ranije vidio : bijele ruke kao ruke one žene, podignute iznad vode, koje bacaju hranu ribama?“391. Zamjetljiv je kontrast krhkosti mlade žene sa statuom žene na delfinu, koja predstavlja vitalistički konotiran lik: „Činilo se da se pred životnom, bujnom i razvijenom golotinjom žene na delfinu, premršavi i odviše vitki udovi mlade djevojke, kao iz srama zbog njihove vlastite oskudnosti, bojažljivo zamataju u crnu odjeću““ ${ }^{392}$

Treba također spomenuti i opis seoskog mladića i djevojke, pri čemu se ističe njihova androgina samodostatnost, dok opis djevojke ipak nosi svojevrsne crte femme fragile:

Ispod ocvalog grma divljih ruža ležao je seoski mladić na leđima: pored njega se, poluuspravljena, podbočila djevojka na obronak travnjaka, i, smiješeći se, mahala prema prozoru vlaka. Ponad njih oboje ljuljale su se na vjetru isprepletene grane, a jaka je struja zraka zahvatila bijelog leptira i bacila ga na djevojčin obraz. (...) Posuta svjetlom bila je njezina gola smeđa ruka, (...) tvrda i opora bila je poleđina njezine ruke, koju je sunce opalilo; rad po mrazu i po vlazi i po vjetru učinio ju je popucalom i grubom, poput kore mladog drveta; ali meka i blago užarena od tople krvi koja je strujala, bila je unutarnja strana njezine ruke kad bi se ovila oko zatiljka voljenoga; (...) poput netaknutih teških, mekih krila noćnog leptira, ili cvjetovi tamne perunike... ${ }^{393}$

\footnotetext{
390 „sie trugen dunkle Kleider; ihre Züge unterschied er nicht.“, Der Tod Georgs, str. 182.

391 „Wo hatte er es gesehen: weiße Hände wie die einer Frau, über einem Wasser erhoben, Futter den Fischen streuend?", Der Tod Georgs, str. 182.

392 „Vor der lebenerfüllten, reichentfalteten Nacktheit der Frau auf dem Delphin, schienen die überschlanken Glieder des jungen Mädchens, wie aus Scham über ihre eigene Dürftigkeit, ängstlich sich in den schwarzen Stoff zu hüllen“, Der Tod Georgs, str. 184.

393 „Unter einem verblühten Strauch wilder Rosen lag ein Bauernbursch auf dem Rücken: neben ihm stemmte sich halb aufgerichtet ein Mädchen gegen den Rasenhang, und winkte lachend zu den Fenstern des Zuges auf. Über den beiden schwangen im Wind wirr verschlungene Zweige, und der starke Luftstrom faßte einen weißen Schmetterling, riß ihn und warf ihn an die Wange des Mädchens. (...) Überflossen von Licht war ihr entblößter brauner Arm, (...) hart und rauh war der Rücken ihres Armes, auf den die Sonne brannte; Arbeit in Frost und in
} 
Žena u Beer-Hofmannovom djelu postaje objektom kontemplacije umjetnika, dok je njezina vlastita pripovijest potpuno izbrisana: nedostaje psihološki uvid u konkretnu ženinu stvarnost, empatijsko približavanje njezinom unutarnjem životu koji se ne prikazuje. Naravno, psihološki uvid u ženin unutarnji svijet onemogućen je iz razloga jer ženski likovi u BeerHofmanna, Andriana i Hofmannsthala ne predstavljaju samosvojne subjektivitete, već simbole psihe (anime) umjetnika. Može se zaključiti uzrok fascinacije prikazima umirućih žena u romantizmu i u fin-de-siècle-u: pretvorivši ženu u statični i pasivni simbol, ona postaje: 1. simptom feminizacije psihe umjetnika (njegove androgine samodostatnosti), i 2 . lišena ovozemaljskih karakteristika koje bi bile „demonske“, odnosno prijeteće za ravnotežu psihe muškarca. Paulova (na fikcionalnoj razini romana) umiruća žena postaje odrazom umirućeg Georga, a njih oboje postaju odrazom od života zamorenog esteta Paula, čovjeka čiji se rodni identitet rastače (postaje fluidan), dok s druge strane postaje rodno neutralan (androgina samodostatnost), budući da u sebi utjelovljuje i stereotipno muške (kreativna snaga, distanca, kontrola) i stereotipno ženske (gubitak kontrole, pasivnost i receptivnost, kontemplacija, imaginacija) karakteristike.

Postavivši se u hijerarhijski nadmoćan položaj nad ženskim likom koji umire, Paulu postaje mogućim uspostaviti svojevrsnu kontrolu nad iracionalnom i prijetećom snagom ženske senzualnosti, pa se na taj način i Beer-Hofmannovo viđenje ženske senzualnosti približava Weiningerovoj koncepciji u djelu Geschlecht und Charakter. Žena u Der Tod Georgs ima funkciju ponovne uspostave Paulovog samopouzdanja, budući da je naglašeno da ona u njega vjeruje kao u hijerarhijski nadređenog stvaratelja. Fundamentalna nesigurnost esteta $\mathrm{u}$ njegovom (rodnom) identitetu tema je djela Der Tod Georgs.

Estetizacija ženskog tijela bliska je, kao što je već rečeno, poetici Jugendstila. Međutim, u ovu se estetizaciju utiče i opisivanje tjelesne krhkosti žene i njezina fizička iscrpljenost i bolest. Ova je fizička iscrpljenost (koja se često u poetskim slikama umirućih žena vezala uz pojam tuberkuloznih, krhkih žena) temeljni dio toposa (franc. beauté malade), ali ukazuje i na stilizaciju ženskog tijela (usporedba dijelova ženskog tijela s cvjetnim motivima). U BeerHofmannovoj slici umiruće žene, čestom toposu u književnosti fin-de-siècle-a ${ }^{394}$, koja se konstituira kroz stereotipni muški pogled na ženu, teži se za prikazom: 1. mortifikacije

\footnotetext{
Nässe und der Wind, hatten ihn rissig und rauh gemacht wie die Nordrinde eines jungen Baumes; aber weich, sanftglühend von warmströmendem Blut, war die Innenseite ihres Armes, wenn sie sich um den Nacken des Geliebten legte; (...) wie die unberührten schweren, weichen Flügel eines Dämmerungsfalters, oder die Blüten der dunklen Schwertlilien...", Der Tod Georgs, str. 143.

${ }^{394}$ Vidi Pohle 1998, str. 57-66.
} 
stereotipno ženski konotirane senzualnosti i uzdizanjem žene u sfere sublimnoga i androginoga, 2. ipak donekle prisutne ženske senzualnosti (kosa kao erotski simbol) koja ponovo ženu čini privlačnom muškarcu-umjetniku, i 3. ornamentalnosti i dekorativnosti ženskog tijela, koja se nalazi na pola puta između stereotipizacije i androginizacije žene, 4. prikazu društvene dekontekstualizacije žene.

Međutim, umiruća žena u imaginaciji umjetnika predstavlja i narcistički zrcalni odraz njegove pozicije esteta te na taj način lik žene postaje simptom feminizacije umjetnika i njegove internalizacije ženskosti.

Tipičan odgovor na problematičnu egzistenciju narcističkog esteta nudi epizoda svetkovine u Hijerapolisu: ova se epizoda pojavljuje u drugom dijelu romana, a uklopljena je u Paulov san o smrti njegove žene. ${ }^{395}$ Ova izrazito ornamentalno (esteticističkom manirom) opisana epizoda smještena je u mitska, pretpovijesna vremena, a predstavlja ritual plodnosti koji se odvija u čast sirijske božice Astarte. Ova je epizoda utemeljena na lektiri jednog antičkog teksta, naime Lukijanovom spisu pod naslovom De Dea Syriaka, koji Beer-Hofmann koristi kao intertekstualnu potku a u kojem se opisuje kultno mjesto (mjesto odvijanja rituala plodnosti) staroazijske božice prirode i plodnosti Astarte u Hijerapolisu u Siriji. Prema Jens Malte Fischeru, Beer-Hofmann je parafrazirao gotovo jednu desetinu Lukijanovog teksta: koristio je ovaj izvor sve do sličnosti koja se može uočiti čak i u jezičnim detaljima. ${ }^{396}$ Uočljiva je paralela između proljetne svečanosti i rituala u Hijerapolisu s jedne, te dionizijske seksualne orgije Gustava von Aschenbacha u Mannovoj noveli Smrt u Veneciji, gdje Mannu isto tako kao inspiracija služi trački kult boga Dioniza. Ovakvo ,gašenje“ individualnog identiteta u dionizijskoj opojnosti predstavlja u književnosti o prijelomu stoljeća tendenciju za dokidanjem monotonije života esteta.

Izvori za ovu pripovijest, koja se u djelu predstavlja kao Paulova lektira (te je, kao fikcija unutar fikcije, dva puta odmaknuta od stvarnosti), navedeni su u djelu Rainera Hanka: ${ }^{397}$ to su Burckhardtovo djelo Die Zeit Constantin's des Großen, zatim Lukijanovo djelo Die syrische Göttin. Ovaj kult plodnosti posvećen mitskoj božici Astarte služi kao ,egzotična kulisa, ispred koje se odvija problematika modernog subjekta““398, svjedočeći o feminizaciji jastva esteta.

Osamljeni estet Paul teži za dokidanjem svog otuđenja od stvarnosti i građanskog društva u dionizijskoj, raspojasanoj opojnosti bitka (aluzija na Nietzschea) koja upućuje na ženski

\footnotetext{
${ }^{395}$ Vidi Paetzke 1992, str. 82.

${ }^{396}$ Fischer 1978, str. 198.

397 Usp. Rainer Hank: Mortifikation und Beschwörung. Zur Veränderung ästhetischer Wahrnehmung in der Moderne am Beispiel des Frühwerks Richard Beer-Hofmanns, 1984.

398 Paetzke 1992, str. 82.
} 
konotiranu senzualnost. „Nasuprot izolaciji i stilizirajućoj distanci prema vanjskom svijetu opisuje tekst u ovome dijelu sna sjedinjenje u gomili i iskustva jednog naoko ,izvornog“

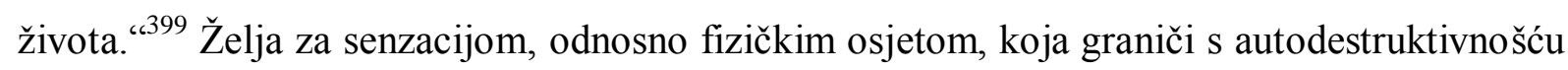
naznačena je i u sljedećoj rečenici: „Željeli su osjećati- konačno osjetiti svoj život; raskinuti krug monotonih dana, u koje je njihov život bio izgnan, i- kako su poznavali urođeni duboki, jezivi strah od smrti- kličući probuditi usnulu strast za životom“. ${ }^{400}$ Patetično veličanje života, koje se pretvara u egoizam kulta jastva (franc. „culte du moi“), upućuje na Nietzscheov prikaz dionizijskog jastva, njegovu opreku dionizijskog (iracionalnog) naspram apolonijskog (racionalnog, harmoničnog, uređenog) koje će se u djelu povezati s oprekom umjetnikgrađanin, o kojoj je implicitno govorio i Nietzsche. Friedrich Nietzsche je naglašavao da je umjetnost jedini način da se izađe iz kolotečine svakodnevnog života i da jedino umjetnost $u$ doba moderniteta može pojedincu pružiti utjehu. U epizodi je predstavljena svojevrsna rodna asimetrija (u opisu muškog naspram ženskog tijela), dok ipak, s druge strane, dolazi i do zamjene rodnih uloga (prikaz nestereotipnog muškog prepuštanja ženskom tijelu). Dionizijski bitak označava ,razbijanje individuacije“401, odnosno utapanje jastva (esteta) u „kvazimističnom jedinstvu“ ${ }^{\star 402}$, koje se ipak reducira isključivo na spolni čin i predstavlja „biologistički reduciran životni koncept"“. 403

U ovoj se epizodi spominju i likovi svećenika koji su prikazani izrazito androginizirano (fizički izgled- našminkane usne), a i ostatak opisa je ženski konotiran, što ponovo upućuje na latentni homoeroticizam.

\subsubsection{Implicitni rod}

Od svih književnika bečke moderne, Richard Beer-Hofmann u svojim narativnim konstrukcijama najkonzekventnije demonstrira Zeitdehnendes Erzählen (prev. s njem, usporeni tempo pripovijedanja), budući da, s malom razlikom od djela Leopolda von Andriana Der Garten der Erkenntnis, koje ipak pokazuje svojevrsnu konciznost, ovo djelo obiluje izrazito dugačkim opisima i minucioznim prikazima fluktuacija psihe glavnog lika. Najvažnije je stoga obilježje ovog djela introspektivnost prikaza i naglasak na kaleidoskopskom nizanju misli i raspoloženja glavnog lika (njem. Stimmungen).

\footnotetext{
399 Paetzke 1992, str. 82.

400 „Fühlen wollten sie- endlich ihr Leben fühlen; den Kreis gleichverrinnender Tage, in den es gebannt, sprengen, und- wie sie die eingeborenen tiefen Schauer vor dem Tode kannten- die schlummernde Lust des Lebendigseins jubelnd wecken“, Der Tod Georgs, str. 62.

${ }^{401}$ Paetzke 1992, str. 82.

402 Ibid.

${ }^{403}$ Ibid., str. 83.
} 
Prema Jens Malte Fischeru, brižljivost jezičnih konstrukcija zamjetljiva je u djelu Der Tod Georgs $^{404}$ : ona odražava impresionističko-simbolističko tkanje naracije, u kojoj se dojmovi Paulovog unutarnjeg svijeta neprestano izmjenjuju a poneki se i ponavljaju po obrascu repetitivnog pripovijedanja. Repetitivni obrasci na simboličkoj razini romana 1. simboliziraju hermetičnost narativnih motiva, pri čemu se djelo približilo simbolističkoj poetici, 2. oni odražavaju habitus esteta, čija se egzistencija doima otuđenom (te na taj način simboliziraju monotoniju Paulova života).

Obris nježnog djevojačkog lika pretapa se u cvjetnu „tapetu“: priroda (život!) se pretapa u umjetnost, artificijelnost. Sve je podređeno kontemplativnoj bjelokosnoj kuli. Parkovi i vrtovi, koje Beer-Hofmann opisuje, sa svojim su jezerima i lokvama simboli povlačenja estetskoga jastva (a time i svojevrsne feminizacije, pasivizacije ,građanskog“ muškarca) u unutarnji prostor, odijeljeni otok ili bjelokosnu kulu, na kojoj se osniva narcistička i pred-edipalna egzistencija feminiziranog esteta Paula.

Princip narativne konstrukcije romana je ciklički i diskontinuiran, asocijativni tokovi se prelamaju jedni preko drugih. Paetzke naglašava da se „,bezgranična sloboda esteta ispostavlja kao manjak strukturirajućeg principa“ (i u narativnoj strukturi romana) ali i kao svjedočanstvo „potpune dezorijentacije“ uslijed rastuće modernizacije u razdoblju bečke moderne, pri čemu lik femme fragile ,zadržava tek funkciju kompenzacije“ za neproživljeni život esteta.

U prvom i drugom dijelu romana prevladavaju opisi ženskih likova, a u tim se opisima naglašava ambivalentan stav onodobnog muškarca prema ženama i ženskosti: s jedne strane udivljenje, a s druge strah, pa i svojevrsni prikaz „demonskih“ ženskih karakteristika koje potencijalno ugrožavaju stabilnost muškog identiteta. S druge strane, u romanu se pojavljuju naznake utopijski konotiranog narcizma (slično kao u Hofmannsthalovoj Bajci 672. Noći), čežnje za vlastitom animom (odnosno, podsvjesnom ženskom stranom i podsvjesnim ženskim imagom) koji se ocrtava u prikazima stiliziranih ženskih likova.

Roman Der Tod Georgs spada u tipična djela Jugendstila. Jugendstil, pravac u bečkoj moderni koji karakterizira izrazita ornamentalnost i dekorativnost kako stila pisanja, tako i prikaza likova i motiva razvio se kao kritička reakcija na sve veću industrijalizaciju u drugoj polovici 19. stoljeća. U umjetničkim je krugovima toga vremena nastala potreba za suprotstavljanjem, odnosno stvaranjem alternative ovom brzom razvoju. Iako je u prethodnim desetljećima bilo novih pravaca (neo-gotika, neo-renesansa itd.), sada je ipak trebalo domisliti nešto potpuno novo, jedan stil koji bi se razvio sam iz sebe. „Svijet se promijenio, ali još nije

\footnotetext{
${ }^{404}$ Fischer 1978, str. 198.
} 
postojao stil koji bi izrazio ovu promjenu. Novo se doba još izražavalo u starim formama: klasika, gotika, renesansa, barok... Jugendstil je bio prvi stil koji nije imao svoj početak u europskoj povijesti. No on je bio prvi stil novoga stoljeća, i to objašnjava zašto se on tako brzo prometnuo.“405 Nazivi za ovu epohu variraju: Art Nouveau u Francuskoj, Modern Style u Engleskoj, Jugendstil u Njemačkoj i Austriji. Najvažnija je karakteristika Jugendstila ornament, koji se trajno ne ponavlja, već se neprestano mijenja. U svezi s tim je i nestajanje ravnih linija i pravokutnih oblika: „Jugendstil je odbijao ravne linije i pravokutne oblike i preferirao ornamentalne, vegetabilne i floralne oblike“. ${ }^{406}$ Česti su bili motivi iz prirode, posebno biljne, kao i karakteristične valne strukture: „I čovjek je samo val u vječnoj struji nastajanja i odumiranja“. ${ }^{407}$ Tipična je jaka stilizacija motiva i oblika koji se koriste. Također je karakterističan princip gubitka prostornosti (trodimenzionalnosti) (njem. Enträumlichung) i plošnost (njem. Flächigkeit). Redanje plošnosti (ploha) je sredstvo prikazivanja povezanosti stvari, koje čine cjelinu, jedinstvo, pa se po tim karakteristikama književnost Jugendstila približava tumačenju svijeta iz pozicije književnog monizma, koji simbolički naglašava mistično jedinstvo svega i upućuje i na niveliranje svih, pa i rodnih karakteristika (svojevrsna androginizacija epohe). Filozofija Jugendstila naglašavala je da je ono što stvari u stvarnosti izolira jedne od drugih njihova tjelesna trodimenzionalnost, njihov volumen koji potiskuje prostor. $^{408}$ Stoga treba nastupiti pojednostavljenje, treba se odreći individualizirajućih detalja: „Ovo relativno de-individualiziranje (njem. Entindividualisierung) čini stvari manifestacijom jedne te iste supstance. Redukcija individualnoga znači pojačavanje univerzalnoga (njem. eine Steigerung des Universellen). ${ }^{409}$

U umjetnosti Jugendstila uočavamo korištenje tema i motiva iz mitologije. Time se proizvode određeni ugođaji (njem. Stimmungen). U Beer-Hofmannovom romanu, osim mitske koncepcije vremena, uglavnom prevladava narativna koncepcija prikaza subjektivnog, odnosno psihološkog realiteta esteta povezanog s unutarnjom transcendencijom njegove psihe ${ }^{410}$, čiji se cijeli unutarnji realitet asocijativno i ciklički rastače upravo na dojmove (njem. Eindrücke), raspoloženja (njem. Stimmungen) i osjećaje (njem. Gefühle), prikazane kroz izrazitu sklonost glavnog lika autorefleksivnosti. Predstavljene su osobe (umiruća žena, zatim Paulov prijatelj Georg, te dvije mlade žene koje Paul promatra dok šeta parkom) jedna vrsta

\footnotetext{
${ }^{405}$ Usp. William Hardy, Jugendstil: Hamburg 1987, str. 8.

${ }^{406}$ Usp. Hardy 1987, str. 9-10.

${ }^{407}$ Usp. Wolfdietrich Rasch: Fläche, Welle, Ornament. Zur Deutung der nachimpressionistischen Malerei und des Jugendstils., u: Rasch, Wolfdietrich: Zur deutschen Literatur seit der Jahrhundertwende. Gesammelte Aufsätze. Stuttgart 1967, str. 201.

408 Ibid., str. 191.

409 Ibid., str. 192.

${ }^{410}$ Vidi Nünning/Nünning 2004, str. 88-89.
} 
međubića (njem. Zwischenwesen): kroz cijelu diskontinuiranu naraciju, koja se ogleda kroz rodni hibriditet Paulove psihe (androginu samodostatnost i narcizam psihe umjetnika), sve stilizirane pojave prelaze jedna $\mathrm{u}$ drugu, a one su refleksije stanja psihe osamljenog $\mathrm{i}$ perceptivnog esteta. Mitološkim bićima pridaje se više značenja u arsenalu dekorativnih motiva.

Tipičan ženski lik Jugendstila je femme fragile. Femme fragile je nježne, krhke građe (lika), blijede kože, s ogromnim očima i bujnom kosom, koja stoji u suprotnosti sa njezinom tjelesnom krhkošću. Kao žena ona je boležljiva (često tuberkuloza), ima tendenciju da bude aseksualna i živi distancirani život aristokratkinje. Prijezirno se odnosi prema životnim užicima i nalazi ispunjenost u ,lijepom umiranju“. U prikazima krajolika u Jugendstilu najvažniju ulogu igra voda, zajedno sa posebnim ugođajima dana ili godišnjih doba, kao što su proljeće, jesen, noć ili svitanje. Ova epoha teži za uljepšanjem (estetiziranjem) života (njem. Verschönerung des Lebens). Ovdje možemo primijetiti kako u djelu Der Tod Georgs lik femme fragile na simboličkoj razini predstavlja animu samog esteta, budući da i on, poput aristokrata, živi distancirani život i teži zamoru od života te ljepotu pronalazi u smrti.

Književnost i likovna umjetnost Jugendstila usmjerena je protiv naturalizma i njegove strogo mimetičke reprezentacije, te se u njoj sve pojave poimaju fluidno, pretapajući se jedna u drugu u stilu filozofskog koncepta monizma. Ispreplitanje elemenata (često ornamenata), koji inače egzistiraju odvojeno, također je karakteristično za pjesništvo Jugendstila. Oduzimanje prostorne dimenzije svega prikazanoga karakteristika je Jugendstila, tako da plošnost postaje optimalna baza za dekorativnost. Budući da se fizička pozadina i fizička daljina u principu dokidaju, čini se da su sva bića i stvari blizu. Dekorativni pejzaži odnosno toposi opisani su visoko stiliziranim, biranim jezičnim konstrukcijama. Književnost Jugendstila nam predstavlja likove esteta i dendija, koji se (poput dječačkih, aseksualnih i bolećivih ženskih likova) često prepuštaju solipsističkoj i narcističkoj bujici misli.

Budući da se vežu uz perspektivu esteta i personalnu perspektivu pripovijedanja, likovni i književni motivi i stilski postupci Jugendstila predstavljaju više od pukog ornamenta: prema Iris Paetzke, oni označavaju cjelokupnu stilizaciju stvarnosti, koja „u Paulovom estetskom pogledu“, koji sadrži rodno hibridne crte, ne zadobiva neku samostalnu, vlastitu vrijednost te se neprestano pretvara u puku sliku (odnosno, reprezentaciju) same sebe. I način pripovijedanja prati ovu problematiku esteta i njegove vizije stvarnosti, u kojoj se rodne tipologije i rodni identiteti isprepliću: ,time što se svijest glavnog lika rastače u kaleidoskopski niz pojedinačnih sjećanja, predodžbi i misli, ona na negativan način pokazujeodričući se autorske nemogućnosti da se pronađe neki sintetizirajući i objasnidbeni 
princip. “411 „Estetska forma stoga djeluje kao generalizacija (poopćenje) krize koja se razvija u psihi glavnog lika, a u koju je čitatelj neposredno uključen. ““112

Isprepletenost fikcije i zbilje jedna je od temeljnih karakteristika ovog Beer-Hofmannovog romana: heterodijegetski pripovjedač (minimalna pripovjedna distanca od lika, dominacija slobodnog neupravnog govora) završava prvo poglavlje romana rečenicom „Zaspao je“413, a potom u drugom poglavlju sugerira da je u međuvremenu prošlo već 8 godina $^{414}$, te nam tek na kraju drugog poglavlja otkriva da se zapravo radilo samo o snu, koji je ispripovijedano vrijeme (njem. die erzählte Zeit) pomaknuo naprijed za samo pola sata. Drugo poglavlje također završava riječima „Zaspao je“ ${ }^{415}$ Beer-Hofmann svjesno otežava čitatelju orijentaciju u naraciji ovim naoko nesukladnim ispreplitanjima fikcije i zbilje, čime se postavljaju dva temeljna pitanja: pitanje psihičke dezorijentiranosti i fluidnog jastva glavnog protagonista, te pitanje subjektivacije fikcije i njezine veze sa „stvarnošću“. Ako, prema Fischerovim riječima, čitatelj ovaj put odluči da ne nasjeda pripovjednom „triku“ te ne shvati sljedeću etapu naracije kao snoviti događaj (,,smrt tada još zdravoga Georga može se stoga protumačiti samo kao snoviti događaj“" $)^{416}$, baš kao i postojanje žene i slika njezinog uznesenja u smrti, on će ipak morati spoznati da je zaveden na krivi trag.

Umiranje Paulove žene predstavlja dio općenitog toposa bečke moderne, zamora od života (njem. Lebensüberdruss), koji je sveprisutna tema vezano na likove senzibilnih esteta i na njihov način života. Život postaje umjetničko djelo, naglašava se supremacija umjetnosti nad životom. Vrijeme koje neumitno teče uključeno je u estetizaciju života: osjećaj protoka vremena, pa i vremenskog trajanja pojedinih trenutaka. Bergsonovski durée, izražen kroz Zeitdehnendes Erzählen odvija se kroz psihu senzibilnog esteta, čiji se detaljni prikaz nalazi u fokusu djela.

\subsubsection{Zaključak}

Budući da je kompleksno psihološki koncipirani lik esteta Paula koncipiran kao flaneur, odnosno receptivni promatrač ljudi, stvari i pojava oko sebe, on poima svijet iz vizure hipersenzibilnog umjetnika kod kojeg se može zamijetiti svojevrsna androgina samodostatnost (potpunost) umjetnika (njem. androgyne Vollkommenheit), dok lik umirućeg Georga, koji na fikcionalnoj razini predstavlja Paulovog prijatelja, jednako kao i lik Paulove

\footnotetext{
${ }^{411}$ Paetzke 1992, str. 77.

412 Ibid.

413 „Er schlief“, Der Tod Georgs, str. 23.

414 Fischer 1978, str. 198.

${ }^{415}$ Fischer 1978, str. 199., vidi u originalnom tekstu, Richard Beer-Hofmann: Der Tod Georgs, str. 107.

${ }^{416}$ Fischer 1978, str. 199.
} 
umiruće žene predstavljaju dio Paulovog unutarnjeg univerzuma, u kojem se ogleda hibridni rodni identitet esteta koji naginje biseksualnosti. Iako se u ovome djelu pojavljuje jasna aluzija na homoerotične, ne toliko na homoseksualne impulse, treba naglasiti i činjenicu da se najsuptilniji i najdetaljniji opisi u djelu odnose upravo na ženski subjekt, ali i općenito na prikaze ženskog tijela. Stoga se može zaključiti da je Paulov rodni identitet kompleksan. U Paulovim se mislima ocrtava stlizirani lik Paulove umiruće žene, a pojavljuje se također i lik dviju žena koje Paul promatra u parku te još jedan lik mlade žene, što upućuje na to da se Paulov (rodni) identitet rastače i da se on nalazi u dubokoj krizi. Destabilizacija pojmova anima/animus na formalnoj se razini očituje u cikličnom i diskontinuiranom, pa i kontrastnom (epizoda u Hijerapolisu naspram ostatka radnje) narativnom ustrojstvu, pri čemu fikcija i san prevladavaju nad onim što bi se moglo nazvati intradijegetičkim „stvarnim“ događajima. Djelo stoga sadrži više fikcionalnih razina (fikcija unutar fikcije; lektira unutar lektire djela Der Tod Georgs), što upućuje i na neodvojivost heterodijegetskog, gotovo u potpunosti personalnog pripovjedača od samog lika senzibilnog i pasivnog esteta Paula. Budući da predstavlja izrazito feminizirani lik nepragmatičnog esteta i sanjara sa izraženim smislom za impresionistička opažanja, glavni muški lik participira u stvaranju vlastitog svijeta imaginacije, u kojem se miješaju nesvjesni strahovi, nade, razočaranja, žudnje, snovi i nostalgična sjećanja. Na tematskoj je razini djelo koncipirano i kao svojevrsni quest (traženje korijena vlastitog (rodnog) identiteta), budući da se postavlja pitanje i o smislu ljudske egzistencije i o smislu traganja, a dva temeljna toposa predstavljaju pojmovi života (njem. das Leben) i smrti (njem. der Tod), koja je sveprisutna na razini cjelokupne naracije: smrt drugoga (vlastite Paulove Drugosti, umiruće žene, i njegovog prijatelja Georga) postaje poligon za razmišljanje o vlastitoj smrtnosti i neproživljenom životu esteta. Dionizijska opojnost predstavlja kratkotrajnu i nedostatnu alternativu otuđenoj egzistenciji esteta koji je uronjen u vlastiti kontemplativni svijet, u vlastiti „umjetni raj“ ili „bjelokosnu kulu“. Međutim, ovakav narcizam sadrži i pozitivnu karakteristiku potrage za samim sobom, raščlambe vlastitog unutarnjeg svijeta i, naposljetku, čežnje za monističkim jedinstvom sa svijetom i bićima oko sebe.

Beer-Hofmannovo je djelo Der Tod Georgs ,lirsko-simfonijska ${ }^{417}$ pripovijetka o ljubavi i smrti, a sve se te vizije prelamaju kroz Paulovu kompleksnu i višedimenzionalnu psihu melankoličnog, pasivnog i receptivnog esteta. Hibridizacija roda prezentira se kroz Paulovu ambivalenciju između homoerotičkih impulsa (njegov prijatelj Georg) i heteroseksualnosti

\footnotetext{
${ }^{417}$ Fischer 1978, str. 202.
} 
(umiruća mlada žena), pri čemu fikcionaliziranje oba lika doprinosi ukupnoj reprezentaciji krize identiteta. Kao što ističe Iris Paetzke: dok u Andrianovom djelu Der Garten der Erkenntnis patnja esteta zbog gubitka realiteta stoji u središtu razmatranja, u BeerHofmannovu djelu Der Tod Georgs kritika je usmjerena na ono dehumanizirajuće u esteticističkom načinu života. ${ }^{418}$ Ovom nesputanom, divljem ,esteticizmu“ i vitalizmu BeerHofmann suprotstavlja kvazi-religiozno štovanje femme fragile i Kindfrau, a također i uzdržavanje od spolnosti (asketski način života). „U svojoj krhkosti, infantilnosti i manjku vitalnosti“", naglašava Paetzke, femme fragile nalikuje estetu zamorenom od života, koji sreću traži izvan polja djelatnog života i izvan polja čisto fizičke žudnje“, pa na toj razini odabir ove književne tipologije ženskosti najbliže odgovara stanju primarnog narcizma i asketizma esteta. Paul čezne za duševnim mirom koji mu svakodnevica narušava, za onom vrstom spokojnosti koja se tek neznatno razlikuje od „,̌ežnje i odricanja“, ali takvu vrstu mira nužno povezuje ponovo s pojmom ljepote. Na taj način i žena koju Paul susreće u večernjoj šetnji postaje dvodimenzionalna, gotovo plošno i stilizirano prikazana, odnosno, opredmećena: „hohe schwankende Kinderstimme“, die „schlanke“, „knabenhafte“, „schmächtige Gestalt“, „das schmale blasse Gesicht“ und die „hagern Kinderarme“- ovi opisi karakteriziraju ju kao krhki ženski lik, tipičan za književne i likovne prikaze fin-de-siècle-a. Paradigma ljepote promijenila se shodno rastućoj modernizaciji i dobila pečat sterilne ljepote lišene stereotipnih ženskih atributa: ovakva ljepota na metaforički i analogijski način odražava sterilnost egzistencije esteta, njegov asketizam, ali i regresivni nazor na svijet uobičajen u doba esteticizma. Paulova stvarnost isprepliće se sa njegovim vizijama u snovima, a u jednom od snova on sanja kako njegova vlastita žena umire: poticaj za ovaj san upravo je susret s njemu potpuno nepoznatom mladom ženom: na taj način, naglašava Paetzke, „ženski lik postaje objekt narcističke volje za moć“, odnosno, žena postaje kontemplativno kreirana reprezentacija ili projekcija psihe esteta koja se odvaja od građanskog svijeta i osamljuje. Senzibilni estet Paul demonstrira ženski konotirano prepuštanje ženskoj „esenciji“ i perceptivnu prijemčivost za dojmove koji ga okružuju: time on odražava habitus umjetnika koji svijet sagledava unutar vlastitog unutarnjeg svijeta, a ženski lik postaje poligon za njegovo umjetničko oblikovanje i dopunjavanje. Umjetnik, prema Paetzke, ,zauzima ulogu genijalnog stvaratelja, Pygmaliona, budući da se na mitski način zaljubljuje u svoju statuu tako da ona postaje živa, umjetnost postaje stvarnost, a žena u Paulovom snu se pretvara u neživi artefakt, u djelo esteta“. ${ }^{419}$ Uznesenje ženskog lika u smrti- takva estetizacija žene bila

\footnotetext{
${ }^{418}$ Paetzke 1992, str. 72-73.

419 Ibid., str. 72.
} 
je zajednički topos kako književnosti romantizma, tako i, na ponešto izmijenjen način, i književnosti neoromantizma i simbolizma, koja ističe hipostaziranje žene kao lirske šifre i udaljenog simbola. Obuzetost ženskom „esencijom“ postaje u razdoblju bečke moderne simbolom feminizacije umjetnika.

\subsection{Arthur Schnitzler: Die Fremde (Neznanka)}

\subsubsection{Uvod}

Kraća pripovijetka Arthura Schnitzlera Die Fremde (Neznanka ili Strankinja) prvi je put objavljena 1902. godine u dnevnom listu Neue Freie Presse, u Beču, pod naslovom Dämmerseele ${ }^{420}$ (Sutonska/sanjarska duša). Oba naslova implicitno najavljuju tematsku okosnicu pripovijetke: u fokusu pripovijetke je žena viđena kroz mušku vizuru, psihološki kompleksan i višedimenzionalan ženski lik pojmljen kao zagonetna „Drugost““. Pripovijetka je koncipirana kao analitička „studija“ ženske psihe, srodno pripovijetci sličnog obujma, Die Braut. U pripovijetci Die Fremde, ženska se psiha i spolnost dijelom stilizirano prikazuju u vidu numinoznog umjetničkog objekta (više nego u Die Braut, gdje je stilizirano koncipiranje žene kao objet d'art zanemareno) i poligona za (mušku) umjetničku kreaciju, odnosno estetski senzibilitet, a dijelom se uvodi problematika gubitka identiteta u bečkoj moderni i narcistički orijentiranog ženskog subjekta. ${ }^{421}$ Radi se o psihoanalitički intoniranoj analizi hermetične ženske svijesti i podsvijesti (pri čemu ženski objekt pripovjedne ,analize“ funkcionira kao das Unheimliche, te u muškom subjektu pripovijetke izaziva miješani osjećaj žudnje i nelagode). Struktura naracije pripovijetke rekapitulira hijerarhizaciju rodnih odnosa, dok se u koncepciji likova Alberta i Katharine primjećuju naznake odstupanja od stereotipnih rodnih uloga te se hijerarhijski odnos među spolovima preokreće u svojevrsnoj zamjeni rodnih uloga. Na psihološki rafiniran, realističan i ne odveć sentimentalan način, autor djela Arthur Schnitzler nastoji kritički i dijelom (auto)ironijski prikazati gubitak sigurnosti muškog subjekta u doba dehijerarhizacije muško-ženskih odnosa u bečkoj moderni, kao i „dramatizirati“ obuzetost onodobne kulture ženskim subjektom i zagonetnom aurom ženstvenosti, odnosno ,androginizaciju“ bečke moderne i fin-de-sièclea općenito (njem. Verweiblichung der Kultur), epohe koja hipostazira ženskost ali ujedno potiče stereotipne i mizogine prikaze

\footnotetext{
${ }^{420}$ Perlmann 1987, str. 140.

${ }^{421}$ Vidi Le Rider: Das Ende der Illusion, 1990, str. 91-94.
} 
žena. ${ }^{422}$ Odlika je mnogih djela Arthura Schnitzlera melankolički intonirano dramatiziranje teme ljubavi i smrti: naglašavanje ,snovitosti““ oba naslova ove pripovijetke (njem. Dämmerseele i Die Fremde) ukazuje na asocijativno (dijelom mizogino koncipirano) povezivanje žene i melankolije, žene i smrti. Nemogućnost shvaćanja vlastite žene i koncipiranje (vlastite) žene kao zagonetne Drugosti te osjećaj zamora od života odraz je kako razmišljanja glavnog lika pripovijetke Alberta von Webelinga, tako i Schnitzlerove vlastite anksioznosti i ambivalentnog stava prema ženskosti, nemogućnosti potpunog razumijevanja ženskog individualizma i biti ženske psihe, koje je zajedničko i mnogim njegovim suvremenicima. Tipološki koncipirano zazivanje žene kao esencije „vječne ženstvenosti“ (njem. das Ewig-Weibliche), ali istovremeno i demoniziranje žene kao femme fatale književno je svjedočanstvo duha jedne epohe u kojoj se s jedne strane ,znanstvenički“, psihoanalitički i narativno secira ženska psiha, a s druge strane ženskost stilizira i hipostazira u nedostižnu i zagonetnu žensku esenciju.

Arthur Schnitzler jedan je od onih književnika bečke moderne koji je, koristeći se svojom ambivalentnom pozicijom ironičnog kritičara (spolnog) licemjerja onodobnog društva s jedne, a reproduciranjem muško-ženskih stereotipa i podržavanjem stereotipnih rodnih odnosa i konstelacija s druge strane, nastojao revalorizirati društveni i književni interes za pojam ženskosti i pripovijest o ženi. Iako je njegov stav prema ženama duboko rodno ambivalentan (a nerijetko poprima i mizogine crte), Schnitzler promiče antropološko-psihološku spoznaju o esencijalnoj sličnosti i „,ravnopravnosti“ muške i ženske prirode vezano na spolno ponašanje i rodne obrasce. Usprkos dekonstruiranju onodobne sociološko-antropološke slike o ženi kao podređenoj muškarcu što se tiče spolne žudnje, u njegovim su djelima vidljivi oblici mizoginije i objektifikacije žena, a u privatnom životu često je naginjao njihovoj eksploataciji. U pripovijesti Die Fremde prisutna je koncepcija žene kao esencijalne Drugosti, kao „tajanstvenog“ bića koje je strano muški konotiranoj civilizaciji, kulturi i progresu, pa i građanskoj pragmatičnoj i materijalističkoj svakodnevici. Schnitzler implicitno problematizira i preispituje mušku (dijelom rodno anti-stereotipno koncipiranu) distanciranost prema upoznavanju vlastite žene, koncipirajući lik Alberta dijelom kao senzibilnog esteta, pasivnog i receptivnog promatrača kojem nedostaje snaga volje i inicijativa prema vlastitoj ženi. $\mathrm{Na}$ određeni je društveno-kritički način izrečena također i ambivalentnost mogućnosti afirmacije koncepta ženske individualnosti, ženske želje za samoostvarenjem, individualnim izborom i

\footnotetext{
${ }^{422}$ Idealizacija žene (književna koncepcija femme fragile) s jedne i demonizacija žene (koncepcija femme fatale) s druge strane., usp. koncepcije žena u knjizi Elfriede Wiltschnigg iz 2001., pod naslovom Das Rätsel Weib. Das Bild der Frau in Wien um 1900. Berlin: Reimer.
} 
promicanjem vlastite žudnje. Budući da i Schnitzler i pripovjedač s kojim se on dijelom konsolidira slijede kolektivnu podsvijest svojih muških suvremenika, narativno predočena izrazita fascinacija zagonetnošću i „metafizičkom“ autonomijom ženske psihe pretače se u esencijaliziranje žene kao zagonetne Drugosti. Primarna intencija djela Die Fremde dijagnosticiranje je onodobnog pojma gubitka identiteta (njem. Identitätsverlust) i ženskog narcizma. $^{423}$

\subsubsection{Eksplicitni rod}

Tematizira se impresionistički intonirana promjenjivost ljudskog (napose ženskog), ,jastva“ u kojem se mogu iščitati podsvjesni impulsi, a koji upućuju na iracionalnu, oscilirajuću, i intuitivnu (žensku) prirodu. U djelu Die Fremde, obilježenom impresionističkom letimičnošću narativnog prikaza ženske prirode, heterodijegetski pripovjedač progovara o krajnje individualiziranoj i kompleksnoj ženskoj psihi (Katharina) koja je u fokusu razmišljanja muškog protagonista (Albert von Webeling), zaokupljenog ženskim subjektom koji neprestano izmiče fiksnoj rodnoj definiciji i fiksnoj definiciji identiteta. Katharina je u Albertovim razmišljanjima stereotipno polarizirana između koncepcije femme fragile (nježne, krhke ženstvenosti koja posjeduje auru tajanstvenosti i nedokučivosti vlastite „esencije“ i koja uranja u vlastite podsvjesne domene) i femme fatale (sudbonosne, fatalne žene koja muškarcu donosi nevolje zavodljivošću svoje pojave): ona je primjer hibridnog roda, budući da 1 . pokazuje mješavinu stereotipno ženskih i stereotipno muških karakteristika, 2. demonstrira koncepciju das unrettbare Ich i Wandelbarkeit der Persönlichkeit, dakle, promjenjivost karaktera koja ovisi o trenutku i percepcijama, i 3. demonstrira svojevrsnu androginu samodostatnost psihe, budući da je njezin promiskuitet ponajprije odraz autistične i depresivne psihičke konstitucije.

Motiv gledanja kroz prozor često se pojavljuje u književnosti fin-de-siècle-a: on je simboličan kao prag između unutarnjeg i vanjskog svijeta ${ }^{424}$, između ženski konotiranog prostora (privatne sfere) i muški konotiranog prostora (javne sfere). Budući da Albert i Katharina zajedno gledaju kroz prozor, ovaj moment u pripovijetci također svjedoči o njihovoj distanciranosti od vanjskog svijeta. Motiv daljine, diskontinuiteta psihe i otvorenih, nejasnih i neizvjesnih mogućnosti ukazuje na eskapističku koncepciju Katharinine psihe: i ovdje se otkriva simptomatika krize i destabilizacije identiteta i rodnih odnosa o prijelomu

\footnotetext{
${ }^{423}$ Vidi Le Rider, poglavlje o narcizmu kod žena u njegovoj knjizi Das Ende der Illusion, 1990., str. 91-94.

${ }^{424}$ Vidi Nünning/Nünning 2004, str. 53.
} 
stoljeća. ${ }^{425}$ Nakon vjenčanja uslijedili su „idilični“ trenuci kratkotrajne, utopističke, sreće: naracija prikazuje Alberta i Katharinu kako putuju idiličnim austrijskim mjestima i krajolicima, daleko od alijenacije grada, pri čemu idilična priroda djeluje kao „ženski““ konotirani, utopijski element i, uspostavljajući kratkotrajnu harmoniju između bračnih partnera, načas obustavlja njihovo međusobno otuđenje.

Lik Katharine, usprkos tome što je iz Albertove vizure koncipiran kao ženska Drugost muškarcu, pokazuje svojevrsni emancipacijski impuls odupirući se tradicionalnoj i stereotipnoj koncepciji žene kao supruge i majke kako bi na taj način afirmirao sebe kao subjekt žudnje (ili, označitelj u Lacanovskom smislu). I Albert i Katharina demonstriraju svojevrsnu psihološku kompleksnost, budući da se odvajaju od pragmatične građanske svakodnevice. Albert, naoko uredan građanski muškarac, usprkos tome što obavlja tipično građansko zanimanje, nakon susreta s „tajanstvenom“ Katharinom gubi interes za realnost i prestaje biti odraz stereotipno koncipiranog racionalnog, aktivnog i produktivnog tipa muškarca. Albertov se hibriditet roda ogleda upravo u njegovom odvajanju od ove za ono doba (fin-de-siècle) uvriježene koncepcije muškog karaktera: fascinacija Katharinom jednako je iracionalna kao i Katharinina fascinacija nizom drugih (potpuno nepoznatih, čak i imaginarnih) muškaraca. Međutim, Katharinina se žudnja prema muškarcima beskonačno umnaža, što ona sama predstavlja kao „otvorenost mogućnosti“،, dok Albertova žudnja ostaje, shodno njegovoj moralnosti i vjernosti, fokusirana isključivo na Katharinu. Ona svojim „promiskuitetom“, koji se također može usporediti sa iracionalnim oblikom ženske senzibilnosti, predstavlja otklon od građanskog morala i postaje odraz impresionističke letimičnosti epohe, a Albert se svojom moralnošću i stabilnošću svoje vezanosti uz Katharinu priklanja moralnim normama građanskog društva. Albertova i Katharinina psiha, s druge strane, pokazuju svoju zasebnost od građanskog društva kroz (tipično ženski konotirano) melankolično i asocijalno ponašanje. Albert traži izlaz iz melankolije i osamljenosti unutar moderne građanske egzistencije u ljubavi prema zagonetnoj i nedostupnoj Katharini: iracionalna ženska psiha time postaje izvor svojevrsnog mitskog obilja ${ }^{426}$ i majčinskog utočišta za mušku psihu, ali i poligonom za reproduciranje stereotipa o ženskosti, ,,anđeoskoj“‘ i „demonskoj“ koncepciji ženskosti koja u građanskom muškarcu izaziva ambivalentan osjećaj fascinacije i zazora.

Albert von Webeling i Katharina odraz su individualističkih stremljenja epohe: oni su izrazito psihološki kompleksni, višedimenzionalni i otvoreno koncipirani književni likovi. No

\footnotetext{
${ }^{425}$ Vidi Le Rider 1990.

${ }^{426}$ Vidi Felski 1995, str. 38.
} 
dok Albert više odgovara stereotipu onodobnog muškarca-građanina, budući da u svome ponašanju slijedi zasade normativnog građanskog morala, Katharina se u potpunosti oglušuje o te norme i demonstrira krajnji individualizam. Lik Katharine, iako naoko prikazan kao tipološka, ženska Drugost, u svojoj je višedimenzionalnosti, heterogenosti, otvorenosti i zagonetnosti karaktera odraz impresionističke letimičnosti i fluidnog jastva (njem. das unrettbare Ich), dok je lik Alberta odraz viteške muškosti i odlučnosti, ali i krhkosti (muškog) jastva i bolećivosti esteta-građanina. Svojom ravnodušnošću i emotivnom hladnoćom prema Albertu Katharina predstavlja svojevrsno utjelovljenje ,femme fatale“, a s druge strane, svojom mirnoćom karaktera, nenametljivošću, tipično ženskom pasivnošću, apatičnošću i melankolijom demonstrira tipološku ,femme fragile“. Katharinina bit, odnosno, njezina „ženska esencija“ ipak ostaje nedokučivom upravo stoga jer je u Albertovim mislima portretirana statično, kao stereotipna ženstvenost koja odgovara onodobnoj književnoj i društvenoj slici o ženi. No pravi je uzrok Katharinine zagonetnosti njezin individualizam, neovisnost, promiskuitet, odnosno, metaforički rečeno „otvorenost karaktera pred mnogim mogućnostima“, „plovljenje prema nepoznatim i neizvjesnim ciljevima“. Raspršenost žudnje i apatičnost, koja je uvjetovana možda traumom iz djetinjstva (prema Freudu), ili nekim podsvjesnim imagom (idealom muškarca) (prema Jungu) čini Katharinu nespremnom za brak s Albertom, donekle dokidajući mogućnost njezine karakterizacije shodno jednoznačnostima tipoloških koncepcija ženskosti kao femme fragile i femme fatale i čineći ju pravim primjerom (ženskog) individualizma i hibridnog roda. Postojanje podsvjesnog imaga ili animusa kod Katharine moguće je lako ustvrditi: 1. u dijelu pripovijetke koja opisuje incident s navodnom Katharininom vidovitošću oko smrti orguljaša Banettija, 2. u lociranju svojevrsne psihičke traume oko smrti njezinog brata, budući da u jednom momentu pripovijetke Katharina pripovijeda Albertu kako je sa svojim bratom nekoć šetala nekim imaginarnim brežuljkastim krajem, 3. u početnom dijelu pripovijetke, dok Albertov prijatelj Vinzenz pripovijeda Albertu o jednom incidentu koji se dogodio na pogrebu Katharininog brata, kad se ona nenadano bacila u naručje jednom bratovom prijatelju kao da je on njezin zaručnik. Svi ovi događaji upućuju na neke skrivene žudnje i traume ženske individualne psihe koje su, kako se čini, samo zastrte ,promiskuitetom“ i ,hladnoćom“ karaktera (svojevrsni oblik melankolije).

Pripovijetka Die Fremde započinje Albertovim buđenjem u jednom hotelu u Innsbrucku, u kojem je proveo noć sa svojom ženom Katharinom, i njegovom spoznajom da ga je ona iznenada napustila, ostavivši mu ceduljicu na noćnom ormariću. Već se u prvim rečenicama ogleda Albertovo fatalističko shvaćanje ljubavi i njegova želja za suicidom, spremnost na žrtvovanje vlastitog života, koje ga čini atipičnim muškarcem fin-de-sièclea i odvaja ga od 
stereotipne koncepcije racionalnog, aktivnog i produktivnog građanskog muškarca. Slijedi analeptičko vraćanje u prošlost, koje čini glavninu pripovijesti, kroz Albertovo sjećanje na poznanstvo sa zagonetnom Katharinom, koje služi kao uvod u objašnjenje njegova sadašnjeg stanja: „To je ipak već bilo odlučeno kad je prije dvije godine na plesu prvi put osjetio dašak tajanstvenih usana na svome obrazu. “427 Albert se prisjeća kako ga je prijatelj Vinzenz upozoravao vezano na Katharinu, s obzirom da je poznavao povijest njezine obitelji: rastrošnost njenog brata i njegovo samoubojstvo, zatim jedan neobičan događaj za vrijeme pogreba njenog brata, kad se Katharina jecajući bacila u naručje jednom njoj do tada potpuno nepoznatom bratovom prijatelju, kao da je on njezin prijatelj ili zaručnik“4428, nakon čega je barun Maaßburg, koji je slovio kao Katharinin zaručnik, obustavio svoje posjete u njezinoj kući. Godinu dana kasnije, Katharina se, jednako iracionalno, prepustila sanjarenju o poznatom orguljašu Banettiju, koji je napustio Beč a da ona čak nikada nije niti razgovarala s njim. Slijedi jedan neobičan događaj, koji ukazuje na duboku melankoličnost, iracionalnost, ali i intuitivnost Katharininog karaktera: Katharinina vidovitost vezano na Banettijevu smrt, nakon koje se „kod Katharine pojavljuju naznake duševne bolesti, koja se intenzivirala sve do najdublje potištenosti““. ${ }^{429}$ Ovdje možemo primijetiti da koncipiranje žene kao sklone histeriji i melankoliji odgovara onodobnim stereotipnim prikazima ženskog roda, koje ženu nadalje često na metaforički način povezuju sa pojmovima Erosa i Tanatosa. Katharina se nakon ovog razdoblja potištenosti naglo probudila iz svoje letargije: na jednom balu upoznaje Alberta von Webelinga, koji se prije nije puno kretao u društvu i koji biva fasciniran njezinom tajanstvenošću:

svaki je susret produbljivao njegovu naklonost prema njoj. Katharina je uvijek imala jednostavno držanje, ali njezina joj je visoka pojava, a posebno jedinstveni, pa i kraljevski način držanja glave dok bi nekoga slušala kako govori, davao jednu otmjenost posebne vrste. Nije mnogo govorila, a njezine su oči često, kad je bila u društvu, bile zadubljene, izgubljene u nekoj drugima nepristupačnoj daljini. Prema mlađim se muškarcima odnosila prilično nehajno, radije je razgovarala sa zrelijim muškarcima visokog ranga ili ugleda. ${ }^{430}$

\footnotetext{
427 „Entschieden war es doch schon gewesen, als er vor zwei Jahren beim Tanze das erstemal den kühlen Hauch der geheimnisvollen Lippen seine Wangen streifen fühlte“, Schnitzler: Meistererzählungen, 1950, str. 205.

428 ,Katharina war einem ihr bis dahin ganz unbekannten Kameraden ihres Bruders schluchzend in die Arme gefallen, als wäre er ihr Freund oder Verlobter", Die Fremde, str. 206.

429 „,bald darauf begannen sich bei Katharinen die Anzeichen einer Gemütskrankheit zu zeigen, die sich allmählich bis zu tiefster Versunkenheit steigerte“, Die Fremde, str. 206.

${ }^{430}$,Jede Begegnung vertiefte seine Neigung für sie. Katharina trug sich immer einfach, aber ihre hohe Gestalt und ganz besonders ihre einzige, ja königliche Weise, das Haupt zu neigen, wenn sie jemandem zuhörte, verlieh ihr eine Vornehmheit von ganz eigener Art. Sie sprach nicht viel, und ihre Augen pflegten oft, wenn sie in Gesellschaft war, wie in eine für die andern unzugängliche Ferne zu blicken. Die jüngeren Herren behandelte sie mit einiger Unachtsamkeit, lieber unterhielt sie sich mit reiferen Männern von Rang oder Ruf“, Die Fremde, str. 206-207.
} 
Albertova fascinacija Katharinom poprima rodno-atipične razmjere, budući da je pored nje prožet kompleksom manje vrijednosti, što ukazuje na sveopće društveno stanje gubitka muškog dominantnog položaja u doba ugroženog patrijarhata iz kojeg proizlazi i gubitak sigurnosti građanskog muškarca i njegovog identiteta. Umjesto da Katharinu izvuče iz autistične izoliranosti, Albert se na autodestruktivan način sve više prilagođava tom njenom neobičnom stanju. ${ }^{431}$ Treba istaknuti da na ovaj gubitak sigurnosti muškog (racionalnog) identiteta utječe i u fin-de-siècle-u sveprisutna destabilizacija normativno muški konotirane racionalne, prosvjetiteljske slike svijeta:

\begin{abstract}
Godinu dana nakon što ju je Albert upoznao, krenula je glasina da se zaručila s grofom Rummingshausom, koji se baš bio vratio s jedne znanstvene ekspedicije u Tibetu i Turkestanu. Već je tada Albert znao da će dan kad Katharina bude drugome muškarcu pružila svoju ruku za brak biti zadnji dan njegovog života. On, čiji je život do njegove 30. godine nepokolebljivo tekao, odjednom je shvatio sve opasnosti i svo ludilo u koje čak i najrazboritijeg i najopreznijeg muškarca može strmoglaviti njegova žestoka strast. Bio je potpuno uvjeren u svoju ništavnost naspram Katharine. ${ }^{432}$
\end{abstract}

Stereotipno muško koncipiranje žene kao tajanstvene Drugosti koja se nalazi izvan društva i koja jednako tako figurira kao odraz sublimnog i „,demonskog ${ }^{\text {‘433 }}$ prisutno je u Albertovim razmišljanjima o Katharini: „I tako je osjećao da bi se jedno biće kao Katharina, tajanstveno i istovremeno s jednog drugog svijeta, moralo s visine njemu obratiti kao nižemu po rangu, da bi se ona morala umilostiviti kad bi poželio da bude njegova“. ${ }^{434}$ Isključivši Katharininu pripovijest iz naracije, pripovjedač povlađuje reprezentacijskim strategijama koje isključuju žene iz simboličkog društvenog poretka, a esencijaliziraju ženu kao simboličko utjelovljenje prirode, senzualnosti i zagonetnosti.

Bezuvjetna Albertova ljubav prema Katharini odvodi ga u za onodobno vrijeme za muško biće „proskribirana“ i neshvaćena tipično ženska, iracionalna ponašanja, čime njegov identitet stabilnog, građanskog i autoritativnog muškarca koji posjeduje dominaciju nad ženom biva doveden u pitanje: „Mislio je da bi ona čak imala, u svakom slučaju, pravo zahtijevati od njega da skupo plati svoju nezasluženu sreću. No kako je bio spreman na svaku žrtvu da bi ju

\footnotetext{
${ }^{431}$ Vidi Perlmann 1987, str. 140.

432 „Und, wieder ein Jahr, nachdem Albert sie kennengelernt hatte, verlobte sie das Gerücht mit dem Grafen Rummingshaus, der eben von einer Forschungsreise in Tibet und Turkestan heimgekehrt war. Damals wußte Albert, daß der Tag, an dem Katharina einem andern die Hand zur Ehe reichte, der letzte seines Lebens sein würde, und er, dessen Dasein bis zu seinem dreißigsten Jahr unbeirrt hingeflossen war, begriff mit einem Male alle Gefahren und allen Wahnsinn, in die heftige Leidenschaft den besonnensten Mann zu stürzen vermag. Von seiner Nichtigkeit Katharinen gegenüber war er völlig durchdrungen“., Die Fremde, str. 207.

${ }^{433}$ Vidi koncepcije ženskosti u moderni u knjizi Bettine Pohle pod naslovom „Kunstwerk Frau“. Koncepcije žene kao ,prirodnog bića“ suprotstavljene su koncepciji muškarca kao bića kulture.

434 „Und so fühlte er, daß ein Wesen, geheimnisvoll und gleichsam aus einer andern Welt wie Katharina, sich tief zu ihm herablassen müßte, wenn er sie gewinnen wollte...", Die Fremde, str. 207.
} 
osvojio, činilo mu se da malo-pomalo postaje dostojan Katharine“. ${ }^{435}$ Nakon što je Albert zaprosio Katharinu, ona reagira s njoj uobičajenom mirnoćom i ravnodušnošću. Stereotipno promatranje žene ogleda se i u sljedećoj rečenici, u kojoj se otkriva sličnost s Freudovom koncepcijom žene kao „tamnog, neistraženog kontinenta“: „I kad je kasnije kročio niz sive stepenice, u svojoj je duši osjećao ne blaženstvo ispunjene želje, već samo svijest o tome da je kročio u jedno čudesno, ali neizvjesno i mračno razdoblje svoga života““. ${ }^{436}$ Usprkos opredmećenom i dijelom stereotipnom koncipiranju lika Katharine, slijedi prikaz Katharine koji upućuje na koncepciju njezine psihe kao odraza fluidnog jastva (das unrettbare Ich), podsvjesnih slika i erotičko-impresionističke letimičnosti s kojom ona promatra svijet oko sebe, ukazujući na krajnji individualizam i neovisnost koji utječu na dehijerarhizaciju odnosa između nje i Alberta:

\begin{abstract}
Čudnovate stvari su se potom dogodile, koje su možda mogle biti beznačajne, ali koje su u svakom slučaju ostale nerazjašnjene. Tako je Albert jednoga dana oko podneva susreo svoju zaručnicu na Stephansplatzu u društvu jednog elegantnog gospodina u koroti, kojeg nikad prije nije vidio. Albert je zastao, ali ga je Katharina samo hladno pozdravila i nastavila dalje šetati s nepoznatim gospodinom a da se nije niti osvrnula na njega. Albert ju je neko vrijeme slijedio, dok je gospodin ušao u kočiju, koja je na uglu ulice čekala na njega, i odvezao se. Katharina je pošla kući. Kad ju je Albert navečer upitao tko je bio onaj gospodin, ona ga je začuđeno pogledala i rekla mu jedno posve nepoznato poljsko ime te se ostatak večeri povukla u svoju sobu. Jedan drugi put ona ga je navečer ostavila a on ju je uzalud čekao. Naposljetku se pojavila kad je već otkucalo 22 sata, sa kiticom cvijeća u ruci i ispričala mu da je bila na selu i zaspala na jednoj livadi. Cvijeće je bacila kroz prozor. Kad je opet jednom s Albertom posjetila galeriju, stajala je dugo s njim ispred jedne slike koja predstavlja osamljeni zeleni brežuljkasti krajolik iznad kojeg su bili bijeli oblaci. Nekoliko dana nakon toga mu je pričala o tome kraju, kao da je u stvarnosti šetala tim uzvisinama, i to kao dijete, u drušstvu svog pokojnog brata. Isprva je Albert vjerovao da se ona šali, no malo-pomalo je primijetio da je ta slika za nju u sjećanju postala vrlo živa. ${ }^{437}$
\end{abstract}

\footnotetext{
435, ,...und daß sie jedenfalls von ihm verlangen durfte, ein unverdientes Glück teuer zu bezahlen. Da er sich aber zu jedem Opfer bereit wußte, schien er sich auch allmählich ihrer würdig zu werden“., Die Fremde, str. 207.

436 „Und als er später die graue Treppe hinunterschritt, ward ihm nicht die beseligende Empfindung eines erfüllten Wunsches, sondern nur das Bewußtsein, daß er in eine wohl wundersame, aber ungewisse und dunkle Epoche seines Lebens eingetreten war", Die Fremde, str. 208.

437 ,Seltsame Dinge ereigneten sich, die an sich ohne Bedeutung sein mochten, die aber jedenfalls ohne Erklärung blieben. So begegnete Albert eines Tages um die Mittagsstunde seiner Braut auf dem Stephansplatz in Gesellschaft eines in Trauer gekleideten, eleganten Herrn, den er früher nie gesehen hatte. Albert blieb stehen, aber Katharina grüßte kühl, und ohne sich um ihn zu kümmern, ging sie mit dem fremden Herrn weiter. Albert folgte ihr eine Weile, der Herr stieg in einen Wagen, der an einer Straßenecke auf ihn wartete, und fuhr davon. Katharina ging nach Hause. Als Albert sie abends fragte, wer jener Herr gewesen wäre, sah sie ihn befremdet an, nannte einen ihm gänzlich unbekannten polnischen Namen und zog sich für den Rest des Abends auf ihr Zimmer zurück. Ein anderes Mal ließ sie abends lang vergeblich auf sich warten. Endlich erschien sie, als es zehn Uhr schlug, mit einem Strauß von Feldblumen in der Hand und erzählte, daß sie auf dem Lande gewesen und auf einer Wiese eingeschlafen sei. Die Blumen warf sie zum Fenster hinab. Einmal besuchte sie mit Albert das Künstlerhaus und stand lang mit ihm vor einem Bild, das eine einsame grüne Höhenlandschaft mit weißen Wolken drüber vorstellte. Ein paar Tage darauf sprach sie von dieser Gegend, als wäre sie in Wirklichkeit über diese Höhen gewandelt, und zwar als Kind in Gesellschaft ihres verstorbenen Bruders. Zuerst glaubte Albert, daß sie scherzte, allmählich aber merkte er, daß das Bild für sie in der Erinnerung gleichsam lebendig geworden war“., Die Fremde, str. 208-209.
} 
Katharina demonstrira iracionalnost (ženske) psihe, koja se oslanja na snovite i nejasne predodžbe iz podsvijesti, koje bivaju također odrazom hipersenzibilne ženske psihe, u traganju za nekim podsvjesnim idealom: u objašnjenju Katharininog „umjetnog raja“, odnosno, iracionalnih predodžbi i ,transcendentnih realiteta“ njezine psihe mora se uzeti u obzir srodnost Schnitzlerove pripovijetke Die Fremde s Freudovom psihoanalizom, posebice sa njegovim objašnjenjem pojma nesvjesnog (njem. das Unbewusste). Albert se u svojoj fascinaciji ženskom Drugošću približava Katharininoj (ženski konotiranoj) iracionalnosti:

Tada je osjećao da se njegovo čuđenje počelo pretvarati u bolnu jezu. Ali što mu je nepojmljivije njezina bit izmicala, to ga je beznadnije vukla čežnja za njom. Ponekad bi mu uspjelo navesti ju da priča o svojoj mladosti. No sve o čemu je pričala, pripovijesti o stvarnim događajima i priznanja o dalekim sanjarenjima, lebdjela su u istom zagasitom treptanju, tako da Albert nije znao što joj se od svega toga življe urezalo u pamćenje: onaj orguljaš, koji se sunovratio sa crkvenog tornja, ili mladi vojvoda od Modene, koji je jednom kod Pratera projahao pored nje, ili pak Van-Dyckov mladić, čiji je portret kao mlada djevojka vidjela u galeriji Liechtenstein. I tako je njezina duša, njezin bitak sanjareći plovio prema nekim nepoznatim i neizvjesnim ciljevima, i Albert je slutio da on njoj nije ništa drugo značio osim samo kao netko kome bi u društvu, u nekoj sali, pružila ruku za plesnu partiju. I kako mu je ponestajala svaka snaga da ju izvuče iz njezine zagonetne egzistencije, osjećao je naposljetku, kako ga zbunjujući dašak njezina bića omamljuje i kako se malo-pomalo njegov način razmišljanja, pa čak i djelovanja, počeo udaljavati od obveza i nužnosti dnevnoga života. ${ }^{438}$

Katharina je „otvorena“ prema različitim inicijativama, što odražava onodobnu koncepciju gubitka identiteta (njem. Identitätsverlust): „Kad bi razgovarala o svojoj budućnosti, ona to nije činila kao netko kome je već zacrtan neki put ili cilj; štoviše, sve su joj se mogućnosti još činile otvorenima, i ništa u njezinom ponašanju nije upućivalo na neku unutarnju ili vanjsku vezanost za Alberta“. ${ }^{439}$ Albertova čvrsta odluka da napusti ovaj svijet čim izgubi Katharinu čini ga atipičnim muškarcem onoga doba: lik Alberta odvaja se od stereotipno zacrtane muške racionalnosti. Albert je svjestan da mu predstoji neizvjesna i kratkotrajna veza s Katharinom, ali mu je nemoguće zamisliti život bez nje i spreman je i na žrtvovanje vlastitog života. U monotoniji njegove građanske egzistencije Katharina sada postaje jedino što ga veže sa

\footnotetext{
438 „Damals fühlte er, wie sich sein Staunen in ein schmerzliches Grauen zu verwandeln begann. Aber je unfaßlicher ihm ihr Wesen zu entgleiten schien, um so hoffnungslos dringender rief seine Sehnsucht nach ihr. Zuweilen gelang es ihm, sie von ihrer Jugend reden zu machen. Doch alles, was sie berichtete, Erzählungen wirklicher Geschehnisse und Geständnisse ferner Träumereien, schwebte wie im gleichen matten Schimmer vorüber, so daß Albert nicht wußte, was sich ihrem Gedächtnis lebendiger eingeprägt: jener Orgelspieler, der sich vom Kirchturm herabgestürzt hatte, der junge Herzog von Modena, der einmal im Prater an ihr vorübergeritten war, oder ein Van Dyckscher Jüngling, dessen Bildnis sie als junges Mädchen in der Liechtenstein-Galerie gesehen hatte. Und so dämmerte auch jetzt ihr Wesen hin, wie nach unbekannten oder ungewissen Zielen, und Albert ahnte, daß er nichts anderes für sie bedeutete als irgend einer, dem sie in einer Gesellschaft zu einer Runde durch den Saal den Arm gereicht hätte. Und da ihm jede Kraft gebrach, sie aus ihrer verschwommenen Art des Daseins emporzuziehen, fühlte er endlich, wie ihn der verwirrende Hauch ihres Wesens zu betäuben und wie sich allmählich seine Weise zu denken, ja selbst zu handeln, aller durch das tägliche Leben gegebenen Notwendigkeit zu entäußern begann“., Die Fremde, str. 209.

${ }_{439}$ „Denn wenn sie über ihre Zukunft redete, so tat sie das nicht wie jemand, dem ein vorgezeichneter Weg ins Weite weist; vielmehr schienen ihr alle Möglichkeiten nach wie vor offen zu stehen, und nichts in ihrem Verhalten deutete auf innere oder äußere Gebundenheit“", Die Fremde, str. 210.
} 
životom. Na dan njihovog vjenčanja ona mu je jednako strana kao i onoga dana kad ju je upoznao: „bila je njegova bez strasti i bez opiranja“. ${ }^{440}$ Nakon njihovih kratkotrajnih sretnih trenutaka zajedno, u Katharini se opet javljaju nejasni podsvjesni porivi.

\subsubsection{Implicitni rod}

Pripovijedanje u Die Fremde analogno je koncepciji Katharininog karaktera: ono je također impresionistički i hermetično koncipirano, budući da prati i „secira“ emotivna stanja glavnog lika, Alberta von Webelinga, ulazeći na detaljan način (na pojedinim mjestima uz pomoć usporenog tijeka pripovijedanja) u njegove kompleksne percepcije i osjećaje vezane uz ženski objekt razmatranja. Fokusiranje heterodijegetskog pripovjedača na prikaz Albertove psihe odudara donekle od rodnih stereotipa, jer je zapravo u punom fokusu pripovijetke muška intimna pripovijest i narativni prikaz Albertovog samoubojstva. U nekim dijelovima pripovijetke (koji ukratko prikazuju Katharinin životopis), pripovijedanje je koncipirano u ubrzanom tempu (njem. Zeitraffung), čime se pripovjedač strogo sumarno osvrće na problematiku obiteljske povijesti žene.

Što se tiče simbolike prostora, početnim dijelom pripovijetke (upoznavanje i zaruke Alberta i Katharine) dominira simbolika grada kao mjesta otuđenja; u odsječku radnje u kojem Albert dolazi zaprositi Katharinu u njezinoj kući dominiraju sivkasti i mutni tonovi koji simbolički korespondiraju s tajanstvenom i maglovitom ,esencijom ženstva“. Motiv hermetično konotirane, hladne sobe ispunjene nedjeljnom tišinom korespondira s Albertovom unutarnjom spoznajom (predočenom unutarnjom naracijom) o vlastitoj usamljenosti te o mogućim Katharininim obiteljskim traumama i tajnama. Kročeći sivim stepenicama, Albert osvješćuje svoje „sutonsko“ raspoloženje estetski prijemčivog građanskog muškarca i svoju fascinaciju tajanstvenom Katharininom psihom te je obuzet fatalističkim shvaćanjem da je njegova duša zašla u neko neizvjesno i mračno razdoblje. Narativni prijelaz, koji topografski prati Albertov izlazak iz Katharinine kuće na ulicu, među ljude, naznačava izoliranost Alberta od društva i također svjedoči o njegovoj hipersenzibilnoj obuzetosti ženskom „esencijom“. Motiv proljetnog neba, ljepote bečkih vrtova i aleja te bezbrižnih ljudi u kontrastu je sa zamorom Albertova duševnog života i njegovom tajanstvenom obuzetošću fatalističkim i sumornim osjećanjem- ono je simptom njegova udaljavanja od građanske pragmatične egzistencije i skok u ,ženski konotiranu“ spiritualnost:

\footnotetext{
${ }^{440}$ „Sie wurde die Seine ohne Leidenschaft und ohne Widerstreben“, Die Fremde, str. 210.
} 
Tijekom cijelog njihovog razgovora u hladnoj sobi ispunjenoj nedjeljnom tišinom Albert je imao osjećaj da je zašao u jedno područje u kojemu su dugo vremena bjesnile jake oluje, i koji je sada odisao velikom čežnjom za mirom. I kad je kasnije kročio niz sive stepenice, u svojoj je duši osjećao ne blaženstvo ispunjene želje, već samo svijest o tome da je kročio u jedno čudesno, ali neizvjesno i mračno razdoblje svoga života. Šetajući tako, u nedjelju, od ulice do ulice, vrtovima i alejama, s proljetnim nebom ponad sebe, pored nekih vedrih i bezbrižnih, neopterećenih ljudi, osjećao je da odsad više ne spada među njih, i da je njime počela vladati jedna drugačija i posebna sudbina. ${ }^{441}$

Moment u pripovijetci u kojem Katharina pjeva, a Albert ju prati na klaviru naglašava njezinu apatičnost (,pjevala je ugodnim glasom, ali posve bezizražajno“) ${ }^{442}$

Schnitzler ne definira bit Katharinine psihe: poput heterodijegetskog pripovjedača (komentatora) iz njegova djela, koji se drži na svojevrsnoj distanci od ženskog subjekta, a implicitno se konsolidira s likom Alberta, dakle, s muškom pozicijom, Schnitzler pokušava na psihološki način prodrijeti u bit ženskog subjekta (Katharina) koji je u fokusu muške intimne pripovijesti (Albert) a koji i njega intrigira: rodna stereotipnost ovakvog prikaza ogleda se u tome što žena postaje fokus muške svijesti- ona kroz cijelu pripovijetku ostaje nijema, svedena na osobno ime, i prikazana kao objekt (opredmećena). Ženska pripovijest uopće ne dobiva svoj pripovjedni glas, pa ženski subjekt ostaje nedostupan i ,transcendentan“. Korištenjem pripovjedne tehnike slobodnog neupravnog govora („Erlebte Rede“), koja dokida precizno odvajanje perspektive pripovjedača od perspektive lika, heterodijegetska instanca pripovjedača konsolidira se s likom Alberta von Webelinga te time biva muški konotirana. Cijelo je djelo koncipirano u glagolskom vremenu epski obilježenog preterita, bez izravnog dijaloga likova, što ukazuje na analitičku distancu heterodijegetskog pripovjedača od predmeta njegove naracije (djelomično i lika Alberta, a u potpunosti od lika Katharine). S druge strane, samo buđenje interesa za žensku psihu i za ženu kao takvu demonstrira, pored stereotipne objektifikacije žene, i anti-stereotipnu fascinaciju ženom i ženskošću cijele jedne kulture (Verweiblichung der Kultur) i svjedoči o svojevrsnoj feminizaciji (androginizaciji) onodobne muške (i pripovjedne) svijesti. Punktualno korištenje usporenog tijeka pripovijedanja (Zeitdehnendes Erzählen) koristi se u narativnim prikazima Albertove „analize“ tajanstvene Katharine, u svrhu minucioznog prikazivanja svjesnih i podsvjesnih psihičkih impulsa lika. Ova „psihologizacija“ naracije, odnosno inzistiranje na prikazu

\footnotetext{
${ }^{441}$ „Während des ganzen Gesprächs in dem kühlen, sonntagsstillen Zimmer hatte Albert die Empfindung, als wäre er in eine Gegend gekommen, über die durch lange Zeit heftige Stürme gejagt hätten, und die nun eine große Sehnsucht nach Ruhe atmete. Und als er später die graue Treppe hinunterschritt, ward ihm nicht die beseligende Empfindung eines erfüllten Wunsches, sondern nur das Bewußtsein, daß er in eine wohl wundersame, aber ungewisse und dunkle Epoche seines Lebens eingetreten war. Und wie er so durch den Sonntag spazierte, von Straße zu Straße, durch Gärten und Alleen, den Frühjahrshimmel über sich, an manchen fröhlichen und unbekümmerten Menschen vorbei, da fühlte er, daß er von nun an nicht mehr zu diesen gehörte, und daß über ihm ein Geschick anderer und besonderer Art zu walten begann.“, Die Fremde, str. 208.

${ }^{442}$,....sang Katharina mit einer angenehmen Stimme, aber beinahe völlig ausdruckslos...“, Die Fremde, str. 208.
} 
psiholoških nijansi nauštrb izvanjskih događaja i radnje, bila je tradicionalno ženski konotirana. $^{443}$

Metafora „tuga tuđine““444 ima višeznačno određenje: u njoj se isprepliće pojam neizvjesnosti tuđine naspram zaštićenosti i sigurnosti u domovini, a s druge strane pojam žene kao te tuđine („Die Fremde/Neznanka“), koji aludira na književne koncepcije ženskosti kao iracionalne, „demonske“ sile i povezuje ženu s melankolijom i podsvjesnim strujanjima. Motiv muškog pogleda na ženu iz daljine (Alberta koji sa distance promatra Katharinu) svjedočanstvo je onodobnog ambivalentnog stava (žudnja i zazor) prema ženskom subjektu i naglašava poziciju krize muškog (rodnog) identiteta, polarizirane između rađanja impulsa ženske emancipacije i tradicionalnih muško-ženskih uloga. Naracija prikazuje Katharinin ulazak u crkvu, njezino štovanje statue gotskog kralja koje predstavlja najbizarniji moment u pripovijetci, budući da tipološki naglašava iracionalnost Katharinine psihe i, prema onodobnim koncepcijama, podložnost ,ženske prirode“ impulsima iz nesvjesnog, hermetičnog dijela psihe. „Prostorna“ i metaforička usporedba žene sa statuom, odnosno kipom, također je odraz esteticističkog, muškog pogleda na žensko tijelo, i upućuje na književno mortificiranje žene kao umjetničkog objekta koji izaziva strahopoštovanje.

U pripovijetci je naglasak na unutarnjoj vizuri (njem. Innensicht) glavnog lika, Alberta von Webelinga, a (vanjska) je radnja svedena na minimum: prikazuje se stanje svijesti građanskog muškarca koji osjeća kako se njegova poimanja sve više udaljavaju od materijalistički i pragmatički orijentiranog građanskog društva i uranjaju u tajanstvenu i iracionalnu ,žensku Drugost“.

Vremenski obrazac u pripovijetci ukazuje na anakronu vremensku koncepciju, budući da se na samom početku pripovijetke lik Alberta analeptički (kroz sjećanje) vraća u prošlost. Albertova retrospektivna svijest, iznesena posredstvom heterodijegetskog pripovjedača započinje svoje sjećanje na poznanstvo i brak s Katharinom, nakon što, na početku pripovijetke, Albert u hotelu shvati da ga je ona nakon 14 dana braka iznenada i bez objašnjenja napustila. Svijest senzibilnog građanskog esteta stoga postaje svojevrsna „unutarnja transcendencija““445 psihe koja se suprotstavlja građanskom društvu i društvenoj koncepciji vremena. Nakon završetka Albertove reminiscencije, u čijem je fokusu zagonetna ženskost, i kratkog narativnog prikaza njegova suicida simbolički točno $u$ podne, radnja pripovijetke se nastavlja kroz jednako tako sažet opis trenutačnog stanja u kojem se nalazi

\footnotetext{
${ }^{443}$ Vidi Nünning/Nünning 2004, str. 68.

$444, \ldots .$. Trauer der Fremde“

445 Vidi Nünning/Nünning 2004.
} 
Katharina: naznačen je blago ironični prikaz nemogućnosti provedbe ženske individualnosti unutar matrica patrijarhalnog društvenog poretka (kroz pripovjedačev osvrt na Katharinino pismo Andrei Geraldiniju koje ostaje bez odgovora), kao i ironičan komentar na Albertovu „mušku“ poziciju, budući da radnja pripovijetke teče čak i nakon nimalo patetičnog narativnog prikaza Albertova suicida. Funkcija ovog prikaza suicida je, kako se čini, naglašavanje prikaza muške nemoći pred rodnom dehijerarhizacijom onodobnog društva i krize muškog identiteta zbog promjena dinamike muško-ženskih odnosa. Katharina također biva blago ironično predstavljena, napose u zadnjoj rečenici pripovijetke, kad šalje pismo Andrei Geraldiniju u Veronu, a ne dobiva odgovor: odgovor na njezino pismo ostaje jednako obavijen velom tajne kao i cijela njezina iracionalno predstavljena ličnost. Iskazavši narativno kako Katharina ne dobiva odgovor na svoje pismo drugom muškarcu, pripovjedač se na implicitan način ironijski i distancirano odnosi prema ženskom subjektu i problematici ženske psihe.

Metafora die Fremde aludira na književni topos „tuđine“, koji, shodno rodnoj koncepciji prostora u knjizi Erzähltextanalyse und Gender Studies ${ }^{446}$ predstavlja odvajanje od onoga poznatoga (ovdje građanskog, uređenog, patrijarhalnog) i odlazak u neizvjesno u kojem vrebaju razne opasnosti: metaforički pojam „tuđine“ ovdje stoji kao personifikacija za ženu (Katharinu) kao „neistraženi kontinent“ za tradicionalnog muškarca (Alberta). Albertova se pasivnost, ali i nježnost esteta-građanina ogleda u narativnom prikazu njegove nemogućnosti djelovanja (,paraliziranosti“) i nedostatku volje da izvuče melankoličnu Katharinu iz njezinog maglovitog bitka:

Tako se dogodilo da su ga njezin nestanak danas rano ujutro, nakon bračnog putovanja koje je trajalo 14 dana, a isto tako i njezino neobično pismo, samo potresli, ali ga zapravo nisu iznenadili. Mislio je da bi ponizio i sebe i nju kad bi dalje istraživao. Tko mu ju je uzeo: je li to bila ćudljivost ili san ili čovjek od krvi i mesa, to je bilo potpuno nevažno; nije ništa drugo znao, i nije trebao ništa više znati, osim to da mu ona više ne pripada. ${ }^{447}$

Pojam ćudljivosti (njem. Laune) ukazuje na stereotipnu koncepciju ženskog jastva kao nestabilnog, podložnog maglovitim, iracionalnim impulsima iz podsvijesti. Dok su se u ranijim, tradicionalnijim stereotipizacijama ženskih likova žene prikazivale izrazito stilizirano, u ovome je djelu, pored stilizacije ženskog tijela i tipizacije ženskog lika, prikazan

\footnotetext{
${ }^{446}$ Vidi Nünning/Nünning 2004, str. 51.

447 „So kam es, daß ihr Verschwinden heute früh nach einer Hochzeitsreise von vierzehn Tagen, daß auch ihr seltsamer Brief ihn nur erschüttert hatte, ohne ihn eigentlich zu überraschen. Er hätte sie und sich zu erniedrigen geglaubt, wenn er geforscht hätte. Wer sie ihm genommen hatte, ob eine Laune, ob ein Traum, ob ein lebendiger Mensch, war ja völlig gleichgültig; er wußte nichts und brauchte nicht mehr zu wissen, als daß sie ihm nicht mehr gehörte“, Die Fremde, str. 210-211.
} 
i pojam krize kako muškog (Albert), tako i ženskog (Katharina) identiteta u doba bečke moderne. Krajnji čin drame Albertovo je samoubojstvo koje je počinio daleko od gradske vreve, i taj čin predstavlja rodnu ambivalenciju između viteškog, odnosno mučeničkog i odvažnog, muški konotiranog, žrtvovanja vlastitog života zbog neuzvraćene ljubavi prema „krhkoj“ ženi i, s druge strane, pasivog i mirnog, ženski konotiranog, nenametljivog pokoravanja sudbini u liku „fatalne“ žene. Albertovo rodno anti-stereotipno prepuštanje „ženskoj esenciji“, koje je simptom njegove feminizacije, ali i feminizacije cjelokupne naracije, udaljava ga od tipološke odrednice racionalnog i produktivnog muškarca onoga doba, te ga također svrstava u kategoriju melankolika i eskapista, naznačujući na taj način hibridnost i njegovog rodnog karaktera. Albertova bezuvjetna vjernost ženi koja boluje od neodredivosti (fluidnosti) svoga karaktera (identiteta), i koja uranja u vlastite eskapistički obilježene svjetove, a također i njegova odvojenost i otuđenost od građanske svakodnevice, na simboličkoj razini predstavlja onodobnu poziciju nesigurnosti muškoga subjekta pred dobom galopirajuće moderne i strukturalnih promjena u društvu.

\subsubsection{Zaključak}

Arthur Schnitzler je, shodno književnim koncepcijama vremena fin-de-siècle-a, izražavao svoj strah od gubitka muške dominantne pozicije u društvu, no jednako tako i načelnu ravnopravnost izricanja ženske žudnje naspram muške: 1. svoju fascinaciju i prihvaćanje individualnosti ženske psihe time što je kritizirao ustrajanje na koncepcijama izričitih rodnih polariteta i esencijaliziranje muško-ženskih uloga i karaktera, i 2. svoj strah pred ,prijetećom“ ženskošću i ženskom emancipacijom. Schnitzlerova intencija također je samokritički propitati stereotipno (muško) estetiziranje ženske ljepote i objektifikaciju žena, koja vodi u (za stereotipnu koncepciju onodobnog racionalnog muškarca) atipičnu pasivnost $i$ iracionalnost.

Albertovo percipiranje vlastite ništavnosti spram Katharine, njegovo poimanje života kao sjenovitog i samotnog prije pojave Katharine svjedočanstvo je njegovog estetskog senzibiliteta i alijenacije, ali i simptom obuzetosti idealiziranim ženskim bićem. Ova je idealizacija možda potaknuta i osjećajem manje vrijednosti budući da Katharina prema njemu pokazuje ravnodušnost (uočljivo je svojevrsno preokretanje muško-ženskih uloga i hijerarhijskog odnosa među spolovima). Međutim, u ovoj je pripovijetci vidljiva i objektivacija (opredmećenost) ženskog tijela u vidu statičnog ornamenta, sublimacija Albertovih osjećaja i percepcija u umjetničko stvaralaštvo, kreacija žene kao umjetničkog objekta. Nakon trenutaka koje su Albert i Katharina proveli zajedno, počinju se javljati prvi znakovi Katharinine začudnosti: Albert sreće Katharinu u društvu potpuno nepoznatih, 
mahom starijih muškaraca, pri čemu se ona pravi da ga ne poznaje- njezino je ponašanje svjedočanstvo Schnitzlerove književne percepcije o ženi kao zagonetnoj „Drugosti“. Ostali događaji iz djela također su simptomi iracionalne i melankolične, začudne ženske psihe koja stvara svoje „umjetne, paralelne svjetove“, dok je potpuna obuzetost ovom neobičnom mladom ženom odraz Albertove feminizacije, ali i nježnosti i bolećivosti esteta. Katharinin promiskuitetni i eskapistički karakter, koji u sebi nosi karakteristike fluidnosti (nekonzistentnosti) jastva izražen je kroz metaforu „otvorenost mogućnosti““, koja u sebi nosi anticipativni postmoderni potencijal vezano na problematiku rodnih odnosa u suvremenom društvu. Ženska iracionalna psiha ovdje također postaje odraz Machove koncepcije nestabilnog jastva pojedinaca o prijelomu stoljeća: nekonzistentnost jastva postaje simptom pluraliteta i polimorfnosti muško-ženskih odnosa na prijelazu iz 19. u 20. stoljeće.

Iako pripovjedač (narativna instanca) postaje neodvojiv od percipiranja samoga lika Alberta, te iako obje ove instance simbolično naznačuju stereotipnu mušku poziciju promatrača (,analitičara“) ženske psihe, treba primijetiti da se upravo odabirom teme ženskog stremljenja za individualnim izborom i udaljavanjem od konvencionalnog okruženja promiče problematika afirmacije ženskog prava na samoodređenje i izriče njegova načelna (ne)mogućnost unutar matrica patrijarhalnog društva.

\subsection{Arthur Schnitzler: Die Braut (Mladenka)}

\subsubsection{Uvod}

Schnitzlerova kraća pripovijetka pod naslovom Die Braut (Mladenka) i podnaslovom Studie (Studija) nastala je krajem 1891. godine, odnosno početkom 1892. godine. Prvi je put objavljena u Kleine Komödie ${ }^{448}$ kao vrsta ,psihološke studije“. „Pripovjedač u prvom licu jednine na maskenbalu upoznaje prostitutku, kod koje primjećuje visoku stopu inteligencije i iskrenosti““ ${ }^{449}$ „Njezina životna priča, koju pripovjedač pripovijeda vlastitim riječima, tvore glavni dio teksta. Ona potječe iz dobre kuće: međutim, njezina se „čula“ bude već u ranoj dobi i to u „mučnom intenzitetu“: ipak, ona je odlučna da najprije pronađe supruga, no onda se vrlo brzo bude njezini nagoni“. ${ }^{450}$

Autor djela Arthur Schnitzler, shodno svojoj profesiji psihoanalitičara, duboko zahvaća u tabuizirana područja ljudske (napose ženske) seksualnosti, istovremeno propitujući

\footnotetext{
${ }^{448}$ Jürgensen/Lukas/Scheffel 2014, str. 241.

449 Ibid.

${ }^{450}$ Ibid.
} 
legitimnost i reproducirajući stereotipne koncepcije žene kao isključivo senzualnog (prirodnog) bića. Schnitzler također istovremeno reproducira i propituje legitimnost tradicionalnih pripisivanja karakteristika bića kulture muškom spolu (racionalnost, transcendentalno jastvo i individualnost). Time istodobno re-tematizira i postavlja u pitanje, osim hijerarhijske nadmoći (hegemonije) muškarca nad ženom, i stereotipnu sliku muškosti i ženskosti njegova vremena, izgradivši ambivalentan stav koji varira između nesvjesnog reproduciranja rodnih stereotipa i uočavanja neodrživosti stereotipa o ženskoj spolnosti.

Međutim, iako je ženska pripovijest prikazana u tekstu, sam ženski subjekt ostaje nijem, neimenovan i većim dijelom opredmećen kroz samu naraciju: ženska je pripovijest $u$ fokusu muške pripovjedne svijesti koja joj je hijerarhijski nadmoćna, žena predstavlja objekt muške analize, ona je objekt Schnitzlerovog pripovjedača koji na način psihoanalitičara ${ }^{451}$ nastoji „prodrijeti“" u žensku svijest.

\subsubsection{Eksplicitni rod}

Homodijegetička instanca pripovjedača i lika (koji pripovijeda u 1. licu jednine, a na kraju, u okviru auto-refleksivno intonirane poante, i u 1. licu množine) narativno rekapitulira svoj susret s neimenovanom mladom ženom, rekonstruirajući njezinu pripovijest po vlastitom sjećanju. Pripovjedač izražava svoju zaokupljenost ženskom psihom, afirmirajući pravo ženskog subjekta na samoodređenje i afirmirajući žensku spolnost. Na taj način on dekonstruira onodobne stereotipe o ženskosti. Tekst djela Die Braut stoga nehotice demonstrira „hibridnu“ rodnu perspektivu, budući da se homodijegetički pripovjedač fokusira na prikaz ženske pripovijesti u doba ,polovične moderne“, ukazujući na pokušaj ostvarenja ženskog prava na izricanje vlastite žudnje unutar patrijarhalnih matrica društva, i time implicitno izražava svoj kritički odnos prema licemjerju građanske (muške) svijesti o ženi i strogoj rodnoj bipolarizaciji, izričitom odvajanju „tipično muške“ i ,tipično ženske“ žudnje kao i stereotipnim muško-ženskim rodnim ulogama. Iako pokazuje sklonost reproduciranja stereotipa o ženskosti (izjednačujući ženu sa prirodom i senzualnošću i odričući joj individualnost (,transcendentalno“ jastvo) u smislu kako je to postulirao Otto Weininger u svojoj knjizi pod naslovom Geschlecht und Charakter $^{452}$ (Spol i karakter), instanca

\footnotetext{
${ }^{451}$ Treba istaknuti paralelu između liječničke profesije Arthura Schnitzlera i realistično analitičkog pisanja o ženskim problemima i tabuima u građanskom društvu o prijelomu stoljeća, što ukazuje na to da je u Schnitzlerovim djelima (napose proznima) prisutan „Znanstvenički“, muški, pa i Freudijanski, opredmećivajući prikaz ženskog tijela i ženske spolnosti (vidi Bettina Pohle: Kunstwerk Frau, gdje je prikazan muški pogled na žensko tijelo i ženski subjekt, naročito u književnosti i umjetnosti kao odraz problematike čitavog razdoblja o prijelazu iz 19. u 20. stoljeće).

${ }^{452}$ Vidi Weininger 1920.
} 
homodijegetičkog pripovjedača želi pokazati odmak od onodobne seksualne antropologije (naročito Krafft-Ebingovih ${ }^{453}$ teza o manje izraženom spolnom nagonu kod žena), dekonstruirajući stereotipnu patrijarhalnu sliku o ženi, ženskoj žudnji, a time i radikalnoj rodnoj polarizaciji putem afirmiranja žene kao individualnog i autonomnog bića.

U pripovijetci je predstavljen fokus pripovjedača na dublja psihološka stanja žene, budući da je pripovjedač dio pripovjednog svijeta (on je ujedno i lik u pripovijetci, stoga se narativna distanca pripovjedača i ženskog lika još više smanjuje).

Homodijegetička pripovjedna instanca po vlastitom sjećanju rekonstruira svoj susret sa ženom i prenosi čitatelju ženinu ispovijest. Pripovjedač se upušta u svjesna i podsvjesna strujanja ženske psihe, priznajući intuitivno ženi njezinu želju za slobodom vlastitog odabira $i$ ne izričući svoju osudu njenog promiskuiteta: u tome se homodijegetički pripovjedač odvaja od „,moralnih zasada“ građanskog društva i morala suvremenika. U svojem tumačenju ženske psihe pripovjedna instanca fokusira ženinu nagonsku prirodu (njem. Triebnatur) koja usmjerava tijek naracije, a održava cirkularnost i diskontinuitet radnje konfliktom između beskonačnog umnažanja žudnje i neuspjelog pokušaja da se ta žudnja ipak obuzda unutar kategorija građanskog braka (neprestana unutarnja borba između promiskuiteta i morala). Vrsta zapleta ove pripovijetke fokusira se na pripovjedačev prikaz ženinog preispitivanja same sebe (neka vrsta narativne potrage za vlastitim samoodređenjem (tradicionalno definirana kao quest u povijesti književnosti). Ovo se preispitivanje, međutim, prvenstveno odnosi na propitivanje vlastite spolnosti, čime se ženski lik narativno stereotipno konstruira, budući da se prikazuje isključivo kroz prizmu stereotipnog Weiningerovskog koncepta žene kao isključivo senzualnog bića, bića isključivo orijentiranog na vlastitu spolnost.

Instanca pripovjedača izražava želju za dubljim, gotovo empatijskim spoznavanjem jedne individualne ženske psihe koja mu se čini manje stereotipnom. Schnitzlerov odabir homodijegetičke pripovjedne instance, odnosno njegov odabir muškog pripovjedača u 1 . licu jednine, pokazuje veći zaokret prema empatijskom uživljavanju u žensku intimnu priču nego u djelu Die Fremde. Pripovjedač na retrospektivan (anakronijski) način kroz cijelu pripovijetku opisuje svoj susret sa mladom ženom na jednom maskenbalu, iza ponoći. Već u prvim rečenicama izražava svoj interes za dubljim upoznavanjem njezine psihe, distancirajući se od maskenbala i prijetvornosti građanskog društva, napose njegova licemjernog spolnog morala i odnosa prema ženama. Odvratna mu je prijetvornost žena koje povlađuju hipokrizijski nastrojenom građanskom moralu, skrivajući svoj pravi identitet bludnice. Motiv

\footnotetext{
${ }^{453}$ Vidi Krafft-Ebing (1898), 1993.
} 
maskenbala ukazuje na opreku pojmova Sein i Schein, zbilje i privida (fikcije), karakterističnih za svjetonazor bečke moderne i za dvostruki moral društva kojem se kompleksno i oprečno koncipirani lik žene kao individue opire: budući da se žena ne ustručava priznati kako spada u kategoriju bludnica prezrenih od društva, odbacujući kategoriju lažnog društvenog morala i stereotipne slike ženskosti, pripovjedač iskazuje svojevrsno poštovanje prema njoj, ironizirajući time društvo koje ju odbacuje i sebe kao dio tog društva. Pripovjedač naglašava da žena ,pripada kategoriji iskrenih bludnica“‘454, ali da, za razliku od žena koje su, slijedeći rodne norme i stereotipe, skrivale svoju pravu prirodu, nije imala potrebu pretvarati se. Međutim, već je na samom početku pripovijetke uočljivo pripovjedačevo opredmećivanje žene (stvaranje žene umjetničkim objektom), budući da se homodijegetički pripovjedač stereotipno fokusira na elemente njezina vanjskog (fizičkog) izgleda: „tamnoplava haljina“, „mirne i pametne oči“. ${ }^{455}$ Time pripovjedač nesvjesno još uvijek reproducira onodobne stereotipne prikaze žene kao izrazito tjelesnog bića (njem. Frau als Naturwesen). Iskrenost žene koju susreće prvi mu je pokazatelj njezine individualnosti i samosvojnog nepristajanja na društvene laži, neprihvaćanja građanskih normi. Navodi da je bila „neobično inteligentna, po njenom se govoru i u njezinoj gestikulaciji vidjelo da dolazi iz višeg društvenog sloja. “456 Sluteći da ova žena ima posve drugačiju životnu priču koja odstupa od stereotipnih životnih priča žena njezine vrste, on se nada da će spoznati razlog zbog kojeg je postala bludnica. Time izražava svoju apologiju snazi ženskih individualnih karakteristika koje bi nadilazile bilo kakve rodne podjele (bipolarizacije), kao i stereotipna poimanja ženskosti. Za ono doba izniman je samo način na koji se pristupa valorizaciji ženske pripovijesti i ženske žudnje: duboko ispod površine teksta ipak proizlazi da je žena itekako objekt, a ne subjekt naracije. Pripovjedač demonstrira dijelom atipičan stav s obzirom na muškarce onoga doba, budući da izražava neuobičajen interes za afirmacijom ženske psihe, spolnosti, i individualnosti, promičući na površini teksta ideju rodne jednakosti s obzirom na izjednačenost ženske sa muškom žudnjom (odnosno, nagona (njem. Trieb) kao zajedničke, antropološki neutralne egzistencijalne osnove), kao i ženino pravo za performativnim uspostavljanjem vlastite spolnosti. Pripovjedač naglašava da se, budući da mu je to ,žensko biće bilo vrlo drago“, „nije mogao odlučiti da ju jednostavno uzme/shvati“" kao običnu ženu, „što predstavlja završetak vesele noći“, već ju želi dublje upoznati, onkraj rodnih stereotipa njegova vremena, i time odstupa od stereotipa onodobnog distanciranog muškarca i

\footnotetext{
454 ,....sie gehörte zur Kategorie der aufrichtigen Dirnen“, Die Braut, str. 92.

455 Die Braut, str. 92.

456 ,....sie war ungewöhnlich intelligent, man hörte es ihren Reden und sah es ihren Bewegungen an, daß sie aus besseren Kreisen herkam“, Die Braut, str. 92.
} 
konzumenta ljubavi. S druge strane, on kasnije u naraciji itekako poima žensko biće kao objekt (,ponudila se“, „on ju je uzeo“, „otjerao ju je“, bila je ostavljena“). Na taj se način pripovjedač polarizira između angažiranog, empatijski priklonjenog pripovjedača (engl. engaging narrator) i pripovjedača koji, re-etablirajući rodne stereotipe i ženu kao objekt pripovijesti, zadržava pripovjednu distancu (engl. distancing narrator). Iako pripovjedač želi spoznati individualne karakteristike koje ovu ženu odvajaju od drugih žena, ovaj je interes pripovjedača dijelom stereotipan jer odražava onodobni „muški, znanstvenički“ interes za prodiranjem u žensku psihu (npr. Freudijanske koncepcije žene kao „tamnog, neistraženog kontinenta"). Rečenica, ,želio sam znati o muškarcima koje je voljela, prije nego što se odlučila voljeti sve one koji su ju poželjeli“ također demonstrira pripovjedačev stereotipan stav prema ženi: iz drugog dijela rečenice proizlazi da je žena objekt muškog odabira (muške žudnje prema ženi). Pripovjedaču su ipak ostale neopisivo živo urezane riječi žene s kojom je proveo noć, pa ih je pokušao dopuniti u sjećanju, participirajući time u afirmaciji i prihvaćanju žene kao individue i njezine individualne sudbine. Fascinacija homodijegetičkog pripovjedača ženom stoga je dijelom odraz stereotipne zaokupljenosti ženom (njem. Verweiblichung der Kultur) u kulturi bečke moderne, a dijelom želja za odmakom od takvog stereotipiziranja žene time što se pozornost usmjerava na afirmaciju ženske spolne želje i ženskog individualnog odabira. Uživljavajući se donekle u psihološki život žene, instanca homodijegetičkog pripovjedača nastoji percipirati žensko biće ne isključivo kao stereotipnu, rodno obilježenu Drugost, već kao individualnu, autonomnu, slobodnu svijest sa svim sebi svojstvenim slojevitostima psihe. Detaljno se prisjeća svog susreta s njom, naglašavajući time određenu intimnost i bliskost: „imao sam osjećaj da se na mene naslonilo biće koje sam već dugo, dugo poznavao i koje mi je bilo vrlo milo. Osjećao sam se dobro pored nje i dugo vremena nismo uopće ništa govorili““ ${ }^{457}$ Pripovjedač se na razini semantike rodne jednakosti empatijski uživljava u žensku psihu: „Nisam se mogao odlučiti da ju samo uzmem/shvatim kao ženu, što bi predstavljalo završni čin vesele noći, već sam ju želio upoznati. Želio sam znati o njezinom životu, o njezinoj mladosti, o muškarcima koje je voljela prije nego što se odlučila voljeti sve one koji su ju željeli. “458 Iako je već u ovoj posljednjoj sintagmi vidljiva objektifikacija žene, pripovjedač ipak ističe vlastitu želju za otkrivanjem sudbine jedne od društva odbačene i prezrene žene. On reproducira rodne stereotipe (i svoju hijerahijsku

\footnotetext{
457 ,...hatte ich das Gefühl, als wenn da ein Wesen an meiner Seite lehnte, das ich schon lange, lange kannte und sehr lieb hätte. Mir war sehr wohl neben ihr, und geraume Zeit sprachen wir gar nichts“., Die Braut, str. 92.

458 „Ich konnte mich nicht entschließen, sie schlechthin als das Weib zu nehmen, das den Abschluß einer lustigen Nacht bedeutet, ich wollte sie kennenlernen. Von ihrem Leben wollte ich wissen, von ihrer Jugend, von den Männern, die sie geliebt, bevor sie sich entschloß, alle zu lieben, die sie wollten“, Die Braut, str. 92.
} 
nadmoćnu poziciju muškarca) svojim postepenim suverenim komunikativnim i narativnim „osvajanjem“ žene, a kasnije, nakon njihovog intimnog „poznanstva“, budući da biva zaintrigiran problemom ženske individualnosti i anti-stereotipnošću jedne ženske priče, nesvjesno dopunjava u sjećanju ,praznine koje je ona ostavila u pripovijedanju.“459 Napominje njezinu obiteljsku pozadinu i ranu mladost, navodeći da je potjecala iz vrlo ugledne i poznate građanske obitelji. Činjenica da su se njezina čula rano probudila ukazuje na prijetvornost građanskog morala i na „nelagodu“ građanskog pojedinca u građanskoj kulturi koja, prema Sigmundu Freudu, sputava nagone moralnim zasadama i društvenim kodeksima. ${ }^{460}$ Kao mlada djevojka, žena se osjećala vrlo osamljenom, ali se odlučila na apstiniranje od spolnosti, budući da se u njoj se probudila nekakva nejasna, subliminalna (podsvjesna) želja da bude vjerna supruga. Međutim, njezina prvobitna spolna apstinencija ne odgovara želji za nekim podsvjesnim idealom muškarca: ona je prije odraz vrijednosti usvojenih u strogom građanskom odgoju koji izvire iz moralnih zasada građanskog sloja. Kad bi došla u poziciju da ostvari vezu s jednim muškarcem, u njoj se ponovo pojavila žudnja za uvijek novim ciljevima. Ovaj oprečno (a time i rodno hibridno) koncipiran ženski lik poprima obilježja neprestane potrage za novim vezama i na narativnoj razini odgovara muški konotiranom konceptu „,becoming“ (engl.), ${ }^{461}$ odnosno konceptu neprestane i nemirne težnje za uvijek novim ciljevima koja u ovom slučaju rezultira u promiskuitetu. Pobuna protiv zauzdavanja spolnosti poprimila je oblik prvobitnih i ,divljih“ nagona njezine prirode. U želji da ostvari svoju žudnju, ona je željela ,uživati u muškoj ljepoti i muškoj snazi, tamo gdje se ona nudi. ${ }^{\text {‘462 }}$

U Schnitzlerovim se djelima inače seksualnost emancipira od vladajućeg društvenog morala, tako da ljubav postaje slobodnom, lišenom društvenih stega. ${ }^{463}$ Dakle, spolnost u ovome djelu postaje neovisna kako o instituciji braka, tako i o konceptu trajne ljubavi. Ženski lik u djelu demonstrira oblik disperzne žudnje koja nije usmjerena prema jednom objektu: ako se ona postavi kao transcendentalni označitelj u Lacanovskom smislu, dakle, u poziciju koja je nekoć bila namijenjena isključivo muškarcima, onda ne postoji označeno (muškarac) koje bi odgovaralo tom transcendentalnom označitelju: žudnja žene postaje disperznom, budući da konstantno divergira prema novim objektima. S obzirom na to da ne može niti u jednom

\footnotetext{
459 (...)“Lücken, welche sie im Erzählen ließ, habe ich unbewußt im Bedenken, im Erinnern ausgefüllt‘, Die Braut, str. 93.

${ }^{460}$ Usp. također Freud: Das Unbehagen in der Kultur, 1994.

${ }^{461}$ Vidi Nünning/Nünning: Erzähltextanalyse und Gender Studies, 2004, str. 86.

462 „wollte sie sich freimütig den ursprünglichen und wilden Trieben ihrer Natur, wollte sich jedem hinschleudern, der ihr gefiel...Männerschönheit und Männerstärke genießen, wo sie sich bot", die Braut, str. 93.

${ }^{463}$ Vidi Janz/Laermann 1977, str. 73.
} 
muškarcu pronaći subjekt vrijedan divljenja, njezina će žudnja, prema Lacanu, uvijek biti usmjerena prema novim ciljevima. ${ }^{464}$ Pojam fluidnog jastva (,das unrettbare Ich $^{\circ}$ ) $\mathrm{u}$ potpunosti je izražen u njezinom karakteru, što upućuje na koncepciju hibridnog roda budući da ovaj ženski lik odstupa od onodobne normativne ženskosti: želju za uzdržavanjem od spolnosti, odnosno seksualnu askezu u želji da pripada samo jednom muškarcu, na narativnoj razini ciklički zamjenjuje želja za slobodnom ljubavlju, lišenom bračne vjernosti. Na taj način i tijek radnje u ovoj pripovijetci biva obilježen diskontinuiranom i cikličkom spolnom žudnjom žene, budući da njezini spontani nagoni usmjeravaju tijek radnje, a ne nekakvi normativni koncepti. Njezina je pobuna protiv zauzdavanja spolnosti brakom izražena kroz nesvjesni otpor muškom egu (i egu njezinog zaručnika), što se može povezati sa cjelokupnim društvenim kontekstom razdoblja bečke moderne i ženskim odgovorom, odnosno protestom na njihov inferiorni položaj u društvu. Kod ovog ženskog lika vidljiv je također čisto psihološki element neurastenije (jednog oblika anksioznosti) koja vodi u nimfomaniju a na razini naracije i konteksta naracije zapravo predstavlja želju da se muška hegemonija (hijerarhijski odnosi muškarac-žena koji su bili nametnuti rodnom bipolarizacijom) nadomjesti podsvjesnom pobunom protiv zauzdavanja ženske spolnosti. Tako jedna vrsta autodestruktivnog i hedonističkog predavanja spolnim užicima u Die Braut simbolizira podsvjesnu želju žene za (performativnim) uspostavljanjem vlastite žudnje, za re-etabliranjem same sebe kao transcendentalnog označitelja.

U ženinom je životu razdoblje stabilizacije žudnje nastupilo samo nakratko, kad se sa 17 godina zaručila: ,sad je došlo u njezinom životu jedno kratko razdoblje, o kojem se izjasnila gotovo sentimentalno. Tu sam našao ono čudnovato mjesto u njezinu srcu, koje se može otkriti i kod najizopačenijih osoba- nostalgičnu čežnju za nevinošću. Jer i za one bez domovine postoji čežnja za domom, i možda ju baš oni osjećaju najbolnije od svih“، 465

Pripovijedanje dobiva svoj zaokret kroz spontani obrat u razmišljanju ženskog lika (subliminalno uvjetovan): „Ali sada se dogodilo nešto neobično. Počela je iskreno voljeti svoga zaručnika, koji joj je isprva bio samo sredstvo za postizanje svrhe...kako se može objasniti to što se odjednom počela sramiti svojih prijašnjih namjera- tako snažno i bolno, kao što se niti jedna stvarna grešnica ne bi sramila svoje prošlosti- da se pokajala za ono otprije? Htjela mu je biti istinska supruga, vjerna i odana. Postala je mirnija. Njezini su osjećaji

\footnotetext{
${ }^{464}$ Usp. također Lacan: Écrits, str. 290.

465 „Mit siebzehn Jahren verlobte sie sich, und nun kam in ihrem Leben eine kurze Zeit, über die sie sich in fast sentimentalen Worten ausließ. Da fand ich jene merkwürdige Stelle in ihrem Herzen, die man auch in den Verworfensten entdeckt- das Heimweh nach der Unschuld. Denn es gibt ja auch ein Heimweh für die Heimatlosen, und vielleicht empfinden die es am schmerzlichsten von allen“, Die Braut, str. 93.
} 
poprimili neobičan dašak mira i čednosti, i duboko ga je voljela. Nekoliko mjeseci (,ili se radilo samo o tjednima, ne mogu se više sjetiti“- treba napomenuti da su ovo pripovjedačeve riječi $)^{466}$ potrajalo je ovo stanje. ${ }^{467}$ Ova iznenadna promjena u percepciji zaručnice spontana je i subliminalna (podsvjesna), budući da se zaručnica rukovodi isključivo svojim nagonskim strukturama ličnosti (Trieb). Kako se dan vjenčanja približavao, u njoj se opet spontano probudila želja za pobunom: pripovjedač implicitno aludira na poseban razlog te pobune (koji je vjerojatno potaknut nesvjesnim otporom bračnoj zajednici). No pripovjedač ostavlja prostora i za objašnjenje takvih njezinih postupaka poimajući ih kao konstitutivne dijelove njezine individualne psihe, odnosno manifestacije njezinog temperamenta (ćudi), ne svodeći taj temperament isključivo na oznaku ženske konstitucije (stanja). Međutim, ostaje nejasnim aludira li ovdje pripovjedač na psihoanalitički obilježen pojam, „ženske“ histerije kao oznaku ženske konstitucije ${ }^{468}$, budući da se o prijelomu stoljeća ženska psiha shodno rodnim stereotipima poimala kao zagonetna Drugost, kao fluidna i promjenjiva i kao dio prirode, suprotne muški konotiranoj kulturi i civilizaciji. Ponovni zaokret u radnji pripovijetke prati kontradiktoran ženin duševni život (izmjenu spolne žudnje i čednosti) i vraća ženski subjekt na njegovo prvobitno stanje: „Spopalo ju je na užasan način. Deset je puta razmišljala o tomene, neće se predati svome zaručniku- već će ga uzeti, povući sa sobom u mračnu sobu pored salona...ali okolnosti to nisu dopuštale, nije nikada ostajala sama s njim“. U ovoj je sekvenci radnje uočljivo kako građanske konvencije ponašanja sprječavaju ženu u provođenju njezinog nagona, dok ona na agresivan način želi prekršiti te konvencije, odupirući se time stereotipnoj koncepciji ženske čednosti i uzdržljivosti.

„Možda ju je, kad bi se ukazala prilika, i hrabrost napuštala, i uskoro je opet počela primjećivati, kako je njezin žar poprimio sveopće crte, i kako on više nije bio onaj kojeg je voljela. Da, željela je njega- naravno-ali i onoga drugoga-i opet nekoga drugoga-i onoga- i sve njih. Osjećala je da je neopozivo bilo gotovo sa njenim jednim, jedinim muškarcem, ah, općenito sa njenom ljubavlju. Opet se pojavio nagon, divlji, žedni nagon, koji je želio muškarca, jednostavno muškarca, ne njega, jednoga!“ No nešto je ipak ostalo od njezine duboke naklonosti: ona je bila nešto dužna muškarcu koji joj je pružio osjećaj nečega

\footnotetext{
${ }^{466}$ Ubačena perspektiva homodijegetičkog pripovjedača, koja ukazuje na to da je cijeli ispripovijedani događaj rekonstrukcija njegovog razgovora s ženom.

467 „Nun aber geschah etwas Seltsames. Sie begann den Bräutigam, der ihr anfangs nur Mittel zum Zwecke bedeutet hatte, ernstlich zu lieben... (...) denn wie anders war es zu erklären, daß sie sich plötzlich ihrer früheren Vorsätze zu schämen anfing- so heftig und schmerzlich, wie vielleicht keine Sünderin der Tat sich der Vergangenheit zu schämen vermag-, daß sie bereute? Sie wollte ihm eine brave Gattin werden, treu und ergeben. Sie wurde ruhiger. Ihre Empfindungen bekamen einen eigentümlichen Hauch von Frieden und Keuschheit, und sie liebte ihn tief. Ein paar Monate, oder waren es nur Wochen...dauerte dieser Zustand an“, Die Braut, str. 93. ${ }^{468}$ Vidi Pohle 1998, str. 26.
} 
beskrajno uzvišenog, muškarcu koji ju je na neko vrijeme izvukao iz umrtvljenosti grozničave žudnje i uzdignuo do lijepe i nepomućene vedrine ljubavi, ovome je muškarcu ona bila nešto dužna. Istinu!...Morala mu se razotkriti, jer je znala kako će sve to završiti. Stoga ga je željela poštedjeti sramote i žalosti. Nije bila stvorena za pristojnu ženu, ali isto tako nije željela postati njegova, jer bi ga možda već nakon prve noći morala prevariti- i on bi ju tada... sljedećeg dana već otjerao. Pomisao da će joj on ipak biti dovoljan na kraju, da bi, ako ga bude imala za muža, njezino ludilo moglo biti ublaženo, utaženo, ta joj se pomisao sada činila kao djetinjasto sjećanje. “469 $\mathrm{U}$ ovome odlomku naracija prati ambivalenciju i oscilaciju žene u percipiranju vlastite psihe, ali i njezinu spoznaju o ,pravoj“ naravi njezine spolne žudnje: spoznaju da nije stvorena za to da prihvati normalan bračni život zbog preintenzivnog spolnog nagona, koji je tradicionalno bio konotiran kao obrazac muškog (agresivnog) ponašanja, dok se ženama pripisivala pasivna uloga. Zbog želje za ostvarenjem vlastite žudnje, ženski lik ne želi pristati na pasivnu, rodno-stereotipnu poziciju supruge i kućanice, opirući se na taj način rodnim ulogama žena o prijelomu stoljeća. U njezinom se ponašanju pojavljuju ranije spomenute naznake hedonizma, histerije i nimfomanije, budući da ona sve više osjeća „bolnu, neutaženu, neobuzdanu čežnju za muškarcem“, koju naracija afirmira kao neku vrstu ženskog „samoostvarenja“, potaknutu sve većom rodnom dehijerarhizacijom društva.

Nakon što zaručnica priznaje svoju žudnju svom zaručniku, ,gorljive želje svoje netom probuđene mladosti, kratko vrijeme svoje spokojnosti i sreće i konačno, nestanak toga sna““470, on, shodno rodnim stereotipima (odnosno, hijerarhijama), biva osupnut: „nije tako nešto očekivao od pristojne djevojke iz dobre kuće, koju je želio oženiti uz radostan pristanak njezinih roditelja“. Nadao se da će u njoj naći upravo ono što svi muškarci očekuju od svoje

\footnotetext{
469 „Es kam in einer entsetzlichen Weise über sie. Zehnmal war sie daran- nicht sich ihrem Verlobten hinzugeben- nein...ihn zu nehmen, selbst zu nehmen, mit sich zu ziehen in das dunkle Zimmer neben dem Salonoder dorthin in die Nische- oder dort...Aber die Umstände fügten es nicht, sie war nie allein mit ihm. Vielleicht auch verließ sie der Mut, wenn die Gelegenheit kam, und bald begann sie auch wieder zu merken, wie ihre Glut ins Allgemeine ging, wie er eigentlich nicht mehr der Geliebte war. Ja, sie wollte ihn- freilich- aber auch denund jenen- und jenen- und alle. Sie fühlte, daß es unabänderlich vorbei war mit ihrer einen, ach, mit ihrer Liebe überhaupt. Es war wieder Trieb geworden, wütender, durstiger Trieb, der den Mann wollte, einfach den Mann, nicht ihn, den einen! Etwas war dennoch von ihrer tiefen Neigung zurückgeblieben: sie war dem Mann, der sie unendlich Hohes hatte empfinden lassen, der sie aus der Dumpfheit fiebernden Verlangens für einige Zeit zur schönen Heiterkeit der Liebe hinaufgehoben hatte, diesem Mann war sie etwas schuldig geworden. Wahrheit!...Es wühlte in ihr, es ließ sie nicht ruhn. Sie mußte sich ihm entdecken. Sie wußte, was es für ein Ende nehmen mußte. Darum wünschte sie ihn von Schmach und Gram frei zu erhalten. Sie war nicht geschaffen zum braven Weib, aber sie wollte auch nicht das seine werden, den sie vielleicht schon nach der ersten Nacht hätte betrügen müssen- und der sie dann- das schwebte ihr wohl auch dunkel vor- am nächsten Tage davongejagt hätte. Der Gedanke, daß er ihr am Ende genügen, daß mit seinem Besitz ihr Wahnsinn gemildert, gestillt sein könnte, war ihr zu einer kindischen Erinnerung geworden, aber gestehen wollte sie's ihm, ihm sagen: Ich bin nicht geschaffen, deine brave Hausfrau zu werden, laß mich frei“, Die Braut, str. 93-94.

${ }^{470}(\ldots)$ ".da gestand sie's ihm ein. Alles. Die brennenden Wünsche ihrer kaum erwachten Jugend, die kurze Zeit ihrer stillen erwachenden Glückseligkeit und endlich das rasche Untergehen dieses Traumes“. Die Braut, str. 9495.
} 
buduće žene: „,̌udesnu, svetu, kreposnu opreku ludoj strastvenosti naših mladenačkih ljubakanja...“. ${ }^{471}$ Prema Freudovoj studiji pod naslovom Über die allgemeinste Erniedrigung des Liebeslebens, zaručnik demonstrira rascijep između nježne (njem. zärtliche) i čisto fizičke (senzualne) (njem. sinnliche) ljubavi. Budući da s jedne strane idealizira svoju zaručnicu kao aseksualno biće, a s druge strane svoje bivše ljubavnice poima isključivo kao senzualna bića, on u svojim poimanjima ženskog bića demonstrira oštro odvajanje idealizacije voljene žene i uniženja žuđene žene (žene prema kojoj se osjeća isključivo spolna žudnja). Na taj način zaručnik predstavlja pravi odraz društva koje tabuizira incest, simbolizirajući patrijarhalno društvo utemeljeno na egzogamiji, ženjenju izvan obitelji.

Problematičan odnos prema incestuoznim željama prema Freudu rezultira ovakvim oštrim odvajanjem nježne (i bračne) i čisto tjelesne (fizičke, promiskuitetne, vanbračne) ljubavi unutar modernih zapadnjačkih, patrijarhalnih društava, čije bi izmirenje omogućilo, kako normalan ljubavni i bračni odnos, tako i normalan odnos prema ženskom biću. Tabuiziranje incesta uvjetuje problematičan odnos muškarca prema svakoj ženi izvan svoje obitelji, pa tako i prema vlastitoj ženi koja se poima kao dvojnost spiritualne s jedne i čisto tjelesne, požudne ljubavi s druge strane: ondje gdje se žena previše voli i idealizira, ona ne može predstavljati objekt spolne žudnje, a tamo gdje ona predstavlja objekt spolne žudnje, ne može biti poštivana i voljena (,Wo man liebt, begehrt man nicht, und wo man begehrt, kann man nicht lieben“). ${ }^{472} \mathrm{U}$ zaručnikovom je govoru vidljiva idealizacija vlastite žene s jedne i rezerviranje spolne žudnje za svoje mladenačke ljubavi s druge strane, prema kojima se osjeća isključivo animalna žudnja (,strastvenost mladenačkih ljubakanja“). Zaručnik, čiji misaoni diskurs homodijegetički pripovjedač preuzima, također reproducira rodne stereotipe i naglašava hijerarhijsku dominaciju muškarca nad ženom, budući da shodno onodobnim antropološkim i psihološkim poimanjima biti muškog i ženskog spola, muškarac, prema stereotipima patrijarhata, može sebi dopustiti seksualne eskapade koje ne bi mogao dopustiti svojoj ženi, odnosno koje ne bi bile dolične njezinoj rodnoj ulozi žene i majke. Značajno je u ovome govoru mladoženje primijetiti kako njegovo razmišljanje (a time i razmišljanje homodijegetičkog pripovjedača) reproducira fin-de-siècle-ovsku rodnu bipolarizaciju, dakle participira u oštrom odvajanju biti muškog i ženskog spola: dok se od žene, u skladu sa dvostrukim moralom bečke moderne, očekuje moralnost (krepost) i poslušnost (u skladu sa

\footnotetext{
${ }^{471}$ Nie hatte er Ähnliches in dem braven Mädchen aus gutem Hause vermutet, das er mit der freudigen Zustimmung seiner Eltern zur Frau nehmen wollte und in dem er wahrscheinlich auch das zu finden hoffte, was wir ja alle von unserem künftigen Weibe erwarten: den wundersamen, heiligen, tugendhaften Kontrast zu der tollen Leidenschaftilchkeit unserer Jugendliebeleien...", Die Braut, str. 95.

${ }^{472}$ Usp. Freudovu studiju pod naslovom Über die allgemeinste Erniedrigung des Liebeslebens.
} 
koncepcijom vječne ženskosti, žene kao Kindfrau i femme fragile, pojmova koji predstavljaju književne i umjetničke tipologije ženskosti), muškarac si može dopustiti i „mladenačka ljubakanja“, odnosno predbračne spolne odnose. ${ }^{473}$ Standardnom patetično-licemjernom ljubavnom retorikom zaručnik pokušava uvjeriti svoju zaručnicu u iskrenost svoje ljubavi, govoreći joj da ona „umanjuje vrijednost jedne prirodne i načelno lijepe žudnje“"474 (spolne žudnje) i da tu žudnju „obeščašćuje jer je se srami zbog svojeg ponosnog djevičanstva“ (zaručnik misli da zaručnicu brinu moralni obziri, principijelno spolno ponašanje prije braka), dok pripovjedač istovremeno, izravnim prikazom zaručnikovih riječi, također participira u njegovom stavu.

Pripovjedač sada stavlja naglasak na ženski subjekt: zaručnica se na zaručnika obrušava sve žešćim riječima deziluzironirane žene i želi, shodno svom nezadovoljstvu monotonom malograđanskom svakodnevicom i normativnim konceptima „normalnosti“ „nestati iz kruga svojih ukućana, želi „dalje od svih ovih ljudi, koji su tako mirni i zadovoljni i zdravi i kojima ona ne pripada, dalje odavde, želi kličući ući u život neobuzdane strasti, za koji je stvorena, u koji mora krenuti, ako ne misli poludjeti, ako ne misli propasti“ ${ }^{475}$ Pojam obiteljske (roditeljske) kuće, iz koje su mlade djevojke nerijetko izravno prelazile u bračni život, ovdje biva doveden u pitanje: zaručnica pokazuje anti-stereotipno žensko ponašanje budući da (pod psihološkom prisilom svoje deziluzioniranosti navaljivanjem zaručnika, ali i svog muški konotiranog spolnog nagona) negira sigurnost, statičnost i zaštićenost obiteljskog doma (privatna sfera koja je bila namijenjena ženama), odnosno, opire se domestifikaciji kao „tamnici nepremostivih konvencija“4776 i želi ,pobjeći na ulicu“, što na kraju i čini, ponudivši se prvom prolazniku koji joj se svidio.

Nagli izlazak žene na ulicu kod Schnitzlerovog pripovjedača revaloriziran je kao „samorazumljivi““ pokušaj ženske afirmacije, kao pokušaj ženskog subjekta da potvrdi svoju žudnju. Kroz gotovo cijelu pripovijetku, ovaj proces ženskog poniranja u vlastiti unutarnji svijet nagona i unutarnji konflikti koji ga prate odražavaju subjektivno koncipiranje

\footnotetext{
${ }^{473}$ Vidi prikaz fin-de-siècleovske koncepcije rodnih odnosa i stereotipa kod Richarda Krafft-Ebinga u knjizi pod naslovom Psychopathia Sexualis, uvodni dio, a također i u članku Horsta Thoméa pod naslovom Arthur Schnitzlers Reigen und die Sexualanthropologie der Jahrhundertwende, u kojem Thomé ističe Schnitzlerovu ironičnu kritiku rodnih postavki onodobne seksologije i antropologije.

${ }^{474} \mathrm{Daß}$ sie ein natürliches und im Grunde schönes Verlangen heruntersetze und entweihe, weil sie sich in ihrer stolzen Jungfräulichkeit desselben schäme“, Die Braut, str. 95.

475 ..."mit einem Male verschwunden aus dem Kreise der Ihren, weg von allen diesen Menschen, die ruhig und zufrieden und gesund waren und zu denen sie nicht gehörte, fort von hier und toll hinausgejubelt in ein Leben ungezügelter Lust, für das sie nun einmal bestimmt war, in das sie hineinmußte, wenn sie nicht verrückt werden, wenn sie nicht zugrunde gehen sollte“, Die Braut, str. 95.

${ }^{476}$ Vidi Nünning/Nünning 2004, str. 53.
} 
vremena. ${ }^{477}$ Budući da se ovaj dinamično, oprečno, višedimenzionalno i otvoreno koncipiran ženski lik opire strogoj definiciji na muškost i ženskost, on je tipičan primjer hibridizacije roda zbog: 1. svoje ambivalencije između početnog stanja seksualne askeze i krajnjeg stanja promiskuitetne žene prezrene od društva, odnosno svoje ambivalencije između stereotipne ženske podložnosti muškarcu i želje za uspostavljanjem autonomije vlastite ličnosti, za kreiranjem vlastite žudnje koja se odvaja od rodno-stereotipnog poimanja žene; i 2. fluidnog jastva, odnosno nestabilnosti karaktera, jastva koje se opire bilo kakvoj fiksnoj definiciji i ontološkom utemeljenju identiteta. Pripovjedna nit prikazuje ženinu ambivalentnu poziciju (hibridizaciju njezine psihe) između spolne uzdržljivosti koja se odražava u strpljivosti da pronađe muškarca kojeg bi istinski voljela i kojem bi bila odana, dakle, tipično ženski konotirane pozicije, i, s druge strane, njezinog spolnog nagona (Trieb), dakle tipično muški konotirane pozicije, koja predstavlja njezinu pobunu protiv spolnog uzdržavanja (zauzdavanja nagona).

Burna ženina ispovijest ne ostavlja zaručnika ravnodušnim: ona mu se čini još privlačnijom, čime on demonstrira onodobno muško stereotipno poimanje žene kao čisto senzualnog bića. ${ }^{478}$ Zaokret u pripovijetci sada čini pripovjedačevo direktno navođenje zaručnikovih riječi, prikazanih u 1. licu jednine. Pripovjedač zaručnikove riječi prenosi direktnije nego riječi zaručnice (koje prenosi u 3. licu jednine), čime se može iščitati određena identifikacija homodijegetičkog pripovjedača sa onodobnom stereotipnom muškom pozicijom. Uvjeravajući ju da niti ona ne može sama sebe razumjeti, zaručnikov ton glasa poprima bolećivi, drhtavi ton (spolne) žudnje, dok ona njegov ton radikalno počinje percipirati kao drzak i brutalan. Zaručnikovo uvjeravanje kako ona prvo treba pripadati njemu, koji ju „obožava“ a onda svima drugima koji ju žele, te njegovo spominjanje fraze „dobra kućanica“ može se percipirati kao odraz tipične mizogine muškosti onoga vremena, t.j. kao odraz želje za eksploatacijom žene (kao senzualnog), a zatim idealizacijom žene kao pasivnog bića putem stereotipnog odvajanja njezine erotske poželjnosti s jedne (stereotipna slika žene kao bliske prirodi, kao animalnog i iracionalnog bića) i njezine idealizacije od strane muškarca s druge strane. Deziluzionirana stereotipnom muškošću svoga zaručnika, zaručnica ga napušta, ponudivši se prvom prolazniku na ulici, no shodno patrijarhalnom ustrojstvu društva i muški kodiranom predatorstvu prolaznika, doživljava još brutalniji odnos nepoznatog muškarca

\footnotetext{
${ }^{477}$ Vidi četiri dimenzije proživljenog vremena u knjizi Erzähltextanalyse und Gender studies, (str. 74.) vidi također Middeke, Martin: Zur Poetologie gelebter Zeit im spätviktorianischen Roman (2002), u: Middeke, Martin (Hg.): Zeit und Roman. Zeiterfahrung im historischen Wandel und ästhetischer Paradigmenwechsel vom sechzehnten Jahrhundert bis zur Postmoderne. Würzburg: Königshausen \& Neumann 2002.

478 Usporedi s onodobnom analizom ženskosti u knjizi Otta Weiningera pod naslovom Geschlecht und Charakter, str.182-185., str. 232 i str. 385.
} 
prema njoj: ,još iste te noći lutala je sparnim gradskim ulicama, iste te noći ponudila se nekome neznancu na ulici, koji je baš šetao ispred nje i čiji je hod bio lagodan i bezbrižan i kojeg nikad prije nije vidjela. On ju je uzeo i onda ju je otjerao, i to je bio njezin prvi ljubavnik!““. ${ }^{479}$ Iako iz konteksta proizlazi da je žena subjekt pripovijetke (ženska pripovijest u fokusu), iz naracije itekako proizlazi da je žena objekt: instanca pripovjedača stereotipno narativno izvještava o ženinom promiskuitetu. Izrazi poput „ponudila se“, „on ju je uzeo i onda ju otjerao“, „bila je napuštena“ zapravo kreiraju ženu kao objekt pripovijetke i objekt muške spolne žudnje u kojoj participira i sam pripovjedač. Činjenica da je pripovjedač i sam na kraju prolazno konzumirao ljubav s neimenovanom mladom ženom svjedoči o njegovom participiranju u mizoginoj eksploataciji žene, pri čemu se podudaraju eksploatacija ženskog tijela i svojevrsna eksploatacija ženske pripovijesti. Nakon ženine intimne ispovijesti, ispričane od strane pripovjedača s naglaskom na personalnu perspektivu (prikaz ženinih misli kroz unutarnju fokalizaciju), fokus se ponovo sa žene vraća na lik homodijegetičkog pripovjedača i na njegovo razmišljanje o ženi u 1. licu jednine: „Postao sam znatiželjan i želio sam saznati više. Tko je on bio, je li ga voljela, je li plakala za njim, što je osjećala, kad ju je uzeo, i kako joj je bilo, kad je prvi put bila ostavljena. No onda me ona začuđeno pogledala. I onda je, kao da se radi o nečem posve samorazumljivom, jednim odlučnim tonom, koji mi još odzvanja u uhu, rekla: „Pa to je potpuno nevažno.““،480

Iako homodijegetički pripovjedač ima određenu aspiraciju za afirmacijom individualnosti pojedinca, njegov je krajnji kulturno-pesimistički zaključak da spolni nagon briše svu ljudsku individualnost, budući da se i muškarac i žena u spolnom činu svode isključivo na (nagonsku) muškost i (nagonsku) ženskost. Iako homodijegetička instanca pripovjedača počinje svoju implicitnu kritiku stereotipne muškosti u 1. licu množine (te tako predstavlja kolektivno „,mi“, odnosno izriče kolektivnu krivnju koja proizlazi iz kolektivne podsvijesti), ona ipak implicitno reproducira rodne stereotipe naglašavajući hegemoniju muškog nad ženskim spolom: „mi, sa cjelokupnom uzvišenošću našega jastva“, „sa svim našim vlastitim, najposebnijim osobinama, sa našim duhom i našom ljepotom, sa svim vrlinama i svim

\footnotetext{
479 „Und noch in derselben Nacht verließ sie das Haus ihrer Eltern, in derselben Nacht irrte sie durch die schwülen Straßen der Stadt, in derselben Nacht noch trug sie sich irgendeinem auf der Straße an, der eben vor ihr her spazierte und dessen Gang leicht und vergnügt war und den sie früher nie gesehen hatte. Und der nahm sie und jagte sie wieder fort, und das war ihr erster Liebhaber!“, Die Braut, str. 96.

480 „Ich war neugierig geworden und wollte mehr wissen. Wer er war, ob sie ihn geliebt, ob sie ihm nachgeweint, was sie empfunden, als er sie nahm, und wie ihr war, als sie das erste Mal verlassen wurde. Da aber sah sie mich mit großen Augen an. Und dann, als wäre das etwas ganz Selbstverständliches, in einem Tone der Bestimmtheit, der mir jetzt noch im Ohr klingt, sagte sie:, Das ist ja vollkommen gleichgültig'.“, Die Braut, str. 96.
} 
manama, s kojima smo ih pridobili...““81. Ističući ,individualnost““ i autonomnost muškaraca pomoću koje su pridobili svoje žene, „veličanstvenost njihovog jastva“, on istodobno potkopava tu veličanstvenost sintagmom ,naša nevažna osobnost““. Iako iz naracije proizlazi da se radi o pripovjedačevoj spoznaji ženske percepcije o samodostatnosti, ipak se implicitno kroz ovu sintagmu provlači i pripovjedačeva određena kritička distanca spram rodnih stereotipa. Međutim, on itekako povlađuje Weiningerovoj koncepciji hijerarhijske nadmoćnosti muškoga spola, budući da, za razliku od žene kao čisto senzualnog bića, isključivo muškarci, prema njegovom mišljenju, posjeduju duh (njem. Geist), racio i transcendentalno jastvo. Pripovjedač naglašava ono nagonsko u čovjeku (spolnu žudnju, uvjetovanu strogom društveno konstruiranom rodnom diferencijacijom) kao neizbježnu, ali i difamirajuću bit odnosa muškarca i žene. Homodijegetički pripovjedač, komentirajući položaj žene u društvu kao „die Verworfene ${ }^{6482}$, povezuje ovaj položaj sa strogom rodnom bipolarizacijom društva u kojoj participira i društveno diferenciran spolni nagon. $\mathrm{Na}$ transpsihološki način, preuzimanjem kolektivnog identiteta, pripovjedač se kritički distancira od svoje rodne pozicije i na neki način afirmira žensku samodostatnost:

zar nismo (muškarci) upravo u trenutku njihove (žene) najveličanstvenije ekstaze, mi, sa svim našim najposebnijim osobinama, sa našim duhom i našom ljepotom, sa svim našim vrlinama i svim manama, $s$ kojima smo ih pridobili, postali tako neopisivo suvišni, nasuprot onom vječnom principu, koji se nužno pojavljuje pod krinkom individue, kako bi mogao zavladati: jer samo kratki i nesvjesni trenutak, u kojem priroda zna provesti svoju svrhu, treba muškarca i ženu. Pa iako tako domišljato obasjamo ono prije i ono poslije tog trenutka tisućama svjetala naše individualnosti- ona se ipak ugase, kad nas obuzme mukla noć ispunjenja. ${ }^{483}$

Pripovjedač u prvom licu množine izražava svoju kulturno-pesimističku duboku intuitivnu spoznaju o nemogućnosti ostvarenja (ženskih) individualnih potencijala i autonomnosti u jednom strogo bipolariziranom društvu: svojevrsnu nemogućnost da se snaga ženske psihe odupre rodnim podjelama, koje uvjetuju odnose muškarac-žena. Govoreći o nemogućnosti potpunog ostvarenja androgine samodostatnosti i vladavini odnosa moći (njem. Machtgefälle) u falogocentričkom društvu (i pojedincu, muškarcu i ženi kao dijelu tog društva), homodijegetički pripovjedač rekapitulira i reproducira moć rodne bipolarizacije. Pripovjedač spominje zaboravljanje vlastite individualnosti (gubitak vlastitog identiteta) koji se događa u erotskom sjedinjenju sa drugim bićem, gdje vlada isključivo zakon spolne žudnje i rodne

\footnotetext{
${ }^{481}$ „wir, mit der ganzen Majestät unseres Ich“, „mit allen unsern höchst eigenen Eigenschaften, mit unserem Geist und unserer Schönheit, mit all den Tugenden und all den Lastern, womit wir sie gewannen,...", Arthur Schnitzler, Die Braut, str. 97.

${ }^{482}$ Onodobni stereotipni koncept ženskosti, koji u prijevodu znači „od društva odbačena, prezrena žena“, Die Braut, str. 97.

${ }^{483}$ Die Braut, str. 96-97.
} 
podjele. Usprkos snazi ljudskih individualnih karakteristika, koje se u ovoj pripovijetci razmatraju u svjetlu metafizičke samodostatnosti (ženske) psihe, ipak „noć ispunjenja“ (u kojoj se najbolje uočava podjela na muškost i ženskost) odnosi (ironičnu) prevagu nad tim karakteristikama. Iako homodijegetički pripovjedač na razini semantike rodne jednakosti izriče svoj afirmativan odnos prema ženskoj žudnji, i ženskom pokušaju odvajanja od falogokracije: ,zar nismo svi već tisuće puta, od žena koje smo istinski voljeli, grozničavo i u nijemom očaju doživjeli da smo za njih postali ništavni u trenutku ispunjenja... “. ${ }^{484}$, on isto tako naglašava svoj stav da je ljubav između spolova prvenstveno odraz muško-ženske privlačnosti, odnosno rodne podjele (bipolarizacije), bez uplitanja karaktera: ,...mi, sa cijelom uzvišenošću našega Ja, i kako je naša uzgredna osobnost samo još više označavala premoćni zakon, za čije smo slučajne predstavnike bili određeni““. ${ }^{485}$ Premoćni zakon ovdje označava afinitet, odnosno erotsku privlačnost između spolova, koja je za Schnitzlerove suvremenike trebala biti odraz stroge polarizacije muškog i ženskog spola: kroz tu se misao provlači misao o kontingentnosti, artificijelnosti, društvenoj iskonstruiranosti ali na kraju ipak neiskorjenjivosti rodne podjele. ${ }^{486}$

\subsubsection{Implicitni rod}

Schnitzlerov homodijegetički pripovjedač započinje pripovijetku više u stilu autorskog pripovjedača (autorska pripovjedna perspektiva) koji ima „kontrolu“ nad i distancu od ženskog lika, budući da je njegovo referiranje o njihovom susretu prikazano u obliku izvještaja, da bi, u trenutku kad počinje u cijelosti pripovijedati ženinu pripovijest $u$ slobodnom neupravnom govoru (riječima „Sie war aus einer guten Familie...") postepeno sve više, uživljavajući se u njezinu psihu, prešao u personalnu perspektivu, u kojoj se distanca pripovjedača prema liku smanjuje na minimum. Pripovjedačev narativni prikaz ženine pripovijesti ispresijecan je povremenim komentarima pripovjedača (npr.: „,sie schilderte mir die Stimmung jenes Abends" ${ }^{487}$ i njegovim auto-refleksivnim stavovima (,was wir ja alle von unserem künftigen Weibe erwarten“) ${ }^{488}$. Pripovjedač minuciozno i jezgrovito rekonstruira i reproducira ženinu ispovijest. Homodijegetički pripovjedač zatim u slobodnom neupravnom

\footnotetext{
${ }^{484}$ „denn haben wir's nicht alle an den Frauen, von denen wir wahrhaftig geliebt wurden, schaudernd und in stummer Verzweiflung hundertmal erlebt, wie wir im Moment der Erfüllung für sie verlorengingen...", Die Braut, str. 96-97.

${ }^{485}$ „wir, mit der ganzen Majestät unseres Ich, und wie unsere gleichgültige Persönlichkeit nur mehr das allmächtige Gesetz bedeutete, zu dessen zufälligen Vertretern wir bestellt waren.“, Die Braut, str. 97.

${ }^{486}$ v. Opreku Essentialismus/Konstruktivismus, u: Metzler Lexikon: Gender-Studies/Geschlechterforschung, 2002.

${ }^{487}$ Die Braut, str. 94.

${ }^{488}$ Ibid., str. 95.
} 
govoru (Erlebte Rede) započinje fokusirati zaručnikovu perspektivu (,Wie er, der Bräutigam, sie so reden hörte" $)^{489}$. Govor ženinog zaručnika predstavljen je kroz još manju distancu lika pripovjedača od lika zaručnika nego što je to bio slučaj sa ženskim likom (što naznačuje pripovjedačevu identifikaciju sa onodobnom stereotipnom muškom pozicijom): uvjeravanje zaručnika predstavljeno je najprije u indirektnom govoru i konjunktivu (,sie mißverstehe sich selbst, und er verzeihe ihr alles...“). ${ }^{490}$, potom se taj oblik prikaza postepeno transformira u pripovjedačevo preuzimanje zaručnikovog brutalnog glasa (direktno navođenje zaručnikovih riječi) u 1. licu jednine: „wenn es schon sein muß...“. ${ }^{491}$ Pripovjedač potom ponovo fokusira reakciju zaručnice: „Ihr aber war dieser Mann...“. ${ }^{492}$, da bi nakon toga započeo svoj autorefleksivni komentar u 1. licu jednine (,Sie schwieg, nachdem sie mir das gesagt“) i u kolektivnom 1. licu množine („denn haben wir's nicht alle..."). ${ }^{493}$ Približavanje ženskom i muškom liku u Die Braut neposrednije je nego u pripovijetci Die Fremde prvenstveno zbog uključenosti samog pripovjedača u priču (on je ujedno i jedan od likova pripovijetke, čime se pripovjedna distanca smanjuje. Pripovjedač s različitim stupnjem distance fokusira misli zaručnika (u indirektnom govoru i direktnom govoru) i zaručnice (neposrednije, uglavnom u slobodnom neupravnom govoru, a samo na 2 mjesta u direktnom govoru), što svjedoči o njegovoj rodno-stereotipnoj većoj identifikaciji sa zaručnikovim diskursom. Na početku i na kraju pripovijetke pojavljuje se i „monolog“ homodijegetske instance pripovjedača: „pronašao sam ono čudnovato mjesto u njenom srcu, koje se može otkriti i kod najopakijih žena... “494; koji semantički još više naglašava pripovjedačevo stereotipno zauzimanje onodobne muške pozicije (koja žensko biće poima kao puki umjetnički objekt), o čemu svjedoči i njegovo monološko preuzimanje (muškog) kolektivnog identiteta: „u kojoj se nadao da će pronaći ono što svi mi očekujemo od svoje buduće žene...“”; „nismo li svi mi od žena koje su nas uistinu voljele.. stotinu puta doživjeli...“. ${ }^{495}$ U govoru homodijegetičkog pripovjedača prisutno je onodobno muški kodirano stereotipiziranje žene i dihotomizirajuće poimanje žene na tradicionalan tipološki način (djevica naspram bludnica), kao i isticanje hegemonije muškog spola nad ženskim (,transcendentalno jastvo“ muškarca u

\footnotetext{
${ }^{489}$ Die Braut, str. 217.

490 Ibid.

${ }^{491}$ Ibid.

${ }^{492}$ Ibid., str. 218.

${ }^{493}$ Ibid., str. 218 . i str. 219.

494 Ibid., str. 214.

495 „,...da fand ich jene merkwürdige Stelle in ihrem Herzen, die man auch in den Verworfensten entdeckt...", Die Braut 2015, str. 93.; ,und in dem er wahrscheinlich auch das zu finden hoffte, was wir ja alle von unserem künftigen Weibe erwarten...“, Die Braut 2015, str. 95.; „,denn haben wir's nicht alle an den Frauen, von denen wir wahrhaftig geliebt wurden...hundertmal erlebt", Die Braut, str. 96.
} 
Weiningerovskom smislu). Punktualno upotrijebljen slobodni neupravni govor (naročito u prikazu ženske pripovijesti kroz približavanje personalnoj perspektivi), koji služi kao poveznica između pripovjedne instance i ženskog lika kao fokalizacijske instance, prema teoretičarki Kathy Mezei, može se shvatiti kao hijerarhijski odnos, kao odnos moći muškog nad ženskim spolom. ${ }^{496}$ Međutim, dok se kod običnog izvještavanja, a naročito u monologu pripovjedača (njem. Ich-Erzählsituation), osjeća da je autoritet u pripovijetci na strani pripovjedača, kod slobodnog neupravnog govora sve se više smanjuje kontrola pripovjedača, te se čitatelju neposrednije predočavaju procesi unutar svijesti književnog lika. Budući da između udjela pripovjedača i udjela lika postoje varijabilni odnosi dominacije, Mezei polazi od teze da se kod interakcije govora pripovjedača i govora lika u slobodnom neupravnom govoru (njem. Erlebte Rede) događa borba za autoritet, „,borba između muške moći i ženske žudnje“497, fiksnog roda i fluidnog (hibridnog) roda. Slobodni neupravni govor izraz je borbe lika za slobodu od kontrole pripovjedača: budući da kod slobodnog neupravnog govora više nije moguće strogo razlikovanje između glasa pripovjedača i glasa lika, prema Kathy Mezei ovaj oblik prikazivanja svijesti predstavlja idealno sredstvo književnog insceniranja fluktuirajućih (hibridnih) rodnih koncepcija: kad muški autor u svome fokusu ima ženski lik, kontradiktorna aktivnost zauzimanja rodnih pozicija $\mathrm{s}$ jedne i zamućivanja rodnih uloga $\mathrm{s}$ druge strane odražava neku vrstu imaginarne borbe između pripovjedača i fokalizacijske instance.

Ženska je pripovijest prikazana kroz Zeitraffendes Erzählen (njem.), dakle strogo sumarno pripovijedanje i (psiho)analitički pristup, bez upliva dubljih emocija, u skladu s podnaslovom pripovijetke Studie, no ipak uz korištenje manje pripovjedne distance nego u Schnitzlerovoj pripovijetci Die Fremde, u kojoj je kroz cijelu naraciju prisutno pripovijedanje u slobodnom neupravnom govoru (koristeći 3. lice jednine i preterit kao glagolsko vrijeme) i time je postavljena minimalna narativna distanca pripovjedača od lika o kojem se pripovijeda od distance homodijegetičkog pripovjedača od lika žene u djelu Die Braut.

Prema analizi rodne simbolike prostora u knjizi pod naslovom Erzähltextanalyse und Gender Studies (Nünning/Nünning 2004), pojam domovine predstavlja pred-edipalne fantazije želje, zaštićenost, sigurnost, osiguranje identiteta a napose obitelj (bračni život) kao izvor stabilnosti i utočišta za ženski subjekt. Domovina i u kontekstu ove pripovijetke predstavlja zaštićenost žene unutar okvira građanske obitelji i građanskog braka. Tuđina (ovdje simbolički izjednačena sa promiskuitetom i životom izvan obitelji), nasuprot tome,

\footnotetext{
496 Vidi Nünning/Nünning 2004, str. 172-173.

497 Ibid.
} 
predstavlja neku situaciju van uobičajenog (simboličkog) poretka, ona utjelovljuje ono nepredvidivo i iracionalno.

Prostor salona figurira kao javni prostor, dio muški kodirane javne sfere u kojoj je ovakvo impulzivno žensko ponašanje, shodno onodobnim obvezujućim moralnim kodeksima ženskog ponašanja, bilo zabranjeno.

U ovome dijelu pripovijetke homodijegetički pripovjedač teži za afirmacijom ženske psihe i ženske spolnosti koju na razini rodne semantike donekle poima kao ravnopravnu s muškom. $\mathrm{Na}$ implicitan način dekonstruira isključivo svođenje duševnog nemira, otpora društvu i nestabilnosti i fluidnosti karaktera žene na neku vrstu ženske histerije ili neuroze, koja je, prema Sigmundu Freudu, mogla nastati zbog a) pretjeranog spolnog uzdržavanja (potaknutog hipokrizijski usmjerenim spolnim moralom) i b) neurastenične konstitucije koja se općenito vezala uz kaotično i pluralističko moderno doba, i koja je bila posljedica individualne reakcije na nagle društvene promjene o prijelomu stoljeća.

Ulica, odnosno gradski prostor za žensko ponašanje donekle znači određeni pojam „slobode“, odnosno donekle zamjenu rodnih uloga (žena koja ide u „svijet“ gdje traži ljubavnika i time dekonstruira onodobne normativne zasade ženskog spolnog ponašanja). Ulica, odnosno velegrad u ovom kontekstu simboliziraju, osim muški konotirane javne sfere i muške hegemonije nad javnim prostorom, 1. prostor društveno zabranjenog, budući da se ženama do 20. stoljeća nije pripisivala kompetencija za javnu sferu, i 2. muški konotirano osvajanje i agresivno spolno ponašanje (njem. Eroberung, ulica kao Jagdrevier), budući da zaručnica pokazuje znakove muški konotiranog predatorstva i hedonizma (donekle zamjena muško-ženskih uloga). Ovdje je prisutna još jedna prostorna simbolika: pogled zaručnice kroz prozor (prije nego što izlazi na ulicu) predstavlja njezinu još uvijek ambivalentnu rodnu poziciju (pasivnost-aktivnost), budući da je pogled kroz prozor u rodnoj semantici prostora predstavljao „granicu između unutarnjeg i vanjskog prostora, privatne i javne sfere“, ${ }^{498} \mathrm{i}$ simbolizirao ujedno alijenaciju modernog pojedinca i teškoće pojedinca u prekoračivanju granice prema van.

Pripovjedač izražava afirmaciju semantike rodne jednakosti na površini teksta, ali itekako reproducira rodne stereotipe- iznošenjem riječi ženinog zaručnika u 1. licu jednine i vlastitim stereotipno muški konotiranim komentarima, također monološki koncipiranim- (IchErzählsituation). Njegova krajnja spoznaja glasi da je rodna bipolarizacija ipak neiskorjenjiva iz društva, a ona je najvidljivija upravo u spolnom odnosu, u kojem se briše individualnost

\footnotetext{
${ }^{498}$ Vidi Nünning/Nünning 2004, str. 53.
} 
pojedinca i ostaje samo podjela na muškost i ženskost. Prema pripovjedaču, nagon je spolno diferenciran (različit kod žena i muškaraca), ali ipak rodno neutralan i univerzalan antropološki egzistencijal, budući da ,priroda“ u spolnom činu briše sve individualne razlike, jer ih u tom trenutku ,ispunjenja“ ne treba. Iako priznaje jednakost muškog i ženskog spola pred vladavinom spolnog nagona, pripovijedanje se odvija iz stereotipno muške perspektive: prema pripovjedačevim riječima, žene izgube svijest o individualnosti koja bi bila isključivo muška karakteristika: žena je ovdje predstavljena kao isključivo prirodno biće, kao objekt (Naturwesen Frau), dok je muškarac predstavljen isključivo kao stvaralačko biće kulture, kao subjekt (Kulturwesen Mann) koji posjeduje transcendentalno jastvo koje se osporava ženama.

\subsubsection{Zaključak}

„Studija“ pod naslovom Die Braut konstatira da je rodna bipolarizacija (temeljena na koncepcijama rodnih odnosa i rodnih identiteta o prijelomu stoljeća), neiskorjenjiva. Schnitzler, koji je započeo karijeru liječnika (laringologa), ali se posebno zanimao za psihičke fenomene, istražuje skrivene, tabuizirane sfere ženske psihe, manje dostupne njegovim drugim muškim suvremenicima. Njegova je primarna intencija bila senzibilizirati suvremenike za probleme (ženske) psihe, te prikazati, u vidu književnog noviteta, jednu žensku psihu koja radikalno odstupa od onodobnih normativnih rodnih obrazaca. Schnitzler prikazuje problem ženske (spolne) žudnje i (ne)mogućnosti njenog ostvarenja u društvu koje počiva na rodnoj bipolarizaciji. Njegov homodijegetički pripovjedač, iako na površini teksta izražava određenu afirmaciju rodne jednakosti što se tiče (ženske) spolne žudnje, ipak djelomično reproducira rodne stereotipe, izražavajući stereotipno (muško) poimanje žene kao „esencijalne Drugosti“, ali i stereotipno poimanje žene u njezinim oprekama sa muškarcem: senzualnost (Naturwesen Frau) naspram spiritualnosti (Kulturwesen Mann). Iako je žena narativno konstruirana kao bludnica (Weinigerovska „Dirne“ koju vodi isključivo impuls spolnog nagona), pripovjedač ipak ne izražava svoju osudu takvog ženinog ponašanja, već na razni rodne jednakosti žene i muškarca pred premoćnosti spolne želje, nagon (Trieb) ocrtava kao neutralnu, iako diferenciranu, antropološku egzistencijalnu osnovu.

U pripovijetci je stavljen naglasak na žensku intimnu pripovijest (doduše, ispričanu kroz mušku vizuru i uz nešto veću identifikaciju pripovjedača s likom nego u djelu Die Fremde). Sam naslov pripovijetke (Die Braut, Zaručnica) ironijski potkopava sam sebe, implicirajući dijelom ženinu samosvojnu, muški konotiranu želju za provođenjem vlastite volje, vlastitog odabira (njem. Durchsetzungsvermögen), želju za odmakom od stereotipne rodne uloge supruge i majke zamjenom rodnih uloga, odnosno prisvajanjem za ono doba muški 
konotiranog spolnog ponašanja, a dijelom implicirajući (samo)kritički osvrt pripovjedača prema neupitnosti onodobnih normativnih koncepata. Ambivalentna pozicija homodijegetičkog pripovjedača prema ostvarenju ženske individualnosti izražena je u jednom dijelu pripovijetke u zauzimanju sličnog stava prema ženi kao i njezin zaručnik, čiji govor (uvjeravanje, navaljivanje na zaručnicu) pripovjedač prenosi neposrednije (u indirektnom i direktnom govoru) nego ostali diskurs u pripovijetci. Homodijegetički pripovjedač se identificira s govorom zaručnika i njegovim stavom prema zaručnici, što je još jednom prethodno u pripovijetci izraženo u govoru samog pripovjedača, njegovom postepenom prijelazu iz modusa narativnog izvještaja u komentar u 1. licu množine: ,nikada nije slutio da će nešto slično čuti od dobre djevojke iz dobre kuće, djevojke koju je uz radostan pristanak njenih roditelja želio uzeti za ženu i u kojoj se vjerojatno nadao da će pronaći ono što, naravno, mi svi očekujemo od naše buduće žene: čudesnu, svetu, kreposnu suprotnost ludoj strastvenosti naših mladenačkih ljubakanja...“. Ovakav stav Schnitzlerovog pripovjedača odražava onodobnu freudijansku opreku spiritualiziranja vlastite žene s jedne strane i čuvanja nagonske žudnje prema ljubavima izvan braka. ${ }^{499}$ Prema Freudu, ovakva je dihotomija nastala zbog oštrog odvajanja nježne ljubavi (njem. zärtliche Liebe) i čisto spolne, senzualne ljubavi (njem. sinnliche Liebe). Ona je potaknuta zazorom od incesta, odnosno neriješenog edipalnog kompleksa, a uvjetuje stereotipne slike o ženi u građanskom društvu. U ovom se odlomku može primijetiti hipokrizijski stav prema ženskoj spolnosti naspram muške: ono što je, shodno dvostrukom moralu građanskog društva fin-de-siècle-a bilo dozvoljeno muškarcu (predbračni spolni odnosi), nije bilo dozvoljeno ženama. Sljedeći segmenti pripovijetke također svjedoče o objektifikaciji žene i muškoj eksploataciji ženskog tijela, kao i o perpetuiranju hijerarhijske nadmoći muškarca nad ženom: iz većeg dijela naracije pripovijetke proizlazi da je žena objekt žudnje, dok joj se, s druge strane, na razini semantike rodne jednakosti priznaje i određeno pravo afirmacije vlastite žudnje i vlastite mogućnosti odabira unutar ograničavajućeg patrijarhalnog okruženja. Sintagma „zdravi i zadovoljni“, koju pripovjedač prenosi uz izričito fokusiranje na ženinu perspektivu, odražava svojevrsni pripovjedačev kritički stav o „normalnosti“ građanskog društva. Međutim, u dubinskim strukturama cijele pripovijetke otkrivaju se elementi pripovjedačevog ambivalentnog stava o dvostrukom moralu građanskog društva i njegovo perpetuiranje rodne bipolarizacije koja uvjetuje rodnu diferencijaciju i time onemogućuje žensku individualnost.

\footnotetext{
${ }^{499}$ Vidi Freudovu studiju pod naslovom Über die allgemeinste Erniedrigung des Liebeslebens.
} 
Arthur Schnitzler upotrijebio je književni žanr kratkog pripovjednog djela s podnaslovom „Studie“, u kojem je na način psihoanalitičara u vidu avangardnog novuma ocrtao jednu žensku psihu koja odstupa od onodobnih normativnih koncepata ženskosti. Dekonstruirajući u fin-de-siècle-u često uvriježeno antropološko-medicinsko stajalište da je ženska spolna žudnja manje izražena od muške ${ }^{500}$, Schnitzler pokazuje strukturu nagona kao diferenciranog, ali neutralnog antropološkog egzistencijalnog temelja. Time on, usprkos difamiranju žene kroz njezino izrazito opredmećivanje, ipak afirmira pojam ženskog samoodređenja i ženske spolnosti kao ravnopravne sa muškom. Naglašavajući kolektivno poimanje hegemonije muškog spola u vidu esejističkog završetka pripovijetke, time što se kako samome sebi tako i suvremenicima obraća sa mi (njem. „wir"), Schnitzler komentira onodobni mizogini odnos prema ženama (vlastiti odnos i odnos suvremenika) i na određeni način afirmira pokušaj ženskog individualizma da se odupre zakonima čvrsto uvriježene rodne bipolarizacije. Schnitzler ipak kroz cijelu pripovijetku na kolektivnoj razini reproducira (muško) znanstveničko poimanje žene kao objekta i seciranje ženske psihe zbog dubljeg uvida u njezinu tajnovitost.

U djelu Die Braut nailazimo na hegemoniju muškog sjećanja, unutar kojega figurira žensko sjećanje, a to opet odražava opće kulturalno sjećanje (kolektivnu podsvijest). Funkcija kako kolektivnog, tako i osobnog sjećanja Schnitzlerovog pripovjedača tako istovremeno služi kako ponovnom legitimiranju rodnih odnosa i rodnih stereotipa, tako i svojevrsnoj afirmaciji ženske spolne žudnje. Tekst predstavlja avangardni iskorak u poimanju i analizi ženske spolnosti: fiktivni su čitatelji Schnitzlerova opusa prije svega njegovi (mahom muški) suvremenici, koji rekapituliraju, i na taj način, potaknuti onodobnom mijenom u rodnim odnosima, revaloriziraju svoje poimanje žene i ženske psihe s obzirom na onodobnu bipolarizaciju spolova i svoj ambivalentan stav prema ženi (mješavina žudnje i zazora). Prikaz jedne ženske psihe koja se opire normativnim obrascima onodobne ženskosti i koja se ne da lako kategorizirati u stereotipne rodne kategorije Schnitzlerov je izvještaj o naravi jedne epohe, komentar o lažnosti onodobnog morala i antropoloških zasada, potvrda neiskorjenjivosti rodne bipolarizacije $\mathrm{u}$ društvu, i avangardni iskorak $\mathrm{u}$ dekonstruiranju onodobnih tabua o ženskoj spolnosti. Schnitzlerova konstatacija na kraju pripovijetke kako sve individualne karakteristike uzmiču pred podjelom muškarac-žena rekapitulacija su i reprodukcija onodobne kolektivne svijesti i podsvijesti koja ustraje na rodnoj bipolarizaciji shodno svojim stereotipizacijama muškog i ženskog spola. Schnitzlerovo djelo tako ponovno

\footnotetext{
${ }^{500}$ Usp. Krafft-Ebing: Psychopathia sexualis, 1993.
} 
služi kao stabilizator i najava neiskorjenjivosti rodne bipolarizacije prezentirajući žensko sjećanje kroz vizuru muškog sjećanja (homodijegetičkog pripovjedača čija je rodna pozicija ipak neupitna). Na taj način Schnizler istovremeno rekapitulira (etablira) a kroz prikaz ženske spolnosti i dekonstruira vrijednosne predodžbe o hijerarhiziranim rodnim razlikama, ženskosti i ženskom subjektu koje se nalaze u ambigvitetu između tradicionalnog (patrijarhalnog) svjetonazora i modernizma (avangarde). Schnitzlerovo načelno iznošenje ženskog sjećanja unutar jednog vrlo kratkog književnog teksta (kraća pripovijest) s druge strane svjedoči i o njegovoj želji za naglašavanjem novuma ženske individualnosti i neprilagođenosti normama kao simptoma jednog razdoblja (avangardistički zaokret u rodnim odnosima, zamjena rodnih uloga): njegovo je djelo eksperimentalno u smislu dekonstruiranja onodobnih tabua, otkrivanja načelne izjednačenosti ženske sa muškom žudnjom, i revalorizacije pojma autonomnosti ženske psihe. Koncizna i psihoanalitički intonirana pripovijetka s esejističkim komentarom na kraju odraz je kako Schnitzlerove bliskosti sa Freudovim diskursom, tako i vlastite, rodno-znakovite pozicije u društvu kao liječnika i psihoanalitičara, koji je kako kroz svoje zanimanje, tako i kroz osobno iskustvo bio dobro upoznat sa ženskom problematikom i onodobnim rodnim odnosima.

Ovakav koncept ženske spolnosti blizak je i tezi teoretičarke Julie Kristeve, koja u svom eseju Women's Time (1979) postulira određenu vezu između ženske subjektivnosti i cikličkog iskustva vremena koje je orijentirano na biološke, prirodne, pa i kozmičke procese. ${ }^{501} \mathrm{U}$ tome neprestanom konfliktu vlastite spolnosti primat odnose podsvjesne želje i nagoni, čime autor pokazuje svoju bliskost s Freudovim psihoanalitičkim diskursom.

\section{8. $\quad$ Arthur Schnitzler: Reigen (Kolo)}

\subsubsection{Uvod}

Schnitzlerovo dramsko djelo Reigen (Kolo), napisano 1896-97. godine, izazvalo je, pri svojoj izvedbi u Beču i Berlinu 1920-21. godine jedan od najvećih književnih i kazališnih skandala, s obzirom da je ovo djelo prvo u kojem se na sceni, kroz deset dijaloga, tematizira spolni odnos, do kojega i dolazi u svakom dijalogu, iako se, dakako, ne prikazuje na sceni. Ovdje se ne tematizira istinska ljubav, odnosno iole trajnija, na odgovarajućim emocijama zasnovana intimna veza. Većina likova koji stupaju u odnos u ovome se djelu jedva i poznaju, a između

\footnotetext{
${ }^{501}$ Vidi Nünning/Nünning 2004, str. 74.
} 
njih se ne rađa ljubavna veza, već isključivo veza spolne naravi. ${ }^{502}$ Schnitzler želi razotkriti hipokriziju onodobnog morala i krizu normativne spolnosti, a iz razloga cenzure ne prikazuje izravno seksualnost likova na sceni. Schnitzlerov primarni interes ipak nije prikazati sam ljubavni čin, već elaborirane i manje elaborirane kodekse (spolnog) ponašanja koji slijede prije i poslije ljubavnog čina, dakle, ponašanje ovih deset likova, čiji društveni status uvelike odlučuje o strategijama zadovoljenja nagona. ${ }^{503}$ Društveno uvjetovano prešućivanje spolnosti ima za posljedicu cijeli niz jezičnih manevara $i$,,mimetičkih zamjenskih radnji“ koje same po sebi insceniraju na sceni neprikazanu seksualnost. Prema Freudovom tumačenju u njegovoj knjizi Das Unbehagen in der Kultur (Nelagoda u kulturi), ovi likovi upravo i ulaze u takve odnose koji služe kao posljedica reakcije na društvenu represiju vezano na spolnost.

Schnitzler prije svega želi prikazati promiskuitet ljudi u jednom društvu u kojem sve vrijednosti bivaju uzdrmane, dok se s druge strane upravo na te vrijednosti stavlja naglasak (normativna spolnost i kriza normativne spolnosti). Prema tumačenju teoretičara Horsta Thoméa, koji obrazlaže Krafft-Ebingovo djelo Psychopathia sexualis, Schnitzlerov tekst reagira na onodobnu krizu znanosti o seksualnosti, koja, prema tradicionalnom obrascu prosudbe, ističe muški libido, a potom postavlja kategoriju braka kao neupitnu, dok Schnitzler upravo želi razotkriti hipokriziju (onodobnog) morala kršenjem tih normativnih obrazaca. ${ }^{504}$ Schnitzler na svojevrstan način izjednačuje ženu i muškarca pred vladavinom libida, uz iznimku nijansiranja te razlike kroz različite društvene slojeve. Schnitzlerove dramatis personae (lat.) ne kreću se u okvirima građanskog morala postulirane bračne pa čak niti „potkupljive“ ljubavi, već svih deset osoba ulaze iz scene u scenu u različite veze s uvijek novim partnerom. Svim likovima u drami Reigen zajednički je samo seksualni (ili erotski) interes, njima vlada nagonska priroda (njem. Triebstruktur), za koju Schnitzler pokazuje da općenito vrijedi za svako ljudsko biće, bez obzira kojem društvenom sloju pripada. Međutim, osim poante Schnitzlerovog djela koja se očituje isključivo u bijegu od realnosti kroz spolni čin i traganju tipološki koncipiranih likova za otklonom od monotone svakodnevice njihova okruženja, bit njegovog djela su također i krinke (maske) koje likovi navlače kako bi postigli svoj cilj, manevarske strukture dijaloga u kojima se otkriva sva licemjernost društva. S jedne su strane likovi podložni normativnim obrascima u rodnim odnosima za koje hine da ih poštuju, a potom ih krše. Bez obzira na to što su svi likovi u ovoj Schnitzlerovoj drami iz

\footnotetext{
${ }^{502}$ Janz/Laermann 1977, str. 55.

503 Ibid., str. 56.

${ }^{504}$ Vidi članak Horsta Thoméa pod naslovom Arthur Schnitzlers „Reigen“ und die Sexualanthropologie der Jahrhundertwende, u knjizi Text+Kritik, Zeitschrift für Literatur, 138/139, Arthur Schnitzler, 1998, str. 102 103.
} 
različitih društvenih struktura, ono što ih povezuje upravo je spolni nagon, koji se, prema Schnitzlerovom tumačenju, pojavljuje kao univerzalna matrica koja rukovodi ponašanje ovih izrazito tipološki koncipiranih likova u djelu: stoga djelo na neki način, posebice po svojoj cikličkoj strukturi, nalikuje gotovo „srednjovjekovnom mrtvačkom plesu (njem. Totentanz)“ ${ }^{505}$ u kojem razlika u rangu između cara i prosjaka što se tiče pojma tanatosa $\mathrm{i}$ erosa postaje gotovo nevažnom. Pa ipak, svaki društveni sloj zahtijeva vlastite obrasce (spolnog) ponašanja, neki rafiniranije, a neki manje rafinirane.

\subsubsection{Eksplicitni rod}

Schnitzlerovo djelo Reigen strukturirano je kao jednočinka (njem. Einakter), sastavljena od deset scena u kojima se u svakoj od tih scena pojavljuje par (muškarac i žena), pri čemu se jedan od tih dvaju likova ponovo pojavljuje u svakoj sljedećoj sceni. Ciklička je struktura vidljiva već u samom naslovu.

Tematski se u djelu želi naglasiti kratkotrajna ćutilna ekstaza ${ }^{506}$ likova u sklopu frivolnosti i hedonizma njihova okruženja, a posebno se naglašava motiv otuđenja (njem. Entfremdung) svih likova jednih prema drugima, što je vidljivo i kroz njihove dijaloge. Dovode se u pitanje i normativni obrasci braka i općenito vjernosti u rodnim odnosima. Provodni motiv kola i ciklička struktura demonstriraju princip prolaznosti i kruženja čiju matricu predstavlja seksualnost, a implicitno se naglašava i destruktivnost seksualnosti, budući da likove u djelulikove koji su izrazito tipološki koncipirani, a pripadaju različitim, ponekad i potpuno oprečnim društvenim slojevima- rukovodi isključivo nagonska želja (njem. Trieb), prema tumačenju Sigmunda Freuda. Oni „uskaču“ u različite rodne i društvene uloge koje im omogućuju da provedu svoj cilj. Spolnost tako postaje sama sebi svrhom, a prisutan je i problem dvostrukog morala (njem. Doppelmoral) u kojem se na mušku i žensku spolnost gleda nejednako, dok se ipak naglašava načelna jednakost i muškarca i žene pred vladavinom nagonske strukture ličnosti. Schnitzler je u ovom dramskom djelu dao presjek srednjoeuropske seksualnosti prikazavši kroz deset scena susret različitih društvenih slojeva kojima je seksualnost zajednička karakteristika: u prvoj sceni vojnika i prostitutku, u drugoj sceni vojnika i sobaricu, u trećoj sobaricu i mladog gospodina, u četvrtoj sceni mladog gospodina i mladu ženu, u petoj mladu ženu i njezinog muža, u šestoj sceni muža i ,slatku pucu“ (süßes Mädel), naziv koji djeluje pogrdno, ali je onodobno bio uvriježen za siromašne djevojke iz predgrađa Beča, zatim u sedmoj sceni „slatku pucu“ i pjesnika, u osmoj sceni

\footnotetext{
505 Janz/Laermann 1977, str. 56.

${ }^{506}$ Usp. Žmegač: Bečka moderna, 1998, str. 161., vidi također str. 157-163.
} 
pjesnika i glumicu, u devetoj sceni glumicu i grofa, te u zaključnoj, desetoj sceni grofa i prostitutku. Treba uzeti u obzir da su ove rodne konstelacije, osim što prikazuju presjek kroz različite društvene slojeve, također i eksperimentalne naravi.

Istovremeno su iznijansirana stupnjevanja ljubavnog ponašanja i ljubavne ideologije: dvostruki moral, fingirana krepost, želja za spolnim posjedovanjem, idealistička slatkorječivost. $^{507}$

Likovi u ovoj drami posloženi su na svojevrstan stupnjeviti način iz različitih društvenih struktura (od onih nižih prema višima pa opet prema nižima, na samom kraju), ali korespondiraju u pogledu zajedničke matrice (spolni nagon). Oni se nalaze i u određenim kontrastnim relacijama zbog svojih neprestanih „verbalnih“ dvoboja i jezičnih manevara, koji su u skladu s društvenim slojem kojem pripadaju. Reigen je drama koncipirana kroz deset dijaloga, u kojima se otkriva, pored svojevrsnog otuđenja likova i njihov gubitak identiteta, budući da na performativan način uskaču svaki put u nove uloge. Iako likovi sami sebe eksplicitno prikazuju kroz međusobne dijaloge, vidljiva je i prijetvornost $u$ njihovim dijalozima koja zahtijeva, „čitanje između redaka“ kako bi se razotkrile sve onodobne društvene laži i kriza u rodnim odnosima. Prema teoretičaru Horstu Thoméu, onodobna se kultura kretala između viktorijanskih (normativnih) obrazaca patrijarhalnog društva i tzv. permissive society (liberalnog društva, prev. s engl.), ${ }^{508}$ koje se odražava u promiskuitetnom ponašanju likova, a potom u svojevrsnom prikrivanju toga ponašanja.

Dvostruki je moral, na kojem počiva onodobna rodna bipolarizacija, najizraženiji baš u sceni između muža i mlade žene, u kojoj ona njega upita o njegovim predbračnim vezama, na što on licemjerno odgovara da je za njega brak ,nešto puno tajanstvenije nego za vas mlade djevojke“, budući da su, prema njegovom mišljenju, „muškarci posve zbunjeni i nesigurni kroz sve te višestruke doživljaje, koje „silom prilika“ moraju proći prije braka“. ${ }^{509} \mathrm{U}$ ovoj sceni i muž i mlada žena pokazuju svoje licemjerje ad infinitum, jer treba uzeti u obzir da je i mlada žena prije susreta s mužem bila s mladim gospodinom. Muž se „samilosno“ osvrće na svoje veze s prostitutkama, za koje licemjerno tvrdi da su „bijedna bića“, a upravo je on taj

\footnotetext{
${ }^{507}$ Pfister 2001, str. 239.

508 Thomé 1998, str. 106.

${ }^{509}$ Cit. iz: Reigen: „(...) Für einen Mann, der sich ein bißchen in der Welt umgesehen hat- geh, leg den Kopf an meine Schulter- der sich in der Welt umgesehen hat, bedeutet die Ehe eigentlich etwas viel Geheimnisvolleres als für euch junge Mädchen aus guter Familie.“, Reigen 1962, str. 91.; „Gewiß. Denn wir sind ganz verwirrt und unsicher geworden durch die vielfachen Erlebnisse, die wir notgedrungen vor der Ehe durchzumachen haben. (...) Uns wird das, was man so gemeinhin die Liebe nennt, recht gründlich widerwärtig gemacht; denn was sind das schließlich für Geschöpfe, auf die wir angewiesen sind!“ „Sei froh, mein Kind, daß du nie einen Einblick in diese Verhältnisse erhalten hast. Es sind übrigens meist recht bedauernswerte Wesen- werfen wir keinen Stein auf sie.“, Reigen 1962, str. 91.
} 
koji ih seksualno koristi (eksploatira), pri čemu možemo naslutiti Freudovu tezu o udvajanju muške žudnje na „,idealiziranu“ ženu i na ,posrnule“ žene, odnosno udvajanje žudnje građanskog muškarca na idealnu (nespolnu) ljubav unutar braka i čisto spolnu žudnju izvan braka. Međutim, treba napomenuti i to da Schnitzler u prikazu svojevrsne ,rodne ravnopravnosti“ (engl. gender equality) postavlja svoju skepsu i prema ženskoj nevinosti, okarakteriziravši i ženu kao spolno biće koje svojom „emancipacijom“ ne pristaje na licemjerje muškarca i stoga kaže: „Da, a kakva su to bića?“, a na muževljevu repliku odgovara: ,ali, molim te- ta tvoja samilost- to mi se sada uopće ne čini primjerenim. ${ }^{\text {(510 }} \mathrm{Na}$ ženino licemjerno nerazumijevanje položaja prostitutki u društvu, muž na ironičan ili krajnje ludičan način aludira na „nevinost“" vlastite žene i njezinu moguću kompromitaciju. Stoga se baš u ovome Schnitzlerovom djelu mogu uočiti sve društvene laži i laži u međuljudskim odnosima u onodobnom strogo rodno diferenciranom društvu. Žena potom licemjerno pita da joj muž ispriča nešto iz svoje mladosti, na što on jednako licemjerno kaže da bi to bilo svojevrsno obeščašćenje njihove veze, i to riječima: ,pomisli ipak, da si majka...da tu u tvome trbuhu leži naša curica““. ${ }^{511}$ Nakon što ga žena upita o drugim ženama s kojima je bio u prošlosti, on joj odgovara: „Volio sam samo jednu- a to si ti. Čovjek voli samo onu osobu u kojoj može naći čistoću i istinu““ ${ }^{512}$ U ovoj sceni djelomično je uočljiva rodna bipolarizacija, u vidu spleta društvenih laži- jedan standard vrijedi za muškarce, a drugi za žene, no ni žene se ne pridržavaju tradicijom danih rodnih uloga (mlada je žena prije muža bila s mladim gospodinom).

Scena koja se odvija između pjesnika i glumice puno je kompleksnija u rodnom smislu, iako podliježe rodnim stereotipima. Glumica „uskače“ u razne rodne uloge, što je i bit njezine profesije koja joj nalaže promjenu temperamenta i preuzimanje svaki put nove uloge, no ovdje joj to prvenstveno služi kako bi postigla svoj krajnji cilj. Ponajprije igra ulogu pobožne žene, a dok ju pjesnik pita: „Vjeruješ li u Boga?“, ona mu odgovara: „Pa naravno, pa nisam ja hulja.“, na što pjesnik ironično odgovara: „A, tako!“. Glumica ga čak na ludički i ironičan način poziva da moli zajedno s njom, da mu „neće kruna pasti s glave“, na što mu ona, kad ju on pokuša zagrliti, licemjerno odvrati: „Pohotljivče“. Optužuje ga da je zavodnik, dok se i ona

\footnotetext{
510 „Ja, was sind das für Geschöpfe?“; „Bitt dich- dieses Mitleid.- Das kommt mir da gar nicht recht angebracht vor.", Reigen 1962, str. 91.

511 ,...denk doch, daß du Mutter bist...daß unser Mäderl da drin liegt...“, Reigen 1962, str. 92.

512 „Geliebt hab ich nur eine- das bist du. Man liebt nur, wo Reinheit und Wahrheit ist.“, Reigen: str. 94.
} 
poslije pretvara u stereotipno muški konotiranu ulogu zavodnice $(\text { femme fatale })^{513}$, odnosno obrće rodne uloge između žene i muškarca.

Scena između pjesnika i glumice te glumice i grofa najviše svjedoči o mogućim potencijalima androginog ponašanja u djelu. Teoretičari Janz i Laermann ${ }^{514}$ ustanovljuju da je u sceni u kojoj se pojavljuju pjesnik i glumica na satiričan način opisan spolni interes i samostilizacija pjesnika kao androgino samodostatnog umjetnika. Što očitijim postaje to da je i pjesnikov cilj isključivo spolni čin, utoliko su veći i njegovi napori koje poduzima kako bi, obmanjujući glumicu sa svojim čestim mijenjanjem pseudonima, potvrdio i zadržao svoju društvenu anonimnost i neodredivost umjetnika. Moć spolnoga čina prisutna je kod njega kao umjetnika samo kao poza za potvrđivanje samosvijesti pjesnika (za samoinscenaciju). Neodredivost identiteta ukazuje na lik pjesnika kao tipološki lik modernog umjetnika. Dok je u ovoj sceni neodredivost umjetnika satirički demantirana ciljnom usmjerenošću njegovog spolnog interesa, ta se neodredivost njegovog identiteta u sljedećoj sceni na jedan drugi način iz temelja potresa kroz lik glumice. U odnosu sa süßes Mädel, koja ga naziva njegovim pravim imenom (Robert), pjesnik tvrdoglavo inzistira na pseudonimu kao utjelovljenju književnog digniteta; dok glumicu, nasuprot tomu, gotovo preklinje da ga naziva njegovim pravim imenom: „Ta ja imam ime: Robert ${ }^{\star 515}$, a ona mu prezirno odgovara: „Ah, to je preglupo“. ${ }^{516}$ Glumica, nakon toga, nastojeći poniziti pjesnika, preuzima mušku, odnosno agresivnu ulogu i prijezirno se odnosi prema njemu nazivajući ga pogrdnim imenima, koja sadrže aluzije na spolnost. ${ }^{517}$ Ovaj niz uvreda glumica koristi kako bi ustvrdila kako svoju „emancipaciju“ i dominirajući status, ali i u svrhu potvrde svoga poimanja društvenog statusa glumice nad pjesnikom. Glumica na rodno performativan način „uskače“ u različite rodne uloge: čas glumi naivnost, a čas se na arogantan (stereotipno muški konotiran način) odnosi prema svome partneru. Nakon ovakvog vrijeđanja, pjesnikova poza literata (odnosno, književnika) biva toliko do temelja uzdrmana da on počinje tražiti utočište $u$ profanom identitetu. ${ }^{518}$ Glumica, koristeći razne proizvoljne i pogrdne nazive za pjesnika (u čemu se vidi obrtanje rodne uloge muškarac-žena, odnosno zamjena rodnih uloga), upravo naglašava njegovo prvobitno neprestano mijenjanje pseudonima, koje bi metaforički značilo neodređenost, pa i svojevrsnu anonimnost umjetnika, tako da se on osjeća prisiljenim vratiti

\footnotetext{
${ }^{513}$ Usp. koncepcije ženskih subjekata i oblike mizoginije kod Weiningera u njegovom djelu pod naslovom Geschlecht und Charakter, 1920.

${ }^{514}$ Janz/Laermann:1977, str. 63-69.

${ }^{515}$ U prijevodu: „Ich hab doch einen Namen: Robert“, Reigen, str. 118.

${ }^{516}$ U prijevodu: „Ach, das ist zu dumm“, Reigen, str. 119.

517 Vidi Janz/Laermann 1977, str. 66.

518 Ibid.
} 
se na svoje pravo ime, koje je uskratio „slatkoj pucici“. Osim toga, on čezne za profanim identitetom, budući da i glumica prema njemu nastupa kao inkarnacija umjetničke neodređenosti (njem. künstlerischer Indetermination). ${ }^{519}$ Jer za pjesnika je u svakom slučaju bez ikakve razlike suočava li se on $\mathrm{s}$ emancipiranom ženom ili s glumicom, koja na performativan način igra tu ulogu, budući da on to $u$ tome trenutku ne može ocijeniti. Glumica ne osporava pjesniku samo njegov pjesnički talent, već i njegov „ljubavni trud“: njegovi pokušaji da kićene metafore stavi u službu zavođenja ona nemilosrdno odbija. Kad pjesnik na auto-ironičan i feminiziran način kaže: „Ići ću pod prozorom gore dolje. Vrlo volim šetati noću vani. Najbolje mi misli tako dolaze. A još u tvojoj blizini, ovijen, tako rekuć, tvojom čežnjom... živeći u tvojoj umjetnosti.“, glumica mu na grub način odgovara: „Govoriš kao idiot...“, na što pjesnik (bolno) odgovara: „Ima žena, koje bi možda rekle... kao pjesnik“. 520

Ovakav rodno subverzivan i prijeziran odnos glumice prema liku (feminiziranog) pjesnika odraz je izokretanja rodnih uloga, pri čemu muškarac biva podčinjen ženi. No i sam pjesnik na auto-ironičan i ne tako naivan način pristaje na igranje (rodne) uloge podčinjenog $\mathrm{i}$ feminiziranog esteta. Pjesnik na ironičan i hipokritičan način spominje svoje oduševljenje prema pobožnom seoskom puku: „Lijepe li sobe... a ljudi su ovdje pobožni. Same svete slike...Bilo bi zanimljivo provesti neko vrijeme među ovim ljudima... ipak drugi svijet. Mi zapravo znamo vrlo malo o drugima., na što mu glumica grubo odgovara: „Ne govori gluposti, nego mi radije daj tu torbicu sa stola“, dok je njegova ironična i hipokritična replika sljedeća: „Evo, jedina moja!“. ${ }^{521}$ Glumica također, kao i pjesnik, hini stereotipno ženski konotiranu naivnost, npr. u sljedećem dijalogu: „Molim- ja mogu i otići, ako sam ti dosadna.“, ali ova rečenica slijedi tek nakon njezinog priznanja da je na mjestu na kojem se njih dvoje nalaze (pjesnik i glumica) proživjela mnoge godine sa drugim muškarcem (Fric). Pjesnik glumicu pomalo ironično uvjerava u svoju ljubav: „Ti da si mi dosadna?... Ti ni ne slutiš, što si ti meni... Ti si za me čitav svijet... Ti si božanstvo, ti si genij... Ti si... Ti si zapravo sveta

\footnotetext{
${ }^{519}$ Vidi Janz/Laermann 1977, str. 66.

${ }^{520}$ Arthur Schnitzler: U kolu (Reigen), deset dijaloga, preveo: Dr. E. Dominiković, Koprivnica, 1920, str. 78., u originalu: „Dichter: Ich werde vor dem Fenster auf und ab gehen. Ich liebe es sehr, nachts im Freien herumzuspazieren. Meine besten Gedanken kommen mir so. Und gar in deiner Nähe, von deiner Sehnsucht sozusagen umhaucht...in deiner Kunst wehend.; Schauspielerin: Du redest wie ein Idiot...; Dichter (schmerzlich): Es gibt Frauen, welche vielleicht sagen würden...wie ein Dichter., Reigen, str. 115.

${ }^{521} U$ kolu, str. 77., u originalu: „Was für ein hübsches Zimmer...und fromm sind die Leute hier. Lauter Heiligenbilder...Es wäre interessant, eine Zeit unter diesen Menschen zu verbringen...doch eine andre Welt. Wir wissen eigentlich so wenig von den andern.“, Reigen 1962, str. 115., „Schauspielerin: Rede keinen Stiefel und reiche mir lieber diese Tasche vom Tisch herüber.“; Dichter: „Hier, meine Einzige!“, Reigen, str. 115.
} 
Nevinost... Da, ti... Ali sad ne bi smjela govoriti o Fricu. “522 Njezino hinjenje naivnosti ogleda se, osim u rečenici: „To je doista bilo u zabuni! No!“ i u njezinoj „molitvi““ samome pjesniku umjesto Boga, lažno veličajući tako samog pjesnika da bi ga istog trena ponizila nazvavši ga zavodnikom. U ovome dijalogu pjesnika i glumice oba lika se pretvaraju: pjesnik glumi ulogu naivnog esteta (treba spomenuti da scena između pjesnika i glumice slijedi nakon scene $u$ kojoj se dogodio susret između pjesnika i „slatke pucice“ (süßes Mädel), dok glumica ponekad igra na kartu vlastite nevinosti i naivnosti, a ponekad preuzima stereotipno mušku ulogu zavodnice i čak u toj strategiji zavođenja ponižava muškarca.

I pjesnik i glumica, „žrtve“ su spolnog nagona koji se na rafiniran način prikazuje kroz njihov dijalog, a predstavlja se u vidu društvenih laži u kojima oni oboje hine ljubav jedno prema drugome. Glumica: „Tako, sad možeš sjesti k meni, pa mi nešto pričati.“; Pjesnik: „A što bih ti pričao?“; „No, komu si ovaj čas nevjeran.“; Pjesnik: Nažalost, nisam još. (...). I u ovoj se sceni očituje pozicija pjesnika kao feminiziranog esteta, nakon čega slijedi i glumičino priznanje o nevjeri. U priznanju, prije vođenja ljubavi, da varaju jedno drugo s drugim osobama, njihova se dotadašnja ljubavna retorika ispostavlja kao oblik društvene laži kojoj je jedina svrha postizanje krajnjeg cilja. U ovome pogledu tzv. „rodne ravnopravnosti““ Schnitzler i muškarca i ženu izjednačuje pred vladavinom spolnog nagona. Glumica optužuje pjesnika da bi i on, poput mnogih drugih, s njom želio ljubakati, na što joj on licemjerno i ironično odgovara: „Ali se ne može dvojiti, da ja ovaj čas imam najviše izgleda“. ${ }^{523} \mathrm{Na}$ glumičino ironično pitanje koga to ona sama vara, a pjesnik odgovara da je možda on taj kojega vara, ona ga uvrijedi, nakon čega slijedi njegova replika koja hini njegovu iskrenost, a samo u svrhu postizanja krajnjeg cilja: „Ili nekoga...koga sama nisi nikada vidjela...nekoga, koga ne poznaš, nekoga koji je određen za te, a koga nikada ne možeš naći (...), nakon čega nadodaje: „Zar nije čudno... i ti- - a moralo bi se ipak vjerovati.- Ali ne, značilo bi oduzeti ti najbolje, što imaš, kad bi ti se htjelo... dođi, dođi- -dođi“. ${ }^{524}$ Glumica naziva pjesnika pogrdnim imenima, njegove riječi smatra „bajkovitim“ i „djetinjastim“, dok on na te njezine replike daje polu-ironične ili pak naivne komentare: u njihovom se susretu ljubav pokazuje kao puka iluzija. Oni na performativan način ili udovoljavaju tradicionalnim rodnim ulogama ili ih pak krše. No najvažnije je istaknuti provodni motiv građenja nepovjerenja jednog

\footnotetext{
${ }^{522} U$ kolu, str. 76., u originalu (Reigen und andere Dramen): „Schauspielerin: „So jetzt kannst du dich zu mir setzen und mir was erzählen.“; Dichter: Was soll ich dir erzählen?“; Schauspielerin: „Nun, wem bist du in diesem Moment untreu?"; Dichter: „Ich bin es ja leider noch nicht.“, Reigen, str. 116.

${ }^{523}$ U kolu 1920, str. 80.; Dichter: „Es ist aber doch nicht zu bezweifeln, daß in diesem Moment ich die meisten Chancen habe.“, Reigen, str. 117.

${ }^{524}$ Dichter: „Oder einen...den du selbst nie gesehen...einen, den du nicht kennst, einen- der für dich bestimmt ist und den du nie finden kannst... (...) ,Ist es nicht sonderbar...auch du- und man sollte doch glauben. -Aber nein,es hieße dir dein Bestes rauben, wollte man dir...komm, komm—komm-, Reigen, str. 117.
} 
partnera prema drugome, iz čega i proizlazi „mrtvački ples“, odnosno cikličko odvijanje kola (Reigen), ulazak jednog od partnera u uvijek novu vezu, ali i međusobno nadmudrivanje i nepovjerenje dok su u vezi jedno s drugim.

Čak i pjesnikovo neoromantičko „sanjarenje“ o prirodi i o ljubavnom odnosu glumica prevodi u čisto fraziranje. Njezina ponižavanja pjesnika odnose se i na status njega kao umjetnika, ali i kao ljubavnika. Može se pretpostaviti da ovakvo ponašanje glumice služi prvenstveno njezinoj tehnici zavođenja pjesnika, pri čemu ona zauzima agresivnu ulogu koja se nekad tipološki pripisivala muškarcima. Glumica pjesniku čas zapovijeda, čas ga mami (odnosno, doziva) k sebi, pa ga potom odbija. Prema tome, ona očigledno prema pjesniku, kao i prema grofu igra ulogu koja se tradicionalno pripisivala muškarcu: na verbalan i psihološki način ponizuje drugu (mušku) osobu kao uvjet vlastitog spolnog zadovoljenja i odriče se emocionalne veze naspram one čisto spolne. ${ }^{525}$ Daljnji dokaz da glumica igra stereotipnu mušku ulogu nalazi se i u pitanju izmučenog pjesnika: „A što sam ti ja to učinio?““. ${ }^{526}$ To je isto ono pitanje koje - upravo nakon spolnog čina süßes Mädel postavlja suprugu. Kao što suprug odlazi s djevojkom, tako i glumica odlazi s pjesnikom, koji je u sceni prije toga ponizio djevojku. Zbog naivnosti kojom je pjesnik okarakterizirao djevojku i time ju želio pridobiti na spolni čin, sada se, u izokretanju rodnih uloga i u činu kvazi „rodne ravnopravnosti“, njemu isto to vrijeđanje događa od strane glumice. ${ }^{527}$ Ovakva se „rodna ravnopravnost" očituje u glumičinoj konsolidaciji s ulogom muškarca: glumica se u svojoj ulozi muškarca nastoji „emancipirati“ od svog statusa podložne žene, ali cijena koju ona plaća za to je, prema teoretičarima Janzu i Laermannu, njezina podložnost normativnoj i stereotipnoj muškoj normi agresivnog ponašanja. Ona je neprestano uronjena u svoju glumačku profesiju, koja joj nalaže pretvaranje iz jedne uloge u drugu, a ona sama time gubi identitet. Njezin se modus nadmoćnog agresivnog ponašanja potvrđuje i u njezinoj izričitoj podložnosti i pristajanju na stereotipno mušku normu ponašanja: ovakva se dominacija žene nad muškarcem ispostavlja kao posljedica onodobne krize u muško-ženskim odnosima. Nakon koitusa, glumica na ironičan način tvrdi da je njezin odnos sa pjesnikom ,ipak nešto ljepše nego glumiti u glupim kazališnim djelima“, ali ona to ne kaže kako bi izrazila svoje zadovoljstvo, već kako bi ponovo ponizila pjesnika kao svog ljubavnika, stoga mu i kaže: „Da, ti si veliki genij, Roberte!“ 528 Njezinom opsesivnom željom ispostavlja se ponižavanje drugoga kao uvjeta vlastitog spolnog zadovoljstva čak i nakon koitusa, kao da se on nije niti

\footnotetext{
525 Janz/Laermann 1977, str. 66.

526 „Was hab ich dir denn getan?“, Reigen, str. 117.

${ }^{527}$ Vidi Janz/Laermann 1977, str. 66.

528 „Ja, du bist ein großes Genie, Robert!“, Reigen, str. 117.
} 
dogodio, dok ovdje emocionalne potrebe postaju bespredmetnima. U svom opsesivnom oponašanju muške uloge, čak i u svrhu postizanja kratkotrajnog i prolaznog spolnog užitka, ona sada nehotice čak nalikuje i samom pjesniku, koji, potpuno bezdušno i ravnodušno se odnoseći prema svom spolnom činu sa „,üßes Mädel“, ostaje zaokupljen stilizacijom samoga sebe u umjetničko djelo. Dakle, cijena glumičine emancipacije je njezino usiljeno, odnosno prisilno (njem. „,zwanghaft ${ }^{\circ}$ ) približavanje muškom pan-danu, odnosno agresivnoj muškosti. $^{529}$

Dok je u susretu s pjesnikom glumica raskrinkavala pozu literata (književnika), u susretu $s$ grofom ona raskrinkava grofovu aristokratsku pozu svjetskog čovjeka. I u susretu s grofom ona zadržava svoj habitus profesionalne glumice, budući da zavođenje inscenira kao kazališni čin. Grofa izvrguje ruglu nazivajući ga pogrdnim imenima („tvor“, „mali filozof“, „Zavodnik“, „slatko dijete“, itd.), a nikad mu se ne obraća na dostojanstven način, odnosno nazivajući ga njegovim vlastitim imenom. Čak i u susretu s grofom glumica nastoji obezvrijediti i demaskirati povlašteni stalež grofa, koji je sam ukotvljen u konvencijama svoga staleža. Cilj njezinog zavođenja u ovoj sceni nije, prema Janzu i Laermannu, u tolikoj mjeri provođenje svoje vlastite žudnje već kompromitacija muškarca kao „mladolikog starca“ (njem. ,jugendlicher Greis"). Prema Janzu i Laermannu, iza poze njezine ravnodušnosti do izražaja izlazi na vidjelo to što ona njemu predbacuje: „da on pred njom (i njezinom agresivnošću) osjeća strah“. ${ }^{530}$ Problem krize njegovog muškog identiteta upravo se ogleda u „navodnoj“ čežnji za njenom problematičnom naravi: i njega zanima samo avantura s njom, i on se na retorički način želi domoći nje, budući da ga uopće ne zanima apsolutnost i jedinstvenost ljubavne veze, čak iako on to tvrdi, npr. u rečenici: ,čovjek ne smije lakomisleno unaprijed pokvariti ono što bi možda kasnije moglo biti vrlo lijepo “. ${ }^{531}$ Grofa više zanima Stimmung, koji želi postići kod svih svojih ljubavnica, budući da pripada sloju aristokracije. Glumica ga naziva pozerom, a prozrela je njegovu „kavalirsku“ retoriku kao „pokušaje da iz straha pred njenom agresivnom seksualnošću nađe utočište u profinjenosti i otmjenosti svoga staleža“. ${ }^{532}$ Glumica mu, prije samog čina, nemilosrdno diktira svoje uvjete, tako da svoje vlastito zavođenje ona sama osporava, što nalikuje na rat među spolovima, odnosno, odnose moći (njem. Machtverhältnisse) kojima se grof ropski pokorava. Grof u jednom trenutku čak na ironičan način ističe kako su njih dvoje „do sada bili tako iskreni

\footnotetext{
${ }^{529}$ Vidi Janz/Laermann 1977, str. 67.

${ }^{530}$ Ibid.

${ }^{531}$ Vidi prijevod, $U$ kolu: str. 92., njem. original: „man soll sich nicht leichtsinnig von vornherein was verderben, was möglicherweise sehr schön sein könnte “, str. 124.

532 Janz/Laermann 1977, str. 68.
} 
jedno s drugim“. Glumica, u potvrđivanju rodnog modela Mannweib (žene koja pokazuje muški način ponašanja, prev. s njem.), trijumfira nad grofom, u čemu se ponovo potvrđuje izokretanje tradicionalnih rodnih uloga muškarac-žena. Iako ona trijumfira $u$ vidu emancipirane žene, ipak se ne može radovati svojoj pobjedi, budući da je grofa prije rastanka „nekoliko puta poljubila, a onda ga žustro odgurnula od sebe“. ${ }^{533}$ Agresivnost, koja je bila uvjetom da se glumica ,uzdigne“ iz uloge podčinjene žene, ${ }^{534}$ a koja je pokazala svo grofovo pomanjkanje sigurnosti vezano uz tradicionalno konotirani muški identitet, zapravo se konstituira i u njezinoj želji za nadmoćnošću nad muškarcem, ali i u normativnoj društvenoj uvjetovanosti „emancipirane“ žene kojoj društveno isticanje superiornosti muškarca nad ženom nameće slijeđenje stereotipno muškog, odnosnog agresivnog, načina ponašanja. Stoga njezina spolnost biva okarakterizirana tradicionalno muški konotiranom žestinom, a ne isključivo strašću prema svom ljubavniku: „emancipaciju“ ona plaća opsesivnom željom za agresivnošću, koja joj uskraćuje trajne ljubavne veze. Prema Janzu i Laermannu, tako ona na neki način postaje većom žrtvom od grofa, jer robuje tradicionalno muški konotiranom načinu ponašanja. Glumica se opsesivno prepušta tradicionalnom muškom modelu ponašanja kako bi zaobišla psihičku i društvenu podložnost žene u patrijarhalnom društvu. Cijena emancipacije, koja u slučaju glumice prelazi u boemštinu, ovdje bi ipak bila njezino djelomično dokidanje. Želi li ona, prema Janzu i Laermannu, izbjeći ponovno zapadanje u tradicionalnu ulogu žene, koju zapravo (osim mlade žene) jedino ona u potpunosti ne želi provesti, ona to ipak čini na radikalan način: nije pošteđena od toga da se pretvori u fatalnu ženu (femme fatale). U žestini, u kojoj ona ljubi grofa, pa ga potom $u$ istom tom trenutku odgurne od sebe, izražava se sva ta ambivalencija. „Sveza spolne ljubavi i psihičke (duševne) vezanosti za osobu, koju Schnitzler barem daje naslutiti u grofu kao dijelu aristokracije, pokazuje se kao luksuz, koji si glumica zbog svoje muški konotirane grubosti, nestalnog identiteta koji joj, uostalom, nalaže i njezina profesija, ne može dopustiti““ ${ }^{535}$ Grof postupa prema glumici prema modelu aristokratske „pažnje“, koncipirajući time žensko biće kao čudnovato i zagonetno biće ${ }^{536}$, aludirajući na gotovo polu-ironičan način na stereotipizaciju ženskosti. Na njegovu rečenicu upućenu glumici: „Ali što vam ja tu pričam dosadne pričice, gospojice?“, ona mu prijetvorno odgovara: „O molim, ja se zabavljam kraljevski“. Njegova polu-ironična replika glasi: „Znate

\footnotetext{
${ }^{533}$ Vidi Janz/Laermann 1977, str. 68.

${ }^{534}$ Ibid.

${ }^{535}$ Ibid.

${ }^{536}$ Vidi prijevod, $U$ kolu, str. 86., u originalu: „Sie sind ein sonderbares Wesen...rätselhaft könnte man fast sagen.“, Reigen, str. 121.
} 
gospojice, s vama se da pričati, to mi je rekao već Lulu, a to je ono, što se rijetko nalazi““. ${ }^{537}$ Grof glumici pripovijeda o nedostatku ljubavi i sreće u svijetu, a potom na način feminiziranog esteta tvrdi da je senzualni užitak i opojnost nešto što mu pruža zadovoljstvo, dakle on ističe nešto što je trenutačno, a ne trajnu emociju, što je vidljivo u njegovoj rečenici: „Ali čim se ne... kako bih se izrazio, ali čim se čovjek ne poda momentu, dakle misli na kasnije, ili na minulo vrijeme... no, već ga nema. (...) jednom riječju...čovjek se zbrka““ ${ }^{538} \mathrm{U}$ njegovoj se koncepciji razmišljanja uočava Machovo fluidno jastvo i impresionistička letimičnost dojmova. Glumica na ironičan i ludički način povlađuje ovim riječima, namigujući mu: „Vi ste zbilja pogodili smisao“, a zatim, kako bi ga pridobila za spolni čin, što je bila i njegova prvotna taktika, na rafiniran način kaže: „Amo. Znala sam, da ćete doći danas. (...) Znala sam već jučer u kazalištu. (...) Ali, čovječe! Zar niste primijetili, da glumim samo za vas?““(...) Kad glumica na ironičan način izrazi svoje oduševljenje u trenutku kad je ugledala grofa u publici, grof joj na sličan način ironično odgovara: „Poletjeli ste? Zbog mene? Nisam imao ni pojma, da ste me opazili.“539 Glumica preuzima tradicionalno shvaćenu mušku ulogu (agresivnost i ironičnost u nastupu), dok joj grof na to odgovara: „Ali žene kao ti...ne, možeš me sto puta nazvati luđakom. Ali žene kao što si ti..." “540 a ona mu na prijetvoran, čak i drzak način laska.

\subsubsection{Implicitni rod}

Upravo zbog svog eksperimentalnog obrasca, Reigen nema strukturu klasične drame, iako naginje tipu komedije ili čak farse. Eksperimentalna struktura ove drame služi tome da se prikaže presjek rodnog (odnosno, spolnog) ponašanja muških i ženskih likova kroz različite društvene slojeve onodobne bečke kulture. U djelu nema razrješenja nekog konflikta $u$ teleološkom smislu klasičnog (i zatvorenog) tipa drame, već se prikazuju društvena manevarska ponašanja vezana uz seksualnost koja vlada likovima u djelu, tako da svaka pojedina scena Schnitzlerovog djela Reigen zapravo prikazuje konfliktnu muško-žensku

\footnotetext{
${ }^{537}$ U kolu, str. 88., „Aber was erzähl ich Ihnen da für fade Geschichten, Fräulein.“; Schauspielerin: „O bitte, ich amüsiere mich königlich“; „Wissens S, Fräulein, mit Ihnen kann man plaudern, das hat mir der Lulu schon gsagt, und das ists, was man selten findt", Reigen, str. 122.

${ }^{538}$ U kolu, str. 89., u originalu: „Aber sobald man sich nicht, wie soll ich mich denn ausdrücken, sobald man sich nicht dem Moment hingibt, also an später denkt oder an früher...na, ist es doch gleich aus. Später...ist traurig...früher ist ungewiß...mit einem Wort...man wird nur konfus.“, Schauspielerin: „Sie haben wohl den Sinn erfaßt", Reigen, str. 122-123.

${ }^{539}$ U kolu, str. 91., Schauspielerin: „Hierher. (...) Ich hab gewußt, daß sie heute kommen werden! (...) Ich hab es bereits gestern im Theater gewußt. (...) Aber Mann! Haben Sie denn nicht bemerkt, daß ich nur für Sie spiele?“, Graf: „Geflogen? Meinetwegen? Ich hab keine Ahnung gehabt, daß Sie mich bemerkten!“, Reigen, str. 123.

${ }^{540}$ U kolu, str. 92-93., „Aber Frauen wie du...nein du kannst mich hundertmal einen Narren heißen. Aber Frauen wie du...", Reigen, str. 125.
} 
seksualnost. Schnitzlerovo djelo moderni je i ciklički (donekle zatvoreni) oblik drame, u kojoj, iako se ciklički-repetitivno zatvara krug s prvim likom koji se pojavljuje u djelu, nema klasičnog jedinstva mjesta i vremena radnje, a nema ni klasičnog stupnjevanja napetosti radnje, osim kroz dijaloge likova i napetosti u njihovim rodnim odnosima (konstelacijama). Umjesto toga, demonstrira se trajno stanje likova i njihov eskapizam (svojevrsni bijeg) koji se odvija kroz spolni čin. Međutim, u Schnitzlerovoj je drami prisutno i cikličko-repetitivno ponovno „ulijevanje“ u početak drame, što dramu donekle čini i dramom zatvorenog tipa. ${ }^{541}$ Prema Manfredu Pfisteru, konstantnost ove drame postaje konfiguracija udvoje likova koji se lančano međusobno povezuju, a glavni je provodni motiv onaj spolnog sjedinjenja i niveliranja društvenih razlika što se tiče spolnog čina. ${ }^{542}$

Već je na razini konfiguracijske strukture prepoznatljivo da se ovdje ne radi o dramskom tekstu koji, shodno konvencionalnom razumijevanju radnje, predstavlja linearni tijek radnje, već se likovi izmjenjuju. Prema Pfisteru, ovaj dramski tekst karakterizira ekstremno epizodna struktura, u kojoj su svi likovi na isti način glavni, odnosno, epizodni likovi, a dokaz takve epizodne strukture je mala konfiguracijska gustoća. ${ }^{543}$

Dramska komunikacija uglavnom je usmjerena na apelativnu funkciju, budući da kroz ovu funkciju dramskog govora svaki lik želi utjecati na misli, radnje i odluke onoga drugog lika, a prisutna je i ekspresivna funkcija, s obzirom na to da se (rodni) karakter lika odražava u njegovom vlastitom govoru. ${ }^{544}$ Verbalna ironija i stilizacija govora stalne su karakteristike ove drame. Ovakva se vrsta drame približava stilu commedie dell'arte (tal.), u kojoj statični likovi i polumaske odudaraju od identifikacijskog potpunog prelaženja lika u „svoju ulogu“, pri čemu se događa svojevrsna napetost između lika i njegove (rodne) uloge. Fatička je funkcija u Kolu dijelom poremećena, budući da se među likovima događa svojevrsno otuđenje vezano na rodne odnose: svi oni kroz replike komuniciraju jedni s drugima, ali je njihova komunikacija prožeta međusobnim nepovjerenjem, iz čega izrasta kriza normativno utemeljenih rodnih odnosa.

U Schnitzlerovoj se drami Reigen autorski intendirana recepcijska perspektiva ne otkriva eksplicitno, već kroz „čitanje između redaka“ replika likova jednih prema drugima, kako bi se utvrdila njihova povlađivanja ili pak kršenja rodnih normi u svrhu postizanja cilja, te na taj način otkrio sav subverzivni potencijal ove drame. Međutim, likovi se podjednako koriste i eksplicitnim i implicitnim prikazom samih sebe, s time da se, posebice u implicitnom prikazu,

\footnotetext{
${ }^{541}$ Vidi Pfister: Das Drama, 2001, str. 140.

${ }^{542}$ Pfister 2001, str. 239.

${ }^{543}$ Ibid., str. 239.

${ }^{544}$ Ibid., str. 152.
} 
otkriva njihova hipokrizija, odnosno Doppelmoral (dvostruki moral, prev. s njem.). Jezično izražavanje varira kroz različite društvene slojeve, od onoga najbanalnijega i najvulgarnijega (npr. vojnik i prostitutka), pa sve do onoga retorički stiliziranog, gotovo kićenog, pa i klišejiziranog govora koji služi u svrhu uvjeravanja (ostali likovi). Repetitivnu elipsu u drami Reigen predstavlja izostavljanje prikaza spolnog čina. Didaskalije u drami Reigen imaju funkciju prikazivanja afektivnih stanja likova s jedne strane, a s druge strane služe prikazu interijera i eksterijera (impresionistički konotirani Stimmung, u prijevodu s njem. raspoloženje ili ozračje) prije dijaloga likova, kako bi se naznačio njihov društveni status.

\subsubsection{Zaključak}

Odnos svih likova u drami Reigen, uz svu njihovu frivolnost, sklonost hedonizmu, prijetvornost, ali i melankoličnost, ispostavlja se kao simptom esencijalnog otuđenja u rodnim odnosima koje upućuje na prolaznost užitka, ali i zavisnost ljubavnih odnosa od onodobnih društvenih normi. U deset scena u kojima se likovi susreću s jedne se strane potvrđuje dominacija muškog libida nad ženskim, dok se s druge strane izokreću uloge muškarac-žena i narušavaju obrasci normativne spolnosti (ženska ,agresivnost““ i „emancipacija“). Arthur Schnitzler, slijedeći učenja Sigmunda Freuda, prezentira nagonsku strukturu ličnosti od koje, prema Schnitzlerovom mišljenju, nije izuzet niti jedan društveni sloj, a pred snagom spolnog nagona Schnitzler donekle, u stilu ,rodne ravnopravnosti““ izjednačava ženu i muškarca. Schnitzler je u ovome djelu dao presjek seksualnosti u bečkom miljeu, na prijelazu iz 19. u 20. stoljeće, prikazavši i nijanse koje razlikuju jedan spol od drugoga i jedan stalež od drugoga. Ovisno o društvenom statusu, među spolovima se gradi ili rodna asimetrija u odnosima, gdje je više naglašen muški libido ili, s druge strane, svojevrsni pokušaj pojedinih ženskih likova za dominacijom. Hibridni rod se očituje baš u dvije predzadnje scene, u kojima se pojavljuju pjesnik i glumica, te grof i glumica, gdje cijena ženske „emancipacije“ postaje muški konotirana agresivnost glumice, dok se muškarci u ove dvije scene (pjesnik i grof) mogu okarakterizirati kao esteti s jedne strane, u kojima s druge strane prevladava doza frivolnosti i samoironije.

Treba napomenuti da odnosi muškaraca i žena u Schnitzlerovoj drami Reigen uglavnom podliježu normativnoj muško-ženskoj spolnosti, da prate obrazac rodne bipolarizacije, i da podliježu dvostrukom moralu onodobnog društva. Stoga je androginija u ovome djelu prisutna samo u tragovima i u određenim modusima ponašanja pojedinih likova. 


\subsection{Prozne crtice Petera Altenberga}

\subsubsection{Uvod}

Austrijski književnik Peter Altenberg (zapravo Richard Engländer, 1859-1919) ni u književnom ni u autobiografskom smislu nije skrivao svoju gotovo opsesivnu naklonost prema pred-pubertetskim djevojčicama. U svojoj 1901. godine pod naslovom Was der Tag mir zuträgt (Što mi donosi dan) objavljenoj zbirci proznih crtica izrazio je esteticistički stav da je cijeli njegov život posvećen ,nečuvenom oduševljenju Božjom umjetničkom tvorevinom, ženskim tijelom“. ${ }^{545}$ Altenberg je u sobi držao uramljene aktove ženskih tijela $\mathrm{i}$ povodio se za esteticističkim geslom o supremaciji ljepote, koja je za njega bila gotovo poput neoplatonističke Ideje: „Ljepota je vrlina“. ${ }^{546}$ Posebno se ističe djetinja gracilnost Altenbergovih ženskih likova, koja je i za mnoge Altenbergove suvremenike (Hugo von Hofmannsthal, Thomas i Heinrich Mann, Rainer Maria Rilke, Frank Wedekind, Arthur Schnitzler) bila najvažniji element atraktivnosti ženskog bića. „Bolećivo-hipohondrični“ pjesnik i umjetnik, koji se smatrao „spasiteljem“ i zagovarateljem ženske ljepote, osjećao se ne samo u stvarnom životu privučen djevojčicama, već je i u književnom smislu doprinio mistificiranju žene-djeteta. ${ }^{547}$ Njegov dekadentni esteticizam naglašava supremaciju ženskog tijela kao poligona za mušku, umjetničku kreaciju te je odraz larpurlartističko-narcističkog životnog stava. Za Altenberga je nezahtjevnost i „hermafroditska“ samodostatnost „malih nimfica“ estetskija od spolne zahtjevnosti i pragmatičnosti zrelih žena, koje je prijezirno opisivao. Zazor prema zrelim ženama uvjetovan je njegovom anksioznošću vezanom uz vlastitu seksualnost ${ }^{548}$ te odražava demonizaciju ženskosti potaknutu društvenom pozicijom esteta u krizi svog muškog identiteta. Strah od spolnosti senzibilnog esteta odražava se kroz dualizam duše i tijela, spiritualnog i materijalnog: Altenbergov se utopijski eskapizam zrcali u liku pred-pubertetske djevojčice koja simbolički predstavlja utopijsku alternativu pragmatičnoj građanskoj stvarnosti i pragmatizmu građanskog braka s jedne strane, a s druge strane predstavlja problematiku primarnog narcizma umjetnika koji je ,zaustavljen“ i statičan u sferi mitskog majčinskog obilja.

\footnotetext{
${ }^{545}$ Pohle 1998, str.116.

${ }^{546}$ Pohle 1998, str. 116., cit. iz: Peter Altenberg, „Selbstbiographie“ (1901), u: Ausgewählte Werke, Bd. I, str. 81-85.

${ }^{547}$ Pohle 1998, str. 116.

${ }^{548}$ Vidi Edward Timms: Dynamik der Kreise, Resonanz der Räume, Die schöpferischen Impulse der Wiener Moderne, 2013, str. 80., i str. 94.
} 
Prededipalna ženskost se, za razliku od drugih tipova ženskosti prema kojima je Altenberg gajio prijezir (posebice prema prostitutkama, „Dirne“) ${ }^{549}$ izjednačava s prirodom (Naturwesen Frau) te se postavlja kao opreka umjetniku-stvaraocu (Kunstwesen Mann), koji stvara ženu nanovo u svoj njenoj simboličnosti. U opisima tijela i odjeće djevojčica, $u$ metaforama žene kao prirode (livada, park), te u mitski konotiranoj personifikaciji žene kao Grčke posebice je vidljiva, s jedne strane, objektifikacija ženskoga koje se poima kao utjelovljenje čiste senzualnosti, a s druge strane hipostaziranje i uzdizanje žene kao utjelovljenja nečega sublimnoga što izlazi iz reprezentacijskog i simboličkog poretka. Na taj način Altenbergove djevojčice bivaju dekontekstualizirane i izjednačene $\mathrm{s}$ prirodom $\mathrm{i}$ slobodom od društvenih konvencija. Prema Freudu, umjetnik prevodi svoju nekonzumiranu ljubav prema djevojčici u umjetničko stvaralaštvo pomoću sublimacije nagona, a to odražava njegovu poziciju senzibilnog, pasivnog i receptivnog esteta.

U Altenbergovim zbirkama proznih crtica središnji je lik mnogobrojnih tekstova djevojčica u dobi između 4 i 16 godina. Svi su ti djetinjasto-ženski likovi „nježni“, ,slatki“, „blagi“ ili „nevini“, svi susreću jednog rodno-hijerarhijski nadmoćnog, starijeg obožavatelja (,,pjesnik“, „mladić“”, „sin“ i, naposljetku, ,ja“). ${ }^{550}$ Dobna razlika uspostavlja rodno-asimetričan i rodnostereotipan odnos između djevojčica i starijeg obožavatelja, dok sam odabir teme, prikaz pred-pubertetske, pred-edipalne, krhke ženstvenosti koja je u svojoj naravi androgina ukazuje na dijelom rodno-atipično veličanje djevojčica od strane senzibilnog i receptivnog esteta. Treba istaknuti da se ovakva psihološka regresija u ljubav prema pred-pubertetskim djevojčicama često u diskursu knjiga koje analiziraju problematiku u bečkoj moderni označava kao svojevrsna erotska i estetska supkultura. ${ }^{551}$

Mnoge Altenbergove prozne crtice impresionistički su deskriptivne i nemaju neku izraženu (vanjsku) radnju, pa čak niti poantu (sklonost unutarnjoj vizuri i defabularizaciji). Ono što je atipično i što dijelom odvaja Altenbergove prozne crtice od čisto „dekadentne“ književnosti njegova vremena je repetitivnost književnog motiva žene-djeteta (njem. Kindfrau). ${ }^{552}$

Prema Jens Malte Fischeru, „ono što Altenberga razlikuje od eklektičnih ezoterika Maeterlincka i Huysmansa je životno-reformističko, prema van usmjereno držanje“. ${ }^{553} \mathrm{U}$ nizu skica pod naslovom Der Revolutionär u djelu Wie ich es sehe, glavni junak ne može poreći svojevrsnu sličnost sa samim piscem. Altenbergova je „dijetetika“, nasuprot onoj

\footnotetext{
${ }^{549}$ Vidi objašnjenje Altenbergove nesklonosti drugim tipovima žena u poglavlju o Altenbergu u knjizi Jens Malte Fischera pod naslovom Fin de siècle, 1978.

${ }^{550}$ Pohle 1998, str. 116.

551 Vidi Timms 2013, str. 25.

${ }^{552}$ Vidi Pohle 1998, str. 117.

${ }^{553}$ Vidi Fischer 1978, str. 161.
} 
Huysmansovoj, jedan ipak anti-dekadentan program, koji više ukazuje na reformističke elemente o prijelomu stoljeća. Međutim, Altenbergov način života pokazuje da je patio od neurastenije, što ponovo naglašava problematiku dekadentnog umjetnika u moderno doba. Ovaj „elastični kulturni akrobat“ ovjekovječio je mitske prikaze stilizirane žene-djeteta: njegova slika žene (njem. Frauenbild) nosi pečat fin-de-sièclea. Smatrao se zagovarateljem i spasiteljem ženske ljepote, koju je smatrao vrlinom, u stilu paradigme ,umjetnost=život““. Altenberg nosi odliku esteta koji pokazuje infantilnu strukturu karaktera i infantilnu seksualnost (prema konstataciji teoretičarke Arianne Thomalla). Njegov erotizam često nosi obilježja žene-djeteta kao utočišta u mitskom svijetu umjetnosti kroz metafore ženske senzualne (fizičke) ljepote: „Nikad nisam ništa drugo u životu smatrao vrijednim doli ljepotu žene, gracilnost dame, to slatko, djetinje! A anonimnog, običnog čovjeka (njem. „Jedermann“), smatram prevarenim za život, onoga koji ovdje, na ovome svijetu, nekim drugim stvarima pridaje veću vrijednost!“. ${ }^{554}$ Altenberg se ne umara u izricanju udivljenja prema fizičkoj ljepoti žene-djevojčice, koju je štovao i veličao preko svake moralne granice, kršeći time spolne i pravne tabue građanskog društva i vremena u kojem je živio. U prikazima stilizirane žene-djeteta on se uvrštava među književnike Mladog Beča (Das junge Wien). Njegov fetišizam i voajerizam ogleda se u zapadnjačkom, okulocentričnom pogledu na ženu: oko kod njega postaje, kao odraz razmišljanja pasivnog i receptivnog, distanciranog esteta, „organom požude“. Što se tiče stava o zrelim ženama, kao i stava prema prostitutkama, njegovi se stavovi poklapaju s nazorima Otta Weiningera u knjizi Geschlecht und Charakter, u Weiningerovom poglavlju pod naslovom Sittlichkeit und Kriminalität. ${ }^{555}$ Altenberg izriče sljedeći stav: „Što se tiče „,seksualne“ strane moga karaktera, ja sam, Bogu hvala, brzo ustanovio da je ,koitus“ atavistički, povijesni, potpuno nedostatan, grub i bezdušan čin, koji ne bi mogao prirediti (prije svega) konačna blaženstva nježnoj ženskoj duši koja je sposobna zauvijek čekati na ljubav“. ${ }^{556}$ Naravno, mora se uzeti u obzir, napominje Fischer, da je ovo mjesto u Altenbergovom pismu Juliusu Muhru iz 1917. godine nesumnjivi znak neurotičnih crta Altenbergove ličnosti, ali ipak i uvid u neobičnu mješavinu svojevrsne aseksualnosti (asketizma esteta), koja nije u proturječju s umjetno intenziviranim erotizmom a koji proizlazi iz fetišističkog stava prema ženi-djetetu. Žene-djevojčice Altenberg je smatrao manje opasnim (prijetećim, demonskim) pojavama što se tiče spolnosti i pragmatizma spolnosti njegova vremena: na razini personifikacije one predstavljaju simbole ženskosti i lirske šifre, budući da

\footnotetext{
${ }^{554}$ Vidi Peter Altenberg, Was der Tag mir zuträgt, str. 10.

${ }^{555}$ Vidi Otto Weininger: Geschlecht und Charakter, 1920, str. 273-306.

${ }^{556}$ Pismo Juliusu Muhru u: Altenbergbuch, str. 283., cit. u: Fischer 1978, str. 165.
} 
predstavljaju utočište umjetnosti i odmak od rodne bipolarizacije Altenbergova vremena. Žena-dijete predstavlja simboličku uspostavu harmonije Altenbergove muškosti sa ženskošću i ojačava rodni identitet esteta, dakle, rodni identitet koji je narušen sve većom modernizacijom, individualizacijom i dehijerarhizacijom rodnih odnosa. Ljubav prema ženidjetetu, imitirajući način na koji je to činila tradicionalna kultura, istovremeno nastoji uspostaviti i hijerarhijski dominantan (opresivan) i zaštitnički odnos muškarca prema ženi, odnos koji je duboko uzdrman pojavama ženske emancipacije.

\subsubsection{Altenbergove prozne crtice}

Der Grieche

(Der Revolutionär fliegt aus dem Leben heraus)

Griechenland! Diese schwere, dumpfe Sinnlichkeit, ${ }^{557}$ ganz gasförmig gelöst in ästhetischem Empfinden! Die Materie überwunden durch das, was sie ausstrahlt- Schönheit! In Bewegung befreit! In Gracie verzaubert!

Er sass in einem Parke. Um ihn herum, auf den Wegen, in den Alleen, schwer-fällige Organisationen---Menschen!

Ein weisses Battistkleid fliegt heran---. Aschblonde, lange, offene, seidene Haare. Schlanke zarte Beine in schwarzen Strümpfen. Sie ist dreizehn Jahre alt. Man sieht oberhalb des Knie's die weissen Unterhöschen. Sie fliegt über den Weg mit ihrem Reifen. Alles federt. Olympische Spiele---!

Er starrt ihr nach. Sie wendet und fliegt vorbei. „Ah, schön---!“, haucht er. „Du bist ein Mensch“, fühlt er, „Du bewegst Dich.“

Sie kehrt langsam, in Curven, zurück. Der Reifen tanzt---tanzt.

„Ah, Dich, nackt, ganz nackt, auf einer duftenden, sammtenen Wiese im Abendschatten Reifen schlagen sehen und fliegen---fliegen! Und dann stehst Du da und wirfst in runder Bewegung die blonden Haare nach rückwärts, und wir trinken mit den Augen, diesem Liebesorgane der Künstlerseele, deinen schlanken, weissen Leib---in Schönheits-Liebe!““

Er sagte: „Fräulein, der Reifen ist ein edles Instrument---.“

„Wieso?!“ sagte das Kind-Jungfrau, „ein gebogenes Holz---. Es geht ganz leicht.“

Er sah sie an, wie man eine Edeltanne im Hochwald ${ }^{558}$ anschaut, das herrliche Schweben des Hühnergeiers auf einem Punkt über dem abendlichen Walde, einen Schwan auf einem See

\footnotetext{
${ }^{557}$ Wie ich es sehe, str. 117., S.Fischer Verlag, Berlin, 1928.

${ }^{558}$ Wie ich es sehe, str. 118-119.
} 
und ein Künstlerantlitz, wenn der Gedanke auf ihm liegt. Er sah sie an, wie man das Freie, Edle, Natürliche anschaut--in Schönheits-Liebe!

Sie flog um die grosse Wiese herum und blieb in seiner Nähe.

Sie wurde müde. Sie stand da, die Holde, leise auf ihren Reifen gestützt---und blickte ihn an.

Diana---!

Er sagte: „Sie werden sich verkühlen. Sie sind ganz nass. Sie werden bleich vom Laufen.“

„Ich bin immer blass“" sagte sie.

„Und doch scheint Bewegung Ihre Natur zu sein.“

„Ich liebe die Bewegung“, sagte sie.

Sie setzte sich auf die Bank neben ihn.

Er hatte die Empfindung: „Du bist ein Werdendes.“ Er war in Schönheits-Liebe versunken-.

Mit den Augen trank er die Schönheit dieses Menschen und berauschte sich.

Ihr Kleid duftete nach dem heissen, kindlichen Leibe. Die Haare dufteten---.

Der süsse Athem schwamm ihm entgegen--. In den Linden dufteten die gelblichgrünen Blüthen. Zwei Athem der Natur!!

Sie sass regungslos---. ${ }^{559}(. .$.

Dann stand sie auf und sagte: „Adieu. Kommen Sie morgen wieder?!“

Und Griechenland entschwand in den nebelgrauen Wiesen---.

Er blickte ihr nach: „Dich, Dich, nackt, ganz nackt, auf einer duftenden Wiese im Abendschatten Reifen schlagen sehen und fliegen--fliegen, und, wenn Du müde bist, neben Dir zu sitzen, am Waldessaum, im Abendschatten und den Duft der feuchten Walderde und der Wiese und deines Leibes einzuathmen und die Schönheit der Welt in sich einzusaugen und in diesen Schönheitskräften, die durch tausend Strahlen in's Auge, durch tausend Atome in's Gehirn dringen, zu wachsen und voll, übervoll zu werden und diese concentrirten latenten Spannkräfte in Reichthum zu empfinden und diesen Reichthum in Liebe, in Gedanken umzuwandeln und diese in Bewegung umgesetzten Kräfte neue Kraft zeugen zu lassen-unerschöpfliche, das ist „ein Lebendiger“ sein! Das!!

Aber Wir--Wir leben nicht!! 6560

\footnotetext{
${ }^{559}$ Wie ich es sehe, str. 119.

${ }^{560}$ Ibid., str. 120.
} 


\section{Prijevod Altenbergove prozne crtice „Der Grieche ${ }^{6561}($ Grk $)$}

Grk

(Revolucionar biva izbačen iz života)

Grčka! Ta troma, potmula senzualnost, posve eterično rastočena u estetskom osjećanju! Materija prevladana kroz ono što ona isijava- ljepotu! Oslobođena u pokretu! Začarana u gracilnost!

Sjedio je u parku. Svuda oko njega, na stazama, u alejama, trome nakupine- ljudi!

Bijela batistna haljinica doleti-. Pepeljasto-plava, duga, raspuštena, svilenkasta kosa. Vitke, nježne noge u crnim čarapama. Ona ima trinaest godina. Iznad koljena se vide bijele gaćice. Trči putem sa svojim kolutom. Sve odskače. Olimpijske igre-!

On zuri za njom. Ona se okrenu i proleti pored njega. “Ah, lijepo-!” uzdahnu on. “Ti si ljudsko biće", osjeća on, "ti se krećeš."

Ona se polagano vraća natrag, u krivuljama. Kolut pleše- pleše.

«Ah, tebe, golu, posve golu, na mirisnoj, samtastoj livadi u predvečerje gledati kako se igraš s kolutom i letjeti- letjeti ! I onda ti stojiš tu i zabacuješ kružnim pokretom svoju plavu kosu unatrag, i mi pijemo očima, tim ljubavnim organom umjetničke duše, tvoje vitko, bijelo tijelou ljubavi prema ljepoti ! »

On reče : « Gospođice, kolut je plemeniti instrument-. »

« Kako to ?! » reče dijete-djevica, « kolut je samo savijeno drvo-. Ide posve lagano. »

Gledao ju je kao što se gleda bijela jela u dubokoj šumi, veličanstveno lebdjenje orla na jednom mjestu ponad šume obasjane večernjim sjajem, labuda na jezeru i lice umjetnika, kad je obuzet mislima. Gledao ju je kao što se gleda utjelovljenje slobode, plemenitosti i prirodnosti- u ljubavi prema ljepoti !

Proletjela je oko velike livade i ostala u njegovoj blizini.

Postepeno se umorila. Stajala je tamo, anđeoska ljepotica, lagano obočena o svoj kolut- i promatrala ga.

Dijana-!

On joj reče: „Prehladit ćete se. Posve ste mokri. Problijedit ćete od silnog trčanja.” „Uvijek sam blijeda”, reče mu ona.

„A ipak, čini se da je kretanje u vašoj prirodi.“

\footnotetext{
${ }^{561}$ Wie ich es sehe, str. 117-120.
} 
"Volim se kretati", reče ona.

Sjela je na klupu pored njega.

Imao je ovakav osjećaj : «Ti si tek u razvoju.. » Utonuo je u ljubav prema ljepoti-.

Očima je pio ljepotu tog ljudskog bića i oduševljavao se.

Njezina je haljinica mirisala po vrućem, djetinjem tijelu. Kose su joj mirisale-.

Slatki je dah doplivao do njega-. U lipama su mirisali žućkasto-zeleni cvjetovi. Dva daha prirode !!

Sjedila je nepomično-. (...)

Potom je ustala i rekla : «Zbogom. Hoćete li sutra ponovo doći ?»

I tako je Grčka nestala u magličasto-sivkastim livadama-.

On je gledao za njom : «Tebe, tebe, golu, posve golu, na mirisnoj livadi u predvečerje gledati kako se igraš s kolutom i letjeti- letjeti i, kad se umoriš, sjesti pored tebe, na rubu šume, u predvečerje, i udisati miris vlažne šumske zemlje i livade i tvoga tijela i upiti u sebe ljepotu svijeta i u tim silnicama ljepote, koje kroz tisuće zraka prodiru u oko i kroz tisuće atoma prodiru u mozak, rasti i postati pun, prepun i te skoncentrirane latentne naponske snage osjećati u blaženstvu i to bogatstvo pretvoriti u ljubav, u misli i dopustiti da te pokrenute snage proizvedu novu snagu- neiscrpnu, to znači ,živjeti” !

To !!

Ali mi- mi ne živimo !!

\section{Prijevod Altenbergove crtice Nacht Cafe ${ }^{562}$ (Noćna kavana)}

Zašto se Cäcilia smješka kada me pozdravlja-?!

Zašto se Bertha smješka kada me pozdravlja-?!

Ali zašto tvoje slatko lice leži u tamnom spokoju kada me Ti pozdravljaš, Camilla - - -?!

Potonula - - Utonula!

Brzo je Bog u ljudskom nastajanju-progresu zamro - polako uskrsava čovjek u nastajanju Boga!

Polako - - polako.

Kamo Ti gledaš, Camilla, Ti pepeljasto plave kose, Ti nježna-- ?!

Spuštaš li svoj pogled, svoj umorni tamni pogled, u bijele dane svog djetinjstva, tada, kada si u vrtu pod voćkama zametak cvijeta zakopala i kada je tvoje cvijeće bilo tvoja sreća, tvoja ljubav- ?! Tada si Ti stajala , Ti sa svojim nježnim obličjem, sa svojim nježnim bijelim

\footnotetext{
${ }^{562}$ Wie ich es sehe, str. 141-143.
} 
ručicama i nožicama, sa svojim licem koje se činilo da će biti u svojoj čistoći posvećeno Bogu, tada si Ti stajala tamo između svojih cvjetova u svojoj nijemoj djetinjoj sreći - - -. I kako si Ti tako tamo stajala između tvojih ruža, tvojih karanfila u svojoj nijemoj djetinjoj sreći, tada je počeo jedan anđeo gore na nebu gorko plakati.

A Bog, vječno blagi otac je rekao: „Anđele, zašto plačeš ?!“ A Anđeo je pokazao prema dolje. Tada je Bog vidio jedan veliki, veliki vrt pun voćki i ispod svakog drveta je rastao jedan cvijet.

A jedna mala djevojčica sa svojim nježnim likom, sa nježnim bijelim ručicama i nožicama, sa licem koje se činilo da je posvećeno čistoći, išla je od jednog cvijeta prema drugome i nježno dodirivala latice cvjetova u svojoj nijemoj djetinjoj sreći.

Ona je stajala tamo u velikom vrtu, lijepa i sama, a njezino maleno srce je bilo puno ruža i karanfila.

Ali u daljini je ležao život, teški tamni život - - -

Stoga je Bog znao zašto je anđeo tako gorko plakao - - -

\section{Prijevod Altenbergove crtice $\mathrm{Musik}^{563}$ (Glazba)}

\section{Glazba}

Malena je svirala klavir. Imala je 12 godina i divne blage oči.

Tiho je šetao sobom, gore-dolje, gore-dolje.

Odjednom je zastao i osluškivao i bio je ganut.

Bilo je to nekoliko prekrasnih taktova koji su se uvijek ponavljali.

Mala djevojčica je iznijela sve što je bilo u toj skladbi.

Kao kada dijete odjednom postane odrastao čovjek!

Što ti to sviraš, upita gospodin.

Zašto pitaš!? To je moja Albert-etida, Bertini br. 18, kada sviram tu skladbu uvijek pomislim na tebe._- - -

Zašto - - ?!

Ne znam, to je već tako kako jest.

Kao kada dijete odjednom postane ženom!

On je išao polagano gore-dolje - - -

${ }^{563}$ Wie ich es sehe, str. 59-60., vidi također u: Das große Peter Altenberg Buch, str. 297. 
Mala djevojčica je dalje vježbala Bertini br. 19, Bertini br. 20, Bertini br. 21, 22, 23---, ali se duša nije vratila.

\section{Prijevod Altenbergove crtice Annie Kalmar ${ }^{564}$}

Rođena 1878. godine, a umrla 1901. godine.

Idealni nadgrobni natpis:

„Kao jedna od najplemenitijih paradigma stvarnih planova Stvoritelja s ovim umjetničkim djelom ,ženom“, bila si Ti, najdraža, poslana u ovu „dolinu nesavršenosti““, Annie Kalmar! A da su barem muškarci naučili biti sretni već videći slatku ljupkost tvoga osmijeha! Ali oni to nisu naučili! (...) A onda je Stvoritelj prerano uzeo svoju najplemenitiju paradigmu, pozvao je natrag k sebi, jer je ona ipak bila „nepotrebna“ među ljudima!“”

\subsubsection{Analiza}

Podrobnije ću se posvetiti analizi Altenbergove prozne crtice pod naslovom Der Grieche. Uklopljena je u niz od sedam proznih crtica Revolutionär/Studienreihe u zbirci Wie ich es sehe, objavljenoj 1896. godine. I ova se prozna crtica može razmatrati u okviru diskusije infantilizirane ženskosti.

Likovi su stariji estet i djevojčica (odnosno, Kindfrau) koju on promatra. Cijeli je tekst prozne crtice koncipiran kroz muško esteticističko percipiranje tipološke žene-djeteta, pri čemu je muškarac subjekt (a muška ispovijest i žudnja u centru razmatranja), dok je u fokusu te muške ispovijesti idealizirani lik žene-djeteta. Oba su lika koncipirana djelomice stereotipno (tipizirano), pri čemu stariji estet na kolektivnoj razini kulture bečke moderne predstavlja specifičnog esteta s obzirom na ostatak književnika-suvremenika, dok djevojčica predstavlja simbol nježne ženskosti- tipološko utjelovljenje Kindfrau i, djelomice, aristokratske femme fragile. Lik stilizirane žene-djeteta koncipiran je statično, jednodimenzionalno (tipološki), djelomično otvoreno ${ }^{565}$ a djelomično zatvoreno.

Način promatranja djevojčice stoga djelomice podliježe rodnim stereotipima, pri čemu Altenberg rabi metaforu oka kao „ljubavnog organa umjetničke duše“6566, čime se s jedne

\footnotetext{
${ }_{564}^{564}$ Wie ich es sehe, str. 284, vidi također u: Das große Peter Altenberg Buch, str. 224.

$565 \mathrm{~S}$ jedne je strane djevojčica definirana kao statični simbol, a s druge strane i sam estet naglašava njenu pokretljivost i dinamičnost kroz činjenicu izraženu sljedećim riječima: „Du bewegst dich“ i „Du bist ein Werdendes“, vidi Altenbergovu proznu crticu Der Grieche, str. 119.

566 ,wir trinken mit den Augen, diesem Liebesorgan der Künstlerseele“, Altenberg, Der Grieche, str. 118.
} 
strane djevojčicu i njeno tijelo promatra kao umjetnički fetiš (objektifikacija žene-djeteta), a s druge naglašava pasivnost i voajerizam esteta. Stereotipnost (čisto fizičkog) opisa djevojčica ogleda se i u pluralitetu i fizičkoj sličnosti likova djevojčica (i u drugim Altenbergovim proznim crticama opisana je po jedna djevojčica), s naglaskom na slavljenje pojma generičke i mitske ženstvenosti te poimanje žene-djeteta kao utjelovljenja (personifikacije) prirode i prirodnog (Naturwesen Frau). S druge se strane pak na rodno nestereotipan način naglašavaju: 1.motiv žene-djeteta koja krhkošću svog fizičkog izgleda na metaforički način simbolizira krhkost i senzibilnost (jastva) samog esteta, i 2. supremacija čisto umjetničkog, larpurlartističkog promatranja žene $\mathrm{s}$ neoplatonističkim primjesama, koja odražava problematiku razdoblja esteticizma.

Dva su glavna, međusobno povezana formalno-stilska obilježja prozne crtice Der Grieche: manjak radnje (defabularizacija uslijed naglaska na unutarnjoj vizuri esteta) i, shodno tomu, sklonost personalnoj perspektivi- postepenom empatijskom uživljavanju heterodijegetskog pripovjedača u unutarnji svijet lika, najprije mjestimično kroz slobodni neupravni govor, a kasnije preuzimanjem glasa glavnog lika, odnosno potpunom konsolidacijom s glavnim likom esteta kroz direktni prijenos njegova unutarnjeg monologa (pozicija između upravnog govora i unutarnjeg monologa). Glavni se lik djevojčici indirektno obraća, a njegove misli (imaginacija esteta) dobivaju karakter unutarnjeg monologa. Prozna crtica započinje uvodnim komentarom (evokacija estetske kulture antičke Grčke), zatim slijedi opis djevojčice i oskudni dijalog esteta s djevojčicom. Na kraju pripovijetke slijedi unutarnji monolog esteta u kojem se, uz dokidanje početne narativne distance, evocira sjedinjenje s djevojčicom unutar utopijskog prostora imaginacije: na taj način umjetnik ,narativno osvaja ženu“, s obzirom na to da cijela prozna crtica, shodno svojevrsnom galantnom kodu esteta, poprima obrazac svojevrsnog romantičkog traganja (engl. ,quest“). Postoje i malobrojne dijaloške scene, u kojima se neizravnim obraćanjem djevojčici nastoji prikriti stvarni motiv razgovora.

Perspektiva pripovijedanja je ambivalentna: autorsko-personalna, a u zadnjoj sekvenci, kad imaginacija muškog lika doseže svoj vrhunac, ona prelazi u čisto personalni vid, odražavajući unutarnje stanje (misli, imaginaciju) glavnog lika. Određena narativna distanca prisutna je sve do te zadnje sekvence ${ }^{567}$, budući da se (osim rijetkih dijaloga s djevojčicom, gdje je narativna distanca smanjena na minimum) pripovijedanje u prvom dijelu pripovijetke odvija uglavnom u 3. licu jednine, a korespondira sa stvarnom fizičkom distancom esteta od djevojčice u parku te s kulturalnom i rodno-hijerarhijskom distancom starijeg esteta od djeteta. Stoga narativna

\footnotetext{
${ }^{567}$ Osim jedne slične takve sekvence ranije u pripovijetci- repetitivni obrazac koji počinje sa evokacijom u 2. licu jednine, gdje stariji estet djevojčicu oslovljava sa „dich“, str. 118. i str. 120.
} 
distanca kroz Erlebte Rede odražava Altenbergovu (donekle) (samo)kritičku distancu od predmeta vlastitog pisanja.

Vremenski okvir prozne crtice nije pobliže naveden, no s obzirom na to da Altenbergov tekst sadrži izrazite autobiografske konotacije (ljubav prema pred-pubertetskoj ženskosti, koju je gajio i sam Altenberg) nesumnjivo se radi o razdoblju bečke moderne (o čemu svjedoči i transpsihološki izražena kritika i implicitni komentar onodobnog društva u kolektivnom obraćanju suvremenicima sa „wir" u rečenici ,Aber wir-wir leben nicht“).

Što se tiče koncepcije vremena i prostora, budući da se radnja prozne crtice odvija u parku (statični topos prirode kao utjelovljenja ženskosti), a kasnije se spominje i liminalni prostor ruba šume (njem. Waldessaum) te romantički topos predvečerja (njem. Abendschatten), Altenbergov tekst evocira i kreira ženskost kao utopijski mentalni prostor kroz unutarnju transcendenciju psihe ${ }^{568}$ umjetnika, odražavajući povučenost lika esteta u podsvjesne psihičke predjele. Sam motiv bezvremenske, asocijalno konotirane prirode i ljubavnog zanosa također nosi neo-romantičku simboliku i metaforički odražava pasivnost, receptivnost i statičnost esteta.

Narativna koncepcija vremena polarizira se između subjektivnog poimanja vremena (transcendencija unutarnjeg svijeta ${ }^{569}$ ) i mitskog poimanja vremena, u čemu participira i topos prirode, s kojim je žensko tijelo na konceptualnoj (i metaforičkoj) razini nerazdruživo povezano.

Nekoliko je provodnih motiva: 1.motiv žene-djeteta kao simbola umjetnikove narcističke ljubavi prema ljepoti i umjetnosti (pred-edipalna faza umjetničkog jastva, odnosno primarni narcizam) 2. motiv parka kao mjesta susreta esteta i djevojčice: motiv bezvremenske prirode predstavlja (rodno-stereotipiziranu) metaforu za ženskost i služi kao kontrast i kritika (građanskog) društva i društvene koncepcije vremena, 3. motiv koluta s kojim se djevojčica igra, koji nosi faličke konotacije, 4. motiv zemlje kao metafore za ženski konotiranu senzualnost, pasivnost i reprodukciju (priroda koja stvara i priroda koja je stvorena u umjetnikovom umu), i za umjetnikov povratak u majčinsko jastvo i „mitsko obilje“. ${ }^{570} 5$. stilski i tematski motiv umjetnikove kritike i ironiziranja građanskog društva i pragmatizma braka s odraslim, spolno zahtjevnim ženama.

Književni žanr prozne crtice poslužio je estetu Altenbergu u konciznom i ekstatičnom izricanju udivljenja prema jednom specifičnom idealu ženskosti, za koji je naumio

\footnotetext{
${ }^{568}$ Usp. Nünning/Nünning 2004, str. 68-89.

569 Ibid.

${ }^{570}$ Vidi Felski 1995, str. 38.
} 
senzibilizirati svoje suvremenike. Altenbergova je namjera bila na autobiografski način izraziti svoja poimanja o idealu ženskosti u jednom onodobnom književnom, modernističkom novitetu (tematski i strukturalno). Ova prozna crtica teško može skriti svoje načelno pedofilne crte, stoga pripovjedač nastoji prikriti pedofilnu problematiku (posebice $\mathrm{u}$ dijalozima $\mathrm{s}$ djevojčicom): ovakav je pripovjedni sadržaj bio proskribiran i u javnosti često osuđivan u onodobnom društvu, pa Altenbergov odabir teme (žudnja za infantiliziranom ženskošću) predstavlja društveno-kritički i subverzivni iskorak s obzirom na onodobne društvene norme. Altenbergov opus s jedne strane kritizira izrazitu rodnu bipolarizaciju, a s druge strane ipak promiče svojevrsnu rodnu asimetriju (hijerarhizaciju).

$\mathrm{Na}$ samom se početku, prije kratke evokacije antičke Grčke koja je koncipirana kao svojevrsni latentni društveno-kritički komentar pripovjedača, navodi moto koji ujedno služi kao podnaslov i provodni motiv cijele prozne crtice a on glasi: „, Revolucionar nadilazi život (život izopćuje revolucionara)“. ${ }^{571}$ Provodni motiv eskapizma, odnosno bijega od materijalistički i pragmatički konotiranih građanskih konvencija, odnosno pragmatizma stereotipne muško-ženske ljubavi i braka djelomice upućuje na gubitak sigurnosti senzibilnog esteta unutar modernog građanskog okruženja, a djelomice i na njegovu čežnju za nečim izvornim i prirodnim, sublimnim u neo-romantičkom smislu: ženskost u metafizičkim horizontima umjetnikovog uma figurira kao tajanstvena Drugost kulturi i civilizaciji, koja je konotirana kao muška, produktivna domena. Samim odabirom žene-djeteta Altenberg sebe smatra revolucionarom koji je zaobišao stereotipnost patrijarhalnih struktura građanskog društva.

Crtica započinje pripovjedačevim komentarom supremacije antičkog ideala ljepote i evokacijom stare Grčke i njene trome senzualnosti, koja se pretače u spiritualno, estetskoneoplatonističko osjećanje. Već u ovim prvim redcima pripovjedač posredno, na historicistički način, zaziva aristokratski konotirani neoplatonizam stare Grčke koji najavljuje umjetničku (i dekadentnu) pozu esteta. Na kraju pripovijetke ta je zanosna evokacija pretočenu u kulturno-pesimističko i dekadentno žaljenje zbog nedostatnosti egzistencije Altenbergovih prozaičnih suvremenika i ograničenosti njegove vlastite epohe (,Aber wir- wir leben nicht $\left.{ }^{6}\right){ }^{572}$

Zatim se uvodi glavni protagonist, lik starijeg esteta za kojeg heterodijegetski pripovjedač kaže da sjedi u parku i da je u kontrastu s (pragmatičnim i prozaičnim) građanima oko njega.

\footnotetext{
${ }^{571}$ „Der Revolutionär fliegt aus dem Leben heraus“, vidi u: Peter Altenberg: Wie ich es sehe, cijela prozna crtica od str. 117-120.

572 „Ali mi- mi ne živimo“, vidi u: Wie ich es sehe, prozna crtica Der Grieche, str. 120.
} 
Umjetnikovo promatranje djevojčice uglavnom prenosi heterodijegetski pripovjedač u formi unutarnjeg monologa i slobodnog neupravnog govora, samo mjestimično u prezentu, a većinom u epskom preteritu. Uz to još postoje i kratke dijaloške sekvence umjetnika $\mathrm{i}$ djevojčice (u upravnom govoru), te dvije imaginarne invokacije, jedna u središnjem dijelu, druga na kraju crtice; izravno ekstatično obraćanje umjetnika djevojčici u 2. licu jednine i u glagolskom vremenu prezentu, u vidu unutarnjeg monologa koji odražava onodobnu poziciju pasivnog i receptivnog esteta.

Radnja je (osim kratkih dijaloga glavnog lika, starijeg esteta, s djevojčicom) uglavnom orijentirana na fetišističke opise djevojčina tijela (kosa, odjeća, noge), u kojima glavni lik percipira ženu i žensku ljepotu. U središnjoj, a potom i u zadnjoj (djelomice repetitivnoj) sekvenci djela, u tim direktnim evokacijama djevojčice, koncipiranim kao svojevrsni unutarnji monolog esteta, struktura (sublimirane i kontrolirane) žudnje nalazi se na poziciji između muški konotiranih fantazija svemoći (njem. Allmachtphantasien) ${ }^{573}$ i ženski konotirane jouissance, odnosno evokacije beskrajnog erotskog zanosa.

U opisima djevojčice vidljiva je izrazita objektifikacija ženskog tijela, čime se žensko biće stavlja izvan muški konotirane kulture i civilizacije (društvena dekontekstualizacija ženedjeteta), te ono postaje metafora za izricanje onoga što je načelno neizrecivo: žena se, unutar romantičarsko-neoplatonističke čežnje esteta, pretapa u apstraktni pojam prirode i sublimnoga. U građenju takve koncepcije žene služi i svojevrsna imitacija trubadurskog poetskog izricanja udivljenja prema idealu ženskosti.

$\mathrm{Na}$ početku prozne crtice, kad je stariji estet ugledao djevojčicu, ona nije opisana kao biće, već kao predmet u vidu sinegdohe (njem. „ein weißes Batistkleid fliegt heran“). Daljnji opisi slijede ovu objektifikaciju ženskosti, budući da se estet fetišistički usredotočuje na pojedine dijelove djevojčina tijela i odjeće, koji su u vidu metafora i sinegdohe (pars pro toto) vizualno prikazani na sljedeći način: „pepeljasto plava, duga, raspuštena, svilenkasta kosa“, „vitke, nježne noge, crne čarape“, „ona ima 13 godina“, „iznad koljena se vide bijele gaćice“, „tvoje vitko, bijelo tijelo“6774, zatim slijedi usporedba djevojčice s prirodom i iskonskom, nepatvorenom, djetinje nesputanom (slobodnom), neokaljanom (djevičanskim) i mitskom ženskosti u nizu personifikacija. Altenberg veliča fizičku ljepotu djevojčice, personificirajući

\footnotetext{
573 „,...und fliegen-fliegen“; , und die Schönheit der Welt in sich einzusaugen und in diesen Schönheitskräften (...) $\mathrm{zu}$ wachsen und voll, übervoll $\mathrm{zu}$ werden und diese concentrierten latenten Spannkräfte in Reichthum $\mathrm{zu}$ empfinden und diesen Reichthum in Liebe, in Gedanken umzuwandeln und diese in Bewegung umgesetzten Kräfte neue Kraft zeugen zu lassen- unerschöpfliche...", Altenberg: Wie ich es sehe, str. 120.

574 „Aschblonde, lange, offene, seidene Haare“, „schlanke, zarte Beine in schwarzen Strümpfen“, „sie ist dreizehn Jahre alt“, „man sieht oberhalb des Knie's die weissen Unterhöschen“, „deinen schlanken, weissen Leib“, Altenberg, Wie ich es sehe, str. 118.
} 
ju u vidu stare Grčke (,und Griechenland entschwand in den nebelgrauen Wiesen“ (njem.) ${ }^{575}$, usporedivši djevojčicu s mitskom boginjom Dijanom, koja ujedno simbolizira nesputanost i androgini oblik djevičanstva (androgina samodostatnost). Metafora „Du bist ein Werdendes“ simbolizira rodnu poziciju žene-djeteta koje je ,tek u razvoju“, a na općenitoj razini tumačenja aludira i na stereotipno shvaćeni položaj žene u povijesno-antropološkom razvoju, za koju se smatralo da se biološki nalazi na pola puta između muškarca i djeteta.

$\mathrm{Na}$ kraju prozne crtice slijedi umjetnikovo ,uranjanje“ $\mathrm{u}$ ženski princip, u kojem on u svojoj imaginaciji simulira duhovno i tjelesno sjedinjenje s djevojčicom. Ovo je „sjedinjenje“ $u$ umjetnikovoj imaginaciji opisano bujnom, gotovo orgijastičkom metaforikom, ${ }^{576}$ koja naznačuje, prema Freudovim tumačenjima, sublimaciju umjetnikovih (Kulturwesen Mann) kulturno neprihvatljivih nagona $u$ umjetničko stvaralaštvo i time odražava poziciju senzibilnog i pasivnog esteta.

Prema riječima teoretičarke Bettine Pohle, ,pod krinkom umjetničke ljubavi prema ljepoti i dekadentnog žaljenja svakodnevne prozaične egzistencije, umjetniku o prijelomu stoljeća postaje mogućim izraziti književnoj publici svoju opsesivnu fascinaciju ženskošću na pragu puberteta, publici koja je dobro upoznata $\mathrm{s}$ formulaičnom upotrebom različitih slika o ženi. “577

Usklične rečenice u pripovijetci odražavaju umjetnikovo stanje zanosa dok promatra djevojčicu. Obožavanje žene-djeteta donekle se približava dvorsko-srednjovjekovnom konceptu (shodno analizi Bettine Pohle), dok je sama tematika galantne ljubavi umjetnika prema djevojčici bliža renesansnom poimanju, koje ističe slavljenje života i ljubav prema (fizičkoj, dijelom senzualno, a dijelom neoplatonistički koncipiranoj) ljepoti. Ovakvo slavljenje senzualnosti žene još se kreće u okvirima standardnog i stereotipnog poimanja ženskog tijela kao dijela prirode, dok je, s druge strane, koncepcija lika djevojčice kao aseksualne $\mathrm{i}$ androgine nimfe ipak djelomice odvojiva od onodobnih stereotipnih prikaza Ženskosti i kao avangardni novitet predstavlja eskapizam umjetnika.

Altenberg za mjesto radnje odabire park, koji ima simboličnu vrijednost umjetnikova otpora svakodnevici i pragmatičnom društvenom ustrojstvu njegova vremena. Slavljenje efekta „istinske ljepote“ dijelom je narcistički konotirano, budući da se u pripovijetci pojavljuje i sintagma Schönheitsliebe (ljubav prema ljepoti, prev. s njem.), a ona odražava larpurlartističku ljubav umjetnika prema vlastitoj kreaciji (umjetnosti) i najavljuje

\footnotetext{
${ }^{575}$ Altenberg, Wie ich es sehe, str. 120.

${ }^{576}$ Vidi također komentar Bettine Pohle na str. 120-121. u knjizi Kunstwerk Frau, 1998.

${ }^{577}$ Pohle 1998, str. 121.
} 
problematiku pasivnog (bezinteresnog) promatranja ljepote. U tom je smislu lik senzibilnog esteta u Altenbergovoj pripovijetci-crtici djelomice odraz hibridnog roda, jer ga ne vodi isključiva, pragmatična žudnja za konzumacijom ljubavi s ženskim bićem (latentna kritika rodne bipolarizacije), već estetika „bezinteresnog“ promatranja djevojčice, njegovu konverzaciju sa svojim vlastitim mislima. Pripovijetka je izrazito utopijski i eskapistički konotirana, i to kroz dva vida: 1. ženu i žensko tijelo, koji predstavljaju mitsko obilje, otkupljujuće (majčino, žensko) tijelo i utopijski potencijal pred prijetnjama beznadnog pluralizma i moderniteta epohe, i 2. Altenbergov primarni narcizam i odvajanje od društvenog svijeta, koji uvjetuju to da umjetnik djevojčicu koncipira isključivo kroz svoje vlastite misli (svojevrsni unutarnji monolog esteta izražen kroz direktnu evokaciju djevojčice od strane glavnog lika, uz smanjivanje narativne distance).

Odabir anti-stereotipnih, androginih žena u vidu pred-edipalnih djevojčica, s druge strane, predstavlja problematiku primarnog narcizma pasivnog i senzibilnog esteta, odnosno zaustavljanja umjetnika $\mathrm{u}$ vlastitom pred-edipalnom svijetu mističnog zaljubljenika $\mathrm{u}$ umjetnost i ljepotu, odražavajući donekle njegovu nemogućnost premošćivanja vlastite prededipalne faze ${ }^{578}$, ali također i uzimanje artističke slobode od konvencija u izricanju umjetnikove ljubavi prema vlastitom idealu i njegove težnje da stvori utopijski konotiranu Ženskost $\mathrm{i}$ harmoniju vlastitog jastva.

Fetišizam kod Altenberga ima obilježja androgine konstitucije umjetnikovog uma, gdje fetišizam služi kao simptom feminizacije esteta ${ }^{579}$ i predstavlja mušku „kompenzaciju“ za ženske stvaralačke (reproduktivne) moći. Budući da se žensko biće općenito iz muške vizure smatra kao „kastrirano“, odnosno, vizualno se primjećuje falički „nedostatak“ koji ženskost obilježava manjkom i razlikom, muškarac nastoji tu razliku kompenzirati pridajući ženi neke „dodatne“ karakteristike, fokusirajući se na pojedine dijelove ženskog tijela (fetišizam). Time žensko biće s jedne strane dobiva status „objekta“ dok biva konstituirano unutar muške vizure i muškog (umjetničkog) jastva, dok, s druge strane, muškarac svojom internalizacijom ženskih karakteristika (,simbolička maternica“) nastoji regenerirati vlastitu ženskost, a u Altenbergovom slučaju, vlastito ženski konotirano pred-edipalno stanje esteta.

Koncepcija hijerarhijski nadmoćnog umjetnika (njem. Kulturwesen Mann) naspram ženskog lika koji se tradicionalno i stereotipno povezuje s prirodom i statičnošću (njem. Naturwesen Frau) može se također povezati s koncepcijom umjetnika kao genija koji posjeduje kreativne

\footnotetext{
${ }^{578}$ Usp. Kristeva: Powers of Horror, 1982.

${ }^{579}$ Usp. Krafft-Ebing: Psychopathia sexualis (1898) (1993), u poglavlju o fetišizmu.
} 
(stvaralačke) moći: Le Rider posebice govori o Weiningerovskom pojmu genija ${ }^{580}$ koji se, budući da istodobno uz kreativnost demonstrira i krhkost svoga jastva, ${ }^{581}$ približava ženskom i time demonstrira radikalni oblik feminizacije jastva. Prema Weiningerovim riječima, „ova krhkost jastva ocrtava pjesničkog genija, koji se, budući da je otvoren svijetu i Drugosti, sastoji isključivo od senzibilnosti““: ${ }^{582}$ Altenbergove se zanosne, dekadentno-esteticističke i gotovo mistične evokacije ljepote ženskog tijela na kraju prozne crtice ulijevaju u postepeni gubitak njegovog jastva, verbalno izražen kroz „orgijastičku““583, dionizijski konotiranu metaforiku koja je sublimirana u gotovo narcističku „ljubav prema ljepoti“ (Schönheitsliebe), kao i ljubav prema ljepoti vlastitog umjetničkog izričaja. Heterodijegetski pripovjedač sada, smanjivši narativnu distancu od predmeta svog prikaza i gotovo se poistovjetivši s likom bolećivog esteta ili „lijepog duha“ (odnosno, njem. Schöngeista) u pripovijetci, direktno prenosi unutarnji monolog esteta, o čemu svjedoči dokidanje distance između pripovjedača $i$ lika i direktno obraćanje esteta djevojčici u 2. licu jednine. Treba uzeti u obzir da, budući su ovakve gotovo pedofilne evokacije djevojčica u cijeloj Europi bile nedopustive, bečka moderna dijelom odudara od ostatka Europe. Edward Timms progovara o tome da su u Austriji djevojčice u dobi od 14 godina već slovile kao spolno zrele: da tomu nije bilo tako, Altenbergovo veličanje pubetetskih, pred-edipalnih djevojčica ne bi bilo javno prihvatljivo. ${ }^{584}$ Altenbergov se prozni izričaj približava ženski konotiranoj struji svijesti: ženski konotirana orgijastička metaforika približava se ženskoj ,jouissance“, budući da estet gubi kontrolu nad sobom i svojim izričajem. S druge strane, ovakav izričaj predstavlja i hijerarhijsku nadmoć esteta (predstavnika kulture) nad ženom-djetetom (koja simbolizira ženski konotiranu prirodu), budući da se tematizira pojam umjetnika kao stvaraoca (muške stvaralačke moći, muške reproduktivne moći i muškog užitka u osjećaju ljepote i ljubavi). Element muške imaginacije odvaja umjetnika od konvencionalnog građanskog društva i svrstava ga u ženski konotiranu privatnu sferu, naglašavajući njegovu crtu iracionalnosti i pasivnosti.

\footnotetext{
${ }^{580}$ Usp. Weininger: Geschlecht und Charakter, 1920.

581 Vidi formulaciju Johna Keatsa iz 1818. godine citiranu u: Le Rider, 1990, str. 115.: „Wenn ich mich mit anderen Leuten in einem Raum aufhalte und überhaupt davon frei bin, an die Schöpfungen meines eigenen Verstandes zu denken, dann kehrt mein Ich nicht zu sich selbst zurück, sondern die Identität eines jeden im Raum beginnt einen Druck auf mich auszuüben, sodaß ich in sehr kurzer Zeit vernichtet bin“. (,When I am in a room with people if I ever am free from speculating on creations of my brain, then not myself goes home to myself, but the identity of everyone in the room begins to press upon me, so that I am in a very little time annihilated"), usp. David D. Perkins, English Romantic Writers, New York 1967, str. 1220.)

582 Vidi Weininger 1920, str. 240., cit. u Le Rider 1990, str. 115-116.

${ }^{583}$ Vidi Pohle 1998, poglavlje o Peteru Altenbergu, str. 116-121.

${ }^{584}$ Vidi Timms, 2013, str. 81.
} 
Altenberg u sljedećoj crtici, odnosno proznoj skici pod naslovom Nacht Café, tematizira bolan proces odrastanja iznimnog i senzibilnog (ženskog) bića, koje je uvjetovano stanjem ženskog narcizma (Freudov pojam ženskog narcizma). ${ }^{585}$ On suprotstavlja ovaj proces socijalizacije zlatnom dobu djetinjstva, u kojem djevojčica još pokazuje androginu samodostatnost, koja je simbolički prikazana kroz lik anđela. Altenberg djevojčicu, odnosno mladu ženu poima onako kako umjetnik poima žensko biće, na jedan rodno-senzibiliziran način. Altenberg promatra mladu ženu, kojoj se u očima nazire tuga, i, poput senzibilnog esteta, shvaća i internalizira problematiku melankolične i samozatajne ženskosti. Nježnoj i samotnoj ženskosti, kojoj je androgini lik anđela jedini pan-dan (ekvivalent), odnosno jedino biće koje djevojčicu istinski razumije, pripovjedač-umjetnik suprotstavlja muški konotiranom, agresivnom progresu, rodnoj bipolarizaciji i procesu socijalizacije, koji sa sobom donosi „teški, tamni život“. Anđeo predstavlja utjelovljenje bezvremenske ljepote i dobrote, ženski konotiranu intuiciju, a simbolizira i nježnost ženske psihe, budući da ga se može povezati s majčinskim i mitskim obiljem. ${ }^{586}$ Cvijeće općenito simbolizira ženski konotiranu prirodu, odnosno vegetativni ciklus rađanja i umiranja, dok ruže simboliziraju božansku ženskost i Kristu sličnu patnju, koja odražava habitus nježne ženske psihe unutar modernog doba beznadnog pluralizma, a koju umjetnik veliča na sebi svojstven način. Motiv karanfila pojavljuje se i u Hofmannsthalovoj pripovijetci Das Märchen der 672. Nacht, u kojoj taj motiv predstavlja čežnju esteta za nekom idealnom, bezvremenskom ženskošću. Pripovjedač na samom početku pripovijetke prezentira razlike među ženskim iskustvima, budući da sudbine dviju žena koje susreće (Cäcilia, Bertha) ne nalikuju sudbini treće žene (Camilla). Pripovjedač-estet, budući da je rodno senzibiliziran, odmah uočava ove razlike u sudbinama žena, internalizirajući i sam žensku problematiku u svoj habitus umjetnika-esteta. Ova se kratka crtica sastoji od pripovjedačevih „dijaloga“, pa i svojevrsnih monologa (retoričkih pitanja) sa ženskim bićem (Camilla), u kojima on na transpsihološki način tumači habitus senzibilne ženske psihe, koja je još ostala u svojoj pred-edipalnoj fazi, odnosno fazi primarnog narcizma.

Pripovjedač u kratkoj crtici pod naslovom Musik tematizira starmalost djeteta, odnosno djevojčicu odviše zrelu za svoju dob, koja se bolje osjeća u društvu od sebe starije muške osobe, a koju ona poima kao svojevrsnog zaštitnika. Međutim, u ovoj crtici Altenberg ipak kritizira muški karakter naspram ženske suptilnosti. Tematika ove crtice prvenstveno

\footnotetext{
${ }^{585}$ Vidi Le Rider 1990, str. 91-94.

${ }^{586}$ Vidi Felski 1995, str. 38.
} 
predočava prijelaz djeteta (djevojčice) iz njenog prededipalnog stanja primarnog narcizma, $\mathrm{u}$ kojem je ona još činila cjelinu s vlastitim identitetom (dušom) u stanje žene. Ova crtica predstavlja prijelaz još androginog djeteta (djevojčice) u ženu.

U svojoj kratkoj crtici o Annie Kalmar (naslov: Annie Kalmar) Altenberg naglašava ženu kao umjetničko djelo, kao savršeni plan Boga-stvaraoca-umjetnika te nesumjerljivost umjetnikovog poimanja žene sa dolinom nesavršenosti, pri čemu Altenberg u ovoj metafori ipak na neki način (re)producira rodne stereotipe, iako se donekle kritički distancira od strane „običnih“ muškaraca (u ovom slučaju njegove prijateljice ili poznanice Annie Kalmar). Sama Altenbergova kritika muškaraca njegovog vremena, bilo da se radi o muškoj grubosti ili o muškoj slabosti, demonstrira njegova shvaćanja, te apostrofira pojam senzibilne (nježne) žene za koju nema mjesta u beznadnom pluralizmu modernog doba.

U crtici o Annie Kalmar Altenberg pretpostavlja Stvoritelja-senzibilnog umjetnika običnom čovjeku, pri čemu i sam Altenberg kao umjetnik u svojoj nutrini osjeća njenu žensku bit, te poima njenu samoću kao pokušaj odvojenosti od ili pak nadilaženja grube stvarnosti (Altenbergova kritika agresivne, ali i pasivne muškosti njegova vremena). Ovime Altenberg pokazuje svoju želju za ravnopravnošću žena i muškaraca.

\subsubsection{Zaključak}

Richard Engländer (alias Peter Altenberg) demonstrira ambivalentnu mješavinu veličanja ženskosti s jedne, i demonizacije ženskosti s druge strane. Usprkos svojoj sanjarskoj i utopijskoj izgradnji vlastitog ideala žene-djeteta, Altenberg izriče sljedeći, generalni stav o ženama: „Žene su genijalno vješti razaratelji naše životne energije (...)“. ${ }^{587}$ Ovaj Altenbergov generalni stav o ženi u Weiningerovskoj maniri naslućuje se i u Altenbergovom dopisu Krausu povodom smrti Annie Kalmar, u kojem Altenberg uz tugu izražava i svoj stav o ženi kao prirodno lijepoj, ali orijentiranoj isključivo na spolnost i na animalno: „Vaša kukavička filozofija o ženi koja mora biti voljena isključivo ako može seksualno usrećiti muškarca!!! ‘588 Ovaj Altenbergov stav zapravo negira činjenicu da su uglavnom tradicionalni oblici muške spolne žudnje prema ženi i muško veličanje ženske senzualnosti i fizičke ljepote uzroci stereotipno koncipiranom ženskom stavu da nužno „mora seksualno usrećiti“ muškarca.

\footnotetext{
${ }^{587}$ Cit. prema Camillo Schaefer: Peter Altenberg oder Die Geburt der modernen Seele, Wien-München 1992, 65.str. i dalje, cit. u: Elfriede Wiltschnigg, Das Rätsel Weib, Das Bild der Frau in Wien um 1900, 2001, str. 200. ${ }^{588}$ Wiltschnigg, 2001, str . 201.
} 
Altenbergov je izlaz i otklon od demonske i prijeteće ženskosti izgradnja mita o ženi-djetetu koja predstavlja njegov eskapistički ideal, kako sam naglasila u prethodnoj analizi, gracilni, vitki i androgini prototip žene, koji je uočio na slikama Gustava Klimta: njegov ideal žene bile su prije svega mlade djevojke ili djevojčice u kojima se još nije probudio spolni impuls, a koje su odgovarale njegovoj predodžbi o gracilnosti i ljepoti: ${ }^{589}$ „Nikad nisam ništa drugo u životu smatrao vrijednim doli ljepotu žene, gracilnost dame, to slatko, djetinje!“590 Ovo poistovjećivanje ljepote s androginom Kindfrau, koja predstavlja suprotnost zrelim, spolno zahtjevnim ženama, nosi u sebi također imperativ generičke ženske ljepote, koja se kod umjetnika Altenberga svodi na isključivo vizualno promatranje žene, kreiranje žene kao prirodnog bića (Naturwesen), senzualnog i fizičkog bića. Poimanje žene (i žene-djeteta) isključivo kroz prizmu fizičke ljepote predstavlja svojevrsnu objektifikaciju ženskog bića i prema tumačenjima teoretičarke Bettine Pohle služi kao paravan za uzdizanje umjetničkog ega i promicanje stereotipno muške žudnje prema ženi; pa ipak, ova je objektifikacija i hipostaziranje ženskog lika također odraz poetskog senzibiliteta, receptivnosti, ali i krhkosti (muškog) umjetnika i krhkosti umjetnikovog jastva, odraz želje da se poetizira surova i pragmatična stvarnost umjetnikova vremena. Zrele žene s pragmatičnim i seksualnim prohtjevima ispunjavale su Altenberga- kao i mnoge njegove suvremenike- osjećajem nelagode i jeze. ${ }^{591}$ Altenbergovi opisi Klimtovih slika žena ubrajaju se u značajne dokumente umjetničkih razmatranja vremena oko 1900. godine u Beču. Tako on, promatrajući Klimtove slike žena, piše:

ovi su ženski portreti kao krajnje tvorevine najnježnije romantike prirode. Kao što ih pjesnici zamišljaju, nježna, krhka stvorenja nježnih udova, za njihove najnježnije zanose koji nikada ne iščezavaju i nikada ne nalaze spasenje! Njihove ruke izraz su ljupke duše, djetinje, sanjarske duše, plemenitosti i dobrote! Sve one se nalaze izvan dosega sile teže (...) Sve su one princeze, stvorene za bolje i nježnije svjetove. (...) To su trenutci za umjetnika. Tako on poima ženu! Zureći u otajstvo (zagonetku) bitka, on je ponosan, nepobjediv pa ipak već tragično tužan i povučen u sebe! ${ }^{592}$

U mnogim svojim kratkim crticama Peter Altenberg tematizira ženu i ženskost, posebice specifičnu prirodu senzibilnih žena koje su bliske njegovom habitusu umjetnika. On promatra ženska bića općenito sa stajališta pjesnika, naglašavajući esencijalnu osamljenost femme fragile.

Za Altenberga poetski nastrojeni pojedinci (bilo da se radi o ženama ili muškarcima) nadilaze građansku svakodnevnicu: „Knjige pjesnika su poput zvijezda. Tako beskonačno

\footnotetext{
${ }^{589}$ Wiltschnigg, 2001, str . 201.

${ }^{590}$ Vidi Pohle, 1998, pogl. o Altenbergu, str. 116-121.

${ }^{591}$ Wiltschnigg 2001, str. 201.

592 cit. u Wiltschnigg 2001, str. 201., Altenberg, Kunstschau (1908), cit. prema Nebehay, Gustav Klimt, str. 423.
} 
daleko od nas. Pa ipak, one svjetlucaju“. ${ }^{593}$ Altenberg naglašava kult umjetnosti (larpurlartizam) i izjednačava kult umjetnosti sa ženskom ljepotom: „Umjetnost je umjetnost, život je život, ali živjeti život na umjetnički način, to je umijeće života. Želimo umjetnost povezati sa svakodnevnicom“. 594

Altenberg ženu poima kao Stvoriteljevo umjetničko djelo (njem. ein Kunstwerk Gottes), pri čemu on izjednačava umjetnika sa Bogom-stvoriteljem, ističući iznimnog i suptilnog umjetnika- stvaratelja koji duboko shvaća (internalizira) žensku suptilnost. Naglašavanjem vizualnog pri promatranju ženskog bića Altenberg ipak donekle podliježe fetišizmu i objektifikaciji ženskog bića, budući da se (u većini ostalih njegovih crtica) fokusira isključivo na izvanjsku ljepotu žene, mahom djevojčica.

\subsection{Hermann Bahr: Die Mutter (Majka)}

\subsubsection{Uvod}

Hermann Bahr je svoju dramu Die Mutter (Majka) objavio 1891. godine. Drama se sastoji od 3 čina. Konflikt u drami proizlazi iz psiholoških stanja 3 glavna lika (Edi, majka Fredegonde i Terka) i jednog sporednog lika (homoseksualni klaun) koji predstavlja satiru onodobnog kulturnog života (svijeta). ${ }^{595} \mathrm{U}$ Bahrovoj se drami radi o njegovom mladenačkom, zaboravljenom kazališnom komadu. Osim toga, Bahr je bio plodan dramatičar, ali nisu ostala njegova djela: komadi i romani, nego uglavnom eseji i programatika.

Radi se o svojevrsnom Bahrovom satiričnom prikazu onodobne dekadencije, no istodobno ovo djelo predstavlja Bahrov afirmativni prilog dekadentnoj modi. U ovom djelu, prožetom perverznim i dekadentnim idejama, Bahr je upotrijebio svu svoju moć imaginacije u prikazu eksperimentalnih rodnih konstelacija: poigravajući se ekstremnim koncepcijama hibridnih rodnih identiteta i rodnih odnosa, Bahr izriče djelomice ironijsku kritiku fin-de-siècleovske dekadencije, ali i kritiku onodobnih rodnih polariteta: Bahr također kritizira stereotipno poimanje muškosti i ženskosti. Ova sublimna igra hibridnih rodnih odnosa i rodnih identiteta prikazuje dekadentne, esteticističke i groteskne likove, koji su dijelom individualistički, a dijelom tipološki koncipirani, a čiji rodni identitet odstupa od njihove žudnje: neurastenični sin (Edi) patološki je ovisan o majčinoj lezbijskoj ljubavnici (Terki), koja predstavlja femme

\footnotetext{
${ }^{593}$ Wie ich es sehe, str. 277.

594 Ibid., str. 294.

595 Vidi analizu djela Die Mutter: Lacko Vidulić: Sprachkunst, Beiträge zur Literaturwissenschaft Jahrgang XXIX/1998, 1. Halbband, Wien 1998, Verlag der österreichischen Akademie der Wissenschaften: Dramaturgie des ,,Supranaturalismus“, zu Hermann Bahrs Die Mutter, 1998, str. 24.
} 
fatale i pripada polusvijetu ${ }^{596}$, a dijelom je ovisan i o vlastitoj majci, te je dramski koncipiran kao dendijevski lik feminiziranog esteta koji naginje čak i ženski konotiranoj koncepciji histerije. Treba također naglasiti da Bahrovo djelo Die Mutter ,,potječe iz njegove pariške faze, što je odgovaralo njegovom dinamičnom duhu, a koje su Bahrovi suvremenici žestoko napali, a nije bila do kraja rastumačena ni kroz kasnije germanističko istraživanje“ ${ }^{597}$ Drama varira između naturalističke poetike, i tzv. „Nervenkunst ${ }^{\text {‘598 }}$ (prev. s njem. „kulture živaca“, budući da ova fraza označava neurasteniju). U drami je također zamjetljiva izrazita individualizacija likova, koji su opisani kroz svoja duševna stanja (njem. Seelenstände). ${ }^{599}$ Pedantno iscrtavanje scenskog prostora, uvodna karakterizacija likova i precizno protokoliranje njihovog verbalnog i neverbalnog ponašanja elementi su epiziranja sporednog teksta. No Bahr ipak djelomično oponira naturalizmu, te razvija svoj stil iz eklekticizma književnih pravaca simbolizma, dekadencije i fin-de-siècle-a.

\subsection{2. $\quad$ Eksplicitni rod}

Drama Die Mutter obrađuje temu straha od ženskosti koja je groteskno izrečena mišlju da „ljubav uništava muškarca“ i da su „sve žene ubojice muškaraca“, naglašavajući time čest stav o prijelomu stoljeća da žena i ženskost predstavljaju Drugost, odnosno demonsku, iracionalnu stranu. Višeslojnost i polifonost ove drame sastoji se upravo u gotovo neplauzibilnim i ishitrenim rodnim konstelacijama, u kojima je, s jedne strane, sin Edi, iako opsesivno zaljubljen u Terku, bivšu lezbijsku ljubavnicu svoje majke, zapravo također opsjednut željom za majčinom pažnjom, dok je, s druge strane, majka lezbijka ,pretjeranom ljubavlju“ usmrtila svoga muža, pa svome sinu savjetuje da se kloni žena. Razlog ove pretjerane majčinske „pažnje“ je taj što majka Fredegonde time nastoji sačuvati „svoga tjelesno nejakog sina od iste sudbine koja je zadesila njegovog oca. “600 Traži savjet i podršku od svoga prijatelja, homoseksualno orijentiranog cirkuskog klauna, i nada se da će njegovo ponašanje postati uzor njezinom sinu kako sin jednog dana ne bi pretrpio istu sudbinu kao njegov otac. Sin se, doduše, već zaljubio u lezbijsku partnericu svoje majke, Terku. Budući da Edijeva majka nije u stanju spasiti svoga sina iz ralja njegove ljubavnice, Terke, ona pretuče ili ubije Terku u očajničkom pokušaju da spasi sina. Međutim, njezin se očajnički čin

\footnotetext{
${ }^{596}$ Lacko Vidulić, 1998, str. 21.

${ }^{597}$ Ibid., str. 17-18.

${ }^{598}$ Ibid., str. 18.

${ }^{599}$ Ibid.

${ }^{600}$ Daviau 1984, str. 82.
} 
ispostavlja uzaludnim: iako Fredegonde dovodi sina natrag kući, on ipak umire u histeričnom napadu, očajnički pokušavajući vratiti Terku.

Ova je pripovijest puna motiva ekstremnih demonskih strasti i seksualnih perverzija ${ }^{601}$, koje se očituju i kroz provodni motiv drame, a to je patološka majčina ljubav prema sinu i mužu, te patološka želja majčine bivše ljubavnice da se osveti Edijevoj majci time što će joj oduzeti sina. Ova drama trivijalno-satiričnog karaktera prikazuje psiho-patološku konstelaciju odnosa $^{602}$ : činjenicu da je Fredegonde ubila vlastitog muža, pa onda tu „ljubav“ prema mužu zbog iste te patnje transformirala u previše prisan odnos sa sinom, te da je njezina lezbijska partnerica ujedno i partnerica njezinog sina, koji je prije nje imao druge partnerice, a potom na paradoksalan način umire zbog neuzvraćene ljubavi svoje agresivne partnerice (Terka). Također se u djelu pojavljuje i motiv ljubičaste boje, koji predstavlja homoeroticizam, dendizam (Edi predstavlja prototip senzibilnog dendija) i dekadenciju. Bahr u ovoj drami, koristeći izrazito artificijelne i eksperimentalne, hibridne rodne konstelacije, na pomalo ciničan $\mathrm{i}$ ironičan način želi preispitati postojeće fin-de-siècleovske rodne konstelacije i slobodu u kreiranju i re-kreiranju rodnih odnosa i rodnih identiteta.

U ovoj Bahrovoj rodno-subverzivnoj groteski tematizira se iracionalna ženska priroda, koja postaje pogubnom za muškarca (Edijeva majka postaje pogubnom za Edijevog oca, a Terka postaje pogubnom za Edija). Neurotičnost majke, ali i Terke, patološka je crta; međutim, ovaj je pojam također povezan i s onodobnom predodžbom o histeričnom karakteru ženskog bića. ${ }^{603}$ Za Edija je karakterističan mazohizam, budući da odabire ženu (Terka) koja pripada polusvijetu, a usto je još i bivša lezbijska ljubavnica njegove majke. Terka se sadistički ponaša prema Ediju, time iskazujući bijes i osvetu prema Edijevoj majci, koja ju je napustila udajom za Edijevog oca. Općenita i fluidna teza ovog grotesknog Bahrovog djela, u kojoj sama majka (glumica Fredegonde, koja predstavlja glavni lik u djelu), izriče stav kako „ljubav uništava muškarca“, može se povezati kako s onodobnom problematikom ženskog pojma histerije (kojoj Edijeva majka naginje), tako i s gubitkom sigurnosti muškog karaktera (Edijeve slabosti), koji naginje mazohizmu.

Tema ovoga djela je $\mathrm{s}$ jedne strane psihološko problematiziranje iracionalne ( $\mathrm{pa} i$ demonske) ženske prirode, a s druge strane muška slabost i nesigurnost karaktera koja se može okarakterizirati kao neurastenija (ipak poročnog) i senzualnog esteta. Teza o „,razornoj

\footnotetext{
${ }^{601}$ Daviau 1984, str. 82.

${ }^{602}$ Vidi u: Lacko Vidulić 1998.

${ }^{603}$ Usp. Krafft-Ebing, Psychopathia sexualis, cit. u: Lacko Vidulić 1998, str. 21.
} 
moći ženske ljubavi i kobnoj ropskoj podložnosti muškarca ženi““604 upućuje na hibridne rodne konstelacije koje su vjerojatno postojale $\mathrm{u}$ onodobnom društvenom miljeu, iako to pitanje ipak ostaje donekle otvorenim, budući da je Bahrova subverzivna groteska prožeta eksperimentalnim rodnim konstelacijama.

Prvi čin Bahrove drame uvodi se didaskalijom u kojoj se opisuje interijer (,veliki salon u tamnim bojama“), koji predstavlja dekor, dakle, ornamentalnu i dekorativnu, kićenu i artificijelnu sredinu koja ukazuje na dekadenciju. Sljedeća didaskalija opisuje majku, koja ima četrdeset godina i koja se ističe velikom ljepotom. ${ }^{605}$ Kod nje se vide znaci zamora od života, a zamjetan je bol i razočaranje, ali i svojevrsna grubost i jezovitost (što sve zajedno upućuje na ženski konotiranu iracionalnost) njezine prirode. ${ }^{606}$ Ovdje se već mogu naslutiti znakovi histerije, a treba napomenuti i to da je majka po profesiji glumica, što upućuje na često mijenjanje uloga $\mathrm{i}$ identiteta.

$\mathrm{Na}$ početku drame pokazuje se majka, glumica koja očajava zbog ljubavi svog promiskuitetnog sina Edija i Terke, koja predstavlja tip zavodnice (,femme fatale ${ }^{6}$ ). Majka, odnosno glumica pod imenom Fredegonde, izražava svoju nervozu i ozlovoljenost jer ima tremu pred nastup (dakle, muči ju bučni auditorij i njezina glumačka profesija), ali ono što ju zapravo karakterizira je njezina vlastita, ženski denotirana iracionalna priroda, koju, prema njezinom mišljenju, ne može shvatiti nijedan muškarac (misli prvenstveno na muža i sina). Histerija moderne umjetnice kod nje (odnosno, nervozna razdražljivost) se ispostavlja kao produkt ne samo njezine stresne glumačke profesije i njezinog odnosa prema sinu, koji predstavlja lik amoralnog, ali senzibilnog dendija, već i u hibridizaciji roda, koji varira između heteroseksualnosti i lezbijstva.

Drugi čin drame odvija se uglavnom u dijalogu između Edija i Terke, i to u Terkinom boudoiru, odnosno malom ženskom salonu. Već uvodna didaskalija upućuje na svojevrsnu amoralnu rafiniranost, odnosno amoralni esteticizam. U drugom činu Edi, nakon konzumirane veze s Terkom u njezinom malom kućnom ženskom salonu, izgleda kao da je hipnotiziran, dok se Terka naslađuje njegovom ropskom podložnošću (njem. „sexuelle Hörigkeit“). ${ }^{607}$ Nakon što Edijeva majka ujuri u kuću u kostimu Fredegonde, kako bi Edija otrgnula iz Terkinih ruku, nastaje borba, koja kulminira Terkinim otkrivanjem njezine prijašnje veze $\mathrm{s}$ Edijevom majkom, nakon čega majka ili pretuče ili čak i ubije Terku.

\footnotetext{
${ }^{604}$ Lacko Vidulić 1998, str. 30.

${ }^{605}$ Die Mutter, str. 9.

${ }^{606}$ Ibid., str. 10.

${ }^{607}$ Lacko Vidulić 1998, str. 23.
} 
Treći čin pokazuje majku uz Edijevu bolesničku postelju. Na Edijevu zamolbu majka navodi svoje strahove vezano uz Edija, time što ga upućuje u sudbinu njegovog oca, koji je umro zato što ju je volio (odnosno, Edijeva je majka, kako se čini, „ubojstvom iz strasti“ usmrtila njegovog oca). Edi umire, a majčin suicidalni skok s prozora sprječava njezin partner, homoseksualni klaun, koji ju povlači natrag u sobu. ${ }^{608}$

Glavni lik, lik majke, predstavlja nestabilan karakter, koji varira u dinamici između stanja afekta i stanja iscrpljenosti: njezino „nemirno oko“ svakog trenutka mijenja svoj izraz, od „,iscrpljenosti pa sve do grozničavog sjaja“, njezini su pokreti „nemirni“, sve na njoj predstavlja neurotičnost i užurbanost “. ${ }^{609}$ Psiho-seksualni profil majke vodi nas u područja, koja se, prema normativnim obrascima spolnog i rodnog ponašanja, jednoznačno mogu označiti kao patološka. ${ }^{610}$ Dijagnoza bi glasila: „biseksualna hiperestezija sa sadističkim i incestuoznim crtama“ ${ }^{611}$ Lezbijska veza majke s Terkom, koja je ujedno i sadašnja ljubavnica njezinog sina Edija, pripada u pretpovijest drame. Pisma, koja je majka uputila Terki, svjedoče o ,spolnoj podložnosti“612 majke prema Terki, čime ona zapostavlja svoje majčinstvo sljedećim riječima: „Moje mi je dijete, za koje sam nekoć mislila da ga volim, postalo zazorno, kao posljednja opomena (...) na porok (... “. ${ }^{613}$ Bahrova drama prikazuje jednu majku, koja se mora odlučiti između ljubavi prema svome djetetu i ljubavi prema svojoj lezbijskoj ljubavnici, u čemu se predočava onodobna diskusija o patološkom karakteru „,nesvrhovite“ ženske spolnosti (problem lezbijstva) i ženskog brakolomstva. ${ }^{614}$

Majka svoju lezbijsku partnericu ni pod koju cijenu ne želi preporučiti svome sinu, na što joj klaun odgovara da ju ona bolje poznaje od njenog sina. ${ }^{615} \mathrm{U}$ didaskalijama se naglašava majčina iracionalna priroda, koja čas poprima oblike neuroze (histerije ili pak neurastenije), a čas neke vrste zamora od života i melankolije. Nakon klaunovog komentara kako bi ona svom sinu, budući da je mlad, trebala dopustiti veću „slobodu“, majka klaunu ironično odgovara kako je Edi ionako već do sada imao previše ljubavnica, usporedivši u ranijem dijelu drame

\footnotetext{
${ }^{608}$ Bahr: Die Mutter, str. 64, cit. također u: Lacko Vidulić 1998, str. 20.

${ }^{609}$ Bahr: Die Mutter, str. 64, cit. također u: Lacko Vidulić 1998, str. 21

${ }^{610}$ Ibid., str. 22.

611 Ibid., str. 22.

${ }^{612}$ Krafft-Ebingov stručni termin za „psihički abnormalne“, no ipak ne ,perverzne“ pojave ovisnosti podložnog/e o vladajućoj ,polovici“ ljubavnog para., usp. Krafft-Ebing: Psychopathia sexualis, 1993, cit. u: Lacko Vidulić 1998, str. 22.

${ }^{613}$ Ibid.

${ }^{614}$ treba napomenuti onodobne predodžbe o ženskoj spolnosti o kojoj govori Krafft-Ebing u svome djelu Psychopathia sexualis, str. 13.: „U svakome je slučaju muškarac koji bježi od žene, kao i žena, koja isključivo slijedi samo svoj spolni užitak, abnormalna pojava“, usp. također poglavlje o ,patološkoj ljubavi supruga prema svojim muževima“.

${ }^{615}$ Die Mutter: „Nie! Nie! Mit ihr- niemals! Solange ich lebe, nicht! Das schwöre ich Dir. Du kennst die Canaille nicht.“, Die Mutter: str. 15., Der Clown: „Du mußt sie ja natürlich besser kennen“., „Bis er sie vergessen hatfrüher nicht- bis er sie vergessen haben wird.“, Die Mutter, str. 17.
} 
njegovu egzistenciju čak i s haremom. ${ }^{616}$ Sada majka pokazuje određenu vrstu iracionalne Ženski konotirane posesivnosti: „S njom je drugačije: nju on voli“617 (misleći pritom na svoju bivšu i sinovljevu sadašnju ljubavnicu). Klaun joj na to kritički odgovara da pusti sina da radi po svome ${ }^{618}$, na što mu majka opet ironično odgovara: „Pa da mu se dogodi isto ono što se dogodilo njegovom ocu“, aludirajući na svoj zločin prema vlastitom mužu, koji je proizišao iz dekadentnog duševnog ustrojstva, a može se povezati i sa stereotipno ženski konotiranom posesivnošću, iracionalnošću, pa i „demonskom“ prirodom žene.

Lik homoseksualnog klauna, koji također predstavlja hibridni rod, u ovome se djelu pojavljuje kao „barometar“ onodobnih društvenih konstelacija, izražavajući „kritiku“ i subverziju rodnih odnosa u drami. On daje groteskne komentare a pritom ima i karikirani

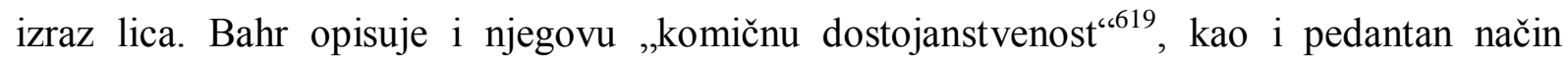
izražavanja, usprkos njegovom lakrdijaštvu.

Kao krajnje ironiziranje, pa i karikiranje klišeja o iznimnom estetskom senzibilitetu može se okarakterizirati ovaj lik klauna koji dijeli stan s Edijem i njegovom majkom. Lik klauna može u svakom slučaju predstavljati i satiru kulturnog trenutka i miljea vremena, ali i umjetničkog ukusa publike. ${ }^{620}$

U razgovoru sa svojim prijateljem, homoseksualno orijentiranim cirkuskim klaunom, koji predstavlja jedinog glumičinog životnog partnera, a uz kojeg ju veže neka vrsta nespolne veze ili prijateljstva (prema tumačenju Hermanna Bahra, Russische Reise), Fredegonde izražava svoje nezadovoljstvo, koje se tek u potpunosti otkriva na kraju drame: Edijeva ljubav prema Terki nužno će uništiti glumičinog sina, jer ,ljubav kvari muškarca“ (izjava koja proizlazi iz usta Edijeve majke), baš kao što je i Edijev otac propao zbog ljubavi prema Edijevoj majci. ${ }^{621}$

U jednom drugom kontekstu klaun bi ipak predstavljao i središnju poantu ove drame. Njegovo konträre Sexualempfindung, odnosno homoseksualni porivi postaje pretpostavkom za inače nemoguću harmoničnu i bezrizičnu vezu između muškarca i žene. Moguće svjesno odgajanje Edija prema homoerotičkoj spolnosti pokazuje se u ovoj drami ipak naposljetku kao jedino pouzdano sredstvo zaštite muškarca pred navodnim opasnostima heteroseksualne ljubavi:

Klaun: „Da, ali nikad to nisam shvaćao“(

\footnotetext{
${ }^{616}$ Der Clown: „Mein Gott, er muß eben austoben. Jugend hat keine Tugend“, Die Mutter (nervös): „Austoben, austoben! Als ob er sein ganzes Leben jemals was Anderes gethan hätte! Er war kaum ein Bube von dreizehn Jahren, da lebte er schon wie ein türkischer Prinz.“, Die Mutter, str. 19.

${ }^{617}$ Die Mutter: „Mit ihr ist es anders: sie liebt er“, Die Mutter, str. 19.

${ }^{618}$ Der Clown: „So laß ihm doch das Vergnügen!“”, Die Mutter, str. 19.

${ }^{619}$ „,komische Würde“, vidi Die Mutter, str. 10.

${ }^{620}$ Lacko Vidulić 1998, str. 24.

${ }^{621}$ Ibid., str. 20.
} 
Majka: „Zato što nikada nisi bio muškarac, sa tvojom zabludjelom prirodom“.

Klaun: „Trebala si ga (Edija) odgojiti prema mome primjeru“.

Majka: „Ja sam to već nekoliko puta tako i mislila, je li uistinu jedino sredstvo za postizanje sreće- kad se pojedinca odgoji protuprirodno“. ${ }^{622}$

Klaun daje svoje ironične, gotovo transpsihološki koncipirane i društveno-kritičke komentare (vezano uz amoralni esteticizam). On Terku karakterizira kao femme fatale, te aludira na to da je ,posve neobično kako ponekad jedan određeni tip žene može postati sudbonosan (koban) svim spolovima““ ${ }^{623}$

Lik Edija tipološki odgovara liku senzibilnog dendija, jer je opisan kao odjeven u „ogrtač od žute svile“, a njegove psihološke karakteristike ukazuju na „neurozu“, feminiziranost u vanjskom izgledu i u svakoj gesti. ${ }^{624}$ Izražena je i njegova fizička i psihička sličnost majci (,nervozni, nagli pokreti“) koji odaju nezadovoljstvo, ali i dozu „drskosti“. Njegovo je cijelo biće prožeto nekom vrstom raspojasane melankolije i blaziranosti zbog zamora od života. S jedne strane nalikuje djetetu koje je prerano sazrelo, a s druge nekom prerano „iskvarenom“ uličnom „deranu“, a na licu mu se vide znakovi nečega prerano „staračkoga“. Svaka njegova gesta ukazuje na veliku taštinu i određenu samodopadnost ${ }^{625}$. Kod Edija je donekle naglašeno i stanje primarnog narcizma esteta. ${ }^{626}$ Kretnje su mu nemirne i pomalo „kicoške“. Na njegovu feminiziranost upućuje, osim njegova ,zamora od života“ također i nedostatak tradicionalno muški konotirane odlučnosti i čvrstine karaktera, te njegov odnos prema dekorativnim predmetima koji ga okružuju, što sve upućuje na habitus senzibilnog esteta. U njegovom se nastupu može primijetiti i ponešto od „kapriciozne ženske tvrdoglavosti““ ${ }^{627}$ nakon čega se on na ironičan i pomalo prijeziran način obraća majci, a ona ga sa određenom „suzdržanom nježnošću poljubi u čelo“. ${ }^{628}$

\footnotetext{
${ }^{622}$ Die Mutter, 1891, str. 19.

${ }^{623}$ Der Clown: „Es ist doch merkwürdig- wie manchmal ein bestimmter Typus ganzen Geschlechtern verhängnißvoll wird! Diese Terka- erst die Geschichte mit Dir- und jetzt wieder“, Die Mutter, str. 20.

${ }^{624}$ Edi (Er ist in einem gelbseidenen Schlafrock und Pantoffeln; zwanzig Jahre alt, klein, nervös, sehr weiblich im Aussehen und in jeder Geberde, (...) bleiches, verwüstetes, völlig bartloses Gesicht mit einem Ausdruck übernächtiger Ermüdung., Die Mutter, str. 20.

${ }^{625}$ Edi (...) Um die Lippen dasselbe nervöse, hastige und unbefriedigte Zucken und dasselbe freche spöttische Aufwerfen, wie seine Mutter. Sein ganzes Wesen ist aus verlumpter Schwermuth und verdrossener Blasiertheit gemischt. Er hat etwas von einem frühreifen Kinde, von einem vorzeitig verdorbenen Straßenjungen und zugleich etwas vorzeitig Greisenhaftes an sich. Jede Geberde zeigt große Eitelkeit und Selbstgefälligkeit: er sieht jeden Augenblick nach dem Spiegel. Seine Bewegungen sind unruhig, fahrig und geckenhaft“, Die Mutter, str. 20.

${ }^{626}$ vidi Le Rider: Das Ende der Illusion, 1990, str. 88-91.

627, ,...) und eine capriciöse weibliche Starrköpfigkeit. Mit einer höhnischen Verbeugung zur Mutter: „Du hast befohlen, Mama!“, Die Mutter, str. 21.

${ }_{628}$, ,küßt sie ihn mit verhaltener Zärtlichkeit leise auf die Stirne, während er sie mit einer ungeduldigen Geberde abwehrt", Die Mutter, str. 22.
} 
Dok Edi pred klaunom komentira kako cijela situacija sliči na društvenu satiru i na neki način se izruguje, majka se grčevito brani od sinovljeve ironije i uvjerava ga u svoju ljubav. Ovdje se može uočiti očaj majke koja je zbog vlastite krivnje izgubila muža a onda tu ljubav i strast transformirala na svoga sina koji na to čas odgovara s prijezirom, a čas mu to, budući da tipološki predstavlja dendija, godi i laska. Majka Edija uvjerava da je njezina lezbijska ljubavnica potpuno kriva osoba za njega, jer ju je ona dobro upoznala. ${ }^{629}$ Edi ipak žudi za Terkom, i tvrdi da mu je to u krvi, da je tu osobinu naslijedio od oca. Majka ga i dalje uvjerava da je Terka poročna, a on joj se ruga da su o njih dvije, kao o lezbijskim ljubavnicama, kružila razna ogovaranja. No kasnije upravo Edi tvrdi da ne može živjeti bez Terke, i ne zna jesu li za to ipak krivi živci (time i Edi pokazuje svoju izrazitu neurasteniju esteta). Potom se Edi obraća majci, vezano na svoga oca i njezinog muža, sljedećim riječima: „Ali on te volio. On te volio“. ${ }^{630}$ Majka ga ponovo uvjerava isključivo u svoju ljubav, ali ju Edi prijezirno odbija, jer više voli Terku, jer prema njoj osjeća „neodoljivi nagon“631, koji se na psihološki način može protumačiti kao stereotipno muški konotirani libido, uza svu feminiziranost esteta. Edi odbacuje majčinu ljubav kao „opsjenu“, kao puku „sentimentalnost““, povezujući ju s obmanom majčine vlastite glumačke profesije. No već se u slijedećem trenutku Edi, na paradoksalan način, nastoji ponovo približiti majci, umiljavajući joj se u stilu dendija.

Ugledavši Terku, Edi se s izrazom bespomoćnog očajanja, baca ničice pred nju, moleći ju da mu uzvrati ljubav, na što ona odgovara s dozom zlobne ironije: „Sad ćemo tek malo pričekati, što će o tome reći milostiva gospođa mama“. ${ }^{632} \mathrm{U}$ ovoj je sceni vidljivo da su i Terka i Edi, usprkos svojoj psihološkoj kompleksnosti tipološki koncipirani likovi: dok Edi predstavlja izrazito feminiziranog esteta, odnosno mladića s gubitkom sigurnosti u svom tradicionalno muškom (čvrstom) identitetu i ovisnog o ženskosti, a posebice fatalnoj ženskosti, Terka s druge strane predstavlja tipološki lik femme fatale koja se prema muškarcu odnosi s prijezirom, te se ruga Edijevoj ovisnosti o majci. Na taj način Terka predstavlja tradicionalno muški konotiranu, agresivnu ćud s obzirom na način na koji se obraća Ediju, dok pretjerana Edijeva vezanost na Terku opet upućuje na hibridizaciju roda, na njegovu feminiziranost i podložnost ženskoj agresivnosti. Međutim, i Edi kao lik pokazuje preveliku putenost, odnosno senzualnost, te pokazuje tradicionalno ženski konotiran način ponašanja:

\footnotetext{
${ }^{629}$ Vidi Die Mutter, str. 24.

${ }^{630}$ Edi: ,-aber er liebte Dich. Er liebte Dich“, Die Mutter, str. 26.

${ }^{631}$,....aus einem unwiderstehlichen Zwange heraus“, Die Mutter, str. 27.

${ }^{632}$ Terka (regungslos, mit tückischer Ironie): „Nun wollen wir erst einmal abwarten, was die gnädige Frau Mama dazu sagt“", Die Mutter, str. 32.
} 
time on zapravo poprima karakteristike tipološkog lika amoralnog esteta. ${ }^{633}$ Terka na ironičan način tvrdi da, ako se Edi ipak odluči za majku, da će ona to već lako prebroditi. ${ }^{634}$ Edi je ipak vezan uz majku, pa kaže Terki da ne želi da mu majka nepotrebno pati, dok mu Terka na to prijezirno odgovara da njegova majka uopće nije tako osjetljiva, kao što on misli, da ju ona dobro poznaje. ${ }^{635}$ Nakon što Terka uvrijedi Edija nazvavši ga kukavicom, Edi osjeća neku vrstu „mrzovoljne znatiželje“ i odgovara Terki da nešto „mora biti““ što se tiče veze između Terke i njegove majke, nešto začudno ${ }^{636}$. Edi spominje (što predstavlja svojevrsnu prolepsu u drami) situaciju s njegovim ocem, aludirajući na to kako je njegova majka „ubila“ njegovog oca, izjednačivši žensku narav s određenom tipološkom iracionalnošću. Međutim, on napominje da je njegova majka jako voljela njegovog oca, a Terka mu odgovara da je to upravo zato što je umro, čime i Terka aludira na stereotipno konotiranu žensku iracionalnu i demonsku stranu.

Nastaje tučnjava između majke i Terke, a Terka se obraća Edijevoj majci grubim riječima, naglašavajući to da ona baš želi Edija oteti njegovoj majci, iz osvete što ju je napustila, što ukazuje na agresivnost Terkine prirode. Majka se pak na teatralan način obraća Terki, koja je glumica po struci, poput nje: optužuje Terku da joj je uzela sina, da joj vrati njezino dijete. ${ }^{637}$ Terka prijeti Edijevoj majci da će na požudan način uništiti njenog sina, aludirajući na demonsku žensku stranu, te joj se prijezirno smije, ističući da se majka ponaša teatralno, aludirajući na to da se „njih dvije već dobro poznaju“. Edi nekakvom zazornom „dijaboličnom radošću“ promatra svađu između majke i Terke. ${ }^{638}$ Majka kaže da joj nikad ne

\footnotetext{
${ }^{633}$ Edi (indem er sich mit dem Ausdrucke der höchsten Wollust ihren Küssen überläßt, die Augen schließt, (...), den Kopf hintenüber in das Kissen zurückbeugt, wie wenn er das Übermaß von Wonne nicht ertragen könnte (stammelnd, lechzend)- „Mehr, -mehr- immer- bis an“s Ende- immerfort!“; Terka (wird immer heftiger und wilder in ihren Küssen, ihn immer brünstiger an sich pressend, und schiebt allmählich ihren ganzen schweren Leib über den seinen“, Die Mutter, str. 30.

${ }^{634}$ Terka: „Sie ganz allein ist an Allem schuld. Was braucht sie sich in unsere Angelegenheiten zu mischen? Sie hat Dich von mir gerissen. Sie hat Dich vor mir versperrt. Gewalt, gegen Gewalt, Gemeinheit gegen Gemeinheit. Mir blieb nichts anderes übrig, als Deinen Kerker aufzubrechen und Dich zu entführen. Aber soll das in alle Ewigkeit so fortgehen? (...) Wir wollen uns ganz ruhig und klar auseinandersetzen. Du weißt, was sie Dir bietet, Du weißt, was ich Dir biete. Nun magst Du Dir aussuchen, was Dir lieber ist Du kannst Dich ja auch für sie entscheiden! Ich werde daran nicht sterben-da brauchst Du keine Angst zu haben.“, Die Mutter, str. 34.

${ }^{635}$ Edi (in den Knieen aufgerichtet, indem er sie unheimlich anstarrt): „Ich muß ja doch-daß weißt Du ja doch, daß ich nicht anders kann- aber warum denn sie erst unnütz foltern und quälen!“, Die Mutter, str. 34.

${ }^{636}$ Edi (das Zucken einer häßlichen Neugier um die Lippen)- „Es muß etwas zwischen Euch sein, zwischen Dir und ihr- etwas ganz Merkwürdiges- Ihr wißt allerhand von einander", Die Mutter, str. 34.

${ }^{637}$ Die Mutter (mit immer wachsender Leidenschaft und Wuth, aber immer noch stark theatralisch): „Terka, gieb mir mein Kind! Ich sage Dir, gieb mir mein Kind! Ich rathe Dir gut- für Dich und für mich und für ihn- Du weißt nicht, wie das rast und tobt und wühlt in mir- reize mich nicht zum Außersten, ich schrecke vor nichts!“, Die Mutter, str. 39.

${ }^{638}$ Vidi Die Mutter, str. 39.
} 
bi prepustila Edija, ${ }^{639}$ na što Terka zatim na ironičan način pred Edijem i pred njegovom majkom čita pismo koje je majka kao njena lezbijska partnerica njoj uputila. Nakon što je pročitala pismo, Terka optužuje majku da ju je maločas nazvala prostitutkom, a nekoć ju je nazivala „anđelom“, „svetom golubicom“ i „glasnicom neba i mira“. ${ }^{640}$ Edi govori da se majka na isti takav sentimentalan način izražavala prema njemu, i to izražava prijezirnim smijehom prema „majčinskoj ljubavi“, kojoj se on sada na jednako patološki način (kao i Terka) izruguje. Majka se u tome trenutku psihički slama, pada na koljena i u očajanju moli Terku da joj oprosti, dok se Terka tome izruguje, na neki način osvetnički „trijumfirajući“ nad majkom. Cijela situacija aludira na to da se ovdje radilo o čistoj ljubomori Terke prema Fredegonde (kao nekoć Fredegonde prema vlastitom mužu), nakon čega sada i Terka na isti takav način želi uništiti njezinog sina kako bi se na patološki način osvetila Edijevoj majci. Majka na očajnički način uzvikuje da je to sve njezina krivnja, i traži način kako da se „oduči“ od neprestane ovisnosti majke o sinu.

Treći čin započinje didaskalijom koja opisuje Edijevu spavaću sobu, u kojoj se nalazi portret njegova oca, kojemu on jako nalikuje po svojoj ljepoti. Majka jeca za Edijem, a didaskalija opisuje i „monotoni šum jakih kapi kiše“ koje padaju na prozor Edijeve sobe. I ova didaskalija naznačuje sumorni, gotovo gotički dekor, esteticizam i dekadenciju. Majka se osjeća umorno, dok Edi vapi za Terkom i želi da mu se vrati. U svojoj čežnji za Terkom Edi pokazuje znakove u ono doba ženski konotiranog pojma histerije, što ukazuje na feminiziranost esteta i hibridizaciju Edijevog rodnog identiteta. Međutim, Edi također čezne i za majkom, koja ga potom uvjerava da će pronaći najbolju ženu za njega, neku sirotu djevojku koja neće imati iskustva u ljubavi, ali ovim riječima majka zapravo samo prikriva svoju vezanost na Edija.

Za Edija prekasno dolaze očajnički pokušaji njegove majke da ga spasi: on se već zaljubio. Terka, objekt njegove žudnje, je doduše moralno devijantan karakter, no ne nosi tipične karakteristike fizičke ili spolno- psihološke ,izopačenosti“, kod nje je više prisutna poročnost nego bolest. ${ }^{641}$ Budući da Terka predstavlja običnu zavodnicu iz polusvijeta, ${ }^{642}$ glavno oružje njezinog umijeća zavođenja njezin je $\operatorname{spol}^{643}$, a ostatak „krivnje“ je na Ediju i gubitku sigurnosti njegove muškosti, a dijelom i na njegovom habitusu rafiniranog dekadenta, koji

\footnotetext{
${ }^{639}$ Die Mutter: „(...) ich weiß nur das Eine: ich lasse ihn Dir nicht. Weil ich das Liebste nimmermehr der niedrigsten und gemeinsten Dirne“, Die Mutter, str. 40.

${ }^{640}$ Vidi Die Mutter, str. 41.

${ }^{641}$ Vidi cit. u: Lacko Vidulić, 1998, str. 25. ,vidi također i Krafft-Ebing: Psychopathia Sexualis, 1993, str. 68., o razlici između riječi Perversität (,,porok“) i Perversion (,,bolest“).

${ }^{642}$ Lacko Vidulić 1998, str. 25.

${ }^{643}$ Ibid.
} 
traži isključivo senzualne podražaje. Terka drži svoju bespomoćnu žrtvu s banalnim sredstvima „neumjesne koketnosti“6444 i „raspojasanosti““ ${ }^{645}$ Motivi njezinog latentnog sadističkog naslađivanja Edijevom apsolutnom ropskom spolnom podložnošću su sljedeći: znatiželja, želja za dominacijom i osveta njegovoj majci-njenoj bivšoj nevjernoj ljubavnici. ${ }^{646}$

Terka povlači eksplicitno usporedbu između njene veze sa Edijem i veze Edijeve majke sa Edijevim ocem, koji se očituju u motivima radnje ženskog aktera, a ipak ne kroz psihološki mehanizam „ubojstva radi ljubavi“. 647

Terkine riječi upućene njezinoj bivšoj lezbijskoj partnerici, Edijevoj majci, svjedoče o tome da ona Edija uopće iskreno ne voli, već ga želi oduzeti majci i pokvariti ga, na isti način kakav je bio odnos Edijeve majke prema njegovom ocu. Terka utjelovljuje tipološki lik femme fatale u jedno „banalno vulgarnoj varijanti““, ${ }^{648}$ doduše ne posredstvom njenih osobnih karakternih crta već posredstvom njezinog ženskog spola-u horizontu slike čovječanstva ove drame žena postaje fatalna za muškarca kojemu se dogodi nesreća da se zaljubi. ${ }^{649}$ Edijeva sudbina, izrečena u zadnjoj izjavi ove drame, postaje reprezentativna za muški spol. Njegova strast ilustrira sveopće zakonitosti heteroseksualne ljubavi; dok njegov „degenerirani“ , pa i dekadentni karakter još intenzivira njegovu prijemčivost za sveopće muške strasti. Edi kao žrtva zavodničke ženskosti (u čemu Bahr ocrtava sudbinski put muškarca) predstavlja lik neurastenika, odnosno muškarca željnog ćutilnih podražaja. Ovaj motiv se često pojavljivao u onodobnoj dekadentnoj književnosti i višestruko se varirao. Paralele između Edijevog portreta i opisa u poglavlju o androginiji kod Krafft-Ebinga u poglavlju o androginiji su impozantni: „Ženski atributi fizičkog izgleda“, „ženske“ kretnje,“ „,neuropatski““ izraz u očima, postaju simptomi neurastenije koji se čak manifestiraju kroz iscrpljenost, glavobolje i umor. ${ }^{650}$

Majka pokušava zagrliti Edija i obrazlaže svoje ponašanje željom da ga „spasi“, dok Edi izražava svoj strah od smrti, u čemu se nazire ispreplitanje Erosa i Tanatosa u ovoj drami. Majka, vidjevši da Edi umire, pokušava na očajnički način vratiti ga u život. Sada Edi moli majku da mu ispriča neku priču ili bajku, kao nekad kad je još bio dijete: ovdje se može primijetiti da Edi zapravo nikad nije premostio vezanost uz majčino tijelo, i boravak u neizdiferenciranom stanju mitskog obilja ${ }^{651}$ i primarnog narcizma esteta. ${ }^{652}$ Majka govori

\footnotetext{
${ }^{644}$ Lacko Vidulić 1998, str. 25.

645 Ibid.

${ }^{646}$ Ibid.

${ }^{647}$ Ibid.

${ }^{648}$ Ibid.

${ }^{649}$ Ibid.

${ }^{650}$ LackoVidulić, 1998, str. 25, cit. iz djela: Krafft-Ebing, Psychopathia Sexualis, 1993, str. 295.

${ }^{651}$ Vidi Felski: Gender of Modernity, 1995, str. 38.

${ }^{652}$ Vidi Le Rider: Das Ende der Illusion, 1990, str. 88-94.
} 
Ediju kako „ljubav kvari muškarca“653 te priznaje da je ubila vlastitog muža zbog prevelike ljubavi prema njemu, time otkrivajući svu iracionalnost svoje ženske prirode. ${ }^{654}$ Majka uvjerava Edija da će mu pronaći neku bolju ženu od Terke, uvjeravajući ga kako ona za njega želi neku jednostavnu i priprostu djevojku iz provincije. ${ }^{655}$ Nakon što Edi umire u histeričnom napadu, što upućuje na neurasteniju esteta, majka upada u histeričan smijeh, koji ponovo odražava iracionalnost njezine ženske prirode.

Sličnost Edijevog oca s Edijem je neosporna, samo što postoji plemenita sjeta u licu oca koja u Edijevom nedostaje. ${ }^{656} \mathrm{U}$ trenutcima kada Edi umire, hereditarni izvor njegove sudbine još jednom napominje njegova majka. Povik majke osigurava vezu između slike pretka i slike potomka. $^{657}$

\subsubsection{Implicitni rod}

Što se tiče recepcije književnog žanra ove Bahrove drame, pitanje je li za suvremenike oko 1890. godine ovaj model drame kao takav prepoznatljiv, je li predstavljao znanstvenu spoznaju ili čak općepoznatu stvar, može se formulirati vezano na bliskost stvarnosti ove drame u smislu naturalističke poetike. ${ }^{658}$

Odlučujuće za uvrštavanje Bahrove drame Die Mutter (majka) u naturalizam odnosi se prvenstveno na individualističku koncepciju likova i nagonsko-psihološku zakonitost njihova djelovanja. Element razmatranja ovoga djela također je i mehanizam spolnog nagona, koji muškarca tjera u smrt posredstvom neumitne biološke zakonitosti. ${ }^{659}$

Šarena kulisa (nakićeni interijeri) i turbulentni događaji u drami, kao i upute za režiju drame (njem. „Regieanweisungen“), koji ocrtavaju jednu provokativnu ljubavnu dramu, spadaju u područje književne dekadencije. ${ }^{660}$ Ovi nakićeni interijeri, koji su u tekstu detaljno opisani, odgovaraju dekorativno-historicističkom ukusu onodobnog vremena te esteticističkim nagnućima dekadenata željnih senzacija (ćutilnih) podražaja. Salonom u majčinoj i Terkinoj kući (opisanom u prvome i drugome činu Bahrove drame) dominiraju različiti stilovi, koji su

\footnotetext{
${ }^{653}$ Vidi Die Mutter, str. 60.

${ }^{654}$ Ibid. Str. 62

${ }^{655}$ Die Mutter (in großer Angst, indem sie verzweifelnd im Zimmer auf und niederschreitet): „Nein, nein, Edidu wirst sie ja vergessen- ganz sicher wirst Du sie vergessen- ganz leicht, wenn Du Dir nur etwas Mühe dazu giebst- schau, Edi, es ist ja gar keine Kunst! (...) Und alle Weiber kannst Du haben, und wenn Du dann müde bist, dann suche ich Dir eine liebe, kleine Frau, schön, demüthig und fröhlich, ganz dumm und kindlich (...) irgendwo in einem stillen, verschlossenen Winkel der letzten Provinz (...)“, Die Mutter, str. 60-61.

${ }^{656}$ Lacko Vidulić 1998, str. 27.

${ }^{657}$ Ibid.

${ }^{658}$ Ibid., str. 28.

${ }^{659}$ Ibid., str. 19.

${ }^{660}$ Ibid.
} 
„dopunjeni““ modernim „drangulijama“ u baroknom, rokoko i japanskom stilu (prema opisu u didaskalijama). Ove „neukusno uređene prostorije odražavaju habitus senzibilnih, 'degeneriranih' i 'superiornih' stanovnika, koji ipak ne spadaju u skupinu običnih 'izopačenih', vezano uz njihov socijalni status. Međutim, njihove umjetničke djelatnosti ostaju ograničene na 'rafinirano zadovoljenje neurastenične razdraženosti', odnosno nervoze“. ${ }^{661}$

Uvodna karakterizacija likova i precizno protokoliranje njihovog verbalnog i neverbalnog ponašanja elementi su epiziranja popratnog teksta (njem. „Nebentext“). U individualiziranom govoru i gestikulaciji likova preklapaju se njihov karakter i poslovni život, idiolekt i sociolekt kao rezultat „borbe jezično-psiholoških determinanti“ kojih ni sami likovi nisu svjesni. ${ }^{662}$

U svojoj vezanosti isključivo na Terkinu ljepotu, a zanemarujući njezinu agresivnost, Edi predstavlja lik hipersenzibilnog esteta. Majka ga uvjerava da „mora ozdraviti“, i da mu tek onda ona može pronaći djevojku koja bi predstavljala neku iskonsku ljepotu i nevinost. Međutim, Edi očajnički želi vratiti Terku, govoreći da mu ništa na svijetu nije važnije od nje. ${ }^{663}$ Vezano na ženski konotiranu senzualnost, i Edi predstavlja svojevrsnu Drugost. Edi predstavlja zaljubljenog neurastenika, a u zadnjoj se fazi njegovih ljubavnih jada mogu prepoznati simptomi neprirodno naglašenog spolnog nagona, tzv. ,spolne hiperestezije“. ${ }^{664}$

U Bahrovom fikcionalnom portretiranju onodobne kliničke slike krize muškosti (muške slabosti vezane na ženskost) dobiva lik androginog neurastenika Edija daljnje karakteristike: njegova potreba za ćutilnim senzacijama i sinestetičkim podražajnim asocijacijama; nadalje, Edija karakterizira svojevrsni spoj sjete i blaziranosti-dosade-zamora od života) ${ }^{665}$; ovaj Edijev „zamor od života“ na neki način stoji u suprotnosti sa nervoznim-hiperaktivnimnestalnim karakterom njegove majke: Bahr ove karakteristike definira kao „kapricioznu žensku tvrdoglavost“, „dijaboličnu“ zluradost, bolesnu znatiželju, groteskni kukavičluk. ${ }^{666}$

U sličnom smislu bi se mogli i simptomi ekscentrične i devijantne spolnosti, u sindromu ljubavi zbog koje Edi pati, prikazati kao intenziviranje uobičajenog ljubavnog osjećanja.

Osim latentnog transvestizma (Terka Edija preoblači u ženu), koji se tada prikazivao kao dekadentno naličje androginog karaktera, Edi prije svega pati zbog perverzno intenzivirane ropske podložnosti (ženskosti). Razlozi ove ropske podložnosti odgovaraju Krafft Ebingovoj procjeni ove pojave: neobičan stupanj zaljubljenosti zajedno sa slabošću karaktera. ${ }^{667}$

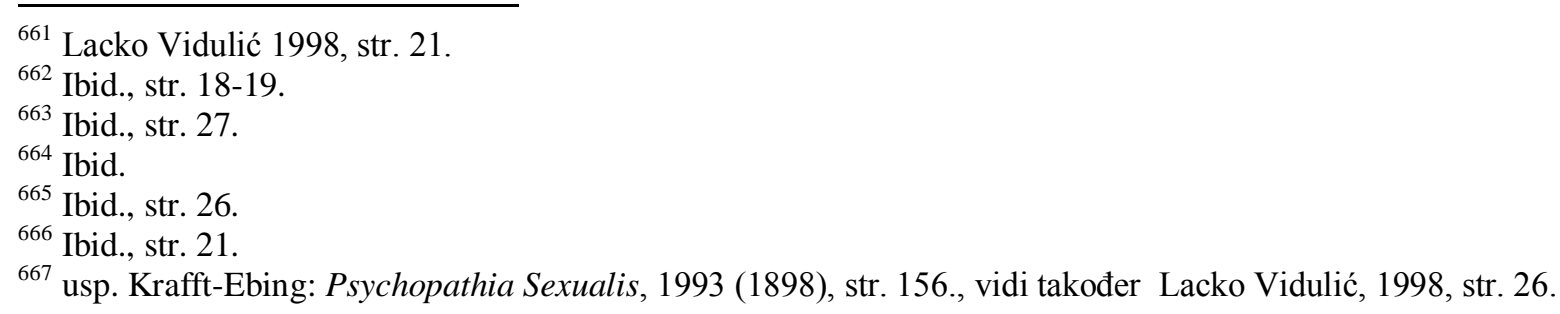


Ako se uzme u obzir Krafft-Ebingovo determinističko tumačenje zaljubljenosti kao fiziološko stanje izazvano individualnim fetišizmom, prema tim mjerilima Edijevo ponašanje nije ništa drugo nego simptom jedne nezdravo potencirane zaljubljenosti. Edi sam opisuje svoje stanje vokabularom onodobnog pretjeranog naglašavanja organskih i fizioloških faktora u etiologiji duševnih stanja. ${ }^{668}$ Ako se ipak uzme u obzir onodobna psihopatologija, i poveže se sa dramskom sudbinom zaljubljenog neurastenika tada se u konačnoj fazi njegovih ljubavnih jada mogu prepoznati simptomi nezdravo intenziviranog spolnog nagona, seksualne hipererestezije (Krafft- Ebing), koja se intenzivira sve do delirija zbog apstinencije. Čežnja za putenošću popraćena strahom od smrti završava Edijevom smrću; Krafft-Ebing bi ovdje, na psihoanalitički način, dijagnosticirao akutnu smrtonosnu satirijazu (nimfomanija kod muškarca). ${ }^{669}$

Kroz lektiru ovoga djela ocrtavaju se onodobne znanstveno utemeljene teorije seksualne degeneracije i moguća terapeutska sredstva protiv muške ropske podložnosti i nagonske ovisnosti o gruboj, odnosno agresivnoj ženskosti.

Karakteri likova prikazanih u djelu pokazuju kako njihove patnje tako i turbulentne ćudljivosti, budući da likovi predstavljaju nestabilne i popustljive-kolebljive likove, dok uzroci njihovih patnji postaju same nagonsko-psihološke determinante. ${ }^{670}$

\subsubsection{Zaključak}

U ovoj su Bahrovoj drami na satiričan način prikazana odstupanja od onodobne rodne bipolarizacije. Hibridizacija roda jednako je prisutna u sva četiri glavna lika ove drame: majka Fredegonde je ,pretjeranom ljubavlju“ ubila svoga muža, a zbog veze s njenom lezbijskom partnericom (Terka), koja je ujedno i partnerica njezinog sina Edija, pokušava Edija upravo iz tog razloga odgovoriti od veze s njom, tvrdeći da ,ženska ljubav ubija muškarca“. Bahr na ironičan način prikazuje u svom tradicionalnom muškom identitetu nesigurnog muškarca (Edi), koji na neki način želi „prkositi““ majci time što izabire baš Terku, majčinu bivšu lezbijsku partnericu i pripadnicu polusvijeta, a Terka se izruguje njegovoj vezanosti uz majku, rekavši mu da bira između nje i majke. ${ }^{671}$ Edi, budući da predstavlja lik senzibilnog esteta, ne želi napustiti Terku, iako ona pokazuje muški konotiranu agresivnost prema njemu (književna tipologija lika Mannweib): na kraju Edi umire u histeričnom napadu, koji odražava

\footnotetext{
${ }^{668}$ Lacko Vidulić 1998, str. 26.

${ }^{669}$ Ibid., str. 27., cit. iz: Krafft-Ebing: str. 360-367.

${ }^{670}$ Ibid., str. 28.

${ }^{671}$ Vidi Die Mutter, str. 37.
} 
iracionalnost esteta. Majka je, s druge strane, patološkom ljubavlju ubila svoga muža, a onda tu ljubav transformirala na sina, što pokazuje iracionalnost njezine prirode koja je kao takva u ono doba (o prijelomu stoljeća) bila ženski konotirana (povezana s pojmom histerije), baš kao što i Edijeva pretjerana vezanost uz Terku odražava feminiziranost esteta. Hermann Bahr u ovoj drami koristi eksperimentalne rodne konstelacije kako bi se narugao strogo polarizirajućim onodobnim shvaćanjima rodnih odnosa i rodnih identiteta.

Edi tipološki predstavlja lik dendija, odnosno hipersenzibilnog esteta no ujedno i dekadenta koji pokazuje znakove seksualne hiperestezije, dok s druge strane i majka pokazuje iste takve znakove. Ako se ova drama razmatra u kontekstu književnog i kulturnog obzorja vremena u kojem je nastala, u dekadentnom se društvenom miljeu može prepoznati deterministička teza o ljubavi koja donosi smrt. Stoga je ovo Bahrovo djelo, koje predstavlja djelo književne dekadencije, jedinstvena reakcija na tada aktualne poetološke koncepte i samovoljni odgovor na pitanja koja su tada kolala (ne samo intelektualnom) svakodnevicom i predstavljala kulturalno-povijesnu simptomatiku ove drame. ${ }^{672}$ Značajno je, u svrhu tumačenja ovoga djela, ispreplitanje znanosti, pseudo-znanosti, književnosti i svakodnevice u oblikovanju onodobnih predodžbi o rodu, degeneraciji i spolnoj devijantnosti, pri čemu treba uzeti u obzir djelo Krafft-Ebinga, koje govori o spolnoj znanosti. Bahrova drama prikazuje rodne devijantnosti, koristeći obilje motiva književne dekadencije, te naglašava i groteskno izokretanje rodnih konstelacija (donekle i eksperimentalno postavljena zamjena rodnih uloga).

Bahrova koncepcija (heteroseksualne) ljubavi, njegovo izjednačavanje muške ljubavi sa fiziološkom ropskom (spolnom) podložnošću muškarca dominantnim tipovima žena, ${ }^{673} \mathrm{i}$ tumačenje rodnih odnosa kao sadističke volje za moć dominantne žene nad muškarcem koji postaje njezina bespomoćna žrtva, jednoznačno označava paradigmu onog shvaćanja ljubavi, koja se u fin-de- siècle-u izriče u pojmu ,femme fatale“ (fatalne žene) i oslabljenju muškog karaktera, ${ }^{674}$ a predstavlja donekle i sliku Bahrovih suvremenika. Bahr uklapa ovaj „erotski mit“ fin de siècle-a u okvire determinističke slike čovjeka, time što fatalistički element ovakve koncepcije rodnih odnosa predstavlja psihološku zakonitost u ljubavnom životu nasljedno-biološki opterećenih ljudskih priroda.

Psihoseksualni profil žene „vampa“, koji se može okarakterizirati kao conditio feminina (lat.), postaje modelom hereditarnog (nasljednog) i društveno determiniranog ženskog ponašanja, dok se ropska podložnost muškarca koji pokazuje znakove neurastenije može

\footnotetext{
${ }^{672}$ Vidi Lacko Vidulić 1998, str. 20.

${ }^{673}$ Vidi Lacko Vidulić: ,panerotische Domina“, 1998, str. 31.

${ }^{674}$ Ibid., str. 31.
} 
označiti kao conditio masculina (lat.) te postaje modelom nasljedno i društveno determiniranog muškog ponašanja. ${ }^{675}$

Determinističko legitimiranje dekadentnog ljubavnog iskustva jasno upućuje na hereditarni izvor oboljenja zbog ljubavi, a otkrivanje prethodne povijesti i prikaz simptoma oboljenja uklapaju napadnu tematiku i apsurdno sročenu tezu o ljubavi koja donosi smrt u trijezne okvire determinističke slike čovjeka. Etiologija, anamneza i simptomatika nagonsko psihološke pojave ovdje je dio psihološke eksperimentalne konstelacije čija polazna teza glasi: „Ljubav kvari muškarca“. ${ }^{676}$

Deterministička teza o „ljubavi koja sa sobom donosi smrt“ i teza o spolnoj devijantnosti otkrivaju Bahrovu provokativnu analizu suvremenika, koju on iznosi kršenjem onodobnih tabua.

Usprkos nehotičnoj komičnosti ove drame svjedoče ova spolno-edukacijska razmišljanja o ozbiljnosti s kojom je Bahr opisao problem ljubavi koja donosi smrt: ova začuđujuća deterministička teza predstavlja problematiku nagona $\mathrm{u}$ onodobnim rodnim odnosima. $\mathrm{S}$ druge strane, odnos između klauna i majke postaje model idealnog rodnog odnosa: problematika trećeg spola, nespolne žudnje sa zamjenom običnih erotskih organa finim nervima- dugo je ta ideja zaokupljala Bahra. U djelu Die Mutter za koje Bahr naglašava da ga nitko od suvremenika nije razumio, predstavljen je, prema Bahrovim riječima, odnos koji uopće nitko nije razumio: onaj između majke i klauna. Oni nikad nisu spolno žudjeli jedno za drugim: i upravo stoga su jedno drugome mogli biti oslonac. Njihove duše su se mogle posestriti u čistim i unutarnjim nagonima, jer su njihova tijela bila razdvojena drugim porocima“. 677

\subsection{Robert Musil: Die Verwirrungen des Zöglings Törleß (Pomutnje gojenca Törlessa)}

\subsubsection{Uvod}

Roman ili duža pripovijest Die Verwirrungen des Zöglings Törleß (Pomutnje gojenca Törlessa) ${ }^{678}$ prvi je Musilov roman, objavljen 1906. godine u Beču (Wiener Verlag) i predstavlja ranu fazu njegovog stvaralaštva.

\footnotetext{
${ }^{675}$ Vidi Lacko Vidulić: ,panerotische Domina“, 1998, str. 31.

${ }^{676}$ cit. u: Lacko Vidulić 1998, str. 27.

${ }^{677}$ Usp. Hermann Bahr, Russische Reise, Dresden 1891., str. 132, cit. u: Lacko Vidulić, 1998, str. 25.

${ }^{678}$ Pomutnje gojenca Törlessa, u prijevodu Benjamina Tolića, Zagreb, 1979., naslov izvornika: Robert Musil: Die Verwirrungen des Zöglings Törleß, Suhrkamp Verlag Berlin, 2013.
} 
Ovaj roman, napisan u stilu psihološkog romana razvoja ličnosti (njem. Entwicklungsroman), problematizira razdoblje proživljavanja puberteta glavnoga muškog lika, mladog gojenca Törlessa, u njegovu suživotu $\mathrm{s}$ četvoricom kolega u provincijskom vojnom internatu Habsburške Monarhije, koji predstavlja autoritarnu instituciju. Treba napomenuti da Musil Törlessova pubertetska proživljavanja isprepliće sa spoznajnom teorijom Ernsta Macha, koji je bio začetnik empiriokriticizma i književnog impresionizma, naglašavajući neprestanu izmjenu percepcija, osjeta i misli mladića (pojam fluidnog jastva).

Musil u glavnome liku prikazuje razvojnu fazu intelektualno i umjetnički senzibilnog pojedinca, a roman nosi i određene autobiografske crte. Kao što ćemo pokazati, problematika hibridnog roda značajna je i za ovo djelo. Musil će se ovom problematikom pozabaviti i kasnije, u svom kapitalnom djelu Der Mann ohne Eigenschaften.

Prema Iris Paetzke, Musilov roman Pomutnje gojenca Törlessa prikazuje oblik subjektivizma pojedinca kao vrstu djetinjeg narcizma, koji prerasta u pomutnje i trpnju umjetnički senzibilnog esteta. Paetzke također navodi da se ovo djelo donekle može usporediti s djelom Leopolda von Andriana Der Garten der Erkenntnis gdje je također prikazana upućenost esteta samog na sebe, koja predstavlja vrstu pogubnog gubitka realiteta, a koji se poslije mistificira u tajnu života. ${ }^{679}$

\subsubsection{Eksplicitni rod}

Roman prvenstveno prikazuje poniranje glavnog lika, gojenca Törlessa, u vlastiti unutarnji svijet (usporavanje tempa pripovijedanja, odnosno Zeitdehnendes Erzählen), koji se, kao prikaz subjektivnog svijeta i vremena, razlikuje od društvenog okruženja (vremena) u kojem se Törless zatekao. ${ }^{680}$

Kroz glavni lik djela, gojenca Törlessa, prikazuje se unutarnja transcendencija psihe mladog čovjeka u njegovim pubertetskim previranjima. Cijelo se djelo može okarakterizirati kao svojevrsna potraga za smislom egzistencije mladog Törlessa (engl. quest), ${ }^{681}$ iako djelo ulazi u sferu pubertetske pripovijesti, u kojoj se buđenje spolnosti u Törlessu usko može povezati uz njegovu rodnu ambivalenciju i traganje za pravom definicijom njegovog rodnog identiteta. Bitno je naglasiti da se početna Törlessova rodna ambivalencija, koja se u razradi romana sve više očitovala kroz ambivalenciju između homoeroticizma i heteroseksualnosti, ipak na samom kraju romana (re)definirala kao povratak normativnoj, heteroseksualnoj matrici-

\footnotetext{
${ }^{679}$ Vidi Iris Paetzke: Erzählen in der Wiener Moderne, 1992, str. 111-112.

${ }^{680}$ Vidi Nünning/Nünning 2004, str. 74.

${ }^{681}$ Ibid., 2004, str. 106.
} 
zadnje sekvence u romanu prikazuju Törlessovo viđenje vlastite majke kao odvojivog, heteroseksualnog objekta za kojim on može razviti svoju žudnju.

Ovaj roman razvoja ličnosti (njem. Entwicklungsroman) na rodno subverzivan način prikazuje homoseksualne, mazohističke i sadističke odnose među mladićima u internatu, time potkopavajući tradicionalne i normativne rodne obrasce. ${ }^{682}$

Tema romana je pokušaj pronalaženja vlastitog (rodnog) identiteta mladića čije ponašanje varira od potpune ,estetske“ ravnodušnosti preko racionalnosti (kritičkog promatranja stvarnosti) do emocionalnosti, pa i određenog „mističnog“ iskustva svijeta. Djelo prikazuje krizu identiteta mladića $\mathrm{u}$ njegovom odlasku iz građanskog doma $\mathrm{u}$ vojni internat te upoznavanju novih kolega i sučeljavanju posebno s kolegama Beinebergom, Reitingom i Basinijem. Nužno je naglasiti njegov ambivalentan homoerotički, homoseksualni, a povremeno i sadistički konotirani odnos prema kolegi Basiniju po uzoru na kolege Beineberga i Reitinga, dok Basini, koji pokazuje crte feminizacije, postaje njihovom žrtvom.

Törlessa duboko obilježava esencijalna osamljenost $u$ internatu te pasivnost i receptivnost esteta. Već u ranoj fazi odrastanja otkriva se njegova sklonost esteticističko-intelektualnom promatranju svijeta, budući da posjeduje sposobnost „čuđenja“ nad samorazumljivim, odnosno otkrivanja neke druge stvarnosti, koja se na trenutke miješa s krizom identiteta. Törless ponire $u$ prostore svojeg unutarnjeg svijeta (,unutarnja transcendencija“6833 psihičkog života), koji se isprepliće s njegovom senzualnošću.

Što se tiče motiva u djelu, oni se povezuju na način kompozicijsko-estetske motivacije. Provodni motivi su sljedeći: 1. homoeroticizam koji se isprepliće sa sadističkim porivima, 2. žudnja i zazor prema ženama i ženskosti mladića u razdoblju puberteta, 3. fluidan identitet mladića u pubertetu koji zapravo naginje biseksualnosti (odnosno, oscilacije Törlessova rodnog identiteta).

U Musilovu djelu prevladava prikaz percepcija, osjeta i osjećanja mladića-gojenca, koji se našao u specifičnim i otuđenim društvenim okolnostima (vojni internat). Jezikom psihologa pripovjedač komentira iskustva lika. Individualno i razvojno-psihološko objašnjenje veže u ovom romanu konflikt između probuđene spolnosti i zadanih normi na individualni slučaj mladoga gojenca. ${ }^{64}$ Pripovjedač u djelu prikazuje Törlessove pomutnje kao jednu prolaznu, iako kritičnu fazu njegovog života. On objašnjava ono što sam lik još ne razumije, i prepoznaje ono što roditeljima izmiče. Stoga mu je moguće generalizirati iskustva gojenca jer

${ }^{682}$ Usp. također analizu u: Robert Musil Handbuch, Nübel/Wolf (Hrsg.), Walter de Gruyter GmbH, Berlin/Boston 2016, str. 102., zatim str. 109.

683 vidi Nünning/Nünning 2004, str. 88-89.

${ }^{684}$ Paetzke 1992, str. 113. 
je informiran o tome kako mladi ljudi prolaze kroz period odrastanja. ${ }^{685}$ Dok gojenac još uvijek ne može razlikovati između dobra i zla, pripovjedač je, što se toga tiče, u svojoj prosudbi siguran.

Djelo pripada žanru pubertetske pripovijesti, a taj je žanr odlučujući u odnosu između pripovjedača i glavnog lika: ovo je relacija između pripovjedača i glavnog lika koja odgovara odnosu odraslog čovjeka i gojenca. ${ }^{686}$ Treba napomenuti da se pripovjedač, iako zadržava određenu pripovjedačku distancu kako bi prikazao pubertetski razvoj jednog mladića, ipak u pojedinim trenutcima gotovo u potpunosti konsolidira s likom Törlessa, odnosno uživljava u njegove percepcije i duševna stanja. Ovim je načinom pripovijedanja problematika krize identiteta, koja je prikazana na iskustvima učenika u vojnom internatu, ograničena na nesigurnost gojenca koji još nije pronašao stabilno jastvo. ${ }^{687}$ Međutim, i pripovjedač svojim pripovijedanjem prikazuje područja koja nisu prisutna razumu (iracionalna su) i time ograničava suverenitet subjekta (u svrhu kvazi-mističnog obogaćenja). Međutim, pripovjedačka gesta ipak signalizira sigurnost pripovjedača u dodjeljivanju prosudbe, budući da on ipak može s višeg stanovišta komentirati sve događaje. ${ }^{688}$

Lik mladog Törlessa predstavlja individuu u svom psihološkom procesu sazrijevanja, koja još nije do kraja dobila jasne konture stabilne ličnosti. Ovaj izričito individualno, višedimenzionalno i otvoreno koncipirani lik mladića ipak donekle tipološki pripada liku amoralnog esteta. On je psihološki rascijepljen između građanskog morala svojega podrijetla s jedne i nazora svojih agresivnih kolega Beineberga i Reitinga s druge strane. Prema Paetzke, Törless se osjeća rastrganim, odnosno rascijepljenim između dva svijeta, jednim solidnim građanskim, u kojem se sve odvija po pravilima i razumski, i jednim avanturističkim,

punim tame, tajne, krvi i neslućenih iznenađenja. Činilo se zatim da jedan isključuje drugi. Podrugljiv smiješak, što bi ga rado bio zadržao na svojim usnama križao se s jezom koja ga je podilazila. Nastajalo treperenje misli..." (...) Zatim je čeznuo da napokon u sebi osjeti nešto određeno; stalne potrebe koje bi lučile dobro od lošega, uporabljivo od neuporabljivoga; da znade birati makar i pogrešno-ipak bolje nego da odveć prihvatljivo sve prima u se. ${ }^{69}$

\footnotetext{
${ }^{685}$ Paetzke 1992, str. 123.

686 Ibid.

${ }^{687}$ Ibid.

688 Ibid.

689 „Er fühlte sich gewissermaßen zwischen zwei Welten zerrissen: Einer solid bürgerlichen, in der schließlich doch alles geregelt und vernünftig zuging, wie er es von zu Hause her gewohnt war, und einer abenteuerlichen, voll Dunkelheit, Geheimnis, Blut und ungeahnter Überraschungen. Die eine schien dann die andere auszuschließen. Ein spöttisches Lächeln, das er gerne auf seinen Lippen festgehalten hätte, und ein Schauer, der ihm über den Rücken fuhr, kreuzten sich. Ein Flimmern der Gedanken entstand...Dann sehnte er sich danach, endlich etwas Bestimmtes in sich zu fühlen; feste Bedürfnisse,die zwischen Gutem und Schlechtem, Brauchbarem und Unbrauchbarem schieden; sich wählen $\mathrm{zu}$ wissen, wenn auch falsch-besser doch, als überempfänglich alles in sich aufzunehmen..., Robert Musil, Die Verwirrungen des Zöglings Törleß, str. 58-59., usp. također Pomutnje gojenca Törlessa, str. 44.
} 
Törless se zbog svojih homoerotičkih sklonosti nije mogao oduprijeti odnosu s Basinijem, iako ne na toliko grubo fizički, sadomazohistički način kao što su to činili njegovi kolege. Pred sam kraj romana, Törless se razvija u „mladića vrlo otmjena i osjetljiva duha“: „Ubrajao se tada među one estetično-intelektualne prirode kojima uvažavanje zakona, a jamačno djelomice i javnoga ćudoređa, daje neko smirenje... “. 690

Prisutne su, u njegovom karakteru, i naznake svojevrsne androgine samodostatnosti, koje se otkrivaju i u njegovom ,internaliziranju“ vlastite ženskosti, odnosno ženskog identiteta, budući da je on u razdoblju prije puberteta povremeno sam sebe doživljavao kao djevojčicu:

U njegovoj koži, oko cijeloga tijela, budio se pri tomu nekakav osjećaj, koji najednom postade spomenslikom. Kad je bio posve malen- da, da, tada je to bilo - kad je još nosio košuljicu i još nije išao u školu, bilo je vremena kad je u njemu bila posve neizreciva čežnja da bude djevojčicom. (...) Da, bilo je trenutaka u kojima se tako živo ćutio kao mala djevojčica da je vjerovao kako to i ne može biti drukčije. Jer tada nije ništa znao o značenju tjelesnih razlika, i nije shvaćao zašto su mu sa svih strana govorili da sada mora jamačno zauvijek ostati dječakom. A kad bi ga pitali zašto bi radije bio djevojčica, osjetio bi da se to nipošto ne da reći...“ (...) „Nešto što se činilo da je istodobno tijelo i duša. ${ }^{691}$

Ovaj citat odražava Törlessovu želju iz djetinjstva da postane ženskim bićem, što upućuje na zamjenu rodnih uloga (muškarac, odnosno dječak koji se u svom rodnom identitetu poistovjećuje s djevojčicom). Ovaj odlomak u djelu naznačuje i njegovu onodobnu fazu primarnog narcizma esteta. U sadašnjoj fazi Törlessova razvoja ličnosti (razdoblje puberteta) ova vrsta identifikacije sa ženskošću ipak donekle predstavlja želju za premošćivanjem homoerotičkih impulsa, kao i želju za približavanjem ženskom spolu.

Glavni lik pokazuje crte esteticizma, a također i crte mazohizma (odnos s prostitutkom Boženom, koju na trenutke uspoređuje sa svojom majkom) i sadizma, budući da prešutno sudjeluje u fizičkom i seksualnom zlostavljanju kolege Basinija zajedno sa Beinebergom i Reitingom. Treba spomenuti i kontekst posebne forme intelektualizma i estetske ravnodušnosti čudnovato povezane s elementima mističnog uranjanja u pojave koje prožimaju

\footnotetext{
690 „Törleß wurde später,nachdem er die Ereignisse seiner Jugend überwunden hatte, ein junger Mann von sehr feinem und empfindsamen Geiste. Er zählte dann zu jenen ästhetisch- intellektuellen Naturen, welchen die Beachtung der Gesetze und wohl auch teilweise der öffentlichen Moral eine Beruhigung gewährt", Die Verwirrungen des Zöglings Törleß, str. 162., usp. također Pomutnje gojenca Törlessa, str. 118.

${ }^{691}$ „In seiner Haut, rings um den ganzen Körper herum, erwachte dabei ein Gefühl, das plötzlich zu einem Erinnerungsbilde wurde. Als er ganz klein war, -ja, ja, da war's,- als er noch Kleidchen trug und noch nicht in die Schule ging, hatte er Zeiten, da in ihm eine ganz unaussprechliche Sehnsucht war, ein Mäderl zu sein (...) Ja es gab Augenblicke, wo er sich so lebhaft als ein kleines Mädchen fühlte, daß er glaubte, es könne gar nicht anders sein. Denn er wußte damals nichts von der Bedeutung körperlicher Unterschiede, und er verstand es nicht, (...) warum er denn glaube, lieber ein Mäderl zu sein, so fühlte er, daß sich das gar nicht sagen lasse........) Etwas, das Körper und Seele zugleich zu sein schien.“, Die Verwirrungen des Zöglings Törleß, str. 124, usp. također Pomutnje gojenca Törlessa, str. 91.
} 
lik senzibilnog esteta Törlessa. Törless, dakle, ipak predstavlja kompleksan lik senzibilnog esteta, u kojem je latentno, ali snažno, prisutna senzualnost koja ga opterećuje:

Törless nije sudjelovao u toj obijesnoj, starmaloj muškosti svojih prijatelja. Razlogom je tomu djelomice svakako bila stanovita plahost u spolnim pitanjima, što je osobina gotovo svih jedinaca, ali većim dijelom osebujna vrsta njegove ćutilne naravi, koja je bila skrovitije, jače i mračnije obojena nego u njegovih prijatelja i teže se očitovala. Dok su drugi sa ženama besramno postupali, gotovo više da bi bili ,gizdavi“, nego zbog požude, duša je šutljivog malog Törlessa bila razrovana i šibana pravom besramnošću. ${ }^{692}$

„U Zavod je naime jednoga dana stupio mladi knez H., koji je vukao lozu od jednoga od najutjecajnijih, najstarijih i najkonzervativnijih plemićkih rodova velikog carstva“ ${ }^{693}$

Već u prvim opisima mladoga kneza opisuje se njegova nježnost i feminiziranost, kroz opis blagih očiju, te način na koji ga drugi, agresivni kolege tretiraju: „način kako je stojeći gnječio kuk i pri govoru lagano poigravao prstima ismijavali su kao ženskost““. ${ }^{694}$

Znakovit je Törlessov odnos s mladim knezom H., koji je Törlessu postao „vrelom istančana psihološkog užitka““695: „u društvu toga kneževića ćutio se otprilike kao u kakvoj crkvici podaleko od puta“. ${ }^{696}$ Mladi knez H. predstavlja u punom smislu lik nježnoga mladića, te je Törless neprestano žalio za tim što su se razišli (nakon njihovog kratkotrajnog poznanstva, mladi je knez napustio konvikt), što ukazuje na Törlessove prve homoerotičke sklonosti. Lik mladoga kneza H. predstavlja donekle jedinu harmoničnu i uporišnu točku u tadašnjem Törlessovom identitetu, pa se ova faza Törlessova razvoja ličnosti može okarakterizirati kao vrsta „djetinjeg“ narcizma esteta.

„Törless je to kratko vrijeme živio kao u kakvoj idili. Nije se spotaknuo na religioznost svoga novog prijatelja, koja je njemu, izdanku slobodoumne građanske obitelji bila nešto

\footnotetext{
${ }^{692}$ „Törleß beteiligte sich nicht an dieser übermütigen, frühreifen Männlichkeit seiner Freunde. Der Grund hiezu lag wohl teilweise in einer gewissen Schüchternheit in geschlechtlichen Sachen, wie sie fast allen einzigen Kindern eigentümlich ist, zum größeren Teile jedoch in der ihm besonderen Art der sinnlichen Veranlagung, welche verborgener, mächtiger und dunkler gefärbt war als die seiner Freunde und sich schwerer äußerte. Während die anderen mit den Weibern schamlos- taten, beinahe mehr um „fesch“ zu sein, als aus Begierde, war die Seele des schweigsamen, kleinen Törleß aufgewühlt und von wirklicher Schamlosigkeit gepeitscht.“, Die Verwirrungen des Zöglings Törleß, str.23., usp. Pomutnje gojenca Törlessa, str. 18.

693 „Eines Tages war nämlich der junge Fürst $\mathrm{H}$. ins Institut eingetreten, der aus einem der einflußreichsten, ältesten und konservativsten Adelsgeschlechter des Reiches stammte. (Alle anderen fanden seine sanften Augen fad und affektiert; die Art und Weise, wie er im Stehen die eine Hüfte herausdrückte und beim Sprechen langsam mit den Fingern spielte, verlachten sie als weibisch)“, Die Verwirrungen des Zöglings Törle $\beta$, str. 14., usp. Pomutnje gojenca Törlessa, str. 11.

${ }^{694}$ Alle anderen fanden seine sanften Augen fad und affektiert; die Art und Weise, wie er im Stehen die eine Hüfte herausdrückte und beim Sprechen langsam mit den Fingern spielte, verlachten sie als weibisch“, Die Verwirrungen des Zöglings Törleß, str. 14., usp. Pomutnje gojenca Törlessa, str. 11.

${ }^{695}$ „Der Umgang mit dem Prinzen wurde so zur Quelle eines feinen psychologischen Genusses für Törleß“, Die Verwirrungen des Zöglings Törleß, str. 14., usp. Pomutnje gojenca Törlessa, str. 11.

${ }^{696}$ „In der Gesellschaft dieses Prinzen fühlte er sich etwa wie in einer abseits des Weges liegenden Kapelle“, Die Verwirrungen des Zöglings Törleß, str. 15, usp. Pomutnje gojenca Törlessa, str. 12.
} 
posve tuđe.“697 Tako je Törlessu prekid s mladim knezom H. izazvao u njemu osjećaj da je nešto lijepo razbijeno, u čemu se ogleda njegov prvi homoerotički impuls.

U Törlessovom odnosu prema mladom knezu nameće se pojam tzv. ,psihološki užitak“, čiji opis predstavlja intuitivnu spoznaju koju propagira onodobna filozofija života: „osjećajno zahvaćanje cjeline, (...) duševno ljudskoga u kojoj se pojedina gesta pojavljuje kao pravo znanje o čovjeku“. 698

Törlessova prava previranja počinju upravo nakon gubitka ove relativno harmonične komunikacije: „Nakon odlaska mladoga kneza iz konvikta „oko Törlessa je zavladala posvemašnja pustoš i dosada, te se u njemu mračno i postupno počela javljati spolna zrelost. “699

Beineberga, koji predstavlja lik tiranina, oduševljava indijska filozofija, kojom se bavio i njegov otac, a kojom on opravdava mučenja Basinija. Njegova neemotivna „volja za moćc i grubost izraz su poklonika nihilizma i protivnika kršćanskog morala koji, suprotno tome, naučava milosrđe i ljubav prema bližnjima. Na taj način Beinebergov Nietzscheanski konotirani nihilizam odražava njegovu „volju za moć“, odnosno želju za grubom, homoseksualno obilježenom dominacijom nad Basinijem, koga poima kao žensko biće. „Beineberg je pripovijedao o Indiji, gdje je njegov otac, koji bijaše general, službovao nekad kao mladi časnik u engleskoj službi“ “ ${ }^{700}$ Beineberg, budući je njegov otac upućen u indijsku filozofiju, pokazuje crte Nietzscheanskog pojma vitalizma, a time i muški konotirane agresivnosti, koje su protivne suptilnom načinu uživljavanja u ljude i pojave i introvertiranosti koje karakteriziraju Törlessa. Beineberg predstavlja kontradiktornu ličnost jer s jedne strane (iako na ironičan način) ne poriče postojanje ljudske duše, a s druge se strane na brutalan način odnosi prema Basiniju.

Törlessov odnos prema Beinebergu također dobiva svojevrsno homoerotičko obilježje: razmišljajući o Beinebergovu izgledu, posebno o „rukama“: „mršavi prsti, ovalni, lijepo zasvođeni nokti; bilo je stanovite otmjenosti u njima, i u tamnosmeđim očima. I u protegnutoj mršavosti cijeloga tijela bilo je nečega takvog; (njegove ruke) imale su u sebi nešto

\footnotetext{
${ }^{697}$ „Törleß lebte während dieser kurzen Zeit wie in einer Idylle. Er stieß sich nicht an der Religiosität seines neuen Freundes, die ihm, der aus einem bürgerlich-freidenkenden Hause stammte, eigentlich etwas ganz Fremdes war“, Die Verwirrungen des Zöglings Törleß, str. 15., usp. Pomutnje gojenca Törlessa, str. 11.

${ }^{698}$ Vidi Paetzke 1992, str. 117.

699 „Nach einiger Zeit trat dann auch der Prinz, der sich im Konvikte nicht wohl befunden hatte, wieder aus. Nun wurde es ganz leer und langweilig um Törleß. Aber er war einstweilen älter geworden, und die beginnende Geschlechtsreife fing an, sich dunkel und allmählich in ihm emporzuheben“, Die Verwirrungen des Zöglings Törleß, str.16., Pomutnje gojenca Törlessa, str. 12.

700 „Beineberg erzählte. Von Indien. (...) Denn sein Vater, der General war, war dort als junger Offizier in englischen Diensten gestanden“, Die Verwirrungen des Zöglings Törle $\beta$, str. 25., usp. Pomutnje gojenca Törlessa, str. 19.
} 
razvratno). ${ }^{701}$ Vidljiva je Törlessova homoerotička sklonost prema Beinebergu, dok s druge strane Törless prema tim istim homoerotičkim impulsima osjeća odvratnost.

Međutim, već kao gojenac, Törless se razlikovao od Beineberga time što je zadržao opreku između „tajanstvenih slutnji“ i ,normalnosti““. Beineberg je društvene norme i vrijednosti koje roditelji i učitelji zastupaju, kao i matematičke spoznaje, proglasio besmislicom te se $\mathrm{u}$ potpunosti predao misaonom sustavu koji, prema Paetzke, graniči sa srednjovjekovnom mistikom i budizmom. Beineberg se, shodno ničeanskoj volji za moć, suprotstavlja moralnim načelima i legitimira pravo sile jačega.

Suprotnost između Törlessa i Reitinga vidljiva je odmah, kao razlika između jedne aristokratsko-misaone prirode esteta s jedne, i agresivnog intriganta koji svoju racionalnost koristi samo u pragmatične svrhe, odnosno da bi proširio svoju moć s druge strane. „I Beineberg također polazi od opreke razuma i duše i teži k tome da nađe pristup logički neobjašnjivom području“. ${ }^{702}$ Reiting se može okarakterizirati i kao lik nasilnika željnog dominacije, koja se povezuje s njegovom željom za isključivo vojnom karijerom. Reiting također predstavlja i lik spletkaroša: „(...) uprizorenju i tijeku mnogobrojnih spletaka što ih je poticao među svojim drugovima. Jer Reiting nije poznavao većeg zadovoljstva od toga da ljude huška jedne protiv drugih, da jednoga svladava uz pomoć drugoga (...). ${ }^{703}$ On također, kao i Beineberg, svoga kolegu Basinija smatra manje vrijednim zbog njegove feminiziranosti.

Beineberg i Reiting optuže Basinija za krađu i koriste tu situaciju kako bi ga mogli kažnjavati i mučiti na homoseksualan i sadomazohistički način. Iako se Törless svojim unutarnjo-filozofskim promišljanjima nastoji distancirati od tog mučenja, a čak na momente pokazuje i gađenje prema Beinebergovom i Reitingovom mučenju, on ipak degradira Basinija u puki erotski objekt. Ponižavanje Basinija on još u svojoj pubertetskoj fazi poima kao fascinaciju odnosima moći (dominacija jednog pojedinca nad drugim), te se na kraju ipak iskupljuje, pomogavši Basiniju, kojeg je prije prezirao. Na samom kraju romana pripovjedač konstatira kako je ,jedna razvojna etapa bila dovršena“, pa je Törlessova duša ,započela nov

\footnotetext{
701 „Magere Finger, ovale, schön gewölbte Nägel: es lag eine gewisse Vornehmheit in ihnen. Auch in den dunkelbraunen Augen. Auch in der gestreckten Magerkeit des ganzen Körpers lag eine solche. (...) Auch die Hände, (...) sie hatten etwas Unzüchtiges an sich“, Die Verwirrungen des Zöglins Törleß, str. 27-28., usp. Pomutnje gojenca Törlessa, str. 21. i 22.

${ }^{702}$ Paetzke 1992, str. 127.

703 „Ähnliches wußte er auch von Reiting. (...) Inszenesetzung und Verlauf der zahlreichen Intrigen, die er unter seinen Kameraden anstiftete. Denn Reiting kannte kein größeres Vergnügen, als Menschen gegeneinander zu hetzen, den einen mit Hilfe des anderen unterzukriegen (...), Die Verwirrungen des Zöglings Törleß, str. 55-56., usp. Pomutnje gojenca Törlessa, str. 42.
} 
god, poput mlada stabla““, ${ }^{704}$ tako da je Törless, na način amoralnog esteta, postao gotovo ravnodušan prema događanjima $\mathrm{u}$ internatu.

Basini, iako predstavlja lik senzibilnog mladića, kasnije svjesno i na mazohistički način prihvaća svoju ulogu žrtve. Neprestano je naglašen njegov vlastiti osjećaj manje vrijednosti. Posebice je neobičan Törlessov odnos prema Basiniju, koji ima jasna homoerotička, a kasnije i homoseksualna obilježja, dok ga on s druge strane poima sa svojevrsnom ravnodušnošću, koja se vrtoglavo mijenja u senzualnost i Törlessovu žudnju prema Basiniju:

(...) osjećaj vrtoglavice. U to su poput prštavih točaka u bojama vrcali osjećaji što ih je Basini u njemu pobuđivao u različna vremena. Pravo govoreći, bijaše to zacijelo svagda samo jedan te isti osjećaj. A posve pravo, uopće nikakav osjećaj, nego više nekakav potres posve duboko na dnu, koji nije izazivao nikakvih vidljivih valova, a od kojega bi ipak sva duša tako suzdržano silno uzdrhtala da se valovi i najburnijih osjećaja pokraj toga ukazuju kao bezazleno mreškanje površine“ ${ }^{705}$ „Ali gdje bi u njemu zapravo valjalo tražiti tu iluzivnu-a ipak uvijek za dlaku premalo iluzivnu- snagu, on nije znao. Samo je nejasno slutio da je ona u vezi s onim zagonetnim svojstvom njegove duše (...); „, Törless je dakle sjedio posve mirno i ukočeno, neprekidno gledao prijeko u Basinija i bio posve obuzet bjesomučnim kovitlanjem svoje nutrine. ${ }^{706}$

I uvijek je iznova odatle izranjalo ono jedno pitanje: Kakvo je to osobito svojstvo što ga imam?“ (...). ${ }^{707}$ Ova rečenica prikazuje Törlessov homoeroticizam, koji je upućen isključivo prema feminiziranim mladićima, te se njegova žudnja prenosi s feminiziranog Basinija na glumicu, koja je u mladosti pobuđivala duboke osjećaje u njegovoj duši:

Bio je u onom stanju više duševne nego tjelesne groznice, koju je jako volio. Sve je više bujalo to raspoloženje u koje se bijahu umiješali i nježni osjećaji. U tom se stanju prije rado predavao onim uspomenama što ih za sobom ostavlja žena kad njezin topli dah prvi put okrzne takvu mladu dušu. A i danas se u njemu budila ta umorna toplina. (...) Svake su večeri ondje davali istu operu, (...). A ipak je svake večeri sjedio uz otvoren prozor i slušao. Tako se zaljubio u jednu od glumica, a da je nikad nije vidio. Nikad ga kazalište nije ganulo tako kao tada; osjećao je strast melodija kao lepet krila velikih tamnih ptica, kao da je mogao osjetiti linije što ih je njihov let risao u njegovoj duši. To što je slušao nisu više bile ljudske strasti, ne, to su bile strasti koje su pobjegle iz ljudi, kao iz preuskih i odveć

\footnotetext{
704 „Eine Entwicklung war abgeschlossen, die Seele hatte einen neuen Jahresring angesetzt wie ein junger Baum“, Die Verwirrungen des Zöglings Törleß, str. 194., Pomutnje gojenca Törlessa, str. 139.

705 „daß sich sofort in ihm etwas regte wie eine wahnsinnig kreiselnde Bewegung, die augenblicklich das Bild Basinis zu den unglaublichsten Verrenkungen zusammenbog, dann wieder in nie gesehenen Verzerrungen auseinanderriß, so da $\beta \mathrm{ihm}$ selbst davor schwindelte. (...) Im Augenblicke selbst hatte er nur das Gefühl, da $\beta$ etwas in ihm wie ein toller Kreisel aus der zusammengeschnürten Brust zum Kopfe hinaufwirble, das Gefühl seines Schwindels. (...) Eigentlich war es ja immer nur ein und dasselbe Gefühl gewesen. Und ganz eigentlich überhaupt kein Gefühl, sondern mehr ein Erdbeben ganz tief am Grunde, das gar keine merklichen Wellen warf und vor dem doch die ganze Seele so verhalten mächtig erzitterte, daß die Wellen selbst der stürmischen Gefühle daneben wie harmlose Kräuselungen der Oberfläche erscheinen“, Die Verwirrungen des Zöglings Törleß, str. 130., usp. Pomutnje gojenca Törleßa, str. 95.

${ }^{706}$ „Törleß saß also ganz still und starr, sah unaufhörlich zu Basini hinüber und war ganz in dem tollen Wirbeln seines Inneren befangen“, Die Verwirrungen des Zöglings Törleß, str. 131., usp. Pomutnje gojenca Törlessa, str. 96.

${ }^{707}$ „Und immer wieder tauchte daraus die eine Frage auf: Was ist das für eine besondere Eigenschaft, die ich besitze?“, Die Verwirrungen des Zöglings Törleß, str. 131., usp. Pomutnje gojenca Törlessa, str. 96.
} 
svakodnevnih kaveza. (...) Taj tmurni plamen, te oči u tami, taj crni lepet krila volio je tada pod imenom one njemu nepoznate glumice. ${ }^{708}$

Dok je s jedne strane Törlessov odnos prema Basiniju prožet određenom estetskom ambivalencijom, pripovjedač opisuje Törlessovu platonsku ljubav na daljinu prema mladoj glumici.

U Törlessovoj se psihi, dakle, uz homoseksualna, pojavljuju također i heteroseksualna previranja. On još nije premostio svoju fazu pubertetskih i biseksualnih previranja: „Jedna misao stezala je Törlessa po svemu tijelu. Jesu li i odrasli takvi? Je li svijet takav? Je li to nekakav opći zakon da u nama ima nešto što je jače, veće, ljepše, strastvenije, mračnije od nas? ${ }^{6709}$

U sljedećem citatu vidljivo je Törlessovo rodno ambivalentno osjećanje prema Basiniju, koje ima obilježje homoeroticizma, a kasnije i homoseksualnosti, ali prerasta također i u neku vrstu estetske ravnodušnosti, koja se ipak miješa s određenom vrstom fizičke žudnje, budući da Törless Basinijevo tijelo poima kao žensko: „Ali zaista ne valja misliti ni da je Basini u Törlessu pobudio pravu i- kako god površnu i smetenu- istinsku požudu. Istina, u Törlessu se bijaše probudilo nešto poput strasti, ali ljubav je tomu posve sigurno bila samo slučajnim, približnim imenom, a čovjek Basini tek nadomjesnim, privremenim ciljem toga čeznuća.“710

Uopće, bijaše ga prije svega zabljesnula samo golotinja vitkoga dječačkog tijela. Dojam nije bio drukčiji od onoga što bi ga na nj bili ostavili samo lijepi oblici kakve djevojčice, koji su još daleko od svake spolnosti. Svladavanje. Čuđenje. I upravo je čistoća, koja je nehotice proizlazila iz toga stanja, unosila u njegov odnos prema Basiniju privid nagnuća- taj novi divno nemirni osjećaj. Ali sve je drugo

\footnotetext{
708 „Er befand sich in jenem Zustande eines mehr seelischen als körperlichen Fiebers, den er sehr liebte. Immer mehr wuchs diese Stimmung, der auch zärtliche Regungen beigemengt waren, an. In diesem Zustande hatte er sich früher gerne jenen Erinnerungen hingegeben, welche das Weib hinterläßt, wenn sein warmer Atem zum ersten Male an solch einer jungen Seele vorbeistreift. Und auch heute erwachte in ihm diese müde Wärme. Da: eine Erinnerung... (...) Jeden Abend gaben sie dort dieselbe Oper, und jeden Abend hörte er jedes Wort und jeden Ton herüber. Aber er war der Sprache nicht mächtig. Und jeden Abend saß er dennoch am offenen Fenster und hörte zu. Auf diese Weise verliebte er sich in eine der Schauspielerinnen, ohne sie je gesehen zu haben. Er war nie vom Theater so ergriffen worden wie damals; er empfand die Leidenschaft der Melodien wie Flügelschläge großer dunkler Vögel, als ob er die Linien fühlen könnte, die ihr Flug in seiner Seele zog. Es waren keine menschlichen Leidenschaften mehr, die er hörte, nein, es waren Leidenschaften, die aus den Menschen entflohen, wie aus zu engen und zu alltäglichen Käfigen. (...) Diese düstere Flamme, diese Augen im Dunkel, diese schwarzen Flügelschläge liebte er damals unter dem Namen jener ihm unbekannten Schauspielerin.“, Die Verwirrungen des Zöglings Törleß, str. 132. , Pomutnje gojenca Törlessa, str. 97.

709 „Sind auch die Erwachsenen so? Ist die Welt so? Ist es ein allgemeines Gesetz, daß etwas in uns ist, das stärker, größer, schöner, leidenschaftlicher, dunkler ist als wir?“, Die Verwirrungen des Zöglins Törleß, str. 133., Pomutnje gojenca Törlessa, str. 97.

710 „Aber man darf auch wirklich nicht glauben, daß Basini in Törleß ein richtiges und- wenn auch noch so flüchtig und verwirrt- wirkliches Begehren erregte. Es war allerdings etwas wie Leidenschaft in Törleß erwacht, aber Liebe war ganz gewiß nur ein zufälliger, beiläufiger Name dafür, und der Mensch Basini nicht mehr als ein stellvertretendes und vorläufiges Ziel dieses Verlangens.“, Die Verwirrungen des Zöglings Törleß, str. 159., usp. Pomutnje gojenca Törlessa, str. 115.
} 
imalo s tim malo veze. Taj preostatak žudnje postojao je već odavno- već kod Božene i još mnogo prije. Bila je to skrivena, besciljna, ni na koga upravljena, melankolična putenost mladića,... (....). ${ }^{711}$

Ova ni na koga upravljena, melankolična putenost mladića upravo odražava habitus primarnog narcizma esteta, koji se ipak nalazi u fazi pubertetskih previranja, a još nije premostio edipalnu fazu. Na taj način Törlessa načelno privlači ono ženstveno u muškarcu, odnosno, privlače ga androgine (gotovo nespolne) pojavnosti kod muškarca, a nalazi se u internatu gdje mu je pristup ženama onemogućen, dok s druge strane osjeća i odbojnost $\mathrm{i}$ privlačnost prema prostitutki Boženi:

sve ono skriveno, zabranjeno, zapareno, neizvjesno i samotno u Törlessovoj duši i usmjerili te tamne pobude prema Basiniju. Jer tu su one najednom naletjele na nešto što je bilo toplo, disalo, mirisalo, bilo put, koja je tim sanjama, što su neodređeno lutale, dala oblik i dio svoje ljepote, umjesto jetke rugobe kojom ih je u samoći šibala Božena“. (...) „Ali ni sam Törless više nije mogao sve to razlučivati i sve mu je bilo spojeno u jednom jedinom, nejasnom, neraščlanjenom osjećaju, koji je u prvom iznenađenju jamačno mogao smatrati ljubavlju. ${ }^{712}$

\section{Nejasnost Törlessovih osjećaja upućuju na fluidnost njegova jastva.}

Törless Basinijevo tijelo poima kao žensko tijelo, i u tome se trenutku bude njegovi homoerotički impulsi, koji prerastaju u ljubav prema umjetnosti:

Iznenadni ga je pogled na to golo, snježnobijelo tijelo, (...) zabljesnuo i zaprepastio. Basini je bio lijepo građen; na njegovu tijelu nije bilo gotovo nikakva traga muškim oblicima, ono se odlikovalo nekom nevinom, vitkom mršavošću, poput tijela kakve djevojčice. (...) Nije se mogao oteti vlasti te ljepote. Prije toga nije znao što je ljepota. Jer što je njemu, u njegovoj dobi, bila umjetnost, koliko ju je, najposlije, i poznavao?!. ${ }^{713}$

Basinijeva krhka građa tjela, meke trome kretnje, ženskaste crte lica, „koketna“ ljubaznost, pa i njegova naklonost prema vlastitoj sestri (u čemu se vide naznake i svojevrsnog fetišizma)

711 „Vorerst war es überhaupt nur die Nacktheit des schlanken Knabenkörpers gewesen, die ihn geblendet hatte. Der Eindruck war nicht anders, als wäre er den nur schönen, von allem Geschlechtlichen noch fernen Formen eines ganz jungen Mädchens gegenübergestanden. Eine Überwältigung. Ein Staunen. Und die Reinheit, die unwillkürlich von diesem Zustande ausging, war es, die den Schein einer Neigung- dieses neue wunderbar unruhige Gefühl in sein Verhältnis zu Basini trug. Alles andere aber hatte damit wenig zu tun. Dieses übrige des Begehrens war schon längst, -war schon bei Božena und noch viel früher dagewesen. Es war die heimliche, ziellose, auf niemanden bezogene, melancholische Sinnlichkeit des Heranreifenden, (...), Die Verwirrungen des Zöglings Törle $\beta$, str. 159., usp. Pomutnje gojenca Törlessa, str. 115-116.

${ }^{712}$,....alles Heimliche, Verbotene, Schwüle, Ungewisse und Einsame von Törleß' Seele gesammelt hatte, aufgestoßen und diesen dunklen Regungen die Richtung gegen Basini erteilt. Denn da stießen sie mit einem Male auf etwas, das warm war, atmete, duftete, Fleisch war, an dem diese unbestimmt schweifenden Träume Gestalt gewannen und Teil seiner Schönheit, statt der ätzenden Häßlichkeit, mit der sie Božena in der Einsamkeit gestäupt hatte. (...) Aber dies alles war für Törleß selbst nicht mehr unterscheidbar und war für ihn in einem einzigen, unklaren, ungegliederten Gefühl vereint, das er in der ersten Überraschung wohl für Liebe nehmen mochte.“, Die Verwirrungen des Zöglings Törle $\beta$, str. 160., Pomutnje gojenca Törlessa, str. 116 -117.

713 „Der plötzliche Anblick dieses nackten, schneeweißen Körpers, (...) blendete und bestürzte ihn. Basini war schön gebaut; an seinem Leibe fehlte fast jede Spur männlicher Formen, er war von einer keuschen, schlanken Magerkeit, wie der eines jungen Mädchens. (...) Er (Törless) konnte sich der Macht dieser Schönheit nicht entziehen. Er hatte vorher nicht gewußt, was Schönheit sei. Denn was war ihm in seinem Alter Kunst, was kannte er schließlich davon?!“, Die Verwirrungen des Zöglings Törleß, str. 143., usp. Pomutnje gojenca Törlessa, str. 104. 
ukazuju na njegovu nježnost i feminiziranost. K Boženi je dolazio „samo da se pravi muškarcem“, što upućuje ne samo na njegovu sklonost homoeroticizmu, nego i na pomanjkanje tradicionalno muški konotirane požude vezane uz muški libido, budući da Basini predstavlja krhkog mladića, koji upravo stoga postaje žrtvom nasilnika Beineberga i Reitinga. Odnose s Boženom on osjeća kao prisilu: „Osjećao je to, naprotiv, samo kao prisilu, kao pristalost ili obvezu da se na njemu nađe miris galantnih doživljaja. Najljepši mu je trenutak bio onaj kada bi odlazio od Božene, a to već prošlo, jer mu je bilo samo do posjedovanja uspomene“. 714

Basinijeve riječi: „Kaže, kad me ne bi tukao, morao bi misliti da sam muškarac, pa tada ne bi smio biti prema meni ni tako mek i nježan. A ovako da sam njegova stvar, pa se ne susteže“", ${ }^{715}$ upućuju na njegovu homoseksualnu vezu s Beinebergom, koja sadrži crte Basinijevog mazohizma prema samome sebi, kao i Beinebergovog sadizma prema Basiniju, budući da Beineberg Basinija poima kao žensko biće. Tako Basinijev rodni identitet dobiva ženska obilježja.

„Nekakvo neodređeno, skriveno gađenje nikad ga nije posve napuštalo, a nekakav ga je neizvjesni strah progonio kao čovjeka koji u tami više ne zna ima li svoj put još pod nogama ili ga je negdje izgubio. Još ga nije ostavilo, ali na kraju toga razdoblja Törless ipak nije pružao nikakva otpora kad se dalje odlučivalo o Basinijevu udesu““. ${ }^{716}$ Ovaj citat svjedoči o Törlessovoj dubokoj ambivalenciji prema vlastitim homoerotičkim porivima, koji na momente prelaze i u sadistički odnos prema Basiniju.

„Sjećanje na osjećaj napuštenosti u djetinjstvu, osjećaj tišine pri pogledu kroz prostor slastičarnice, osjećaj poniženja kod prostitutke Božene, homoerotički doživljaji vezano uz Basinija, pogled prema nebu- svi ti raznovrsni događaji međusobno su povezani metaforom određene „šutnje“ i zrenja, koje se odnosi na nepojmovnu „spoznaju“, jednu vrstu mistične slutnje, kako ju Maeterlinck prikazuje“ ${ }^{717}$

\footnotetext{
714 „Er empfand es vielmehr bloß als Nötigung, als Angemessenheit oder Verpflichtung, daß man den Duft galanter Erlebnisse an ihm nicht vermisse. Sein schönster Augenblick war der, wenn er von Božena wegging und es hinter sich hatte, denn es war ihm nur um den Besitz der Erinnerung zu tun.", Die Verwirrungen des Zöglings Törleß, str. 72., Pomutnje gojenca Törlessa, str. 54.

${ }^{715}$ Basinis Worte: „Er (Beineberg) sagt, wenn er mich nicht schlagen würde, so müßte er glauben, ich sei ein Mann, und dann dürfte er mir gegenüber auch nicht so weich und zärtlich sein. So aber sei ich seine Sache, und da geniere er sich nicht.“, Die Verwirrungen des Zöglings Törleß, str. 146., usp. Pomutnje gojenca Törlessa, str. 107.

${ }_{716}$ „Ein unbestimmter, versteckter Ekel verließ ihn niemals ganz, und eine ungewisse Angst verfolgte ihn wie einen, der im Dunkel nicht mehr weiß, ob er noch seinen Weg unter den Füßen hat oder wo er ihn verloren. (...) Noch ließ er ihn nicht, aber doch setzte Törleß am Ende dieser Zeit keinen Widerstand mehr entgegen, als über Basinis Schicksal weiter beschlossen wurde.“, Die Verwirrungen des Zöglings Törleß, str. 166., Pomutnje gojenca Törlessa, str. 121.

${ }^{717}$ Vidi Paetzke 1992, str. 113.
} 
Prema Paetzke, prijetnja koju Törless osjeća rezultira iz osamostaljenja stvari koja se događa zato što subjekt gubi vladavinu nad objektom. U osjećaju „srodnosti između jastva i stvari očituje se gubitak autonomnog razuma koji sebi podređuje svijet u procesu spoznaje“. ${ }^{718}$ „S izgubljenim povjerenjem u snagu pojma koji bi jednoznačno određivao objekte događa se iritirajuće podvostručenje pojava, u kojemu svi ljudi, stvari i pojave postaju nešto dvoznačno“ -čak i u smislu Törlessova rodnog identiteta. „Zajedno s tim ide zakazivanje tradicionalnih moralnih vrijednosti koje lik osjeća kao temeljnu nesigurnost. Za razliku od Beineberga koji se beskrupulozno prepušta svom „vjerovanju“, kod Törlessa se ipak daje naslutiti čežnja za čvrstim mjerilima koja bi dopustila razliku između dobra i zla odnosno između korisnog i nekorisnog“، 719

S tim temeljnim gubitkom sigurnosti Törlessove muškosti, koja se razvija u pojedinim fazama njegovih doživljaja u internatu, povezana je, prema Paetzke, i kritika jezika kao sredstva sporazumijevanja i racionalnosti. ${ }^{720} \mathrm{Na}$ taj način djelo postaje odrazom subjektivnog iskustva narušenog identiteta, iz čega proizlazi i Törlessova ambivalencija između homoseksualnosti i heteroseksualnosti.

Prema Paetzke, objekti percipiranja, odnosno ljudi i predmeti gube tako svoje uobičajene dimenzije $e^{721}$ :

Najčudnovatije je bilo kad bi za tim išao više sa snovima nego s premišljanjima. Tada mu se Basini ukazivao dokučiv, svakodnevan, jasnih obrisa, onako kako su ga mogli vidjeti njegovi roditelji i njegovi prijatelji: i u idućem bi trenutku nestajao i opet dolazio, uvijek iznova, kao kakva sitna, posve sitna figura koja bi povremeno bljesnula pred nekom dubokom, vrlo dubokom pozadinom. ${ }^{722}$

Iskustvo lika gojenca pokazuje dalekosežnu krizu rodnog identiteta i gubitak moralnih vrijednosti, a prema Paetzke pripovjedač se orijentira u svojim prosudbama na predodžbe filozofije života (njem. Lebensphilosophie). Musilov roman želi naglasiti pojam života kao racionalno neshvatljivoga. ${ }^{723}$

U pojedinim trenutcima Törlessova boravka u internatu, obuzima ga eskapistički osjećaj ljubavi prema neizrecivom koje služi kao zamjena za religiju, odnosno za sve ranije izvjesnosti i ćudoredne vrijednosti. Jedini trenutci u kojima Törless osjeća neku emotivnu

\footnotetext{
${ }^{718}$ Paetzke 1992, str. 113-114.

719 cit. prema Paetzke: str. 114.

${ }^{720}$ Ibid., str. 114.

${ }^{721}$ Ibid., str. 116.

722 „Am merkwürdigsten war es, wenn er (Törleß) mehr mit Träumen als mit Überlegung dem (Basinis Vergehen) nachging. Dann erschien ihm Basini verständlich, alltäglich, mit klaren Konturen, so wie ihn seine Eltern und seine Freunde sehen mochten: und im nächsten Augenblicke verschwand er und kam wieder, als eine kleine, ganz kleine Figur, die zeitweilig vor einem tiefen, sehr tiefen Hintergrunde aufleuchtete...", Die Verwirrungen des Zöglings Törleß, str. 75., usp. Pomutnje gojenca Törlessa, 1979, str. 56.

${ }^{723}$ Paetzke 1992, str. 119.
} 
stabilnost njegova su sjećanja na pisma roditeljima, zatim poznanstvo s mladim knezom i sjećanje na mističnu zanesenost na daljinu jednom glumicom (,neomistična ljubav na daljinu“ ). ${ }^{724} \mathrm{U}$ trenutcima takvih prisjećanja Törless poput Hofmannsthalova Lorda Chandosa postaje svjestan mogućnosti novog slutnjom ispunjenog odnosa prema cijelom bitku, samo kada bi se započelo razmišljati srcem. ${ }^{725} \mathrm{U}$ romanu stoga nailazimo na usporedno pojavljivanje skepse prema jezičnoj komunikaciji i mistike života s druge strane. Musilov roman i Hofmannsthalovo djelo Ein Brief prihvaćaju (donekle) formulaciju Ernsta Macha, koja propagira tada popularnu određenu senzualističku skepsu, a koja se ogleda i u kritici određenja stvarnosti preko principa kauzalnosti i uspostavlja umjesto toga primat osjećanja (ćutilnosti). ${ }^{726}$ Ovaj pozitivistički senzualizam može se povezati s krizom identiteta (građanske) svijesti oko 1900. godine: rastakanjem stvarnosti na mnoštvo elemenata, osjeta i umjetničkih impresija pokazuje se krhkost cjelovitosti jastva.

Prema Paetzke, narcističko uživanje u vlastitoj čežnji i samoći predstavlja nužan habitus esteta koji se odvaja od građanskog društva. Sljedeća etapa razvoja Törlessove ličnosti obilježena je početkom spolne zrelosti. U intenzitetu ćutilnih osjeta i fantazija razvija se posebna dispozicija Törlessa kao esteta. Iskustva s Boženom i Basinijem, zatim poznanstva s Beinebergom i Reitingom, postaje su na putu pubertetskog razvoja Törlessove seksualnosti. $\mathrm{Na}$ kraju romana nazire se donekle Törlessovo premošćivanje homoerotičkih impulsa i iskustava kojima je bio izložen u internatu. Isto tako i poznanstvo s Beinebergom i Reitingom, a i Boženina kuća ne ostavljaju na njemu sada više dublje emocije, budući da je jedna etapa njegova razvoja ličnosti dovršena. Na kraju razvojnog procesa koji pripovjedač anticipira stoji odrasli pojedinac koji se integrira u društvo time što se konsolidira s vrijednostima društva. Prema Paetzke, Törless je ipak izišao iz svojih pomutnji kao razvijeni individuum. ${ }^{727}$

Moralnost koju Törless prihvaća kao građanski princip u stvarnosti njemu služi ipak samo kao garancija za uređene izvanjske odnose koji mu dopuštaju da se u potpunosti posveti kultiviranju vlastitog habitusa esteta u svojoj privatnoj sferi. Njegov je vlastiti interes već u djetinjoj i mladenačkoj dobi introvertiran, odnosno usmjeren na vlastitu estetizaciju duha. ${ }^{728}$ No treba naglasiti i to da Törless ipak nije premostio ulogu primarnog narcizma esteta, o čemu svjedoči susret s vlastitom majkom.

\footnotetext{
${ }^{724}$ Pojam koji se spominje u biografiji samog autora Roberta Musila, „Im August verliebt er (Musil) sich in Schladming in die Münchner Pianistin Valerie Hilpert. (...) Musil erlebt Gefühle einer neomystischen Fernliebe (Vorbild für den ,,anderen Zustand“).“, Die Verwirrungen des Zöglings Törleß, Zeittafel, str. 210.

725 Prema Iris Paetzke 1992, str. 119.

${ }^{726}$ Paetzke 1992, str. 119.

${ }^{727}$ Ibid., str. 125 .

${ }^{728}$ Ibid.
} 
Paetzke napominje upitnost pomirenja individue i građanskog društva u egzistenciji esteta. Ljepota umjetnosti, intuicija velikih umjetnika i pjesnička inspiracija u ovome su djelu pozitivne odrednice i one tvore mjeru prema kojoj pripovjedač prosuđuje iskustva gojenca i korigira njegove zablude tijekom odrastanja. ${ }^{729}$ Paetzke napominje dva središnja mjesta u djelu koja opisuju ovaj habitus esteta: „Ali on se među svim tim ukaza sebi kao izabranik. Kao svetac koji ima nebeska viđenja; jer, ništa nije znao o intuiciji velikih umjetnika“" ${ }^{730}$ Paetzke napominje Törlessov habitus umjetnika odnosno njegove umjetničke talente, koji se ipak naposljetku lako mogu preobraziti u puku senzualnost. „Volio je računati s tim da su sposobnost za uživanje, umjetnički talenti, sav profinjeni duševni život ukrasom na koji se čovjek lako ozlijedi““. ${ }^{731}$

Već kao mali dječak osjećao je Törless nešto „izvanredno, ekskluzivno u sebi“: kao mladoga čovjeka vrijeđalo ga je ono obično, odnosno neestetsko. Prema Paetzke, ovaj profinjeni način osjećanja koji Törlessa karakterizira već od djetinjstva ima nesumnjivo aristokratsku crtu koja ga razlikuje od banalne racionalnosti. ${ }^{732} \mathrm{U}$ prikazu veze između Törlessa i mladog kneza povezuje se opozicija razuma i užitka sa opozicijom građanstva i aristokracije. Pozitivno označeni atributi „profinjenosti“ i „užitka“ dobivaju novu socijalnu dimenziju: onu aristokracije. Ovoj Musilovoj kritici racionalnosti koju predstavlja građanski princip suprotstavlja se veličanje feudalnog koje je slično kao u Andrianovom djelu Der Garten der Erkenntnis. Prijateljstvo s knezom pripovjedač komentira kao mogućnost razvijanja intuitivnih načina spoznaje; religiozni motivi pomoću kojih Törless poima mladog kneza odaju aristokratski kult forme, koji ga integrira u iskustvo nečeg neizrecivog, a s čime se povezuju homoerotički impulsi. Törless iznalazi puteve osjetilnih spoznaja, u kojima su umjetnost i habitus esteta u romanu nerazdruživo povezani.

S tematiziranjem esteticizma nadovezuje se Musilov roman na prethodne teme bečke moderne, odnosno na pripovijetke kao što su Das Märchen der 672. Nacht, Der Tod Georgs i Der Garten der Erkenntnis. ${ }^{733}$ Suprotno od kritičkog prikaza esteticističke egzistencije, u

\footnotetext{
${ }^{729}$ Paetzke 1992, str. 125.

${ }^{730}$ Cit. u Paetzke, usp. Die Verwirrungen des Zöglings Törleß, str. 133.: „Aber er kam sich unter all dem wie ein Auserwählter vor. Wie ein Heiliger, der himmlische Gesichte hat; -denn von der Intuition großer Künstler wußte er nichts., usp. također Pomutnje gojenca Törlessa, str. 97.

${ }^{731}$ „Er (Törleß) liebte es damit zu rechnen, daß die Fähigkeit zu genießen, die künstlerischen Talente, das ganze verfeinerte Seelenleben ein Zierat sei, an dem man sich leicht verletze.“, Die Verwirrungen des Zöglings Törleß, str. 163., usp. Pomutnje gojenca Törlessa, str. 119.

${ }^{732}$ Paetzke 1992, str. 126.

${ }^{733}$ Ibid., str. 127.
} 
ovome se Musilovom djelu pojavljuje mogućnost zadnjeg utočišta individualnosti u habitusu esteta. $^{734}$

Homoerotički i sadomazohistički odnosi Törlessa prema Basiniju predstavljaju otkrivanja senzualnosti u pubertetu koja zaoštravaju prijašnju Törlessovu slutnju da se izvan razumskog svijeta nalazi nešto što se ne poklapa sa racionalnošću i što uzdrmava sve izvjesnosti i sigurnosti koje su mu na tradicionalan način prenosili roditelji i učitelji. ${ }^{735} \mathrm{Na}$ taj se način prikaz pubertetske seksualnosti uklapa u jednu spoznajno-teoretsku problematiku, time što se iskustvo spolnog uzbuđenja na jednoj razini povezuje s doživljajima koji se u djelu komentiraju kao pripremni stupnjevi u razvoju osjetilnih spoznaja. Zlostavljanje Basinija i filozofiranje o beskonačnosti i o imaginarnim brojevima dovode se u Musilovom djelu jasno u svezu jedno s drugim. Musilov roman se u autorskoj perspektivi ne distancira od sadizma već ga legitimira kao put prema jednom „intelektualno estetskom“ stavu (vidi Paetzke). Pripovjedačev komentar opravdava iskustvo gojenca kao nužni zaobilazni put prema estetskoj egzistenciji, u djelu je predstavljen kao nužan razvojni stadij. ${ }^{736}$

Međutim, Paetzke napominje da pripovjedačev komentar govori i o socijalnoj dimenziji i predstavlja razvojno-psihološko tumačenje: „Jer prva strast čovjeka koji odrasta nije ljubav prema jednoj, nego mržnja prema svima“. ${ }^{737}$

Törlessova ponižavajuća iskustva s Boženom i Basinijem predstavljaju za njega „nužnost“ u njegovom razvoju prema esteticistički konotiranoj prirodi. Za razliku od agresivnosti Beineberga i Reitinga, Törlessa ipak karakterizira određena sposobnost uživljavanja u bića i pojave oko sebe, iako njegov sustav morala nije do kraja izgrađen, budući se on nalazi u prijelaznoj fazi. Prema Paetzke, pripovijedanje o homoseksualnim vezama i sadomazohističkom ponašanju kod mladeži moralo je važiti kao provokacija: u onodobnom društvu o prijelomu stoljeća homoseksualnost se smatrala zločinom i bila je pravno i zakonski kažnjiva. ${ }^{738}$ Ono što Musilov roman ipak temeljno razlikuje od prikaza homoerotičkih odnosa i tzv. perverzne erotike u europskoj književnosti dekadencije je strogo psihologiziranje ove tematike. Erotska iskustva ovdje nisu prikazana kao ekskluzivne senzacije koje služe stimulaciji oslabljenog vitaliteta nego kao doživljaji preko kojih se odvija subjektivni konflikt i koji se prati do granica svijesti i podsvijesti. Pri tome pripovjedač zauzima distanciranu i

\footnotetext{
${ }^{734}$ Prema Paetzke 1992, str. 127.

${ }^{735}$ Ibid., str. 128.

${ }^{736}$ Vidi Paetzke 1992, str. 129.

737 „Denn die erste Leidenschaft des erwachsenden Menschen ist nicht Liebe zu der einen, sondern Haß gegen alle. Das sich unverstanden Fühlen (...), Die Verwirrungen des Zöglings Törleß, str. 42-43., usp. Pomutnje gojenca Törlessa, str. 32.

${ }^{738}$ Vidi Paetzke 1992, str. 130.
} 
„znanstvenu“ poziciju i pokazuje u svojim općenitim komentarima psihološku i pedagošku kompetenciju. $^{739}$

Za lik mladog Törlessa vrijede razvojno-psihološka tumačenja, dok se ponašanje drugih čini motivirano osobnim slabostima i nemoći (Basini) ili zlim nakanama (Beineberg i Reiting).

Međutim, Törlessova biseksualna priroda ogleda se i u njegovoj sklonosti kako homoseksualnim, tako i heteroseksualnim maštanjima i iskustvima, npr. u njegovom susretu s prostitutkom Boženom, koja ga podsjeća na njegovu majku.

Iako Törless osjeća homoseksualno nagnuće prema Basiniju, on s druge strane osjeća gađenje prema tim homoerotičnim i homoseksualnim impulsima. U trenutcima kontemplacije i sjećanja njegovim mislima prolazi slika jedne glumice u koju se zaljubio, tako da se $\mathrm{u}$ njegovoj psihi može naznačiti duboka rodna ambivalencija između homoseksualnosti i heteroseksualnosti, odnosno neka vrsta androgine samodostatnosti pomiješane s pubertetskim oblikom biseksualnosti. Njegove se pomutnje događaju i zbog njegove izloženosti sivilu atmosfere $u$ internatu, koja još dodatno pojačava krizu njegovog identiteta:

„Znao je samo da je putom što je vodio duboko u njegovu nutrinu išao za nečim još nejasnim; i pri tomu je sustao. Bijaše navikao nadati se izvanrednim, skrovitim otkrićima, a pri tom je dospio u uske, krivudave odaje putenosti. Ne iz perverznosti, nego zbog trenutno besciljne duhovne situacije". ${ }^{740}$

\subsubsection{Implicitni rod}

Umjetnost u svijesti pripovjedača dobiva veliko značenje, i to na temelju (tradicionano ženski konotirane) intuitivne spoznaje. Paetzke također napominje da se umjetnost u ovom djelu pojavljuje u vidu nepojmovnih uvida, kao mogućnost uranjanja u samog sebe i kao područje određenog odmaka od vreve svakodnevice. Prema Paetzke, umjetnost se pojavljuje kao kvazireligiozna forma: stoga djelo Pomutnje gojenca Törlessa ne predstavlja roman o umjetniku odnosno portret umjetnika kao dječaka, budući da u samom djelu nema pune tematizacije umjetnosti. Umjetnost u ovom djelu, prema Paetzke, ne dobiva sadržajno određenje, već postaje dijelom kulta forme, koji u esteticizmu odrastajućeg Törlessa nalazi svoj najčišći izričaj.

\footnotetext{
${ }^{739}$ Paetzke 1992, str. 130.

${ }^{740}$ „Er wußte nur, daß er etwas noch Undeutlichem auf einem Wege gefolgt war, der tief in sein Inneres führte; und er war dabei ermüdet. Er (Törleß) hatte sich gewöhnt, auf außerordentliche, verborgene Entdeckungen zu hoffen, und war dabei in die engen, winkligen Gemächer der Sinnlichkeit gelangt. Nicht aus Perversität, sondern infolge einer augenblicklich ziellosen geistigen Situation.“, Die Verwirrungen des Zöglings Törle $\beta$, str. 166., usp. Pomutnje gojenca Törlessa, str. 121.
} 
Porast publikacija o homoseksualnosti, odnosno žustre diskusije u pedagoškim krugovima o odgojnim mjerama vezano na pubertetsku seksualnost primjeri su rastućeg interesa o prijelomu stoljeća za ljudsku seksualnost, što upućuje na krhkost važećih normi i dotad važećih tabua. ${ }^{741}$ Ovom problematikom se u svojim psihoanalitičkim djelima bavio i Sigmund Freud. Njegovo djelo Drei Abhandlungen zur Sexualtheorie iz 1905. godine u onodobnom je društvu smatrano šokantnim. U svojim djelima Freud relativira razliku između onog što je perverzno i onog što je normalno, a razotkriva i pojam infantilne seksualnosti. ${ }^{742}$ Freudova teza da je „sklonost perverzijama nešto općenito ljudsko i izvorno“ smatrala se radikalnim napadom na onodobni pojam građanstva, kao razaranje kanona moralnih vrijednosti. ${ }^{743}$ Međutim, Musilov se roman ipak razlikuje od općenitih tvrdnji u Freudovu znanstvenom diskursu, budući da, prema Paetzke, „ograničava“ relativiranje moralnih vrijednosti i pravi razliku između „nadarene“, odnosno ,profinjene prirode“ esteta i prirode „običnog“ građanskog pojedinca: kod esteta se homoseksualnost i sadomazohizam izričito ne tretiraju kao perverzni, odnosno devijantni načini ponašanja, dok se kod građanina takvo seksualno ponašanje smatra perverznim. ${ }^{744}$ Paetzke napominje da je pitanje ljudske spolnosti uzdrmalo racionalističku sliku svijeta, koja je nastojala potisnuti senzualnost uopće. Istovremeno je tematiziranje pubertetske seksualnosti značilo napad na građansku predodžbu obitelji, koja je posebice prikazana u Freudovim razlaganjima o incestuoznim maštanjima kod mladeži. ${ }^{745}$ Djelo Pomutnje gojenca Törlessa radikalni je napad na tradicionalnu sliku građanina, budući da prikazuje razaranje kanona moralnih vrednota, u čije se univerzalno važenje moglo biti tako sigurno, da se sve što je odstupalo od norme izostavljalo kao patološko. ${ }^{746}$

Prema mojem mišljenju, Musilovo se djelo može smatrati također i posljedicom onodobnog vakuuma, odnosno nedostatka moralnih vrijednosti u društvu općenito, jednako kao i subverzivnom kritikom onodobne hipokrizije morala, odnosno dvostrukih mjerila vezano na rodne odnose. Törlessova kriza identiteta izražava se i kroz njegovo relativiranje razlike između perverzije i seksualnosti. Tako se on u svojoj pubertetskoj fazi još nije jasno ogradio od Beinebergovog i Reitingovog maltretiranja Basinija, kao što se ni Basini zbog svoje feminiziranosti nije do kraja ogradio od svojih mazohističkih impulsa. Törless se ipak zbog svoje prirode senzibilnog esteta ograđuje od Beinebergovih i Reitingovih mučenja Basinija, pa mu naposljetku donekle i pomaže, iako se sam distancira od cijelog tog događaja.

\footnotetext{
${ }^{741}$ Vidi Paetzke 1992, str. 131.

742 Ibid.

${ }^{743}$ Ibid.

${ }^{744}$ Prema Paetzke 1992, str. 132-133.

${ }^{745}$ Ibid., str. 132.

${ }^{746}$ Ibid., str. 131.
} 
Prema Paetzke, pubertetski razvoj u romanu protječe baš onako kako ga Freud opisuje, kao napuštanje, odnosno odbacivanje incestuoznih misli i kao bolno odvajanje djeteta od roditelja. ${ }^{747}$ Žudnja koju je na neki način osjećao prema svojoj majci je kao faza ovog procesa na kraju premošćena i Törless sada mirno prihvaća majku kao ženu. Zadnje rečenice romana pokazuju u odnosu prema roditeljima i Boženi svladavanje nesigurnosti i time okončavanje Törlessovih seksualnih pomutnji. ${ }^{748}$

Treba spomenuti i instituciju razreda i škole koja povezuje izvanjske, odnosno društvene odnose sa subjektivnim iskustvima mladoga Törlessa. Pa ipak, u djelu izneseno objašnjenje Beinebergovog, Basinijevog, ili Törlessovog ponašanja ne odnosi se direktno na izvanjske školske uvjete koji upućuju na društvene odnose već je individualno zasnovano.

Oblikovanje nekih odlomaka testa u slobodnom neupravnom govoru (Erlebte Rede) dovodi do toga da se u istraživanju pravi razlika između perspektive lika i perspektive pripovjedača, tj. da se govori o tzv. dvostrukoj perspektivi. Ovim načinom pripovijedanja koje realizira autorski komentar i slobodni neupravni govor razbija se obrazac tradicionalnog romana razvoja ličnosti. ${ }^{749}$ Prema Paetzke, iako se pripovjedač donekle konsolidira s likom mladog Törlessa, ipak ne može biti govora o potpunoj personalnoj perspektivi jer se viđenje lika ne nalazi paralelno, nego hijerarhijski ispod autorskog pripovjedača. Prednost pripovjedača je njegovo prethodno znanje, kojim on nadgleda cijeli Törlessov razvoj.

U tekstu je naglašena razlika između individualne sfere, u koju se uklapaju Törlessova osobna razmišljanja i percepcije, dok je javna sfera Törlessovog svijeta obilježena njegovim pismima roditeljima $\mathrm{s}$ jedne, te njegovim boravkom $\mathrm{u}$ provincijalnom internatu s druge strane.

Što se tiče pripovjedne perspektive, ona se, iako je predstavljena kroz autorskog (heterodijegetskog) pripovjedača, donekle približava personalnoj perspektivi pa u nekim trenutcima čak i određenoj nepouzdanosti pripovjedača budući da pokazuje pomutnje jastva gojenca Törlessa. Pripovjedač ipak zadržava određenu ,analitičku“ distancu prema glavnom liku. Prema riječima Iris Paetzke, ,pripovjedna se perspektiva približava samodeformaciji pripovijedajućeg subjekta (jastva)“ ${ }^{750} \mathrm{U}$ prvom redu to je razrušeni način poimanja vanjskog svijeta s neke čvrste točke u sebe sigurnog promatrača. U Musilovom romanu ne prikazuje se iskrivljena stvarnost sama po sebi već čin percipiranja odnosno imaginacije pojedinca. Tako ovdje ostaje razlika između sivila svakodnevne stvarnosti i posebnih trenutaka u kojima Törless proživljava svoja iskustva, koja pripovjedač prikazuje kao neobične doživljaje

\footnotetext{
${ }^{747}$ Paetzke 1992, str. 132.

748 Ibid.

${ }^{749}$ Vidi Paetzke 1992, str. 124.

${ }^{750}$ Ibid., str. 116.
} 
senzibilnog dječaka. ${ }^{751}$ Pojedina iskustva gojenca odaju problematiku otuđenja koja je, slično kao u Hofmannsthalovu „Pismu“ lorda Chandosa (Ein Brief), povezana s kritikom jezika (ograničenost sporazumijevanja jezikom i nedostatnost jezika kao medija sporazumijevanja i spoznaje stvarnosti).

Pripovjedačka instanca romana načelno je heterodijegetska (pripovjedač koji pripovijeda u trećem licu jednine), te tako donekle stvara i određenu distancu od lika, koja, međutim postaje neznatnom distancom čim se ovaj autorsko koncipirani pripovjedač počinje približavati (gotovo kroz cijelo tkivo romana) liku u smislu personalne pripovjedne perspektive.

Značajan je također i Maeterlinckov citat koji se nalazi na početku romana a koji formulira sljedeću misao: „Čim nešto izgovorimo čudno to obezvrijedimo. Vjerujemo da smo zaronili u dubinu ponora, a kad se vratimo na površinu, kaplja vode na blijedim jagodicama naših prstiju više nije nalik na more iz kojega potječe. “" ${ }^{\text {752 }}$ Citat govori o onodobnoj krizi jezika i spoznaje i načelnoj nemogućnosti ljudske komunikacije, što ukazuje na skepticizam razdoblja iz kojeg je roman potekao. Prema Paetzke, ova Maeterlinckova rečenica predstavlja također i onodobnu neomističnu predodžbu čudesnoga i otima se pojmovnom fiksiranju. ${ }^{753}$ Kritika racionalnosti nalazi se u ovoj Maeterlinckovoj kritici jezika: sa jezikom kao sa izrazom i instrumentom racija kontrastira se šutnja kao ,pjesma beskonačnog“، ${ }^{754}$ Onkraj riječi i misli u mističnom zrenju može duša koja nas povezuje sa svemirom naslutiti ono što se čini neshvatljivim. ${ }^{755}$ Moto koje Maeterlinckova jezična kritika uzima formulira iskustvo koje stoji iza svakog pojedinog doživljaja mladog Törlessa. Najveći problem koje pojedini događaji ilustriraju je opreka između osjećanja i misli, u čemu se ogleda Törlessova kriza (rodnog) identiteta. Iza svakodnevnog svijeta čini se da se otvara jedan posve novi, drugi svijet, koji izaziva pomutnje mladog gojenca: „Nešto što nadilazi razumsko razmatranje, nešto divlje, razarajuće“, što nije moguće opisati riječima“" 756

\footnotetext{
${ }^{751}$ Paetzke 1992, str. 116.

752 „Sobald wir etwas aussprechen, entwerten wir es seltsam. Wir glauben in die Tiefe der Abgründe hinabgetaucht zu sein, und wenn wir wieder an die Oberfläche kommen, gleicht der Wassertropfen an unseren bleichen Fingerspitzen nicht mehr dem Meere, dem er entstammt.“, Die Verwirrungen des Zöglings Törleß, str. 8., usp. Pomutnje gojenca Törlessa, str. 6.

753 Vidi Paetzke 1992, str. 112.

754 Ibid.

${ }^{755}$ Ibid., str. 112. i 113.

${ }^{756}$ Cit. u Paetzke 1992, str. 113.
} 


\subsubsection{Zaključak}

Törlessove pomutnje, uz duboku krizu tradicionalno konotiranog (muškog) identiteta, pokazuju znakove tradicionalno ženski konotirane iracionalnosti i intuitivne spoznaje života, budući da on na subjektivan, pasivan i receptivan način poima svijet oko sebe uz određenu distancu esteta. Međutim, uza svu svoju senzibilnost, on ipak sa svojevrsnom ravnodušnoću amoralnog esteta promatra kako njegovi kolege zlostavljaju kolegu Basinija. Njegova estetska shvaćanja, koja se mogu, prema Paetzke, tumačiti kao sekularizirano mistično nadahnuće, a koja nedostaju prosječnom građanskom pojedincu, ipak, prema mojem mišljenju, otkrivaju svojevrsnu amoralnost estetske distance prema svijetu. Treba spomenuti dakako i neadekvatnost stroge institucije internata $\mathrm{u}$ kojem Törless boravi sa njegovim habitusom senzibilnog esteta koji naginje homoeroticizmu. Stoga se može zaključiti da se gubitak svake moralne izvjesnosti, koji najavljuje određenu krizu metafizičkog nazora na svijet, ogleda $\mathrm{u}$ liku Törlessa kao mladića kojem nedostaje bilo kakva sigurnost i tradicionalno muški konotirana odlučnost u poimanju stvari i pojava oko sebe.

Törless doživljava i trenutke gotovo pjesničke inspiracije gdje se uočava sinteza osjećaja i razuma, duha i života, koji, međutim, ne predstavljaju njegov trajni stav. ${ }^{757}$ Njegova kriza identiteta ukazuje na pojam Ernsta Macha o fluidnom jastvu odnosno stalno promjenjivoj duševnoj perspektivi i stavu pojedinca, što govori o onodobnom skepticizmu te nesigurnosti rodnog identiteta (muškog subjekta). Pa ipak, razmatranje samoga sebe (introspekcija) kao temeljni čin intuitivne spoznaje života predstavlja trenutak utočišta u kojem se Törless pokušava zaštititi od prijetnja agresivnih mladića Beineberga i Reitinga. Beineberg i Reiting opravdavaju svoja agresivna i sadomazohistička mučenja svoga kolege Basinija nekim višim ciljem, koristeći za to pojmove iz indijske filozofije i religije vezano za ničeovsku filozofiju, dok Törless to sve nijemo promatra. Beineberg i Reiting tretiraju Basinija kao žensko kako bi on na neki način postao ropski podložan, pri čemu se otkrivaju homoseksualni impulsi, koji muče i mladoga Törlessa. Homoerotički i homoseksualni impulsi, koji se bude u Törlessu, najprije prema mladom knezu, a zatim i prema sadistički mučenom kolegi iz internata Basiniju, ostavljaju ga zbunjenim. U njemu se naizmjenice pojavljuje tankoćutnost i osjećaj umjetničke senzibilnosti, očajanje i sadomazohistički porivi. Sadistička primjena sile pokazuje se ipak u različitom svjetlu, kod Beineberga i Reitinga kao jedno pusto mučenje, a kod Törlessa kao pomutnja, odnosno kriza identiteta koja predstavlja zaobilazni put koji Törlessova senzualnost uzima da bi se razvila prema nekom „višem cilju“: „Znao je samo da

\footnotetext{
${ }^{757}$ Prema Paetzke 1992, str. 118.
} 
je putom što je vodio duboko u njegovu nutrinu išao za nečim još nejasnim; i pri tomu je sustao. Bijaše navikao nadati se izvanrednim, skrovitim otkrićima, a pri tom je dospio u uske, krivudave odaje putenosti. Ne iz perverznosti, nego zbog trenutne besciljne duhovne situacije“. 758

Svojom biseksualno obilježenom ambivalencijom Törless pokazuje fluidnost svoga identiteta, koji ne mora nužno biti ženski konotiran, već odražava krizu onodobnog muškog identiteta. U tzv. patosu života on pronalazi utočište od izolacije jastva i mogućnost stvaranja identiteta, kao i jastva svijeta oko sebe, mogućnost iskustva koje se oko prijeloma stoljeća nazivalo „mističnim“. ${ }^{759}$ Törlessov izraziti subjektivizam, odnosno njegovo pounutrenje svih vanjskih doživljaja povezano je i sa patosom života, budući da Törless stvarnost poima u neprestanoj kontingenciji ćutilnih osjećanja. U Musilovom djelu nalazimo obilje vitalističkih motiva koji ukazuju na ćutilnost i senzualnost mladoga Törlessa. Izraziti senzualizam i moderni misticizam na taj način nisu tako daleko jedan od drugoga kako se to na prvi pogled čini.

Shodno Törlessovom habitusu esteta, kojem su, poput lika Erwina u djelu Der Garten der Erkenntnis, stvari, ljudi i pojave odrazi njegova tajanstvenog unutarnjeg svijeta, ljudi koje susreće postaju poligoni i etape za, kako će to sam kasnije reći, „dozrijevanje njegove duše“ i potvrđivanje njegovog habitusa umjetnika.

Sa zakazivanjem jezika kao sredstva komunikacije roman prikazuje gubitak autonomije pojedinca, koja se, prema mojem mišljenju, očituje u gubitku sigurnosti glede rodnog identiteta mladoga Törlessa. Problematika Törlessa, koja je usporediva s Hofmannsthalovim Pismom Lorda Chandosa (Ein Brief) govori o zakazivanju jezika i racionalnosti i time predstavlja krizu građanske svijesti. ${ }^{760}$ Ova se problematika isprepliće s prikazom pubertetskog razvoja i biseksualnih poriva mladića u kojem se događa kriza (muškog) identiteta.

Problematika djela prvenstveno se odnosi na nesublimiranu pubertetsku senzualnost i seksualnost. Törlessov doticaj sa deklasiranima, odnosno poniženima u društvu, s prostitutkom Boženom, on osjeća kao poniženje u društvenom pogledu koje potom vidi utjelovljeno u Basiniju. Utoliko mazohističke pobude kod Törlessa dobivaju socijalnu komponentu koja je jasno izražena. S druge strane, Törless na specifičan način nalazi određenu poveznicu između prostitutke Božene i vlastite majke, tako da odnos majka-sin

\footnotetext{
${ }^{758}$ Pomutnje gojenca Törlessa, str. 121., usp. Die Verwirrungen des Zöglings Törleß, str. 166.

${ }^{759}$ Prema Paetzke 1992, str. 120.

${ }^{760}$ Ibid., str. 122.
} 
postaje ključan element u njegovom doživljavanju samoga sebe: time se pokazuje njegov karakter koji ima obilježja primarnog narcizma esteta, budući da on još uvijek ostaje u nepremošćenoj fazi djetinjstva i povezanosti s majčinskim, koje je na tradicionalan način predstavljalo zaštitničko i mitsko obilje.

Može se zaključiti da je onodobna rodna bipolarizacija, odnosno radikalno odvajanje muškosti od ženskosti kritizirala pojave homoseksualnosti: treba napomenuti da Törlessova iskustva u internatu, u kojem su sveprisutni mladići, pojačavaju njegove pomutnje vezano na homoseksualne porive. Uzevši u obzir Basinijevu obilježenost feminiziranošću, on postaje objektom, odnosno žrtvom sadomazohističkih i homoseksualnih napada njegovih školskih kolega. Törless se, iako i sam suučesnikom, ipak donekle na način „ravnodušnog“ esteta distancira od takvog agresivnog ponašanja, povlačeći se u svoj unutarnji svijet.

Dok ovo Musilovo djelo s jedne strane svojim prikazom individualnog razvoja pojedinca pokazuje moguće pomirenje pojedinca i društva, s druge strane postaje jasnom ta prividnost poistovjećenja s građanskom stvarnošću i Törlessovo konačno odabiranje životne forme esteta. $^{761}$ Prema Paetzke, integracija Törlessa kao esteta u društvo ostaje vanjskom, a ne u potpunosti unutarnjom integracijom.

\section{BEČKA MODERNA U SVJETLU SUVREMENIH DRUŠTVENIH I TEORIJSKIH TENDENCIJA}

\subsection{Sažetak interpretacija: hibridni rod u bečkoj moderni}

Ponajprije se želim osvrnuti na stvaranje imaginacijskih slika ženskosti u bečkoj moderni, koje su potaknule androginizaciju kako ženskih, tako i muških likova.

Uloga žene u fin-de-siècle-u kao ,femme fatale“ , „femme fragile“ ili „Kindfrau“ imaginacijska je (fikcionalna) slika žene, a ona je zapravo posljedica mistificirajućeg uvrštavanja ženskosti u ,arhaične“ pojave uslijed straha od ženskog emancipacijskog pokreta.

Biologija žene vješto se koristila kao poligon za kreiranje ženine „,manje vrijednosti“, ali i za stvaranje mitskih obrazaca o ženskom subjektu. Građanski poredak spolova tijekom 18. i 19. stoljeća ravnao se prema modelu dvaju odvojenih spolova (njem. „Zwei-GeschlechterModell“, pa prema tome i podjela na privatnu (žena) i javnu (muškarac) sferu), pri čemu je žena bivala okarakterizirana kao iracionalno, pasivno i neproduktivno biće. Ova se društvena dihotomizacija spolova samo prenijela u medicinu i antropologiju, gdje se koristila za utemeljenje zasebnih antropoloških karakteristika žene (njem. Sonderanthropologie der

\footnotetext{
${ }^{761}$ Paetzke 1992, str. 125.
} 
Frau). ${ }^{762}$ Ženski se likovi u korpusu bečke moderne pojavljuju u stanovitom ambigvitetu, budući da je u njihovoj koncepciji vidljiva podvojenost između stereotipizacije i androginizacije. Mistifikacija, ali i demonizacija ženskoga subjekta bila je jedan od glavnih pokretača imaginacijske slike androgine ženskosti i muškosti o prijelomu stoljeća.

Različite imaginacijske slike ženskosti o prijelomu stoljeća (femme fatale, femme fragile ili Kindfrau) bile su znak duboke muške ambivalencije (straha i žudnje) prema ženskom spolu: one su odražavale kako fascinaciju ženskom „misterioznom prirodom“ (žena kao „Drugost“ naspram društva i „muške“ civilizacije), tako i strah od ženske emancipacije.

Androginizacija muških likova $u$ djelima bečke moderne tako predstavlja $\mathrm{s}$ jedne strane reakciju na ženski emancipacijski potencijal (poprimivši čak i određene mizogine crte, npr. demonizacija ženske erotike), a s druge strane i jedan zaseban oblik imaginacijske slike ženskosti (muških subjekata) kao svojevrsne muške pobune protiv falogocentričkog društva. Obuzetost ženom i ženskim tijelom (fascinacija i strah) bila je duboko ukorijenjena društvena paradigma u razdoblju bečke moderne i općenito fin-de-siècle-a. Asketska negacija ženske senzualnosti i „demonske“ prirode žene zaogrnuta je u prikaz androgine samodostatnosti muških likova s jedne, ali je i hipostazirana kao jedan od načina kreiranja imaginacijske slike ženskosti kao asketske i bestjelesne esencije. Prikazi feminiziranih esteta bili su svojevrsni kritički osvrt na duboku krizu muškog identiteta, na gubitak sigurnosti muškog subjekta u vremenu modernizacije. Kriza tradicionalnih patrijarhalnih vrijednosti potaknula je stvaranje jedne nove imaginacijske slike ženskosti (i muškosti) koja je nastojala neutralizirati strah od ženske emancipacije, ovladati mješavinom straha i žudnje prema ženi. Prikazom feminiziranih esteta, kao i prikazom „maskuliniziranih“ žena, nastojala se isto tako transcendirati i dekonstruirati radikalna bipolarizacija muškog i ženskog spola koja je bila izražena u građanskom poretku 18. i 19. stoljeća.

U prikazu muških likova u tekstovima bečke moderne s jedne se strane nastoji ponuditi utopijska perspektiva koja se često prikazuje kroz androginu samodostatnost i (primarni) narcizam (njem. androgyne Vollkommenheit), gdje se pojavljuju likovi feminiziranih esteta, ili se pak, s druge strane, naglašava radikalna destabilizacija tradicionalnog i patrijarhalnog muškog identiteta (kriza identiteta u bečkoj moderni, vezana i uz rečenicu ,das Ich ist unrettbar", koja predstavlja teoriju fizičara i filozofa impresionizma Ernsta Macha o neodrživosti subjekta), a koja se može primijeniti i na ženski subjekt u pojedinim djelima bečke moderne. ${ }^{763}$

\footnotetext{
${ }^{762}$ Usp. Honneger: Die Ordnung der Geschlechter, 1991.

${ }^{763}$ Npr. Arthur Schnitzler: Die Fremde, zatim njegova kratka studija Die Braut.
} 
Pokušaj približavanja muškog i ženskog spola postao je najvidljiviji u tekstovima koji kritiziraju i nastoje transcendirati postojeće stereotipe rodnih uloga. U bečkoj se moderni tako tematizira i muški homoeroticizam (pojava trećega spola, njem. „das dritte Geschlecht “) ${ }^{764}$, a u književnosti napose u djelu Leopolda von Andriana, Richarda Beer-Hofmanna, zatim Hofmannsthalov Märchen). Muška androginizacija u djelima bečke moderne očituje se također u prikazima dekadentnog oblika neurastenije i histerije (Hermann Bahr: Die Mutter).

Utopijska s jedne, te dekadentna i esteticistička perspektiva androginizacije s druge strane, predstavljaju kritički pogled na dihotomizaciju muškog i ženskog spola, ali i njeno transcendiranje. Ove perspektive nastoje prevladati tipologiju i jednostranost prikaza oba spola (ističući artificijelnost stereotipizacije ženskosti i muškosti), ali i ukazati na krizu rodnih identiteta potaknutu krizom rodnih uloga $u$ doba sve veće modernizacije, demokratizacije, individualizacije i dehijerarhizacije društva o prijelomu stoljeća. U umjetnosti bečke moderne tako postoji cijela paleta fantazmagorija o rodnoj ulozi kako žene, tako i muškarca. Feminizacijom muškarca (neurastenija) te ženskim emancipacijskim pokretom, rodni konstrukti 18. i 19. stoljeća gube na vjerodostojnosti. Bečka je moderna djelomično prožeta fascinacijom orijentalnom kulturom i dionizijskim principom (Friedrich Nietzsche), koji je predstavljao suprotnost apolonijskoj racionalnosti i bio simbolom umjetnosti. Uslijed pomanjkanja utjecaja metafizičkog pogleda na svijet, moderna se umjetnost više priklanja esteticizmu (ili larpurlartizmu) nego kršćanskoj etičnosti, što je vidljivo u kaotičnom skepticizmu epohe bečke moderne. Međutim, u djelima pojedinih bečkih književnika ipak postoje težnje za cjelovitošću bitka, odnosno za harmonizacijom rodnih odnosa i rodnih identiteta, što je najvidljivije npr. u Hofmannsthalovom djelu „Andreas oder die Vereinigten“, gdje se na mahove pojavljuju odlomci u kojima se naziru znakovi idealizacije (ženskog) bića od strane senzibilnog protagonista.

Koncipiranje likova u književnosti bečke moderne potaknuto je još jednim aspektom društveno-kulturološko-povijesnog konteksta: u Beču o prijelomu stoljeća razvio se, kao protupokret propalom gospodarskom i političkom liberalizmu (nakon 1873) te njegovom apstraktnom propagiranju „slobodnog građanskog subjekta“, jedan oblik estetskog subjektivizma koji je bio akademska i umjetnička reakcija na robnu razmjenu potrošačkog kapitalističkog društva. ${ }^{765}$ Estetski je subjektivizam u djelima mnogih književnika bečke moderne (Hugo von Hofmannsthal, Leopold von Andrian, Richard Beer-Hofmann), međutim,

\footnotetext{
764 Usp. letak Magnusa Hirschfelda pod naslovom Was soll das Volk vom dritten Geschlecht wissen, 1901.

765 Bruns 1997, str. 232.
} 
imao i psihološku karakteristiku primarnog narcizma: potragu za potisnutom ženskom stranom (anima u muškog subjekta).

Književnici koje uzimam kao bazu svoje analize (Hugo von Hofmannsthal, Leopold von Andrian, Hermann Bahr, Richard Beer-Hofmann, Peter Altenberg, Arthur Schnitzler, Robert Musil) kritički reagiraju na onodobnu bipolarizaciju spolova ili pak ironijski (i auto-ironijski) propituju onodobne rodne konstrukte (poput Schnitzlera). Svi oni u svoja djela implementiraju elemente hibridnog roda, ističući time androgine karakteristike (fizičke i psihičke) svojih likova. Treba naglasiti eksperimentalan karakter tekstova bečke moderne vezano uz temu rodnih odnosa, obzirom da mnogi književnici (napose Schnitzler, zatim Bahrove subverzivne groteske) koriste eksperimentalne socijalne konstelacije kako bi se narugali onodobnim društvenim normama. No književnici bečke moderne istodobno se služe i onodobnim konvencijama u prikazima žena, neprestano ukazujući na činjenicu da je bečka moderna prijelazni period između „viktorijanskog“ razdoblja i erotski liberaliziranog, modernog društva, te da ona kao takva odražava simptom krize rodnih konstrukata i rodnih identiteta. Međutim, korištenje strategija stilizacije i mortifikacije (ženskog) tijela zapravo u pojedinim djelima ne predstavlja u potpunosti ustrajanje na rodnim polaritetima, već se ono, kako sam to ranije naglasila, treba dovesti u vezu s androginizacijom muških likova (BeerHofmann: Der Tod Georgs, Hofmannsthalov Märchen), koji odražavaju rodnu koncepciju anti-stereotipne pasivnosti i receptivnosti hipersenzibilnih, aristokratski nastrojenih esteta. Androginizacija ženskih likova treba se razmatrati u svjetlu svojevrsnog odmaka od stereotipne ženske senzualnosti putem korištenja strategija demonizacije ženske erotike i promoviranja aseksualnih i androginih ženskih likova (također prisutnog kod opisa predpubertetskih djevojčica kod Petera Altenberga).

Ova je strategija uočljiva i kod Richarda Beer-Hofmanna, koji, iako u svome djelu Der Tod Georgs s jedne strane ženu svrstava u kategoriju androginije (,knabenhafte, bleiche, körperlose Frauen"), ipak tom vrstom ženske androginizacije provodi svojevrsnu fin-desiècleovsku demonizaciju ženske erotike a manje naglašava potencijal ženske emancipacije. Beer-Hofmann androginizacijom ženskog subjekta pravi racionalni „odmak“ od ženske senzualnosti (tjelesnosti) te žensko biće svrstava u kategoriju androginoga (bezopasnoga, samodostatnoga, asketskoga) koje se perpetuira u slici žene koja umire, te time predstavlja gotovo sakralnu sliku njenog uznesenja u smrti. To je tipična strategija mortifikacije ženske senzualnosti koja, iako na atipičan način, ipak podliježe fin-de-siècleovskim kulturnim obrascima demonizacije ženske erotike, konzervirajući ženu u vidu umjetničkog artefakta i prikazujući ju kao imaginacijsku sliku stereotipne pasivne i neproduktivne, bolećive 
ženstvenosti (njem. das ewig-Weibliche). S druge strane, muški likovi kao što su Paul i Georg, prijatelj osamljenog esteta, koji se mogu okarakterizirati izrazom flaneur (franc. šetač, onaj koji šeće) predstavljaju muški androgini potencijal ovoga djela. Umirući Georg predstavlja gotovo zrcalnu sliku (androgino zrcaljenje, pojam narcisa u književnosti bečke moderne) žene koja umire: njihova jukstapozicija (supostavljanje) u djelu te njihova istovremena prisutnost na razini sna u Paulovoj psihi (androgina samodostatnost esteta) predstavljaju i njihov i njegov androgini potencijal. Treba spomenuti i dionizijsku fantazmagoriju unutar djela (svetkovina u Hierapolisu) koja predstavlja svojevrsnu vladavinu matrijarhata (štovanje kulta božice Astarte). Georgova se pasivnost i neproduktivnost uklapa u imaginacijsku sliku tipične pasivne, bolećive ženstvenosti. Paulova pasivnost i njegovo uranjanje u svijet fantazije kao i vlastite introspekcije pak predstavlja eskapizam esteta -hermetičnost, negaciju (ali u dionizijskoj fantazmagoriji čak i afirmaciju) životnog vitalizma, te s druge strane zamor od života.

U djelima Huga von Hofmannsthala (Das Märchen der 672. Nacht, Andreas oder Die Vereinigten i Gestern) prikazani su feminizirani esteti (posebno Märchen) u neprestanom konfliktu sa svojom potisnutom ženskošću, koja uvijek iznova izbija na vidjelo. U fragmentu svojega romana „Andreas oder Die Vereinigten“, Hofmannsthal prikazuje utopijsku težnju za androginom potpunošću muškog subjekta (androgyne Vollkommenheit), koja bi tom muškom subjektu omogućila približavanje ženskom biću, metaforički rečeno ,principu i shvaćanju vječne ženskosti“. U ovome je djelu vidljiva kritika onodobne bipolarizacije (oštrog odvajanja) muškog i ženskog spola, te istodobno i kritika stereotipne muškosti.

U djelu Das Märchen der 672. Nacht prikazani su i homoerotički impulsi, koji su odraz ženskog podsvjesnog i potisnutog identiteta (ženske psihe) unutar muškog subjekta (prema analizi Krafft-Ebinga: Psychopathia Sexualis). Mistični estet, dakle, demonstrira teškoće u suočavanju sa vlastitom potisnutom ženskošću. Hofmannsthal izražava svoju osudu esteticizma (,tamnice esteticizma“) te svijest o vlastitom promašaju. Ovaj je promašaj visoko estetiziran, ali i prožet onodobnom etičkom problematikom, koja u suvremenom društvu sveopće relativizacije rodnih odnosa i rodnih identiteta postaje smiješnom i bespredmetnom.

Leopold von Andrian u djelu Der Garten der Erkenntnis prikazuje androginu samodostatnost glavnog muškog lika (Erwin) prožetu homoerotičkim impulsima i primarnim narcizmom, ali i demonizacijom ženske erotike. Mistični asketizam (potaknut strahom od spolnosti) i narcizam, svojevrsna idealizacija drugog muškog lika (Lato, Clemens) te fizička sličnost glavnog lika majci manifestacija su pasivnosti i androgine samodostatnosti. 
Hermann Bahr u djelu Die Mutter prikazuje hipersenzibilnog dendija potpuno ovisnog o majci (teorija primarnog narcizma) koja demonstrira lezbijske porive. Ovisnost o autoritetu psihički nestabline i nestaložene majke znak je sinovljeve neurastenije i histerije, a koje su u vrijeme kraja stoljeća smatrane tipičnom kliničkom slikom ženskog roda. Ovo je Bahrovo djelo prikaz neurotičnog esteta koji se odvaja od onodobne stereotipne muške racionalnosti, produktivnosti i aktivnosti. S druge strane, Bahr daje svojevstan ironičan komentar ovakvoj situaciji kroz lik homoseksualnog klauna. Groteska ovoga djela prikazana je putem dekadentne atmosfere i likova koji na radikalan način odudaraju od onodobne rodne bipolarizacije.

U predzadnjem činu dramskog djela Reigen, Arthur Schnitzler predstavlja lik glumice koja ludički ulazi u mušku ulogu te se tako poigrava sa očekivanjima ondašnjih čitatelja. Ovakvo performativno konstruiranje roda, naravno, odražava fluidnost i fleksibilnost identiteta kao kategorije unutar književnosti bečke moderne. Strateško insceniranje roda u ovom činu ima svrhu poigravanja rodnim ulogama i identitetima, ali i ondašnjim tabuima.

Arthur Schnitzler u svojem djelu Die Fremde s jedne strane naglašava pojam vječne ženskosti (svojevrsna stereotipizacija ženskog lika), a s druge strane demonstrira (iako autoironijski) ženski emancipacijski potencijal kreirajući lik žene koja se može odrediti i kao femme fragile (krhka ženstvenost) i femme fatale (agresivni impulsi).

U djelu Die Braut Schnitzler prikazuje samodostatnost ženskog lika, kreirajući lik žene koja se kreće od radikalne seksualne askeze (povezane sa idealizacijom braka i muškarca) pa sve do promiskuiteta (povezanog sa samodostatnošću ženskog bića, deziluzioniranošću muškim subjektom i potkopavanjem muškog patrijarhalnog poretka).

U svojim kratkim proznim crticama Peter Altenberg demonstrira oblik implicitne demonizacije ženske erotike preferirajući likove djevojčica u razdoblju pred-puberteta naspram zrelih ženskih subjekata. Altenberg pod krinkom fetišizma veliča samodostatnost djeteta (djevojčica) koje je obilježeno biseksualnošću (neizdiferenciranošću muškoga i ženskoga principa). Altenbergova je demonizacija ženske erotike povezana kako uz fin-desiècleovski pojam straha od ženskog emancipacijskog potencijala, tako i uz samo vrijeme finde-siècle-a (latentna Altenbergova kritika materijalizma, pragmatizma (braka) i alijenacije industrijskog doba), koje preferira profanu spolnost naspram „sakralne i mitske erotike“, koja u Altenberga često poprima oblik dekadentnog žaljenja zbog nedostatnosti ljudske egzistencije.

Kroz glavni lik djela Die Verwirrungen des Zöglings Törleß (Pomutnje gojenca Törlessa), prikazuje se unutarnja transcendencija psihe mladog čovjeka u njegovim pubertetskim 
previranjima. Cijelo se djelo može okarakterizirati kao svojevrsna potraga za smislom egzistencije mladog Törlessa, iako djelo ulazi u sferu pubertetske pripovijesti, u kojoj se buđenje spolnosti u Törlessu usko može povezati uz njegovu rodnu ambivalenciju i traganje za pravom definicijom njegovog rodnog identiteta- njegova ambivalencija između biseksualnosti, mazohizma i (donekle) sadizma.

Autori bečke moderne s jedne su strane pod pritiskom društvenih normi, a s druge se strane nastoje osloboditi pritiska normi svojim književnim subverzijama i propitivanjima. Koristeći strategije visoko estetizirane sublimne igre, književnici bečke moderne na eksperimentalan način propituju i nastoje transcendirati i dekonstruirati rodne uloge i identitete o prijelomu stoljeća. Ovo visoko estetizirano (i auto-refleksivno) poigravanje rodnim identitetima u službi je implicitne (i kamuflirane) subverzije i kritike onodobnih rodnih polariteta.

Važno je, polazeći od perspektive suvremene fluidizacije roda, osvijetliti bečku modernu kao razdoblje hibridnih rodnih identiteta. U tome se očituje anticipativni potencijal bečke moderne- što je predmet zaključne diskusije u idućim poglavljima 5.2. i 5.3. U poglavlju 5.2. prikazujem mišljenja dekonstrukcijske i postfeminističke kritike, koja polaze od radikalne hibridizacije (i androginizacije) roda u postmoderni, dok je, s obzirom na suvremenu ontološku nestabilnost jastva anticipativni postmoderni potencijal bečke moderne (koji detaljno prikazujem u poglavlju 5.3.) vidljiv u 1. upotrebi eksperimentalnih i rodno subverzivnih rodnih konstelacija, koje odudaraju od normativnih obrazaca rodnih odnosa i rodnih identiteta, ali i 2. upotrebi inovativnih oblika pripovijedanja te kroz takve oblike pripovijedanja prikazivanje fluidnih rodnih identiteta i radikalnog oblika individualizma $\mathrm{u}$ razdoblju bečke (post)moderne.

\subsection{Novije koncepcije androginije i rodnog konstruktivizma}

\subsubsection{Teza o biseksualizaciji suvremene kulture}

Suvremena feministička teoretičarka Elisabeth Badinter, koja predstavlja feminističku i libertinističku afirmaciju biseksualnosti i androginije u kontekstu seksualne liberalizacije od 1960-ih godina nadalje, naglašava biološke i psihološke predispozicije za biseksualnost ljudskih bića, polazeći od hormonalne dvostruke strukture (hormonale Doppelstruktur), pa sve do činjenice da je psihička seksualna izdiferenciranost još manje jednoznačna nego ona fizička. Badinter naglašava Freudovu tezu o čovjekovoj „nesvjesnoj biseksualnosti“. Iako je 
smatrao da su čovjekova tjelesna konstitucija i duševnost usko povezane, Freud ipak tvrdi da je psihička biseksualnost neovisna o biološkoj biseksualnosti. Međutim, Freudova je teza glasila da biseksualnost, koja je najizraženija u predgenitalnoj fazi, sve više ustupa mjesto psihološki jednoznačnom rodnom određenju (koje bi, prema Freudu, nužno moralo uslijediti zbog edipalnog konflikta, uslijed kojega se dječak identificira sa svojim ocem a djevojčica sa svojom majkom).

Badinter navodi činjenicu o sve češćoj pojavi biseksualizacije suvremene kulture: biseksualizacija je prije svega potaknuta korjenitim socio-kulturalnim promjenama, koje ugrožavaju dijalektičku ravnotežu između muškosti i ženskosti. ${ }^{766}$ Ovdje možemo govoriti o socio-kulturalnoj krizi rodnoga identiteta. Biseksualna dinamika odražava se na dva polja: neutrakizmu (želji za nepripadanjem niti jednome spolu), te ultrakizmu (želji da se pripada obima spolovima). ${ }^{767}$ Psihička biseksualnost kod muškarca, moglo bi se reći, ustvari je vrsta pobune protiv kulture falusa (primata falusa), ali je ona potaknuta i strahom od kastracije (strahom od ženskoga subjekta i strahom od edipalnog konflikta). Badinter ističe da za svako ljudsko biće postoji njegova/njezina vlastita seksualna drugost. No ona tvrdi da se žene bolje nose sa vlastitom biseksualnošću nego muškarci, upravo stoga jer su svjesne vlastite ženskosti, pa mogu svoj drugi muški dio koristiti i demonstrirati bez oklijevanja. ${ }^{768}$ Žene tako ne smatraju biseksualnost opasnošću za svoj ženski identitet, dok muškarac tijekom odrastanja uči da mora odbaciti povezanost (identifikaciju) s majkom i tako potisnuti svoj ženski identitet. Na transseksualnim se osobama pokazalo da prevelika simbioza s majkom dovodi do ekstremne feminiziranosti. Prema Freudovima riječima, koje Kristeva navodi u svojoj knjizi Powers of horror, odvajanjem od majke, odnosno od svoje ženskosti, dječak može razviti svoj budući rodni identitet, odnosno muškost, jer jedino tada svoju majku vidi kao odvojeni, heteroseksualni objekt prema kojem može razviti osjećaj žudnje. Budući da muškarac u sebi nosi stalnu potrebu regrediranja u prastanje jedinstva s majkom (prededipalno stanje), ${ }^{769}$ on neprestano mora uključivati obrambeni mehanizam protiv vlastite ženskosti. Stoga homoseksualnost za muškarca predstavlja opasnost gubitka vlastitog identiteta: „mogućnost spajanja sa majčinom ženskošću ujedno plaši i privlači muškarce“. ${ }^{770}$

\footnotetext{
${ }^{766}$ Badinter 1986, str. 213-214.

${ }^{767}$ Ibid., str. 214.

768 Ibid., str. 215.

${ }^{769}$ Usp. Kristeva: Moći užasa. Ogled o zazornosti, 1989, str. 41-67. i str. 68-77.

770 Badinter 1986, str. 215-219. , usp. Kristeva: Moći užasa. Ogled o zazornosti, 1989, str. 41-67. i str. 68-77.
} 
Nasuprot tome, ženskost predstavlja izvornu biseksualnost, te prema tumačenju feminističke teoretičarke Rite Felski predstavlja i određenu organsku cjelovitost i samodostatnost, prededipalno obilje koje može funkcionirati kao utopijska perspektiva unutar moderniteta.

Ova feministička tumačenja pojmova muške i ženske biseksualizacije korisna su u osvjetljavanju pojma hibridizacije roda, odnosno prikaza fluidnih prijelaza između muškog i ženskog ,principa“ (identiteta) i u razdoblju bečke moderne.

Feministička teorija Julije Kristeve uvodi pojam abjekcije (zazora od) ženskosti u patrijarhalnom društvu, koja se kasnije transformira u podsvjesno internaliziranje ženskog identiteta (u muškaraca). Kristeva pobliže objašnjava dijalektički odnos između zazora od internalizacije ženskog identiteta u muškarca (što je uvjetovano patrijarhalnim poretkom) i, s druge strane, privlačnosti povratka u pred-edipalno stanje (strah i žudnja prema majčinskom jastvu). ${ }^{771}$ Ovom Kristevinom teorijom može se objasniti problematika bečke moderne, u djelima čijih književnika se predstavlja kriza patrijarhalnog poretka (kriza logocentrizma i falogocentrizma, uvjetovana dehijerarhizacijom odnosa među spolovima), te se otkrivanje ženskih potencijala (Verweiblichung der Kultur) ${ }^{772}$, potaknuto počecima ženske emancipacije, u kulturi bečke moderne prvenstveno manifestira kroz gubitak sigurnosti (odnosno, krizu) muškog rodnog identiteta: „Oni koji zaziru od majčina tijela (abjekcija majčinskoga/ženskoga) zapravo neprestano traže unutrašnjost majčina tijela koju žele i koje se boje, koja ih hrani i ubija“. ${ }^{773}$ Zakon Oca zahtijeva javljanje vlastitog identiteta, odvojenog od majke: on je temelj društvenog i kulturnog, odnosno ne-biološkog poretka. Dječak, zbog straha od kastracije (vezanog uz Zakon Oca), napušta udivljenje prema majci.

Freud je, prema Kristevoj, sveto doveo u vezu s tabuom i totemizmom, da bi zaključio kako treba „u obrascu totemizma- za odraslog čovjeka- staviti oca na mjesto totemske životinje“. 774 Prema Kristevoj, Freud tvrdi da ljudski moral počinje sa „dva tabua totemizma“: ubojstvom oca i incestom. Totem i tabu počinje podsjećanjem na „fobiju incesta“, vezanu uz majku i sina. Levi-Straussova strukturalna antropologija pokazala je koliko „svi spoznajni sustavi u takozvanim divljim društvima na ljestvici simboličnosti predstavljaju kasniju razradu zabrane koja pada na incest i na kojoj se temelji društvena cjelina“ ${ }^{775}$ Ono što označavamo kao „,̌ensko“, to je neka prirodna, iskonska bit, ali također i neki bezimeni „Drugi“ s kojim se muškarac mora suočiti. Ako je žena kao „Druga“ povezana s funkcijom trokuta očinske

\footnotetext{
${ }^{771}$ Vidi Kristeva: Moći užasa. Ogled o zazornosti, 1989, str. 41-67. i str. 68-77.

${ }^{772}$ Le Rider, 1990, str. 105-112.

${ }^{773}$ Kristeva 1989, str. 66.

${ }^{774}$ Ibid., str. 68.

${ }^{775}$ Ibid., str. 70.
} 
zabrane, onda je posrijedi sučeljavanje s neiskazivim alteritetom- čvrstim osloncem ugode $^{\text {، } 776}$, ekstatičnim uranjanjem u ženu (majku).

Prema Kristevoj, Freud je na početku Totema $i$ tabua silno inzistirao na „dubokoj odvratnosti čovjeka prema njegovim nekadašnjim incestnim željama“. ${ }^{777}$ Pol oca zabranjuje, razdvaja, sprječava dodir sina i majke. Ta očeva zabrana sprječava idiličan dualni odnos (majka-dijete), te kasnije uzrokuje u muškog subjekta odvratnost prema incestu. Odvajanjem od majke (i difamacijom njene tjelesnosti) prelazi se „od prahorde u civilizirano društvo“: sinovi se odriču majki i sestara i oblikuju patrijarhalnu zajednicu. Dakle, ulaskom u simbolički poredak oca niječe se primarni narcizam, stanje kada sin još nije bio odvojen od majke, kada je majka bila dio njega i nije postojala kao odvojivi vanjski objekt. Taj arhaični odnos prema majci nije bio „pouzdan“ za subjekt: „kada bi utonuo u majku, subjekt bi si otvorio put u psihotično stanje. Zabrana incesta ima za posljedicu utemeljenje društvenog poretka i simbolike““.778 „Ona presijeca iskušenje povratka, zazorna i radosna, na status pasivnosti u simboličkoj funkciji u kojem bi, lebdeći između unutra i izvana, između boli i užitka, između čina i riječi, uz nirvanu subjekt našao smrt““ ${ }^{779}$ Prema Kristevoj, religiozni obredi ipak žele spriječiti uranjanje u majčinsko jastvo.

„Zazorna“ je i „demonska“" moć ženskoga (na temelju njezine tjelesnosti) uvijek bila izvor fascinacije i užasa za muškarca: stoga se izuzimanjem od ženskoga i kreiranjem vlastitoga ja uspostavlja patrijarhalni, odnosno očev poredak. „U brojnim su još ,primitivnim“ društvima religiozni obredi očišćenja namijenjeni odstranjivanju neke društvene, spolne ili dobne skupine od neke druge, zabranjivanjem nekog elementa prljavštine ili ljage““ ${ }^{780}$ „Kao da se linija razgraničenja između društva i prirode (muškoga i ženskoga principa) ustanovljuje na temelju logike izuzimanja 'prljavoga'“ ${ }^{781}$ „Ljaga je ono što ispada iz 'simboličkog sustava'ona je ono što izmiče društvenoj racionalnosti, logičnom redu na kojem počiva društvena cjelina“. ${ }^{782}$ Pojedinac se, isto tako, želi odvojiti od majke i potvrditi to razgraničenje konstituiranjem sebe kao samostalnog, vlastitog subjekta (vezano uz dihotomiju unutarnje/vanjsko). Majčinsko je tijelo oduvijek bilo „prijetnja očinskim zakonima u koje će, s faličkom fazom i usvajanjem jezika, kliznuti čovjekova sudbina“ ${ }^{783}$ „Jezik i kultura

\footnotetext{
${ }^{776}$ Kristeva 1989, str. 71.

${ }^{777}$ Ibid.

778 Ibid., str. 76 .

779 Ibid.

${ }^{780}$ Ibid., str. 78 .

${ }^{781}$ Ibid.

782 Ibid.

${ }^{783}$ Ibid., str. 85-86.
} 
uspostavljaju razdvajanje potiskivanjem majčinskog autoriteta“. ${ }^{784}$ „Arhaični se strah od majke (žene) prvenstveno pokazuje kao strah od njezine moći rađanja. Zadaća je porijekla po očevoj liniji da savlada upravo tu moć koje se muškarac boji“. ${ }^{785}$ Prema Kristevoj, religiozne zabrane tako žele odvojiti muškarce od žena i osigurati njihovu dominaciju nad njima.

Gađenje zbog ljage menstrualnog onečišćenja i nečistoća rađanja, dakle, funkcionira kao zaštita od majčinske vlasti. Mitska ljaga predstavlja nečistoću one nedodirljive „druge strane“ (žene kao Drugoga, tajnovitoga). „Žena i muškarac, kao biologija i društvo, razmnažanje i stvaranje, predstavljaju dihotomiju između zazornoga i svetoga, između želje i znanja. Zazorom od majke, u kojem muškarac zastrašeno prevladava užas pred majčinom utrobom i kroz koje izmiče suočavanju s tim Drugim, zaobilazi se opasnost od očeve kazne“ (kastracije). ${ }^{786}$ Samo instanca oca, utoliko što ,uvodi simboličku dimenziju između subjekta (djeteta) i objekta (majke), može uroditi takvim strogo objektnim odnosom“. ${ }^{787}$ Bez toga se „ono što nazivamo narcizmom pretvara u provalu čistog nagona bez objekta koja ugrožava identitet subjekta“" 788

U muškarca se pojavljuje strah od kastracije spolnog organa koji „manjka“ njegovoj majci, od ,gubitka svog vlastitog organa, te od grešne želje da istom sakaćenju ili istoj smrti podvrgne svoga oca“. Za ženski subjekt u nastajanju kastracija je, naprotiv, već „obavljena“ te u ženi proizvodi zavist za penisom, osjećaj inferiornosti prema muškarcu. ${ }^{789}$

Također, i Elisabeth Badinter u svojoj knjizi pod naslovom Ich bin Du: Auf dem Weg in die androgyne Gesellschaft, navodi činjenicu da „dječak kroz proces socijalizacije uči da „,bi morao“ izaći iz prvobitne simbioze, koja ga je činila jednim sa njegovom majkom ili da „mora razriješiti problem identifikacije s majkom kako bi re-definirao ženski dio u sebi““ 790 Kod transseksualnih se osoba pokazuje da prebliska simbioza s majkom može dovesti do ekstremne feminizacije (homoerotički ili pak biseksualni porivi), ali također i do visokog stupnja senzibilizacije za drugo žensko biće. ${ }^{791}$ Ženskost na taj način nalazi svoje mjesto i u muškom identitetu. Badinter slijedi Freudova učenja kad kaže da „samo kad se dječak može odvojiti od svoje ženskosti povezane s majkom, on može razviti svoju muškost, odnosno svoj kasniji čvrsti rodni identitet, budući da samo onda može svoju majku vidjeti kao odvojeni,

\footnotetext{
${ }^{784}$ Kristeva 1989, str. 86.

785 Ibid., str. 91.

${ }^{786}$ Ibid., str. 65.

${ }^{787}$ Ibid., str. 55.

788 Ibid.

${ }^{789}$ Ibid., str. 43.

${ }^{790}$ Badinter 1986, str. 218.

${ }^{791}$ Ibid., str. 218.
} 
heteroseksualni objekt za kojim može razviti žudnju“. ${ }^{792}$ I razvoj srži rodnog identiteta događa se na drugačiji način kod dječaka nego kod djevojčica: konflikt koji dječaci proživljavaju, djevojčice ne proživljavaju. ${ }^{793}$ Budući da „muškarac ima stalnu potrebu regrediranja u pra-stanje jedinstva s majkom, on uvijek uzima obrambeni mehanizam protiv vlastite ženskosti““. ${ }^{794}$ Budući da osjećaj muškosti kod muškarca nije tako čvrsto ukotvljen, homoseksualnost se od strane muškarca percipira i kao smrtna opasnost za njihov identitet. ${ }^{795}$ Privlačnost sjedinjenja s majčinom ženskošću muškarca stavlja u određeni miješani osjećaj zazora i žudnje. Prema riječima Simone de Beauvoir: „i muškarac (kao i žena) ne rađaju se kao takvi, već takvima postaju“. ${ }^{796}$ Izvorna muškost se gubi, budući da slabi muška orijentacija prema uzorima: međutim, oba spola se nalaze u stanju patnje. Poteškoće muškaraca sa svojim (rodnim) identitetom i svojom biseksualnošću odražavaju se i u njihovim vezama sa ženama. Kao što žene postaju žrtvama patrijarhalnog poretka, tako se i muškarci teško snalaze u društvu u kojem se sve više razvija ženska emancipacija. ${ }^{797}$ Zahtjev za jednakošću spolova s jedne je strane ipak bio od strane muškaraca percipiran kao „,nepodnošljiva“ prijetnja za muškost. Izjednačavanje prava spolova stvara strah (odnosno, osjećaj anksioznosti), budući da muškarci smatraju da će pri tome izgubiti svoju zasebnost, te se tako javlja „feminizacija čovječanstva“ (Verweiblichung der Menschheit). Ova predodžba ovisi o žudnji muškarca za prvobitnim (izvornim) majčinim tijelom, odnosno majčinskom svemoći. Badinter smatra da bi se ovaj problem mogao riješiti jednakim odgojem dječaka i djevojčica. Ali, budući da nelagoda dolazi duboko iz podsvijesti, ona se može riješiti jedino kad bi se priznala sličnost spolova. ${ }^{798}$

\subsubsection{Teorija socijalnog konstruktivizma naspram teorije esencijalizma}

Dekonstrukcijske teorije Judith Butler, najeksponiranije predstavnice socijalnog konstruktivizma na području rodnih studija, vezane su uz pojam fluktuacije roda i rada na konstruiranju roda (kreiranje i re-kreiranje rodnih identiteta kao dio svakodnevnih diskurzivnih i performativnih praksi). U teorijama Judith Butler somatski spol ne mora nužno koincidirati sa psihološkim rodom. Ono što određuje osjećaj identiteta pojedinaca nije njihov biološki spol, već njihov socijalni rod, njihovo diskurzivno oblikovanje putem socio-

\footnotetext{
792 Badinter 1986, str. 218.

793 Ibid.

794 Ibid.

795 Ibid., str. 218.-219.

796 cit. u: Badinter 1986, str. 219.

${ }^{797}$ Badinter 1986, str. 219.

798 Ibid.
} 
kulturalnih obrazaca i njihova individuacija (iskustveno oblikovanje putem doživljaja i interakcija u društvenom okruženju). Stoga treba razlikovati između biološkog spola, čiji primat zagovara teorija biološkog determinizma s jedne strane, te s druge strane psihološkog i socijalnog roda (Genus), kojem se subjekt uistinu osjeća pripadnim, a koji zagovara teorija socijalnog konstruktivizma, ali i žudnje, koja se može razlikovati i od biološkog spola i od socijalnog roda (rodnog identiteta). Judith Butler čak postavlja i radikalniju tezu: biološki spol se već otpočetka pretapa u društveno oblikovani rod. Naime, biološka je razlika muškog i ženskog spola već prožeta društvenim i kulturalnim obrascima. Iz te tvrdnje ona izvodi zaključak o performativnom potencijalu roda, koji rod ne smatra nečim fiksnim, već promjenjivim, fluidnim, ovisnim o strukturama moći u pojedinoj kulturi, društvenim interakcijama i osobnim preferencijama. Butler u potpunosti poriče anatomiju i esencijalizam kao sudbinsku odrednicu čovjekovog bića. Teorija socijalnog konstruktivizma na području rodnih pitanja na taj se način suprotstavlja teoriji biološkog determinizma, koju su inaugurirali liječnici i antropolozi 18. stoljeća. ${ }^{799}$ Teorija biološkog determinizma uzimala je biološku konstituciju žena i muškaraca kao osnovu za njihovu dihotomizaciju (odvajanje), ali i kao osnovu za mizogine prikaze ženskoga spola.

Judith Butler naglašava sljedeće pitanje: na koji način regulatorne prakse kojima bi se rodni identitet trebao rukovoditi također usmjeravaju kulturalno raspoznatljive pojmove o rodnom identitetu pojedinca? ${ }^{800}$ Ovo je pitanje vrlo korisno ako se primijeni na razdoblje bečke moderne, gdje je postojala određena pluralnost društva, a također i strukturalna promjena društvenih i kulturalnih dinamika. Butler naglašava da su stabilni rodni identiteti, koji su zapravo u postmodernim društvima vrlo rijetki, oni u kojima bi se uspostavila i održala čvrsta poveznica (koherencija i kontinuitet) između biološkog spola, roda, spolne prakse i žudnje, dakle tek kad bi sve ove komponente bile harmonično usklađene. ${ }^{801}$ Butler postavlja ključno pitanje: „Predstavljaju li rodne norme matricu koherentnih identiteta pojedinaca?“802 te naglašava: „Radikalna heteroseksualizacija žudnje ponekad može proizvesti upravo asimetrične opozicije između žena i muškaraca, odnosno ,ženskosti“ i „muškosti“““،. ${ }^{803}$ Ona naglašava temeljnu tezu: ,Je li muška osoba uistinu tradicionalno muški konotirana, a ženska osoba uistinu tradicionalno ženski konotirana?“. ${ }^{804}$ Teorija socijalnog konstruktivizma kritizira strogu rodnu diferencijaciju, odnosno predstavlja kritiku fokusiranja na koncepte

\footnotetext{
${ }^{799}$ Usp. Honegger: Die Ordnung der Geschlechter, 1991, str. 145.

${ }^{800}$ Butler: Gender trouble, 1990, str. 17.

${ }^{801}$ Ibid.

802 Ibid.

${ }^{803}$ Ibid.

${ }^{804}$ Ibid., str. 18.
} 
jednakosti ili pak razlike, koju promiče teorija biološkog esencijalizma. ${ }^{805}$ Teorija konstruktivizma zagovara analizu (re)-produciranja društvenog poretka kao smislenog okvira postupanja i analiziranje roda (rodnih identiteta) $\mathrm{u}$ smislu generativnih obrazaca uspostavljanja društvenog poretka. Stroga podjela u dva spola postaje shvaćena kao društvena konstrukcija, pri čemu se mogu razlikovati tri analitički jedni od drugih odvojeni elementi: tjelesni spol koji odgovara biološkim klasifikacijskim kriterijima, a koji zagovara biološki determinizam; društvena pripadnost rodnom identitetu, koja se može razlikovati od tjelesnog spola, te spolna (rodna) orijentacija, koja se intersubjektivno potvrđuje u interakcijskim procesima. Prema stajalištu socijalnog konstruktivizma, iz bioloških parametara još ne nastaju rodni identiteti, a čak niti rodni poredak: ovi se rodni parametri tek oblikuju u društvenom okruženju ili u individualnim događanjima. ${ }^{806}$ Time se rod (odnosno rodni identitet) shvaća kao „kontinuirani društveni proces, kao interaktivna praksa prikaza i pridavanja rodne pripadnosti pojedincu, a sa ovom se performativnošću roda (re)-producira svakodnevno znanje o strukturama društvene stvarnosti““ ${ }^{807}$

Judith Butler, dakle, kritizira potpunu rodnu diferencijaciju žena i muškaraca. Prema Butler, nema esencijalističke opreke muškarac-žena, budući da su spol i rodni identitet već jedna te ista kategorija. Ona čak tvrdi da postoji isključivo rodni identitet, a ne spol, budući da je spol svakog pojedinca već prožet rodnim identitetom: „Spol je uvijek rodni identitet““. ${ }^{808}$ Prema Elisabeth Badinter, u stvarnosti ,smo svi mi androgini, jer su ljudi u višestrukom pogledu i u različitom razmjeru dvospolni. U svakome od nas muškost $\mathrm{i}$ ženskost isprepleteni su jedno $\mathrm{s}$ drugim, čak i kad bi nas većina kultura radije opisala isključivo kao pripadnike jednog spola““ ${ }^{809}$ „Ideal bi bio odvojiti se od stereotipa postojanja samo 'virilnih' muškaraca i samo 'naglašeno feminiziranih' žena. “610

\subsection{Bečka (post-)moderna}

Opća teza o anticipaciji postmodernih tendencija u bečkoj moderni nije nova, nalazimo je kod Žmegača (1981), Le Ridera (1990), Csákyja (1996) i Kernmayer (1999).

\footnotetext{
${ }^{805}$ Usp. Metzler Lexikon: Gender Studies, Geschlechterforschung 2002, str. 210-211.

${ }^{806}$ Usp. Metzler Lexikon, Gender Studies, Geschlechterforschung, poglavlje o konstruktivizmu, 2002, str. 210211.

${ }^{807}$ Ibid., str. 210-211.

${ }^{808}$ Butler, 1990, str. 7.

${ }^{809}$ Badinter, 1987, str. 207.

${ }^{810}$ Ibid.
} 
Žmegač ističe: „U Austriji oko 1900. godine stvorena su djela i misli koji anticipiraju ili već čak i izražavaju u ekstremnom obliku središnje estetičke i intelektualne tematske komplekse našeg sadašnjeg stoljeća“، ${ }^{811}$ Le Rider smatra da se u djelima književnika bečke moderne može uočiti inačica (post)modernog oblika radikalnog individualizma (umjetnika). ${ }^{812}$ Prema tumačenjima Le Ridera, karakteristika bečke moderne postaje (post)moderna neodredivost identiteta. ${ }^{813}$ Posebna osobina umjetnika i autora bečke moderne sastoji se u tome što su oni prikazali krizu individualizma, još prije negoli je ona postala temom drugih teoretskih, književnih i umjetničkih djela, te ju također proživljavali kao (vlastiti) gubitak identiteta subjekta, koji nisu (barem ne do kraja) uspjeli rekonstruirati. Moderna egzistencija pojedinaca pojavljuje se prvenstveno uslijed slabljenja tradicionalnih nazora na svijet, kao „trijumfiranje dezorganizirajućih sila“, prema kojima se svaki pojedinac nalazi u situaciji neizvjesnosti, nesigurnosti i dezorijentiranosti, koja se samo s mukom može premostiti. ${ }^{814}$

Percipiranje iluzijskog karaktera koncepata konzistentnih identiteta Jean-Francois Lyotard označava kao glavni sadržaj postmodernog pristupa svijetu. Čak je i čežnja za izgubljenom pripovijesti za većinu ljudi u postmoderni izgubljena. Vrijeme između 1880. i 1930. godine, analiza filozofskih, književno-umjetničkih i političkih diskursa Austrijske Monarhije pokazuje nešto drugo: sigurno je da identitet, ako se shvaća kao sličnost sa samim sobom, kao jedinstvo, koherencija i kontinuitet, baš pod specifičnim uvjetima ove moderne postaje problematičnom kategorijom. Međutim, svoje dominantne diskurzivne manifestacije suprotstavlja moderni Bečanin, odnosno austrijsko društvo, raspadu konzistentnih identitetabilo da se radi o oblicima osobnog identiteta ili o konstruktima kolektivnih identiteta, o rodnom identitetu, etničkom identitetu, nacionalnom identitetu ili o identitetu umjetničkog djela- projekte cjelovitosti (Ganzheitsentwurfe), koji reetabliraju i održavaju iluziju jednoznačnosti i izvjesnosti. ${ }^{815}$ Proces moderniteta je prepun dvoznačnosti i ambivalentnostiodnosno, (ne)odredivosti rodnog identiteta ${ }^{816}$. Moritz Csáky rezimira kako se „u intelektualnom diskursu postmoderne u ovoj specifičnoj situaciji bečke moderne već mogu utvrditi karakteristični kriteriji postmodernog stanja stvari“، 817

Postmoderno stanje stvari anticipirano je, dakle, $\mathrm{u}$ različitim tematskim kompleksima $\mathrm{u}$ razdoblju bečke moderne, što je posebice vidljivo u oblicima radikalnog individualizma,

\footnotetext{
811 vidi Žmegač 1981 , str. 55.

812 vidi Le Rider 1990, str. 40-61.

${ }^{813}$ Le Rider: 1990, str. 409-420.

${ }^{814}$ Le Rider 1990, str. 409.

${ }^{815}$ Kernmayer 1999, str. 21.

816 vidi Le Rider 1990, str. 409.

${ }^{817}$ vidi Csáky 1996, str. 64, u: Rudolf Haller (Hg.): nach kakanien, Annäherung an die Moderne, 1996.
} 
subjektivizma i esteticistički intoniranog senzualizma, što proizvodi krizu (rodnog) identiteta subjekta. Posebice onodobni znanstveno-društveni diskursi utječu na književne konstrukte i rasprave o krizi identiteta.

Baš filozofski i književno-umjetnički diskursi postavljaju sve više pitanja o posljedicama gubitka čovjekovog jastva i gubitka svijeta (nazora na svijet), oni pokušavaju prikazati rastvaranje (rastakanje) koherentnih slika o identitetu pojedinaca u pluralne (ili pluralističke) koncepte identiteta, proklamiraju zamjenu ontološkog razumijevanja svijeta za pluralne ili pluralističke koncepte svijeta koji se temelje na teorijama socijalnog konstruktivizma. ${ }^{818}$ „Skepsa prema logičkim fiksiranjima identiteta, izgradnja „utopije eksperimentiranja“, prepoznavanje kontingencije sustava poretka u umjetnosti i književnosti epohe ili razvoj senzualističkog pozitivizma u filozofiji kao i formulacije psihoanalitičke teorije- svi ovi koncepti upućuju na problematiku postmoderne“ ${ }^{819}$ koju bečka moderna anticipira.

Treba naglasiti da i moderna koncepcija kulture, koja se već pojavljuje u razdoblju bečke moderne (iako kao ambivalencija između tradicionalnog i modernog društva), a tako i postmoderna koncepcija kulture, koja radikalizira pojavu hibridnog rodnog identiteta, počivaju na krizi metafizičkog nazora na svijet koja je proizvela decentriranje misaonog subjekta. Metafizički, religiozni nazor na svijet počiva na temeljima čvrstog, ne-fluidnog identiteta, (rodnog) identiteta koji se nikad ne mijenja. Krizom ovog nazora ruše se temelji stabilnog subjekta, tako da rodne kategorije postaju fluidne i postoji opasnost od dezorijentacije i gubitka stabilnog jastva.

„Čini se da se mnoge postmoderne teme već pojavljuju u razdoblju moderne oko 1900. godine: promjena percepcije vremena i prostora, decentriranje nazora o svijetu, estetiziranje svijeta (naspram etičkih ideala, odnosno sukob estetika-etika), relativizacija svih vrijednosnih sustava, rastuća pluralizacija društva, ili, rastakanje „koordinatnih sustava“ fizikalnih, bioloških, socijalnih, moralnih i vremenskih prostora, koji su se smatrali stabilnima $u$ vremenu prije ,,moderne“، 820

$\mathrm{U}$ razdoblju bečke moderne vidljiva je, ponajprije, individualizacija subjekta $\mathrm{i}, \mathrm{u}$ naznakama, spolna liberalizacija, potaknuta dehijerarhizacijom u rodnim odnosima. Krize i konflikti o prijelomu stoljeća promicali su kontradikcije građanskog obiteljskog i rodnog poretka. Ženski emancipacijski pokret i feministička teorija pojavljuju se kao modus

\footnotetext{
818 vidi Kernmayer 1999, str. 20.

819 Ibid.

${ }^{820}$ Ibid., str. 13.
} 
promoviranja spolnog „oslobađanja“, ${ }^{821}$ koje nastoji dekonstruirati status žene kao objekta. „Pitanje o konzistentnosti, kontingenciji ili također i reprezentaciji identiteta i u ovome smislu stoji u središtu multidisciplinarnog razmatranja modernog čovjeka oko 1900. godine- a posebno bečke moderne, u kojoj je vidljiva estetizacija života, promjena percepcije prostora i vremena, relativizacija vrijednosnih sustava te rastuća pluralizacija društva““. ${ }^{822}$ „Decentriranje subjekta- to je decentriranje životnih nazora koje sa sobom donosi krizu identiteta, a koje u postmodernom smislu već anticipira bečka moderna. Dok je žudnja moderne bila ipak okrenuta žudnji prema identitetu i traganju za smislom života, u postmoderni se pojavljuje paradoksalno 'izmještenje' identiteta, odnosno decentriranje subjekta“. - „Uznapredovala fragmentacija i otuđenje od prirode u procesu modernizacije- ali i otuđenje od tijela, fantazije (mašte), žudnje, osjećaja- doživljavaju se ne samo kao otuđenje modernog pojedinca od postojećeg poretka, već i kao otuđenje od samoga sebe. Ovo otuđenje suprotstavlja modernom- prije svega građanskom- razmišljanju uvijek nove koncepte cjelovitosti, koji sintetiziraju suprotnosti i harmoniziraju ih“. ${ }^{823}$ - „Proces modernizacije proces je diferenciranja i fragmentiranja svijeta““. ${ }^{824}$ Osoba, identitet i priroda u procesu (post)moderniteta raspadaju se u dijelove ili fragmente koji ne stoje više u nužnoj vezi jedno s drugim. ${ }^{825}$

Radikalni oblik individualizacije i dehijerarhizacije u rodnim odnosima i rodnim identitetima može se povezati s početcima i naznakama destabilizacije rodnih odnosa i identiteta u razdoblju bečke moderne.

Međutim, treba također naglasiti da pored sveopće krize rodnog identiteta i rodnih odnosa, $\mathrm{u}$ pojedinim muškim likovima iz djela bečke moderne postoji čežnja za pronalaženjem srodne (ženske ili muške) duše (Hofmannsthal, Andrian, Musil, pa i Altenberg), odnosno, postoji čežnja za stabilizacijom rodnog identiteta, pa i tendencija prema heteroseksualnoj matrici. Međutim, uza sve prikaze ideala ženskosti hipersenzibilnih esteta, postoje i tendencije k njihovom rascjepljenju jastva, koje uvjetuje i ambivalenciju u rodnim odnosima i rodnim identitetima (variranje između heteroseksualnosti i homoeroticizma).

Ako se pitanje anticipacija (post)moderne primijeni na problematiku bečke moderne, onda se u habitusu senzibilnih esteta uočava njihova esencijalna čežnja za internalizacijom (prisvajanjem, pounutrenjem) ženskosti ili pak homoerotički impulsi koji su povezani sa

\footnotetext{
${ }^{821}$ Kernmayer 1999, str. 18.

822 Ibid., str. 13-14 .

${ }^{823}$ Ibid., str. 17.

${ }^{824}$ Ibid., str. 18.

${ }^{825}$ Ibid., str. 19.
} 
zazorom od žena i ženskosti, što dovodi do hibridizacije i androginizacije (pa čak i biseksualnosti) njihovih identiteta. Što se tiče opisa ženskih likova u književnosti bečke moderne, oni demonstriraju ili prototip femme fatale (koji se ponekad povezuje i s prototipom „Mannweib“), prototip femme fragile ili pak kombinaciju (spoj) obje karakteristike. Npr., unutar književnosti bečke moderne (napose djelo Arthura Schnitzlera pod naslovom „Die Fremde") postoji i lik žene koja ne pripada jednoznačno niti jednom od ova tri tipološka prikaza žena, već ovakvi prikazi pokazuju karakteristike fluidnog jastva (svojevrsnog gubitka identiteta). ${ }^{826}$

Rodna ambivalencija u prikazima književnika bečke moderne može se tumačiti uz pomoć teorije Judith Butler o nepodudarnosti između spola, roda i žudnje, dok se gubitak (rodnog) identiteta (njem. Identitätsverlust) u književnosti bečke moderne može tumačiti pojmom nestabilnosti jastva kao ontološke kategorije.

$\mathrm{Na}$ temelju provedene analize, može se zaključiti da je bečka moderna anticipacija postmodernih tendencija i u specifičnom smislu androginije i rodnog konstruktivizma. U sljedećoj tablici ukratko prikazujem najbitnije anticipacije postmodernih tendencija $\mathrm{u}$ analiziranim djelima bečke moderne.

\begin{tabular}{|c|c|c|c|}
\hline \multirow[t]{2}{*}{$\begin{array}{l}\text { postmoderne } \\
\text { tendencije }\end{array}$} & \multicolumn{2}{|c|}{$\begin{array}{c}\text { anticipacija u bečkoj } \\
\text { moderni }\end{array}$} & \multirow{2}{*}{$\begin{array}{c}\text { ključni književni } \\
\text { primjeri }\end{array}$} \\
\hline & eksplicitni rod & implicitni rod & \\
\hline $\begin{array}{l}\text { feministička teorija } \\
\text { - } \quad \text { biseksualizacija kulture } \\
\text { uslijed sociokulturne } \\
\text { krize rodnih identiteta } \\
\text { (E. Badinter) } \\
\text { - } \\
\text { zazor od ženskosti; } \\
\text { internalizacija ženskog } \\
\text { identiteta (J. Kristeva) }\end{array}$ & $\begin{array}{l}\text { motiv } \\
\text { demonizacije } \\
\text { žene, krize } \\
\text { muškog identiteta } \\
\text { i hibridnog roda u } \\
\text { kontekstu } \\
\text { sociokulturne } \\
\text { krize }\end{array}$ & $\begin{array}{l}\text { moderna } \\
\text { revizija } \\
\text { rodno } \\
\text { konotiranih } \\
\text { narativnih i } \\
\text { dramskih } \\
\text { postupaka }\end{array}$ & $\begin{array}{l}\text { - demonizacija žene iz } \\
\text { perspektive muškog lika } \\
\text { (Hofmannsthal: Das Märchen } \\
\text { der 672. Nacht) } \\
\text { - homoerotične konstelacije } \\
\text { (Andrian: Der Garten der } \\
\text { Erkenntnis; Musil: Die } \\
\text { Verwirrungen des Zöglings } \\
\text { Törleß) } \\
\text { - radikalne alternativne } \\
\text { konstelacije (Bahr: Die } \\
\text { Mutter) } \\
\text { - Altenbergova fascinacija } \\
\text { pred-pubertetskim } \\
\text { djevojčicama uslijed } \\
\text { eskapizma i zazora prema } \\
\text { zrelim ženskim osobama; } \\
\text { primarni narcizam esteta } \\
\text { - internalizacija pripovijedanja } \\
\text { (Beer-Hofmann: Der Tod } \\
\text { Georgs; Hofmannsthal: Das } \\
\text { Märchen der 672. Nacht; } \\
\text { Schnitzler: Die Fremde) }\end{array}$ \\
\hline
\end{tabular}

\footnotetext{
${ }^{826}$ O pojmu gubitka identiteta, ali i koncepciji primarnog narcizma kod žena vidi Le Rider 1990, str. 91-94.
} 


\begin{tabular}{|c|c|c|c|}
\hline & & & $\begin{array}{l}\text { - ravnopravna ili privilegirana } \\
\text { perspektiva ženskog lika } \\
\text { (Schnitzler: Die Braut) } \\
\text { - otvorena, >asocijativnar } \\
\text { dramska forma } \\
\text { (Hofmannsthal: Gestern; } \\
\text { Schnitzler: Reigen) }\end{array}$ \\
\hline $\begin{array}{l}\text { postfeministička teorija } \\
\text { - } \text { rodni identiteti kao } \\
\text { konstrukt i } \\
\text { performativna praksa (J. } \\
\text { Butler) }\end{array}$ & $\begin{array}{l}\text { motiv } \\
\text { eksperimentalnog, } \\
\text { ironijskog, } \\
\text { paradoksalnog } \\
\text { (re-)kreiranja } \\
\text { rodnih identiteta }\end{array}$ & $\begin{array}{l}\text { ludički } \\
\text { pristup rodno } \\
\text { konotiranim } \\
\text { narativnim i } \\
\text { dramskim } \\
\text { postupcima }\end{array}$ & 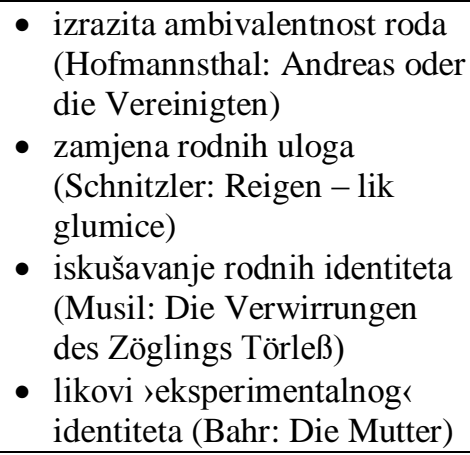 \\
\hline
\end{tabular}

U prethodnoj tablici prikazala sam poveznice između postmodernih karakteristika (rodnog) identiteta (fluidnosti i rasapa rodnih identiteta), odnosno anticipacija (post)moderne u djelima bečke moderne. Kriza individualizma u bečkoj moderni prije svega proizlazi iz rastuće modernizacije i dehijerarhizacije u rodnim odnosima, dok se $s$ druge strane u većini djela književnika bečke moderne (re)produciraju rodni stereotipi (mizogine slike o ženama). Ovakvi mizogini prikazi žena (femme fragile, femme fatale) proizlaze iz ambivalentnog stava onodobnih (prijelaz sa 19./20. stoljeće) muškaraca (pa i esteta-umjetnika) prema ženskosti, iz čega proizlazi, na psihološkoj razini, strah i udivljenje prema ženskim bićima. Ovakav ambivalentan stav prema ženama rezultira krizom muškog (rodnog) identiteta (pojava homoeroticizma, pa i ,četvrtog spola“). Ženski konotirane koncepcije prostora i vremena postaju ipak načinom umjetnikovog pounutrenja (internalizacije) ženskosti, pa i svojevrsnog empatijskog približavanja ženskim bićima, što se odražava u narativnoj (pripovjednoj) strukturi.

\section{ZAKLJUČAK}

Svoju doktorsku disertaciju strukturirala sam u šest ključnih poglavlja, počevši od uvoda, sažetka povijesti pojma androginije (Aurnhammer), preko prikaza bipolarizacije spolova u građanskom društvu te odstupanja od bipolarizacije spolova u djelima književnika bečke moderne ili pak reproduciranja istih stereotipa, zatim analize pojedinih književnih djela književnika bečke moderne, analize dekonstrukcijskih i postfeminističkih tumačenja rodnih identiteta (teorija društvenog konstruktivizma), zatim analize bečke (post)moderne te na kraju ovog sažetka disertacije. 
Ciljevi moga istraživanja bili su prikazati motive i tipove androginije u poznatim i manje poznatim tekstovima bečke moderne. Istraživanje polazi od hipoteze da motiv androginije nije povezan samo s formulacijom rodne krize, nego i s dekadentnom i društveno-kritičkom motivacijom. Drugi cilj istraživanja je bio dovesti u vezu hibridni rod u književnosti bečke moderne s ,konstruktivističkim“ shvaćanjem roda koje je postalo samorazumljivo u kontekstu postfeminističke teorije i rodnih studija. Istraživanje polazi od hipoteze da je analitički instrumentarij suvremene teorije primjeren u istraživanju pojava „hibridnog roda“ i u starijim razdobljima. Treći je cilj bio istražiti hibridni rod u kontekstu teze o anticipativnom (post)modernom potencijalu bečke moderne. Istraživanje polazi od hipoteze da se dekadentne, esteticističke, (auto)ironijske i društveno-kritičke paradigme u oblikovanju hibridnog roda u suvremenoj recepciji mogu reaktualizirati: u kontekstu suvremenih predodžbi o diskurzivnoj i performativnoj konstrukciji rodnih identiteta, književni eksperimenti bečkih autora anticipiraju elemente tzv. postmodernog stanja. Rezultat moje disertacije je detaljna analiza književnih konstrukcija rodnih identiteta i rodnih odnosa u razdoblju bečke moderne, koje dijelom anticipiraju postmodernu fragmentaciju identiteta.

Povijest pojma i motiva androginije, počevši od antičkog doba pa sve do bečke moderne i dalje do danas, pokazuje, kako je to opsežno prikazano u početnom dijelu rada, veliku varijabilnost. O prijelomu stoljeća (19./20.stoljeće) nastavlja se, s jedne strane, u društvu još ranije utemeljena bipolarizacija spolova (u građanskom društvu fin-de-siècle-a), dok, s druge strane, književnici i umjetnici modeliraju rod u smislu hibridnih struktura, koje se, u djelima književnika, očituju u krizi, dekonstruiranju, subvertiranju ili čak i utopijskom potencijalu rodnih identiteta i rodnih odnosa. Važno je napomenuti i činjenicu da su mnoga djela bečke moderne pisana u duhu ,impresionističke letimičnosti“, što upućuje na skepticizam, pa i kulturalni pesimizam ove epohe. S druge strane, impresionistički stil pisanja ukazuje i na uživljavanje pripovjedača u psihu senzibilnih esteta, koji zbog beznadnog pluralizma moderne epohe zapadaju u regresivno konotirano stanje primarnog narcizma, a koje je pretežno obilježeno pojmom „feminizacije esteta“ (Hofmannsthal, L. von Andrian, Beer-Hofmann, Bahr, Musil, Peter Altenberg, pa donekle i Schnitzler). Ova „feminizacija esteta“ usko je povezana uz onodobni strah od ženskog emancipacijskog pokreta, ${ }^{827}$ čiji su se začetci tada mogli nazreti. Iako se ipak rodna hijerarhija načelno o prijelomu stoljeća održala, sve su više zamjetljivi znakovi maskulinizacije žena i feminizacije muškaraca.

\footnotetext{
${ }^{827}$ Vidi Frevert 1990, str. 106-112.
} 
Bečka moderna, prema tome, predstavlja razdoblje izrazitog skepticizma prema ontološkom i metafizičkom fiksiranju (rodnih) identiteta. Međutim, i moralne (etičke) vrijednosti zakazuju, a kao surogat za gubitak ovih vrijednosti pojavljuje se esteticistički nazor na svijet. Također se u djelima književnika bečke moderne može uočiti inačica (post-)modernog oblika radikalnog individualizma ${ }^{828}$ (umjetnika- esteta).

Posebna osobina umjetnika i autora bečke moderne sastoji se u tome što su oni prikazali krizu individualizma, još prije negoli je ona postala temom drugih teoretskih, književnih i umjetničkih djela, te ju također proživljavali kao (vlastiti) gubitak identiteta subjekta, koji nisu (barem ne do kraja) uspjeli rekonstruirati. Moderna egzistencija pojedinaca pojavljuje se prvenstveno uslijed slabljenja tradicionalnih nazora na svijet, kao „trijumfiranje dezorganizirajućih sila“, prema kojima se svaki pojedinac nalazi u situaciji neizvjesnosti, nesigurnosti i dezorijentiranosti, koja se samo s mukom može premostiti. ${ }^{829}$

Androginizacijom oba spola (njem. das männliche Weib und der weibliche Mann) nastoje se transcendirati i dekonstruirati jednoznačna i stereotipna rodna određenja. Međutim, treba također naglasiti da u pojedinim muškim likovima iz djela bečke moderne postoji čežnja za pronalaženjem srodne (ženske) duše (Hofmannsthal, Andrian, Musil, Beer-Hofmann, pa i Peter Altenberg), odnosno, postoji čežnja za stabilizacijom rodnog identiteta, pa i tendencija prema heteroseksualnoj matrici. No uza sve prikaze ideala ženskosti hipersenzibilnih esteta, postoje i tendencije k njihovom rascjepljenju jastva (odnosno, krizi identiteta), koja uvjetuje i ambivalenciju u rodnim odnosima i rodnim identitetima (variranje između heteroseksualnosti i homoeroticizma), budući da njihova interakcija u društvenom okruženju biva ometana kako njihovom hipersenzibilnošću i pasivnošću, tako, s druge strane, i njihovom problematičnom obiteljskom situacijom.

Bečka moderna stoga predstavlja prijelazno razdoblje između tradicionalnog, „,viktorijanskog“ doba i liberalnog društva (,permissive society“), budući da književnici toga razdoblja na manje ili više radikalan način propituju, reproduciraju i subvertiraju onodobne rodne obrasce.

\footnotetext{
${ }^{828}$ Vidi Le Rider 1990, 409-420.

${ }^{829}$ Ibid., str. 409.
} 


\section{Literatura}

\section{Primarna literatura}

1. Hugo von Hofmannsthal (1979): Andreas. Die wunderbare Freundin. U: Gesammelte Werke. Erzählungen, Erfundene Gespräche und Briefe, Reisen. Frankfurt am Main: Fischer Taschenbuch Verlag, str. 198-319.

2. Hugo von Hofmannsthal (1992): Das Märchen der 672. Nacht. U: H. von H.: Das Märchen der 672. Nacht, Reitergeschichte, Das Erlebnis des Marschalls von Bassompierre. Frankfurt am Main: Fischer Taschenbuch Verlag, str. 9-30.

3. Hugo von Hofmannsthal (1979): Gestern. U: Gesammelte Werke in zehn Einzelbänden. Gedichte, Dramen I (1891-1898). Frankfurt am Main: Fischer Taschenbuch Verlag, str. 212-243.

4. Leopold von Andrian (1990): Der Garten der Erkenntnis. Zürich: Manesse Verlag.

5. Richard Beer-Hofmann (1928): Der Tod Georgs. Berlin: S. Fischer Verlag.

6. Arthur Schnitzler (1950): Die Fremde. U: Meistererzählungen. Frankfurt am Main: S. Fischer Verlag, str. 205-212.

7. Arthur Schnitzler (1987): Die Braut. Studie. U: Die Frau des Weisen und andere Erzählungen. Das erzählerische Werk. Fischer Verlag, str. 92-97.

8. Arthur Schnitzler (1962): Reigen, u: Reigen und andere Dramen. Das dramatische Werk, Band 2. Frankfurt am Main: Fischer Taschenbuch Verlag, str. 69-132. (prijevod: U kolu, prev. Dr. E. Dominiković, Koprivnica 1920).

9. Peter Altenberg (1928): Wie ich es sehe. Berlin: S. Fischer Verlag.

10. Das große Peter Altenberg Buch (1977): Herausgegeben und mit einem Nachwort versehen von Werner J. Schweiger. Wien, Hamburg: Paul Zsolnay Verlag.

11. Was der Tag mir zuträgt (1924). Fünfundsechzig neue Studien von Peter Altenberg. Berlin: S. Fischer Verlag.

12. Hermann Bahr (1891): Die Mutter. Berlin: Sallis'scher Verlag.

13. Robert Musil (2013): Die Verwirrungen des Zöglings Törleß. Text und Kommentar. Berlin: Suhrkamp, (prijevod: Pomutnje gojenca Törlessa, prev. B. Tolić, Sveučilišna naklada Liber, Zagreb 1979).

\section{Sekundarna literatura}

Aurnhammer, Achim (1986): Androgynie. Studien zu einem Motiv in der europäischen Literatur. Wien: Böhlau.

Badinter, Elisabeth (1986): Ich bin Du: Auf dem Weg in die androgyne Gesellschaft. München: Deutscher Taschenbuch Verlag. 
Beck, Ulrich; Beck-Gernsheim, Elisabeth (1990): Das ganz normale Chaos der Liebe. Frankfurt am Main: Suhrkamp Verlag.

Bei, Neda i dr. (ur) (1986): Das lila Wien um 1900. Zur Ästhetik der Homosexualitäten. Wien: Promedia.

Bruns, Brigitte (1997): Hermaphrodit oder das Geschlecht der Moderne. Zur Präsentation des Weiblichen und der Auflösung des Subjekts. U: Die Frauen der Wiener Moderne. Ur. Lisa Fischer, Emil Brix. München: R. Oldenbourg Verlag, str. 218-233.

Buljubašić, Eni: Vježba iz feminističke stilistike. Umjetnost riječi 3/4 2013, str. 183-203. Hrvatsko filološko društvo.

Bußmann, Hadumod; Renate Hof (ur.) (2005): Genus. Geschlechterforschung/Gender Studies in den Kultur- und Sozialwissenschaften. Ein Handbuch. Stuttgart: Kröner.

Butler, Judith (1990): Gender Trouble. Feminism and the subversion of identity. New York, London: Routledge.

Csáky, Moritz (1996): Die Wiener Moderne. Ein Beitrag zu einer Theorie der Moderne in Zentraleuropa“. U: Nach Kakanien. Annäherungen an die Moderne. Ur. Rudolf Haller. Wien i dr.: Böhlau. Str. 59-102.

Daviau, Donald G. (1984): Der Mann von Übermorgen. Hermann Bahr 1863-1934. Wien: Österreichischer Bundersverlag.

Doppler, Alfred (1990): Mann und Frau in Wien der Jahrhundertwende. Die Darstellungsperspektive in den Dramen und Erzählungen Arthur Schnitzlers. U: A. D.: Geschichte im Spiegel der Literatur. Aufsätze zur österreichischen Literatur des 19. und 20. Jahrhunderts. Innsbruck: Innsbrucker Beiträge zur Kulturwissenschaft, str. 95-109.

Felski, Rita (1995): The Gender of Modernity. Cambridge: Harvard UP.

Fischer, Jens Malte (1978): Fin de siècle: Kommentar zu einer Epoche. München: Winkler Verlag. Fliedl, Konstanze (1997): Arthur Schnitzler. Poetik der Erinnerung. Wien; Köln; Weimar: Böhlau. Freud, Sigmund (1994): Das Unbehagen in der Kultur. Frankfurt am Main: S. Fischer Verlag.

Frevert, Ute (1990): „"Wo du hingehst...”-Aufbrüche im Verhältnis der Geschlechter“, u: August Nitschke, Gerhard A.Ritter, Detlev J.k. Peukert, Rüdiger vom Bruch. Jahrhundertwende. Der Aufbruch in die Moderne, 1880-1930. Band 2. Reinbek bei Hamburg: Rowohlt Taschenbuch Verlag, str. 89-118.

Genette, Gerard (1998): Die Erzahlung. 2. Auflage. W. Fink Velag. 
Hank, Rainer (1984): Mortifikation und Beschwörung. Zur Veränderung ästhetischer Wahrnehmung in der Moderne am Beispiel des Frühwerks Richard Beer-Hofmanns. Frankfurt/ Bern/New York: Lang.

Hardy, William (1987):Jugendstil. Hamburg: Xenos-Verlagsgesellschaft.

Hausen, Karin (1976): „Die Polarisierung der Geschlechtscharaktere: Eine Spiegelung der Dissoziation von Erwerbs-und Familienleben“, u: Sozialgeschichte der Familie in der Neuzeit Europas., (ur) Werner Conze. Stuttgart: Klett. 363-393.

Hirschfeld, Magnus (1901): Was soll das Volk vom dritten Geschlecht wissen. Leipzig: Verlag von Max Spohr. (Gesamttext:http://www.schwulencity.de/hirschfeld_was_muss_volk_wissen_1901.html)

Hofmannsthal Handbuch (2016): Leben-Werk-Wirkung, Mathias Mayer/Julian Werlitz (ur.), J.B.Metzler Verlag, Stuttgart.

Honegger, Claudia (1991): Die Ordnung der Geschlechter: Die Wissenschaften vom Menschen und das Weib (1750-1850). Frankfurt am Main; New York: Campus Verlag.

Horst, Fritz (1997): Die Dämonisierung des Erotischen in der Literatur des Fin de Siècle. Zu Literatur und Kunst der Jahrhundertwende, (ur): Roger Bauer: Fin de Siècle. Zur Literatur und Kunst der Jahrhundertwende. Frankfurt/Main, str. 442-464.

Janz, Rolf Peter; Klaus Laermann (1977): Arthur Schnitzler. Zur Diagnose des Wiener Bürgertums im Fin de siècle. Stuttgart: Metzler.

Kernmayer, Hildegard, „Wiener Post-Moderne oder Sehnsucht nach der großen Erzählung? Identitätskrise als Signatur einer Epoche. Einleitung“, u: Zerfall und Rekonstruktion. Identitäten und ihre Repräsentation in der Österreichischen Moderne., ur. Hildegard Kernmayer. Wien: Passagen, 1999, str. 13-27.

Krafft-Ebing, Richard von (1993) (1898): Psychopathia sexualis (Stuttgart). München: Matthes \& Seitz Verlag.

Kristeva, Julia (1989): Moći užasa. Ogled o zazornosti. Zagreb: Naprijed.

Lacko Vidulić, Svjetlan (2004): “Und die Frau gehört der Liebe”. Zur Geschlechterspezifik der Liebesmythen in den Romanen Elfriede Jelineks. Zagreber Germanistische Beiträge, 13/2004, str. 159-175.

Lacko Vidulić, Svjetlan (2007): Lieben heute. Postromantische Konstellationen der Liebe in der österreichischen Prosa der 1990er Jahre. Praesens Verlag, Wien.

Lacko Vidulić, Svjetlan (1998): Dramaturgie des „Supranaturalismus“. Zu Hermann Bahrs „Die Mutter“, u: Sprachkunst 1/1998, str. 17-42. 
Lacko Vidulić, Svjetlan (2010): Erotischer Impressionismus und serielle Monogamie. Zur literarischen Kodierung der Liebe um 1900 und um 2000, u: Željko Uvanović (ur.): Nur über die Grenzen hinaus! Deutsche Literaturwissenschaft in Kontakt mit „Fremdem“. Osijek: Filozofski fakultet Sveučilišta Josipa Jurja Strossmayera.

Le Rider, Jacques (1990) : Das Ende der Illusion. Die Wiener Moderne und die Krise der Identität. Wien: Österreichischer Bundesverlag.

Lorenz, Dagmar (1995): Wiener Moderne. Stuttgart Weimar: Verlag J.B. Metzler.

Martinez, Matias, Michael Scheffel (2007): Einfuhrung in die Erzahltheorie- 7.Auflage. Verlag C.H. Beck, München.

Metzler Lexikon Gender-Studies/Geschlechterforschung (2002). Ur. Renate Kroll. Stuttgart: Metzler.

Narration und Geschlecht. Texte-Medien-Episteme. Ur. Sigrid Nieberle und Elisabeth Strowick.

Nünning, Vera; Ansgar Nünning (ur.) (2004): Erzähltextanalyse und Gender Studies. Stuttgart und Weimar: Verlag J.B. Metzler.

Paetzke, Iris (1992): Erzählen in der Wiener Moderne. Tübingen: Francke Verlag.

Perlmann, Michaela L. (1987): Arthur Schnitzler. Stuttgart: Metzler.

Pfister, Manfred (2001): Das Drama. 11. Auflage. Wilhelm Fink.

Pohle, Bettina (1998): Kunstwerk Frau: Inszenierungen von Weiblichkeit in der Moderne. Frankfurt am Main: Fischer Taschenbuch Verlag.

Przybyszewski, Stanislaw (2012): Androgyne, edition mabila, Reihe Europäische Klassiker.

Rasch, Wolfdietrich (1967): Fläche, Welle, Ornament. Zur Deutung der nachimpressionistischen Malerei und des Jugendstils, u: Rasch, Wolfdietrich: Zur deutschen Literatur seit der Jahrhundertwende. Gesammelte Aufsätze. Stuttgart.

Renner, Ursula (1981): Leopold Andrians Garten der Erkenntnis- Literarisches Paradigma einer Identitätskrise in Wien um 1900, Izdavač Peter Lang, Frankfurt am Main, Bern.

Robert Musil Handbuch (2016). Ur. Birgit Nübel, Norbert Christian Wolf. Berlin/Boston: Walter de Gruyter.

Rossbacher, Karlheinz (1992): Literatur und Liberalismus. Zur Kultur der Ringstraßenzeit in Wien. Wien: J \& V, Edition Wien, Dachs Verlag, (pogl.: Frauenbilder, str. 317-388.).

Schnitzler Handbuch (2014): Leben-Werk-Wirkung. Ur. Christoph Jürgensen, Wolfgang Lukas, Michael Scheffel. Stuttgart: Metzler.

Schorske, Carl E. (1997): Beč krajem stoljeća. Politika i kultura. Zagreb. 
Tegtmeier, Ralph (1986): Zur Gestalt des Androgyns in der Literatur des Fin de siecle, u: Ursula Prinz. Androgyn. Sehnsucht nach Vollkommenheit. Berlin, str. 113-119.

Thomé, Horst (1998): Arthur Schnitzlers „Reigen“ und die Sexualanthropologie der Jahrhundertwende, u: Text + Kritik, Heft 138/139 (Arthur Schnitzler), str. 102-113.

Timms, Erward (2013): Dynamik der Kreise, Resonanz der Räume. Die schöpferischen Impulse der Wiener Moderne. Weitra: Bibliothek der Provinz.

Weininger, Otto (1920): Geschlecht und Charakter. Wien und Leipzig: Wilhelm Braumüller, Universitäts-Verlagsbuchhandlung Gesellschaft M.B.H.

Wiltschnigg, Elfriede (2001): Das Rätsel Weib. Das Bild der Frau in Wien um 1900. Berlin: Reimer.

Wunberg, Gotthart (ur.), (1981): Die Wiener Moderne. Literatur, Kunst und Musik zwischen 1890 und 1910. Stuttgart: Reclam.

Wunberg, Gotthart (ur.), (1976): Das junge Wien. Österreichische Literatur- und Kunstkritik 18871902. 2 Bde. Tübingen: Niemeyer.

Žmegač, Viktor (1978): Geschichte der deutschen Literatur vom 18. Jahrhundert bis zur Gegenwart.

Band I/1. Athenäum Verlag.

Žmegač, Viktor (1993): Duh impresionizma i secesije. Zagreb: Zavod za znanost o književnosti Filozofskoga fakulteta Sveučilišta u Zagrebu.

Žmegač, Viktor (1998): Bečka moderna. Portret jedne kulture. Zagreb: Matica hrvatska.

Žmegač, Viktor (1981): Zur Aktualität der Wiener Moderne, u: Studien zur Literatur des 19. und 20. Jahrhunderts in Österreich. Festschrift für Alfred Doppler zum 60. Geburtstag, ur. Johann Holzner i dr., str. 55-67.

Žmegač, Viktor (1991): Dijagnostika epohe u bečkoj moderni, u: Umjetnost riječi 35 (1991), str. 135-154. 


\section{Životopis doktoranda}

Ime i prezime: Miljenka Došen

Datum i mjesto rođenja: 21.06.1982. u Zagrebu.

\section{Obrazovanje}

Sveučilište u Zagrebu, Filozofski fakultet, Studij engleskog jezika i književnosti i njemačkog jezika i književnosti , 2008./2009. Magistar engleskog jezika i književnosti i magistar njemačkog jezika i književnosti.

Sveučilište u Zagrebu, Filozofski fakultet, Svjedodžbe o znanju francuskog jezika, 2014. i 2015.

\section{Naziv poslijediplomskog studija, fakultet i godina upisa}

Poslijediplomski doktorski studij književnosti, izvedbenih umjetnosti, filma i kulture, Filozofski fakultet u Zagrebu, 2010./2011.

\section{Radno iskustvo}

2020-2008. Prevoditeljica u privatnoj građevinskoj tvrtci.

\section{Javno objavljeni rad}

The perception of eternal womanliness in Joyce's story "The Dead" and Schnitzler's "Die Fremde" // International interdisciplinary Student conference 2013 "It's not all black and white: Perspectives on otherness", Ljubljana, Slovenija, 2013. /CIP-316.7(82) Kataložni zapis o publikaciji, Narodna i sveučilišna knjižnica, Ljubljana; ISBN 978-961-93401-3-4. 